NATABELE
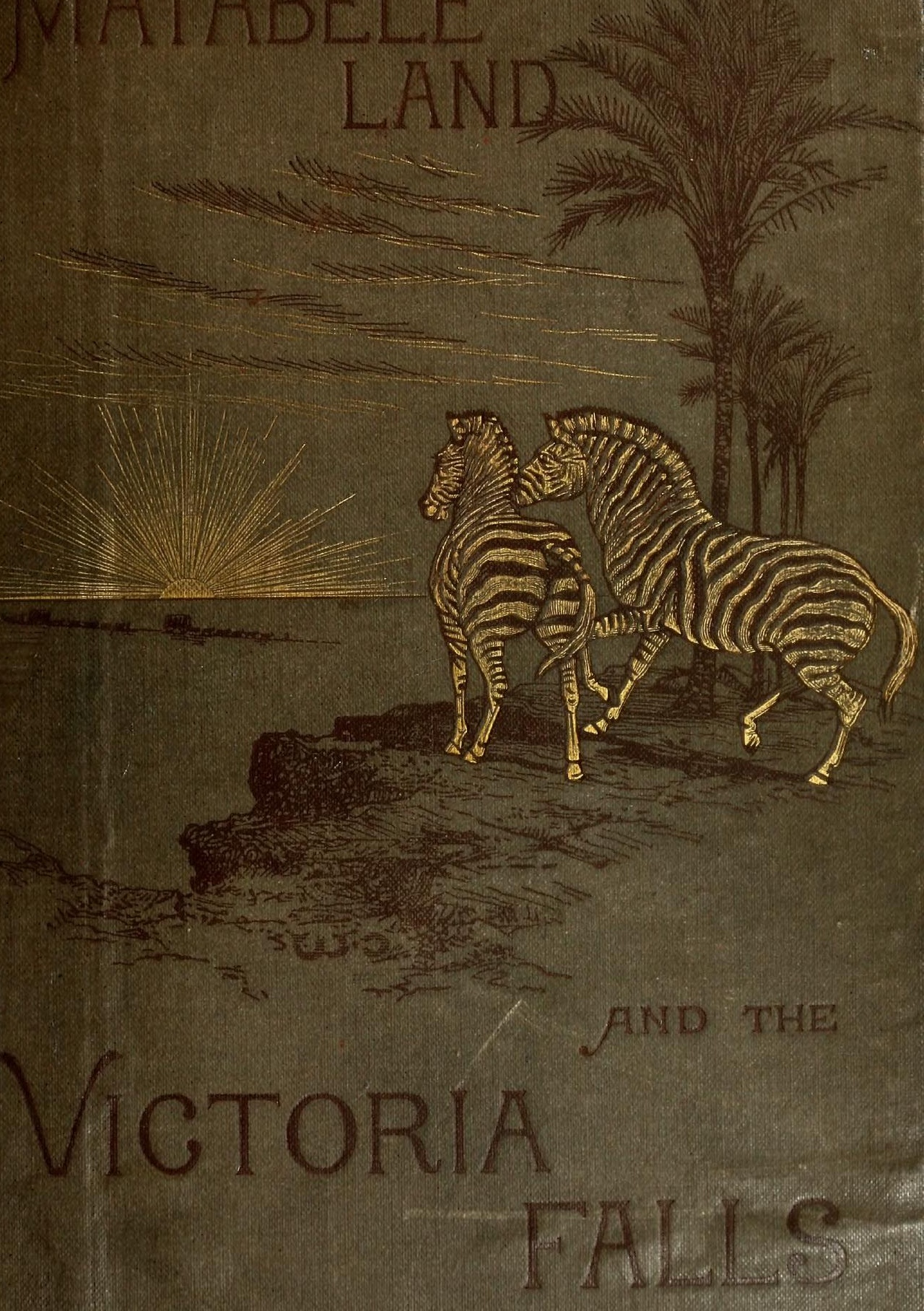

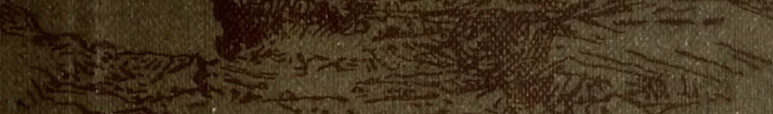


THE FIELD MUSEUM LIBRARY

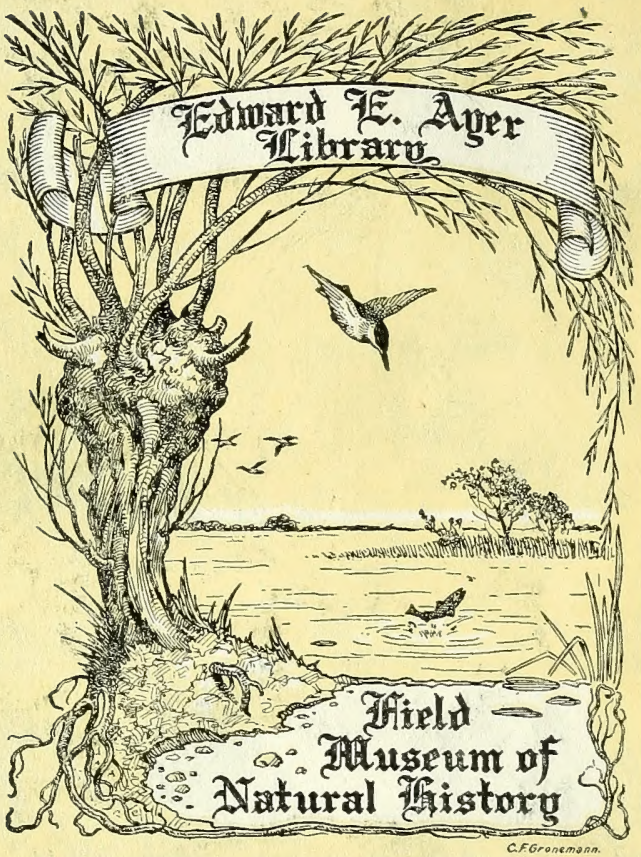

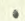


MATABELE LAND

AND

\section{THE VICTORIA FALLS}





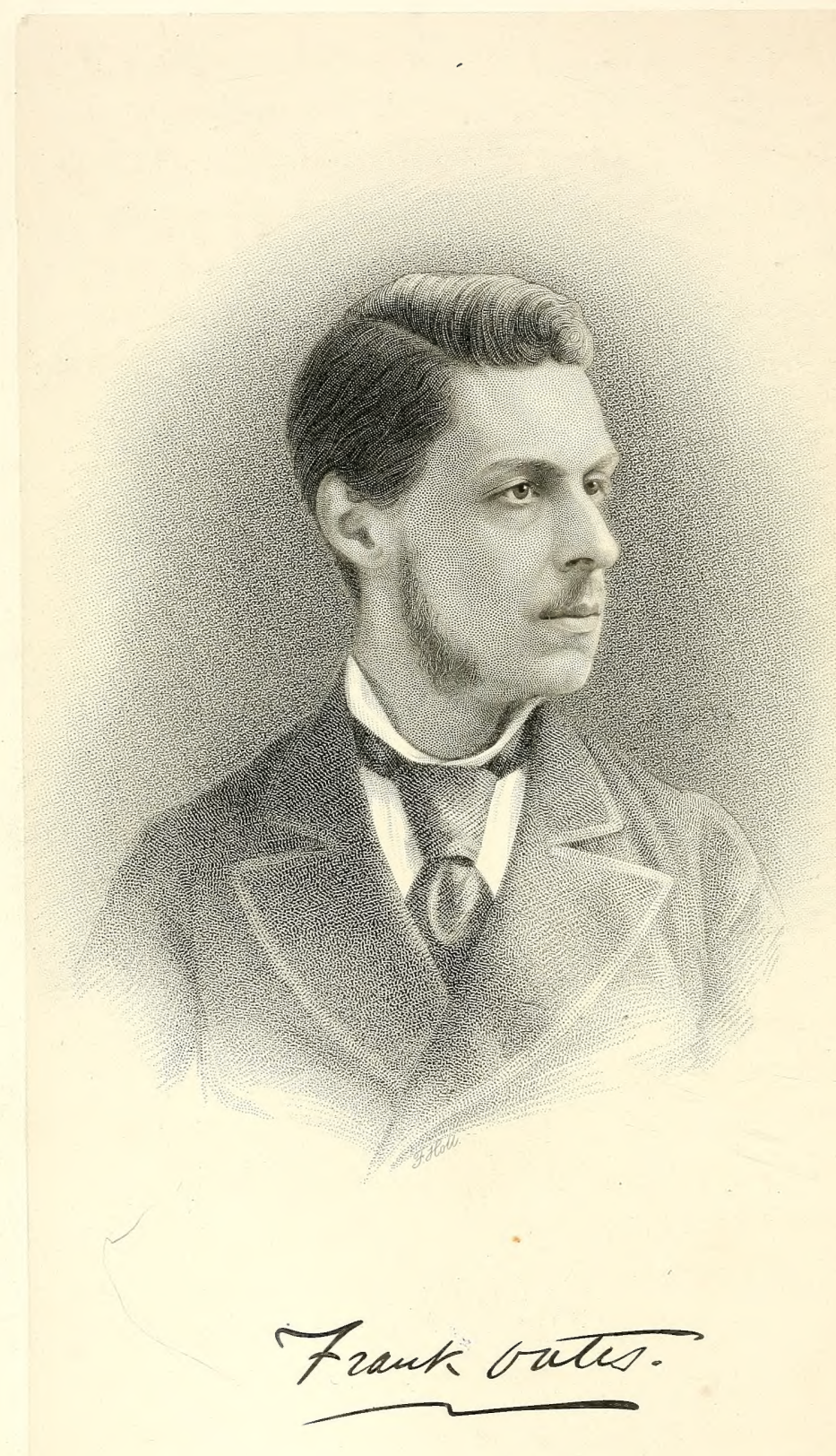




\section{MATABELE LAND AND}

\section{THE VICTORIA FALLS}

A NATURALIST'S WANDERINGS IN THE INTERIOR OF SOUTH AFRICA

FROM THE LETTERS \& JOURNALS OF THE LATE

FRANK OATES, F.R.G.S.

EDITED BY C. G. OATES, B.A.
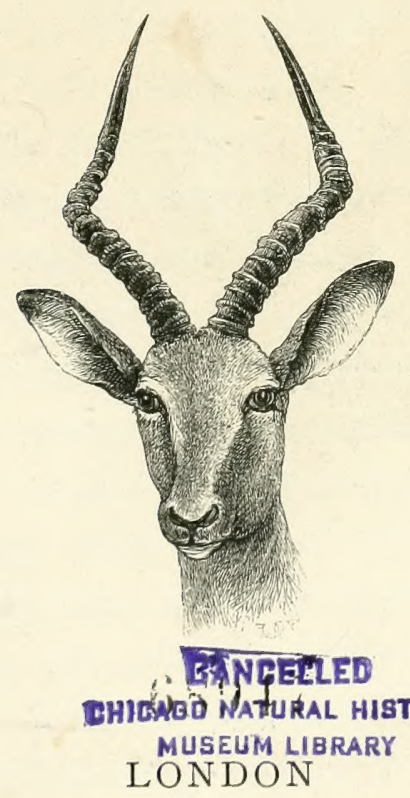

C. KEGAN PAUL \& CO., I PATERNOSTER SQUARE I 88 I 


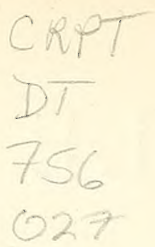

Printed by R. \& R. Clars, Edinburgh. 


\section{P R E F A C E.}

IN offering to the public the following pages, I feel, as editor, that I owe a few words of apology and explanation to the reader by way of prefaceapology for the imperfections of the volume; explanation how such imperfections have arisen. The traveller whose journey to the Zambesi is here recounted died of fever a few days after he had left that river on his way homewards, and the book has been compiled from his note-books, and letters home. The latter were written with no view of publication; the former were intended only for the writer's own subsequent use and as suggestive guides to memory. It is always a question in such a case how far the surviving friends of the deceased writer or traveller do well in publishing the unfinished labour of his pen. What his own wish would have been cannot be known, or even guessed at, unless specially expressed; and the reflection forcibly presents itself to the mind that perhaps a certain injustice may be 
done to the memory of the dead by publishing, in a form which may fairly challenge the criticism of the general reader, a few hasty jottings by the wayside, written under circumstances the least favourable to literary composition, and a limited number of letters home, meant merely for the perusal of the writer's nearest and most indulgent friends. On the other hand, however, it must be borne in mind that, much as must inevitably be lost in editing pages such as these for want of the inspiring touch which the writer himself could alone have finally given them, there will probably be a directness and freshness of the expressions which a traveller makes use of on the spot, hampered as he then is by no oppressive consciousness that he is addressing that imaginary "public"-consisting after all but of a number of individuals like himself, all with the same human heart and interests,--which might be wanting in his more matured work.

Guided, then, by the latter consideration, and by the reflection that every day the number of our countrymen is increasing who look to South Africa with a growing interest-whether as a land for colonization, exploration, or scientific research,- - I venture to add another to the long list of already published books upon that country, hoping that the reader may find therein matter of some general interest, and that, if not, he will look leniently on 
the error of judgment which has led me, together with those who have here shared my responsibility, to offer for his perusal pages prepared at first mainly for private friends, but which it was afterwards thought might possibly prove of interest to a somewhat wider circle.

Further, with reference to the length of time which has elapsed between the date of the writer's death and the publication of this volume, I can only claim in extenuation of this circumstance the fact that a considerable period necessarily intervened before the traveller's journals and papers reached this country, that they required on their arrival much care in their disposal, and that the whole of the natural history collections had to be gone through systematically before being finally placed in competent hands for arrangement and classification. The delay, then, has enabled me to include in the volume the papers in the appendix on the latter subject, contributed by such able hands, which I believe will add interest to the whole; and that not only in the case of scientific readers, but of all those who would realize in a measure what it is which makes up the life and experiences of the naturalist traveller in his wanderings in distant lands. I may add, moreover, that the general state and condition of the country of which these pages treat would appear, from the accounts of those who have recently 
visited it, to remain substantially the same, or only changed in points of minor interest. The abandonment, however, of the Tati Gold-mine and the establishment of Kama in the Bamangwato sovereignty perhaps demand attention.

In editing this work it has been my object to preserve, wherever possible, the writer's narrative in exactly his own words; and this plan has been steadily adhered to throughout, those passages only being omitted which appeared little likely to interest the general reader, or in which-as several times occurred-old ground was re-traversed. In such cases the intervening periods have been bridged over by a short narrative of my own, intended merely to connect the story and weld the whole together. The maps, it may be added, are all of them the result of the traveller's own special observations, recorded as he went along.

Of the illustrations in the body of the work, I may remark that they are all from original drawings taken on the spot, or from the objects they purport to represent. Some are from sketches by the late Frank Oates; the remainder-and these the larger number-from those of his brother, W. E. Oates, who accompanied him during a portion of his journey. It may therefore perhaps be fairly claimed for them that, whatever their artistic 
merits, these drawings are-what alone they claim to be-faithful representations of the scenes and objects they depict. In the "List of Illustrations" it will be found to which of the two brothers each drawing may be respectively attributed.

And now there only remains to me the pleasing duty of returning my warmest thanks to the many friends who have helped me with my task. To those gentlemen who have contributed the valuable papers which form the appendix to this volume, my thanks are especially due; I refer to Professors Rolleston, Westwood, and Oliver, Dr. Albert Günther, Mr. R. Bowdler Sharpe, and Mr. J. G. Baker. And in this connexion I have also to thank Captain G. E. Shelley, who named the majority of the birds in my late brother's collection before they passed into the hands of Mr. Sharpe, to be permanently deposited in the British Museum. From all of these, and especially from Mr. Sharpe, I have received, besides, much friendly help and advice with reference to the general arrangements of the volume, as I have proceeded with my labours; as well, also, as from Mr. H. W. Bates, the able Assistant Secretary of the Royal Geographical Society, to whose kindness I am deeply indebted for many valuable suggestions and much practical assistance. The four beautiful plates which accompany Professor 
Westwood's paper have been drawn by his own hand to illustrate his descriptions of new or remarkable insects.

Of those gentlemen, moreover, who have contributed their professional assistance, I must also in common gratitude add a word. Mr. Francis Holl has bestowed much pains on the production of a portrait of my late brother, from a photograph by Gowland of York, which I believe to be very successful; Mr. Kaufmann's chromo-lithographs are the result of much careful effort on his part to catch the spirit and preserve the effect of the original water-colour drawings from which they have been taken; the lithographs in the appendix, drawn respectively by Messrs. J. G. Keulemans, R. Mintern, W. H. Fitch, and (as already mentioned) Professor Westwood, have been accurately rendered by the skilful hands of Messrs. M. and N. Hanhart, and Messrs. Mintern Brothers; and the wood-engravings have been skilfully and conscientiously executed by Messrs. G. Pearson, J. D. Cooper, and E. Evans, all of them with a faithful determination to do the fullest justice to their respective subjects, and I believe with admirable result. The birds and animals have been placed on wood chiefly by Mr. Smit, and some by Mr. Davenport; whilst Mr. Charles Whymper has contributed two original drawings of the author's dogs and the 
designs upon the cover. Mr. Edward Weller also and his son have spared no pains to make the maps which accompany the volume as perfect and complete as possible; to whom, as well as to all the others named, my grateful thanks are due, and most heartily do I acknowledge what I owe them.

To enumerate more fully the names of those who have further assisted me, either professionally or as private friends, I must now forbear from undertaking; suffice it to say there are many, especially of the latter class, without whose assistance and encouragement I should probably never have succeeded in bringing my labours to a close. Let me thank them now for the generous help and sympathy so ungrudgingly given, and which, alas, it is so impossible for me to recompense.

It may be proper to add, before concludingwhat I have failed elsewhere to mention - that a considerable number of specimens in my brother's collection were destroyed at Shoshong in his lifetime by the unroofing, during a gale, of the hut where they were stored, and that some of the spirit jars of reptiles and beetles were afterwards left behind when the collections were conveyed to England ; circumstances which led in all probability to the loss of many valuable specimens.

There are not many who will need to be re- 
minded that to "inspan" and "outspan," words of frequent occurrence in the traveller's journal, mean, in South African parlance, to "yoke" and "unyoke," and that "spoor" means "footprints" or "track." All other words of Dutch or native origin introduced into the text are explained, I believe, where they occur. The accent in the word "Matabele" falls, it may be added, on the third of its four syllables.

My task is ended-in many respects a very mournful, yet a very pleasing one; and if there be found but a few readers who derive either pleasure or profit from a perusal of these pages, I shall feel amply rewarded for my trouble.

C. G. O.

May I88I. 


\section{E M O I R.}

"To be able to give one's name to a bird, or a flower, may seem to many but a poor ambition; and yet, materially considered, it is quite as likely to be perpetuated as to give it to a street or town, and is much more likely to define the tastes and individuality of the giver."-Bret Harte.

THE saying has seldom been truer of any one than of the writer of the succeeding pages, that "the child is father of the man." His love of nature generally, and of natural history in all its branches, was one of Frank Oates's earliest instincts ;

- and to the study of our English wild-birds-their ways and haunts, their comings and their goingshe was especially devoted from boyhood. The pages of Waterton and Buffon, treating of wider fields of study, supplied his imagination at that period with richer food; and the plates of Audubon's Birds, when access could be had to them, were turned by him with feelings little short of reverence. From his earliest days he had resolved to visit those distant, and, to him, still mysterious lands, where the page of nature was yet to the white man in great part an unread book; and those who, after 
his death in the full prime of manhood, witnessed the arrival at his English home of his large collections of natural history specimens, brought from the interior of South Africa by the devoted service of a friend, realized strangely how the boy's ambition had been fulfilled in after life, and felt that, though cut off in the very perfection of his powers, the purpose of his being had not wholly failed. Those even who knew him best were surprised indeed, when these evidences of his work abroad arrived, to see how much he had accomplished in the brief period - a little short of two years - of his absence. As, one after another, the packing-cases were opened, each in its turn afforded to the looker-on some fresh illustration of the untiring determination of the deceased traveller to make the very utmost of his opportunities whilst abroad. The voice that could alone have told the story of those collections, the hand that had brought them thus together, were silent and still in a far distant grave; but an utterance-the more pathetic because it was inaudibleseemed to go forth, unbidden, from those speechless records of devoted work and enterprise, and tell the secret tale of a life in earnest sympathy with nature curtailed,- - the hand, as it were, yet warm from its labours.

There, on the one hand, lay the opened cases of rare and brilliant bird-skins, each specimen with its 
separate label, in the collector's writing, carefully recording its habitat, and other particulars useful to the student, accompanied in many instances by examples of nests and eggs. There, on the other hand, were lesser boxes, filled with varied specimens of insects, some from those very Victoria Falls of the Zambesi, the rich and almost untried harvest-ground of the naturalist, whose attractions had lured the wanderer to his untimely grave. And there, again, were those large wide-necked bottles, familiar to the collector, containing, some of them, strange-looking beetles, others still stranger reptiles; there the packets of botanical drying paper, each sheet enveloping its floral treasure. Turning again to other cases, were found in numbers the singular implements of savage warfare, or industry, and with them many of those rude yet tasteful attempts at ornamentation suggested by native fancy; evidences - the whole of them-of that untutored skill and delicate refinement of workmanship which characterize many of the finer races of unlettered savages. Whilst further, the mighty tusks of the huge African elephant, the skins of the lion, the leopard, and the cheetah,-for it was these beasts of prey that the traveller had especially loved to hunt, - besides those of many an African antelope, with horns and heads of equal grace and beauty, told silently of stirring adventures in the bush. Lastly, but yet not 
least, were those scientific instruments he had used in taking observations of his journey with so much faithful perseverance; the note-books; the letters of friends (some of these unopened, containing those trifling items of home news, so sweet to the far-off traveller, which his eyes had never seen, for they had arrived after his decease); the pencilled outlines of the country's scenery; the water-colour drawings of those fatal Falls; how much did not these records breathe to the silent bystander, how much suggest of what had been, and still more what might have been! Poor fellow! not there himself to speak to us, those records of an earnest life, those cared-for and well-worn letters which he had received and treasured, how far more eloquent they were to us than any words could have been! They told us all, more than all, than any words which he could, or at least would, have spoken - so lightly did he ever treat his own achievements - and seemed to leave the world and ourselves poorer and yet richer by his death!

But the subject has led me, in my capacity of editor of these pages, beyond the proper limits of my duties, and I must crave the indulgence of the reader for this long digression. My object is merely to relate, as briefly as I can, such simple facts of Frank Oates's earlier life as may serve to illustrate the scope and bearing of the ensuing pages, and 
bring to view the motives which led him to enter on his life of travel. What I have said, indeed, may perhaps, it is true, help to show-what I was anxious early to point out-how very catholic were the interests of the deceased, how great the hold each separate department of the world's life, and history, and daily growth, had laid upon him. Devoted to the study of natural history, as I have already pointed out, and especially to that of birds-the pursuit of which might be called his ruling passion -yet never did he close his eyes to all those varied interests of other kinds, which were constantly opening round him in his life of foreign travel. "He was not" indeed, as has lately been said of the young French naturalist Jacquemont, who, like Frank Oates himself, died early and in harness,"He was not at all one of those specialists who shut themselves up in a narrow speciality, and become blind and deaf to the great interests of human life." I Rather may it be said of him, that his interests were perhaps too wide, and that he overtaxed his strength and powers in following the promptings of his nature. Speaking indeed in homely phraseology, whilst out in Africa, he admitted himself that he had "too many irons in the fire," and some of the difficulties and vexations which beset him upon his journey must be attributed

'Mr. P. G. Hamertọ, Lives of Modern Fronchmen, p. 95. 
to the delays which were occasioned by his desire of embracing every opportunity which presented itself, not only of adding a new specimen to his collection, but also of noting any fresh fact with regard to the country and its inhabitants which came before his notice. For, in addition to his natural history pursuits, he was, as above intimated, engaged on this journey in taking observations of the country which he passed through, and laying down his route, and also, wherever possible, in seeking intercourse with the natives, and gaining knowledge of their character.

This same tendency of his-to attempt too much-had once before also served him in evil stead when at the University in earlier life. Born on the 6th of April I840, a son of the late $\mathrm{Mr}$. Edward Oates, of Meanwoodside, near Leedshimself a lover of nature, and a man of literary tastes-Frank Oates entered at Christ Church, Oxford, at the close of I860. And here his love of nature and her teachings soon displayed itself by his choice of reading for a class in the Natural Science Schools. His work, however, in this direction did not keep him from study in many other departments of knowledge; and, besides his studies, all out-door pursuits had each their respective fascination for him. Of these, riding held with him, as it had always done, the foremost place; and when the time of year or incidental circumstances 
kept him from an occasional gallop with the hounds, he would have a long day's ride into the country instead, drinking in, the while, deep draughts of enjoyment from the scenes he passed through. One such ride, still showing him faithful to his love of birds, he describes himself in a letter to one of his brothers on May Day, I864, as follows :-

"I had a jolly ride," he writes, "to Wychwood Forest a few days ago, with S- of Wadham. We both enjoyed it, as we both entered into the loveliness of the scene. Unfortunately the day was cold, and few birds were seen, though we did hear the nightingale once, and the cuckoo once or twice. We were riding about the forest in the dark, with some prospect of being lost, and did not get back to Oxford till eleven o'clock, having ridden about thirty-six miles."

The exhilaration of these long rides was almost a necessity to him, counteracting, as they did in a measure, the strain of mental work. He also loved bathing, swimming, and sailing, the first two of which Oxford supplied him with in liberal measure, whilst even the last-named he found occasional opportunity of indulging his taste for on the Isis. Then there were cricket and rowing, to both of which he gave a share of his attention, with rifleshooting at the butts, and fencing at the gymnasium.

This is a tolerable list of occupations, in addition 
to which Oxford had also its social attractions for him; for, besides the undergraduates of his own standing whom he knew, he was further privileged with the acquaintance of a few such men as the present Dean of Westminster-then Regius Professor of Ecclesiastical History in the Universitythe present distinguished Master of Balliol, the late Sir Benjamin Brodie, and Professor Henry Smith; whilst the nature of his studies brought him into frequent pleasant intercourse with Professor Rolleston and others at the museum. The second year of his residence he sustained a loss, which he long felt, in the death of his young tutor, Mr. G. R. Luke, Senior Student of Christ Church, to whom he had formed no slight attachment. Of this event, rendered doubly sad by the circumstances under which it occurred, he wrote to a friend the day afterwards (March 4, I862) as follows :-

"Oxford," he says, "has just lost one of its brightest lights, and I a valuable friend, whom, I fear, I did not sufficiently appreciate in his lifetime -poor Luke! It would be too much to say that there was not so good, but I can confidently assert that I do not think there was a better, man in Oxford. He was such a genuine, worthy, and conscientious fellow as is rarely met with; and his kindness was equalled by his noble spirit - his modesty by his high learning and abilities. And this 
valuable life, difficult as it is to realize it, has been cut short;--Luke was drowned in the river yesterday, having gone alone, quite contrary to his custom, in a whiff. It seems that he was near half an hour in the water, and dead when taken out. This sad accident, coming so suddenly, must throw a damp over the feelings of many; and if there is any gratitude amongst men, there must have been many a sigh for him last night. I heard the news before six o'clock, and it had reached Christ Church some time before, the accident having happened about four. You may imagine my horror when, on entering my rooms to put on my cap and gown for hall, I was met by my scout, and asked if I had heard that Mr. Luke was drowned. In an hour or two I should have been reading with him."

And now enough may have perhaps been said to give some insight into Frank Oates's life at Oxford, and with one more quotation from his letters, this period of his history shall be closed. His first year at college an attack upon his chest in early spring had prevented his residence during the summer term at the University, and led to his spending as much of the succeeding winter as the Oxford terms admitted of in Italy, where he gathered many pleasant reminiscences. The following spring, too, he was late in coming up, owing to a return of his ailment during the Easter vacation, 
when he was again a prisoner to his room at home. Writing on April 23d (1862), during this period of confinement, he says, "I see the tree-tops tipped with green, and hear the thrush's voice, telling me of old times, and asking me why I keep house, and I've no doubt spring is here. So I want to be out again, and to greet her as an old friend." And presently he was out again, revelling in the spring sunshine with his friends, the birds. But this is not the intended quotation. Sufficiently recovered from this illness for the journey back to Oxford, he returned there on May 9th to find the place "shaded with its great green trees, and with its gray old walls looking almost joyous." It was not, however, till two evenings later that he "came in for the full benefit of the May aspect of things," as he describes it, when he took a long ramble into the country to Wytham, and first saw the rich pastoral country which surrounds Oxford in its summer dress. His account of this walk, written (again to the same friend) on May I2th, tells forcibly of his appreciation of all country sights and sounds.

". . Your letter arrived yesterday morning," he says, "and of course my evening was at once laid out for me, and now I come to what I ought to have begun with-my ramble of last night. You perhaps thought, as it grew dusk, that I was still 
lingering about the scene you describe; and so I was. It was with really joyous feelings that I set out at six o'clock, and trudged along the Sevenbridge Road. It was Sunday evening, and the road was crowded with Oxford folks and the militia. The floods which surrounded the road seemed an object of interest to them, but I pushed on, bestowing a hurried glance now and then at the tufted willows, and islands, and shores of long grass, which dotted over and surrounded the lakelike fields, with the dappled sky reflected on their watery surface. Botley reached, I inquired the way to Wytham. A shady green lane was pointed out to me, and I was soon away in thought, all alone in that quiet place; and so on I strolled, through the fields, past the wood, through the village, and, as night closed in, back again. If I were a word-painter I might describe my walk; but not being one, should any attempt of mine thereat be intelligible to you, it will only be because you know what I would describe, and can realize my feelings.

"There had been some little rain, and it was still rather dull and damp when I set out; but I should have gone if it had been worse, and really the evening ended almost brightly. I enjoyed the freshness of everything, and the wild-birds seemed to enjoy it; they did not appreciate it as I did, but 
they enjoyed it more. The notes of many a songster rang out from the thick cover of the wood on my left, and amongst the well-known notes some strange music was mixed, now and then becoming louder and more distinct. These must have been the wonderful soft strains of the nightingale. The woodpeckers were laughing wildly, and the rooks returning to the tops of the elms, and talking as is their wont; the youngsters responding eagerly, and seeming as if they were chattering and being fed at the same time. The cows were placidly grouped about the hedges, or wandering leisurely to and fro, favouring the passerby with a whiff of their scented breath. On the other side, flooded fields were rich in the most luxuriant vegetation; whilst continually, and, as it grew later, more continually, the cuckoos answered one another from many a deep shade. I was glad to think that you would be thinking me there, and hoped you would not fancy that I should give up the excursion."

Nor, passing now from reminiscences of his Oxford life, was his love of the country and its associations, here sufficiently evinced, confined to one particular sort of scenery; and the wild moorlands of his native county attracted him as strongly as the quiet and peaceful beauties of Oxfordshire, or even more so. During the Easter vacation of 
I 864 he had been on a short walking tour into the Yorkshire dales with one of his brothers and some other friends.

"There is always a sense of freedom," he writes from near Leeds soon afterwards, "in getting away to the moors and mountains which surround us, and lie so near that they seem to invite Leeds men to visit them. For though the river at Kirkstall is sadly changed from the stream that leaves Malham Tarn, and the mountain air has lost somewhat of its freshness when it sweeps over this place, the sight and sound of railways are a constant reminder that a few minutes' consignment to the train, and the payment of a few shillings, are sufficient charm to place one in the world of nature. May those moors and valleys long continue desolate, if desolation may be understood to mean no presence but that of the spirit of nature. I care not what that spirit may be, but I feel a breathing life and an unsurpassable harmony, where man has not utterly defiled the face of the country. What I long for," he concludes, "is a fishing tour in the neighbourhood of Kilnsey or Wensleydale. I must be incorrigibly idle, and born to hate anything that even looks like work; and yet I want to be active, to do something, to find a field for my energies, such as they are."

In the last passage the writer did himself some 
injustice, and what he seems to have taken for "incorrigible idleness," was in reality nothing else than the demand of nature within him for some real rest and relaxation from his Oxford studies. His scrupulous conscientiousness, moreover, was already beginning to cause him much anxiety with regard to his future life, as the time for his leaving Oxford was approaching. That warning voice of nature, however, unhappily was not attended to. He would have entered the Schools for his final examination the succeeding autumn, or at latest the following spring; but in the latter part of the summer of this year (I864), under the strain of overwork, his health broke completely down, and for a period of some years he was obliged to live in a state of enforced, and to him scarcely endurable, inactivity. A great portion of this time he spent in the retired parts of Wales, and the English Lake District, and some part of it in Ireland. On one occasion, during this period, writing to one of his brothers on his experiences of overwork, he says :-

"Let me advise you earnestly not to try to do too many' things. I killed the goose with a vengeance, and got no golden egg. I was expecting in a few weeks [when taken ill] a degree with honours, and a good start in life, and . . . had to leave Oxford without even an ordinary degree, which I knew 
more than enough to have taken the Easter before, if it would have satisfied me. I should have been surprised to have been told that season, when I was riding $\mathrm{H}$ - - 's little cob in Rotten Row, in the glory of summer and all the hope of youth, that before the leaves had all left the trees that very horse would have been H_-'s death, and that I should be a hundred times worse than dead."

Throughout the whole of this weary time, however, he never relinquished-so indomitable was his spirit - the hope of a better time approaching. Once at Liverpool, indeed, for a short stay in I 869 , he writes upon this subject, "I like to be where I can be amused and see life without having to take part in it, though I would fifty times rather be at work at something. I wonder," he adds, "whether I ever shall be again." And he was at work again, not quite two years later, once more restored to health, and busily preparing for a trip across the Atlantic, which had been recommended to him for the thorough re-establishment of his health, and which accorded happily with the early fancies of his boyhood. It was by this time almost too late for him, even had he now wished it, to have thought seriously of adopting one of the recognized professions. A few years earlier he had thought both of the army and

${ }^{1}$ His friend here referred to was killed by a fall from his horse late that autumn. 
the bar ; but with the love of adventure and research so strong within him, it is scarcely probable, had he adopted either, that he would have endured their trammels long. Once, too, it had seemed not unlikely that his strong love of painting, which held with his passion for natural history divided sway over his earlier years, might have proved the more powerful impulse of the two, and led him ultimately to the definite pursuit of art. In choosing against it, however, he probably selected well, as the somewhat sedentary life thereby involved would not so well have harmonized with his constitutional need for physical activity.

On this expedition to America he was absent about a year, a considerable portion of the time being spent in Central America-chiefly in Guatemala,and a part of it in California, camping out amongst the Rocky Mountains. Unlooked for circumstances brought his journey to a speedier close than he had intended; but if unaccompanied by other results, he was at least successful in forming a collection of birds and insects of some interest and value, and contracted several valuable friendships. "His manliness and irreproachable conduct and kindliness," wrote Sir Henry Scholfield, the British Consul at Guatemala, after his decease, "gained for him, during his short stay here, a friend in every one he met." And wherever else in the country he 
made any sort of stay, he appeared to have been scarcely less fortunate in this respect.

Soon after his return from America in 1872 he began to make arrangements for a more extended journey - the one of which this volume treats, and on which he started in March 1873. His plan on this occasion was to reach the Zambesi from Natal, and if possible visit some of the unexplored country to the north of that river. In the latter hope he was destined to disappointment, and the number of obstacles he met with in realizing the former serve to illustrate some of the ordinary difficulties which may be encountered in African travel. Of the results, however, such as they were, of this journey, in which he lost his life, the reader must be left to form his own judgment from the perusal of the ensuing pages. He had at least acquired much of that needful experience of rough travel and adventure, without which little can be accomplished in the way of exploration or research. It is almost certain that, had he lived, his next journey would have been of a more ambitious kind, remarkable as he was for that love of enterprise which characterizes the true explorer; of this he spoke merely as a "little trip." His experiences, moreover, in this two years' travel, must still further have convinced him, if in a different manner, of those evil effects of attempting too many things, which his Oxford career had 
previously warned him of. The diversity of his pursuits led him into many delays, each one of which no doubt contributed its share, together with the obstructiveness of native tribes, to that long detention on his journey which finally threw his visit to the Zambesi into the unhealthy season of the year. It must be granted, however, at the same time, that his love of adventure led him into places where the field for inquiry was especially inviting, and offered exceptional advantages; and also that his devotion to natural history beguiled throughout his journey what might otherwise have proved many a weary march. It is more than probable-so fully had the need of this now been brought home to him - that on another journey, had he been spared to make one, he would have concentrated his chief energies upon fewer objects. What these might have been must remain, indeed, matter of conjecture; but whatever else he had abandoned, the pursuit of ornithology would certainly have held a place second only to that of exploration.

In character and temperament Frank Oates was admirably fitted for his work. "I like anything," he once wrote when at Oxford, "that seems difficult of attainment," - the very zest of the pursuit proving in such cases its own reward to him. So too, in disposition; he had just the one which recommends itself to strangers. "There was something singularly 
winning about him," wrote a friend, upon his death ; "that peculiar combination of courage and gentleness, which is one of the finest traits of character." It was, in fact, this very association of a genial nature with a remarkable openness and candour of disposition, that won for him friends, especially amongst his own countrymen, wherever his lot was cast, and so smoothed his way over many difficulties. And if, as would sometimes happen, he fell amongst unfriendly natives, he preserved himself on such occasions by a seeming show of condescension, and a coolness under danger which commanded their respect. A faithful and accurate observer, but little was lost that came before his notice; and if at the time of his death-in February I875-he had not realized all that he had hoped from his expedition, he may at least be said to have justified the choice that he had made, and had contributed a measure of faithful labour to the causes of progress and research.

On hearing of his death, the Dean of Christ Church, who had always particularly regretted the illness which in earlier life had prematurely closed his University career, wrote of the untimely termination of his later efforts in a spirit of no less concern. "His name," wrote the Dean at this time, "must be added to the list of those devoted and enterprising Englishmen, who!scorn delights and live laborious 
days,' who by their frank love of truth and justice have made our name respected from one hemisphere to the other. I retain a dear memory of him," he concludes, "and grieve to think that so much manly spirit has so soon been quenched."

This manly love of truth here noticed, his zeal in action, and energy for work, had marked Frank Oates conspicuously from a boy. Life was for him no lounge, merely to be dreamed through, but an active, burning reality, from which the fruit that the hour yielded was to be plucked and harvested. From his earliest days, when he watched at springtide the coming of the swallow, or lurked in autumn by the hedgerow, to note the flocks of redwings as they passed-from the time when those authors whom he loved had given him his first glimpses into that distant realm of nature where his imagination loved to wander, and he hoped one day to follow themtill the arrival of the period when that desire was at length destined to be realized, and he had threaded the forests of tropical America, and roamed through the thorny wastes of Southern Africa, was he ever adding something to his knowledge of nature, something to his love of science, or something to his appreciation of the beautiful. With him, indeed, were no half measures. His interest once fairly roused in any subject, he gave to it the strength of his whole soul; a purpose once formed rarely failed 
in its fulfilment; and such was the elasticity of his temperament that he would turn from one subject to another, each as a mere refreshment from the last. To this was added, in no common measure, a certain freshness and buoyancy of the spirit, which enabled him in a moment to throw off the spell which bound him, and join on occasion in the frolic of the hour. A peculiar brightness characterized his being, and rendered the common incidents of life attractive to him ; and should any be found who regard as incongruous the lightness of spirit which occasionally manifests itself even in the ensuing pages, in connexion with more serious subjects, such ones may read with interest the following extract from the writings of the late Charles Kingsley, with reference to this very tendency, as manifested in another posthumous author, whose book was edited by a friend. "With a reverence for the dead," he says, "which will at once be understood and honoured, he [the editor] has refrained, perhaps here and there too scrupulously, from altering a single word of the documents as he found them, respecting even certain scraps of Cambridge and Winchester slang, which may possibly offend that class of readers who fancy that the sign of magnanimity is to take everything an grand séricux, and that the world's work must needs be done upon stilts; but which will be, perhaps, to the more 
thoughtful reader only additional notes of power, of that true English 'Lebensgluckseligkeit,' as the German calls it, which makes a jest of danger and an amusement of toil. Jean Paul makes somewhere the startling assertion that no man really believes his religious creed unless he can afford to jest about it. Without going so far as that, I will say boldly," adds the writer, "that no man feels himself master of his work unless he can afford to jest about it ; and that a frolicsome habit of mind is rather a token of deep, genial, and superabundant vitality, than of a shallow and narrow nature, which can only be earnest and attentive by conscious and serious efforts." 1 There were few circles of society where Frank Oates was not welcome; and once received in any of them, a place was ever after reserved for him in their midst. Whatever raciness or originality of character was to be met with where his lot for the time was cast, he failed not to find it out; and he eagerly availed himself of every opportunity which enabled him to see life in its less conventional aspects. A certain chivalry endeared him to the weak, his fearlessness attached to him the strong, and no act of kindness was ever lost upon or forgotten by him. He wandered far afield; but at home or abroad it ever was the same with him, and he had friends, go where he would : for the intellect, 
in his case, never overruled the affections; and perhaps it has fallen to the lot of few, dying at his comparatively early age, to leave so many sorrowing hearts behind them.

And now, but one word further. The late Charles Kingsley - again to quote his writings, still in the same connexion as before, with reference, that is, to his friend, Charles Mansfield, traveller, ornithologist, and devotee of science, the posthumous writer above referred to-has said some touching words, which the editor of these pages, too partial, it may be, in his estimate of the deceased, would fain transcribe, and apply to the subject of the present memoir. "He was one of those rare spirits," writes Charles Kingsley," "to whom this life and this world have been, as far as human minds can judge, little beyond a schoolhouse for some nobler life and world to come. Cut off at the very climacteric of his years, just as he was beginning to give the world evidence of his faculties, and just as he had acquired the power of using them in an orderly and practical method, he has left little behind but the disjecta mombra philosophi. . . . Never have I met a human being to whom as clearly as to him the thing which seemed right was a thing to be clone forthwith, at all hazards, and at any sacrifice. . . . He had gathered

I Paraguay, Brazil, and the Plate. By C. B. Mansfield, M.A. With a Sketch of the Author's Life by the Rer. C. Kingsley, pp. xi.-xvi. 
round him [ere he died], friends, both men and women, who looked on him with a love such as might be inspired by some being from a higher world. . . . Oh, fairest of souls!" concludes the writer, "Happy those who knew thee in this life! Happier those who will know thee in the life to come!"

C. G. O.

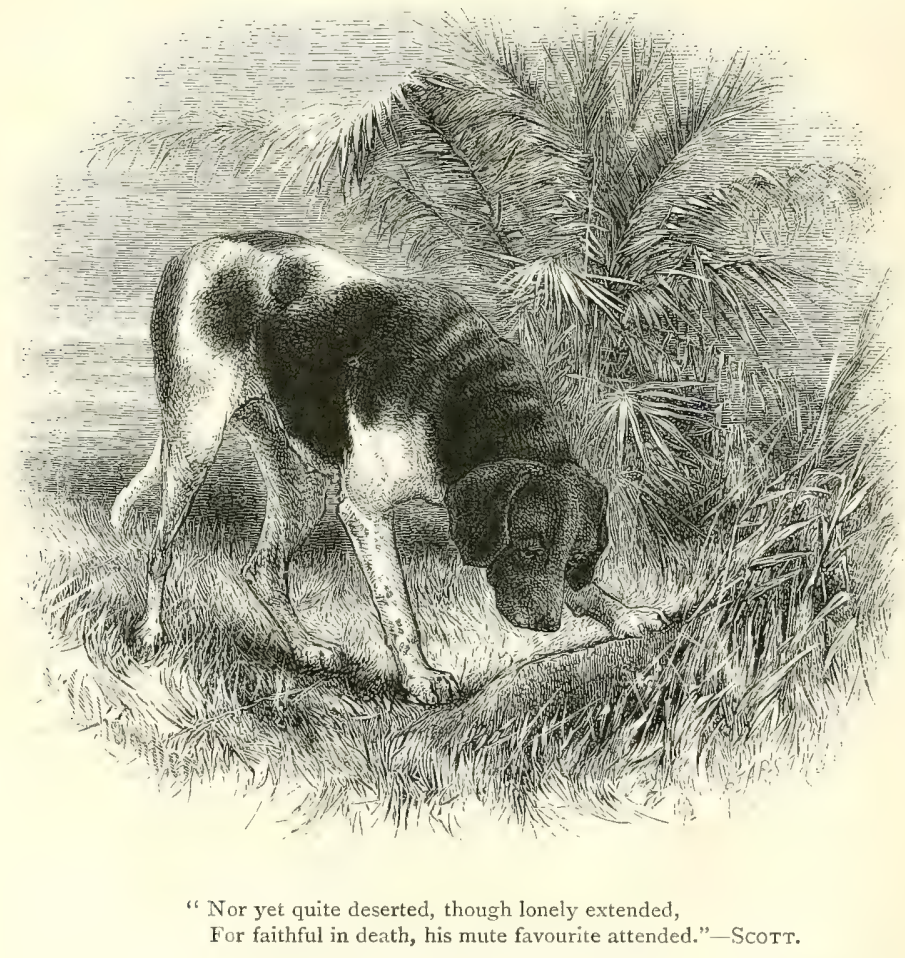

see page $26_{5}$. 


\title{
CONTENTS.
}

\author{
CHAPTER I.
}

Departure from England-St. Helena-Cape Town-Arrival at Durban-Pietermaritzburg-Start up country-Pretoria; its climate and vegetation - The High Veldt-Dutch Boers - The Crocodile River-Bamangivato . . . . Page $\mathrm{I}$

\section{CHAPTER II.}

The journey resumed-Halt on the Seruli-Bushmen on the Gokwe - The Shashe-The Tati Settlement-Adventure with a lion -W. E. Oates returns to the coast; particulars of his journey

\section{CHAPTER III.}

Frank Oates proceeds to the King's Town - Crosses the Ramaqueban-Dutch hunters on the Impakwe-The Inkwesi ; picturesque scenery - John Lee's farm-Manyami's Kraal-The Shashani-Fine country-Kumala River . . . 42

\section{CHAPTER IV.}

Arrival at Gubuleweyo-Interview with the King-Start for the Zambesi - Hope Fountain — Inyati — Difficulty of obtaining bearers - The Zambesi abandoned-Hunting expedition on the Umvungu and Gwailo Rivers-Experiences of a half-casteBirds' nests - The indunas' tree-Hunting - A lunar eclipseReturn to Gubuleweyo-Wild fruit . . . 58

\section{CHAPTER V.}

Stay at Gubuleweyo-New Year's Day_-The Great Dance-Cattle slaughtered - Departure of the King; the royal procession-A dispute referred to him-Lobengula's court . . . 92 


\section{CHAPTER VI.}

Return to Tati-Changed aspect of the country-Constant delays - The Mashonas -At Manyami's again-John Lee's-Letter home-The Inkwesi-Wild fruit-A hornbill's nest-The Impakwe and Ramaqueban Rivers-Graves of Englishmen-White ants_Bushman remains_-The Tati reached Page i 16

\section{CHAPTER VII.}

Hunting trip on the Semokwe-A native musician-Gigantic baobabs -Return to Tati-Journey to Shoshong-The Bamangwato and Matabele nations - Fighting amongst the natives - Start back for Tati-Misadventures and delays - Fresh arrangements

\section{CHAPTER VIII.}

Again at Tati_-Fresh causes of delay-Lions on the MotloutsiThreatened by natives-Forthcoming prospects . . I6 I

\section{CHAPTER IX.}

Fresh start for the Zambesi-The Ramaqueban again-A lion shotSingular building-Wild fruit-First Kraal of the MakalakasStopped by the induna-Return to Tati-To Gubuleweyo and back-Fresh leave obtained-Altered arrangements for the journey

\section{CHAPTER X.}

Third start for the Zambesi-Again stopped by natives-Fresh leave from the King - The journey resumed-Frank Oates's companion obliged to leave him- He goes forward aloneBreakdown of his waggon-Annoyances from the natives-Help from Tati-Return there-Letters home-Future plans $\quad 192$

\section{CHAPTER XI.}

Final start from Tati-Bushman remains-A game-drive-Wild dogs_-The Makalakas again - The Matengwe River-English hunters met with-The Nata River-The PantamatenkaChristmas Day-Start on foot for the Zambesi-The goal at last 


\section{CHAPTER XII.}

Main features of the Falls - The return commenced_Frank Oates attacked by fever-Course of the illness; improvement and relapse-His death-Dr. Bradshaw takes his effects to Bamangwato-His favourite dog-Arrival of W. Oates and Mr. Gilchrist in Natal-Conclusion . . . . Page 253

\section{APPENDIX.}

I. Ethnology, by George Rolleston, M.D., F.R.S., Linacre Professor of Anatomy and Physiology in the University of Oxford 273

II. Ornithology, by R. Bowdler Sharpe, F.L.S., F.Z.S., Senior Assistant, Zoological Department, British Museum . 294

III. Herpetology, by Albert Günther, M.A., Ph.D., M.D., F.R.S. 329

IV. Entomology, by J. O. Westwood, M.A., F.L.S., etc., Hope Professor of Zoology, in the University of Oxford . $33 \mathrm{I}$

V. Botany, by D. Oliver, F.R.S., F.L.S., Professor of Botany in University College, London . . . . . 366

VI. List of Makalaka Words AND Phrases, from one of Mr.

F. Oates's Note-Books, I874-5 . . . . 370

INDEX • . . . . . . . . 37 I 



\section{LIST OF ILLUSTRATIONS.}

PORTRATT OF Mr. Frank OATES . . . Frontispiece

\section{CHROMOLITHOGRAPHS.}

High VELDT, TransvaAl. From a water-colour drawing by

W. E. Oates. . . . . . . To face page 8

Tati Settlement. From a water-colour drawing by W. E.

Oates . . . . . . To face page 30

HUNTERS' CAMP, SEMOKWE RIVER. From a water-colour

drawing by W. E. Oates . . . To face page I 43

Shoshong, BAMANGwATO. From a water-colour drawing

by W. E. Oates . . . . . To face page I 55

DRY BED OF THE INKWESI RIVER. From a water-colour

drawing by W. E. Oates . . . To face page 208

Victoria Falls, Zambesi (Western Extremity). From

a water-colour drawing by Frank Oates . To face page 258

\section{WOODCUTS.}

HEAD OF PALLAH. Drawn by Charles Whymper

Title-page

"FaithFul IN DEATH." Drawn by Charles Whymper . xxxvi

PRETORIA, TRANSVAAL. From a water-colour drawing by

W. E. Oates . . . . . . 7

Boer's Farm, High Veldt, TransvaAl. From a drawing

by W. E. Oates . . . . . . . 9

Game on the High Veldt, Transvaal. From a drawing

by W. E. Oates . . . . To face page 12

Limpopo or CROCODIle River. From a water-colour draw-

ing by W. E. Oates • . • . . . I9

SNUFF-BOXES MADE FROM GOURDS. From a drawing by

W. E. Oates . . . . . . 22 
DOUble-BAnded SAND-Grouse (Pterocles bicinctus). From a drawing by W. E. Oates . . . . .

BOERS' FARMS, Crocodile RIVER. From a water-colour drawing by W. E. Oates

SOUTH AFRICAN WART HOG (Phacochants athiopicus). From a drawing by W. E. Oates . . . . $4 \mathrm{I}$

Manyam. From a sketch by Frank Oates . . . 52

Manyami's Attendant. From a sketch by Frank Oates . 52

FEATHER HEAD-DRESS. From a drawing by W. E. Oates . 56

HeAD-DRESS OF ZEBRA SKIN AND FEATHERs. From a drawing by W. E. Oates . . . . . 57

BiRDS' NEsTs. From a drawing by W. E. Oates • . 77

THE FIRST Elephant. From a sketch by Frank Oates . 84

KNob-BILLED Goose (Sarkidiomis melanonotus). From a drawing by W. E. Oates . . . . . $9 \mathrm{I}$

DANCING-STICK, BOW AND ARROWS, and KNOB-KERRIES. From a drawing by W. E. Oates . . . . 95

OX-HIDE SHIELD. From a drawing by W. E. Oates . . 100

AssegaI-HEADS AND BATtLE-AXE. From a drawing by W.

E. Oates . . . . . . . IO2

Musical Instrument. From a drawing by W. E. Oates. I I 5

Native Hunting-Knives. From a drawing by W. E. Oates I20

AFricAN GREY HoRnBILL (Tockus nasutus). From a drawing by W. E. Oates. . . . . . I32

YELLOW-BILLED HORNBILL (Tockus flavirostris). From a drawing by W. E. Oates. . . . . . I33

Gigantic ANT-Hill. From a water-colour drawing by W.

E. Oates . . . . . . . . . 135

WoOden Vessel. From a drawing by W. E. Oates . . $\quad 138$

Salt PAN, Bamangwato. From a water-colour drawing by W. E. Oates . . . . . . .

Church and Mission Station, Shoshong, Bamangwato. From a water-colour drawing by W. E. Oates . . I49

"Rock" AND "RAIL." Drawn by Charles Whymper . I60

WATtLED STARLING (Dilophus carunculatus). From a drawing by W. E. Oates. . . • . • I7I

Native Building, Shashe River. From a water-colour drawing by Frank Oates . . . . . 176 
KLIPSPRINGER (Oreotragus saltatrix). From a sketch by Frank Oates . . . . . .

Verreaux's Whydah Bird (Viduca Verreauxi), AND THE Shaft-Tailed Whydah Bird (Viduca regia). From a drawing by W. E. Oates . . . To face page 220

BLUE Wildebeest (Catoblepas taurina) From a drawing by W. E. Oates . • . . . . . . 228

CAMP IN THE VELDT. From a water-colour drawing by Frank Oates . . . . . . . 230

AFrican DWARF Goose (Nettapus auritus). From a drawing by W. E. Oates . . . . . 243

Wooden Pillow. From a drawing by W. E. Oates . . 252 Victoria Falls, Zambesi (THe outlet). From a watercolour drawing by Frank Oates . . . 256 "RAIL." From a Photograph . . . . . . 27 I

\section{COLOURED PLATES.}

PLATE.

\section{(APpendix.)}
A. Saxicola Shelleyi. Drawn by J. G. Keulemans
B. BRADYORNis OATESII. To face page 328
C. CORONELLA TRITÆNiA.
D. DRYIOPHIS OATESII.

E-H. New and Remarkable Insects. From drawings by Professor Westwood . . . To face page 364

J. Anthericun OAtesil. From drawings by W. H. Fitch K. Adiantum Oatesil. $\}$ To face page 368

MAPS.

ROUTE FROM SHOSHONG to TATI To face page 23 ROUTE fRom TAti to the Umgwanya River . " 43 Route From Tati to the Victoria Falls . 



\section{CHAPTER I.}

Departure from England-St. Helena-Cape Town-Arrival at Durban-Pietermaritzburg-Start up country-Pretoria ; its Climate and Vegetation-The High Veldt-Dutch Boers-The Crocodile River-Bamangwato.

ON the 5th of March 1873 , Frank Oates and his brother, W. E. Oates, sailed from Southampton for Natal on board the Union Company's steamship "African." It was the intention of the former, as already explained in the introduction to this volume, to make a journey to the Zambesi, and, if possible, push on thence to some of the unexplored country northwards. His brother contemplated a shorter trip in the same direction, which was to occupy about a year.

The only land sighted, after leaving England and passing the Needles, were the islands of Porto Santo, Madeira, and Teneriffe, and one of the Canaries, besides Cape Verd on the African coast, until on March 25th the vessel reached St. Helena, where she touched and remained a few hours. The fruit in the island at this time (including figs, bananas, and very fine peaches) was in perfection, whilst scarlet geraniums, fuchsias, and petunias-all 
growing wild-were in full bloom. Head winds, after leaving St. Helena, considerably delayed the vessel's progress, and Cape Town was only reached on the $3 \mathrm{~d}$ of April. Here passengers for Natal were transferred from the "African" to a coasting steamer, the "Zulu," which sailed five days later, and reached Durban on the i 9 th of the month. The view here across the bay was pretty enough, with ships lying at anchor inside and out, and the lighthouse, a marked feature on the green headland opposite. The brothers left Durban for Pietermaritzburg to prepare for their expedition into the interior soon after landing, the journey, in a six-horse waggon, occupying about twelve hours. The country passed through was for the most part hilly, with very little timber. Here and there some fields of Indian corn ("mealies") were seen, and also some pretty bits of mountain scenery with abrupt crags, but the land is chiefly pasture, and the general aspect of the country not unlike that of the American prairie. A number of ox-waggons were met and passed upon the road. Near Maritzburg a few trees were seen; the approach is pretty, and the place has an English air about it.

At Maritzburg the brothers remained about three weeks, making preparations for their journey northwards. Their plan was to go by the usual trade route through the Transvaal, and then on to Shoshong, the town of Sekomi, chief of the Bamangwato, from here either taking the direct route towards the Zambesi by the Tati River, or making a circuit in a north-westerly direction by way of Lake Ngami. 
They accordingly each purchased a waggon and the requisite number of oxen for the journey, and engaged some native attendants. Before leaving Maritzburg, W. E. Oates wrote home as follows :-

May I 4 th, 1873 .

"We only stayed a few days in Durban, and came on here, as this is a much better place for getting an outfit for the interior. It is 54 miles from Durban, and not a particularly interesting place. There are hills all round, without much vegetation, and covered with long coarse grass. It is much cooler than it is at Durban, as it is 2000 feet above the level of the sea. It is winter now, and rather cool at night, but still very hot during the day. We arrived here three weeks ago to-morrow, and tomorrow we intend making a start up country. We have each got a waggon and fourteen oxen, besides five ponies between us, and three Kafirs to each waggon. We are going with a man called Gray, who is going up to Lake Ngami to trade. He is quite a young fellow, and has only been out here four years. He knows the country through which we are going, and says it is extremely healthy, and the native tribes all friendly. He has taken five waggons, and left on the IIth instant, but as his waggons are heavily laden, we expect to overtake him in a week. ${ }^{1}$

"Buckley and Gilchrist started with their waggon

${ }^{1}$ Mr. Gray died of fever at the above Lake a few months afterwards. 
yesterday, but Frank is not ready, he has so many things to get. ${ }^{1}$

"We have got some blankets, beads, knives, etc., as there is no good taking money, and everything you want you must pay for in that way. The waggons are very comfortable and hold a great deal, including a mattress which lies on the top of the boxes. We are taking coffee, sugar, tea, flour, oatmeal, pickles, some brandy, and several other things for our own use. The Kafirs are supposed to get nothing but meal, which they boil in a large pot and eat with the help of pieces of stick. They occasionally get a little coffee also. . . . There is very little here in the way of fruit and vegetables. The only fruit now is oranges, though there are peaches and apricots in the season. Altogether, there seems very little pains taken to cultivate the land, as the niggers are too lazy to work, and white labour is expensive."

On May i 5 th the waggons of the two brothers started, with W. E. Oates's servant, Thomas Bell, who had accompanied him from England, and made their first halt about four miles from Maritzburg.

Frank Oates, still at Maritzburg, writes thence the following day, May i6th :-

"Our waggons left yesterday, and we went with

1 Mr. T. E. Buckley, the gentleman here alluded to, had come out from England in the same ship as Frank Oates and his brother, on a shooting expedition, and had been joined at Maritzburg by Mr. Gilchrist, of Ospisdale, Sutherlandshire, who had already been out upwards of two years, travelling and hunting in South Africa. These gentlemen both accompanied the brothers as far north as the Tati River, whence Frank Oates went on alone towards the Zambesi. 
them on horseback, Willie remaining to sleep with them, and I returning here for the night. W. has ridden in here this morning, and we shall both go on again to the waggons, which travel very slowly. I think we have been fortunate in getting good oxen for them. We have also a young horse, a very pretty bay, which had only begun to be broken a fortnight when we got him, but which is four years old, and likely to turn out very well. We have also another bay horse, which $W$. rides. These two are about I $4 \frac{1}{2}$ hands high. We have three smallish poniesone a very pretty brown one, and two little rough black ones. Of course we are taking dogs also. We bought four pointers, and have likewise had a rough dog given us, and another promised, and shall try to pick up as many as we can as we go along, for they are invaluable to have about the camp. . . We go with Gray as far as Bamangwato, and shall then either go on with him to Lake Ngami, or visit the Victoria Falls direct, or we may go first to the Lake, and make little explorations to the north and north-west, and in the May following go on to the Victoria Falls, and thence return here.

Gray is on excellent terms with the King Lecheletebe, a good native, who would assist us in every way in his power. If we go to the Falls we pass through the country of Lobengula, the son of Mosilikatze, whose name you will see in maps. Lobengula is reported to be a 'decent chap' by a friend of ours, a doctor here, from Dewsbury, whose Christian name is Oates. We go by Mooi River, 
Colenso, Ladysmith, Newcastle, Pretoria, Crocodile River, and Bamangwato. ... This country is not to be compared with America. The most of it about here is hilly, the hills in places becoming mountains, and all covered with coarse dry grass, and scarcely a stick of timber. There is nothing to compare with the lovely tropical scenery of Central America, or the magnificent mountains, prairies, lakes, and rivers of the United States. I never expect to admire any country so much as I do the western world. Perhaps one reason that the North American Indians were for savages a superior race was their fine scenery."

Again, from the Umgeni River, a few miles upon the journey, he writes, May i 7 th :-

"We are now fairly on our way. Last night was my first night in the waggon, and W.'s second. We are 13 miles on our way. Our waggons are most comfortable. We have a wooden framework in each waggon, surmounted by a substantial mattress and lots of blankets. We have tin wash-hand basins, cups, and plates, and fare luxuriously. Bell is now cooking some chops. I am reminded of some very pleasant days in the wilds of America."

Ladysmith was reached on the 24th of May and Newcastle on the 3 Ist, a halt of two or three days being made at each place. On the $23 \mathrm{~d}$ of June the party arrived at Pretoria, and Frank Oates writes from that place, June 27 th :-

"We have now been 'trekking' (i.e. travelling in waggons) for six weeks from yesterday. We have, 
however, gone slowly, and have been delayed once or twice. We stayed a few days at Ladysmith and Newcastle, two towns, as they are called here (we should call them small villages); we then got into the Transvaal Republic, and had a very bad tract of country to cross, the high veldt. This country is very high, about 5000 feet above the sea, and as it was dead of winter when we crossed it the cold at

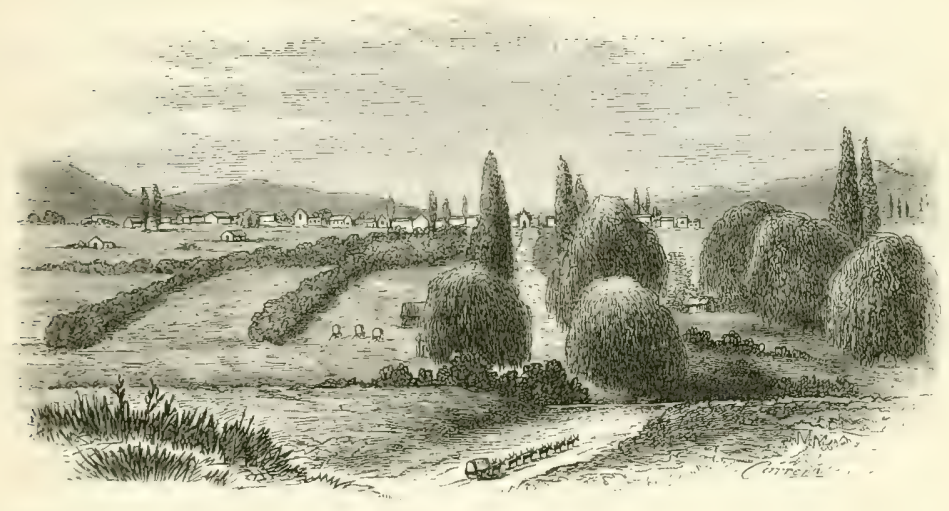

PRETORIA, TRANSVAAL.

night was rather severe. One of the coldest nights I think we had, was that of the 8 th of June, when the thermometer showed 8 degrees of frost Fahrenheit. This may not seem very much, but the days being hot you feel the cold a good deal, and are glad of a good lot of blankets. In this respect I had taken care that we should be all right. The morning after the night I speak of my hand was numb with the cold, and I clropped and smashed my only thermometer.' My aneroid barometer, which tells me

1 This instrument was afterwards kindly replaced by Mr. Lys of Pretoria. 
the height above the sea really very accurately as far as I can judge, is still all right, but my sextant suffered so much on board the 'Zulu' that I have some difficulty, being a novice, in making use of it.

"In crossing the high veldt the cattle suffer not only from the cold nights but the poverty of the grass, which will get worse and worse till the rainy season, which will be about September. ${ }^{1}$ The disease called 'red water,' which is so bad on the coast, and which has caused so many oxen to die and the price to rise so much, does not seem to extend beyond Natal. Out of twenty-eight oxen we lost only three, which is considered a very small percentage. A few of our oxen got into low condition, and we have got seven new ones coming along the road. We shall try to leave the poor ones at some farm, or exchange them for fat ones.

"We arrived here (at Pretoria) on the morning of the $23 \mathrm{~d}$ of June. It is very different from what it was in crossing the Drakensberg. There is scarcely ever ice here, and now (the coldest season) the temperature is perfection-neither hot during the day nor cold at night. There are orange-trees with fruit on them in the gardens, and high hedges of monthly roses in flower ; there are also a few large trees (blue gums), something like poplars in mode of growth, but with dark foliage. These are planted

1 The accompanying illustration of the high veldt is from a sketch taken early in December, when the grass has grown after the summer rains, the country then presenting a very different appearance from its dried and parched aspect in winter. 


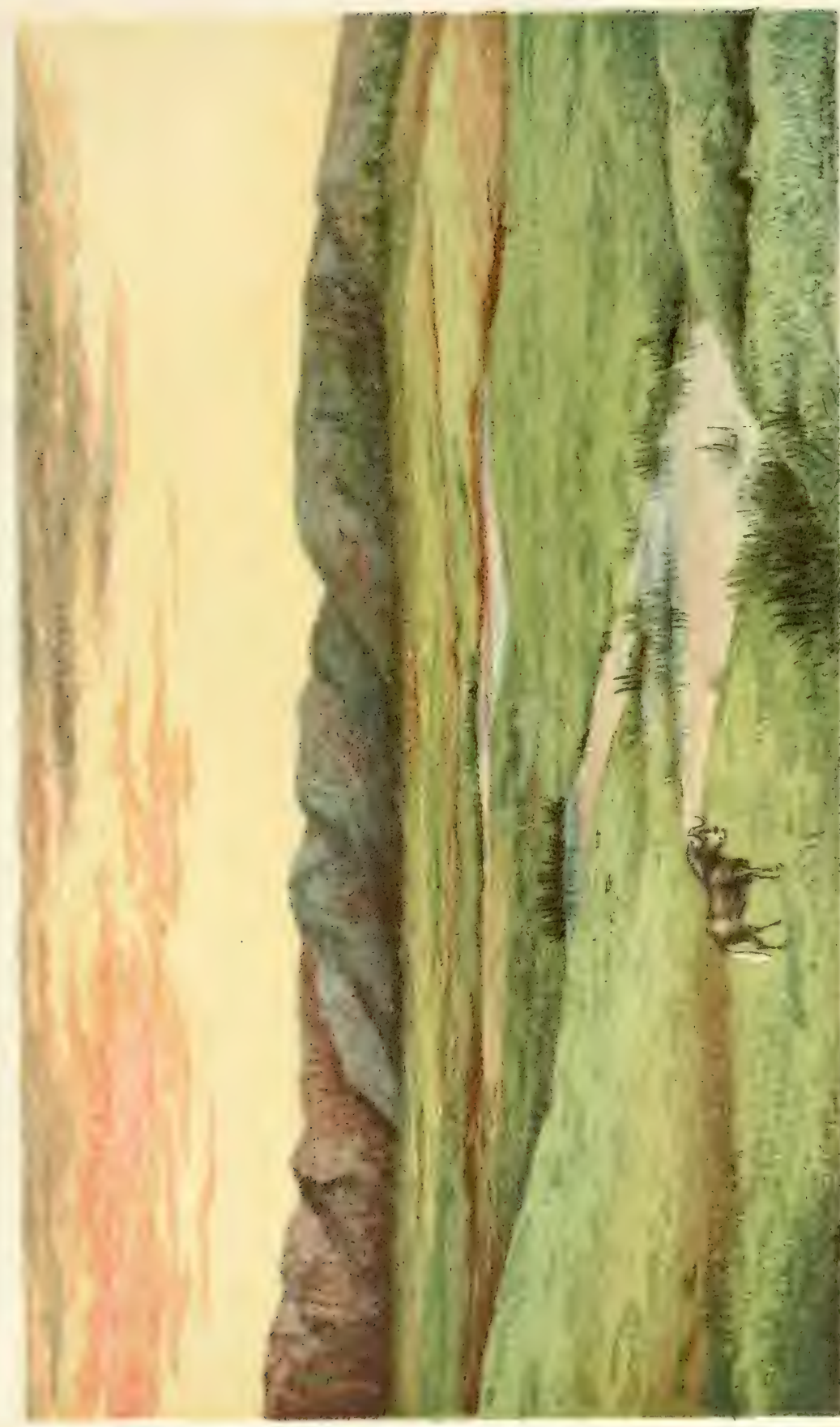



here, for the country does not seem to bear much timber naturally. There is plenty of scrub on the slopes of the high land as you descend, and I believe there is a large extent of bush country round here, and when we get into the regular bush, plenty of timber, I imagine, such as it is; but this part of

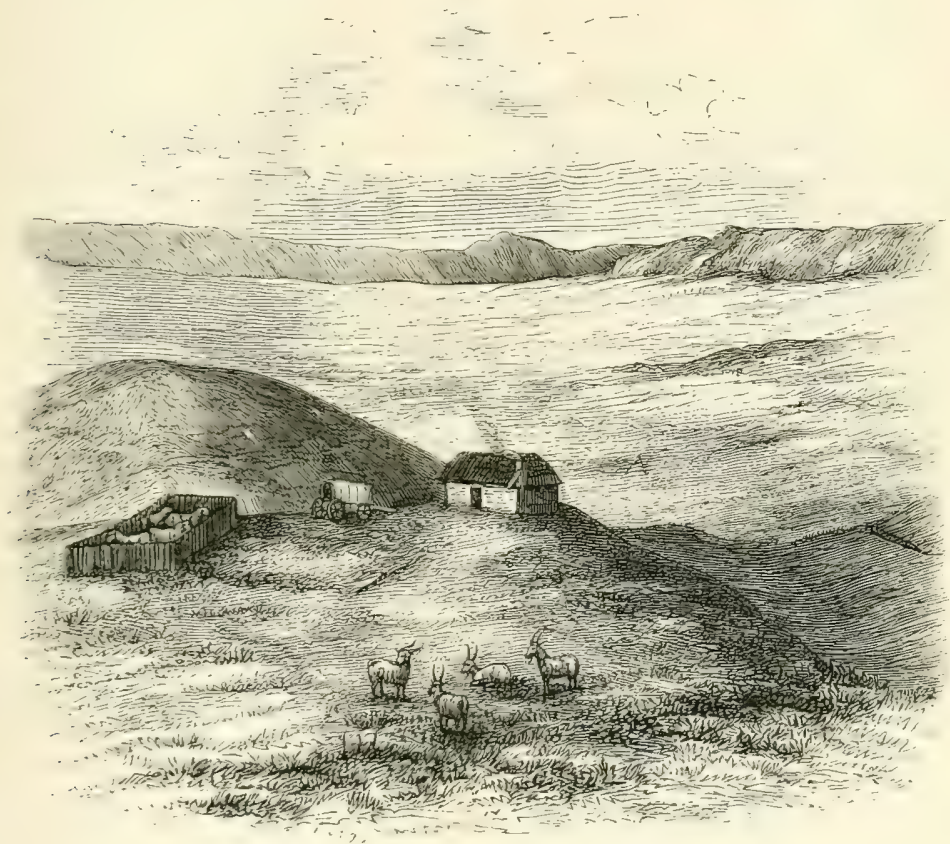

BOER'S FARM, HIGH VELDT, TRANSVAAL.

Africa is no timber country. On the high veldt there is nothing but parched grass, in many places burnt for a whole day's trek, as fires are of everyday occurrence. On one occasion we had $£ 5$ to pay a man in front of whose house our men had set fire to the veldt whilst lighting our camp fire. The 
farms are few and far between in that desolate region; they grow Indian corn and a few peaches, and have a few cattle and sheep. The Boers are rather good sort of people, and though trying to get every penny they can in a bargain, honest, I should say, on the whole, and hospitable. I cannot speak any Dutch yet, so communication is limited, having to be carried on through an interpreter.

"Here in Pretoria are a great many English. The English keep stores; the Dutch Boers stick to farming. The latter come in with their waggons of grain, wood, and other produce, which is sold by auction at 8 A.M. in the market-place. 'Mealies' (unground Indian corn) fetch fifteen shillings a muid, which is about $200 \mathrm{lbs}$. This the Englishmen buy, get ground for two-and-sixpence a muid, and ask twenty-two and sixpence, or even twenty-five shillings for, and make a good thing of the numbers of people passing through here to the Marabastadt and Leydenburg gold-fields. The latter fields were newly discovered and much talked about when we were at Durban and Pietermaritzburg, but do not seem as good as the Marabastadt. No one thinks much of the Tati or Baines's gold-fields in Mosilikatze's country.

"I fear the English who are here are a bad lot, with few exceptions. One man who cheated me I asked if he had a conscience. He replied that no one here had them.

"Though here and there you see a garden with a few trees in it, and, as I mentioned, orange-trees 
and rose-bushes, do not imagine a scene of the least beauty. The town itself, the seat of the government, does not contain a single good building. It is like some little frontier town in America. There is not even a book-shop in it. The country immediately around is flat and devoid of trees, though in the distance are some ranges of hills. The day we reached Pretoria, the mail, a fortnightly one, arrived from Pietermaritzburg with a paper containing English news, very bare items though, up to May I $5^{\text {th. It }}$ seems dreadful that we were nearly six weeks in coming here, and the mail came in six days. The mail brings passengers also, but they are allowed hardly any baggage. It goes out again today to Pietermaritzburg, so I am writing this letter by the light of my lantern as I recline in my waggon. I think it is now about 6 A.M., but the sun does not rise till after 7 .

"Gray, the trader, left us at Newcastle, and had left here before we arrived for Bamangwato, en route for Lake Ngami, where our programme was to accompany him. ${ }^{1}$ We are not certain whether we shall follow him or alter our plans. I will write again, letting you know what we have decided. If I leave a second letter here, it will go to Pietermaritzburg a fortnight hence, so you will get it in England soon after you get this."

1 Strictly speaking, Bamangwato is the name applied to the district north of the Transvaal inhabited by that branch of the Basuto race, and Shoshong the name of the king's town or residence; but the latter also is more frequently spoken of, in common parlance, as Bamangwato or Mungwato. 
Four days later W. E. Oates writes, also from Pretoria, "We have now been here a week, and are going to start off again to-day for Bamangwato. Buckley and his friend Gilchrist came up on Saturday, and we have decided to keep together. Gray, the trader we talked about, left here for Bamangwato about a fortnight since. . . . I fear we are now too late to get to the Victoria Falls, as the country is not healthy after September. We have been rather more than six weeks in getting from Maritzburg here, and a more wretched country can hardly be conceived-not a tree to be seen, and half the country burnt black, as, if the grass is set on fire, it burns for weeks. The days are intensely hot (not a drop of rain since we left Maritzburg); the nights very cold, with sharp frosts. Countless herds of antelopes are to be seen every day; wildebeest (gnu), blesbok, springbok, and many others called by Dutch names. There are also hyænas, jackals, crows, and vultures.

"The Dutch Boers have farms at intervals. They seem miserably poor; no milk, eggs, meat. I don't know how they live. It is much warmer here, and after to-morrow we get into what is called the bush veldt, where there are lots of trees, and then it begins to get hot. The country we have passed over is from 4000 to 6000 feet above the level of the sea, and on the high veldt there is scarcely any water; the road in many places very bad and strewn with the bones and skeletons of oxen, wildebeest, and other animals, which have been picked clean by the vultures. How people can pass their lives in 


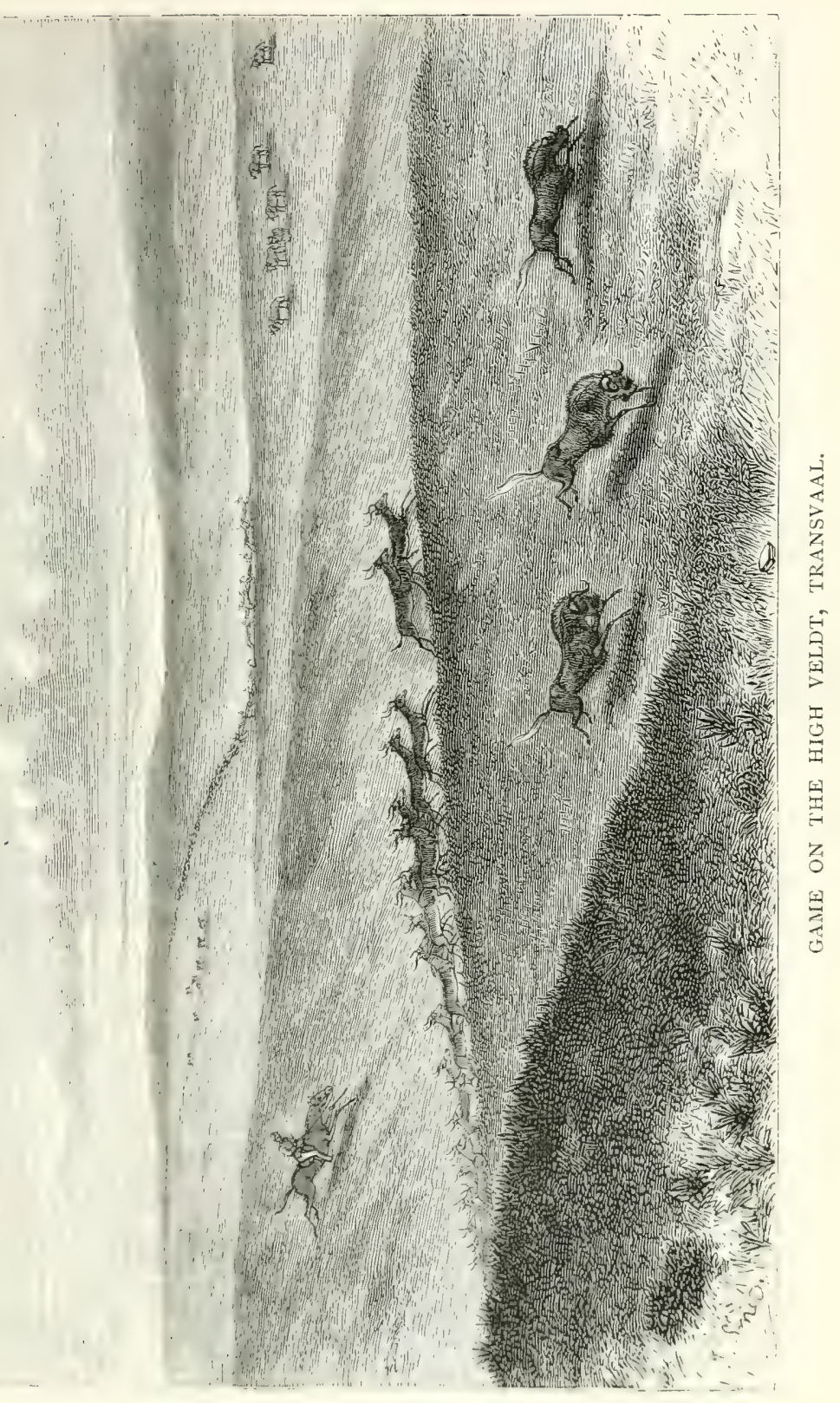



such dreary solitudes it is difficult to conceive. . . . We, however, are very comfortable and well. We have large supplies with us, more than necessary, I think; but we can sell at Bamangwato what we do not want for nearly double what we gave for it at Maritzburg. This is the last place where there is a regular mail, though traders go from Bamangwato, and will take letters. The waggons make snug dwelling-houses. The mattress goes at the top of the things, and you have the canvas all round. You get in at the front, and let a canvas curtain down. There are canvas pockets at the sides, where you put what you want handy.

"We have been exceedingly lucky with our oxen, as many people have lost nearly all they had from the epidemic which is raging in Natal. One man lost his whole span of eighteen. We have only lost three; partly, I think, because we haven't hurried them. They have got poor, owing to the wretched grass on the high flats. They say, however, they fatten immediately they get into the bush veldt.

"Pretoria is a miserable little place, though the capital of the Transvaal. The store-keepers are English, or Africanders (as the native whites are called). . . . The niggers are idle and insolent. It is said the only way to treat them is to thrash them well, and though we have never resorted to this, I have often felt inclined to do so. We have five with us-three Hottentots and two Kafirs. The Kafirs who are total savages are much better to get on with. ... It seems odd that I have such a little 
to tell you about after so long an absence, but one day here is almost exactly like another, and the country hitherto the same day by day."

The travellers left Pretoria for Bamangwato on the 3 oth of June, and after three days' trekking to the north-west, crossed the Crocodile River, keeping for some time afterwards at no great distance from its banks. "On leaving the waggon, to shoot," writes Frank Oates on the $5^{\text {th }}$ of July, "I rode up to the river, which is far the most beautiful thing I have yet seen in South Africa. Trees of various kinds - some resembling willows and oaks, the former in leaf, the latter bare-fringed the river's banks, which are steep. Long grass and bush grew in the country round, and where we outspanned at breakfast there was some very fine grass, tall and drooping, with a tassel. Here too," he concludes, "we got amongst plenty of birds, and to-day is the first that I have felt the country cease to be disappointing."

The following day the road again continued in close proximity to the river. The country was level and covered with trees like those in a fine park, none of them, however, very large. The Hex and Eland's Rivers, tributaries to the Crocodile, were crossed near together the day after, and on the I 2 th a halt of twenty-four hours was made at Holfontein, a good watering-place upon the road, where many birds were met with, including parrots, doves, and hoopoes. Two days later the Crocodile, which had now for some time been lost sight of, again came in 
view - a grand stream - and a fine blue distant mountain range stretched to the right and right rear. A halt of two or three days was made by the river's bank, to give the oxen time to rest. Here buffalo, blue wildebeest, springbok, and other game was found, including wild pigs and pallah; and a little further north eland was met with, and many of the lesser antelopes. About this time the dews, which had hitherto been heavy, ceased altogether ; possibly, in part, owing to the change of locality. The road now for some time again continued near the left bank of the Crocodile, until the 24 th, when, soon after crossing the Notuani, another of its tributaries, the course of the river was finally abandoned, and on the 27 th the blue tops of the Bamangwato "kopjes" (low hills) came in sight. The place itself was reached two days later.

Here a short halt was again made for a few days, to engage fresh Kafirs and prepare for the continuation of the journey northwards. Owing to the want of water in the country between here and Lake Ngami, the part of the proposed expedition which included a visit to the lake had to be abandoned, Frank Oates resolving to proceed, if possible, direct to the Zambesi, the rest of the party accompanying him north as far as the Tati river in search of sport, to return thence by the same route as they had come. Mr. Gray, the trader, had arrived at Bamangwato a few days earlier, and decided to wait there till the rains should come before proceeding on his journey to the lake. The following 
extracts from letters, sent home about this time by Frank Oates and his brother from Bamangwato, give some further details of the journey up to this point, and of the future plans and arrangements of the party. W. E. Oates writes as follows on July 3 oth :-

"We got here yesterday afternoon all right, though for the last four days there has been scarcely any water on the road. When we left the Crocodile River (on the $25^{\text {th }}$ ) we filled our water-casks, and the next night got to some brackish water, which the oxen drank. We trekked all the following day and half through the night, when we reached some water-pits made by the Kafirs, from which the water had to be ladled out in buckets for the oxen. We had then about 25 miles to go without water to get here, which took us two days, all through heavy sand, through which the oxen go about two miles an hour. This is a wretched place; an immense number of Kafir huts, and a few stores belonging to white men. The name of the place is Shoshong, and the king, Sekomi, lives here. He is a hideous old nigger, and this morning came down to our waggons, to beg coffee and sugar. He had about a dozen dirty old wretches with him, who carried jackals' tails, and attend him whenever he goes in state. He jumped up on Frank's waggon, and refused to depart until he had had some coffee given him, which Frank gave him to get rid of him. I offered him a bright green scarf I had, but after examining it carefully he returned it to me. . . . 
"This is a most uninteresting country-all thorns and sand. The whole way from Pretoria here it is thick bush, composed mostly of stunted thorn trees, whose thorns are white and about four inches long. We stayed four days on the Crocodile River, as our oxen wanted rest. The lions were roaring round the waggons at night, in hopes of getting at the oxen. We have the latter carefully tied up to the waggons at night, and two or three immense fires lighted, to keep them off.

"It is impossible, we find, to get to Lake Ngami now, as there are a hundred miles to go through heavy sand without water to get there. Frank still thinks of going to the Victoria Falls, through Mosilikatze's country, by way of the Tati River, and I intend to go as far as the Tati. . . . Every morning here lots of women go out to collect locusts, which swarm a short distance off, and are the only food the natives get now, as their crop of corn has failed, and they are half starving. They have a few little goats, but there is hardly any grass, and only one very small stream of water about two miles off."

Frank Oates also writes the same day as follows:- -

"You have, I hope, got our letters written from Pretoria, the capital of the Transvaal. Since then we have not come more than 250 miles, if as much, and have been about a month in doing it. Buckley and Gilchrist have accompanied us, making, with our waggons, three waggons in all, and I think we shall probably go on together for some time at any rate. 
The present idea is for us all to go together to the Tati, a river marked in the recent maps, where gold is being found. From here I may go on to Mosilikatze's Town, the residence of the King of the Matabele, in the north-east, and thence be able to get on to the Zambesi and Victoria Falls, though I hardly hope it now, on account of the lateness of the season.

"The country we have passed through so far may be divided into two distinct regions - the high veldt and the bush veldt. The former I described in my last letter. At Pretoria we entered the second, and are still in it. The former is high land, covered with grass, and with scarcely a bush on it. The country since then has been covered with bush, and contains many fine rivers. The Crocodile (or Limpopo) is a really beautiful river, its banks covered with fine trees. The 'bush,' as it is called, consists for the most part of smallish trees, most of which are thorny, with park-like glades here and there. In other places there is a great deal of thorny bush, through which you can hardly force your way. The great want here is water, the smaller streams being now dry, and in travelling it is often necessary to go many miles before reaching water. Still, the road is so well known that one can calculate almost to a certainty where and when to get water, and make a push when necessary, taking one's time both before and after it. Water for our own use can be carried easily in our casks, and it is for the animals we have to travel 
quickly on such occasions. Meat is rather scarce, but we generally manage to get enough, and, with bread and porridge, coffee and sugar, make out very well. We shall be glad to get away from here, as

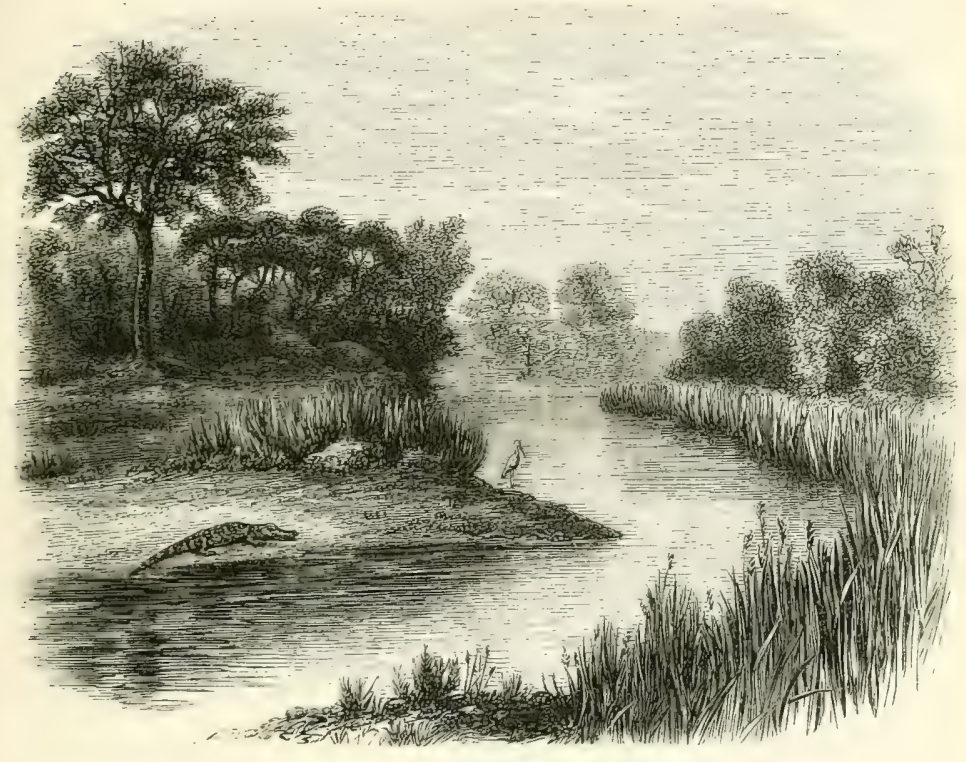

LIMPOPO OR CROCODILE RIVER.

it is difficult to get anything in the shape of food except what we have with us, and what Gray gives us. There has been a scarcity of corn this year, and the people are very hard pressed, living principally on locusts, which are brought in every day in immense sacks carried on people's heads. We buy water of the women, which has to be brought some distance.

"This is a large town of Kafir huts. The people are of the Basuto branch. The king, Sekomi, 
visited me this morning, and seating himself on the front-box of my waggon, commenced a conversation, which one of our drivers interpreted, the end of which was that he wanted some coffee and sugar. I gave him five pounds of gunpowder, worth fifteen shillings. He accepted it, and then returned it, asking for coffee instead. I then gave him two or three pounds of coffee, worth perhaps five shillings, which afforded him great satisfaction, and after thanking me he walked off in a stately manner, followed by his train, his right-hand man carrying the coffee in his robe of skin. During the interview the latter produced a huge sort of bodkin from a sheath, and extracted a thorn from Sekomi's finger with the utmost gravity. There are a good many white men living here to trade, and also a missionary, on whom I intend to call.

"I cannot more fully describe the country at present, or our journey. It has not the charm for me that the western world has, but I think further north there must be far more attractive scenery than anything we have yet encountered. The days are hot, though there is often a refreshing breeze. The thermometer is about $82^{\circ}$ in the shade during the hottest part of the day, and one hot day in the sun it rose to $100^{\circ}$. The nights are cold, and we have yet had no insect pests, but our animals are infested by ticks. . . . It is very annoying never to be able to get letters from home. Mr. Hathorn, of the Standard Bank at Pietermaritzburg, has promised to forward all letters sent to his care 
for us, and to assist us in every way he can. We found him most kind and obliging in every way in Pietermaritzburg:"

On August 4th, the writer, still at Bamangwato, adds:- "Willie, Buckley, and Gilchrist have gone on. They started yesterday, and I intend to start to-morrow, and shall overtake them. I believe the prospects of the journey are very satisfactory. I have had a long talk to-day with Mr. Mackenzie, one of the missionaries here. $\mathrm{He}$ is a very nice fellow, and knows all the country well, and has written out for me a long list of the various wateringplaces on the road to the Tati and on to Mosilikatze's. He is the author of a book called Ten Years North of the Orange River, and is now instructing some natives for missionary work-some six or eight, I think, living in a sort of college. The other missionary is a Mr. Hepburn, who gave a little service in his house yesterday. I am certain they will both do anything they can to help us."

Three years later, one of these missionaries, the Rev. John Mackenzie, left Shoshong for Kuruman, where suitable buildings had been erected by the London Missionary Society for the embryo theological institution he was at the time of the events now narrated conducting at the former place. His loss must have been felt by many, both travellers and others, to whom he was ever ready to lend a helping hand. On the present occasion, Frank Oates felt strongly sensible of what he owed him 
for his friendly aid and counsel, and some time later, after the traveller's decease in 1875 , it was again this gentleman's good services and sympathetic words that first softened the sorrow of his friends at home when they received the unexpected intelligence of his death in the interior.

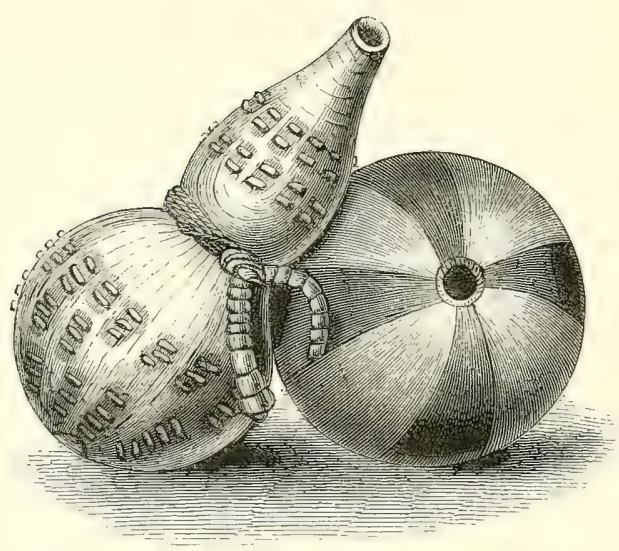

SNUFF-BOXES MADE FROM GOURDS. 


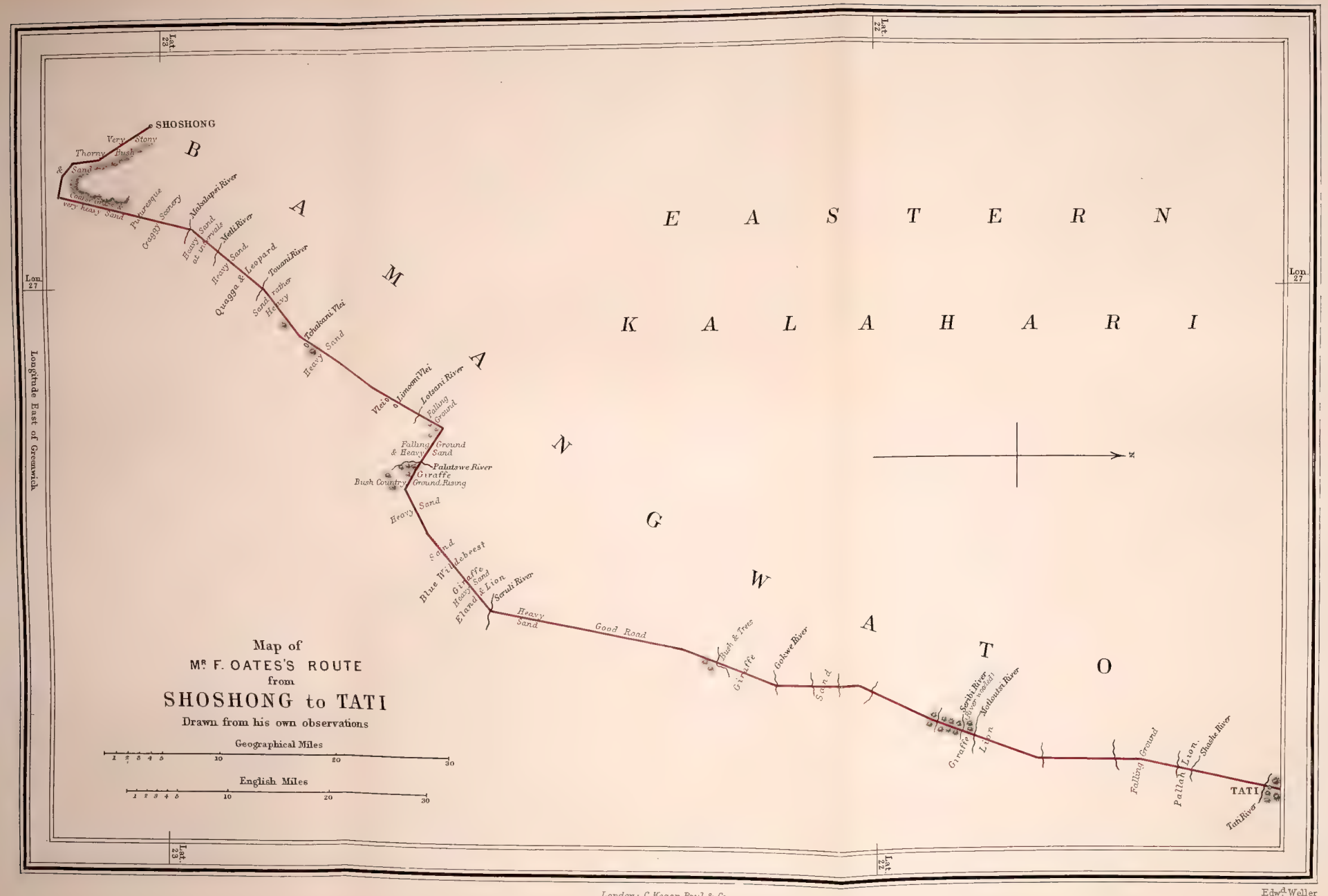

London; C. Hegan Paul \& Co. 



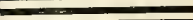

A

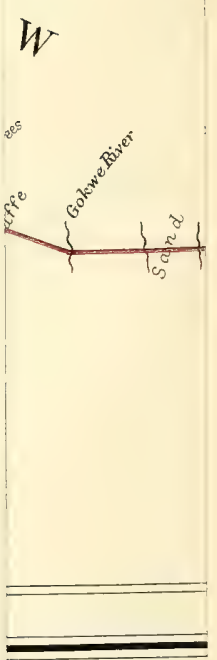




\section{CHAPTER II.}

The journey resumed--Halt on the Seruli-Bushmen on the GokweThe Shashe-The Tati settlement-Adventure with a lion-W.

E. Oates returns to the coast; particulars of his journey.

Frank Oates left Bamangwato on the 7 th of August, and the following day joined his brother, who had been waiting for him a little way out of the town. In the evening the Makalapsi River was reached, where were a number of Dutchmen just returned from hunting on the Motloutsi, to the north of the Limpopo. They had got a number of rhinoceros, but no elephant. Continuing their journey the following morning, and subsequently crossing the Touani and Lotsani Rivers, the brothers reached the Palatswe River on the I2th. "The scenery here," writes Frank Oates, " is very pretty. A row of low kopjes on the right, with large stones piled on one another, forms a natural terrace to the eastward, from which you look over a sea of green bush, with a few kopjes standing out from the midst." Here goat's milk was brought in a large tortoiseshell from a kraal somewhere near, and exchanged for a small piece of tobacco. Most of the natives carried guns, and game was scarce and wild. 
Starting again the ensuing evening, and continuing their journey during the following day, they arrived early on the morning of the $\mathrm{I}_{5}$ th at the Seruli River, where a water-pit, sunk in the dry sandy bed of the river, was found for watering the oxen. Here were a party of natives, living in the bush, hunting. They were said to be Bushmen. One of their number, who came to the waggon the following day, looked very striking-a leopard-skin thrown gracefully over his well-formed person, and a necklace of large lavender beads round his neck. Four days were spent by the brothers at the Seruli, whence they proceeded on their journey on the evening of the Igth, making a halt about midnight. From this point Frank Oates's Journal takes up the story for the next few days-till their arrival at the Shashe on the 24th-as follows :-

"August 20th.- Have coffee, and hear the monotonous call of the night-hawk, as we rest and let the cattle feed. W. called my attention yesterday, at close of day, to another (a clucking) note, which he says proceeds from the hornbill. We have been living, whilst at the Seruli, on ostrich eggs. Fried with a little meal is the best way we have had them, or made into a pudding with maizena. They are strong, unless nicely cooked. Started again at 2.30 A.M., and trekked for three hours. Horned moon and bright morning star in the east; horizon dark against the sky, already glowing with the pale orange of approaching morning, fading into the dark violet of the upper firmament. Notes of birds are heard. 
What a loss not to be able to appreciate beautiful things, as must be the case with our men, and how much less they affect me even than they used to do, when I seemed to find the world more full of hope and high ends to be attained than it looks now.

"Inspanned again about 8, and crossed the dry bed of a large stream, which continued to keep near the road on the right. It was full of sand, with plenty of bush and trees about it. Francolins abundant, also hornbills, and many other birds in numbers, so I think there must be water somewhere in it, or very near. Reached the Gokwe about noon, having gone nine miles. The trek was a slow one, and part of it being when the sun was getting high, the oxen were tired. Found good francolin shooting where we passed the last spur of the range along the river, and where we outspanned; sandgrouse coming to drink in the evening at the latter place. There was fresh giraffe spoor where we crossed the 'spruit' ${ }^{1}$ by the kopjes, and further on fresh lion spoor. .. The people at the Gokwe are a sort of outcast race under the Basutos, called Bushmen. Men, women, and children came to the waggon. They have fine pack-oxen. They live in the bush, Hendrik says, having a sort of temporary abode near the bed of the river to the left of the road. They were ornamented with beads, and had on necklaces of blue cut ones and skins. They always ask for tobacco, making signs 
that they want snuff. They are hunting here. They brought ostrich eggs, exchanging them for a cheap knife, mirror, or handkerchief. I had great difficulty in buying an ostrich feather for about three or four pounds of lead. They wanted a whole bar, and on no other terms would bring more feathers.

"August 2.1st.-Calm day, after a very windy night. ... Started at 7.I5 P.M., and went about seven miles, crossing two spruits, and outspanned for the night about I I.

"August 22d.-Cool morning. Trekked from 6.30 to IO A.M., the road twisting a good deal; say seven miles. . . . Stopped to rest, and inspanned again about 4 P.M., the road now winding through stony crags, and numbers of kopjes appearing to our right, to our left, and in front. Going a fair pace. Crossed the dry bed of the Seribi, apparently a very large river. Deep descent, sand very heavy, banks of river picturesquely wooded. We had seen lots of fresh lion spoor on the road before crossing the Seribi, and on this side I see more. Delicious fragrance from a sort of sallow-like blossom. Later, approaching the Motloutsi, we saw large numbers of sand-grouse flying both towards us and the opposite way - to and from the water. Finished trekking about 7, but did not outspan till much later, as when we entered the broad bed of the Motloutsi we stuck in the deep sand, and made many fruitless efforts to get out before outspanning. There was a little pool of water at which the oxen 
drank, and which the grouse resorted to. The sand around it was covered with feathers of birds.

"Sunset scene very lovely. In the foreground, brown bushes. Two little violet kopjes appear against the sky, behind one of which the sun has set. A lovely rose hue, deepest around the position of the sun, is on the horizon; this fades into violet, and this again into a pale greenish blue. Some very

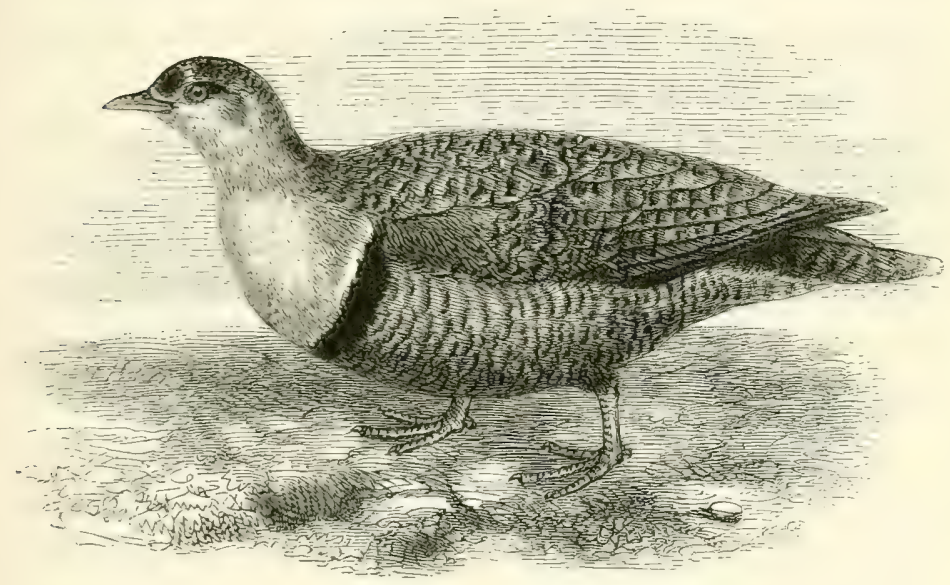

DOUBle-BANDED SAND-Grouse.-Pterocles bicinctus.

small, clearly defined, deep violet clouds, edged with gold, stand out from the sky.

"August 23d.-Before daybreak the little sandgrouse were flying round, and a few settled to drink. I did not disturb them. The Motloutsi is a large river, with a very sandy bed, and here and there large rocks, and a twisting course. Hendrik says all these sandy rivers become dry or nearly so in winter. Both yellow and cream-coloured acacia 
blossoms very beautiful and sweet. Pleasant breeze where W.'s waggon is outspanned, mine being hot in the river-bed. Some people came here, but had neither eggs nor feathers for sale. As usual they carry muskets. It is a wonder they find anything to shoot, as they seem to be spread all over the country. At the Gokwe we were told that the Bamangwato hunters were hunting about in that district, but could get nothing. At this time of year the people seem to come out to hunt from all the kraals, leaving only those unfit for that work at home. A giraffe was killed near here by some Bushmen, who gave us meat in exchange for tobacco. When out this morning I saw some kind of melon, which at first looked like ostrich-eggs, growing by the river-bed-the kind, I think, which the oxen eat in times of drought.

"August 24th.-Trekked for three hours, then rested, and started again at II A.M. . . . Reached the Shashe about two, and outspanned. We had come extremely slow; sun hot, sand heavy, road bad, bullocks tired. Ground broken and stony, and falling towards the Shashe. Many crags crop up around, and in front of us are some kopjesHendrik says where the Tati is. The Shashe is a very broad river, all deep sand, with water in one place where it has been dug for, both for cattle and people. We enlarge the hole (hard work under the heat of the sun), and let the cattle drink. . . . There is an old Bushman here, destitute and alone. He says the Mungwato men took his gun. The 
other side of the river, he says, is under Lobengula, this under Sekomi, and Hendrik says the Makalakas are not independent, all here belonging to the Matabele and Mungwato sovereignties. These Bushmen are, I suppose, the original inhabitants. Hendrik says they are slaves to the others. They certainly are outcasts. This man does not beg, takes what is given him, and lies naked with his head on a stone by the fire at night. He has no blanket. . . . Watched the Bushman make his fire with two sticks. He took off his sandals, placed a stick on one of them, and holding it firm with his foot, twisted the other stick rapidly between both hands, working it in a little hollow of the first stick, till black dust began to form. This soon turned red-hot, and there was fire like that in a pipe."

Continuing their journey on the 26 th, the brothers reached the Tati the same evening, where a small English settlement of a few huts has collected round the gold mines, which are being worked by Sir John Swinburne. "There is nothing remarkable in the scenery here," writes Frank Oates soon after their arrival; "a few kopjes only, with low scrub and trees. Everything is very much dried up. The river is broad, with deep sand in its bed. Yesterday Nelson ${ }^{1}$ gave me a live fish, four or five inches long, something like a perch. He says they live in the sand now. Water is got by digging in the river's bed. . . The veldt where we are outspanned," he concludes, "is quite ploughed up with the spoor

\footnotetext{
I Mr. Nelson of the mine.
} 
of elephants which used to come here five years ago, and have been found quite near here since."

At this point Frank Oates and his brother remained a few days before separating, and on the 29th the former wrote home the following letter, giving some account of his future plans, and adding some particulars to his experiences above related :-

". . . When we left Bamangwato," he writes, "whence I last wrote, Buckley and Gilchrist went on with W. I followed two or three days later, having been busy seeing people and making arrangements. I soon picked W. up, who was waiting for me, the others having gone on in advanceof course, as we thought, to Tati. We, however, met a trader with a note from Buckley saying they had turned off at the Seruli River. . . . We have been here now two or three days, and to-night Buckley and Gilchrist arrived, having abandoned their new route.

"The road we have come crosses a number of sandy river-beds. These rivers are large streams in summer, but are now dry, except occasionally there is a little pool in some, or water may be sometimes obtained by digging. This tract of country through which we have come is called by the Dutch the 'thirst land,' and is now at its worst. On our return it will no doubt be easy enough to cross, but now it is hard work, especially for the oxen. We trek about three hours at a time, doing perhaps seven or eight miles in a trek. Generally two treks are enough in the twenty-four hours, one in the 


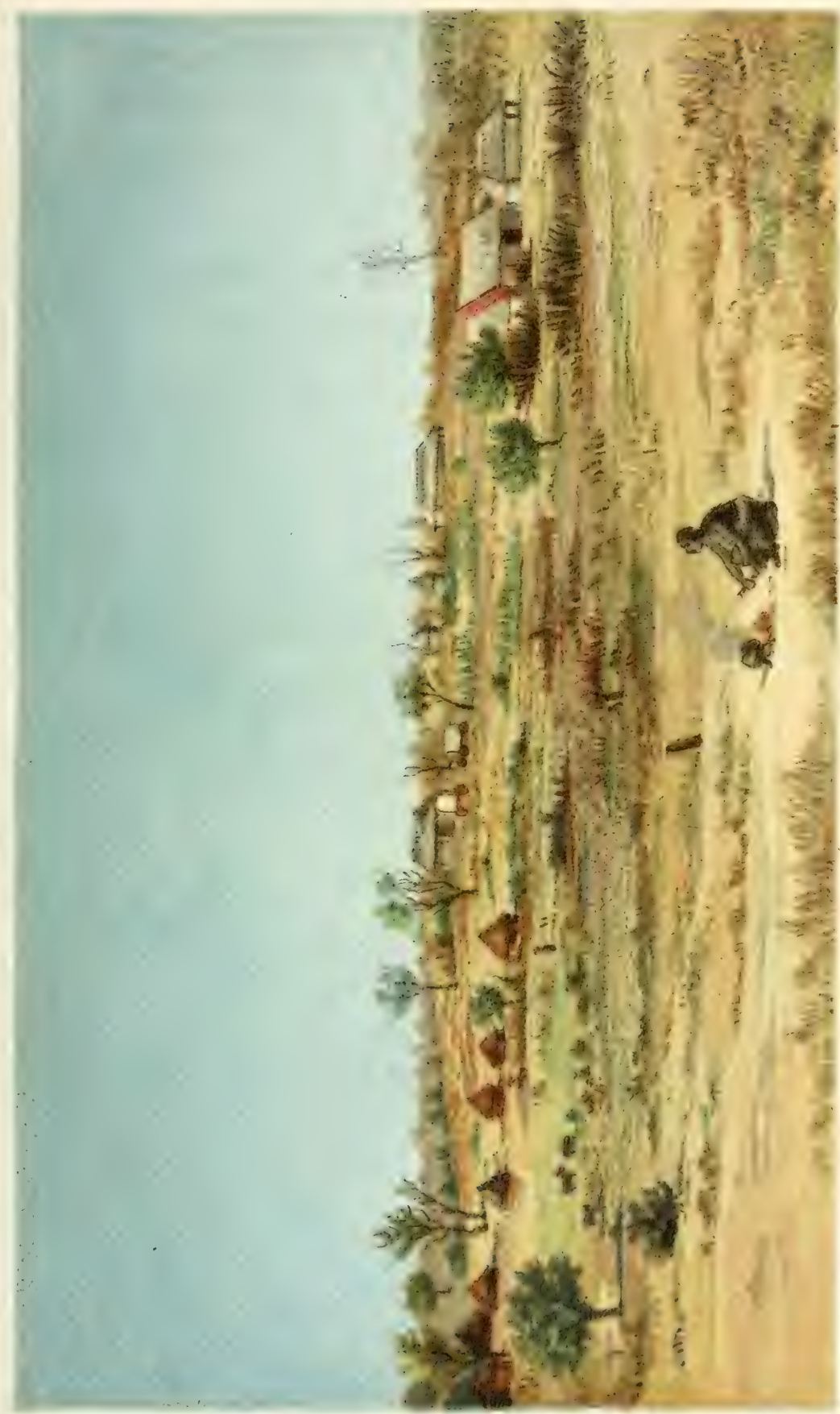



morning and one in the evening, but in going through the 'thirst' we have to push on and trek as much by night as possible.

"I was in advance of W. when I reached the Shashe, and, as it happened, had then only one man, Hendrik, my black servant, with me; for my driver and his boy had decamped, though they afterwards returned - as of course they were likely to do-the same evening. They will not have their wages paid till they return to Maritzburg, and then not unless they have behaved properly, and they would have had a miserable time if they had actually deserted me. Hendrik can drive, and knowing, as I did, the hold I had on the others and the folly of giving way, I let them go, telling them the sooner they left me the better, and the result of this treatment proved satisfactory. The difference originated in the driver asking me for tobacco when I told him to inspan, and refusing to comply till I had supplied him, which of course I would not do, as I treat them quite liberally enough, and indeed too well. Hendrik was a little poorly at the time, but behaved very well, and we reached the Shashe, where we dug for water.

"Being rather tired, we returned to the waggon after watering the oxen, without driving them away from the river first, which I know now we ought to have done on account of lions, but I have never yet thought it necessary to take such precautions except at night, when we tie them up and light fires. Soon after reaching the waggon I heard the loud cries of an ox in distress, and ex- 
claiming to Hendrik that I thought a lion must be the cause, locked up my medicine chest, from which I was taking medicine for Hendrik, and seized my gun. Hendrik followed me, and we both ran to the river. As we peered over the bank, there we saw the ox, the largest and fattest in my span, lying in the grass at the bottom of the bank with a lion tearing him. He was only a few yards below me, and before I could distinguish the lion properly as it lay upon his prostrate form, the brute leapt off the ox and retreated across the river. I fired as he ran, and hit him hard, for he rolled over, and I ought to have given him the second barrel at once, but thinking him mortally wounded, I hesitated a moment, and in the next he had disappeared in the dry reeds. I did not like to follow him at once, and Hendrik would not accompany me, but tried to dissuade me from following him at all. However, in about half-an-hour I went in search of the brute, but never found it, and do not know what became of it. ${ }^{1}$

"I have yet been brought very little into contact with wild beasts, and have had few stirring incidents, but I have been pretty fully employed one way or another, and continue to persevere in my journey. I found on reaching here that it was too late to go to the Victoria Falls without risk of sickness, in

1 The body of the dead lion was found soon afterwards by some natives-for the shot had proved fatal-and the skin taken by them to the Tati settlement. The ox had sustained so severe an injury that he had to be shot the following morning. 
which case I had long before decided to travel in a north-easterly direction to Mosilikatze's country, the country of the Matabele, over whom Lobengula, son of Mosilikatze, now reigns. I am told I shall see some very beautiful scenery on my way there, and I am now interested in pursuing my journey as far as I can. From here to the King's Town they call six days, but it will probably take me more.

"Here I have met two very nice fellows. One of them, Nelson, a Swede, is managing the mine of the Tati Gold Company. It is on a very small scale, and there are, I think, only seven white men here altogether. Brown, the other I refer to, has also some office connected with the mine, and keeps a store. They are both extremely kind, and willing to do anything to help one, and I expect to find more friends at the King's Town-especially Mr. Thomson, the missionary, for whom I have a letter from Mr. Mackenzie, and another from $\mathrm{Mr}$. Hepburn. I likewise carry the mail.

"A flower is almost an unheard-of thing at present, everything being dried up; but the thorny shrubs (mimosas), with their yellow sweet-scented blossoms, are an exception, and a sign of approaching spring. The shrubs they grow on are covered with long sharp thorns, and there are no leaves on them, but blossoms are appearing. There is another kind with hooked thorns and whitish sallow-scented blossoms, which attain the size of a good-sized English fruit-tree. The thorns which defend nearly 
every tree here are a great impediment in travelling through the bush.

"The nights are now cool, though not so sharp as they were a while ago. The thermometer seldom falls much below $50^{\circ}$. It is coolest just before sunrise. At midday and in the afternoon it gets considerably above $80^{\circ}$ in the shade, in fact I should set the point reached at nearer $90^{\circ}$. As I sit writing in my tent, I hear the engine working-an odd sound up in these remote regions."

Three days later, September 2d, W. E. Oates supplements this letter :-

"I am just adding a line to the above, to leave it before I go. Frank left the day before yesterday, to go to the King's Town. The king (Lobengula) is the great nigger chief here, and behaves very well to all white men. I am staying with Buckley and Gilchrist, and we are now going to the Shashani River, about five days' journey. I think Frank will be all right. He has a Cape Colony black man with him, who knows this country well, and speaks excellent English. ${ }^{1} \mathrm{He}$ was up here with Sir John Swinburne, who owns the gold-mine, so I am not afraid for Frank if he takes care of himself. . . .

"The country here is regularly burnt up now, and will continue so till the rains fall in November. The river is nothing but a dry bed of sand, with a little pool of water in it about three miles off-the only

1 This refers to Hendrik, the man of that name above alluded to. 
water near for miles. You may imagine the luxury of a bath, under such circumstances, out of the question. There are two men here who have been very kind, one sending us milk twice a day-and, I can assure you, milk is exceedingly scarce. The country is most uninteresting; nothing to see but thick bush, composed chiefly of low thorn-trees with immense spikes, which hold you fast if you get amongst them.

"The only pleasant part of the day is from sunrise (about half-past six) to half-past eight. After that, the less you do the better until 5 P.M., when it is moderately cool again. At half-past six it is dark. The flies are a perfect plague all day, and get into everything. Towards the end of October there are some heavy thunder showers, and then summer begins, but the regular rains don't fall until November. There are great numbers of hyænas and jackals, which prowl about the waggons all night. Last night one of Buckley's oxen was ill, and the hyænas knowing it attacked him, and this morning we found they had actually eaten part of him alive. Of course the poor brute had to be shot. Unfortunately the hyæna escaped, though fired at by Buckley's driver. The people are very glad when anybody shoots these animals, as they are constantly killing goats, and sometimes oxen. They are, however, so wary, that it is difficult to get them.

"Mr. Nelson, the manager of the mine, lent us some newspapers up to the 24th of May, the latest news we have seen from England. He also 
sent me a small bottle of beer, worth about five shillings here. Nelson is getting the king, Lobengula, some furniture from England, as he told the latter that a king ought not to sit on the ground. Lobengula's country extends from here to the Zambesi, and he is an absolute despot, having the lives of all his people in his own hands. They say if one of the Matabele is found stealing from a white man he has him executed."

Soon after writing the above, W. E. Oates left Tati in company with Messrs. Gilchrist and Buckley, to hunt on the Semokwe River, where they had very good sport. Returning thence in due time to the coast, they took the same route as that by which they had travelled north, the change of season, however, from winter to summer producing, as they returned, a remarkable change in the entire aspect of the country. By the end of October they were back at Bamangwato, and reached Pietermaritzburg on the $2 \mathrm{~d}$ of January. A few extracts from W. E. Oates's letters, written as they proceeded, may here be read with interest. He writes first from Bamangwato on November $3 \mathrm{~d}$ as follows :-

"I arrived here with Buckley and Gilchrist about a week since, and shall probably make a start for Pretoria to-night. The spring has now commenced, and the grass is beginning to grow. There have been heavy thunderstorms, and the lightning is wonderful, never ceasing for a moment during the storms. The heat also is very great. . . There has just been a row here. The old chief's eldest 
son has left the place, and nearly the whole of Mungwato went with him. The chief himself, Sekomi, is still here, and often comes down to the waggons begging. He got quite drunk the other night, and tumbled under my waggon. We had to see him home. He thinks his son means to kill him. He himself killed two or three of his own brothers when he came to be chief, but his two eldest sons are both Christians, and Mackenzie thinks Sekomi is in no danger from them. . . There are some nice flowers of the lily sort sprung up since the rain began, but very few flowers of other kinds yet. The rains, however, have only just commenced, and we shall have all the summer heat going down."

Again, from Pretoria, he writes on December 5 th :-

"I got here on the $2 \mathrm{~d}$ instant, and great was my delight on receiving letters from home-the first I have had since leaving Pietermaritzburg. . . . It seems quite strange to be in a civilized place again. It is very pretty here now, just the height of summer. We are indulging in fruit and vegetables, eggs and milk, to all of which we have long been strangers. The peaches are hardly ripe yet, but apricots are to be bought for a shilling a hundred. ... In coming from Mungwato we had to stop a week at the Meriko, as the river was very high with the rains and we couldn't cross. I had some thoughts of taking my waggon in pieces, and floating the things across on rafts, but the water lept subsiding, 
and at last we got over, the water only just taking the oxen off their feet. In dry weather there is hardly any water, but after the rains the river gets tremendously swollen, and there are very steep banks. Whilst waiting there Dawnay ${ }^{1}$ came up with two

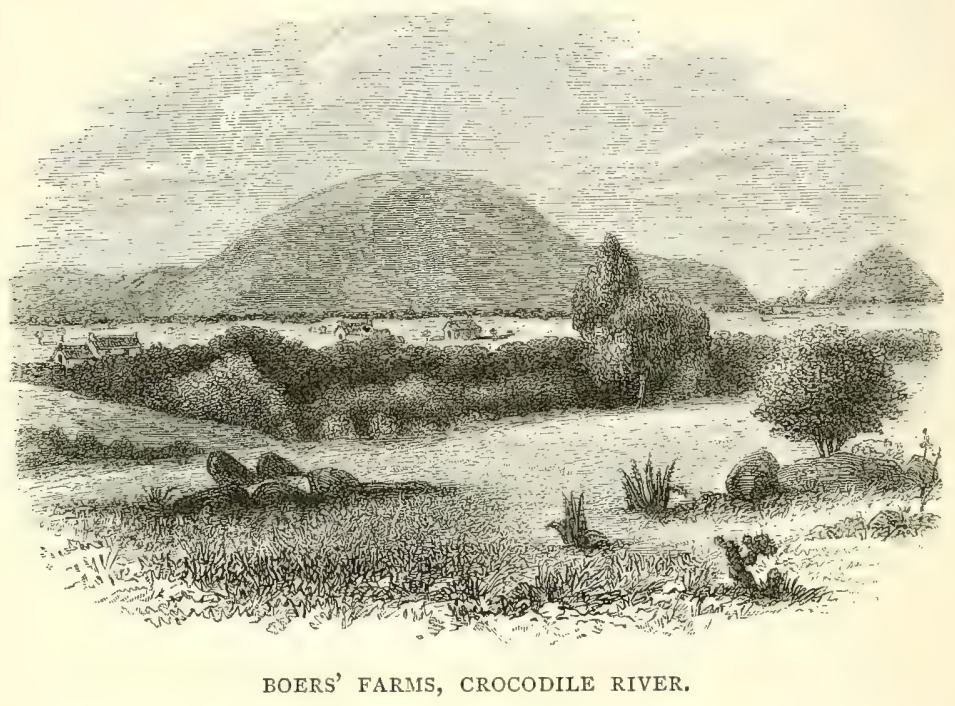

waggons. He has been out two years, and been to the Victoria Falls. He says it would be worth walking from Durban to see them. He showed me some little sketches he had made, but said it was almost impossible to draw on account of the flies. The tsetse-fly, which kills everything except men, wild beasts, and donkeys, swarms there, and bites so furiously that your hands and face are puffed up in no time. He describes the scenery on the Zambesi as lovely.

1 The Hon. G. C. Dawnay, on his way home from the Zambesi. 
"The country is much prettier now than it was when we went up. The grass has sprung up and is quite green, and all the trees are in leaf. The Transvaal, from the Crocodile River here, is beautiful. All along the banks of the river are farms, belonging to the Dutch Boers, surrounded with orange and peach trees. At most of these you can now get milk, butter, and eggs. We have had heavy thunderstorms, which, seen at night, are most gorgeous; lightning all round, all colours, and darting in all directions at the same moment. It is just like a display of fireworks. It is much cooler now than we have lately had it, the thermometer seldom being above $90^{\circ}$ in the shade, and the last few days there has been a nice breeze.

"My Kafir driver, who came up with me from Maritzburg, ran away when we were staying at the Meriko, and Bell and I had to drive the waggon down here. Fortunately they are very good oxen, so there has been no difficulty, and I have managed to get another driver here. Bullock-driving is quite a business in itself, and a very difficult thing in the bush with refractory beasts. This fellow, Solomon, stole a horse which we had found straying. It belonged to the old chief at Mungwato, and when I was going to hand the horse over to a Dutchman, whom Sekomi had authorised to take charge of the horse if he found him, Solomon went to the waggon where he was tied up, jumped on him, and galloped away. He will probably be caught, as the horse is well known. 
' A 'salted,' or seasoned, horse is worth a great deal, as there is a sickness in the bush which is generally fatal to horses which are not 'salted.' It commences when the rains begin to fall. I much regretted losing my little horse. I was told, when I got him, he was salted, but he died after a few hours' illness. There is no cure known for it. $\mathrm{He}$ was looking beautiful; his coat shone like satin, and he was getting quite fat with the young grass and some corn which I got for him at Mungwato. The oxen are thriving tremendously, and, since the grass has grown, from wretched skeletons they have become regular Tichbornes.

"I shall write to you again from Maritzburg, if there is a ship sailing before I go, for I expect I shall have to stay a fortnight or three weeks there, to sell the waggon, oxen, etc. . . . I mean to trek to-night when the moon gets up. We get into the high veldt now, where there is no bush. My waggon looks very seedy, the cover torn in many places by mimosa bushes, and the paint worn off. It is infested with beetles, and occasionally a lizard or scorpion is detected. Ants, too, occasionally pay me visits, to which I greatly object, as they bite uncommonly hard in this country. At night, if you are outspanned near water and have a lanthorn in the waggon, the candle is put out by numberless little beetles which creep in; and the frogs literally yell all night long. It is very pretty to see the fireflies."

On January 2 d, as already stated, W. E. Oates 
reached Pietermaritzburg, where he found the heat very intense. Three weeks later he sailed from Durban, accompanied by Mr. Gilchrist, and landed in England early in the following March.

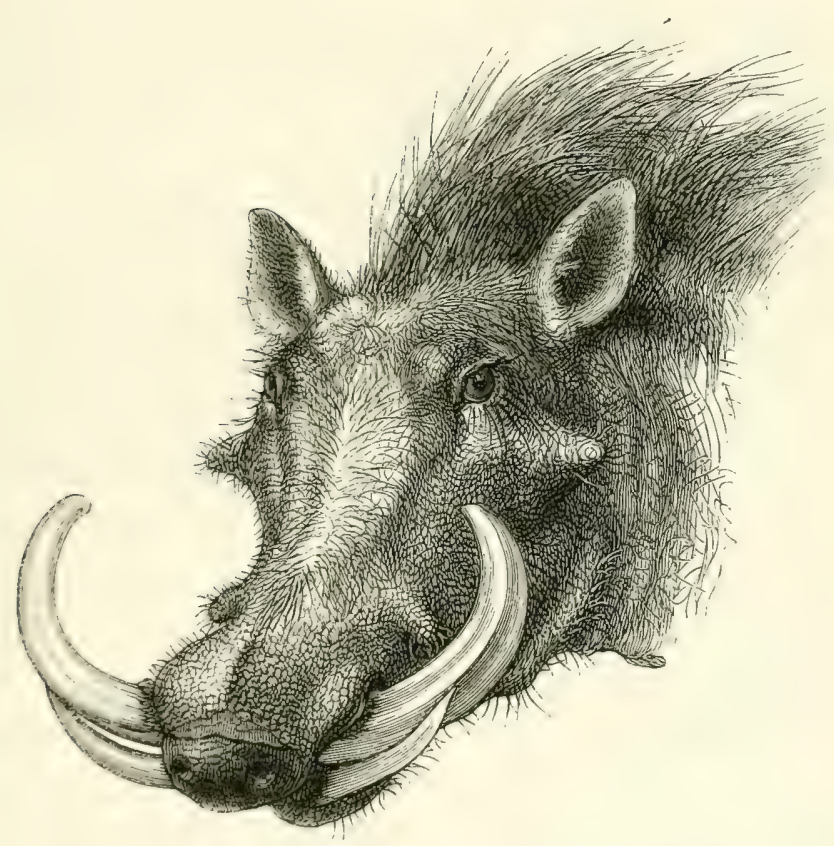

SOUTH AFRICAN WAR'T HOG.-Phacocherus athiopicus. 


\section{CHAPTER III.}

Frank Oates proceeds to the King's Town-Crosses the Ramaqueban -Dutch hunters on the Impakwe-The Inkwesi; picturesque scenery-John Lee's farm-Manyami's kraal-The ShashaniFine country-Kumala River.

Returning now to follow Frank Oates's journey to the King's Town, Gubuleweyo, we find the greater portion of his route described at some length in his Journal. Leaving the Tati, as has been mentioned, on the 3 Ist of August, and advancing slowly, he crossed the Ramaqueban, Impakwe, and Inkwesi Rivers, and reached John Lee's farm on September 6th. This John Lee is a noted Dutchman, who farms a large tract of country under the king. From here proceeding after a night's rest on his journey, he was detained four days at Manyami's kraal, a few miles further on, till leave had been obtained for him from the king to complete the distance, Gubuleweyo being reached by the middle of September. The Journal of this period is as follows :-

"August 3Ist.- . . . Left Tati in the evening. About midnight, whilst trekking, Hendrik calls me, saying that the bullocks which are being driven can't be got on, but keep going into the bush. 




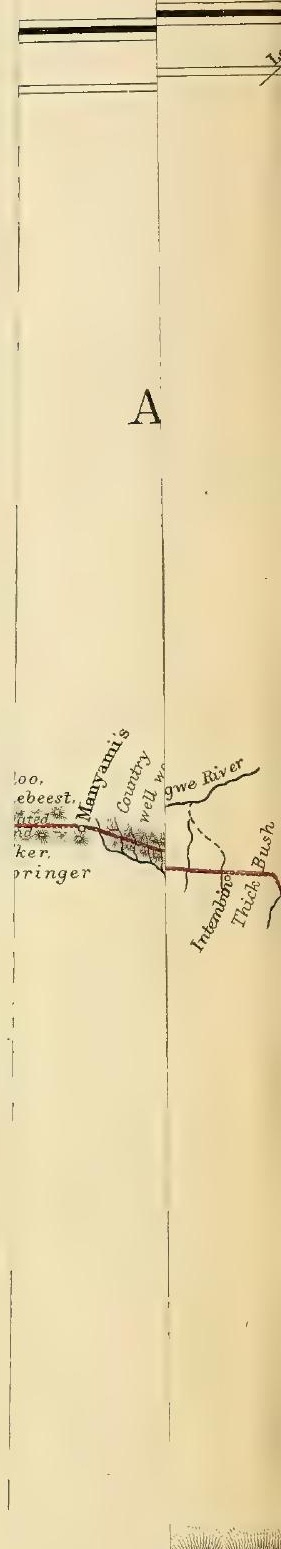


'Donker' and 'Wildeman,' too (the little red wild ox), are getting tired. This is miserable work, and I wish I had brought more bullocks from Mungwato, as I could so well have done, and a far lighter waggon. It is a mild, pleasant, breezy night, and as we outspan, and 'Rail' and 'Rock' come up in their couples, I am reminded of our first trekking on the high veldt, when we were together in force, starting with a good equipment and high hopes. This is an open space where we outspan, with long grass.

"September Ist._Mild, cloudy morning. . . . I had been much discouraged by the oxen being so tired last night, and this morning was pleased to find ourselves arrive at the Ramaqueban River at least an hour sooner than I had hoped. Petersen's waggon was on the opposite side. ${ }^{1}$ However, we stuck in the drift. Poor 'Weiman,' with his blind eye, was in front, and proved awkward, and little 'Vinal' lay down. Petersen, however, sent his driver and two good oxen, and we came out easily and had breakfast. Here some Dutchmen squatted last season to hunt, and took the fever-men, women, and children. Petersen says about half-a-dozen of them died. He thinks it was in January. The trees along the river's bed show a faint budding of green, as I have now seen for some time. The girl who came with us to Tati was travelling on with Petersen, and her brother had come on with us last night to join her. The cool breeze to-day was very pleasant. Petersen's boys had dug for water. Petersen went on,

1. Mr. Petersen was a trader whom Frank Oates had met at Tati. 
as he usually makes one short trek during the day. I followed in the evening, and shortly after midnight crossed the drift of the Impakwe and outspanned. There seems plenty of water in the river. Barking of dogs; encampment of Dutch hunters. Petersen had turned in. Part of this trek was through a somewhat sandy country, but on the whole we are on a much firmer road than we were before reaching Tati. Pitched into marmalade; it is wonderful how much one enjoys such things here, where the coffee is without milk, the bread without butter, and the meat dry as chips.

"September 2d.-Pleasant breeze. Petersen called me. I find I am likely to have great luck. Here lives the Dutchman whose family suffered so much from fever on the Ramaqueban. He has built a straw hut, cool, roomy, and snug, with a higher entrance than the Kafir huts, but shaped like them. His wife and family are with him, his eldest married daughter, and members of the next generation. He has cattle and goats, does his own blacksmith's work, and hunts. They go as soon as the unhealthy season begins to John Lee's. They intend, in four years I think, to return to their farm on the Meriko. Petersen acted as interpreter, and it is arranged that I wait for the Dutchman, who intends going to-morrow in my direction to get wood and hunt. He will lend me some oxen. I believe it is nothing but the brackish water, especially the Seruli water, that has made such a mess of my oxen. The Dutchman says there is plenty of game along 
the road. . . . Noticed when out in the afternoon, and we crossed the river-bed, how easily the water rose, when one of the boys scooped out a hole with his hands; very different from the dry river-beds the other side Tati.

"September 3d.- Morning felt very chilly. Breakfast on 'biltong' " and butter; the fresh butter excellent. We branded and left 'Rondeberg,' 'Engeland,' and 'Vinal.' The Boer put twelve of his bullocks into my waggon, eight of mine in his, and 'Donker,' 'Wildeman,' and 'Spot' were driven. ... Trekked about twelve miles, from the Impakewe to the Inkwesi River, and outspanned about 6 P.M.

"September 4th.-Cup of coffee, and went out about 8 A.M., I and the old man riding, his son walking ahead, and two of their men (Makalakas) accompanying us. ... I do not admire the Matabele particularly. They are independent-looking and well made, but I do not like their countenances. The day following there were a great many about the waggons, attracted by the flesh. They eat like dogs, greedily. Beyond this river, which the Dutchman calls Makobi's, there was a tribe of Mungwato people massacred some thirty or forty years ago by the Matabele; Makobi, the chief, being amongst the slain. They were killed-men, women, and children - to obtain possession of their land. A few only escaped.

"The scenery about our camp is picturesque. The kopjes rise abruptly, and the river has steep 
craggy banks. There is an approach here to American scenery. What a wonderful difference is made in one's feelings by the constant impression caused by fine scenery! South Africa is sadly dull and monotonous, and I believe the influence is a bad one, and the loss of scenery has a depressing effect on the spirits; one's imagination is never called into play. ... I still admire the scenery, as we ride along home amongst the kopjes by the river. Here and there the large fleshy-leaved shrub, ${ }^{1}$ standing boldly out amongst the bare crags, is very striking. There is something here which might remind one a little of Central America, but somehow the charm is wanting.

"September 5th.- . . Inspanned at 7 P.M., and crossed the river. Stony and deep descent and ascent, with very deep sand; very hard work. I feel deeply indebted to the Dutchmen, who not only helped us through it - the young fellow driving, and the old one helping--but, having lent us four oxen for the journey, sent for some more, to help us through this drift, after which they say all is right. Lovely moon as we trekked, but after all it is South Africa, and one cannot feel poetical. Picturesque kopjes on either side the road; the scenery, however, not so striking as it was almost beginning to be at Makobi's. Outspanned at I0.30 P.M., having gone about six miles. Excellent supper on wildebeest steak, fried.

"September 6th.-Dark cloudy morning, with a

1 Doubtless a species of Euphorbia, many varieties of which are met with in South Africa. 
little rain. Started at 7 A.n., and trekked six miles. The country where we stopped had been much burnt, and looked very desolate, with bare ground and bare trees, but there was a fine cool wind and a cloudy sky. I could fancy it a sea breeze. They say at the king's place you get the sea breeze. Started again at I2.3O P.M. Here one enters on a bit of really fine rugged country. Out of the level, scantily covered with dry brown grass and with a thick growth of leafless trees (small for the most part), rise huge boulders, so piled on one another, with here and there a huge stone so nicely balanced on the top, that one wonders how they ever got there. We are in a populous country, strings of people carrying things on the road. Outspanned at 2.30 P.x. Here the Dutchman, Smith, had been located, as there is a straw house, and water, the road crossing a spruit. Here, too, is John Lee's first kraal. People come round the waggon to beg meat. One is a warrior, handsomely adorned with black ostrich feathers and white ox-tails. Went on again at 5 P.M., the ground rising a little. Then as we descend a range of kopjes appears in front. In about an hour a pretty white farm is seen to the right, towards which the road winds, and the wild view makes the farm seem to welcome one.

"Lee came to meet me, and asked me in. He is a fat, red-faced man; his wife very young. His house had an air of comfort, and some luxury about it, owing to some handsome leopard karosses on couch and chairs. There was a picture, too, by 
Baines, of Lee shooting three elephants. The horse here represented, which I think cost him $£$ IOO, was the making of him, he tells me. Lee was a Transvaal Boer, but speaks English. He was about five years hunting. I had supper with him, and a long chat afterwards. Garland, he says, lost seven unsalted horses, and had to send for two salted ones. A good salted horse costs $£$ ioo. Lee described how his old favourite used to snuff when game was near, and when it was elephant his manner was unmistakable. He has tried donkeys in the tsetse-fly country, but the fly has always killed them. He says all horses, with scarcely an exception, must have the sickness, but he has known an exception. This, however, does not apply to stock bred of salted parents, which often live and never have the sickness. This is better, as the sickness breaks a horse down.

"Lee has just sold twelve red oxen-Africanders, with white faces-for $£ \mathrm{I} O 0$, unwillingly. His other oxen are all in the hunting veldt. He has, however, let me have Smith's as far as Manyami's, with a boy to bring them back. I think he calls it ten miles to Manyami's, and from his (Lee's) house to the King's fifty odd miles. He says he saw some eland to-day, but game is not plentiful just here. However, it is worse along the road to the King's, as kraals abound. Lee does not wish to have kraals near him, and the king does not permit any to be made in his neighbourhood. Most of the hunters, he says, make a great deal of money, but spend their money as fast as they get it, saying, "There is more ivory where 
this came from.' Lee himself was careful. His place, he says, is very healthy, and it has got so good a name that in unhealthy times people stay about here, and it has been like a town, so that he opened a store. He is trying peaches, apricots, and pomegranates. Potatoes grow well here, and he is seldom without vegetables. $\mathrm{He}$ is trying several wild fruits. He has always water in the spruit close by, and waters by hand. He showed me a small wild grape.

"Lee tells me that a lion may often be stopped by throwing your hat at him, when you may have time to shoot. He says an elephant gun should never be longer than 27 inches ( 25 is better), nor weigh over $9 \mathrm{lbs}$. He shoots 8 drams of powder, and an 8 to the lb. ball. The recoil is avoided by the barrel being strong, and nearly as thick at muzzle as at breech. His clothing in hunting is as light as possible; veldt schoen, and he says not even a shirt if he could help it. He carries needles and thread in his hat.

"For trading with the Matabele he recommends white, blue, and, I think, red beads. Selampore is much liked, or strips of coloured calico. Beads, he says, seem going out, and printed calico being preferred. The Matabele country, he says, was formerly under a queen. There were, I think, other queens before. An old man has told him the traditions, which he possesses. A famine caused the people to break up; then Kafirs came and conquered the country. Mosilikatze came next, and 
conquered these first Kafirs. Makobi's were Mungwato people, but the old inhabitants of the Matabele country were a distinct race with a distinct language. The Bushmen have nothing to do with either. They seem an altogether different race, speaking a different language, and seem, Lee says, to be scattered all over the country of South Africa, a race apart from the regular inhabitants, and having no connexion with them.

"Lee has a young sable antelope, which goes with the cattle, about a year old. It is a rich deep chestnut colour. Lee says they get darker every year, till they become black. He once had a young elephant for some days; perhaps nine months old. $\mathrm{He}$ describes it as having been a most sensible and amusing pet. When first taken he made it put its trunk under his arm, and after smelling him, it was satisfied and became friendly. It always first smelt at strangers before making friends, and if once repulsed would not be friendly afterwards. It would climb in at the back of the waggon, and out at the front by the wheels, and was accompanying the waggon when it died from diarrhœa, caused by improper food. It would pick up a pin or a needle, placing it first with its foot at the right angle for its trunk to grasp, and then hold it up and examine it with wonderful sagacity. It was excessively mischievous, and would upset everything. It could not bear to be left alone for a moment, and would cry like a child in such a case. The company even of a little child would content it. 
"September 7th.-Breakfast with Lee; dinner also. One of his boys caught some barbel and a curious-looking fish in the river. Talked with Lee, and afterwards saw his garden. Inspanned about 8 P.M., and soon crossed a river with sand and reeds, and a good deal of water in its bed. It was a fine moonlight night, the road winding through picturesque kopjes. Went about six miles, and then halted for the night.

"September 8th.--Started at 7 A.M., and went four miles through flat land, with but few trees, and hemmed in by craggy, bush-covered kopjes. Came in sight of cultivated land and natives, and reached Manyami's kraal at 9 A.M. The country here is really pretty, and presents a pleasing variety to the eye. The ground is open mostly, and covered with long yellow grass; here and there groups of trees, some of a very fair size, some bare, some brown, and a few green or in blossom. Large stones crop up from the ground, and everywhere rugged kopjes rise round us.

"Soon after our arrival Manyami came, attended by another old fellow, each in a shabby old hat, and vying with each other in squalor and dirt. He refused firmly to send to the king till to-morrow, saying the king had not sent for me, but I had come, of my own accord, and must not be in a hurry; the oxen could feed and rest. I gave him a bar of lead. Two messengers were to be sent, and I wrote a note to Fairbairn for oxen, and the boy was directed to 
bring them back. ${ }^{1}$ Manyami insisted on their being paid beforehand, and intimated that they might not carry out their message properly unless I paid them. I was angry at their exorbitance, one demanding

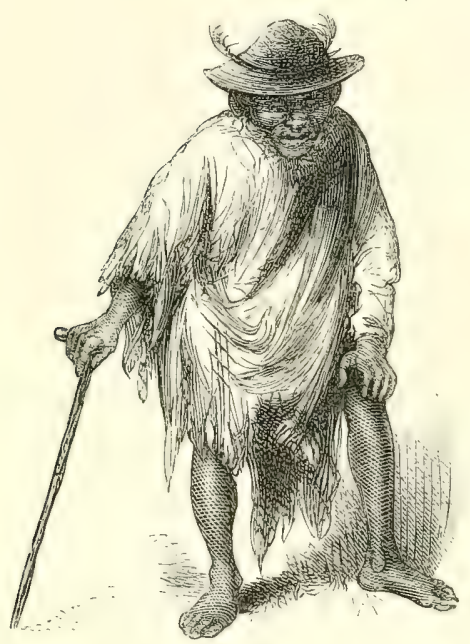

MANYAMI.

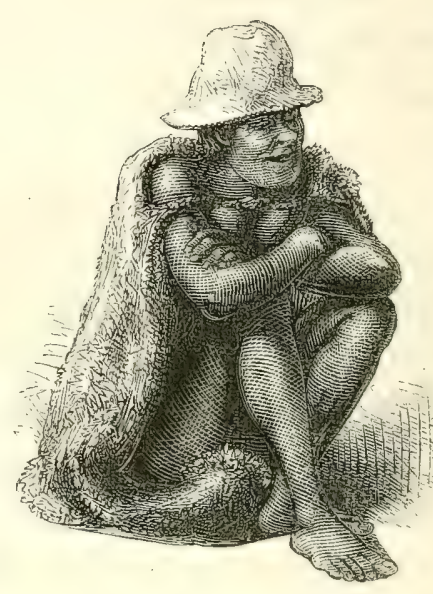

MANYAMI'S ATTENDANT.

two coils of wire; to the other I gave half a bar of lead. The old fellow hung about begging. Women brought mealies and Kafir corn. Milk and beer were also brought, and I told them to bring Kafir corn meal next day, which they did, but were very fanciful in their demands, one wanting beads, another must have brass wire, another a handkerchief, and so on. I find they don't care for mirrors; look at themselves, and are highly amused, but refuse them

1 Mr. Fairbairn was agent at the King's Town for a Mr. Cruickshank, with whom Frank Oates had had business dealings at Bamangwato. 
as payment. Common knives are likewise refused, but gun caps taken eagerly. They like printed calico better than white, which they affect to despise. The outcry was for long strips of coloured stuff, and they preferred the quarter of two handkerchiefs (i.e. half a handkerchief in quantity), cut lengthwise, to one whole one. Stayed about waggon all day. Pitched tent, and got things out.

"September gth.-The night had been very mild. Old Manyami came bothering early. In the course of the day he kept on coming, and I gave him twenty gun caps. Wonder of wonders, he afterwards presented me with a pumpkin, and I felt less hostile to the old creature. He is really a miserable-looking, ugly, and filthy creature. Stayed about waggon again to-day.

"September Ioth.-Early breakfast, and then out with the Kafirs to shoot. One carried my ten-bore, one led the dogs, which I am taking out to help to hunt. Went in a north-easterly direction, through very fine picturesque kopjes, with blue distant ranges; the grass long and yellow, and the trees grouped prettily; some kopjes with craggy tops, and partially covered with evergreens, others showing more of their stony formation. A good many trees are covered with bunches of cream-coloured blossoms something like 'May,' but have no leaves. They remind me a little of 'snow-balls.' Here and there we see a tree whose leaves are brown or scarlet with decay. In places where the grass has been burnt, fresh green blades are springing. There are 
numbers of little burns here with moist oozy banks, and in many places with water in them, that I suppose find their way to the Shashani. We had to go through a burning patch of country. The flames appeared orange-red, and presented a rather formidable phalanx, writhing in the wind, and with wreaths of dun-coloured smoke rising from them, which indeed filled the air with lighter clouds of the same colour, here and there the wreaths appearing bluish, whilst a dusky haze hung over the horizon. As the flames devoured the yellow grass, they left a blackened track behind. The trees, however, seem to escape; some in blossom, some in autumnal tints, but the greater portion leafless.... One of the boys who came to the waggon had a charm of bone suspended from his breast. It consisted of four pieces of bone, carved and strung together. By them he professes to foretell what luck will befall a hunter or any one else. They are unstrung and shaken in the hand, and then thrown on the ground. The person going to hunt must spit on the ground, and as he throws he must say, 'My gun! may I shoot 'something.' The bones, as they are hung, appear about the size and shape of a swallow-tail butterfly. I like the Matabele better than I did. They are good-natured and jovial, and seem to understand a joke. There were great firings and noises at the kraal in the evening, in honour, it appears, of a man returned from the diamond-fields.

"September I Ith. - Fair, pleasant, windy day. Eight oxen and a note from Fairbairn, who says I 
have missed a dance at Gubuleweyo. The king says I am to come and make haste. A letter from Gubuleweyo to forward to the Tati excites more exorbitant demands for payment. Two boys must take it, and each have a pannikin of powder. Manyami said he must see the powder before he would send the boys. Great noises at the kraal again to-night.

"September I 2th.-Manyami brought a small elephant tusk for sale, weighing a little over a pound, and asked five coils of wire for it. I offered him two, which he accepted. He is an extremely ugly little old man, and simply filthy. Packed the waggon and started at I I A.M., the road winding amongst kopjes. We crossed several spruits, and stopped at the Shashani River about I P.M. Beans and guinea-fowl for dinner. Dick went back to look for screw-jack, and we lost a trek in consequence.

"September I 3th.-Inspanned at 3 A.M.; most villainous jolting. Really fine country here; kopjes on every side, rising into fine crags, with huge stones strewed on the ground. In the distance more ranges of kopjes are to be seen, becoming blue against the horizon; and though the kopjes themselves are too stony to give growth to many trees, trees intervene. One could make a picture here. Country a good deal burnt in places, and fresh grass springing up green. Later in the day, after a long rest, we went through ordinary flat bush veldt, and then through an open undulating country, covered with yellow grass; a few trees and 
detached kopjes in the distance. Passed several kraals, and went through mealie stubble-fields, fenced from the waggon-track by branches rudely stuck in the ground. A crowd of Kafirs, making a fearful noise, appeared, and accompanied the waggon to where we were going to outspan, so we went on a little further past the kraal. There was a perfect Babel. A few men came after us when we had halted-swarthy fellows, with splendid teeth. One had a fine leopard-skin he was anxious to sell ; others a wooden dish, beans, Kafir corn, tobacco, and beer. The men's head-dresses were various and becoming. One man we passed had on a skull-cap of spotted tiger-cat skin, with feathers sticking out behind like eagles'

FEATHER HEAD-DRESS. or pauws'. Others wore round masses of feathers (one was of guinea-fowls') nearly as big as their heads, and one had a jackal's tail sticking straight up over his forehead. They were not at all an unpleasant-looking or unfriendly set, though noisy and forward.

"September I 4th.-Fine bright morning; clear sky. Two hours' trekking brought us to Kumala 
River, now dry, which we crossed, outspanning a mile or two further on. The country here is open, park-like, and undulating, extending away in a nearly level plain to the right. After we had stopped, a number of impudent Kafirs crowded round the waggon. One made a fearful row, at last coming to entreaties, saying we had set the veldt on fire.

"Starting again at 4 P.M., we next went over rising ground, the country getting

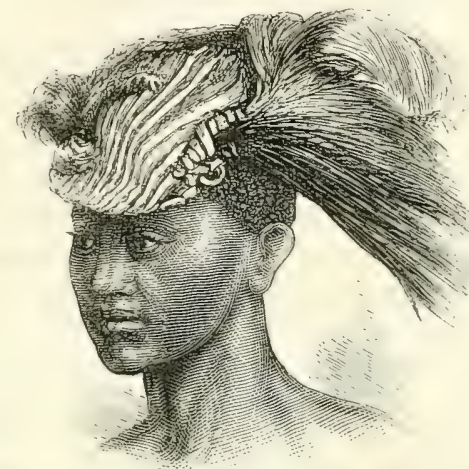

HEAD-DRESS OF ZEBRA-SKIN AND FEATHERS. very clear of timber, and at half-past six stopped at a small spruit with water in it, having crossed two previously. A long, dry, treeless plain here stretched before us, with kopjes rising into ranges against the horizon. It seems the spruit we are now outspanned at is the head-waters of a river flowing into the Limpopo, and where we were outspanned this morning is the head-waters of Kumala River, which flows into the Zambesi."

The day afterwards a short trek of about three miles brought the traveller to the King's Town, as related in the ensuing chapter. 


\section{CHAPTER IV.}

Arrival at Gubuleweyo-Interview with the King-Start for the Zambesi-Hope Fountain-Inyati-Difficulty of obtaining bearersThe Zambesi abandoned-Hunting expedition on the Umvungu and Gwailo Rivers-Experiences of a half-caste-Birds' nestsThe indunas' tree-Hunting-A lunar eclipse-Return to Gubuleweyo-Wild fruit.

THE account of Frank Oates's present stay at Gubuleweyo, and his first impressions of the town and its inhabitants, taken from his Journal, is somewhat scanty. This was one of those more striking episodes in the journey, which needed no written record to impress their details upon his mind, and the narrative of which in this, as in other similar instances, is consequently the most wanting, where the reader would naturally expect and desire to find it the fullest. The account, such as it is, of his arrival at the town, and the first two days spent there, is taken as follows from his Journal :-

"September I5th.-Another trek of about an hour and a half brought us, about 9 A.M., to Gubuleweyo. There is not much timber as the kraal is approached. The scene is picturesque but desolate, the road winding and steep. Some of the peculiarlooking trees ${ }^{1}$ are here of great size. Strings of

${ }^{1}$ Probably the Euphorbia above referred to (vide p. 46), which frequently attains the size of a small tree. 
women were carrying vessels of water on their heads as we arrived. It was bitterly cold, and there was both wind and rain. Fairbairn and a number of others were standing about the kraal. Petersen was there, and introduced me. They asked me in, and I drew up my waggon to Fairbairn's 'scherm,' and had breakfast with them. Fairbairn and Petersen took me to the king, whom I called on out of compliment, telling him that I had not yet unpacked my waggon-a hint that I should have a present for him. He was very gracious, and placed meat and plates before me, and inquired what sport I had had coming up, noticing the dilapidated state of my dress. I was going out of the hut legs first, when he pulled me back and made me go head first. He sent me to look at his new house, of which he is very proud. It is being built of brick by an Englishman.

"In the afternoon Fairbairn and I rode over to see Mr. Thomson, the missionary. He will act as interpreter if I wish, but does not think it necessary. As we returned at sundown, we met a party of natives. They were Umtegan's troop, returning from an 'impey,' or raid, with cattle taken from the Mashonas, a tribe not altogether subject to the king, though a part of them are. Umtegan was in European clothes, and on horseback. They stopped to go through the exercise of certain rites before

1 The term applied to the small fold or enclosure made round a hut or waggon, for shelter and protection, by means of branches rudely placed in the ground. 
entering the town. They had only a few hundred bullocks with them. Lately some thousands were brought in by an impey of a similar kind. At supper I had a young lion to pet; it belongs to the king, and roams about amongst the traders. There is a waggon at Fairbairn's made at Beverley, in Yorkshire, which was brought out here in separate pieces, and fitted together afterwards. Fairbairn says it is a capital one. The poor man who brought it from England died before landing.

"September I 6th.-Took the king my presenta central fire shot gun with ammunition. As I approached, with men carrying it, he took me by the hand and led me to a waggon, and sat on the 'dissel-boom.' ${ }^{1}$ We all sat on the ground. He was much pleased with the gun, and thanked me. The men with me would ask for beer, and he sent us to his sister for it. She was lying on a rug at her hut door, and I was introduced."

It was now ascertained from those here who knew most about the matter, that it was not even yet considered too late to reach the Zambesi that season, by taking a more direct route from this place, to be accomplished for the most part on foot, instead of proceeding along the usual trade route by way of Tati, which is available for waggons, but a good deal further round from the King's Town. On hearing this, Frank Oates at once determined to try and reach the river by the shorter road that season, and the remainder of the time he spent on this

1 i.e. The pole of the waggon. 
occasion at Gubuleweyo was chiefly occupied in obtaining information for the expedition, and making the necessary arrangements for it. The early part of the journey could be accomplished with the waggon and oxen; after that it would be necessary to go on foot.

On the evening of the $24^{\text {th }}$ of September he accordingly started with his waggon, remaining the night with Mr. Thomson, the missionary, at Hope Fountain, a short distance from the kraal. The night was very close,- - the first which had been so,and on the following evening, after they had trekked some miles from Mr. Thomson's in the direction of Inyati to the north-east, there was heavy rain and wind, accompanied by thunder and lightning. This rain, the first there had yet been, was said to be earlier than usual in its commencement by about two months. The other conditions, however, of the projected journey to the Zambesi, all of them, still appeared favourable. It was the traveller's longcherished desire at least to reach the Zambesi, and see the Falls, if he found it inexpedient on the present occasion to cross the river and penetrate into the less known territory to the northward. But there were difficulties, not only of climate, but from the obstructiveness of native character, to be encountered, and endless was the opposition which he met with from the latter cause. Four distinct attempts did he make at various times from this date to reach the river, and in each of the first three was he destined to disappointment. 
His present effort, made in September, was the first of these; his fourth and last attempt was made at the end of the succeeding year, nor was it till the last day of 1874 that he actually beheld the white spray of the great cataract breaking through the trees upon the river's bank. That effort truly was rewarded with success, yet a success how dearly purchased-with his life!

Before leaving Hope Fountain, to resume the journey, he wrote home the following letter to his mother :-

"Mr. Thomson's, near Gubuleweyo,

"September 25 th, I 873.

"You will, no doubt, have more recent news from Willie than from me. I left him with Buckley and Gilchrist at the Tati, meditating a short journey in the neighbourhood before leaving, and came on myself to the King's Town, Gubuleweyo, the site, or somewhere near the site, of the place marked in the maps as Mosilikatze's Town. Mosilikatze was the father of the present king, and conquered this country. The name of the nation is the Matabele, which is always shown in the maps. The former inhabitants of the country were divided into various nations, but it is all called the Matabele country now from the name of its powerful owners. The country reaches to the Zambesi, and produces a great deal of ivory and ostrich feathers. There are a good many white men at Gubuleweyo, trading. Mr. Fairbairn, a young Scotchman, is my agent there. 
"I cannot give you a detailed account of my stay of nine days at the King's Town. It is really to a stranger a most curious place. The king, Lobengula, lives in royal state. He is absolute monarch, and feared and obeyed far and wide. The people inhabiting the country we have passed through in coming here are altogether of an inferior race. At Bamangwato there is a king, but he is thought nothing of. I called on 'Bengula, accompanied by Fairbairn, the day I arrived here, and found him the picture of a savage king, just as one might have imagined, and coming quite up to the standard. The day I first saw him he was nearly naked, and lying on a skin inside his hut, to enter which you have to crawl in on your hands and knees through a little aperture in the front; in fact it is like a beehive entrance. He took me by the hand, and placed meat before me, and asked a few questions about my journey. I told him I should come again next day. Of course I had to make him a present, and I knew he would expect it next day, after which I should ask his leave and assistance to go through his country to the Victoria Falls if possible. I gave him a gun and ammunition, which pleased him very much, and he has done everything he could for me. It appeared that I was still in time to reach the Falls by going on foot, after leaving my waggon at the place marked on the map as Inyati. The king said it was possible to get to the Falls in ten days, and I suppose at my rate of travelling it ought to be done in a fortnight or 
three weeks at most, and the king says I have still two months of favourable weather, but so anxious is he that no white man should come to grief in his country, that he has been urging on me all possible haste from the moment the subject was first mentioned. He has given me two excellent men as guides; these two, having the king's authority, will carry all before them.

"I left Gubuleweyo last night, and came on as far as here, the house of Mr. Thomson the missionary, for my first trek. Mr. Thomson has kindly interested himself in me, and done all he could to assist me. He has a nice wife and children, and this morning I have had the luxury of a civilized breakfast, including tablecloth, bread and butter and eggs, and milk to one's coffee-things that I don't often see now. I am now availing myself of one of his rooms to write to you in.

"One of the men appointed by the king to guide me-himself a man of high character and good family, as Mr. Thomson tells me-left Gubuleweyo with me, and this morning hurried on to get bearers for me at the kraals ahead. I shall want from twenty to thirty, and as it will take some time to collect them, and my oxen want rest, I shall follow slowly, making a three or four days' journey of what is usually done in two days. At Inyati, where I am to leave my waggon, are two white men trading. These are the last outposts of civilization, but up to that point there is regular communication all the way - that is to say, all the way my waggon takes 
me. If I find that I am delayed and cannot reach the Falls as quickly as I had hoped, I shall very likely turn back without accomplishing my object, as I am desirous not to run any foolish risks, and have been at great pains in collecting all possible information.

"The men who carry my things will be most of them of the conquered population, and the two guides appointed by the king (one of whom, as I have mentioned, left me this morning to go on in advance, the other being now at Inyati) are able to do what they like. No one dare oppose the king, and the Matabele men he gives me renders any fear of desertion or disobedience superfluous. Besides, these two men know that they must carry out the king's orders to the letter. I have also got an interpreter, a man who speaks English and Kafir perfectly, my own servant Hendrik, and my driver and his boy. ${ }^{1}$ I shall take my tent if possible, plenty of ground sheets and bedding, meal, tins of biscuits, and coffee. For meat we have to rely on the guns carried by the party, but there seems not the slightest fear of scarcity, in fact the bearers are expected to live entirely on meat, having guns and ammunition allowed them for the purpose. No beast of burden or dog can accompany us, as it is the tsetse-fly country.

"Had it been earlier in the season I should have gone from the Tati, by which route you can take your waggon to within a few miles of the Falls, but

1 The interpreter here spoken of was a native from Graham's Town, who remained with Frank Oates till July the following year. 
as I should have had to see the king first, to get his permission, by the time I could have returned to the Tati it would have been too late. I have not a map before me now, but suppose it may be 200 miles or thereabouts from Inyati, my starting-point, to the Victoria Falls. I shall hurry on to the Zambesi, so as to leave the river as soon as possible. I can then take my time in returning, as when I leave the river the worst is over, and I soon get into a healthy country again, but, as of course every one knows, the Zambesi at certain seasons of the year is unhealthy. All this I have carefully studied, and have been guided by what I consider reliable evidence. I shall be further guided by circumstances that may occur, and shall exercise my judgment as to how far I carry out my original project."

Leaving Hope Fountain after writing the above, on the 25 th of September, the traveller went a short distance that night, and continued his journey early on the following morning. Here the Journal for the next two days resumes the story:-

"September 26th.-Cool, cloudy morning; the wind in our faces. Started about 7.30 A.M., and went six miles. The country we passed through was bush veldt; trees small, and in most places thinly scattered; grass very dry. One of the boys was running wildly about to keep himself warm -a hint for me to give him a shirt. The wind was high, and where we outspanned the boys made a fire in the hollow bed of a spruit. Starting again at I P.M., the country assumed rather a fresh 
aspect, with a green verdure like that of a young corn-field, where the grass had been burnt. The trees here were not close, and some were a good size, with young foliage of a vivid green. Passing next between two kopjes, we descended into a fine, bushy, undulating tract, misty-looking in the distance under a lowering sky. Outspanned at 3.40 P.M. at the Cokhé River, and had tea. Here they told me there was a kraal close by, presided over by 'Bengula's brother, Bolinlila; and as some of the oxen were tired, I sent over to see if I could leave them here. The reply being favourable, and a present requested, I sent the oxen - five in number-with a small strip of coloured calico.

"The boy sent me by the king, who was running about so vigorously this morning, now showed me a small scratch on his heel, and asked to be doctored. I put on some glycerine, but believe it was a ruse, as he afterwards got on the sacks at the back of the waggon, and rode instead of walking. The other man who was sent me by the king is the thinnest mortal I think I ever saw, his legs literally like those of spiders. It was dreadfully cold, and I gave all the poor wretches some hot tea. Towards evening we advanced again four miles further. It was like a cold trek on the high veldt-front sail drawn down, candle lighted, myself in the blankets. Outspanned at 7.40 P.M. Windy and rainy night.

"Scptember 27th.-Dark windy morning; Scotch 
mist. Hendrik woke me soon after six, to say they were inspanned. We made two treks-about twelve miles in all-and stopped about 3 P.M. at the Bembesi River, where some boys herding cattle brought us sour milk curdled for sale, which was very good. During the morning we passed some very striking-looking trees, leafless, but covered with large clusters of bright scarlet flowers on straight, brittle, thorny stalks. At a distance they looked like naked trees covered with scarlet berries, such as one sees in winter at home. Before night we went on four miles further, and stopped one trek they say from our destination."

At ten o'clock the following morning the Inquinquesi, a larger river than the Bembesi, with plenty of water in it and a sandy bed, was crossed, and a halt made upon its banks. Here was Inchlangin, the kraal where the traders were, Inyati itself being a short way off. Thither a messenger was at once despatched to ascertain what success the king's man, who had gone on in advance, had had in obtaining bearers. Soon afterwards this man presented himself at the waggon, saying that the boys required for the journey would be forthcoming the following morning. When the day arrived, however, they were not brought in sufficient numbers to be of any service, and the start had to be postponed a day or two longer, pending the results of further efforts. The following is the day's entry in the Journal :-

"September 29th.-Fine warm day; heavy rain 
in the evening. The king's man came again; this time accompanied by the induna of the kraal (I suppose only the acting induna, as the real one is the man I met at the King's). He brought with him two other chief men, given me as well as himself by the king, and to all three I gave some limbo. The induna said he would rather have a shirt, and I told him I would give it him when he had got me the boys. He only brought three to-day. Two volunteers, whom I told to wait, also presented themselves from another distant kraal.

"After this, as no more could be done, I went out shooting with Mandy (one of the traders here) in the afternoon, and got some birds. We had a pleasant walk, and saw the wild cotton growing. IVe also saw a beautiful tree with delicate green leaves and wreaths of violet-coloured laburnum-like blossoms; also a very sweetly-scented flower, white and star-shaped, growing in small clusters upon a tree of some size. Mandy says there are crocodiles here, but the king does not allow them to be killed, as it is thought that any one possessing the body can work spells. It is death to a native to kill one. A white man on one occasion shot one here eighteen feet long, which had been destroying calves and goats, and the king sent to have it buried, and had men to watch the place.

"It seems that lately, during a ceremony previous to the king's marriage (circumcision), it was thought inauspicious for any guns to be fired in the neighbourhood. They say a Kafir who fired one some- 
where in the veldt at the time was impaled for it."

The greater part of the following day (September 30 th) was spent in packing and arranging things for the walk to the Falls, and it was not till the day after this that the induna reappeared, now stating that he could not get bearers. The natives, it is likely enough, were afraid of fever on the Zambesi at this season, and did not want to go, but it afterwards appeared that the induna of the kraal and the headman sent by the king had made no proper efforts to obtain the staff required for the journey. The upshot of the matter was that the Zambesi had to be abandoned, and the traveller obtained instead permission from the king to go for a few weeks' hunting into the country to the north-east, where good sport was likely to be had. Before starting on this expedition he wrote home from Inyati, on October 5 th, as follows :-

"You will not be much surprised to hear that I have had to give up the Zambesi. I got here just in time to do it, if the carriers had been forthcoming, but the people in authority threw so many difficulties in my way, that I had to send back to the king, and so much valuable time has been lost that I have given up the expedition. I am, however, going a little way into the country with my waggon, and shall probably be a month or two before I am back again here.

"There are three Englishmen living here, trading. Two of them, in whose house I am now writing, are 
very obliging to me. This is a mission station, but there is no missionary here now. It is the last post of white men in this part of the world. When you reach the Zambesi you come to the outposts of the Portuguese traders from the east coast, but between these points are no Europeans settled. The rain is beginning, though the regular rains have not set in yet. It is after the first heavy rains that fever begins to annoy people on the Zambesi, but I believe, generally, even then only slightly, but after the next downfall--when there is much rain and the rain is beginning to dry up, about January, February, and March-the really bad season sets in. However, I am now avoiding even the former risk, and where I am going I shall be so near here all the time that I can return almost when I choose. I don't exactly know where I am going, but it will be somewhere in a north or north-easterly direction from here.

"I hear that Cruickshank, my agent at Bamangwato, is now at the King's 'Town, but I am three days' journey from there, and he will shortly be returning to Bamangwato. Fairbairn, his agent at the King's Town, will, however, in all probability, be there when I return, and here I am in good hands too, so that I have friends all along the road, and letters always come and go as surely, if more slowly, than where there is a regular post, for waggons are constantly coming and going, and everybody helps everybody else in this part of the world. I have been pressed into the service as postman myself before now. Only 
delays must be expected, and are often very vexatious."

On the 7 th of October Frank Oates started on his projected expedition in the north-east, on which he was absent from Inyati in all about seven weeks. The district traversed during his absence was that watered by the Gwailo and Umvungu Rivers, the furthest point reached being the Umgwanya. The circumstances of the first few days of these wanderings may be recounted in his own words as follows, taken from his Journal :-

"October 7th. - Sultry, oppressive day; very cloudy. Packed waggon, and left Inyati about 4 P.M. We passed through bush country, with fine open level spaces, which would be excellent riding ground; some fine old baobab trees in the distance exactly like oaks, with gnarled crooked arms. These trees have dark green foliage, and here and there stand almost isolated. Close; a very disagreeable smell frequent, Hendrik says of black ants. Now and then sweet perfumes from flowering shrubs. . . . As it got dark we outspanned about 7 P.M., having water for our own use in our casks. A large group of men round the fire. We had come perhaps nine miles.

"October 8th. - Mild, cloudy, breezy morning. Crossed the dry beds of two small rivers (branches of the Lelongwe), with a kraal placed between them ; the ground level so far. Men bring ostrich eggs; women bring Indian and Kafir corn and beans. Bought the upper mandible of an eagle from the 
neck of a man, hanging by a thin leather strap. Hendrik says these eagles kill goats. Also bought ostrich feathers and eggs, milk and corn. We had outspanned. Presently resuming the journey, we crossed the third arm of the Lelongwe, and then the reedy bed of a spruit, where we dug in the sand, and found plenty of nice mineral-tasted water, which the men and dogs drank. Reached the site of an old kraal, Intembin, about noon. Hendrik calls these people 'Maholies.' They are far easier to deal with than the Matabele, take what you give them and are satisfied. They asked for red, but took blue, beads, and were delighted with red with white stripe. Stopped to rest at I.I5, and made another trek before night, finally stopping about 6 p.M. near a rather large river, with heavy sand in its bed.

"October 9th.-Overcast, delicious day. Started at 7 A.M., and about 9 crossed the Tchangani-the largest river we have yet seen since leaving Inyati - and outspanned, continuing the journey in the afternoon for about three hours. This last trek was a very pleasant one, over falling ground. As we outspanned (about 4 P.M.), John told me that a 'honey's (bees') nest' had been found by Hendrik. The boys went off, and it was found in the hollow trunk of a large tree, into which the bees went by a hole in the side of the tree. They put fire into the hole, having kindled a small one close to the tree, and then with an axe cut open the trunk. The bees seemed on the whole pretty quiet, and I don't think their sting can be bad, as the men seemed tolerably 
indifferent. The cells, when taken out, proved full of grubs..... One of the boys was carrying two squirrels killed by a dog; another had found roots. I tried the latter, and found them slightly bitter and at the same time sweet. They are chewed and the juice swallowed. The only leaf visible is contained in a small green shoot, apparently just coming out of the ground, but the roots are very large and long. Another boy brought a pretty duiker, which he had killed with an assegai.

"October Ioth.-We seem on a sort of plateau, with lower ground in front. Beyond is high land, blue in the distance. Starting a little before 7 A.M., we reached the Umvungu about 9, a big reedy river with water in its bed. When we arrived one of the boys was calling out, and we found he had shot a sable antelope. Many flowers are now springing up in the veldt, and the tints of the trees are very lovely, reminding one of an English spring, or, in some respects, of autumn; different shades of green and yellow. In the course of the afternoon we entered very thick bush, the thickest I have yet met with in South Africa, and more like English wood in general appearance than what we have hitherto seen, the trees budding with delicate tints of fresh green, brown, and yellow. Soon after entering the bush fresh elephant spoor was announced-the first I have yet heard of - and a few minutes later we came on a broken tree lying across the road, and more fresh elephant spoor. Emerged from the thick bush about 5.20 P.M., and soon afterwards outspanned at a spruit." 
The following day (October I I) the party reached the Gwailo River, which was crossed without difficulty. A half-caste Cape man, who was hunting here, named Nelson, rode up and gave a very bad report. He had shot fourteen elephants in two months, and a few ostriches. He said the Mashonas, hunting the elephants with their assegais, and shouting, had driven them away. His plan now was to go to Damaraland, vi $\hat{\imath}$ Lake Ngami, where he had been before and found elephants abundant.

Resuming his journey in the afternoon, Frank Oates now struck across the veldt to the south-east, and crossed the Umgwanya River the following morning, proceeding afterwards a few miles up its banks. At this point he had intended to encamp for a few days; but hearing from two natives who came to the waggon that there were still elephants in the thick bush which had been passed through the day before, he felt tempted to return there; and on the I 3 th, re-crossing the Umgwanya and Gwailo Rivers, in a more direct line than he had taken coming, went back in the direction of the Umvungu. "A boa-constrictor," he here writes, "six feet six inches long, and as thick as my wrist, lay its length upon the ground, and was skilfully transfixed by one of my boys' assegais, and pinned to the ground. The lads were evidently afraid of his bite, but the men say that it is harmless. . . The Mashonas use these snakes as an article of food."

Next day the spruit which they had outspanned at on the Ioth, near the thick elephant bush they 
were making for, was reached, and here, a short way off the waggon-track, under some remarkably picturesque kopjes, the landscape all budding with the green of spring, a camp was formed, where the party remained about a fortnight hunting. The boys made themselves some snug huts of branches and dry grass to sleep in. Here the Journal again takes up the story :-

"October I4th.- ... Nelson came up to the waggon when we were outspanned. He had not left, but had stopped about near the place where we had outspanned when we first came through the thick bush. He had come on a herd of many (he says forty) elephants, driven six out of the herd, and shot four, but lost two of them-one a large bull. He had killed two bulls. This occurred the day before yesterday. I walked away with him in the evening towards his waggon. We found some nests of amadavats - the little pink ones, I fancy. Some were in course of construction, some finished; all hanging like fruit from a tree. One I took contained two eggs, white speckled with red. Macloule ${ }^{1}$ gave me this evening two goatsucker's eggs he had found, partly sat on. The nest is very slight, and plaçed on the ground. ${ }^{2}$

1 The guide.

2 Frank Oates collected, during his wanderings, a considerable variety of birds' eggs and nests, some of the latter very remarkable in their construction. Two of these are represented in the accompanying woodcut, the first of which-probably that of an Egithalus or Penduline Titmouse-is of the consistency and texture of fine blanket, and nearly white in colour. It appears to be made from white cotton, or 
"October I 5 th.-Woon after 7 A.M. started with boys to hunt. . . Maqueban found the carcass of an elephant killed a few days ago. The two teeth-one broken, but as heavy as the other-weighed together

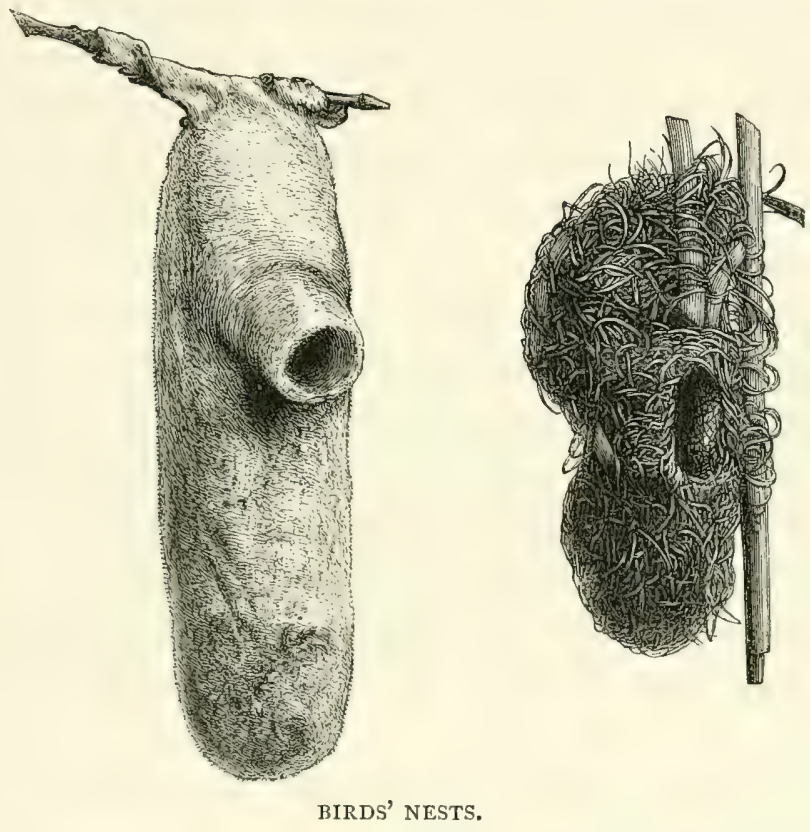

20 lbs., as I found afterwards. The boys rushed to the carcass, and were soon at work dismembering it. It may be one of Nelson's, but my boys think it died before Sunday (the day Nelson killed his). A great many kites flew sweeping round. It was a regular scene, such as one sees in pictures, the Kafirs at work cutting off trunk and feet and strips of flesh. some similar vegetable substance. The second is ingeniously composed of the finer portions of reeds, in the manner of close basketwork, and is found in great numbers along the banks of rivers, and in marshy places, affixed to the rushes. 
It was a cow elephant, and vultures and other creatures had got the end of the trunk and what they could without breaking the skin. Fires were lighted and meat cooked and devoured, whilst large pieces were put aside for removal. When the filth was extracted from one of the tusks, 'Sassaybi'" threw back his head and held it up first to one then to the other nostril. This is supposed to be a good thing for any one troubled with nose-bleeding on hot days. Sassaybi likewise scraped some stuff like cobbler's wax from where the tusk is inserted in the skin. He said it was to be used as a charm. . . . As we travel through the bush Indian file, returning to the waggon, Echle (the chief hunter I have with me), meeting a small tortoise, picks it up, spits on it, and puts it to his forehead. He says this is lucky when you want to get elephants, and he says, however large the tortoise is, this is done. $\mathrm{He}$ is then allowed to walk off.

"October I6th.-Shots heard near the waggon early, and Nelson arrives, having shot a fine bull eland quite near to my waggon. He says he was looking for elephant spoor when he found the eland, and drove him seven miles. He is a mighty brute, bigger than an average bullock. The hide is very thick. We had breakfast on eland steak fried in fat, and enjoyed it very much. Nelson says, when in Damaraland, he got a young elephant, but it died from neglect coming through seventy miles of the 'thirst land.' He says they are easy to keep, and so

1 One of the boys. 
are young ostriches. The latter can be driven with the bullocks. He says there are plenty of crocodiles in the river beyond the Gwailo.

"Nelson showed me, when we were out together in the veldt the day before yesterday, some remains of Mashona huts destroyed by the Matabele. He says they are to be found all over the veldt, and bones amongst many of them. Some of the Mashonas are subject to the Matabele. Those that refuse allegiance are mercilessly hunted down. They are all formed of independent little tribes, and when war is made against one the others don't assist them. Therefore they fall an easy prey. The impeys sent out against them for their cattle are what I heard of at Gubuleweyo. Nelson says lately in an impey a kraal was taken, the young men killed (they throw away their scanty dress and run and are killed 'like springbok'), and the old men and women burnt to death. The young women and children were made slaves of, and the cattle taken. Nelson's Matabele boys wanted him lately to drive off some cattle, saying the king might give him fifty of them, but he refused. The cattle and all the animals are kept in the same place as the Mashonas themselves live in (the same house, Nelson calls it). They are thus easily surrounded by the Matabele. The Matabele despise those who own allegiance to their chief, and call them slaves. One of the latter in Nelson's employ blew his face off with some gunpowder, doing something for his master on one occasion. 'Never mind,' said Nelson's Matabele, 'it is nothing, he is a dog' (the usual 
epithet). The man's father came to Nelson and asked to be paid, and was quite satisfied with a few coils of brass wire. Once, when Nelson killed a rhinoceros, a number of Mashona came for the meat and began fighting. They would cry, "This is mine,' 'This is mine,' and two were killed. Nelson went away, feeling, he says, quite frightened at the scene. An assegai was thrust into one man's heart by another who was quarrelling with him before Nelson's eyes.

"In Damaraland, he says, the Bushmen are much better to get on with than the Matabele are here. They work for you like slaves for a little meat. They are under independent petty chiefs, and bring magnificent ostrich feathers for a small strip of limbo or other very trifling payment. From what Nelson says, it must be a capital place for the hunter, ivory being large, white, and plentiful, and easily got, and the natives most willing to assist.

"October I 7th.-Sleepless night; dogs barking at hyænas. I was kept to the waggon yesterday with a sore heel, and to-day did not go far. Nelson came to the waggon in the afternoon. He tells me that, on the opposite side of the road, about ten miles away, is a 'fountain,' ${ }^{1}$ with one or two waters intervening, and plenty of game. $\mathrm{He}$ does not know whether the king allows any one to go into this veldt; but it is a good country for a waggon to travel in. . . . I went out with him a little in the evening. He says he has seen two elephants' tusks 
from near the Zambesi of $70 \mathrm{lbs}$. each-the largest he ever saw. He has seen an elephant with four tusks, and a Boer he speaks of shot one with eight; one of 70 lbs., the others of about 2 lbs. each.

"When Nelson was a young boy, his father, he tells me, trading near Sechele's, being at feud with the missionary there, who had surrounded his waggon with forty Kafirs, and incited them to seize his goods, he determined to blow them up; but, in applying the light to the inside of the waggon, where was a lot of gunpowder, he was not quite quick enough, and was himself blown up with the missionary (a German) and the Kafirs. Nelson himself lay many hours on the ground insensible, much scorched. He had been standing close to the front wheel ; his father was on the frontbox. Nelson must have escaped thus lightly almost by a miracle. When he came to himself, he saw the wreck, his father and the Kafirs lying dead, and was pursued and fired at by Kafirs. The bullets passed close to him, and the Kafirs pursued, but could not catch him. He has still scars on his legs, made in passing through the thorns, and one on his face, caused by the explosion. He spent three days wandering in the veldt without food, but, it being the rainy season, he had water, and on the fourth day he came to a waggon.

"There was a scene to-day when Nelson's two boys, who claim the ivory we got the other day, came to the waggon. Nelson told me not to give it 
to them, but did not want them to know he had given me this hint. The ivory, it seems, would not be his anyhow, as the king's man who is with him hunts on his own account and would claim it. My boys were resolute to keep it, and we let them fight it out by themselves, which they did very noisily, finally saying it should be referred to the king. It seems to me that, picked up in the veldt, it belongs to the finder, unless the shooter has followed it up himself. This Nelson says his men did not attempt-though he advised it-saying it would be useless."

From this time till the $27^{\text {th }}$ of the month, the party remained in the same camp, making frequent excursions thence in search of game, first in one direction, then in another. Here they met with more quagga and sable antelope than any other game, but there were also eland, koodoo, and sassaybi, besides some of the lesser antelopes and wild pigs in abundance. "Near the spruit on which we stand," writes Frank Oates at this point, "is the most really picturesque bit of craggy and sylvan scenery I have yet seen. Our present camp indeed is far the best in that respect we have ever yet had. It is now spring, moreover; the first rains have fallen, and refreshed nature is beginning to resume her long-lost garb of green."

The following quotation from the Journal of the I 8th gives a pleasant glimpse into one of their longer rambles from this camp:- "Started about 7.30 A.M., 
and walked nearly three hours, first through the thin, then through the thick, bush, striking a path during the walk which we followed to the south-west, and which brought us out under a huge spreading baobab, the largest tree I have yet seen since leaving Pietermaritzburg. They call it the 'Indunas' tree,' for here the indunas from the neighbouring kraals are wont to sit and drink beer when anything particular is on hand. The huge trunk is blackened all round with fire, but the tree seems uninjured, and spreads its huge canopy from a framework of crooked boughs, like a gigantic oak. Stretching my arms round the tree at the height at which I stand from the ground, it took me four times, all but about a foot, to encircle it-say about twenty-three feet for its girth here, but below this it is much more, as it increases towards the roots. Other trees of the same kind stand about, but they are less. A splendid view, such as recalls Wharfedale to the mind, here suddenly bursts in sight. The Umvungu River flows in the valley; at our backs is the thick bush, through which we have come; but before us stretches the green vista of woods far away, till it becomes blue in the distance. We waited here about two hours, and returned as we had come."

In this way the whole surrounding district was gradually traversed. The weather during the stay at the present camp was already beginning to be wet, and there was no improvement in this respect, but the reverse, from that date. On the 27 th, 
moving their position, they again encamped a few miles further to the westward, where they remained till the middle of November, hunting the district, and at times leaving the waggon for some days together. Elephant and giraffe were met with on this occasion, the rest of the game being mostly the same as that found near the previous encampment. The chief trophy of the chase here obtained was a fine bull elephant, its tusks weighing together Io8 lbs.

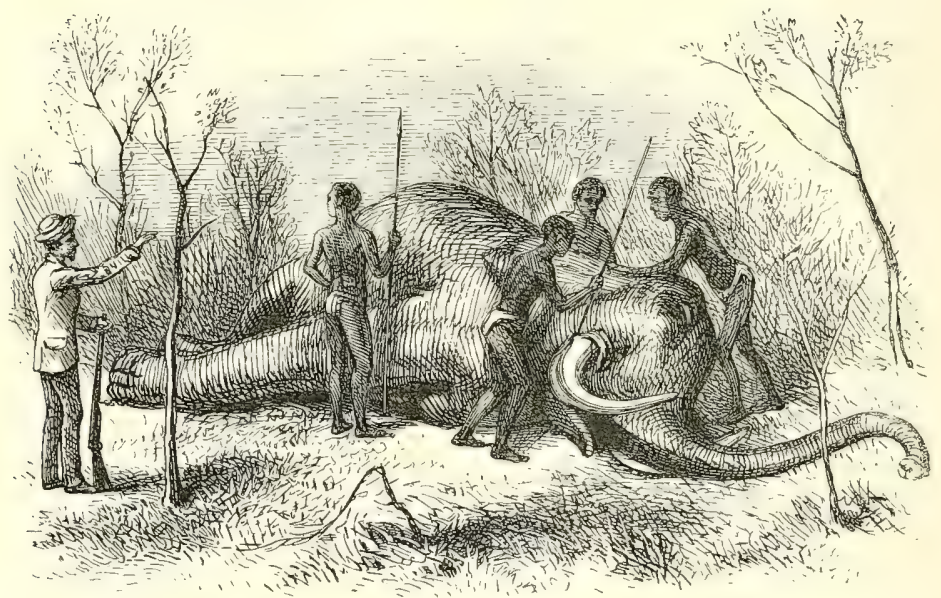

THE FIRST ELEPHANT.

An eclipse of the moon occurring during this period, an opportunity was afforded of observing the effect of this phenomenon on the minds of some of the party. " "Soon after sunset," writes Frank Oates on November $3 \mathrm{~d}$, "the moon rising, I think, a little before, I noticed the upper part of the moon, indeed 
all but a small crescent nearest the horizon, covered with a dingy, smoky shadow. It was an eclipse. I asked John what it was. He said, 'Smoke.' The moment it was shown to Macloule he uttered a cry of conjuration, as it were, and rushing out with a brand, threw it in the direction of the moon. His explanation is that we shall hear something; all the hunters out in the veldt will now return home to hear the news. People are looking at it in Gubuleweyo, England, everywhere. It is a custom, it seems, at all the kraals, when an eclipse is seen, for the people to rush out and throw brands, shouting at the same time. When I suggested a shadow on the moon, he dismissed the suggestion summarily, and when asked to explain the appearance by any other cause, said the moon was changing colour. As the eclipse progressed, I pointed out to him that the shadow kept rising, and more and more of the moon becoming visible, but he only said, 'It looks bad now.' I looked through the telescope, as it was nearly over, to note the exact time of the shadow passing away. Echle took a hasty glance through it, and turned away quickly, saying he did not like to see it."

By the middle of November, when they left their second camp, so much rain was already falling that hunting became difficult, and a return to Gubuleweyo was decided on. Starting back, therefore, on the return journey on November I 6 th, they reached Inyati, travelling slowly, on the $23 \mathrm{~d}$. Here Frank 
Oates was detained about a week, having much trouble and annoyance in paying off the boys he had engaged there for the hunt early in October, and it was the $2 \mathrm{~d}$ of December before he once more found himself at Hope Fountain, near Gubuleweyo, the residence of Mr. Thomson, whence he wrote home the following letter:-

\author{
“Rev. J. B. Thonison's, \\ "Hope Fountain, Matabele Land, \\ "December 4 th, I 873 .
}

"I find there is a good opportunity of writing a line home, as a trader is going with a waggon straight to Hope Town, and starts to-morrow. He has only been a fortnight coming here from $\mathrm{Ba}$ mangwato, so he travels pretty quickly. You will, no doubt, before you get this, have received the last letter I sent you, in which I think I told you that my visit to the Victoria Falls had been abandoned. I was within 150 to 200 miles of them, and had made every preparation for the journey, having got the king's leave to proceed, escorted by one of his chief men, and was already packing the things for the bearers to carry (twenty was the number I required, though I should have been content with fifteen), when all at once the unforeseen difficulty of getting a sufficient number of them presented itself. The king had told me there would be no difficulty, but I was then fifty miles from him, having taken my waggon to be left at Inyati, whence I was starting 
on my walk to the Falls. I see now clearly enough that I was deceived by the man who was given to assist me, or by the headman of Inyati, who had made no attempt to get the men for me, but lulled me with fair promises, whilst in reality doing all he could to prevent my obtaining them. The fact was my guide did not wish me to go to the Zambesi ; partly, no doubt, because they would have had to hurry more than might have been agreeable, but principally from fear of the fever, of which they have a great dread. The king, however, knew what he was doing when he assured me that for two months to come there was no danger whatever, and this was far more time than enough to accomplish my muchdesired object.

"I have now spent two months in the neighbourhood of Inyati, sometimes leaving the waggon for days, and sleeping in the veldt. This was always satisfactorily managed even on a pouring wet night, as the Kafirs in a few minutes build you a hut of branches, perfectly water-tight, with a bed of dry grass upon which to place your bedding. Two Englishmen, tourists, have visited the Falls this season, and I hear that one of them said they were so fine he would rather walk barefoot from Durban to see them than leave them unseen. (Mrs. Thomson, finding me writing in the dark, has just sent Mr. T. to me with a candle, which I hope will improve the style of my letter, for I fear it wants it.) The old guide, who was given me by the king, and 
whom I suspect of doing me out of the Zambesi, was very anxious for me to go to the king to-day, as he has to deliver me back to him in person, and never lets me go out of his sight for a moment if he can help it. This opportunity of writing home, however, is keeping me this evening.

"My old man is the cousin of the king and nephew of Mosilikatze, and the king sent him with me as a special mark of favour. If any harm had befallen me he would have been held responsible, and with most fearful zeal did he fulfil his office. He would never let me sleep without a hut, or do anything he deemed imprudent or unhealthy, carrying his care of me to such a pitch that it was often a very great bore. I am told that if I go away again into the veldt either now or years hence, I shall have to go with this same man, Macloule, or, should he not be living, with one of his sons. I would have forgiven him everything if he had taken me to the Victoria Falls.

"A puppy has been added to my establishment. It was one of a family born in the veldt, on the banks of the Gwailo River, and, with its brothers and sisters, carried over its master's shoulders in a small bark cage when we were on the move. I had several narrow escapes of being bitten by the mamma, who hated me, though I always did my utmost for the comfort of the family.

"I have still two of my original four dogs with 
me, one of which is a great favourite of mine, and one pony. The time is approaching when horses that have not yet had it, get the horse-sickness, which it is a great chance they get over. A good 'salted' horse, or rather pony (that is one that has had the sickness and recovered from it), is worth $£ 50$ to $£ \mathrm{IOO}$, instead of $£ 20$. The king has been telling people to ask me to sell him my pony, and he also wants a gun of mine, for which he has put aside two huge tusks of ivory, double its value. He has been inquiring very much for me, and is anxious to see me back. Tea is nearly ready, so I will now say good-bye. I am anxiously looking forward to getting letters in two or three months at latest. My letters are all to be forwarded to me and await me at Bamangwato."

The day after writing this letter Frank Oates took his waggon on to Gubuleweyo, and once more drew it up in front of Mr. Fairbairn's scherm. The recent rains had wonderfully freshened the country since the outward journey, and the last trek, made through a green meadow-like district, recalled to the traveller's mind the aspect of the country round Oxford in early summer.

The vegetation had of late been frequently remarkable for its beauty, and a number of flowering shrubs, many of them sweetly scented, had been observed from time to time. Flowers of other kinds were also becoming plentiful, and many varieties of wild fruit were met with. 
Some of the latter Frank Oates describes at the Umvungu in his Journal :- " There is a kind of fruit growing in trees here," he says, "which the boys get very eagerly. It is really excellent. It is about the size of a large walnut, with a hard case cleft in four, inside which are glutinous woody fibre and seeds. The seeds are thrown away, and the fibre chewed. The latter contains a large quantity of sweet glutinous matter, the part rejected looking just like wood. There is also another excellent fruit," he continues, "not uncommon, which grows on a small tree, and is larger than a very fine orange. In shape it is spherical, and the outer case, which is hard, is easily broken, and the contents laid bare. The pulp that surrounds the seeds is the part eaten. This is brown in colour, and deliciously acid in flavour, reminding one a little of roasted apple. The pulp of one of these fruits forms quite a refreshing little repast. I believe they are common near Pretoria, - so John tells me, - and no doubt are found all over the veldt. The boys always make a great rush to get them. When quite mature the outer rind is yellow, and they seem to fall to the ground as soon as they are thoroughly ripe."

The description of the first of these fruits corresponds closely, it may be remarked, with that of a fruit named "manéko," which was met with by Livingstone near the Zambesi, in the centre of the continent. The last-named is of frequent occurrence in Zululand, where it is called "inhlala" 
(famine), from its value to the natives in times of scarcity.

Besides these, other fruits were also met with in the district, including a sort of wild grape, acceptable enough on hot days, but somewhat deficient in juiciness and flavour.

No great amount of game was seen upon the journey.

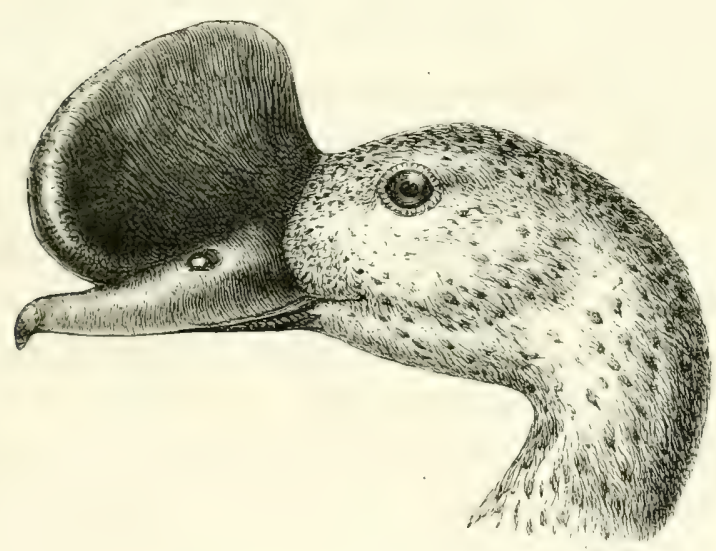

KNOB-BILLED GOOSE. - Sarkidiomis melanonotus. 


\section{CHAPTER V.}

Stay at Gubuleweyo-New Year's Day-The Great Dance-Cattle slaughtered-Departure of the king; the royal procession-A dispute referred to him-Lobengula's court.

Frank Oates remained at Gubuleweyo or in its immediate neighbourhood some time-from December 5 th 1873 to January 26th 1874 . This was considerably longer than he had originally intended, but he was partly detained by the weather, which, besides being close and oppressive, was for a long time very wet and unfavourable for travelling, and partly that he might see the Great Dance, which took place in the early part of January. After this some trouble with his servants still further delayed him, as the case of one of them had to be taken before the king. He was able, however, meantime to make some additions to his collections of birds and other objects of natural history, though owing to the state of the weather he attempted little hunting; indeed, near the kraal, large game was invariably scarce and wild.

The incidents of the first part of his stay-until the end of December-were apparently of little in- 
terest. After that came the preparations for the Great Dance, which took place on the Sth of January. The following day dancing was again continued, though with much less ceremony, and the Ioth was the day appointed for a state slaughtering of cattle-one of the annual customs gone through at this season. This over, the king took his departure next day for a neighbouring abode of royalty. Commencing with the new year, the entries in the traveller's Journal, with some particulars of the above events, stand as follows:-

"Famuary I st, I874.-Intensely hot, as yesterday was, and as they say it will be till the rain falls. Sent bullocks to fetch wood for making a scherm, having engaged John Jacobs and two Kafirs by the day. Rode over to Thomson's to dinner (two and a half miles) and lost myself amongst the kopjes. The fine hot day and the luxuriantly green country and rapidly-growing Indian corn make it seem more like June than New Year's Day to me. Petersen, Fairbairn, and Mandy went to Thomson's in cart, and we sat down to a most excellent dinner-roast and boiled mutton, potatoes, cabbages, and turnips, plum-pudding, and mince-pies. Such dinners as this and my Christmas dinner at Petersen's are worthy of notice, considering how few and far between they are. Pleasant evening just before and after sunset; moon nearly full.

"Famary 2d.-Fine hot day; heat, however, by no means so oppressive as it has been for the last day or two, on account of a pleasant breeze. Un- 
packed the front-box of my waggon. King called, and asked for his bottle of brandy and some large shot. He afterwards sent a boy for the brandy, whom I accompanied back to the king's, and having given the brandy and shot, offered him six muskets I had been hoping all this time to sell him, and without any trouble got four fine elephants' teeth for them, about $\mathrm{I} 5 \mathrm{O}$ lbs. of ivory altogether.

"Fanuary 3d.-Moonlight night-full moon, I think. Looked out early; the moon was still gorgeously bright, and surrounded by a halo of light in a violet sky, studded here and there also with a star. In the east was the deep red of approaching sunrise. Morning at first slightly overcast and tolerably cool, but the day soon became very hot, though tempered somewhat by the wind. Decided to have a new sail made for the waggon. Myers working at the old framework, patching it up. Having things out of the waggon, and also out of the tent (as I was rearranging the latter), I stayed about a good deal, not trusting John. A lot of cheeky 'majachas' (warriors) about. Whilst one of them was selling me honey, a lot came in, and I saw one abstract a knob-kerry of rhinoceros horn from under the waggon, and throw it out of the scherm. $^{1}$ He then ran away, seeing himself de-

${ }^{1}$ These knob-kerries, which answer the purpose of a life-preserver, are made of various kinds of wood or of rhinoceros horn, and carved according to the fancy of the maker. They are sometimes adorned with beads (see one of those in the woodcut), but the more ordinary form is that of a short stick with a single rounded knob at the end, to give it weight. The natives can throw them a great distance with 
tected, but did not go far, and afterwards came and stayed outside the scherm, asking for a 'tonso' (present). However, this must have been mere bravado, as he was too much on his guard to give
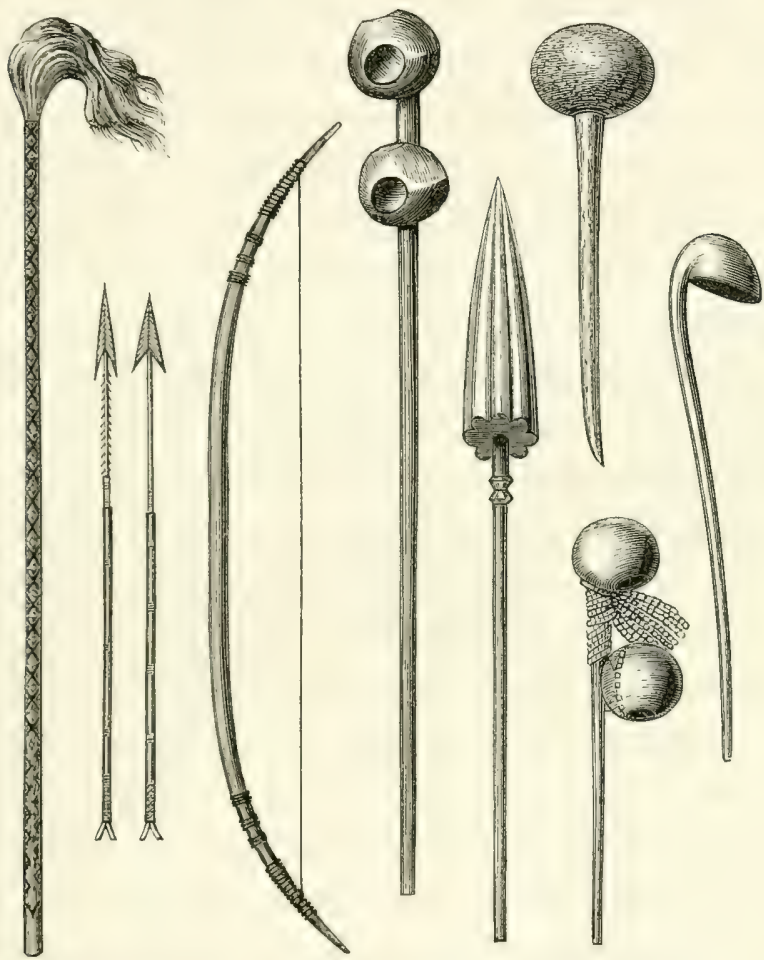

DANCING-STICK, BOW AND ARROWS, AND KNOB-KERRIES.

me a chance of thrashing him, and when I removed a bush for him to come in, only came in a foot or two, and bolted when at length I approached him. I bought guinea-fowls' eggs, some tobacco, and a dancing-stick. The second of the two sheep bought marvellous accuracy, being often able to bring down a bird on the wing with one of them. 
for a cotton blanket and a shirt was killed this morning. It is wonderful what a lump of fat the tail is. A miserable little famished boy, who, they say, was picked up in the veldt and belongs to the king, came into the scherm on being invited, and had food. He speaks by nodding his head. He is a pitiable object, and coughs. . . . Wind rose high at night. Mutton and guinea-fowls' eggs for supper. There are plenty of 'majachas' here now. They are everlastingly dancing. This seems to be their . whole drill.

"Fanuary 4th.-Cool cloudy morning; a little drizzling rain. There are caterpillars here of many very pretty varieties. Old well-known forms both of caterpillars and moths are reproduced in this country, with a change. The king sent me a caterpillar lately-green, with green moss-like horny tufts; a flesh-coloured stripe on each side; on the back a row of snow-white spots, circled with rich blue, and white spots also along the sides. A long string of people came this morning from Inchlangin for the dance. Macloule called on me soon after his arrival; and again in the evening, when he asked me for a blanket, saying he had lost a child through going with me, and had missed the time for burying it. I sent him away till to-morrow. The day has been cloudy and cool, but fair and delightful.

"Fanuary 5 th.- Hot day, and though there was a good deal of wind I felt the heat. Gave Macloule a cotton blanket. Myers and Hendrik working at my waggon sail. Took Hans, and went to king's. 
Dance going on, consisting of the men of two large kraals, forming a circle, ' marking time,' and waving sticks, whilst the king, with rhinoceros-horn knobkerry, acted as bandmaster. There was also singing. Nina ${ }^{1}$ requested me to stand up and join, which I did. Every now and then a man rushes out into the space in the middle, shaking his shield and brandishing his assegai, enacts his fighting, and shows how many he has killed, whilst loud shouts are raised on all sides. The usual dress consists of a head-dress of black feathers, and a bunch of monkeys' tails round the loins, with white frills of ox-tails on the arms, and (in the case of veterans I suppose) a long solitary feather to top all, and a piece of fur round the head. The king had on a broad-brimmed black felt hat, a huge bunch of monkeys' skins round his middle, and carried an Elcho sword bayonet (my present) and a rhinoceros-horn knob-kerry. When the dancing and singing was over, the men defiled past the king in companies, singing a monotonous but not unmusical chorus, which they accompanied by rapping their shields with their sticks, producing a dull heavy sound. Strings of girls bore huge calabashes of beer, under the weight of which some of them staggered, to the kraal. For the most part they were magnificent specimens of shapely young Kafir women. A tall handsome girl, who has been sometimes begging at my waggon, was a looker-on, and presented a fine picture of a well-developed savage

\section{A sister of the king's.}


woman. She seemed fully aware of her own striking appearance. A lot of old Mosilikatze's wives sat watching.

"There is a good deal of wind to-night, and the moon is obscured by dark gathering clouds. Tonight, after I left the king, I was standing beside a group of Kafirs cutting up the carcasses of two oxen just killed, when the king's dogs made a set at me. Afterwards the boys came to my waggon asking a tonso for calling them off. I suspect they set them on on purpose.

"Fanuary 6th.-Intensely hot, and though there are clouds, the rain still keeps off. Sent John with Wankee to cut a tree for a dissel-boom, and he says the axe was taken from him on the pretext that they must not cut wood now, and that the axe would be returned. . . . I asked if I could go shooting, and they say no, not till the dance is over.

"Famary 7th.-Sky overcast, but the heat is still intense. Crowds of people about, as yesterday ; difficult to keep the scherm clear. Dancing going on at the kraal. Heat insufferable. The tent was a furnace, but at sundown there was a little thunder, and it was pleasant and cool. A beautiful mildlooking rose-tinted sunset.

"Famary 8th.-Day of the Great Dance. Very heavy rain fell at sunrise. As rain fell, girls bathing in rain-holes. Things in tent got very wet, and it was late before I could come out and begin to dry them. The heat soon became great, but the sun kept being more or less obscured by clouds. I 
learnt it was the day of the Great Dance, and hurried the drying and locking up of my things, so as to be ready to go and see it. Some majachas came out, and had a row, and bruised one another near my waggon.

"As soon as I had finished packing I joined the Thomsons, whose waggon had drawn up in front of Myers's store, where the dancing was to be. Meantime, Thomson says, they had been going through ceremonies at the kraal, where dancing was still going on, but very shortly they expected the king and people out. However, Thomson and I went to the kraal to see, and were well repaid. In the midst of a large circle formed by warriors, four wives of the king, dressed all alike, and modestly covered, were dancing, or rather slowly pacing. Each had a checked print over her shoulders, and a black skirt reaching low down. With them was a future wife, partially clad in gaily-coloured calicos, but without skirt. The wives, Thomson says, are very nice women. As I went with him through the crowd, I could not help seeing what respect is shown him, and how all make way for him.

"Suddenly the royal sisterappeared, and presented a most singular, not to say magnificent, appearance. It was something like the appearance of the prima donna at the opera, or the leading spirit in some gorgeous pantomime. She is very stout, and tremendously en bon point, and her skin is of a coppery hue. She wore no dress, and the only covering above her waist was a number of gilded chains, some encircling 
her, some pendent. Round her arms were massive brazen bracelets. A blue and white freemason's apron appeared in front, and looked strangely anom-

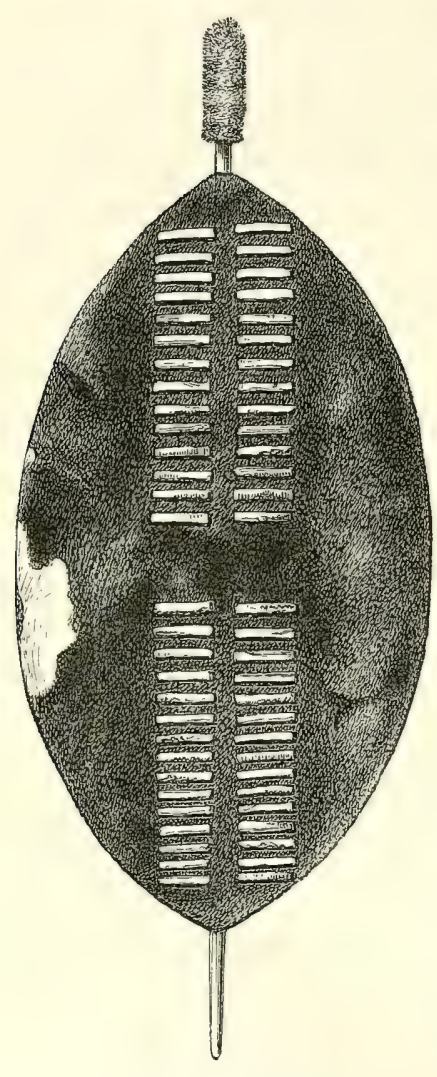

OX-HIDE SHIELD. alous there, though really not unbecoming. From her waist also there hung down behind a number of brilliantly-coloured woollen neck-wraps, red being the predominant colour. Under the apron was a sort of short black skirt, covering the thighs, made of wrought ox-hide. Her legs and feet were bare, but round her ankles were the circlets of bells, worn by the women to make a noise when they dance. Her head-dress was decidedly pretty - a small bouquet of artificial flowers in front, and amongst the hair, standing in all directions, feathers of bee-eaters' tails. A small circular ornament, fashioned out of red clay, was on the back of her head. She put herself in posture for the dance, but did not move very much or energetically whilst keeping time; she suffered too much from adiposity. She held one of the large oval black 
and white ox-hide shields, surmounted by a jackal's tail, such as are carried by the warriors. The wives held long slender wands upright in their hands. The men, when they dance, usually carry a carved stick, with which motions are made, whilst it is generally held upright. The girls carry very pretty brooms, which they likewise raise and move about to time; but the girls' dances were yet to come.

"The dress of the soldiers is very striking, and suggestive of savage warfare. Over the shoulders, and continued into a sort of hood, which either surmounts the back of the head, or hangs loose behind the neck, is a large fabric of jet-black ostrich feathers. Around the forehead is a circlet of tawny fur, and a single long steel-coloured crane's feather rises above, giving a most artistic finish to the picture. Around the loins are a collection of monkey and cat skins, dangling in long strips, together with a number of tails, some of the latter nearly large enough for those of leopards, which hang in thick bunches nearly to the ground. Around each arm is a graceful, wavy tuft of white ox-tail hair, and sometimes the same around the legs. Very little limbo is worn, unless a strip or two-usually of blue selampore or white calico, well worn and defaced -around the waist. The shield and assegais complete the picture. $^{1}$ If all were uniform in appear-

1 The woodcut on the succeeding page illustrates a variety of different assegais. The heads of these weapons are wrought by the natives themselves, and fastened to the shafts by strips of raw hide, which shrink in the drying, and become as hard as a band of iron. The length of the shaft is usually from three to four feet. 
ance the effect would be much heightened; but unfortunately the dress is not de rigueur. Some omit the fur round the forehead; some both fur and

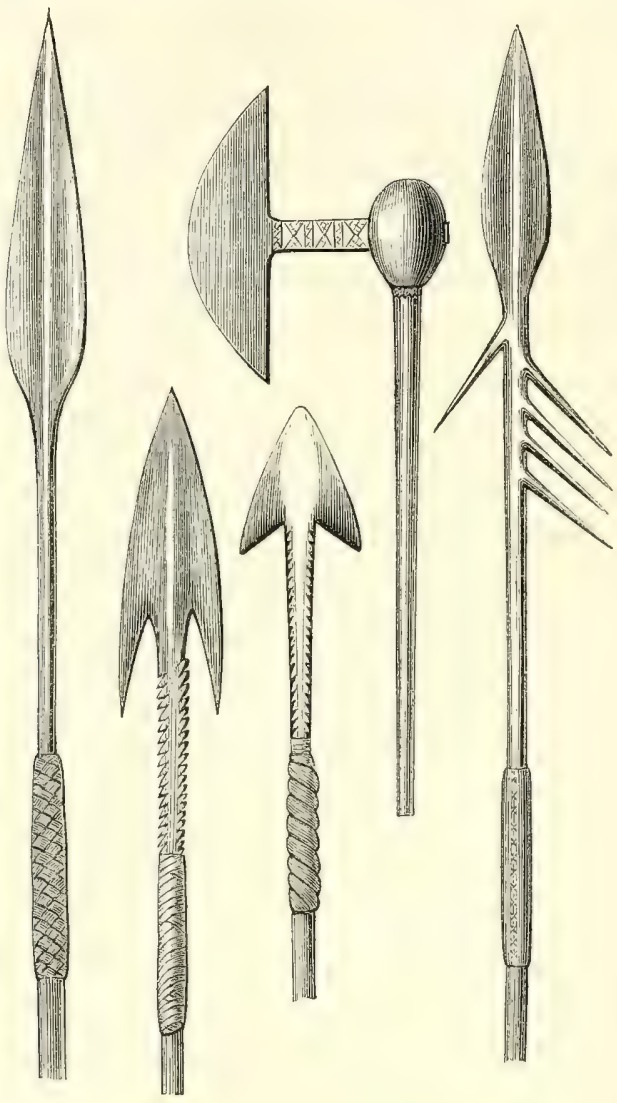

ASSEGAI-HEADS AND BATTLE-AXE,

feather; and some of those in command have even shabby shirts or hats on, contrasting badly with the fine warrior costume of the majority. The only military evolution gone through is marching past in kraals, or what we should call companies, the men 
singing, dancing, and making some most unearthly and awe-inspiring noises the while. One sound is produced gutturally, and resembles the low growl of a wild animal. Another is made by striking the shields-a sound resembling distant thunder. Then they have a way of whistling, not unlike the cat-calls of a London theatre. During their dances a warrior rushes out into the middle of the circle from time to time, and goes through the pantomime of his late exploits, brandishing spear and shield, and rushing wildly about. He denotes, by repeated thrusts, the number of people he has slain, whilst the surrounding warriors shout loudly.

"Standing about are many pretty girls in most fantastic head-dresses, worn only on special occasions, and highly prized. Predominant is the pink bead, appropriated by the royal family. A small group of waggon-drivers, either those who have come up here with white men, or who belong to the doctor's party, whose waggons accompany the king in all his movements, are dressed to the height of fashion-as near as they can manage it-in European dress, for which the stores of the place have been ransacked, and high prices paid, no matter at what sacrifice. One has a chimney-pot. These fellows are usually the greatest scamps in the country-idle, vain, insolent, and vicious. The king is dressed much like his warriors, and looks himself. $\mathrm{He}$ is a fine-looking man, and has an agreeable expression and a ready smile. He is one of the darkest-complexioned people I have seen belonging to this nation. 
"Now Thomson tells me we must make haste and return to the waggon, as the soldiers are beginning to march out, and they are all going outside, accompanied by the king and his court. We return, and the troops march out and take up position in a huge, dense circle outside the kraal. There may be three, four, or even five thousand of them, and perhaps ten thousand people in all." ${ }^{1}$

"Fanuary gth.-Hot day; short heavy shower in the afternoon. Dancing at the kraal-second day (or was Wednesday also a day? If so, this is the third). Different parties dancing; majachas and girls separately, though in some cases girls are introduced into the majachas' dance. King had waggon taken out by Kafirs. Selous ${ }^{2}$ looked at my guns. Rain came on, and he sat in my tent. He tells me how he was once lost between Bamangwato and Tati for four days. He had had a cup of coffee, and gone out hunting. That night he slept in the veldt; it was July, and the nights were very cold. $\mathrm{He}$ had only a shirt and trousers on, and had no matches. He used his last three cartridges in trying to make a fire. The second and third days he still wandered. I think it was the end of the second day that he lost his horse. The evening of the fourth day he came to Palatswe

${ }^{1}$ Here the day's entry ends abruptly, with only a few brief notes intended for the writer's future guidance, and unavailable for another's use.

2 This gentleman, Mr. F. C. Selous, had already been out some time hunting in South Africa, and was subsequently again met with by Frank Oates near the Victoria Falls. 
water, and got milk of a Kafir. He walked back next day to his waggon at Tchagani pool-he thinks about twenty miles. It was on the evening of the third day he reached a hill, by moonlight, whence he saw other hills he knew. Started before daybreak, and that night got the milk. He thinks he could have gone another day without food or water. He had nothing whatever, between the coffee, at starting, and the milk. He carried his gun, perspired profusely, and suffered much from cold at nights. He experienced a difficulty in swallowing.

"A letter from Mandy, at Inyati, to-day, states that he saw a crocodile there the other day, which got hold of his dog, and pursued himself in his bathing hole. It was ten or twelve feet long, he says.

"Dancing in little parties going on all day; the girls very lively in their dance. Bought a goat for about three quarters of a pound of beads.

"Fanuary roth.- - Very cloudy day, inclined to rain. Went up to kraal, where slaughtering was going on. I had heard nothing of it, but the number of bullocks slaughtered this year must have been next to nothing compared with former years. I saw a dozen or twenty down, or being assegaied. The bullocks are driven together, one out of the number being intended for slaughter. The opportunity is watched for to hurl the assegai, which sometimes remains in the ox, who runs some distance before he falls, bleeding at the nostrils, and soon dies. They are stabbed in the region of the heart and lungs. The first thrust is often not successful, 
as it is not easy to hit the victim in the right place when he is in a state of excitement. I went to see the king, who was looking very sulky. There is no dancing to-day. It appears the king is very angry at the fighting of yesterday.

"Fanuary I ith.-Heavy rain very early; a little bright sunshine about breakfast-time, when I partially dried the things that had got wet in the tent, causing me considerable discomfort. It soon came on to rain again, however, and rained more or less during the day. I was to have taken my things out of Myers's store and packed the waggon, but the rain prevented me. In the morning I heard the king was inspanning to go to some neighbouring abode of royalty, and hurried to take him his horse. After handing it over to him, and being told to give it in charge of Petersen, I asked him if he would buy a saddle and bridle, to which he replied, these were always supposed to go with the horse, the saddle being part of its back. However, I hope he won't insist on this any more, and, indeed, I may go away without seeing him again, unless I do so voluntarily. Piet, who interpreted for me, told me that the king is very angry about the disturbance, and will probably kill a number of the people, and for this they think he is going away in such a hurry. There were twelve black, or nearly black, bullocks in the royal waggon, and, when it started, the throne was carried-as it always has to be done-on a boy's head. It is a straight-backed, substantial, and extremely plain, green chair, with red daubs on it. 
Over the back and seat is stretched a piece of lionskin. The dogs rushed off with the waggon, the second waggon started, in the back of which I could seee a lot of meat and two young lambs or kids trying to keep their pins amongst the miscellaneous cargo inside; the majachas started, and the royal procession was on its way. Busy a good deal in Myers's store. Unpacked and packed boxes there, and watched the rain. Terrible soaking wet evening and night. I managed, however, to keep dry in bed."

From this time for some days the weather continued so persistently and miserably wet, that it seemed out of all question to think of commencing the return journey to Tati, which the traveller was now preparing to undertake. The heat, at the same time, was also so intense that any exertion was laborious, and even the occupation of writing was a task. About the 18 th, however, there was some improvement, and two days after this he was ready for a start, when the dispute with one of his servants above referred to necessitated his seeking a fresh interview with Lobengula, whom he followed to his present quarters, but a few miles off, on the evening of the 2oth. This dispute arose from Frank Oates's dismissal of the Kafir driver Dick, who had come up with him from Natal; the latter maintaining his right to retain the services of the young lad Jacob, whom he had originally brought with him for engagement in Pietermaritzburg, and who still accompanied the party. The two appeared to bear no relationship to 
each other, and Frank Oates would have been glad to keep Jacob in his service, but the latter seemed afraid to come, and it was agreed to refer the question to the king. The Journal of this time continues:-

"Famuary 2oth.-Fine, bright, windy morning; a few clouds in the sky. Finished what was left to be done to the waggon, and was going to trek early when Jacob came and claimed his wages, and I decided to go away to the king's to-night, and thence start on my journey. A Kafir woman has also claimed Jacob as her son. Though Jacob asked for his wages and said he did not wish to leave Dick, he half admitted directly that it was only his fear of Dick that made him say so, and that he really wished to go with me. After the waggon was loaded, I waited some time for Jacob's return, he having gone with his would-be mother to the king. He did not come back, and I inspanned for the king's. After about ten minutes' delay in getting off-unruly bullocks and bad trek-gear-started fairly about half-past five, and in about an hour and forty minutes got to where the king is, meeting Jacob with the woman going to Gubuleweyo. Jacob turned back with me. The king has said the woman is not to claim him. It seems she gave Jacob some locusts and milk when he was hungry, for he and Dick have fared badly of late. She then professed to see a likeness in him to her lost child, taken in the war, and he did not deny it, and afterwards she insisted on keeping him. Jacob still says he wants to go 
with me, but is afraid of Dick, and also wishes for his wages, as Dick urges him to get them, though he knows Dick will appropriate them. He will let it be arranged before the king, he says. The sun set as I trekked, and the peculiar aloe-like trees of this country had a fine effect against the glowing sky. I should say this trek is four and a half or five miles pretty direct. The last two days have been fine drying days, but still there are some very soft places in the road. Supped with Fairbairn on some excellent beef, and had a long chat with him. Cool, starlight night, with heavy dew.

"Fanuary 22d.-Fine hot day, but with slight clouds, and at night a heavy shower. Fairbairn had a row in trading with the king, who had chaffed him a good deal last night. A large quantity of ivory had come in (Fairbairn was here by the king's express desire, to trade), and a small tooth had been put down before him. He had made his offer for it, which did not satisfy the king. Fairbairn said, 'It is a small tooth.' 'Did you ever shoot as large a one ?' asked the king. This is considered a poser. Then a hot argument ensued between Fairbairn and the king, through John, the king maintaining that Fairbairn would show unequivocal signs of fear at the sight of an elephant. Fairbairn said white men were not afraid of them; whereupon the king cited, H_- a big man, who had not even shot a little calf; W-, 'Where are the elephants he shot?' Many white men had said the same as Fairbairn, and where were the elephants they had killed ? Then 
Fairbairn referred to Selous, a small man; he had not been afraid, he said. 'Would he tell if he had shown signs of fear, or were you there to see ?' asked the king. Then the king told Fairbairn that he was getting rich and did not want his trade. Fairbairn got angry, and the result was that this morning he had a row. The king sent some large decayed teeth, which Fairbairn bought, and then some other teeth, which he could not buy, and which were sent to Gubuleweyo and sold; but in the meantime the king had offered Fairbairn two small teeth for a doublebarrelled gun, less than cost price, and Fairbairn had left the king in disgust.

"Went to the king's kraal with John, and greeted the king, who was lying in his waggon, but as, after greeting us in return, he took no further notice of us and remained lying, I went away and had a nap in my waggon. Fairbairn afterwards had tiffin with me, and then we went together to the king, but he was still in his waggon-if not asleep, lying invisible; put out, I think, about Fairbairn. We waited long outside the kraal, and at length, near sundown, an induna came in white man's clothing, and with a shield, wearing feathers on his head hanging under his hat, and accompanied by warriors. He, to call the king, began shouting out compliments in a loud voice, amongst which the words 'Mosilikatze' and 'Incose' (king), were frequently repeated, and a request made that the king would treat him kindly. This referred to beer and beef, which of course he would get. At last he finished, and went away 
unnoticed by the king, who, however, soon came out, and Fairbairn, John, and I, went to him, Dick and Jacob following. It was so late that we did little.

"Had supper on Australian meat in Fairbairn's waggon. Rain came on, and I heard showers during the night. When we left the king, he chaffed John, and said he looked weak, as if he was hungry. Last night John had asked for meat, and he said he had no beef and his sheep were poor. He seems really not to be killing oxen at present. Fairbairn has told Nina that we are eating tinned fish. Fish is held in utter abomination by these people, and Nina said her brother ought not to let us eat it. Fairbairn says they used, when they wanted meat, to rig up a dummy fishing-rod, and march off with it, taking care to pass in sight of the king, and the moment he suspected fishing, he would send them a large piece of meat.

"One sees all shades of colour in these people. The Makalakas are much darker as a rule than the Matabele, who are usually coppery red or sometimes yellow. The king, however, is black, and, I believe, about as black as any of his race, and far more so than most. He deserves his epithet of 'black king.' The dogs are a great source of fear at present. They are constantly attacking people, and lately half, if not altogether, killed an induna. Fairbairn says the king showed him his own trousers torn the other day, as proof that even their master was not exempt.

"Fanuary" 23d.-Wretched rainy and gusty morn- 
ing. Nina in Fairbairn's waggon, as she was also a good deal yesterday. She is very fond of him, as of other white men; and is said to wish to marry a certain white trader here, who has left for a time-hoping, I believe, that she may be married when he returns. She can't marry till the king takes his wife from whom the future king is to be born. His present wives have nothing to do with it. “John Lee's waggon arrived to day, to my great pleasure. I had just returned from visiting the king, whom John and I had found standing at the entrance of his kraal in a Mackintosh coat. Dick and Jacob joined us, and the case of Jacob was discussed, Dick also urging the hardship of his own dismissal, in which the king seems partly to agree, and says it would be better not to leave him in his country, but where we can try the case with our own laws. At length the king went to his hut, saying this case would take a long time, and it was not a day to discuss it. Certainly the weather was against a law-suit being carried on in the open air. In the evening I went again to the king. Lee was sitting on the front-box of his waggon, and went over my case with him, and thus I got a decision quickly. The king said his decision had been that I was to take Dick and Jacob, but I had refused to do this, so now I must pay the wages of the boy, as he considered Jacob, having been brought by Dick, was under his protection. I sent for them, and paid the money to the king, who promised to keep it for Jacob as far as he could, though he said if they left 
the country he must then give it up. Supper again with Fairbairn.

"Fanuary 24th. - More promising morning, though cloudy and showery. Fairbairn, Lee, and I, to the king. Fairbairn does a good trade with him after the row. Nina and her friends were eating a large dish of excellent vegetable marrows. The smoke got into my eyes, and Banyai kindly motioned me across the hut. John Lee killed a lung-sick heifer of the king's, and opened her chest with a saw, taking out the liquid which accumulates in the cavity of the lungs during the sickness. With this I helped him to drench some young cattle of the king's. Each has about a small beakerful. Lee says he never lost one that he drenched in this way.

"Fanuary 25th.-Lovely morning. Rose and dressed leisurely. The heat soon became intense, and of that moist character that seems to make it far worse to bear. Felt quite prostrated by it. The wife of Lee's boy, who tried to leave him, and is now undergoing punishment after being tried before the king, came crying to my waggon. Lee drove her away. It appears that the boy had to pay Lee $£ 6$, which the girl owed the latter, before he could have her, both being in Lee's service, as well as the father-in-law, mother, and sister of the boy. The boy told Lee he had paid the money to the king. This was a lie, so Lee demanded the money of the king in the presence of the boy. Thus the offence was shown to be against the king, and 
Lee told the king it was for him to punish it. The two indunas present seized the boy, and he was half throttled, and much knocked about. They would have killed him there and then, had it been Lee's wish. The king said, 'Is he to be thrown out?' which means put to death. Lee, however, said he should be satisfied by the boy being tied up, which was done.... Went with Lee to the king's afterwards. More drenching was going on. I saw the boy tied up; he could neither sit nor stand, but squatted on the ground, his arms nearly on the full stretch, fastened on either side to one of the poles that support the large wooden structures on which meat is piled. When the sun set Lee was told, if he did not give the word to have the boy taken away, he would rot where he was. The king and the indunas then chaffed the poor wretch, as, Lee having consented, he was cut down. He was told that he had been kicking Mosilikatze's bones.

"The scene, with the king sitting on his frontbox, would make a picture: the setting sun; the dark green trees beyond the kraal, and the green walls of the newly-erected kraal; the yellow beehive-like huts; the yellowish trodden grass in the space; the herds of goats and sheep, with lambs and kids, and pack of dogs, crowding round the king's waggon; the group of natives, some all but naked, some adorned with feathers, some with a single article of European dress, as a hat, crouching on their haunches, forming the court of the black king; tusks of ivory lying about. To complete the picture, a white trader or 
two should be introduced, not above crouching before his sable majesty, who sits there in his broadbrimmed black felt hat, pipe in mouth (a small briarroot, worth perhaps 2 d. at home), cotton shirt not over clean, unbraced baggy trousers, and large clumsy shoes, a benignant smile generally on his black face."

The day after this the king took his departure for another place, John Lee left for Mr. Thomson's, and Frank Oates started back to Tati.

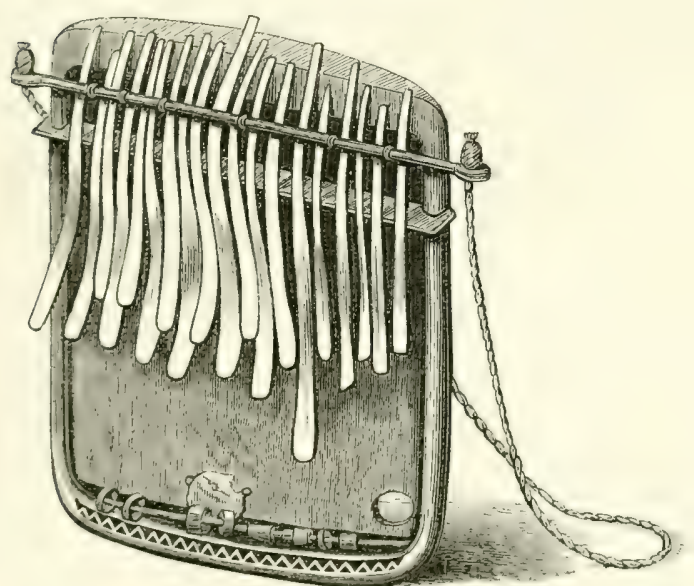

MUSICAL INSTRUMENT. 


\section{CHAPTER VI.}

Return to Tati-Changed aspect of the country-Constant delaysThe Mashonas-At Manyami's again-John Lee's-Letter home -The Inkwesi-Wild fruit-A hornbill's nest-The Impakwe and Ramaqueban Rivers - Graves of Englishmen-White antsBushman remains-The Tati reached.

Frank Oates's plan on leaving Gubuleweyo was to return slowly, by way of Tati, to Bamangwato, there to prepare himself with a fresh outfit of goods and other necessaries for a renewed attempt to reach the Zambesi early in the year; unless on his arrival there he should find letters which required his return to England. As it was yet too soon to think of making at once for the Zambesi, he took his time upon the road to Tati, not arriving there till near the end of February. He stopped to hunt some time upon the Ramaqueban, and, the whole journey, progress was inevitably slow, owing to the heavy state of the country from the recent rains. The waggon was constantly sticking, and delays were endless. The route taken was the same as that by which he had come to Gubuleweyo, but the country was now rendered so much more attractive with the advancing season, that some extracts may be given from the Journal. 
Leaving the neighbourhood of Gubuleweyo, as already mentioned, on January 26 th, he reached Kumala River the following day, and on the 28th again pushed forward towards the Shashani, where he arrived after many stoppages two days later, John Lee's farm being reached early on the morning of the Ist of February. For three days before his arrival at John Lee's, the Journal reads as follows, the first extract finding him at a point in the road still a few miles from the Shashani, where his waggon had sunk deep the night before, necessitating a halt :-

"Famary 29th. - During the night some rain fell; the morning was cloudy, but fine. Got the waggon clear with some difficulty, and started about noon, but it stuck again after going a few yards, the dissel-boom breaking, which was shortened and used again, causing a long delay. . . . At length we started fairly about 5.40 P.M. The sun was getting low, and, as we went through some really beautiful scenery, he set, and the sunset scene was a lovely one. I can now fancy that South Africa may have much fine scenery, and I wish I could see the Zambesi. In the foreground was undulating and broken ground, covered with long grass, showing in some places a silvery white colour, in others a yellow, and in others a green one. Beyond, the deep green of the trees-not uniform in height and growth, but reminding one in their graceful diversity of hedgerow trees or those of copses at home-rose distinct against the deep violet kopjes on the horizon and the sunset sky. The upper part of the sky was blue, 
with large lilac clouds; lower down, the blue was streaked with pale yellow, and this again, as it approached the kopjes, became golden streaked with lilac. We trekked on well through the changing light, for it never became dark, and, ere the sunset hues had faded from the sky, the moon was shedding a clear light over the romantic scene. Fireflies were flitting, and I felt the morning trek, when we entered Pretoria, come back forcibly to my mind. That was then to me a wonderful change, from high veldt to bush veldt, and the time of seeing it - in the weird light of early morning-added to the charm. The road now, as then, was very rough and steep, over stones, up hill and down; and at about 8 p.M. we crossed a steep-banked river. The water was deep, and the bank on which we landed was so steep, that the oxen, the moment before they scrambled up, were up to their breasts in water, but we did it in gallant style.

"On we went, and at last were rising a hill, through what in Rocky Mountain phraseology would be called a 'park.' The word is an appropriate one, and I know no other that would describe this lovely spot, reminding me of similar scenes in the Rocky Mountains. The ground was open and park-like, with a fine sward and a few isolated trees, whilst all around - forming a complete amphitheatre — rose rugged kopjes in the distance. The moon shed a bright light on the whole. Suddenly, smash went the dissel-boom, away went the oxen with it, down went John most ludicrously on to the ground from 
the front-board, and the waggon came to a standstill. The great awkward tree, stuck in by Wankee ${ }^{1}$ and John when we first came to grief, had at last become useless, and now we set about making ourselves comfortable for the night, intending to cut a fresh dissel-boom in the morning. It was about 8.20 when this ludicrous breakdown happened, and it is long since I have so thoroughly enjoyed a laugh as I did then at John's expense. I was not sorry that we were stopping here, and, as I drank in the scene with delight, those parks in the mountains of the Far West were present to my mind, and I felt happy, scarcely knowing why. The part of the country we have passed through is called the 'neck.' To-night I heard the strange melancholy baying of wild dogsan animal I have never seen.

"Famary 3oth.-My pleasure in the place where we are outspanned was put an end to this morning by a crowd of noisy forward Matabele from a kraal a little distance off amongst the kopjes on our right. My men had sent early, and beer and large quantities of milk were brought. There were a few slaves here too, quite different in appearance and bearing from their conquerors. They are quiet and humble in demeanour, and profusely ornamented, where they can afford it, with brass wire in rings round the wrists, of what I have been told is Portuguese or native workmanship, though I think it may be brought up by our own traders. Blue cut beads, too, and skins are much worn. These original in${ }^{1}$ A native temporarily engaged at Gubuleweyo. 
habitants, Mashonas I think, are far more in keeping with the scene, to my mind, than their supplanters. ${ }^{1}$

"Wankee cut a dissel-boom, and we inspanned about 2.I5 P.M. First we went up hill, and then began to descend through a tolerably open grass country, with trees about as far apart as one sees them in an orchard. The country we passed through is extremely pretty-grass long, trees graceful and
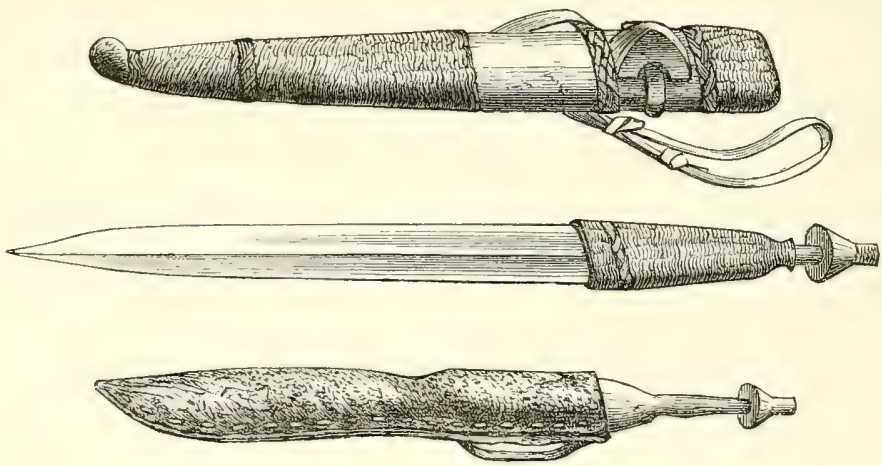

NATIVE HUNTING-KNIVES.

varied, broken crags, with kopjes all round. Through it we descended to the Shashani, which is in a valley, and we must have crossed it say about 3 P.M. We then soon crossed a spruit, and after this in a heavy part of the road, where the ruts had been worn into deep holes, we stuck. This would be about 3.40 P.м. We made vain efforts to get out, let the oxen feed a little, and again tried, and tried in vain. The front oxen,

${ }^{1}$ Brass wire is considerably used by the natives of South Africa for purposes of ornamentation. Above are represented two huntingknives, the upper one of which has the sheath and handle (which are of wood) handsomely adorned with fine twisted brass wire. The sheath of the lower knife is of raw hide strongly sewn together. 
and indeed all the oxen, were very stupid, but I blame the driver, and, though it was a fine moonlight night, he would try no more till next morning.

"Fanuary 3Ist.-Fine hot day. Stupidity again in Wankee. He first tried to pull the waggon back and then forward, and finally raised it and put stones under it, as ought to have been done last night, for it was taken out at once when this was tried. Two girls from the kraal we passed yesterday came to the waggon en route for Manyami's. They were overtaken by us on the road afterwards, and went some distance in the waggon, and again came to the waggon at Manyami's. Two little looking-glasses delighted them beyond measure, and each little gift caused an exclamation of delight and gratitude, ' $\mathrm{O}$ Bossa!' They were perfectly unsophisticated ; one I thought pretty. They sang, evidently studying the most fascinating smiles whilst looking into the mirrors. After we moved I had the oxen unyoked to feed for a short time, and we started fairly at noon. The country was again extremely pretty and well wooded, the road winding like a labyrinth amongst the picturesque kopjes. We crossed several spruits, some of them awkward ones, and at one had a good deal of trouble, but it had a grood bottom, and we pulled through. We reached Manyami's and outspanned on high ground under an abruptlyrising kopje about 3 P.M.

"Here old Manyami came to see me, and presented me with a small pot of beer, begging a 'limbo' for his wife. I gave him a cup of coffec in 
return, and about the value of the beer in limbo, as I am not disposed to be over generous. I bought some calabash pumpkins, which I found afterwards were like excellent vegetable marrows when boiled; also a water-melon, the second I have bought within the last day or two. They are in excellent condition now, and very refreshing. I also bought some sour milk, which my boys like.

"Vincent came up on his way to Mungwato with a waggon and sixteen oxen, returning from Gubuleweyo, where he had been with a load. His waggon went on, and he remained behind to help me. I find him an excellent driver and a very energetic fellow, and I believe he would be very glad to go with me, as he is tired of trading under Hogg. However, he must go on now.

"The sun was getting low as we inspanned. We soon came to a very bad place-a huge pit in fact-where the road had been, to avoid which we had to go through a very soft piece of ground, into which the waggon sank deep, and I thought it was a case of a regular stick, but Vincent got me out of this well, and showed his great superiority as a driver. We got over some bad places after this, but at length got into a heavy rut, the wheels on the off side of the waggon being deep in it, whilst those on the other side were high on firm ground. It looked like a serious case, and the sun set on our efforts. The dissel-boom was pulled out twice, but at length so firmly locked with chains, and the wheels raised so effectually with stones placed 
under them, that, when Vincent left his work, which he had been going at like the fine energetic fellow he is, and we sat down for a moment to drink a cup of coffee, the waggon looked like getting off. This it did without difficulty, and we started again about ro P.м. We had one more stick afterwards in a deep rut, but Vincent levelled the ground in a few minutes, and we were off again, and finally crossed Mangwe drift without a mishap. This was the greatest feat of all. The river was full of water, the men were nearly up to their armpits (one crossed clinging to 'Blackberg's' tail), but we went through it without any delay or trouble, and I was indeed thankful that our dissel-boom was chained. After this we trekked a short distance along a good road to John Lee's. Here were Dawson's two waggons sent up by Cruickshank, and Vincent's waggon sent by Hogg. Skinner's waggon was some little way off. Skinner and Dawson were waiting for the river to go down. We outspanned about I.3O A.M., and had supper."

At this point Frank Oates remained a few days, hoping for some improvement in the weather. Soon after his arrival he wrote home as follows :-

"Mr. John LeE's, Mangiwe,

"Matabele Country.

"February Ist, I 874.

"I take the opportunity of a waggon going to Bamangwato, to send a few lines to let you know how I am getting on. I wrote last to you from Mr. Thomson's at Hope Fountain. Since then I have been detained at Gubuleweyo, the King's Town, first 
by bad weather, and then, as the time of the grand dance of the year was approaching, I waited to see it. The people come from all the neighbouring kraals, and dance and feast for two or three days. It is the feast of the first-fruits of the season, and Mr. Thomson advised me to stay for it. After this, fearful rain again delayed me, and then I had some trouble with my men, and dismissed two, and had to have the case of a third tried before the king. At last, last Monday, I got under weigh once more, with a new waterproof tent on my waggon. The journey here is about three days under ordinary circumstances, but it took me six, in the present heavy state of the country and badness of the river drifts. I had many sticks in the mud and breakages of my dissel-boom. Last night I arrived here, and to-day is Sunday. The man to whom I am going to give this letter drove my waggon for the last eleven miles. He overtook me on the road, and let his own empty waggon go on. We were about six hours in accomplishing the distance, including delays, but, thanks to his timely help, I pulled through. The last river we had to cross, the Mangwe, was so swollen that the water was up to the men's chests, and looked as if it was coming into the waggon. The men who were not in the waggon had to catch hold of the oxen's tails, or struggle through the stream as well as they could. It would have been very unpleasant, especially with bad helpless drivers, to have broken my dissel-boom in the middle of the river, and I felt very glad when safely landed on the bank. 
"From here I intend travelling leisurely to Mungwato, where I hope to find letters. When I get there I shall decide whether or not to make another attempt on the Victoria Falls. By leaving Mungwato about April, I should have the fine season before me, and could probably reach the Falls and return to Mungwato in the space of three months. The worst of this country, however, is that movements here are so slow and dependent on the caprice of natives, and one is too much cut off from the world. Yet I believe the Zambesi would repay one for much sacrifice of time and patience. It is impossible, I am now convinced, to get on with Kafirs and Hottentots without severity. Kindness is thrown away upon them, and makes them worse than they are. I believe I shall have to give the latter method up altogether, and resort to castigation, which is an alternative I don't like. They are, almost to a man, dishonest, lazy, and impudent.

"The scenery about here is pretty I admit, especially at this time of year. Some of my moonlight treks between the King's and this place were very delightful, and wakened a little enthusiasm and thoughts of former days, such as the usual dull uniformity of South African scenery fails to elicit. The ground is broken up into rugged crags, piled one upon another in such a manner that you can't help wondering how the mischief they ever got there. The veldt is covered with long grass, like English mowing grass. The trees are, for the 
most part, like English woodland trees, but less in size; in some places forming a thick bush, in others scattered over the greensward like English park timber. Occasionally a remarkable tree occurs of unfamiliar aspect, but this is quite the exception. The kopjes are numerous; some, merely small piles of huge stones, with trees springing from the interstices; others, hills of respectable size, built up of crags, and sometimes shutting in the horizon on every side. Here and there a stream runs through its deep stony bed in a deep valley, and then comes the tug of war, and the moonlight scenery is forgotten, whilst one's lungs are exerted in yelling to the oxen, calling each by his uncouth name.

"My dogs always ride with me in my bed. One of them is a most faithful friend and agreeable companion to me. I should miss them very much. I had to sell my pony to the king, to keep in his good books, but was sorry to do it, although he may die now any time of horse-sickness. If he lives he is a valuable animal, and henceforth 'salted.' Birds are few here, and, for the most part, not striking in appearance. The same applies to flowers.

"Old John Lee's voice is droning away about some oxen, and the family circle surrounds me, as I write this letter. Lee wants to borrow my waggon for two months to send for some meal, and to do his best to make me comfortable here in the meantime, but I have made a mental vow not to let myself be talked into the arrangement. . . . I shall be very glad to hear recent news of how all are at home. 
"P.S._. . I am adding this P.S. in the waggon, but I miss John Lee's drone, which I find helps me to write. He discoursed on locusts to-night. As he says, Kafirs eat them, horses, sheep, and all sorts of game eat them, lions eat them, wolves eat them, birds eat them-they must be very nice; only white men and vultures don't eat them. I believe but for locusts an immense number of people would have died of famine last year at Mungwato."

It was the 6th of February when Frank Oates left John Lee's, and the 9th when he reached the Inkwesi River. The country round Lee's farm is of a somewhat striking character, and, though much healthier than most of the surrounding district, is not wholly free from the annoyances elsewhere occasioned by the summer rains. "The scenery here," writes Frank Oates, "with the swollen current of the river and huge magnificent boulders, is as fine in its way as any one would wish to see. The gardens, however, which have suffered terribly from the drought, are now suffering equally from the wet. They require both irrigation for the dry, and drainage for the rainy, season." The way in which Lee lived with his family round him, and the sort of relationship existing between them, afforded an odd example of a Dutchman's life in the interior. "It reminds one," says the traveller, "of feudal times: old Lee, the lord; his brother, a wretched serf; his father-in-law, not much better; and all his poor relations living about in little huts round his big house." 
Amongst the waggons stationed at John Lee's during Frank Oates's stay there was that of Smith, the Dutchman, whom he had formerly met on his way up country, near the Impakwe River. Smith was now starting on a hunting trip towards the Tati, and the two again agreed to travel together. Before leaving Frank Oates engaged John Lee's brother, Karl, to accompany him as driver to Bamangwato.

The country was still heavy, though somewhat improved by the last few days of comparatively dry weather. A few miles before reaching the Inkwesi, the road lay through bush veldt and corn-fields, with kopjes interspersed at intervals. "The corn-fields are close to the road," writes Frank Oates, "and a large fence renders the road so narrow that it is a difficult matter to drive a waggon. Some of my loose oxen crossed a corn-field, and of course a row was made. The Hottentot, Klaas, from Lee's, had to give a coat, and some lead and powder, because when he stuck his oxen trampled the corn whilst in the yoke, the road being altogether hemmed in by the corn-fields. Karl says he will get the extortionate payment refunded when John Lee knows. This is the second crop of Indian corn, the former one having been destroyed by locusts. We passed the Hottentot during this trek; he had had to kill one of his best oxen, his driver having broken the ox's leg by throwing a stone. Here we come," continues the writer, "to the last kraal, and outspan, about two miles from the Inkwesi, amongst the 
kopjes. There is a fine sugar-loaf-shaped kopje, craggy and tree-covered to the top, and very steep. I wish I had time to try the ascent; there must be a glorious view from it. The colours on the stones from lichens are most beautiful, yellow predominating. The Kafirs were most impudent and troublesome. The headman, a young fellow in European clothes, is a good-looking and well-behaved fellow. He sat on my front-box; our object is to get boys from him. There were five men killed by the king, at Lee's, Karl says, for refusing to come to live here; they said it was only fit for monkeys. Near here was old Makobi's kraal, where all were massacred for deceiving the king, after owning allegiance to him. A large quantity of milk was brought to us for sale. Heavy showers came on, but the night was fine, clear, and starlight. Where we passed Klaas an elephant had passed during the night. They followed his spoor, but lost it. Smith shot a cow-elephant near here a year or two ago, and they say a surly toothless bull-elephant lives about here now. The kopje looked very pretty at night when all was quiet, and its dark sugar-loaf form loomed up close to us against the starry sky."

Next day (February 9th), on reaching the Inkwesi, Frank Oates chanced to be alone, Smith having gone on in advance, in company with the Hottentot above referred to. "After Karl had been to the kraal about boys," writes the traveller that day, "we inspanned at IO.3O A.M., and trekked about an hour, when we came to the drift of the 
Inkwesi. The induna rode on my front-box. Some of the road was rough; scenery pretty. Had to chop down part of a tree against which we were running. We found Smith had crossed, and I sent in boys to try the depth, and, though it was deep, I resolved to push forward, for fear of rain and a swollen current. In some places it was over a man's middle. We stuck in the river; had many attempts to get out, but without success. Two small oxen got half drowned, and we outspanned them and inspanned two large ones. The boy who was leading the front oxen let go the strap he held them by, and we had a great deal of trouble. At last we off-loaded a large part of our cargo, sending it over on the boys' backs. I worked hard; so did Karl. I then undressed and left the waggon before they tried to get it on again. Old Smith now came up to us, in the unadorned garb of nature, and mounted the front-box. (He thrashed a young nigger for laughing at his appearance.) They got the waggon out this time, but some of the oxen had to swim. Very little water got inside, and we loaded up again, and at sundown inspanned to go a few yards to where Smith and Klaas were already encamped. At night we all had supper together, Smith contributing some excellent 'stamped corn.' This is a capital dish. The corn is first crushed, then boiled, and, when this is over, salt and butter or fat stirred up with it. It is something like stiff rice-pudding."

Advancing together the following morning, the 
three stopped for a day or two's hunting a few miles further on, beyond the river. Here buffalo and blue wildebeest were met with, and the spoor of ostriches was seen. From a fine rocky plateau in the neighbourhood a good survey of the surrounding district was obtained. "Looking to the south-west," writes the traveller, "we saw the distant conical range of the Tati hills, between which and ourselves lay a fine green bush-covered plain, through which flow the Impakwe and Ramaqueban Rivers. This plain extends far to the west and north, but to the north-east is again broken by kopjes in the direction of the Mangwe, whilst the fine craggy hills of the Inkwesi rise nearer in the same direction." Some delicious fruits, not unlike greengages, known by the natives as "marula," were picked up about here on the march. Between the skin and the large stone in the centre of each was a sweet liquid with scarcely any pulp. "We also found," adds the writer, "a number of berries, of which we ate a good lot. These grow on low bushes, which have a sweet-scented yellow flower, with a smell like that of sallow bloom. The fruit is reddish-brown, about the size of a haw; dry, sweet, and containing a stone. It is called 'Kafir plum.'"

Here too a hornbill's nest was found. "The boys," says Frank Oates, "brought me a young hornbill, and I was taken to the nest. A hollow tree, with a hole in it, high up, was where the bird had come from. They poked out and pulled the wing-feathers off the old hen when I was not looking. I kept 
both birds. Karl says the old hen never leaves the young, the cock feeding them all, and that she gets quite bare of feathers. The number of young is two. The natives, he says, are very fond of them to eat, roasted."

The party next moved forward (February I 2 th) to the Impakwe, a further distance of about six miles. "Here," writes the traveller, " is some distinct stone-

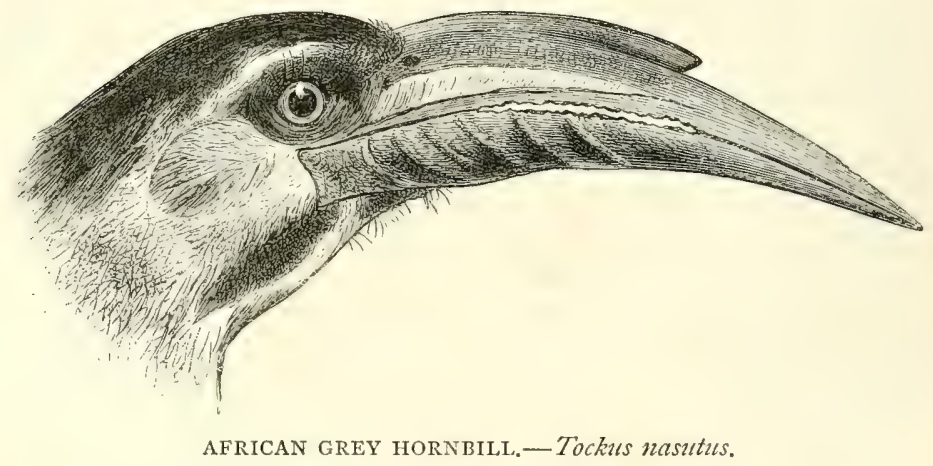

work forming a circular wall, inside which are remains of bricks coated with a substance as if smelting had been done here. No mortar has been used, and the work is rough and I should say of no great antiquity, the stones being small and loose and easily displaced, so that I think they would not stand any great length of time. They are cut in an oblong form and properly placed for building. Karl says it was made for smelting copper, and used by the people whom Mosilikatze found here. That it is any older I should much doubt. Shot here," he concludes, "a beautiful sun-bird, whose beauty awoke my slumbering love of ornithology." Birds had been scarce of 
late, but became much more plentiful at the Ramaqueban, which was reached the following morning.

Encamping on this river, they still remained a few days longer in the neighbourhood before finally separating, usually taking from here different direc-

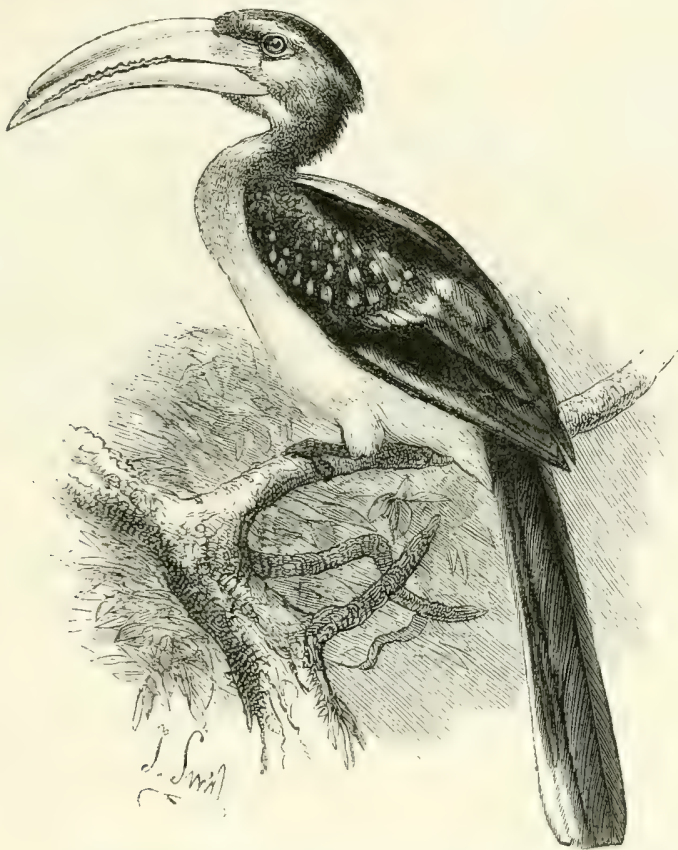

YELLOW-BILLED HORNBILL. - Tockus favirostris.

tions during the day in search of game, and meeting again at night. The game in the district, however, for the most part proved scarce and wild, a circumstance afterwards accounted for by the fact that other parties had been and still were hunting the neighbourhood at the same time. There was, nevertheless, abundant evidence of its being a good game country; and, as it was, giraffe, koodoo, 
waterbuck, and sable antelope were met with, besides wild pig, quagga, and sassaybi. The spoor of elephant and rhinoceros was also seen, none of it, however, very recent.

The Ramaqueban - at this season a fine broad stream, with long grass and a large undergrowth of rank weeds upon its banks-was crossed in many of their rambles, and near it on one occasion were seen the graves of two Englishmen. "Started at nine," writes Frank Oates on February i6th, "crossed the Ramaqueban, and passed the graves of two Englishmen, who died here, one of fever, one killed by an elephant. The latter had come from England to shoot, and was killed by the tusks of the first elephant he saw. The fever is very bad on this river; the vegetation is extremely rank, and the water lies very deep over much of the veldt. The graves," he concludes, "had been surrounded by stakes to keep off the wolves, but the river, overflowing its banks, had nearly washed them away; still the heaps of stones covering the bodies and a few stakes remain."

The same evening, wandering far into the bush, Frank Oates slept out with some of his boys who had accompanied him. "We stopped at 5 P.м.", he says, "and huts were made. It was a hot night, and the big fires made it worse. The white ants too kept tumbling over me all night, and knocking down leaves from the roof. ${ }^{1}$ We were perhaps sixteen miles from the waggon."

1 "These 'white ants' (Termites)," writes W. Oates, "are the curse of 
Still, however, though in a less tried district, there seemed but little game, and what was seen

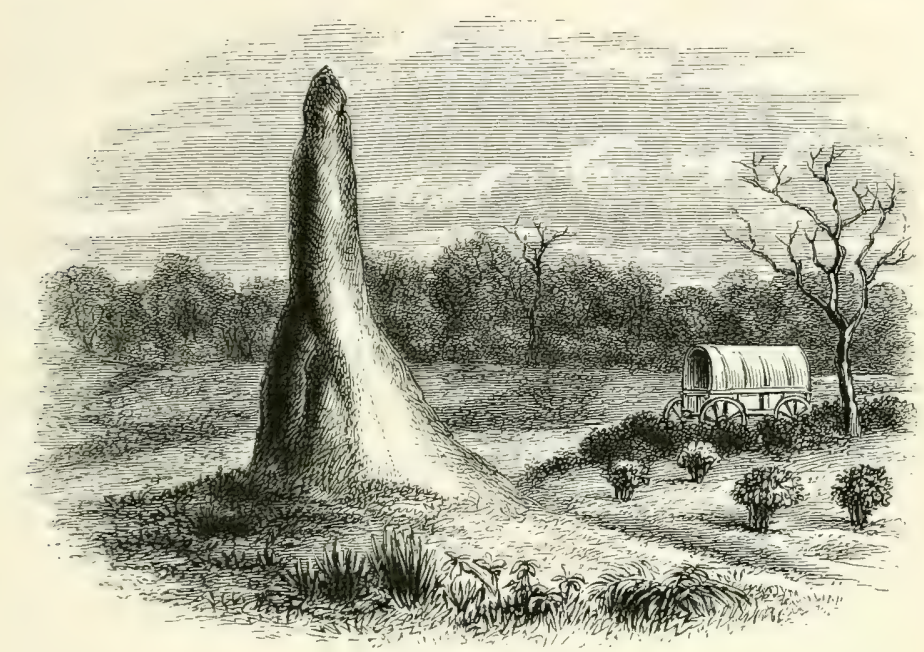

GIGANTIC ANT-HILL.

was wild. Returning to the camp next day, "I stopped in the afternoon," he writes, "when the boys found a nest of small bees, full of delicious honey, on which and coffee I dined sumptuously."

And now discouraged by the wildness and all African settlers and travellers, devouring everything except iron or tin, whilst in time even houses succumb to their ravages. They form, however, an article of food in many places amongst the natives, by whom they are much esteemed on account of their slightly acid flavour. The enormous structures they erect are frequently carried up the trunk of a high tree, or may sometimes be seen standing alone at a height of $\mathrm{x} 8 \mathrm{fect}$, as in the accompanying sketch, which was taken between Tati and Shoshong. The Dutch Boers and others make use of these ant-hills for cooking purposes, hollowing out the lower portion of the heap, and filling the hollow thus formed with wood, which is lighted, and, when consumed, renders the receptacle an admirable oven, retaining its heat for a great length of time." 
scarcity of the game, the Dutchman soon afterabout the 2oth - took his departure, returning to John Lee's, the Hottentot having left two days previously for the Shashe River, whither he had been summoned to join another Dutch hunter, Piet Jacobs, in search of elephant.

A little before the latter's departure Frank Oates had chanced to hear from him that, at a spot not far from their encampment, some miles up the river, a number of Bushmen had been murdered the previous year, and he resolved, if possible, to visit the place, that he might obtain some of their remains. In this search his informant had undertaken to accompany him, and had even sent to Tati for a reliable guide to the spot, when suddenly, at the last moment, he changed his mind, and excused himself from going upon the plea of illness. The circumstances of his defection and some other incidents of the day are thus related in the traveller's Journal :"February 18th.-Fine day; the first day without rain for an age. Last night Klaas (the Hottentot) told me he was going on to Tati to-day, being too unwell to accompany me in my excursion in quest of the bones, but would leave me his two Bushmen-the one he had sent for from Tati, who knew the place, and the one he has had with him here. The former was out hunting, when his fourteen companions-men, women, and childrenwere killed at their hunting kraal by the Matabele. $\mathrm{He}$ found them all dead on his return. It seems that they were a party of Mungwato Bushmen, and 
some of them had taken meat belonging to some Bushmen from Manyami's. The latter complained to the king, who said the Mungwato Bushmen were to be killed. This was last winter. This morning Klaas went away, leaving the two boys. I now found he was going away to hunt. Jacobs had sent for him to hunt for elephants, said to be on the Shashe. Presently the two Bushmen took their guns and skins and walked off. I immediately felt the strongest suspicion, and called Lee's attention to them. He questioned them, and they told him they were going to hunt. I felt very uneasy, and wanted him to stop them, but he seemed to think it was all right. However, they did not return at night. We think Klaas had arranged all this. . . . One of Smith's boys, a Matabele, was one of the party who killed the Bushmen, but he says he thinks he could not find the place, the leaves being now on the trees. He could find it, he says, going from his own kraal, but not from here. He evidently, however, does not want, or care, to go. It is somewhere, a day or a day and a half's walk off, up the Ramaqueban."

The two Bushmen, as Frank Oates had anticipated, failing after this to reappear, the search for the remains had now for the present to be abandoned, but later in the year, as will presently be seen, he succeeded in obtaining possession of them.

The Bushmen of this country-such was Karl Lee's account of them-appear to be scattered over the whole district north of Mungwato, keeping principally near the waggon-road, to get hunting jobs and 
bits of meat. They are without chiefs, and have no fixed place of abode, and no crops, building themselves rough temporary huts when they want to stop anywhere for a time. They are capable of carrying immense loads, and sometimes help the Matabele with their corn, receiving a little of the grain in payment when they return into the veldt. They have no guns, only assegais and dogs, and many of them have wounds of buffalo upon their persons. They snare buck, and occasionally get big game with their assegais.

Still lingering a day or two longer on the Ramaqueban after the departure of his companions, Frank Oates completed the journey to the Tati on the $23 \mathrm{~d}$, whence he did not start for Bamangwato till the $4^{\text {th }}$ of April.

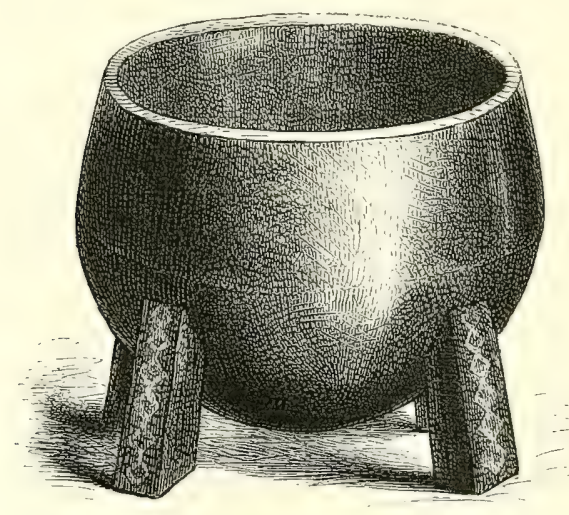

WOODEN VESSEL. 


\section{CHAPTER VII.}

Hunting trip on the Semokwe-A native musician-Gigantic baobabs - Return to Tati-Journey to Shoshong-The Bamangwato and Matabele nations-Fighting amongst the natives-Start back for Tati-Misadventures and delays-Fresh arrangements.

ON reaching Tati, Frank Oates found that a hunting party was just about to start thence for the Semokwe, and being asked to join them, he arranged to do so before going on to Bamangwato. The following is an extract from his Journal of this date (February $23 \mathrm{~d}$ ), after his arrival at the settlement:-

"Tati," he writes, "presented on our arrival a very pretty and lively appearance. I like it better than any place I know of, to stand at. Here are no crowds of rude people to come round the waggon. All is green, and numerous little well-built houses dot the ground; of course I mean well-built for the interior of South Africa, but it is rough work enough nevertheless. There are the three waggons of the Gardens, two English brothers hunting in the country, and the waggon of $\mathrm{Mr}$. Thomson, on his way with his wife and children to a missionary meeting at Kuruman. There is Nelson's waggon, who is going away for a time, and possibly will visit England. 
He leaves to-morrow according to his present plan, with Mr. Thomson, they carrying the mail. Then there is Klaas's waggon, and Jacobs's waggon; the latter ${ }^{1}$ living here with his wife and daughters until the regular hunting season. He makes occasional short excursions from here, and is now about to set off for the Semokwe for a three weeks' hunt after elephant. A troop of they say at least 200 elephant came close to Tati lately, but, probably hearing the engine, turned. One account sets them down at a still larger number. In the letter I found awaiting me here from Willie, written when he came out of the hunting veldt, he tells me he has been to the Semokwe, where he has had good sport. Seventeen elephants, he tells me, had just been killed on that river; this would be by Fejeune. Captain Garden and his brother are accompanying Jacobs on his projected hunt, and I am going to join them too. Klaas and Henry Wall are also going, and a lot of Bushmen. Jacobs shot a fine lion close to Tati lately; brought him to bay with dogs early in the morning, and shot him from horseback. They trapped another; the third, a lioness, escaped. They had been taking Jacobs's bullocks. . . . A lot of people came up to my waggon when we outspanned, and Mr. Thomson invited me to supper. In the evening we all met at Brown's. Brown has given me a piece of bread. I enjoy it without butter or anything else with it; it is a wonderful treat."

The following day the large party here alluded 1 Piet Jacobs, the Dutch hunter, referred to in the previous Chapter. 
to started on their hunt. Before leaving, Frank Oates wrote to his brother William, now in England, as follows :-

"TATI, February 24 th, I874.

"It is quite a pleasure to get a letter from youI mean the one you left for me here. I shall get no more now for five or six weeks, when I expect to be in Mungwato. I am sorry that wretched old croaker, Palmer, ${ }^{1}$ put you in a funk about me. He says it would be a good thing for people travelling to have 'portable coffins.' I am thankful to say my health is excellent. I did not, as doubtless you know by this time, get to the Zambesi. I believe the king was at the bottom of it (not of the Zambesi; but excuse grammar). I took my waggon fifty miles on the way, as far as Inyati, and then put all out for fifteen carriers to take. It was a fortnight's walk through 'the fly' to the Falls. After waiting nearly a week, it transpired that no boys were forthcoming as promised. Partly, I think, they were afraid of fever, and partly of the natives, with whom they are at war; partly also they wanted to get back in time to cultivate their gardens. However, I believe I could have got them myself easily, had I not trusted to the man given me by the king.

"I then sent back to Lobengula, asking him for hunting veldt. I had given him your shot gun, and his sister some furniture print of gorgeous pattern. He gave me a fine veldt between the Gwailo and Umvungu Rivers, where I was six weeks. I then ${ }^{1}$ A trader of that name at Tati. 
returned to the royal residence, and asked the king to let me go back to the same place. He was very crusty, and asked if I wanted to die. I told him I would take my chance, for I did not think there was the least danger then. It is when the rains cease and the rank vegetation rots beneath the sun that it is so bad, and that is not till March in most parts, I believe, though earlier on the Zambesi. However, he said, if I wanted to die, why could I not die somewhere else, and not in his country, and made so many difficulties I had to give it up. I then had so many delays-bad weather, and one thing or another-that I waited till the big dance was over, which is quite a thing to see when one is here.

"After this I had difficulties with my men, and had to part with Hendrik, Dick, and Jacob, all of whom you will remember. About Dick's dismissal I had to wait a week or more, as the case had to be tried before the king, and Jacob was finally handed over to the tender mercies of Dick. Hendrik I dismissed for refusing to cut some bushes, to make a fence round my waggon to keep the niggers out. This he con sidered 'slavish work,' and preferred dismissal to demeaning himself. Then the king would insist on buying my little horse, still well when I left in January, and got the saddle and bridle for nothing. "Since then I have been coming slowly from the King's. I have been hunting, and have Lee's brother to drive for me now, and take me to Mungwato. Here I have fallen in with Captain Garden and his brother, and am joining them and some others for 



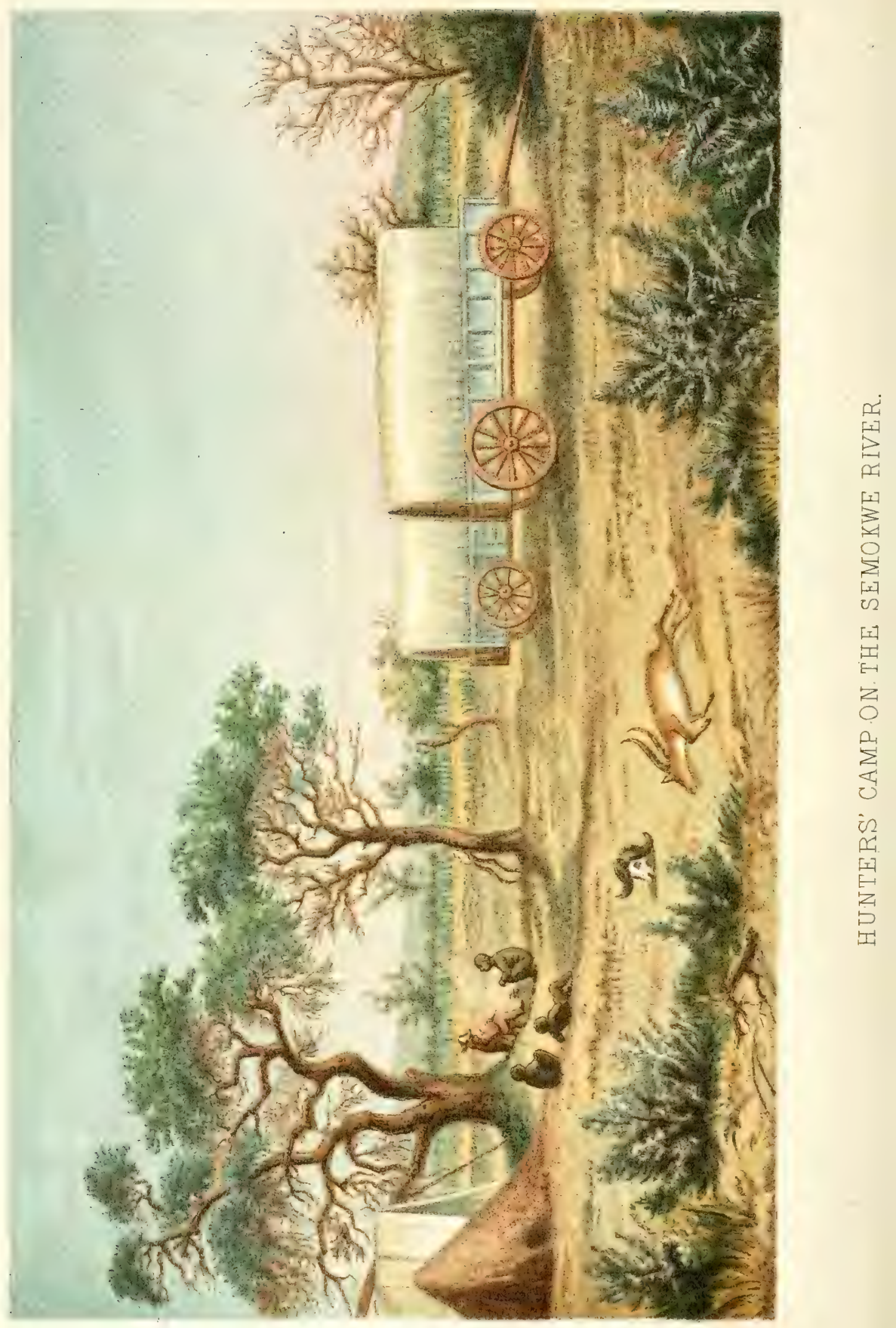


about three weeks' hunting in the veldt. I am spinning out the time, so that if I find all things favourable on reaching Mungwato, I can start in April or May for the Zambesi. ... I have seen Vincent, the driver, who is death on Solomon. ${ }^{1}$ He said he wanted to kill him, but did not like to do it without your leave, which he asked, but you said it would be rather inconvenient to you just then to have him put out of the way."

On the 24th, as already stated, the hunters left the Tati, and crossing the Ramaqueban and Inkwesi Rivers, struck thence eastwards, and crossed the Sakasusi or Dry River on the 26 th, a crowd of Bushmen, with their wives and children, accompanying the waggons. The following day they reached the Semokwe, a fine river surrounded by a sea of green bush stretching in all directions, and here they formed their camp. ${ }^{2}$ "In the evening," writes Frank Oates in his Journal after their arrival at this point, "a boy, who comes from the Zambesi, and knows the Falls, which he calls 'Metse-a-tunya' (watersounding), came and sang, playing on the string of a bow to which a gourd was attached. He sang the 'Song of the Elephants Feeding,' now and

1 The latter was W. Oates's Kafir driver, who, it may be remembered, had turned out a consummate rascal.

2 In the coloured illustration opposite, taken on this river by $\mathrm{W}$. Oates, when there the previous year, the dry sandy bed of the Semokwe is distinguished towards the horizon, with tall rushes upon its bank. The large trees, still in leaf, to the left hand of the picture, are mimosas, near one of which, still further to the left, is seen a large ant-hill, used as an oven, in the manner described above (vide p. 135). 
then pausing and imitating the looking round for danger, then recommencing the feeding, or imitating the running of the elephants. The words were very distinct, with no clicking. The following occurred over and over again, the song sounding very monotonous, but not at all harsh or unpleasant :-

“ 'Wänga marank,

Swot ma ben a marank,

Wātem ba marank,

Obeza marank,

Wāmba marank.'

One of the boys from Mungwato, whose language this man knows a little, explains that he speaks of the game feeding by the river-'all the game.' The minstrel was delighted with some tobacco. $\mathrm{He}$ is a fine, well-made, powerful-looking, and nice-featured young fellow, with a pleasant childish expression."

Next day a large troop of buffalo was encountered near the river, out of which were obtained a cow and three-year-old bull, which supplied the camp with meat. "Went after supper," writes Frank Oates that evening, "to see the Bushmen and their wives dance. They do this when full of meat, making a great noise. The women stand in line, shuffling their feet and clapping their hands, whilst the men come and perform antics in front of them-one now and then stepping out from the ranks and approaching near to the women with dancing and gestures. Now and then one excited will rush away half mad into the veldt, and return again when tired. They must work very hard in this dancing." 
On March 2d, leaving the waggons by the river, the party started for a few days' hunting in the bush, taking with them a couple of pack-oxen. After following the river for some distance nearly south, they entered some very pretty country, characteristic of the best South African scenery-rugged kopjes and thick bush, the kopjes rising round on every side, and stretching far into the distance. Here, crossing the river, they encamped their first night, advancing the following morning in an easterly direction several miles. In the course of this afternoon (March 3d), some trees of unusual size were noticed by some of the party whilst riding in pursuit of eland. "The first which arrested my attention," writes Frank Oates, who was one of this number, "was so striking that I let the others go on following the spoor, and reined in my horse. The tree was perfectly gigantic in girth, thickening as it got higher, though of no great height. It was swollen and bloated in a most extraordinary manner, and is of the same kind as the 'Indunas' tree'-a baobab. Though still flourishing, it is a mere shell, and, looking in at a hole in the side, I saw that it was open to the sky at the top. Inside was a good-sized chamber, strewed with minute bones of rats or some small mammalia. No doubt generations of owls have long had their abode here; one flew out on our approach. We saw another tree afterwards, probably as large, but I did not ride up to it."

After this the same general direction was again 
pursued till evening, when temporary huts were constructed for the night, which, however, unfortunately proved a wholly ineffectual shelter from the heavy rain which fell early the following morning, thoroughly saturating everything inside. The day itself was fine and hot, but was again succeeded by heavy rain at night, which induced the party on March 5 th to retrace their steps to the waggons, recrossing the Semokwe in their march, which was now swollen with the recent heavy rains. One of the Bushmen was carried off his legs in crossing the river, but, seizing hold of another of the party, regained his footing, and reached the opposite bank in safety. The big rifle he was carrying escaped with a severe wetting. After this the party moved slowly back towards the Tati, halting a short time on the banks of the Sakasusi, and elsewhere upon the way; and reaching the settlement on March $I$ th. The game met with during their absence had been much the same as that Frank Oates had found in his former journeyings further to the north, and includedbesides buffalo, quagga, pallah, and sassaybi, all of which were obtained early in the hunt-giraffe, rhinoceros, wildebeest, and koodoo.

Still remaining at Tati a few days after their return there, Frank Oates, as already mentioned, started thence for Bamangwato on April 4th, accompanied by a hunter and two traders, also on their way south. By the middle of March the weather seemed to have become quite settled, and the days were almost universally fine and hot, with only an 
occasional slight shower or a little drizzling rain. This absence of wet had greatly changed the aspect of the country, and that in a short time, for, the day after leaving Tati for Bamangwato and crossing the Shashe River, the veldt presented to the travellers a dry, parched appearance, very different from anything which had now for a long time been witnessed. The grass was yellow, and many of the trees already

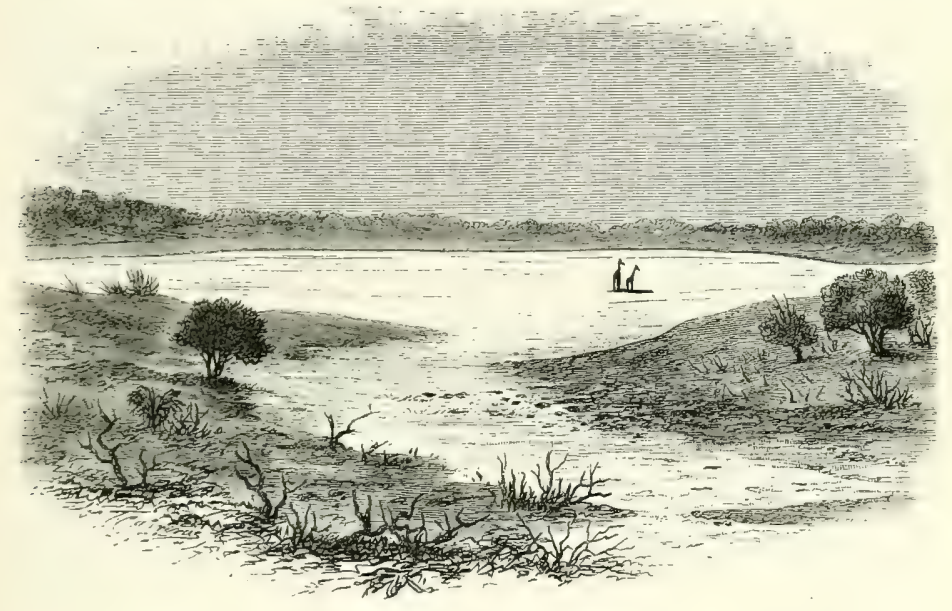

SALT PAN, BAMANGWATO.

bare. A week's trekking brought the party to Bamangwato, which was reached on April IIth, after an uneventful journey. ${ }^{1}$

Here Frank Oates found letters awaiting himthe first he had received from England since leaving

1 The accompanying woodcut, from a drawing taken a little south of Shoshong (Bamangwato), represents one of the salt lakes of this district as seen in winter. The water in these lakes is then all dried up, and their beds, composed of salt and sand, present a dazzling white appearance. 
Pietermaritzburg nearly twelve months before-and, all seeming favourable, at once determined on prosecuting his journey to the Zambesi. There appeared now every reason to anticipate a prosperous and successful expedition, and he began at once to make his preparations for it, laying in fresh supplies at the stores, and otherwise completing his equipment.

Very little worthy of note occurred during the time he was detained at Bamangwato. One evening, however, a great noise and shouting at the kraal, kept up till late, announced the return from the veldt of a number of boys who had been out for circumcision. The following day, according to custom, the same boys went forth again, and Frank Oates saw them starting. "Party, say of two hundred boys, went out," he writes, "into the veldt. They are those who returned yesterday from circumcision, and I am told will have to go to the veldt every day for a week and look after the king's cattle. They presented a striking and uniform appearance. Each had a knob-kerry and a wand, and round the middle a bit of skin. All these and their entire bodies were rubbed with red ochre, their heads shaved except the crown, on which the hair was quite short, crisp, and bead-like. All the crown and the part around it was brilliantly metallic, of a dark steel blue, produced by some preparation of a kind of lead got here."

The evening after this occurrence (April 24th), the traveller's preparations were completed, and a fresh start made up country, but before proceeding further 
with the narrative, it will be proper here to give quotations from some of the letters written during his present stay at Bamangwato. Five days after his arrival he writes to one of his brothers:-

"Bamangwato, April i 6 th, 1874.

"At last I have your and the Mater's letters,

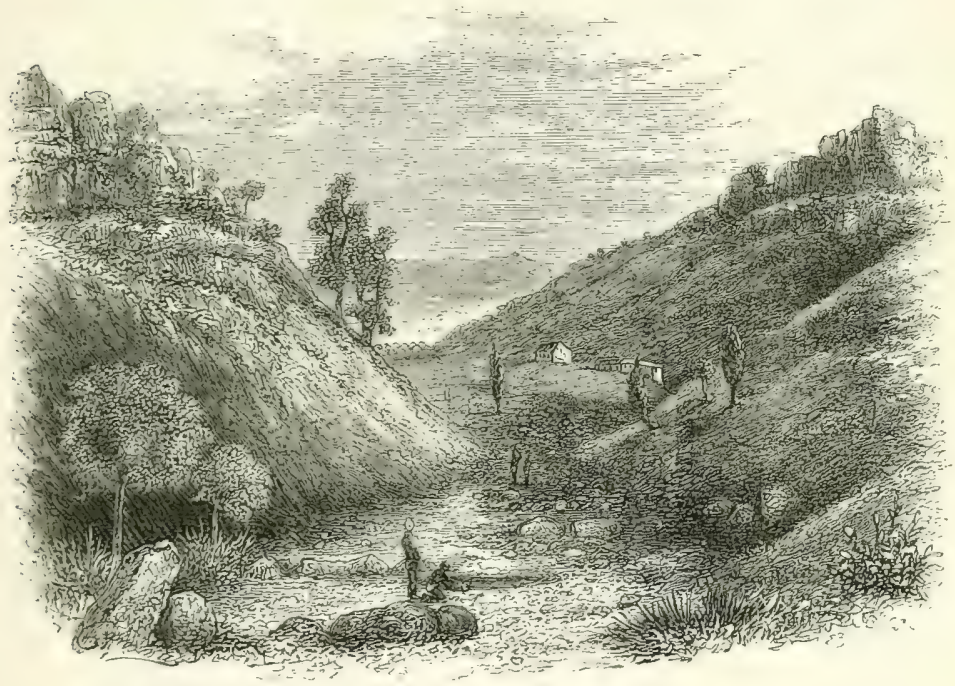

CHURCH AND MISSION STATION, SHOSHONG, BAMANGWATO.

dated September 22d, and containing the first news I have had from home since I left Pietermaritzburg. When I arrived here and found no letters I did not know what to think. Mr. Mackenzie, the missionary, and his assistant, Mr. Hepburn, were both absent, having gone-as well as Mr. Thomson, the Matabele missionary-to a meeting at Kuruman. I had asked Mackenzic to keep letters for me at his own house, and requested Hathorn to 
forward all letters to him from Maritzburg; so when I arrived here and found none I could not make it out. To-day, however, a note arrived, the monthly mail coming in. This note was from Hepburn, telling me that a letter and newspapers were at his house for me, and directing me to apply to a converted native, who is studying for the church, and who, with others like him, forms a college adjoining the missionary houses. I was not long in going up, and found the things as he had said, amongst his books. . . .

"I left Tati for this place on the 4th of April, and reached here in a week. I had to come here for supplies. It is about I 50 miles; but the journey is no triffe. I generally trekked during the night, and slept comfortably, the ground being soft sand for the most part, and the waggon going slowly and without jolts. We usually made two treks of perhaps three hours each, say from 3 to 6 , and from 8 to I I P.M., and set off again about 2 A.M. and trekked till sunrise, which was about 6 A.M., making a trek of about four hours. Call our rate of travelling two miles an hour in heavy ground, this gives about twenty miles a day, roughly, and this is good trekking, and could not be kept up for long. Now. however, there is still plenty of grass and water, though winter is setting in and the rains nearly over. Two waggons accompanied me, with two traders and a hunter in them. The latter is quite a young fellow, who left England three years ago. He was educated at Rugby. One of the two traders was Fairbairn, how supplied me with goods at the town of the 
Matabele king; and the other, a man named Dawson.

"On my birthday I thought of you all, and old times-and had a good wash. ${ }^{1}$. . . I hope not to be more than a week or so here in all, before returning to Tati, en route for the Falls. Selous, the hunting youth above mentioned, set off to-day. His partner, George Wood, a Yorkshireman, is waiting for him at Tati. They are both professional ivory hunters, and have a good deal of roughing it to do. Selous was once lost for four days and three nights in the veldt. The morning of the first day, when he left the waggons, he had nothing but a cup of coffee, and had neither a drop of water nor a morsel of food of any description till the evening of the fourth day, when he found his way back, and got some milk of a native. He thinks he could have held out another day.

"The brothers Garden are going to the Zambesi also, the same way. There is another way of reaching the Falls from here, shorter than the Tati road, but at certain seasons deficient in water. It is to the left of the Tati road. I should have preferred it, but wanted to leave some things at Tati, and was not sure of finding water, going by it. It appears, however, it would have been all right, had I decided on that route. They tell me

1 A rare luxury at the present time, only to be indulged in on great or special occasions, owing to the increasing scarcity of water with the cessation of the rains. "I am miserable," he writes one day about this time, "for want of water to wash myself in, cver so superficially." 
here two English tourists, one of them called Bond, have just left here, trekking slowly to the Falls. This year and last the Falls have been in great request apparently, as Garland and Dawnay visited them last year, and now the Gardens, Bond, and myself, are all bound there, this. Selous too is very anxious to see them, and will probably manage it. We are still in lots of time, in fact the great fear now is of going there too soon, but I shall go slowly, and remain where it is healthy till it is the same at the Zambesi.

"The boys, as one's Kafir satellites are called, whatever their age, are far more liable to fever of course than their 'bosses.' Lying out naked, or with only a skin or blanket and a fire, to keep the cold away at the unhealthy season, is not likely to prevent an attack of fever. Three or four of my boys have had it. I have given them quinine, and there is only one of them ill now. This is a little fellow I call 'Quilp.' He is perhaps eighteen, and a perfect dwarf. The race he belongs to, the Bushmen of this country, are usually tall. These Bushmen are a curious race, who probably had their homes in the veldt long before the Mungwato and Matabele people came here and conquered it, and before the races they conquered came. The Mungwato people are an utterly different nation from the Matabele. The latter have two other nations, the Makalaka and Mashona, living in bondage under them, who are far more ingenious and versed in the arts than their conquerors, having mined and worked 
in metals and woven stuffs for ages. They are not all conquered yet; but the Matabele king is constantly sending out parties of warriors, who steal their cattle, kill the old people, and carry the children into slavery. The little slaves grow up in the families of the Matabele, and when they are old enough to marry, become free and are incorporated into the nation, in which way Lobengula increases his people and his power. The slaves call those of their conquerors to whom they are allotted, their 'fathers,' and they have to work for them, though more like adopted children than anything else. Many of the conquered people, however, are not made part of the nation, but suffered to live on with a Matabele headman placed over them. It is usually slave boys that one gets as servants. They have to look after the cattle and make themselves generally useful, carrying one's arms, blankets, or anything else required, when one goes for a day or two into the veldt. I have now six boys, all young, which I always prefer, besides my driver, a stupid creature, who requires constant blowing up and the use of unpleasantly strong remarks. ${ }^{1}$ When these fail altogether, I shall have to try the argument of knocking him down, which may be slightly beneficial.

1 This refers to John, the man whom Frank Oates had engaged as interpreter at Gubuleweyo some months before, and whom he had since retained in the capacity of general servant. He had recently acted as driver in the place of Karl Lee, who had returned from Tati to his brother's farm, instead of coming forward, as intended, to Bamangwato. 
This is supposed to attach a boy to you. The worst of it is none of my boys are much afraid of me.

"I think I shall be very well supplied for my coming trip. I shall have meal, coffee, and brandy, which I have got here. Sugar is not to be had at present, but may possibly turn up before I leave. However, that doesn't matter much. Coffee is of the first importance, then comes tobacco. To be without these two is a thing I have never yet come to. Meal too is a nice thing to have, though not indispensable, as you can buy Kafir corn, which, when cooked, keeps you going. Brandy, likewise, I am very glad to have got.

"There are, besides the parties I have enumerated, a lot of Boer hunters going to the Zambesi, with their wives and families. Those who go by Tati will leave it about the middle of May, I think, and I suppose the Falls can be reached and seen, and you can be returning in August if you wish to leave so soon. I look forward to the time when I shall be en route for home. When I came here and got Willie's letter, and saw the place where our waggons had stood together, I could not help feeling a sort of yearning for home, and to-day when I got your and the Mater's letters, it seemed as if it would be so jolly to be with you all again soon, but then I comfort myself with thinking that it will only make a few months' difference, going to the Zambesi, and I did not like the idea of leaving the country without accomplishing my object. I hope all will continue to go on well at home. 



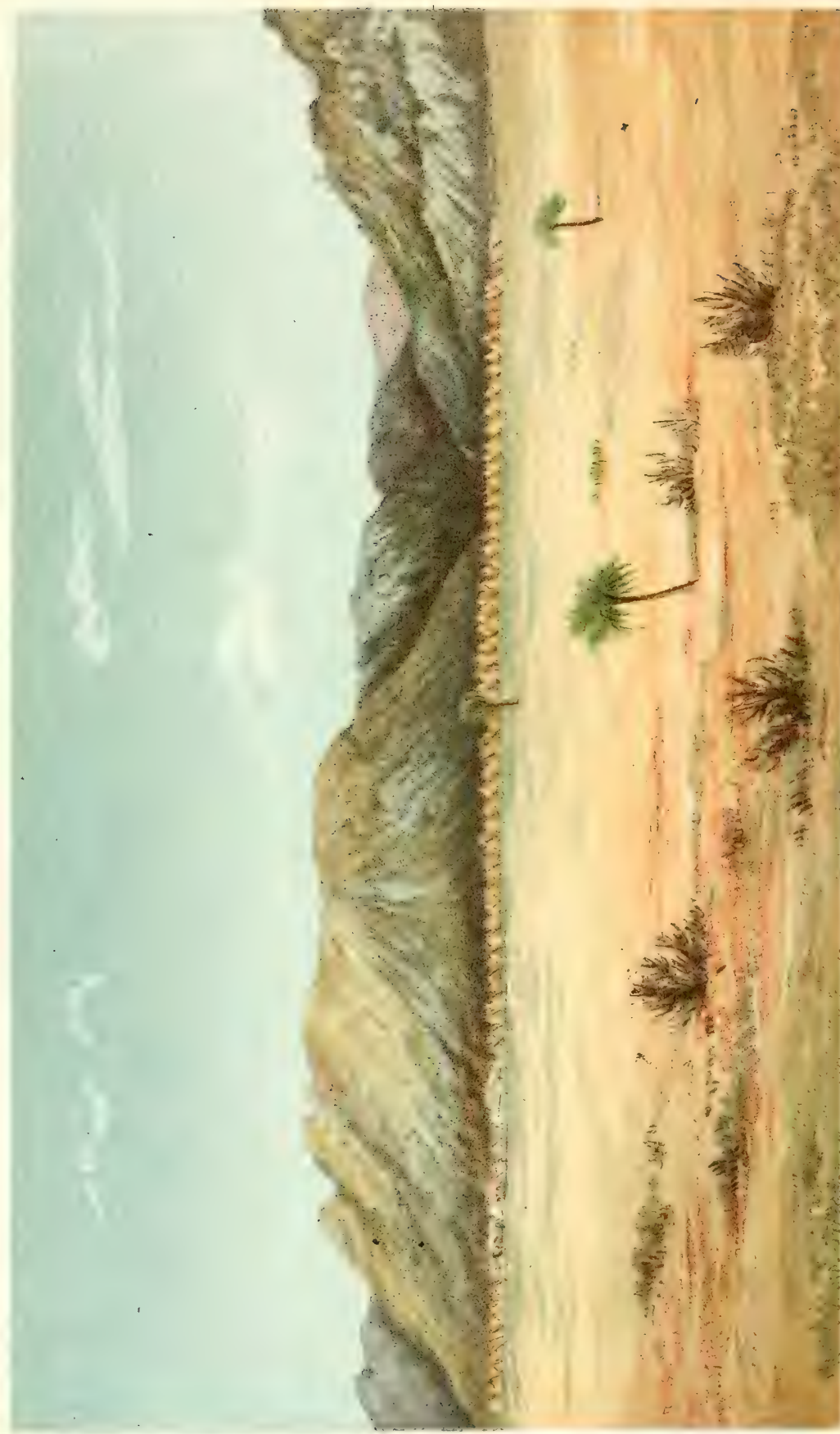

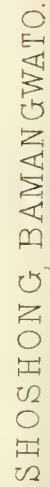


"There has been some fighting going on here of late amongst the natives. It took place just before I arrived. You may be aware that Kama left here, and old Sekomi, his father, remained behind with Kamani, Kama's younger brother. Kama, however, it is supposed, will return and rout Kamani. Sekomi is looked upon as nobody. Kamani is a gentlemanly well-dressed darkie enough, and the other day he and his men gave Matchin a warm reception. Matchin is his uncle, or something of the sort, and once for a short time supplanted Sekomi. He thought the dispute of the brothers a favourable opportunity for retaking Mungwato, but failed. His people had to climb the steep mountain which flanks the town, turning to fire as they fled, whilst Kamani's men shot at them from the plain. A great deal of ammunition was expended, but comparatively few natives slain. There were a dozen or so lying about on the slope of the mountain when I arrived, but the hyænas and crows had had a 'high old time,' and little was left of them but the skulls. A lot of huts were destroyed during the fight; and one of the traders here seized the opportunity to burn down the empty huts all round the store where he lives, and it certainly improves his view. ${ }^{1}$

1 The coloured drawing opposite illustrates the position of the town of Shoshong (Bamangwato). In front stretches a dry sandy plain, the native huts collected under the shelter of the mountains, which afford an easy refuge in times of warfare. The huts and stores of a few English traders, built of wood or clay, are seen grouped together at one extremity of the town - to the left hand. The only water in the dry season, as mentioned in a previous chapter, is got 
"It seems next to impossible to convert the natives here to Christianity, though a good many of them profess it. The worst of it is that when they get so far converted as to wear 'continuations,' they become incorrigible thieves and drunkards. I always infinitely prefer the raw unconverted heathen for my own use, and every one else that I know does the same. I like extremely the three missionaries that I know, and believe them to be most excellent conscientious men. They believe the chief result of their labours is yet to come, and I hope they may be right."

By the 24th of April, as already mentioned, all was ready for a start, and, leaving Bamangwato after sundown, a trek of two hours was accomplished that night. The following morning a like distance had been traversed, when the waggon was suddenly brought to a stand by one of the wheels giving way. It was fortunate, as it happened, they had not got further from the reach of help, and the broken wheel was at once taken back to Bamangwato. It was a tedious business, however, getting it repaired,-so slow are people's movements in this country,-but at last it was ready, and, some fresh oxen being purchased to strengthen the span, the journey was resumed early on the morning of May $5_{\text {th. }}$ Before starting a couple of waggons arrived from Lake from a small stream up the gorge behind the town, some distance off, whence it is taken to the town in small vessels upon people's heads. In this gorge stand the church and mission station of the London Missionary Society, from which are seen a short way off the beehivelike huts of Shoshong on the plain; see the woodcut at page I49. 
Ngami with two traders, both looking dreadfully ill from the effects of fever; indeed they seemed to have had a very narrow escape. They had buried one man, and reported the death of another at the Lake,-Henry Gray, the trader who, the year before, had accompanied Frank and William Oates a good part of the way up country when they first left Pietermaritzburg.

Before resuming his journey Frank Oates wrote home a few lines to his brother William, as follows :-

"Bamangwato, May 4th, i874.

"I wrote to Charley a few days ago, telling him I was just setting off for the Zambesi. As bad luck would have it, one of my hind wheels came to grief in jolting over that vile piece of road you must remember, about ten miles from here, and there I was, laid on my back. However, I put the wheel on a sledge of branches, and brought it with six oxen to be mended here, and once again am off. I am going to ride to the waggon to-night by moonlight, and hope to be at the Makalapsi River before the sun is very high. ...

"We have reckoned up about thirty waggons going Zambesi way this year; some are hunters, some traders, and some tourists. I expect most of them will stand at the same place, beyond Daka, and one must walk from there to the Falls. I suppose twelve white men at least will be at the Falls this year, so I shall not be alone, and one will be in the way of help in case of emergency arising, which is 
not likely. I am sparing no pains to get a good outfit. I have now twenty-six oxen, and am determined to be as well provided in every way as possible for the journey."

After writing the above Frank Oates rode out, as he intended, to his waggon, and by 3 A.M. on the $5^{\text {th }}$ of May was once more upon the road. Again all went favourably for something like three hours after starting, and a further distance of five or six miles had been accomplished when, to the traveller's unspeakable vexation, a fresh catastrophe of a like kind occurred, this time the tire of the same wheel breaking, and necessitating another halt. He now rode back into Bamangwato to see what could be done, the upshot of which was that he there bought two new waggons, and yet more oxen, so as to divide his load and lessen the risk of future accidents of this vexatious kind. He also secured the services of a Dutchman named Van Roozen, and his son, the former of whom would act as driver to one of the waggons, and make himself generally useful.

Whilst still completing these arrangements he added a short supplementary letter to the last, from which the following are extracts :-

"May 9 th, 1874 .

"Since writing the letter of May 4th, which will reach you at the same time this does, I have broken down again. After finishing my letter to you I rode out to the waggon, inspanned, and trekked. I had gone perhaps five or six miles, when the wheel came to grief again, the tire breaking, and I had to 
return here. It has ended in my buying two new waggons, and selling the old one. . . The great difference in my plans, however, is, that I have found a Dutchman and his little boy, who have agreed to accompany me. The former wanted to go hunting with some one, and I engaged him to go with me as driver and general overseer, but have stipulated that he shall only hunt when and where I think fit, as, for instance, when I leave the waggon standing to visit the Zambesi. Of course if he gets any ivory or feathers he gives me half, as is always done in these cases, and there may be enough to pay his wages as driver. His boy is a handy little fellow, and can take charge of a waggon."

It was the I $3^{\text {th }}$ of May, when again, for the third time, Frank Oates started north, but the further tracing of his fortunes must be left to the succeeding chapter. Before, however, concluding the present period of his wanderings, the following brief extract may be given from another of his letters, written about this time, with reference to his dogs. He says :-

"I have the nicest dog now I ever had. He is a pointer, and a most sensible creature. Dogs are indispensable here, if only to guard the waggon. My pointers are both well; I had four originally, but sold two here when I went further into the interior. One poor thing is dead, and the other far from flourishing. It was August when I left them, having a difficulty in feeding so many dogs; and now when I return in April, poor 'Flirt' knows me, and won't 
let me out of her sight for a moment. She had only known me three months, but had formed a very strong attachment to me. She follows me like my shadow. They accuse her of stealing soap, and say she has a penchant for departed negroes. The fact is she is not overfed. I wish that I had kept her. I have besides two puppies. One is five, the other three months old, and I have had them from their tenderest infancy."

The pointer referred to at the commencement of this paragraph was the traveller's favourite, "Rail," the attached and devoted companion of all his wanderings, his friend in solitude, and faithful to him even after death.

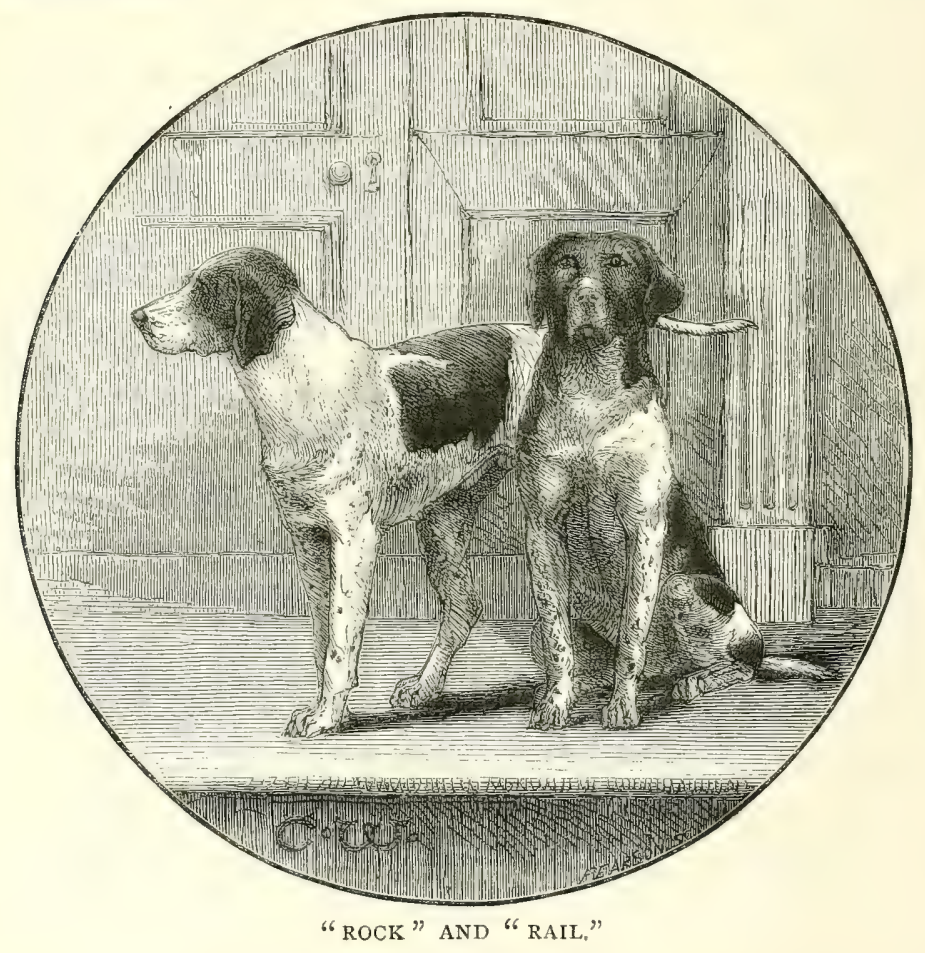




\section{CHAPTER VIII.}

Again at Tati-Fresh causes of delay-Lions on the MotloutsiThreatened by natives-Forthcoming prospects.

By the 2 Ist of May Frank Oates was again back at Tati from Bamangwato, this time completing the journey without further mishap. Little worthy of note occurred upon the road. The weather was now settled; the rains had ceased, and the days were usually bright and fine. The general aspect of the country was bare and brown, though, where water was met with, there was still for the most part a corresponding freshness in the landscape, as was the case at "Tchakani Vlei," a beautiful pond, surrounded by wood and covered with water-lilies, which was reached the second day of the journey. Again at the Palatswe River, further on, was water and abundance of fresh grass, the latter supplying excellent pasture for the oxen. But some days forced marches were required, to get from one watering-place to another, these in the winter season being few in number.

This scarcity of water sufficiently accounted for the general absence of game upon the route, only a few 
small antelope occasionally showing themselves the whole time. In crossing the Motloutsi two lions were observed quite close to the waggons, and Frank Oates gave them chase, but, as related below in a letter referring to the events of this period, was thrown off the scent by the wiles of the Dutchman, Van Roozen, who sought to avoid an encounter. The signs of animal life were rather more numerous on the Shashe River, where some fine water-holes were found in the sand, into one of which a crocodile had recently crawled, leaving the track of his tail behind him at the water's edge. Here pallah and other game spoor was abundant, and three or four large monkeys were observed crossing the river-bed. Birds too were numerous, including herons, kingfishers, and bustards. In the course of the journey one or two curious snakes were met with, one of which was of a fine silvery hue upon the back, and salmon-coloured beneath. Another, quite black, and of a very deadly kind, evinced a remarkable facility for swelling out its head to an enormous size when alarmed or angry. This snake had a habit, it was said, of hanging down from the trees like one of their branches and attacking such creatures as might pass beneath.

On approaching Tati the traveller was struck with the fine autumnal tints of the trees, and observed ahead of him the picturesque range of hilis towards the Ramaqueban. At Tati itself the grass was parched and yellow, and everything had already assumed its autumnal or winter garb. Here he was met on his arrival by Mr. Fairbairn from 
Gubuleweyo, from whom he learnt with pleasure that the king had sent leave for him to go to the Zambesi, a fresh permission having been required. The other travellers for the Zambesi, mentioned above in one of Frank Oates's letters, had most of them already started northwards, but for one reason or another he was himself yet detained some days longer at the settlement.

The only incident of much novelty which occurred during this time was an angry scene with some Kafirs at the mine, arising out of a second attempt he had made, when last at Tati, to get possession of the Bushman remains he had failed to secure when hunting on the Ramaqueban in February. The story of his encounter with these men and other circumstances of the time are related by him at some length in the following letter home :-

$$
\text { "TATI, May 29th, I } 874 .
$$

"I have been here just a week to-day en route for the Zambesi. I have been delayed, in the first instance, by the illness of Brown, who is managing Sir John Swinburne's mine here in the absence of Nelson, who has gone to the colony; and since, by having something done to my waggon wheels. I have been able to be of a little use to Brown, and did not like to leave him as he was, but he is now better. It does not much matter losing a few days, as I always thought the Ist of June would be early enough to leave here, in order to reach the Zambesi as soon as the healthy season there has fairly set in. I may now wait two or three days longer, as 
there seems a possibility of my getting my waggon wheels shortened. I shall be glad if I can get this done, as wood in this country shrinks so much that the tire often becomes loose, and then a blacksmith is wanted to shorten the tire unless the wheel is wedged.

"I am fortunate in having secured the services of the Dutchman and his little boy, whose engagement I informed you of in my letter from Bamangwato. These people are very useful to have about a waggon. There are a thousand shifts, which any one who understands the subject can have recourse to. A Kafir is scarcely ever the slightest good, even if he has been working about waggons all his life. I have now, moreover, far more comfort in the waggon I appropriate to my own use, as it is no longer crammed to overflowing, half my cargo being stowed away in my second waggon, which the Boer occupies. My oxen too are, on the whole, in a very satisfactory state, and I have all the necessary stores. I don't suppose I need be more than a month in reaching the place where my waggons must stand, and then it is two or three days on foot to the Victoria Falls ; but of course I shall go slower than this, and may not be back here till November, or even later. I feel now as if all was going well.

"I was eight days in coming here from the place where I last broke down, and had few incidents on the road. Van Roozen, the Dutchman, however, got a fright one morning from a couple of lions, and showed himself to be rather a coward. We were 
entering the dry bed of the Motloutsi River about two hours before sunrise, and I was asleep in the waggon. It appears that Van Roozen had gone across the river in front of the waggons to ascertain the nature of the opposite bank, which he had just climbed when the roar of a lion resounded in his ears, and he asserts that he was chased by a couple of them, and 'ran like a horse.' The latter part of his statement, no doubt, is perfectly correct, and also it was true that there had been two lions within a yard or two of him at one time, as we saw by the spoor at sunrise. I found the remains of a pallah they had killed in the bed of the river, and the spoor of the lions going away into the bush, and set off to follow it with the dogs and the Dutchman. The latter was in a great fright. I should have thought nothing of it if he had candidly admitted as much, but he thought to put me off by making believe to follow the spoor, and then conveniently losing it. The Kafirs too are most terribly afraid of lions, and will always lose the spoor ; indeed it is almost useless to attempt to follow it with them, but I had thought better things of a Dutchman calling himself a 'hunter.' The fact is, for one man to go alone, or only accompanied by Kafirs, may be dangerous, but for two white men with doublebarrelled rifles the danger is very slight; as, in the remote contingency of an attack, one could help the other, but really Dutchmen are only a degree better than Kafirs. Still they are wonderfully useful about a waggon, and my having this one with me takes a 
great deal of bother off my hands, and may save me no end of trouble and delay. My grand mistake was not taking a good man with me from Natal in the first instance at $£^{8}$ or $£$ ro a month.

"I have had a row with some rascally Kafirs here in this wise. Last year a party of unfortunate Bushmen-men, women, and children-were killed by a party of Matabele. The Bushmen were supposed to have been hunting where they had no right, or committing some other offence-probably an imaginary one. Hearing of this, I thought if I could find the place I could take a sack and fill it with bones, and I instituted inquiries accordingly as to the locality, offering a blanket to any Kafir who would take me to the spot. A Dutchman, who lives here, when he is not away with his wife and daughters in his waggon on a hunting expedition, offered to act as my guide, and it was settled that I should give him $£_{5}$ for doing so. He, however, changed his mind about going, but told me he had got one of the Matabele who killed the Bushmen to go with me in his stead. This fellow was working here at the mine, but when he was brought to me he also refused to go, evidently thinking I had some ulterior object in wanting to go to the place-perhaps to get him punished. These people, too, are very superstitious about going to places where others have been killed.

"This occurred when I was last here, but on my return I was waited on by another coloured gentleman, who said he too had helped to kill the Bushmen 
(and a ferocious beast he looked) - What business was it of mine to visit the bones? All this, of course, arose from the Dutchman having made it known that I wanted the bones. The ferociouslooking Kafir further went on to say that he should complain of my conduct to the king, the only way to avoid which catastrophe being to give him something out of my waggon, to bribe his silence. Moreover, he hinted that if I did not comply, he should not stick at helping himself, and went through a pantomime with his knob-kerry (a stick with a round knob at one end, with which Kafirs knock their enemies on the head), illustrating what he would do to me. All this was bounce, though no doubt he would have liked to do it had he dared, and he thought to frighten me. My pusillanimous Dutchman at once begged me to give the fellow something. This I stoutly refused, not only as a disgraceful proceeding on my part, but as an act of bad policy. I knew better than to show him I was afraid of him, and I knew the king was not likely to go against me, even if the worst came to the worst. There were two other Kafirs with this one, also from the mine, to back him up. Finding the Dutchman disposed to be friendly with them, the spokesman asked him for a cigar, seeing us smoking, and the Dutchman wanted me to comply, as a preliminary to talking the matter over. All I said, however, to the Kafir was a word or two of his own language, meaning 'Go away, you scoundrel.'

"It was Sunday, and at this moment a whitc 
man who works at the mine came up, and I told him the case. He knew the Kafirs, and at once ordered them off, giving one of them a good slap on the side of the head, which upset him. Then they all jumped to their feet and brandished their knobkerries. I threw off my coat, and my ally and I stood ready and waited for the first blow to be struck, whilst Van Roozen stood afar off. This attitude decided the Kafirs not to risk a fight, and they said they would go with me to Brown and talk the matter over. We went accordingly, and Brown told them if they wanted to do so to take the case before the king, and they soon subsided and slunk away. I might have had the greatest possible annoyance if it had not been for the plucky conduct of Dobie from the mine.

"Fairbairn's waggon was stopped when he came here by some Matabele, and he gave them some goods, but vowed he would complain to the king and get them into trouble. I suppose these three Kafirs thought they too could get something. The king, I believe, would kill them if he knew. There are, of course, no prisons; and when any of his subjects go too far they get put to death, and thrown out to the hyænas. $\mathrm{He}$ is an excellent friend to the white men here, and his people live in fear and trembling of their lives. Since I was at the royal residence, I am told he has killed some dozen of the leading men of the country for making suggestions to him. ' I must show them,' said he, 'who is king,' -and he showed them. 
"Winter has now fairly set in; it is extremely cold at night, and not hot even during the day-at least not hot for Africa. The rivers are dry and the bush withered, and all is yellow and autumnal looking, and will remain so till the rains fall in October, and the fresh vegetation springs up. Then the trees will soon be all green, and many of them blossoming, and there will be many wild flowers. Now things are bleak and barren looking enough.

"Before I leave here I shall write a few lines more. . . . I hope every one is well, and shall live in hope, for what else can I do? I can't expect to get any more letters till my return from the Zambesi. It may be some little time before you hear from me again, as I don't know that any waggons will return till November, though there are no end of them gone to the Zambesi. Should any precede me back I can send a letter by them. If, however, you don't hear, you must take for granted all is going well with me. Humanly speaking, there seems no reason for uneasiness."

On the 8th of June, his waggon at last ready, Frank Oates added a few lines to this letter, announcing his intended departure on the following day, and on the gth he started for the Zambesi. There seemed now no reasonable probability of anything occurring to interfere with the successful issue of his journey, yet in reality, as things turned out, this was only the first of three separate attempts he made to reach the Zambesi from this point the present season. By the shorter route now to be adopted-for he was not 
going by Gubuleweyo - he would proceed pretty direct northwards, passing through the country of the Makalakas, who are subject to the Matabele, and hold the key to the Zambesi country by this approach. Before crossing the boundaries of these people, it is necessary for travellers to have first obtained permission from the king to proceed, and such a permission Frank Oates distinctly had; yet, in spite of all remonstrances on his part, the Makalakas refused to let him pass, thinking, perhaps, to reap some profit from his discomfiture, or, it may be, that Lobengula would in reality be no worse pleased if he were stopped. Indeed the traveller did not himself entirely exonerate the king from blame, but suspected at one time he was playing a double game - on the one hand giving him leave to proceed to the Zambesi, whilst on the other purposely neglecting to send the needful instructions to his subjects to let him pass. The king was anxious to encourage a certain number of traders in his country, but may have looked with suspicion on one whose objects were less intelligible to him.

At all events, be this as it may, it is perfectly certain that these Makalakas threw every possible obstacle in the way of his advance-and not once only, but each time he reached their boundaries-whilst several traders, going and coming, were permitted to proceed upon their journey, and the final fatal issue of his expedition to the Zambesi was practically the result of the behaviour of these people. It is true that other circumstances, irrespective of their 
proceedings, combined to hinder and delay him, again throwing his journey into the unhealthy season of the year; but these alone would not have been of the same vital consequence, and the period of his misfortunes dates from the time when the Makalakasthe king's permission already plainly granted-first turned him back, as related in the succeeding chapter, and forced him to seek a fresh interview with Lobengula. In such a country, with but a brief healthy season, delays like this were little short of fatal.

But it is time to follow him in the first of these ill-starred journeys.

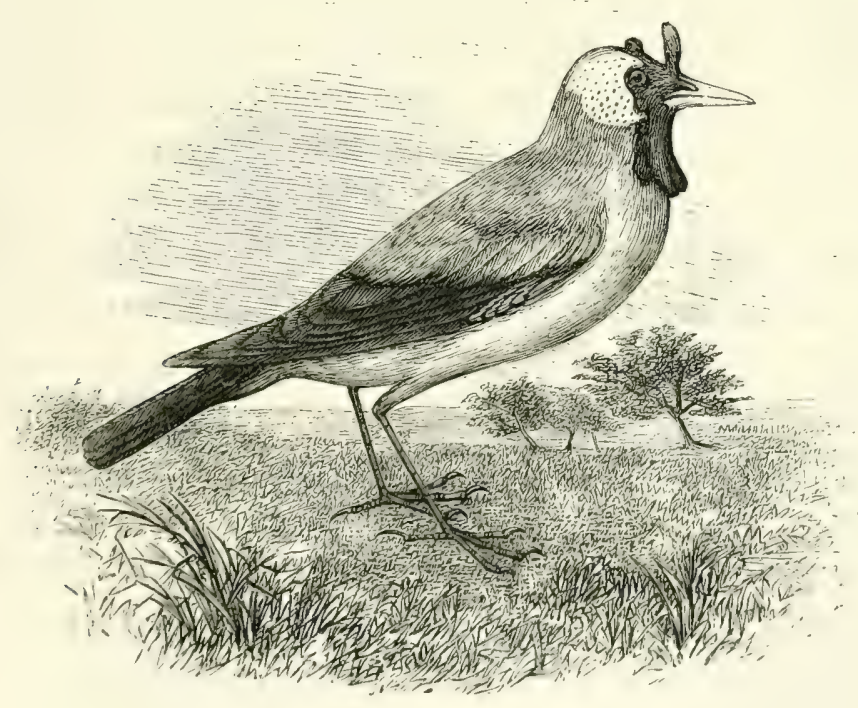

WATTLED STARLING.-Dilophus carunculatus. 


\section{CHAPTER IX.}

Fresh start for the Zambesi-The Ramaqueban again-A lion shotSingular building-Wild fruit-First kraal of the MakalakasStopped by the induna-Return to Tati-To Gubuleweyo and back-Fresh leave obtained-Altered arrangements for the journey.

ON first leaving the Tati, on June gth, the old ground, as though he had been making for Gubuleweyo, was retraced as far as the Ramaqueban River, where, on June Ioth, the traveller halted a short time to hunt. Giraffe, quagga, and blue wildebeest were now abundant in this district, and ostriches were also met with. Van Roozen too, the day before they left, succeeded in shooting a lion which had threatened to attack his horse-a great feat for this intrepid sportsman. An account of this adventure, along with some other matter, is given in the traveller's Journal of this date, as follows :-

"Fune r 2th.-Mild, cloudy day, after a very mild night. . . . Just before sundown Van Roozen returned from hunting, having shot a lion. It seems he had been following a sable antelope bull, and was about two or three miles from the waggon, down the 





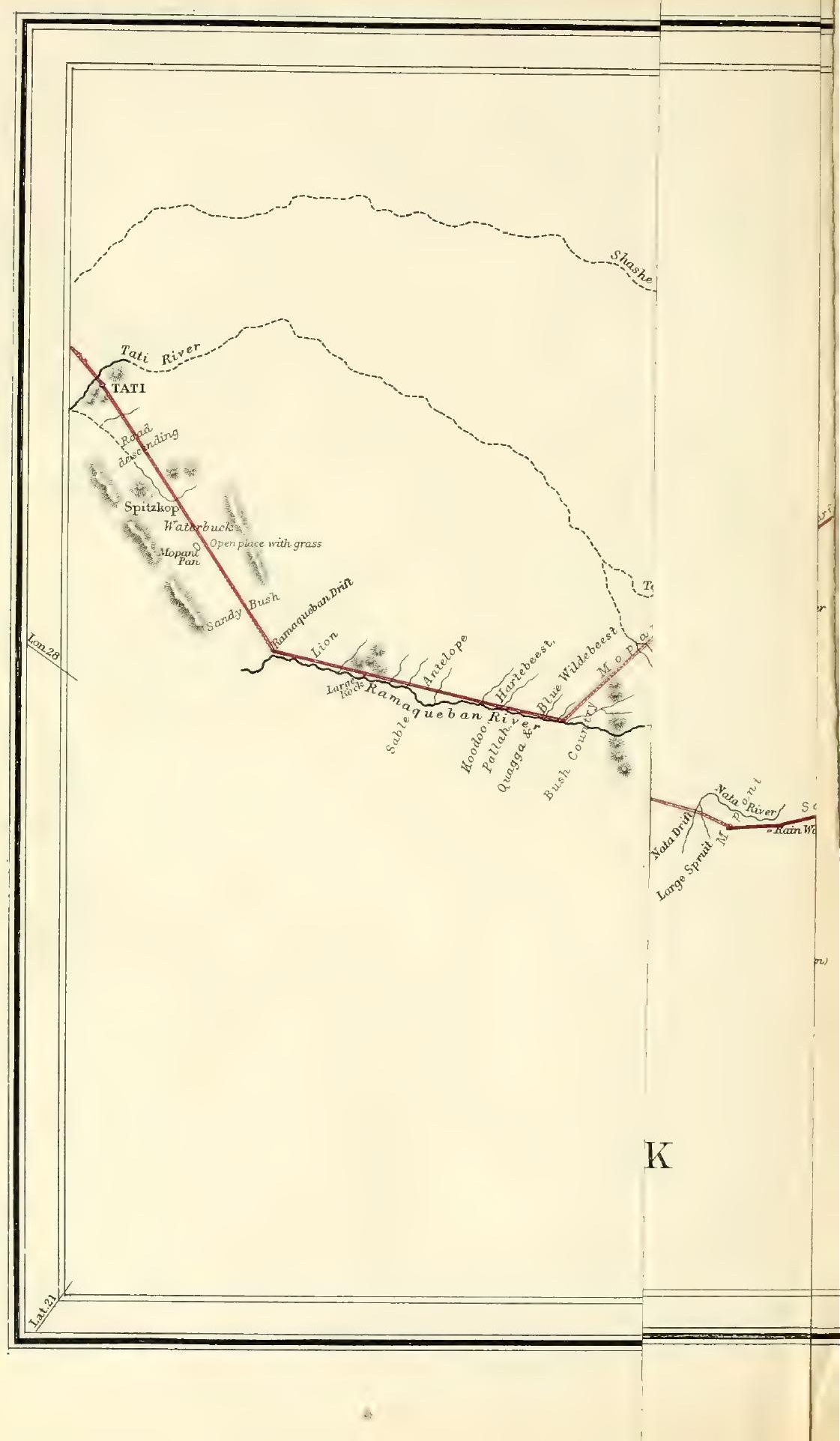


Ramaqueban, when a lion approached his horse quite close. He yelled, and turned his horse. The lion retreated, but soon stopped and seemed inclined to renew the attack. He dismounted and shot the lion at, he says, about 30 yards. He then saw another lion creeping towards him-both 'mannetjes' (males) and he (Van Roozen) made off. After his return he and I rode back together to the dead lion, which we found, and proceeded to skin. He was a yellowmaned one; Van Roozen says the black-maned one is quite distinct. In this the mane was short, the teeth very large and discoloured, but perfect, and the lion apparently in his prime, though he must have been hungry, as he was in poor condition. Van Roozen was alone when it happened, and he probably wanted to get the horse.

"Van Roozen tells me of an Englishman, named Brown, who was killed by a lion on the Crocodile River. One day this man and his son had found and taken three cubs, and the old lion came up to them. The son wanted to fire, but the father forbade him, and threw one cub down, which the old one took away, and they took the others to the waggon. The day following the old man took his gun, and said he was going after ostriches. He had one young Kafir boy with him. It seems he had gone to the place where the lions were, and had met the old one, which he fired at, but did not kill upon the spot--though I believe it was found dead afterwards. It had torn the flesh off one of his arms and both his legs, but he had taken his gun, gone to a hole where 
buffalo wallow, used his pannikin to wash his hands and face, and gone on to the waggon-road (the son followed the blood spoor). He had put his gun in a tree, and hung up his powder-flask, and gone on the road a hundred yards when he had dropped and died."

The day after Van Roozen's encounter with the lion, Frank Oates, whilst out hunting, again visited the carcass, and, kindling a fire, cooked some of the meat. On this the boys who were with him, and both his pointers, had a feast, and he tasted some of it himself, which he found to be coarse in the grain, and not unlike quagga meat.

Resuming his journey to the Zambesi later the same afternoon, he now broke fresh ground, keeping for a day or two in a northerly direction close to the Ramaqueban, a really magnificent river when viewed from the ground above, its broad sandy bed stretching far away into the distance through the veldt. The dry beds of a number of spruits, all rising quite near the river, and suddenly becoming large before falling into it, were crossed as he proceeded. It is no wonder that South African rivers, thus fed by so many tributaries along their entire course, fill with such amazing rapidity directly the rains fall, and swell into large streams almost at their source. Next turning towards the northwest, he presently struck across back towards the Tati River, and joined the more direct road from the settlement to the Zambesi, which here for some distance kept up the river's bank, the country now assuming that broken rugged appearance-here with 
rough craggy kopjes, there with small open park-like glades-which makes at irregular intervals so pleasing a change in this otherwise little-varying landscape, and compensates, where it occurs, for much that is uninteresting.

The Tati, itself one of those rivers which become large so near their source, was again itself shortly left behind, the waggons trekking forward in a direction nearly north. On June $\mathrm{I} 7 \mathrm{th}$, a few miles further on, another river was crossed, and the following entry made in the traveller's Journal :-

"Fune I 7th.-Fine morning, after a mild starry night; warm day. Inspanned at 6.20 A.M. I rode across the veldt to the right; grass very wet. Saw a small buck and three sassaybi, but they got my scent. Going in a direction generally north, I struck a deep sandy river, with plenty of water-holes in it, and banks steep and rocky in places; crossed it, and kept down it till I found the waggons, which had crossed it and outspanned perhaps a mile and a half further down. Just before reaching the waggons (8.20 A.M.), I came to a most singular building, built on a little isolated kopje in the midst of the level tree-studded veldt, but with other kopjes near. There has been an excellently-built wall running round the sides of the kopje, and a regular entrance into it. The boys say it was built in old times by the ancestors of the present race of Makalakas, and was the king's residence. No white man, they say, helped to build it. It is not seen from the waggonroad. 


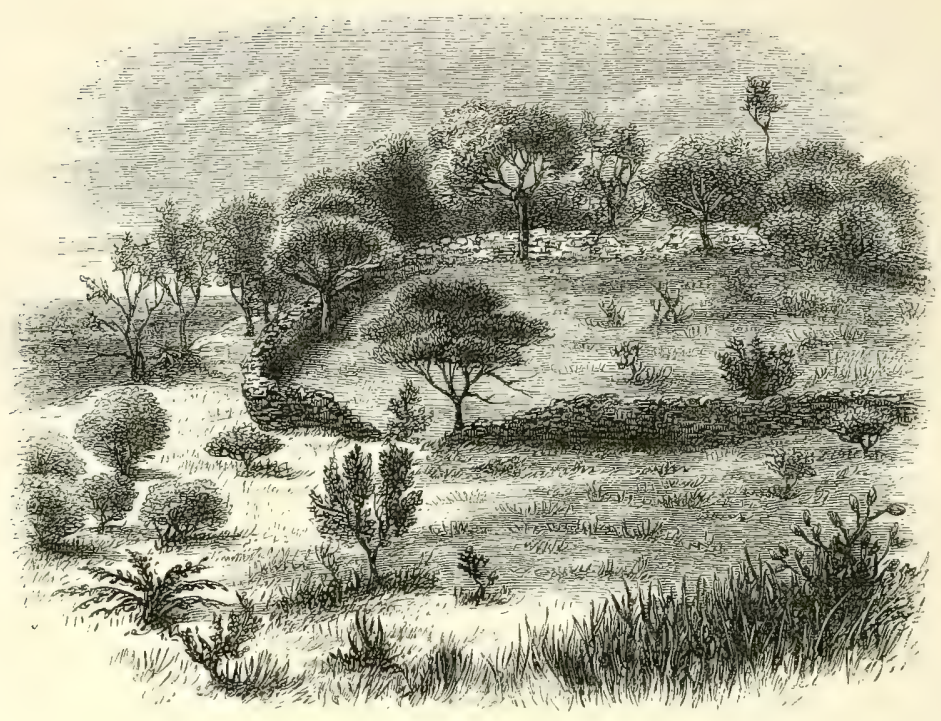

NATIVE BUILDING, SHASHE RIVER.

"The river, which we outspanned at, and which (as before stated) contains plenty of water, flows away towards the south-west, as shown by the bent reeds in its now dry sandy bed. ${ }^{1}$

"Started again at I.2O P.M. and went about eight miles ; first through 'mopani veldt,' with fine fruit-

1 This river, represented in most of the recent maps as taking its rise but a few miles from here, and flowing away directly to the westward towards the salt lakes, is in reality - so the traveller afterwards learnt from at least three distinct witnesses-a part of the Shashe River, the same river which is crossed on the Bamangwato and Tati road, a few miles before reaching Tati, coming north. One of these witnesses, Mr. Dobie of the mine, had, moreover, struck the river, he said, about thirty miles northward of the drift on which the waggons were now outspanned, and had found it a big river even there, where, according to the maps, it is not even in existence. The slate formation in which the gold is found runs, it seems, to a narrow point as far as this river-drift, and there ceases altogether. 
trees in it, and a little before outspanning passed through a range of low kopjes. This 'mopani' is usually very heavy land, so called from the mopani trees (not unlike alders) which grow upon it. Of the fruit-trees referred to, one was my old glutinous friend of the Gwailo hunting veldt-plentiful, but not yet ripe. It is very woody, but when chewed exudes a fine glutinous gum. Another has a small fruit like a little rosy-cheeked apple, containing seeds, and something of the crab nature, but not at all acid. Another, which I should say was also of the apple kind, and like the last in taste and texture, was as large as a plum and of the same colour, and grew on a thick low bushy large-leaved tree.

"In the evening, where we were outspanned, I found a large colony of birds established in three large nests (half-built, I think) in the branch of a tall tree. This is the noisy familiar bird I first met with at Tati." 1

Proceeding forward on the following morning, still through the veldt of large mopani trees, and passing amongst numerous fine rocky kopjes_rising up on every side in bold craggy heaps from the level veldt, tree-covered like the latter wherever trees could find root-Frank Oates next crossed two or three small spruits, now dry, of which the largest was about five yards wide. At this there was a delay of about half an hour, caused by one of the waggons sticking in its sandy bed, and when he had crossed it he outspanned upon its bank. And here, as he

1 The Red-billed Black Weaver-bird, Textor crythrorluynchus. 
rested - the Tati now well behind him, and his imagination full of hope in the future and interest in the present - it is likely enough he may have congratulated himself on the successful progress of his journey, but scarcely probable he should have reflected on the possibility that here, not many hundred yards from this very spot, he might but a few months hence, when returning from the Falls, find his last lonely resting-place; yet so he did.

Again, after a brief rest, renewing the journey about mid-day, he still advanced a short distance further in the same direction before coming to another halt; and here the Journal once more takes up the story :-

"Fune I8t/._. . I Inspanned again about noon, and crossed another spruit with a sharp turn in it. Soon saw cornfields, then the bright green of tobaccofields and a kraal, ${ }^{1}$ and outspanned at I P.M. I was pleased with the appearance of this little kraal, surrounded by its green fields of tobacco, and emerging suddenly to view from amidst the mopani trees; but I little thought of the disappointment in store for me here. Though we had trekked so short a time, and made our previous trek so short as to be scarcely worth mentioning, I almost decided to outspan here before I found that it was absolutely necessary I must. The people told us that there was a message from the king, which the induna would convey to me, but

${ }^{1}$ This kraal, the first outpost of the Makalakas, is described as "Wankee's" in the traveller's later Journals, and is so marked upon the map. 
he was away at another kraal and must be sent for. Sent a boy with the oxen to water, which is some distance off, employing a man from the kraal as guide. Meantime I made it known that I wanted goats and corn, and ere long was hard at work dispensing beads, handkerchiefs, and snuff-boxes. The main run was on the large lavender beads, next came the small lavender ones, and a few wanted blue cut ones. Mealies were brought in large quantities, but sold principally in small basketfuls. There was plenty of Kafir corn too, but not so much as of the Indian corn. Tobacco also was brought, and the sweet kind of beans that are like nuts' kernels.

"The women crowded round to sell. They were many of them recently smeared on their heads with something black like pitch, babies and all. Many of the girls have the hair matted thickly together in lumps. One hanging over the forehead, the end of the lock having brass rings fastened to it, droops down to the nose, and one to each ear. The hair is all drawn out in matted locks. A profusion of brass rings are worn on the arms, and heavy bead necklaces round the neck. Many of them are pretty. There are distinctly perceptible the dark and the light skinned; some nearly black, some copper-coloured. The men are much given to wearing carved charms and other ornaments and curiosities. A lion's claw or a vulture's beak are favourites amongst the latter division. They wear skins - karosses with the hair worn inside. John says there are both Masahras (Bushmen) and 
Makalakas here. I was surprised to hear from him that there are many Bushmen living in kraals and not wandering in the bush, as I had an idea they were exclusively a gipsy race, but it appears by no means so universally. The induna is an old Makalaka, who does not talk the Matabele language, but as it was not till the day after our arrival that I saw him, I will leave him for the present.

"Presently an individual arrived in white men's clothes, who spoke a little Dutch. Without ceremony he jumped up on my waggon-box, and I concluded he was the induna from his free and easy style. I begged him to excuse me, as I was very busy buying corn, after he had asked John a question or two, as, 'Was I going to the Zambesi ?' I never thought I was to be stopped, and went on buying corn, and he seemed glad to let me do so, till at last he came to his final interview - for much of the time he had been with Van Roozen. He then told me that the king had sent to stop all waggons from coming on, on account of the sickness, but the induna himself would be here the following morning. My feelings this evening were ones of intense disappointment, but still I hoped something from my interview with the induna the next day.

"Fune rgth.- Very cloudy day, after a mild night; inclined to rain. The induna and a large crowd here early. I took down the substance of the induna's words. They were thoroughly confirmatory of my worst fears. He said though they here would not stop me by main force, the kraals ahead would 
do so. They spoke as my friends. If I persisted in going on, they would send to inform the king, who would despatch a party of Matabele to seize my waggons and take possession of my goods. I thought it best to take down the substance of what the induna said to me, in order to report it to the king. Umganulo, an induna, he stated, brought the following news from the king four days ago, and went back immediately:-All white men going to the Zambesi to be stopped, and their boys killed if they attempt going on with them; waggons to be taken to the king if orders are disobeyed. The king too has stopped people going by all other roads to the Zambesi, and messengers also passed here the day before yesterday, going on to the Zambesi, to tell all white men who are already there not to return till the rains fall, as they may bring sickness. The king has also said that no one may go across the veldt to him from here, but all must go by way of Tati.

"Fune 21st.-Rather cloudy, but fine. Got up about 5 A.м. . . G Girls here very early with corn; also some goats brought for sale, of which I bought two for a cotton blanket, also a little more corn, some leather bags, and a calabash. A tall lad, formerly a driver for Palmer, and a most free and easy individual, having relapsed into the national dress, offered his services to me as a hunter, if I should return this way. I ask John his character. John says he once took a knob-kerry to Mr. Palmer, when the latter wanted to thrash him. But he was not to blame for 
that, says John; a notion of John's which I had to let him see did not meet my approval.

"Some of the girls who came to-day were very profusely ornamented with beads. The thicklymatted hair, plastered together with black wax-like cement, is disposed of (as I noted before) in three principal locks; one falling over the forehead to between the eyes, and one in front of each ear, surmounted with brass rings. The ears are pierced with small rings. Round the neck hang massive chains of beads, tastefully arranged and blended. A leather kaross, or dressed skin, is worn as a robe, and this is hung with long strings of beads. Long strings of beads too hang round the hips, and in front are long strips of leather. Round the waist are numerous brass rings and bead rings also. The girls are by no means shy.

"To-day poor Mozanga told me of some trouble he was in, and I thought he complained of a beating, but it seemed he had heard of the death of the induna of the kraal where I engaged him, a young man, who they say died in the Zambesi hunting veldt. $\mathrm{He}$ must have gone there at a very unhealthy time. Mozanga wept bitterly; he is a very kind-hearted boy.

"I went with Umfanimboozi to shoot some birds; whilst the oxen, which had got loose, were being fetched, and went through some tobacco 'gardens.' The pink blossoms and green leaves are very pretty. ..."

This same afternoon (June 2Ist) the traveller 
reluctantly commenced his journey back to Tati, resolved to revisit the king, and ascertain from his own lips the real truth of the induna's statement. The fine clear nights, during a part of which he now made a point of trekking, were brilliant as he returned with glittering stars and constellations, the Southern Cross at this time conspicuous amongst the latter a little after sunset. Four days after starting he was back at the Tati settlement, and on the zoth of June started on horseback to the King's Town, with eight boys to take his baggage.

On reaching the King's, Lobengula tried to laugh the matter off, and this time, as an assurance of good faith, appointed one of his own people, a son of the headman, Manyami, to see him safe through the country of the Makalakas. Frank Oates was again back at Tati on the I 5 th of July, and here, before starting once more for the Zambesi, he made some fresh plans and arrangements for the journey. What these arrangements were may best be learned from the ensuing letter, written at this time from Tati, and containing, besides, some particulars of his recent journey to Gubuleweyo. This letter is as follows :-

"TATI, July 2ist, 1874.

"I am, you see, at Tati once more. ... I left here for the Zambesi on the 9th of June, and on the I8th-travelling very slowly, as I had lots of time before me-reached the first Makalaka kraal on the Zambesi road. Here I was stopped, being told that the king had sent a special order to turn all waggons back which might come that way. They 
also said that all waggons coming from the Zambesi were to be turned back, and not allowed to leave till the rains fell, which begin about October. It was in vain I pleaded that I had special leave from the king. They said their orders were peremptory-all waggons to be turned back, and if the people with them refused to obey, the waggons were to be seized, and all the boys who persisted in accompanying them killed. This of course frightened my Kafirs, and all I could do was to turn back, and go to the king in person.

"On the $25^{\text {th }}$ of June I was once more at Tati, and decided to ride to the King's Town, but a fresh difficulty arose in getting boys to go with me, as my own boys say the white men are the cause of all this trouble, for they bring the sickness, and they are afraid the king will kill them for accompanying white nien. At last, however, this difficulty was surmounted, and I set off on the 3oth of June with my two horses, and eight boys carrying my baggage. Gordon, a Mungwato trader, arrived at Tati en route for the King's whilst I was making my preparations, but says there were no letters there for me when he left. He could not go on even to the King's without special leave, as the king has heard of 'red-water,' the Natal cattle disease, and is in a great fright about it. Indeed, if it got amongst his cattle, his nation would suffer terribly. It seems, too, from recent reports, that it is contagious, though we never used to think so.

"Dorehill's waggon and the waggons of another 
trader had been stopped on their way to the King's Town at the Inkwesi River, where the first Matabele kraal is, and were there when I came up. ${ }^{1}$ I got on very well up to the time of my reaching these waggons, and stayed a couple of days at them with Dorehill, who was awaiting further news from the King's. On leaving the waggons I met the messenger he had sent to the king returning with a message from the latter to Dorehill that he was to ride on and see him. I went on, but had great difficulty in keeping my boys from turning back. However, I explained to them that if they kept with me there was no likelihood of their being hurt, as no white man's servants ever were interfered with, whereas, if they turned back, they might be killed. They would of course have liked me to turn back with them; but seeing I was determined to go on, they thought it was their best chance to remain in my company. I of course knew there was not much fear of anything being done to them as long as they were with me, as the king holds everything belonging to white men sacred, and his people dare not commit any violence on Kafirs protected by a white man. The fact is my boys were principally Makalakas, who are slaves to the Matabele, and whose lives are considered worthless.

"One night I was very angry with them, for I had been riding on in advance, and kept on riding

1 Mr. Dorehill had been met by Frank Oates previously at Bamangwato, and subsequently accompanied him part of the way on his final journey to the Zambesi. 
after sundown, as the country for miles round was on fire, and I wanted to get past the fire before we encamped for the night. I lay down with my head on a log, to await their arrival, and fell asleep. By and by I woke up, and found it was colder than agreeable, and at once guessed that they had stopped behind. I had to ride back a good way before I came to their fire, when I pitched into them. They had been afraid to come on after sundown, as the Matabele don't allow their subjects to travel by night, though of course a white man can do what he likes.

"The next day Dorehill overtook me. He had set off the day after me, but without food or blankets, and was very glad to share mine. The following day we rode on to Gubuleweyo, the King's Town. The king seemed surprised to see me, but did not speak to me the first day I saw him, except to greet me, and send me to his sister to drink beer. The next day, when I told him what had occurred, he seemed rather amused than otherwise, and told me the Makalakas had been trying to frighten me, and that he had never sent them any order to stop waggons. I believe, however, he is the one to blame, and had probably neglected to send word to the Makalakas to let me pass. I had written to him from Tati for leave to go to the Zambesi, and he had given it, but could never have sent word about me to the Makalakas, who are his subjects, and very much given to stopping waggons that have not a special permit from him. He now gave me a Matabele boy, at my request, to accompany me. 
"The little horse I sold him for $£ 23$ when last at his town had got over the sickness, as I fully expected he would, and was 'salted,' and must be now worth from $£ 80$ to $£$ roo. I should never have parted with him, had not Mr. Thomson advised me to do so, in order to ensure his goodwill in case I wanted to go to the Zambesi. It seems, however, that he did not do for me what he might have done, and it has been suggested to me that this was because I refused to sell him my gun also! I think I told you that I gave him a gun when first I saw him, but he wanted very much another I had, offering me $£ 60$ or $£ 70$ worth of ivory for it, but I persisted in refusing to let him have it, and then it was he asked for the horse, and would not let the subject drop till he got the animal, and got him at his own price. I am afraid he is very little better than the generality of Kafirs, and certainly I have experienced anything but generous treatment at his hands-indeed scarcely fair play. Yet there is no doubt that he is very much afraid of anything befalling white men in his country, either from sickness or any other cause ; and now, when he told me to go to the Zambesi, he added, 'Unless I was afraid of the sickness.' This idea of sickness, and the new fear of a contagious cattle disease, brought by white men, are causing a good deal of trouble. Dorehill, however, got leave to take his waggon on, and intends to go to the Zambesi when he leaves the King's. I rode back with Dorehill as far as his waggon, and there I met Mr. Thomson and his wife once more, return- 
ing to the Matabele after being absent at a missionary meeting at Kuruman. ${ }^{1}$

"On reaching Tati I had some more trouble, which has ended in my making fresh arrangements altogether. John, my Kafir driver, refused pointblank to go with me to the Zambesi, and though I could have compelled him to do so, I thought it best to be rid of such an unwilling servant. Brown's waggons are starting for Potchefstroom to-morrow, and by them this letter is to be taken, which I hope will reach you by the end of September. John's only chance of leaving is to get away with these waggons, and of course if I say the word Brown will not let him go near them, and he cannot possibly go alone. However, I told John I should not stop him, because I did not think him worth keeping, and he will leave with the waggons to-morrow. Then the Dutchman in two instances had acted very badly whilst I was travelling with him, and when I was obliged to return to Tati I secretly intended to get rid of him, though I did not tell him so.

"It was the I $5^{\text {th }}$ of July when I got back here from the King's, and the very same day a trader arrived from the Zambesi, coming to get a fresh stock of goods. He had had to drive his own waggon, having lost his

1 This was the last occasion on which Frank Oates encountered Mr. Thomson, who, some time after the events here narrated-in 1877 -returned to England, to convey thence, under the auspices of the London Missionary Society, a party of missionaries to Lake Tanganyika. He accomplished the journey successfully, but unhappily was attacked by sunstroke soon after his arrival, and died from its effects in September 1878 . 
driver and other boys through being at the Zambesi in the unhealthy season. Indeed, he went there at what is supposed to be an extremely unhealthy time. I think it was February when he left here, and April and May are, I believe, the very worst months on the Zambesi. I left, as I have told you, early in June, intending to be back again before the end of the year, which every one says is the proper thing to do. Both Garland and Dawnay succeeded in seeing the Falls last year by doing so, and this year there are others who have probably seen them by this time. Now it is not too late to go there this season still, though the time one can spend there is shortened by not leaving earlier, for it takes about a month to reach the place where the waggons stand, and allowing another month for visiting the Falls, and a month for returning here, there is no doubt the Falls could be comfortably visited during a three months' absence from Tati, and there would be nothing remarkable in doing it all in two months with good oxen and good servants. So I can still go there, and be back again as soon as I ever intended to be.

"I am now coming to my new arrangement, which I think is in many respects a very promising one, for a final attempt to reach the Falls. The trader I speak of ('Stoffel Kennedy,' or some such name), has actually been at the Falls. He was there with Garland last year, and knows the country well. He knows where the poison-plant is, and where the tsetse-fly. He knows the people of the country, 
and all its ins and outs. $\mathrm{He}$ is I think partly of Dutch or German origin, but is to all intents and purposes an Englishman, and is very much liked. $\mathrm{He}$ offered to postpone his own trading trip, and turn back at once with me to the Zambesi, guaranteeing to take me to the Falls if I would make it worth his while. He would then, he said, take me there and bring me back, not going as my servant, but undertaking the whole management of the expedition for me. Now I knew I should have one waggon and span of oxen to sell when I came from the Zambesi, and he was willing to take these now at a fair price, deducting the sum which he wanted as a reward for his services. I was a little time before I could make up my mind, but it seemed such a chance for me as I might not soon have again. As for the Dutchman, I had even gone so far at one time as to vow that, rather than set off again with him, I would give up the trip; and though I modified this resolve afterwards, yet I knew he was not so likely to get me to the Falls as this man who knows all the difficulties. Then I thought, after all the time I have spent in order to get to the Zambesi, and being still bent on going there, the best thing would be to embrace this opportunity. I should not even have had the Kafir, John, in the other case, but only the Dutchman and his son, who cannot speak the language, and with the former of whom I had had a most unpleasant row more than once.

"It ended in my entrusting my fortunes to the new man. Brown, I may add, thinks I have done 
well, and I have every confidence in his judgment. $\mathrm{He}$ is a man of whom I have the very highest opinion, and, indeed, the more I know of him, the more I like and admire him. Personally, I have experienced the greatest kindness from him at all times, and know how to appreciate it.

"Stoffel is going to take his own waggon and the ten oxen he bought of me, leaving the new waggon here. ... Brown has just refused $£$ I I o for a little 'horse' - of course you know 'horse' means 'pony' every time I use it-which he bought for $£ 80$. A good horse is worth anything to one here, and I cannot wonder at the price given for 'salted' horses. Suppose, for instance, I had had to go to the King's on foot, and got foot-sore, where should I have been? The question is one not easily answered; but I suppose at any rate I should not have got on as well as I did. The absurdity is, that for a small insignificant-looking pony you have to pay the same price as for a good English hunter. A day or two ago we had some races here. We could only muster four horses, but by varying the riders and riding disputed races over again, we managed to get five races, in all of which I rode, and got the reputation of being a good jockey, as out of the five I rode in I won four."

Favourable as the above arrangements seemed for a renewed attempt to reach the Falls, the traveller's hopes, as will soon be seen, were again doomed to disappointment; and this in a most unlooked-for manner. 


\section{CHAPTER X.}

Third start for the Zambesi-Again stopped by natives-Fresh leave from the king-The journey resumed-Frank Oates's companion obliged to leave him-He goes forward alone-Breakdown of his waggon-Annoyances from the natives-Help from Tati-Return there-Letters home-Future plans.

Leaving Tati on the evening of the 25 th of July, on his third attempt to reach the Zambesi, Frank Oates halted for the night a few miles beyond the settlement, completing the distance to the Ramaqueban the following morning. Here, whilst waiting a couple of days in search of game and for other purposes, he was again unexpectedly stopped by natives, professedly armed with authority from Lobengula to stop all waggons from advancing northwards. The story of this encounter, with its immediate consequences, is thus related in the Journal :-

"Fuly 27 th.-Fine and oppressively hot, after a cold night. The days are now very hot, though the nights continue cold and frosty. I was going to ride over to the Inkwesi to-day, with a letter from Brown to Greit, and to see if Greit could let me have one of his drivers. However, before I set off, a Matabele came down the Zambesi road, bearing a shield, and accompanied by a Makalaka bearing 
another. A second Makalaka appeared later, but the moment the Matabele arrived, he came up to the waggons, and began interrogating us. On hearing that we were going to the Zambesi, he began to leap and dance about like a madman, brandishing a battleaxe. I thought it a case of temporary insanity, brought on by smoking 'dacha, ${ }^{1}$ but it appeared from his statement he had been sent from the king to the Makalakas, with a fresh order to stop waggons, and was now going on to Tati, to tell white men there the same tale.

"I had difficulty in keeping the dogs from attacking him, and once he brought his battle-axe within a few inches of Stoffel's skull. He became quiet, however, when Makabo (Manyami's son) ${ }^{2}$ told him the facts of the case, and said I could go on, but my boys, who were subjects of the king, would be killed, and if I went on I had better pay them off here. I therefore decided on sending to the king,--first, to ask for further security for my boys, second, for leave to take Stoffel with me; and decided to send off Manyami's son, with two others, with a letter to the king and another to Thomson.

"At night there was a tremendous conflagration raging close to us. It was a splendid sight, but made me a little nervous. However, it was principally on the other side of the road, and died before it came quite close. The effect of the burning trees and long line of fire was very fine. One tree in

${ }^{1}$ A kind of hemp, much used for smoking by the natives.

2 The man appointed by the king. 
particular, showing all its twigs red-hot or in flame, reminded me of some part of a display of fireworks."

The following morning Makabo was duly despatched with two boys-Umfanimboozi and Umfanto the King's, and Frank Oates remained hunting on the Ramaqueban, till their return a few days afterwards, with a favourable answer to his message. On the Ioth of August he was once more moving northwards the same way as he had gone before, halting again on the $\mathrm{I} \mathrm{r}$ th for a couple of days' hunting higher up the river, at a point where game seemed more than usually abundant. This was the place where the road branches off from the Ramaqueban across the veldt again towards the Tati.

"I now feel," he writes at this point, on August I3th, "to be realizing almost for the first time some of my old visions of South African sport. To-day, soon after starting, I ascended a kopje near the waggons, and saw a large herd of quagga. Counting roughly, I made out a hundred. It was a beautiful sight. All around was the sea of bush, with here and there bare patches, and here and there kopjes-some of the latter far distant. The winding spruits, too, lay as in a map. The quaggas were quietly moving on, or standing and playing, or brushing away the flies. It was a scene such as I used to fancy must be common, and which probably was so when the accounts I have read were written, and may occur often still in more remote districts."

The day previous the traveller had shot koodoo, hartebeest, and pallah, and seen an immense herd of 


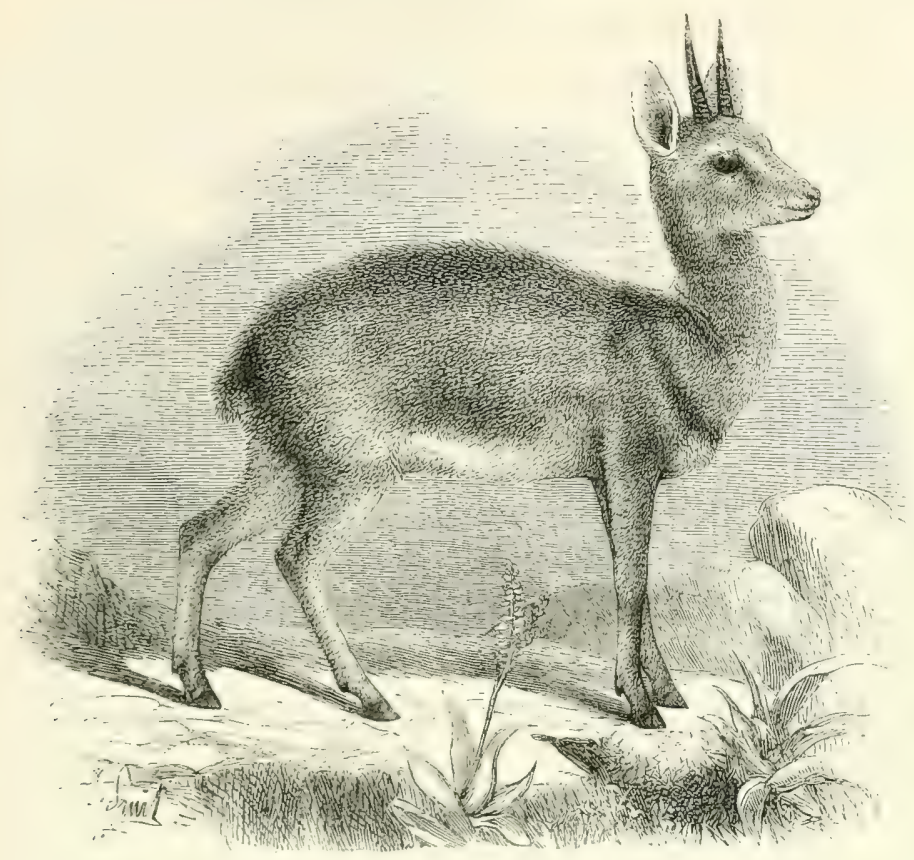

KLIPSPRINGER. - Oreotragyes saltatrix.

(Height about 20 inches.)

quagga and blue wildebeest, numbering not far from a hundred of each sort. Amongst the lesser antelopes, the graceful klipspringer, found only in the hills, was met with in this district.

Resuming his journey to the north-west on the I 5 th, and travelling through mopani veldt, he again struck the Tati River in the afternoon at the same point where the pleasing character of the scenery had been first observed by him when he was here two months before. A spring or "fountain" of fresh water welled up at the foot of a picturesque kopje, and a mile or two up the river was abundance of water in the river-bed. 
"The river here," writes the traveller at the latter point, "flows to the south through a deep sandy bed, kopjes hemming it in on either side. The scenery is remarkably pretty for South Africa, and the long reach of river flowing away to the southward is an object to attract the eye. The water actually runs in the bed here, though there is far more sand than water, and big stones than either. Stoffel says there used to be plenty of elephants here. This was the place where they passed through the kopjes on their way south, and last year he and Garland saw fresh spoor here. Out with rifle down river; pretty little grassy parks amongst the kopjes, and on the kopjes themselves very thick bush. The river where we have struck it—the 'poort' as Stoffel calls it—would be a pretty subject for a sketch."

Again pushing forward the following and two next succeeding days, still by the same route already traversed, Frank Oates once more reached-on August I 8 th - the first kraal of the Makalakas, the former scene of so much trouble and vexation to him. A few days previously it had chanced that Stoffel had slightly hurt his finger, and here, as it began to give him pain, they waited a week before proceeding further from all reach of help, to see what course the injury would take. Supplies of corn had here to be obtained, and the interval of waiting was occupied, partly in striking bargains with the natives, and partly in rearranging the contents of the waggons, to receive the grain; neither of them the 
most agreeable of occupations, as the following extract from the Journal shows:-

"August 2oth.-Windy day; rather cloudy. The wind rose very much towards night. . . . I am now lying in my waggon, glad to rest, wearied out principally with worry, and the dissatisfaction of finding time so miserably wasted as to-day has been; packing, unpacking, stooping, watching lest things are stolen, and having one's patience tried in buying of the natives, putting up with their disagreeable presence and impudence, to say nothing of the annoyances one is subjected to by one's own servants. I had to knock the disgusting servant of Makabo off the dissel-boom before he would go. $\mathrm{He}$ was bothering me for a snuff-box, and would not go away for civil speaking. I am not patient or industrious enough for waggon life. To-day has been one of nothing but unpleasantness to me."

At length, on the $23 \mathrm{~d}$, it became evident that Stoffel must return and seek advice from Mr. Thomson, the missionary, who had some skill in surgery. This change of plan involved a corresponding change in all the arrangements of the journey, and such of Frank Oates's goods as had hitherto been carried in the trader's waggon had now to be taken in his own, already sufficiently loaded when they left the settlement. On the 24th Stoffel took his departure southwards, and two days later Frank Oates went on alone towards the Zambesi. It was a lovely moonlight night when he resumed the journey, the waggon running heavy through thick mopani veldt. The 
prospect of success in his present enterprise now seemed nearing its fulfilment, yet in reality he was but on the eve of a fresh misfortune. "We passed a kraal," he writes in his Journal, "on the left side of the road, perhaps two miles from where we started, and had gone perhaps one mile more, when, in crossing a small 'sloot,' one of the wheels gave way and came down, broken to pieces. So much," he concludes, "for the new waggon, and for my hopes and expectations!"

The day after this catastrophe, which appeared in its results fatal to all hope of his reaching the Zambesi that season, late as it had now become, he arranged to send his driver-a Kafir named Klaas, whom he had engaged from a Mr. Horn upon the Ramaqueban-and three boys, with the broken wheel to Tati, and also with a note to Mr. Brown, asking for assistance. The annoyances he suffered, during their absence of about a fortnight, from the natives of the neighbouring kraals are described at length in some of his letters, largely quoted from below. It is therefore sufficient here to say that he was wilfully subjected by them to every possible inconvenience, was in constant peril of being robbed, and at one time even appeared to be in some danger of his life. The whole of this time he could not leave his waggon, lest he should return to find it plundered, and even his own boys were not all to be depended on.

At last, on the 8th of September, the needful 1 i.e., stream or ditch. 
help arrived, and he was released from his state of bondage. He had just had a most threatening visit from a noisy crowd of natives, when the messengers he had sent returned from Tati with all that he had asked for. After relating in his Journal the incidents of this unpleasant interview, he thus concludes the story :-

"They left me," he says, "the noisy crew; and still, though I felt relieved, a gloom hovered over my feelings, and I lay down to rest. It was then with delight indeed that Maclinwon's announcement, 'incolo' (waggon), broke on my ears, and that, rushing out, I beheld Klaas driving a waggon to my scherm. True enough, Brown had managed to procure an old waggon to help me out, sending me also a wheel of the Scotch cart and four oxen, to ensure my having sufficient. There was a long letter from him, and four newspapers sent for me from England, with news of letters from home awaiting me at Tati."

This was indeed a welcome release to the traveller from his present troubles; but, with such information as he now possessed regarding the period and duration of the healthy season for visiting the Zambesi, he felt that by this time it was too late for him to attempt to reach the river, and that, for the present at all events, he must abandon the idea of getting there.

On the roth of September, therefore, he once more unwillingly started back on the return journey to Tati, where he arrived on the 18 th, to find, with 
delight, a large packet of letters awaiting him from England. After the harass and annoyance of his recent experiences, he was glad to rest here for a while, and was comfortably quartered the chief part of his stay in the house usually occupied by Piet Jacobs, the Dutchman, who was now absent in the hunting veldt. This house was cool and airy, with a thatched roof extending far on every side, so as to form a verandah.

The following entries in his Journal, soon after his arrival, relating mostly to natural history subjects, may here be read with interest. He writes :-

"September 20th.-Rather windy, but pleasant day, after a cold night. I liked my new quarters. . . . To-night, as last night, sat at Brown's talking. We discuss some questions in natural history. . . .

"Wild dogs have been discussed. Dobie has seen them in packs, he says, variegated in colour, with white patches here and there, differently placed in different animals. Brown has seen them, and says they are like what he imagines a European wolf to be-and I think he has a good idea what the latter is like. Johnson says that, when coming here, he saw a hare run against the waggon wheel when they were outspanned at the Shashe, and kill herself; and by the light of the fire he saw distinctly, standing twenty or thirty yards off, a wild dog. He says it was a good deal like a European wolf-an animal he knows-with a fine coat and bushy tail, upright ears, I think, and a long nose. Brown says they often run pallah into the station here, when the 
natives, hearing the cry of the pallah, rush out from the different white men's establishments to assegai it, and the dogs are usually found to have torn at the place where such creatures generally commence their attacks, and even dragged out a portion of the entrails. They must hunt the pallah, he says, for hours with dogged perseverance and fairly weary him out. I know myself what a fleet creature the pallah is, and have no doubt for miles he would far outstrip a pack of dogs.

"Brown says a fine dog in a wild state once hung about here for some time, stealing meat at night, and playing with the tame dogs. He was very cunning, and was off at the slightest indication of danger. If he was heard outside the house and the least noise made inside, he was off. Many shots were fired at him, and he escaped for a long time, but at length was shot when on one of his visits. He lived in the veldt, and always rushed into the bush, just like a hyæna, which he resembled closely in his habits. This was no doubt some white man's dog that had run wild and acquired the habits of a wild animal to a certain extent.

"September 23d.-Pleasant breeze. Did not do much, or feel up to much. Another chat at Brown's in the evening. Brown tells me that once four young guinea-fowls were brought him, which became extremely tame. One only, a hen, survived. She became wonderfully tame, and would follow the Tati people about. When a Tati waggon was sent out for wood, or for any other purpose, she 
would go and return with it, not following strange waggons. She would follow Nelson when he rode to the 'Blue Jacket,' ${ }^{1}$ wait for him, and return home with him. Latterly she got into the habit of going with the oxen when they went into the veldt, would start with them, remain all day, and return at night with them, marching in front. She would even join wild guinea-fowl, if she came across them in the veldt, and would leave them as soon as she found she was getting too far from the waggon or person she was with at the time. She is supposed to have been killed at last by a nigger by mistake. Brown had had her eight or ten months."

With these extracts the present period of the traveller's wanderings, so far as his Journal is concerned, may be allowed to terminate. The weather, which had up to this time continued cool at night, began towards the end of September to be intensely hot and oppressive, though still liable to considerable variation ; so much so indeed that one day about the middle of October the extreme cold brought the swallows into the houses for shelter and protection.

The Zambesi now abandoned, Frank Oates, on the 8th of October, sent two boys with a message to the king, asking for leave to hunt a few weeks on the Shashani, which was readily accorded him; but he did not start immediately-his waggon required some repairs, and he was not feeling well. Whilst thus waiting a while longer, to recruit his health and complete his preparations, two gentlemen-Messrs.

1 A mine near Tati. 
Bond and Robertson-arrived on their return from the Zambesi, having gone there early in the year. They had shot elephants near the river, and the former had made some pretty sketches of the Falls. Other parties also now came in from the Zambesi.

At length, on the $3 \mathrm{~d}$ of November, Frank Oates once more set off into the veldt-not to the Shashani, however, as he had intended, but again in a northerly direction, for reasons shortly to be stated. Before starting on this occasion, he wrote home some letters of considerable length, reviewing his experiences of the past three months, since the date of his last departure from Tati on the $25^{\text {th }}$ of July, which may here be given almost as they stand, entire. The first of these, written to his mother, is as follows :-

" TATI, October Ist, I874.

"When you see the above date, you will perhaps think that I have returned from the Zambesi; but the fates seem to have conspired against my reaching that river. After last writing home I left here on the $25^{\text {th }}$ of July in company with Stoffel, the trader I told you of, and with every prospect of a most successful trip. The series of mishaps which led to my final (for this season at any rate) return here on the I 8th of September, I will presently relate. I say, 'this season at any rate,' but I think I shall now give up the Zambesi altogether, consoling myself with the adage-' 'Tis not in mortals to command success.' I read somewhere of some one replying to this - 'But they can deserve it ;' and a third party, who I think showed his wisdom, suggested, as an 
amendment, that they could 'do without it.' Now, I think, to a certain extent, I deserved it for my persistent efforts to attain it, and may hope to march out with the honours of war, and 'do without it.'

"I can scarcely express the pleasure it gave me to receive, on returning here, a large packet of letters bearing dates from the 4 th of August 1873 , to the 25th of April I874; some to Willie and some to myself, and some which Willie had written to me on his way home. I suppose he had read, and sent on for my perusal, those of the letters which are addressed to him. The letters seem to form a connected series, and I doubt whether any have failed to reach me. After hastily looking over a few of them I proceeded to arrange them according to date, and then to read them through in order. I scarcely hoped that there would be no bad news. . . . Skelton's death must be a terrible blow to his family, who, when I saw them last, were looking forward to a visit from him. It seems only the other day he was at Oxford distinguishing himself in the athletic sports, in which he was generally a successful competitor. I believe every one liked him, and that he was worthy of their high opinion. ${ }^{1}$

"To-day waggons have arrived from Bamangwato, and, to my great joy, another letter was fished up for me from the bag. Hathorn writes from Maritzburg on the 4 th of August, enclosing a letter from Willie,

1 This refers to the late Mr. Henry Skelton, formerly of Wadham College, Oxford, who died in Borneo, in the service of the late Rajah Brooke; soon after his appointment as Resident of Saráwak. 
dated June $2 \mathrm{~d}$, and a line from Charley, dated June 4th. It is very delightful to be brought in contact with you all once more after so long an interruption to communication. I don't believe any thing can make one appreciate home and friends like a long absence from them. Indeed, things we think nothing of at home are often dwelt upon in memory when one is in the midst of the wilderness. The packet of letters, which I have referred to as awaiting me when I came here, arrived at Tati before the end of August, and the latest written of them bears date April 25th; so that, in both instances, about four months have elapsed between the time the letters were posted in England and that of their delivery here. It is the fact of one's moving about that makes the communication with home so desultory. ${ }^{1}$ "To-day the rains may be said to have begun, but there will probably not be much rain for some time yet. However, this morning was dark and gloomy enough, though there are now signs of an improvement in the weather. I have been here a fortnight, and am waiting till certain necessary repairs are made in my waggon, my idea being to spend a few weeks in this neighbourhood before finally leaving for Maritzburg. ... In the meantime I mean to give you a little account of my doings since my last letter to you, encouraged by Charley's assurance that my descriptions of

1 The time occupied in the transmission of letters has, since the above was written, been much curtailed, owing to the establishment, through missionary enterprise, of direct postal communication between Bamangwato and the Cape. 
the country and the account of my wanderings are read with some little interest, though I fear I can only thank the friendliness of my critics for anything interesting being found in them. As, however, I receive the flattering assurance that they do afford a little amusement I will proceed without further apology. A mail is leaving here very shortly, as traders are now here on their way to Mungwato, and will take letters. By the way, I am writing with some of the desiccated ink I brought with me. I had a grand brew of it yesterday, and it is an undoubted success. My table is formed by a packingcase, and my chair is a box of gunpowder-but I am not smoking. I am inhabiting a deserted house made by one of the former gold-diggers here, and appropriated by a Dutch family, who, however, are from home. The paterfamilias has gone to hunt for ivory in the Zambesi direction, and taken his 'vrouw,' family, and furniture with him in his waggon."

The narrative, here broken off, was again resumed, some days later :-

"October 2oth.

"I again take up my pen to continue the letter I began on the Ist of this month, and which I hoped would have been a long way south of Bamangwato by this time. The delay has been occasioned by the drought, rendering the journey full of risk for the oxen. I promised you a short résumé of my doings and sufferings since I last wrote to you. By sufferings, I don't of course mean bodily ones, but what I have suffered from rascally Kafirs, and which are only entitled to be called annoyances. 
"After last writing to you, I left here on the $25^{\text {th }}$ of July in company with the trader I told you of. Some delay ensued when we were one day from here, occasioned by reports of the road being stopped by the king. I had with me the man given me by his Majesty to see me safely through the Makalakas on my way to the Zambesi, and a precious rascal he was. Some people came up to the waggons with great demonstrations, one of them rushing about and flourishing a battle-axe. I adopted my usual course, in such cases, of lighting a pipe and sitting on the front-box of my waggon, watching the performance, varying my tactics by turning my back on him. He professed to have authority from the king to stop all waggons going to the Zambesi, and lugged in poor old Mosilikatze's name, as is usual in grand orations, and made my boys shake in their shoes, metaphorically speaking, by informing them that the order was that any of the king's subjects accompanying white men to the Zambesi were to be killed.

"The son of Manyami, the man given me expressly to shut up this sort of bounce, suggested that this might be some new order from the king. I therefore lost no time in sending him off with a letter to headquarters, requesting full instructions, as Manyami's son had not seen the king at all about the affair, but I had simply taken him, as the king told me, from his father's kraal on my way from Gubuleweyo to Tati. Old Manyami is the man who used to stop all waggons coming into the country 
till the king had given leave for them to proceed, and he stopped me when I first came myself, as I dare say I told you at the time. This is done, however, at a different kraal now-the first one passed by any waggons going from here to Gubuleweyo, about forty miles north-east of Tati. In the meantime I remained on the Ramaqueban, my ally riding over to Tati once or twice.

"Whilst I was here a trader of the name of Horn passed, and had to wait when he was a few miles on the road to ask leave to proceed, as all waggons from Natal are now stopped for fear of the disease, and Horn had to explain who he was and where he came from. Horn, I think, is the man who opened the Zambesi trade, but is at present trading with the Matabele. A lion killed one of his oxen on the Inkwesi one night whilst he was waiting here, and a dozen of them took fright and ran away. I assisted in looking for them, and followed up the spoor next day till late in the afternoon, and must have been close to the oxen, but there was a Scotch mist, and it was a wretched evening, so, leaving three Kafirs to follow and sleep on the spoor, I returned to the waggons. Next day the Kafirs returned without the oxen, and thus much time was lost. The day after this Horn's partner followed the spoor to the water, but from the water followed up, by mistake, some fresh buffalo spoor, and slept on it, to come the following morning on to a herd of buffalo, which rather astonished him. At last Stoffel set off with him, about four or five days after the 


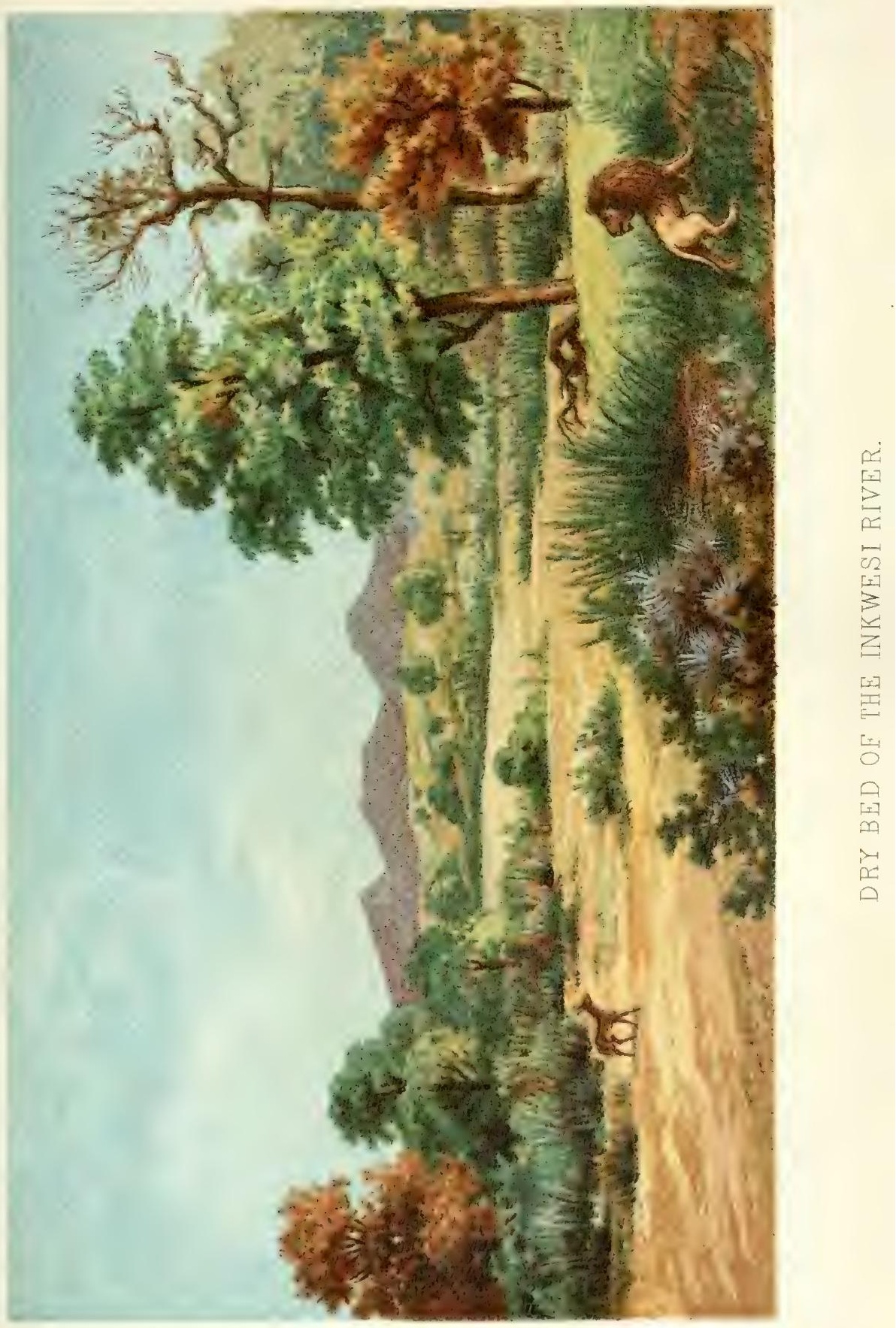



oxen had strayed, and they succeeded in recovering them.

"Whilst Stoffel was away the dogs began to bark late one night, and a man appeared at the fire in a miserable plight. He was a rebellious induna, or headman, whom the king had ordered to be killed. There are a certain number of indunas, who have certain districts given them to rule over under the king, and if they presume too much on their authority they are put to death without much trial. Some of them would be insufferable in their conduct to white men if the king did not keep them in order. This particular man, I believe, the king had given fair warning to, and told him to take a horse and fly the country, but instead of taking one he took two, and he was brought before the king, who thought it best to make an end of the matter. They took him outside the town, and hacked him with their axes, leaving him for dead. What must have been intended for the coup de grâce was a cut in the back of the head, which had chipped a large piece out of the skull, and must have been meant to cut the spinal cord where it joins the brain. It had, however, been made a little higher than this, but had left such a wound as I should have thought no one could have survived. It is wonderful, however, how hard Kafirs are. When I held the lanthorn to investigate the wound I started back in amazement to see a hole at the base of the skull, perhaps two inches long and an inch and a half wide, and I will not venture to say how deep, but the 
depth too must have been an affair of inches. Of course this hole penetrated into the substance of the brain, and probably for some distance. I dare say a mouse could have sat in it.

"His voice was weak, but he evidently enjoyed his supper and the warmth of the fire. My boys said he was a 'wolf' - the term applied to outlaws -and that he ought to be killed or driven away. He told me that it was five days since he had been set upon; and that, after he had been left for dead, he got up and ran away on coming to himself. $\mathrm{He}$ wanted to go under my protection to the Zambesi, an honour, however, which I declined, but I gave him a blanket and some things to buy food with, and told him he must go next morning, and advised him to make for Mungwato. He asked for a pipe, and for a drink of brandy, which reminded me of Old King Cole; and if he had been given to amusing himself by listening to the violin, I have no doubt he would have asked for a tune, as he seemed disposed to take things very philosophically. I poured some arnica and water into the hole, and when he lifted up his head a perfect stream of it ran down his back. He said if he was not killed he should see me at Mungwato when I returned. I believe he did reach Mungwato alive, but I don't know whether he remained there. ${ }^{1}$

"A perfectly favourable communication having

${ }^{1}$ In June the following year, this man was seen by Mr. Gilchristwhose journey into the interior is related in the concluding chapter of this narrative-living near Rustenberg, in the Transvaal, apparently in perfect health. 
been received from the king, I was all ready to continue my journey towards the Zambesi, which I fondly hoped to see in a few weeks. On the Ioth of August I was again en route, and on the I8th I reached the first Makalaka kraal, travelling slowly. This was the same point I reached before, when I started with the Boer and his boy. Here we decided to stay, to lay in our store of corn,-- enough to keep our Kafirs when game could not be got, our dogs, and, above all, our horses. At the place where the waggons stand where they are left by people going to the Zambesi, the journey having to be completed on foot, no corn is to be bought, nor any on the road, as there are no corn-growing people between these Makalakas and the Zambesi. Therefore enough must be taken at this point to last till one is amongst the Makalakas again on one's way back.

"Here my companion was laid up with a bad finger. He had run the head of a needle into it whilst sewing, and not feeling much at the time had taken very little notice of it till it began to give him pain, and then he suffered terribly. The end of the finger appeared dead, and I was so much afraid of mortification setting in that I advised him to lose no time in trying to reach Thomson, the missionary, in order that he might have the first joint of the finger amputated if necessary. I should have gone back with him, but he begged me not to do so, assuring me that I should be of no use to him, which indeed seemed likely to be the case. I therefore determined to push on. 
" Unfortunately my waggon was quite sufficiently loaded at starting, as I had never contemplated having to travel with only one waggon, in which case I should have left everything I could spare at Tati. As it was, I not only had to add to my own load the things belonging to me which were in Stoffel's waggon, but to take besides a large supply of corn and meal, which we had arranged at starting should be taken in his waggon also. The result was, that my waggon was overloaded; and I had not gone more than two or three miles when one of the hind wheels broke, and the weight coming down on it, it was flattened under the waggon, with every spoke smashed. I felt instinctively that it was a hopeless case; and, as I stood looking at it, came to the conclusion that my Zambesi trip was at an end. Now that the season was so late, I was sure no help could arrive in time for me to proceed to the Zambesi, and therefore I saw the best thing was to take the mishap philosophically. It was one of the waggons I had bought in Bamangwato, the wood of which proved rotten. My only wish after this was to get back to Tati as quickly as possible.

"The man that the king had given me to see me safe through the Makalakas now refused to stay any longer, though I did not tell him I should not attempt to proceed. I therefore paid him as the king had directed me, giving him more, in fact, than the latter had said. He was extremely insolent, and demanded double what I gave him. However, I knew he must submit, as the king had sent him with 
me, and he dared not go against his orders. He left me in dudgeon, and I was glad to be rid of him. I had a very slight attack of fever at the time, and his noise and insolence were very annoying.

"After this I sent off my driver with a span of oxen, to take the broken wheel on a sledge of boughs to Tati, and wrote to Brown asking him to send me a waggon, if possible, to bring me out, and a spare wheel also for my own waggon ; or, if not, to get the wheel I sent him mended for me. The oxen that I still had left had to go many miles for water every day. The mare and the goats had nothing but filthy water to drink from holes dug in the ground. For my own use I got water from the pits, where the people dig for it, for I was in the midst of the Makalakas. I myself was a prisoner in my own kraal, for I dared not leave the waggon. I had with me three of my Matabele slave-boys and one Bushman. We got on pretty well for a few days, but soon the people began to drive my boys from the water, which they claimed the right to, having made the pits. This was the water for my own use, and it appeared also that the water at which their own goats drank was denied to mine, and they and my mare driven away from it. I sent for the induna, an old Makalaka, with whom I had hitherto refused to speak in consequence of his having stopped me the first time I tried to go through. I gave him a present of ammunition on condition of his allowing my boys to get water; and, after promising to see that all was right, he asked for more presents, which I refused, and the 
boys were driven away just as much as they had been before. All I could do was to buy water for my own use of the women, who brought it every morning, and to hope that the animals managed to get a little now and then. I had also had a disagreement with the people about some goats which I had bought for a gun. The day after I bought them the gun had been brought back and the goats demanded, which I refused to give up, threatening to shoot any one who touched them. However, as soon as they went out to feed, the goats were seized, as I fully expected they would be, but the gun had been left. After this I refused to trade any more, and drove all the people away except those who brought water.

"Now, whether it was Manyami's son, or whether it was the Makalakas, or whether it was a mere chance, a party of Matabele heard that my waggon was broken, and determined to make capital out of my misfortunes. It was the 7 th of September. The weather was extremely sultry, and I lay nearly all my time in the waggon, reading. This evening, however, a heavy shower of rain, with thunder and lightning, cooled the air-the first rain of the season. I had been a short walk, keeping near the waggon, and looking for a pheasant or partridge. Immediately after my return I was disgusted beyond measure to see a party of Matabele, some twenty in number, filing past with shields and assegais, and sitting down in front of the waggon, after which the oration began. However, the sun set and the rain descended very opportunely, and they left, saying they would return 
in the morning. They told my boys that I must pay for the road to the Zambesi, and that if I did not do so they would break into my waggon and help themselves. My boys, having seen no disposition on my part to give way, were in a great fright, and said if I did not give the Matabele what they wanted they would run away and leave me. In my situation this would have been worse than anything, so I resolved to conciliate my persecutors, and next day gave them what they wanted, amounting in value to a mere trifle, $£ 5$ perhaps, and not a quarter of what I had made up my mind to give them rather than have a row. I should have felt much more humiliated had I first refused and finally had to give way, but it was bad enough as it was. I afterwards informed the king of the whole affair, and perhaps a number of similar complaints may at last bring punishment on the offenders, who are known. I believe it was my firm demeanour of the night before that stood me in such good stead next day, as, when I voluntarily conversed with them, and asked them what they wanted, they thought it best to be civil, and said I must bring out something and they would see if it was enough. After some consultation they accepted what I gave for the induna of their kraal, and then asked for presents for themselves. I therefore added something; and when they saw I had given all I meant they went away, leaving me much relieved in mind.

"Soon afterwards, to my great joy, I heard the boys say that a waggron was coming ; and, sure enough, 
my driver appeared, bringing a waggon borrowed for me by Brown, and an extra wheel for my own waggon. Brown sent me a note informing me that he had letters for me from home, and sending me an instalment of four papers, two others remaining for me in his hands with the letters. I divided my load between the two waggons, and breathed again freely when I was fairly past the Makalaka kraals on my way back. I felt like a prisoner who had regained his freedom. Before reaching Tati, however, I had another little adventure, which I must yet add to this already overgrown letter.

"I had one day left the waggon on horseback with a number of my Kafirs to shoot, as we were rather hard up for food, and had been galloping after some eland. It was late in the afternoon, and when I pulled up I saw nothing of my boys, and turned the horse's head in the direction I had come from, expecting to meet them. However, they had lagged, and I began to think I might not be going quite in the right direction. The mare strengthened this fancy, and kept working round, and wanted, I thought, to take a short cut to the waggon. I trusted implicitly to her, and let her have her head, thinking I would leave the Kafirs to go back by themselves. She, however, went in the same direction I had been galloping in just before, which puzzled me. Still she kept on in a straight, undeviating course, as I could see by the sun, and I thought if it were wrong I could easily return as I had come, when I had let her go on her own way long enough. So I gave her a fair 
chance and on she went. The sun set, and she still kept on as before, the stars now showing me the direction. I began to suspect something wrong, but decided to see what she really would do, as I knew I must sleep in the veldt. At last we came to a broad river without water in it, and, without pausing to look for any, she crossed it, and kept on as before. I thought it must be the Ramaqueban, which is near where I started from, and therefore, after going on some time longer, I turned her and went back to the river, hoping to find water by scraping a hole in the sand, in which I failed. I then tied the mare to a tree, and, making a big fire, had a good night. Next day I was moving at sunrise, and kept down the river, still thinking it the Ramaqueban, when, to my surprise, I suddenly came on the drift where the waggon-road crosses it, and found it to be the Impakwe, the next river that you cross beyond the Ramaqueban in going to the King's. It was now nine or ten o'clock in the morning, and getting very hot. My waggon was thirty miles away, and the mare and myself tired and hungry. I let her feed and drink, for there was plenty of good water. By the time I had gone ten miles towards the waggon she wanted another rest, being much too small for my weight. I therefore gave her a good rest on reaching the Ramaqueban, and it was late in the afternoon when I started off again. By good fortune I met some Boers returning from hunting in the Zambesi direction, and came in for some meat which a Kafir was cooking in the ashes. I never 
enjoyed anything more. I got back to the waggon late that night, and soon afterwards reached Tati, where I have been ever since. Incidents are rather scarce, and I have therefore made the most of the foregoing insignificant ones.

"I have now a new driver, my old one having refused to go with me after my first repulse by the Makalakas. My present man is a huge creature, civil enough, but too fond of brandy. He one evening made a raid when I was absent, and broke open some of my boxes, not leaving a single bottle of brandy in my possession, but how many bottles I had I have no idea. He shared the spoils with his friends, and they were at it all night. Next day I cross-examined him closely, and got a confession out of him. I then fined him $£ 5$, and reduced his wages from $£ 4$ a month to $£ 3$. He got off cheap, as it is common in such cases to tie the offender up and whip him. The whole race of waggon-drivers, with scarcely an exception, are worthless wretches-dissipated, lazy, impudent, and dishonest. It really seems that civilization has no other effect upon Kafirs than to make them worse than they naturally are.

"I must now wind up this terrible letter. I know it is far too long, but it is too late now to obviate that defect."

Another of Frank Oates's letters, written home to one of his brothers about this time, adds yet some further particulars of his late experiences. He says :- 
"TaTi, October I $6 t h$, 874.

"The mail is in, and with it a letter from you, appreciated as usual, which I need not say is not a little. It is dated July $3 \mathrm{~d}$. I am sorry you seem to doubt my getting your letters. In my letter to the Mater I mention the hoard of letters, containing a complete and connected history of home affairs, which met my delighted eyes when I returned here from my third attempt to reach the Zambesi, of which I have given her an account. The road between here and Bamangwato is all but closed from the drought now, as it is the end of the dry season. The waggons that brought this mail in were delayed, and suffered considerably. Several of the oxen died, and one waggon is still in the veldt at the Gokwe River, where there is a little water, and which is the half-way house between Mungwato and here. In distance it is more than half way, but it is always a stopping-place, on either side of which stretches a parched-up country. On the first day of this month I began a letter to the Mater, expecting it would be taken on in a day or two. However, the waggons that were to take it did not set off, preferring to wait for rain, so the letter has been lying unfinished. Now, however, another arrives from you, and sets me off into the writing vein. Moreover, I am expecting very shortly to start into the veldt for a month or two, which means two months, of course, before I fairly set off home. I have in the meantime been collecting bircls here, and reflecting on the vanity of human am- 
bition. It may surprise you that I don't hurry home, now that the Zambesi affair is over. It is certainly not that I don't long to see all the familiar faces once more, and feast my eyes with English scenery. ${ }^{1}$. . .

"The weather is now fairly broken, and it has begun to rain again this evening, with gusts of wind, which flutter my papers from time to time. It has been dreadfully hot the last few days. After the heavy rain at the beginning of the month we have been having a spell of really warm weather, the thermometer often reaching several degrees above Ioo in the shade. I have been busy having my waggon patched up and made weather-tight. It was finished to-day, and to-day the old Boer returned to his happy home and found me in possession. I said I would pack up at once, to enable him to establish himself in his house this evening, but I found I could not be ready, so he and his family are encamped outside, inhabiting their waggons. However, I held out hopes to him of vacating the place to-morrow, which seemed to satisfy him. In fact the Boers are just

${ }^{1}$ The woodcut opposite illustrates two of the whydah-finches, which the traveller collected during his present stay at Tati. The general colour of the upper bird is black, with a collar of ruddy brown, fading into buff beneath; that of the lower one black and pale yellow, the bill and legs coral-red. In the winter season these birds lose their long tail feathers, and their plumage becomes a mottled brown; a great contrast to their striking summer dress. There are many varieties of these finches, one species of which (Chera progne), a native of the Transvaal, suffers serious inconvenience from these adornments in a high wind. The long tail feathers are much used by the natives for ornaments and head-dresses. 


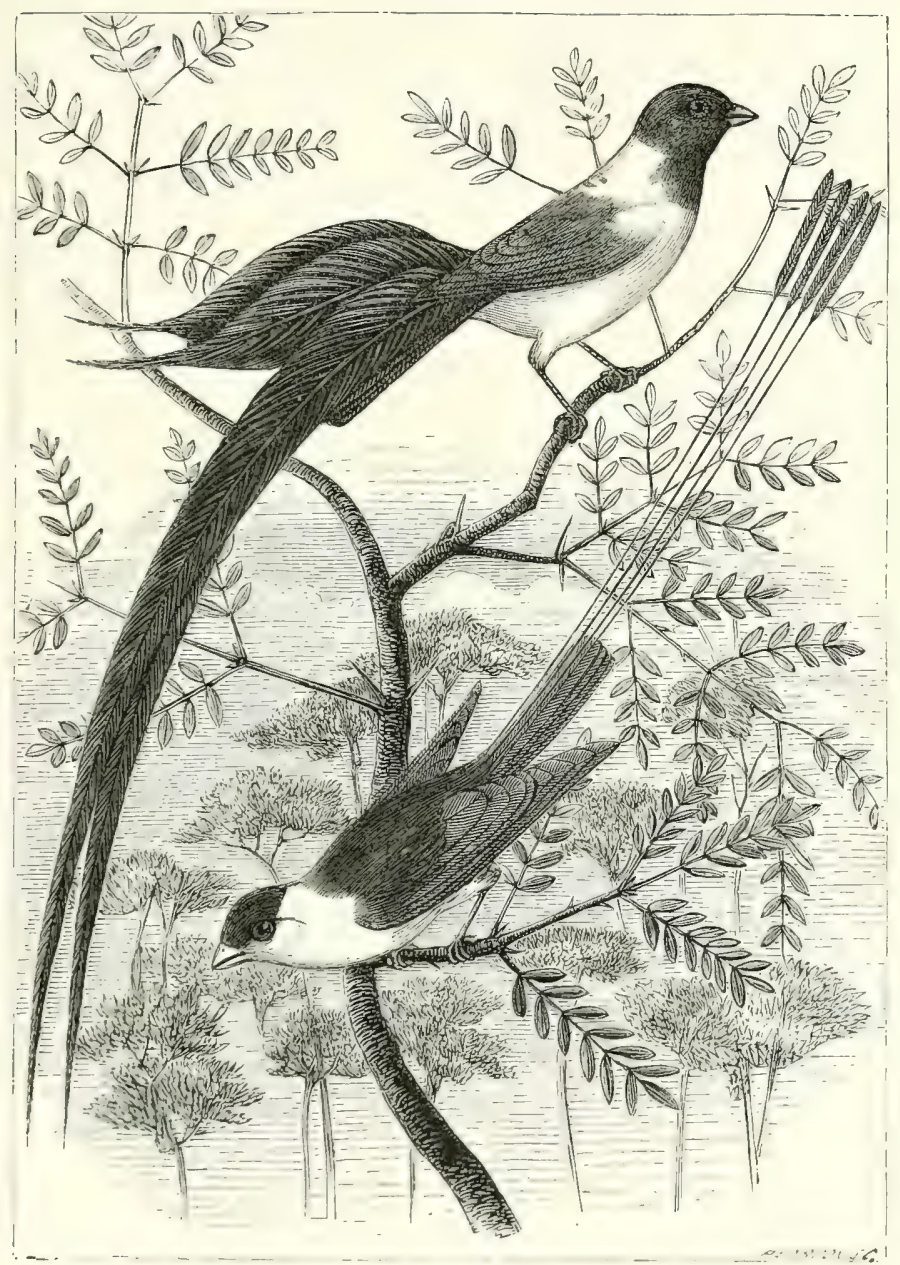

VERREAUX'S WHYDAH BIRD.-Vidwit Verreanai. SHAFT-TAILED WHYDAH BIRD.—Viluaregia. 

as much at home at their waggons as in a house. They have little primitive camp-stools, on which they sit round the fire, and the women go about their household duties, and the children play about, and they seem quite at home. Of course when it rains they sit in the waggons like rats in holes -as I have already done myself, and shall now begin to do again. You have no idea how much a home a waggon becomes. I have my books and all my et ceteras within reach; and, though it is a little cramping, the pleasure of stretching the limbs when you do get out repays you to a certain extent.

"I expect in a day or two a reply from the king, giving me permission to hunt in his veldt. I only wish to go a short distance from here, to the Ramaqueban, and Shashani, and thereabouts - a tract of country that I know pretty well, and for which I have a real affection, so often have I roamed through its wilds. Rivers that I know well I look upon as friends. I wish, indeed, I could be set down now where I was last year, when I was sent by the king into his favourite veldt on failing to reach the Zambesi, but it is too far, and I should have to traverse the thickly-populated part of the country to reach it. The loathing with which I regard this people is in itself sufficient to deter me. The king himself is well enough, and rules the Kafirs with a rod of iron, but the Kafirs, as a nation, I abominate, and not without good reason. The amount of pride you must pocket when sojourning amongst these 
scantily-dressed gentlemen is something not to be forgotten. I don't know whether their condescensions or aggressions are the more difficult to bear with patience. Without patience it is hopeless to think of getting on at all. A long string of them filed past my abode lately, and making for Brown's store requested to be fed. This of course Brown complied with, as the land here is only held on sufferance, and these Matabele were supposed to be out on particular business - to murder a lot of poor Bushmen, as we were told afterwards. The latter are constantly being killed, and their life is one long struggle for existence. A gun is almost useless to them, as the brutal conquerors of the country are pretty sure to bag it, and ten to one knock the owner of it on the head into the bargain.

"The Bushmen are the real wild men of the country, living in temporary huts, and subsisting entirely on what the veldt produces. They are wonderful runners, and possess certain mysterious instincts, raising them in that respect nearly to the level of some of the noblest animals. The Matabele, on the other hand, think themselves the lords of creation, and speak of the slaves (Makalakas) as 'dogs;' and the Bushmen are only looked upon as game. I have one remarkably small creature of the Bushman race with me, who is working for a gun. He always takes to his heels and hides when he sees any Matabele, unless he is with his master and at the waggon. A kraal of these people was lately 
driven from the Shashe, and is now encamped close to the settlement here. I rode through their camp the other day, and felt that I was amongst the true children of the forest, resembling more the North American Indians than the usual Kafir races of this country. Their huts are made of poles, converging together at the top, these laid over with branches, and finally rudely thatched with long grass. I should say there were between fifty and a hundred of them in the camp."

To this letter, here cut short, he adds the following, four days later :-

"October 20th.

"Last night my two Kafirs, whom I had sent to the king, to ask leave for me to hunt a little on the Shashani, returned with a favourable answer. I gave the king a shot gun on first entering his country, much to his satisfaction, and I believe it is now his favourite gun out of the armoury he possesses. I had two cases of 200 cartridges each, and gave him one with the gun, and shall now leave the other, together with the rest of his present, with Brown, to be forwarded to him when a waggon goes up. It is everything here to have the king on one's side, as without it one would have a miserable chance of getting on. Even the king does not care to have too many white men in his country, but likes a few, to enable him to trade. He has a great objection to the Boers, who come only to hunt for skins, thus wasting all the meat, but he knows with me it is a different case, and he does not care where 
I go, as long as I keep him in good humour by giving him presents. He never objects to people who are in the country hunting for meat. However, he is down on you if he sees any ostrich egg-shells lying on the breakfast-table, and asks how you can expect to get feathers if you eat the eggs. $\mathrm{He}$ is also very sensible in his denunciation of killing cow and young elephants, the ivory of which is scarcely worth taking. The Boers, wherever they go, shoot everything, big or little, on the principle that all's fish that comes to the net.

"We have just had a heavy shower, and there was one last night ; in fact the rainy season is setting in. Rain is very much wanted, and all the live stock requires fresh grass."

Amongst the letters, twice alluded to above, which Frank Oates had found awaiting him at Tati, was one from his brother William, who was just about to start at the time he wrote (in the June previous) on a three months' yachting trip to Spitzbergen; after his return from which he contemplated again coming out to Natal, early in the following year, there to rejoin his brother on his way back from the Zambesi, and accompany him-if he cared to go-on a short hunting expedition in Zululand, or, going north as far as Zanzibar, strike inland with him thence instead. To this proposal Frank Oates replied as follows :-

$$
\text { "TATr, October } 27 \text { th, } 1874 \text {. }
$$

"I have been delighted to get your letters, and to find there is a chance of our uniting our forces 
once more. When you wrote of coming out to me I was both pleased and sorry-sorry, because I thought it would be best for me to return home when I reached the coast, and yet, if you had actually met me there, I could not have resisted the temptation of setting off again with you.

"I have often wished I had you with me, and remember, when I got to Mungwato last April, to outfit, as I drove up to Gray's store, I thought if I could have a wish it would be to see your waggon coming in from the opposite direction. I did not even know that you were yourself thinking the same thing about the same time. The same idea occurred to me the last time my waggon broke down on the Zambesi road, and I was left to the mercy of the natives of that part of the country. I thought, if your waggon suddenly appeared, how I could turn the tables on my persecutors, and how we could go on together to the Zambesi. Of course, I felt certain such a thing would not occur, but somehow it got into my head.

"You will be glad to hear that I endorse your theory that trying to trade, when on a sporting tour or exploring, is an utter failure, and that, had we brought up light waggons, we should have been wiser-knowing all I know now. I have been allied with Dutch Boers since parting from you, and the more I see of them, the more I see through them. I have still some of my old Maritzburg bullocks left, a rare good sort, but from time to time upon the journey have bought and broken 
young ones. I have now a good span of fourteen and a couple of supernumeraries, and have likewise bought a heifer, to give me milk. She is of the peculiar small breed, less than Alderneys, bred by the Mashonas. My dogs are invaluable to me. 'Rail' and 'Rock' require the greatest care, and get it.

"I shall wonder how you get on amongst the Spitzbergen game. If as successful as you must have been here, you can claim to count amongst the Nimrods. I don't know what to say to your letter of June $2 \mathrm{~d}$. Of course, if you should come out as you propose, it will be very pleasant to meet, and we might spend a month or two together in the Zulu country before I leave Africa, or, returning viâ Zanzibar, spend a month or two there, as you suggest. I should not care to be very much longer than this, and if, after all, you should not come now, we must do something else again together in the course of time."

The whole of these letters, above quoted from, were despatched to England about the end of October. To one of them a postscript was added on the 28 th, to the effect that the trader, Stoffel Kennedy, whose finger, it appears, had had to be amputated on returning from the veldt, had just arrived at Tati, and that he and Dorehill, the young trader of that name, already mentioned in these pages, were intending to start immediately with two waggons for the Zambesi, and wanted Frank Oates to accompany them. "I hardly think, however, that I shall do so," 
he writes, "as the season is so far advanced. I am principally afraid for my boys, who are far more likely to suffer than a white man is, who has a snug dry bed to lie on, and other comforts; and I distrust my old waggon, which has played me false once already." On further discussing the subject with Stoffel and his companion, he found, moreover, that he had somewhat misunderstood their plan, which was only to be travelling towards the Zambesi now, and wait about upon the road till April or May, when they would go forward to the river. It was too late, they considered, to attempt to reach the Zambesi the present season. Though strongly tempted on some accounts to fall in with their proposal and accompany them, upon reflection he decided not to do so. It was the result, however, of what had passed with them upon the subject that led him to abandon, as intimated above, his projected trip to the Shashani, and accompany the trading party instead, as far upon the road towards the Zambesi as they meant to travel before coming to a stand. This would give him an opportunity of seeing an entirely fresh part of the country beyond the Makalakas, and he could return when it suited him. It is probable, too, that he still -if hardly acknowledging it to himself-may have entertained an ill-defined hope that by travelling in the direction of the Zambesi he might even yet, through some unlooked-for turn of circumstances, find himself enabled to reach that river before the commencement of another year. That hope, assuming its existence, was one destined 
to be realized, little likely as it appeared to be so at the time he left the settlement. It was the $3 \mathrm{~d}$ of November when the united party started on their journey, and for the fourth time Frank Oates turned his face towards the Zambesi.

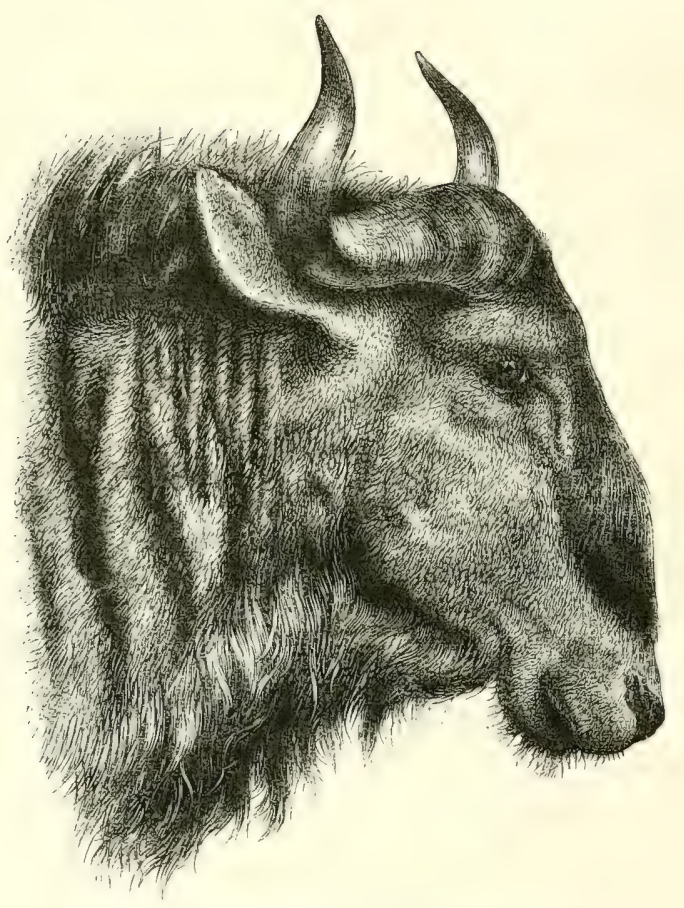

BLUE WILDEBEest,-Catoblepas taurina. 


\section{CHAPTER XI.}

Final start from Tati-Bushman remains-A game-drive-Wild dogs -The Makalakas again-The Matengwe River-English hunters met with-The Nata River-The Pantamatenka-Christmas Day -Start on foot for the Zambesi-The goal at last.

THE country first passed through on leaving Tati was now fresh and green, with abundance of water along the road. Their first evening the party halted at "Mopani Pan," a small pond full of reeds and surrounded by tall mopani trees, a few miles from Tati. This pond is a favourite halting-place for travellers between the Tati and Ramaqueban Rivers, but soon becomes dry in the winter season. Here the party remained four days, hunting; troops of quagga, blue wildebeest, and waterbuck being met with. The veldt about here, though stony and for the most part very bare of vegetation, produced some fine white lilies, now in bloom.

Advancing again, on November 7 th, to the Ramaqueban, they proceeded slowly up that river, and halted again for a short time four days afterwards, at the point where Frank Oates had stopped to hunt when here the previous August, - the point at 
which the road for the Zambesi turns off from the Ramaqueban again towards the Tati. Here the latter had now a hut of branches made by the boys for himself to lie in, as the heat in the waggon was insufferable. This was some relief from the usual state of things experienced about this time. "The flies," he writes one day at this encampment, "are

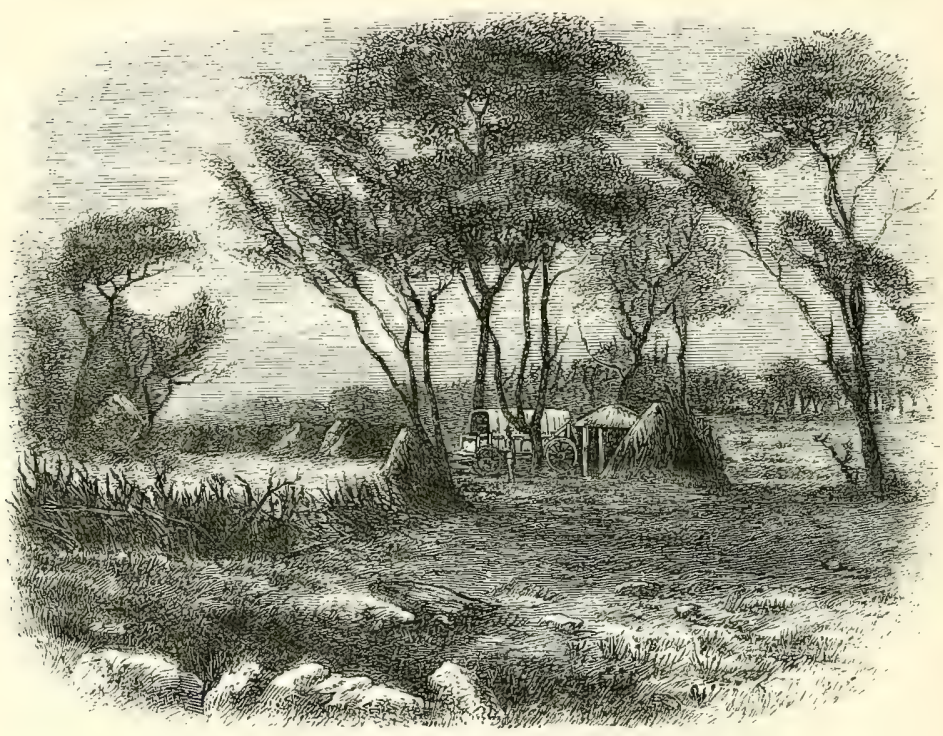

CAMP IN THE VELDT.

perfectly maddening. One wakes early, when it is comparatively cool, looking forward without much pleasure to the coming day of heat and discomfortno comfortable spot to retire to from the heat, and every place dirty and crowded. How different," he concludes, "from the luxuries experienced in some hot countries!" Here, on one occasion, his boys brought him some fine barbel, taken in the river, 
which proved delicious eating when rolled in meal and fried in fat and oil.

On the I3th, whilst still at the same point, Frank Oates's old ally, Van Roozen, arrived with Piet Jacobs, the Dutchman, from the direction of the Makalakas, the former of whom tried, it appears, to dissuade his late employer from attempting the Zambesi at the present season, a notion he was evidently by this time seriously entertaining.

Both these Dutchmen, as it chanced, were acquainted with the spot near the Ramaqueban River where the Bushmen, whose remains Frank Oates had already made more than one fruitless endeavour to obtain, had been massacred the year before. Still anxious, if possible, to secure some of them, and finding he was now within easy access of the spot, he entered into an arrangement with Jacobs to conduct him there; but again, as on former occasions, when the time arrived for setting off, his guide was not forthcoming. Jacobs, however, before leaving, had fortunately on this occasion found a substitute in the person of Van Roozen, through whose guidance the traveller was at last successful in his search, as thus related in his Journal :-

"November I 5th.-Cloudy day. Old Piet left, having deputed Van Roozen to take me to the bones, but wanting to go shares in the profit. He left a boy with a sack; but Van Roozen seemed so lukewarm, I let him send away the boy, and was nearly letting him go too, but Dorehill joined us, and at last we made a plan, persuading Van Roozen 
to take us to the place, whilst the waggons trekked to the big branch of the Tati, where Stoffel was to outspan. Van Roozen seemed a bit nervous; and, indeed, was rather perplexed to find the place, which, however, at last he did. It was a pretty spot. Some large trees, laden with yellow blossoms, growing in rich masses like laburnums, but in spikes, scented the air. Behind these rose a pretty rugged kopje, and in front of them were the old huts of the unfortunate Bushmen, and the screens from the sun which they erect. Heaps of ashes and game bones, broken pots, and other remains lay around, amongst which the skulls of the Bushmen appeared conspicuously. We found three here, and three more lay in the grass at some little distance. We offsaddled and collected some bones, which I tied up, in order to carry on my saddle in front of me, and we again set off, but the sky was clouded over, and we were not sure of our road. However, we came out all right in the waggon-road. Van Roozen deposited his charge, and we rode forward to the waggons. Van Roozen shot a quagga just before we crossed the big spruit, and we soon arrived at the big branch of the Tati, where the waggons were outspanned, Van Roozen having decided to pass the night there with us."I

The following morning, early, Van Roozen took his departure, trekking south, whilst the rest of the

1 The skulls and other remains here obtained were brought to England, with the rest of the traveller's collections, after his decease, and form the subject of the interesting paper kindly contributed to the Appendix of this volume by Professor Rolleston, for whom they were collected. 
party crossed over to the Tati, where, outspanning at the "poort" (the pretty spot already noticed in the preceding chapter), they again stopped for two or three days to hunt, at which point the Journal thus continues :-

"November I 7 th.-Heavy shower early; pleasant cloudy day. Out with two boys, shooting. . . . During the ride I saw a big game-drive, made by the Makalakas, consisting of a long broad alley, the sides composed of large tree branches, forming a strong hedge. At the end were three pits side by side, walled round with stakes. On the top were placed light stakes, and long grass was laid over all. My boys say the Makalakas kill lots of quagga and other game in these traps.

"November I 8th.-Cloudy morning; hot afternoon. Out to the right, amongst the kopjes; game very scarce. . . . Rested, whilst out, under a large tree, with leaves something the shape and appearance of a poplar; the trunk smooth, thick, and of crooked growth. The fruit of this tree is small and green, and, when fresh dropped, useless; but the ground was strewn with last year's fruit, which contains, under a very hard shell, some kernel, not unlike walnut, but softer, and very nice, the only difficulty being the getting at it. Two goats of mine, which I had bought of Piet Jacobs, and had since been lost, turned up to-day, having been absent since Sunday afternoon (the 15 th). They had come on alone, one having given birth to two kids."

The travellers on the 20 th again moved slowly 
forward, and reached the first kraal of the Makalakas (Wankee's) on the 22d, where they laid in a fresh supply of corn, the natives this time making but a very feeble show of attempting to stop their progress. The day before this Stoffel had fallen in with a large pack of wild dogs, a circumstance thus narrated in Frank Oates's Journal :-

"November 2 Ist.-Cloudy morning, after a cold night; cool day. . . . Stoffel rode when we trekked, and shot a quagga. He describes a pack of wild dogs he saw. Two pallah rushed past him pursued by dogs, which stopped when they saw him, and began to bark. They were all black, spotted with white, with thick bushy tails, and dog-like but upright ears. They were the size of his dog 'Bob,' larger than a pointer considerably-i.e. the males; the females, he says, were less. They kept running and then stopping at near range, but he did not get any. He says he has seen a pack once beyond the King's, and once one at Gasuma, near the Zambesi, like these. A pack he once saw in the Free State were of a different colour (reddish or gray). That he saw to-day contained about fifty."

Leaving the kraal again upon the 24 th, the Journal once more continues :-

"November 24th.-Hot, with a breeze. Started at 9.30 A.M., and trekked till noon. Passed the kraal just beyond which my waggon broke before at a small spruit. We ride through mopani veldt, and soon come to another kraal. Pass lots of cultivated land, and then more kraals. The latter are small, 
and generally placed under a kopje, on which often grows one of the few striking and picturesque trees of the country. We crossed two other spruits during the trek, larger than the first mentioned, but not large.

"A rabbit got up close to the waggon directly after we outspanned, and the dogs set off. Dorehill lost one of his, and I lost 'Rock.' Our boys found the spoor, and as it turned out the dogs had been stolen by Makalakas. Stoffel, Dorehill, and I, with Jacob, rode with our guns and a lot of boys to two or three kraals, threatening them all with punishment, unless the dogs were given up. At night they were brought back by one of Stoffel's and one of Dorehill's boys, who had been to a kraal and demanded them. We decided to inspan and ride with the moon. Trekked through trees, thickly placed (mopani mostly), crossed several spruits, and outspanned at the Matengwe River; say three hours.

"November 25th.-Cloudy; heavy rain at night. Here we met a party of Griquas, who have been in Stoffel's employ before as hunters, and they are now willing to turn back their waggon and return with him. They tell sad tales of the Zambesi fever, of which many of them have died. They say it is comparatively healthy at Tamasancha, and they are willing to stand there till April or May, and then go on to the Zambesi. The old man tells me that a man gets a pain in his head and lies down, and next morning, if he is alive, he is 'salted.' Stoffel busy making arrangements with these people. Trekked through 
beautiful green veldt, road winding amongst a great number of kopjes; mopani, and other trees. Several large and rather bad spruits crossed. We kept coming near the Matengwe during this trek, and part of the time the road keeps along its bank. It is an extremely pretty river, and has a fine running stream in its sandy bed. I saw a plant quite new to me, with fine fan-shaped drooping leaves. Some pretty white lilies, delicately striped with lilac, grew close to the river's bank. I enjoyed the scene very much. Few kraals. Where we outspanned, I had a bathe in the river. People came to sell things.

"November 26th.-Cloudy day, but hot; shower at night. Went through mopani veldt, till we came to a big tree, where we stopped. My mare, who I noticed refused her corn, lay down, and on looking at her we found her panting, and that there was a running at her nose. When made to get up, she soon lay down again. Stoffel says it is horse-sickness. I ordered her to be driven slowly on behind us when we trekked. Went past Menon's kraal. Menon and some of his people came out. He was very civil, and appointed to come to us ahead, which he did, when we each gave him a present.

"November 27th.-Cloudy, threatening morning; a few drops of rain. Rain, thunder, and lightning in the evening. Started before daylight, and made a short trek through very heavy mopani to the drift of the Matengwe, where we outspanned. Some yellow matter was running from the mare's mouth and nose, but small in quantity. She pants and coughs, but 
still eats a little. Stoffel, Dorehill, and Jacob rode to shoot, and Jacob shot a giraffe. I went on again a short distance with the waggons, through heavy mopani veldt, finally stopping on a 'sandbelt'1 near a pan of water. Went out on foot in the evening, and saw some pallah, steinbok, and quagga, but they were too wild for me to get a shot.

"November 28th. - Cloudy morning. Heavy shower came on immediately after my return from an unsuccessful hunt on 'Bob.' . . . Busy buying corn. The water lay deep all round my waggon. The mare lying down, every now and then getting up, but breathing very heavily, and, when last I saw her, making a 'roaring' sound. Nothing was running from her nose, but I found inside it a little bright yellow and black matter. I don't know that she ate anything to-day. She lay most of the time with her nose on the dirty ground. The skin of her back is all peeling off.

"November 29th. - Slightly cloudy day; very pleasant. Mare dead; froth like white sea foam on her nostrils, and inside clear yellow liquid, a lot of which had run out. She was not perfectly cold when I saw her. All of them say it is horse-sickness. Dorehill afterwards opened her, and one of his boys found a great number of large fat grubs in her stomach, holding on to the inside. They seemed to have eaten the lining away, and indeed in places to have eaten through the walls of the stomach itself.

${ }^{1}$ An arid ridge or zone of sand, of frequent occurrence in this district, extending sometimes a distance of many miles. 
This might account for the state of her back, and the fact of her slavering when she ate her corn, but I don't think they can have been the proximate cause of death. . . . Out shooting to-day, but the game here is very wild.

"November 3oth.-Cloudy morning; close, hot afternoon. . . . On returning from the veldt in the evening, found every one who had been left at the waggons nearly drunk; the Griquas rushing about with loaded guns and fighting. Inspanned, to restore order, and went about four miles."

The following morning, some five miles further again brought the party to the Matengwe River, where a halt was made. At this point two English hunters, whom Frank Oates had met before during his wanderings-Messrs. Wood and Selous-came up on their way to Tati from the Zambesi. It was the result of this meeting which apparently determined Frank Oates's future plans; for, almost from the first day he left the Tati, the idea seems to have been present to his mind that he might yet make the Zambesi the present season, without waiting for the cessation of the rains. His own inclination was strongly in favour of this attempt, as saving him from the dilemma, otherwise presented, of either leaving the country with the river unvisited, or remaining there another season for the purpose ; and the opinion and experience of the two hunters mentioned above, coincided, as it happened, with his own wish and inclination. They both believed, and perhaps rightly, that the present was a safer time for the Zambesi 
than the month of April, when the rains would only just be over and the moisture not all dried up. Indeed Stoffel, who adhered to his present plan and waited to go on till April, himself took the fever when he reached the river, and died from its effects. The fact is that neither one plan nor the other was a good one, and between the two it was but a choice of evils. So anxious, however, was Frank Oates to reach the river that season, that, gladly catching at the moderate degree of encouragement he now chanced to receive from these two gentlemen, he resolved forthwith to push forward there at once, without intending, however, to make a lengthened stay, or do more on this occasion than merely see the Falls, and obtain a few specimens of natural history. And thus resolved, he again resumed his journey on December $3 \mathrm{~d}$, and with no serious delay or hindrance succeeded in reaching the Zambesi. Before starting, however, he wrote home the following short letter, which Messrs. Wood and Selous undertook to convey as far as Tati :-

"Matengwe River, December $2 d$, i 874 .

"Again I report progress. I am past the obnoxious Makalakas, and am actually going to start for a hurried run to the Victoria Falls. I left Tati with the people I told you of, who were going on to a place about three days ahead of here on the Zambesi road, intending to wait there till April and then go on to the Zambesi. I intended to accompany them and turn back, as I did not wish to wait for another season, and did not think it advisable to 
make a hurried run to the Zambesi and back again now. Indeed, you would infer from my letters that it was not my intention to do so. However, things have so turned out that I think I am choosing the best course in going on now.

"In the first place, I have here met waggons coming from the Zambesi, those of Wood and Selous, two Englishmen, who hunt and know the country well. They both advise me to go on at once. They say they would rather go on now than stand all the time, and then go on in April. In fact it seems that April is too early; and all agree that it is infinitely better to go now that the rains are falling than it is to go too soon after they have ceased to fall. They say the risk of fever is not so great as long as the rains fall, and the really bad time is when they have ceased to fall. The traders, however, must wait, in order to avoid the really bad time, as they could not go there and trade and come back again; whereas in my case I have only to spend a fortnight in getting to the standingplace where the waggons are left, and say ten days or a fortnight in going from there to the Falls and back (it can be walked in three days, I am told, easily), whilst another fortnight will bring me back in the waggons. So you may say six weeks will do it all, and it would not only be possible to be back in Tati before the end of January, but this would allow a lot of extra time. It is only three weeks from Tati to Daka, the standing-place, and I am now a week's journey on the way. 
"A man who knows the Falls and this road well has undertaken to conduct me to the Falls and back. ${ }^{1}$ $\mathrm{He}$ is a coloured individual certainly, but appears a very intelligent and capable fellow. He has been hunting for Wood and Selous, and it is thought he will prove very efficient. He has insisted on large relays of medicine and food, and I have been able to get nearly everything I wanted here. There were in fact eight waggons in all here yesterday. The trader, who lost his finger when coming on with me before, with his two waggons, and a partner of his with one waggon, went on last night. Another trader is turning back now with Wood and Selous, who are going back; and another waggon, belonging to a party of Griquas, has gone on with the traders.

"I expect to be back in Bamangwato in February, en route for home. . . . I can scarcely fancy myself returning so soon from a successful visit to the Falls, having so often failed; but I think you will agree with me that I was not wrong in determining to make another attempt, as things turned out, and acting, as I am, on what I consider to be very competent advice. It is now the beginning of the rainy season, but very little rain has yet fallen; only a few heavy showers, with intervals of very hot weather between them."

The day after writing this letter-on the $3 \mathrm{~d}$ of December-Frank Oates started off again, as above mentioned, towards the Zambesi, and soon came up

1 This was a native from the Cape, named John Mackenna, who, as well as Klaas the driver, remained with Frank Oates till his death. 
with Stoffel, who had left upon the Ist, in company with another trader who had joined him on the Matengwe. Dorehill had turned back with Wood and Selous. From this point to Tamasancha, a watering-place on the road to the Zambesi, where Stoffel and his companion intended standing till April, the road lay chiefly through heavy sand, and was traversed in about a week. Soon after starting, the Matengwe River, which had now been kept near for some time, was left flowing towards the westward, and shortly afterwards the Nata River was crossed. From here to the Daka, a small river not far from the Zambesi, water can only be obtained along the road at the various "pans," or small ponds, which occur at intervals throughout this portion of the country, no other rivers intervening.

At Tamasancha, which was reached on December Ioth, Frank Oates, after a short rest, parted from his companions, proceeding forward on the $\mathrm{I} 4$ th alone towards the Zambesi. The country, from this point, is only varied from sand and thick bush by the occasional occurrence of these "pans" or "vleis," the favourite haunts of wading-birds and wildfowl. Soon after leaving Tamasancha one was passed (Flamakinyani) closely encircled by large trees, and a little later was another (Geruah), about the size of a duck-pond and extremely pretty, surrounded with the greenest of grass, whilst all around it extended the barren and sandy veldt. About here giraffe and other game was met with, including sable antelope, eland, and wild pig. Fresh elephant spoor was seen north of Tamasetsie, 
but the time now allowed of no delays for hunting. The "poison-plant," growing low, and bearing a yellow plum-like fruit, was gathered on one occasion near the waggon-track.

The Daka River was reached upon the 2 ist, and the day after, some miles further on, two other small streams were reached and crossed, and then a third

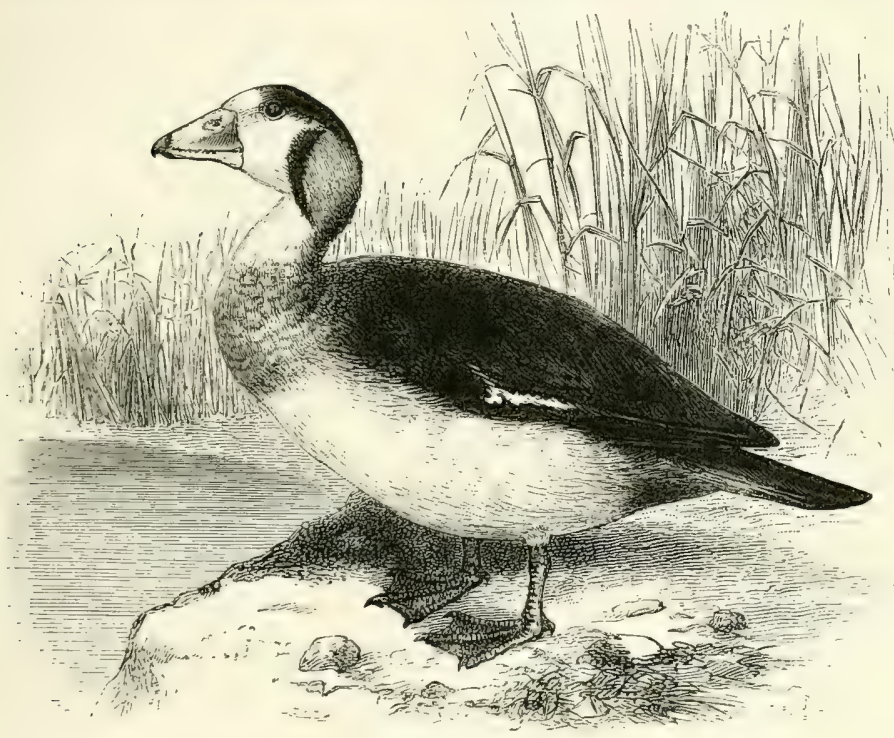

AFRICAN DWARF GOOSE.-Nettapus auritus.

(Length about I I inches.)

into which apparently the first two flowed. This last was a small river called the Pantamatenka, just beyond which is the place where waggons stand for travellers going to the Zambesi. These streams, it was evident, must all be very small, except during the rains. They were small indeed even now, though overflowing their banks and running quickly. Almost immediately after crossing the last-named, Frank Oates's 
waggon stuck in a very soft muddy place, but Mr. Blockley, who was in charge of the trading-station here, came with a span of oxen to help him out, and the following morning his waggon was taken up to where the store was built, on a little stony kopje above the watery flats. Mr. Blockley was here in the capacity of agent for another trader, then absent-Mr. Westbeach - and with him was a Dr. Bradshaw, who had been some time in the country. On the succeeding day, December 24 th, the waggons of two other traders, Messrs. Trescott and Wilmore, arrived from the Zambesi, the former of whom had lately been ill with fever, and was still very deaf and weak, and scarcely able to eat anything. He described their recent sufferings from fatigue, hunger, sickness, and the impossibility of keeping dry, as something truly wretched.

Christmas Day was celebrated at the store by the cooking and eating of a large plum-pudding worthy of the occasion, and the day following Frank Oates busied himself with preparing for his walk to the Falls. This he intended to accomplish in company with Dr. Bradshaw, who had been there before, and volunteered to go with him. The 27 th was the day fixed for the start, and before leaving he wrote home in high spirits the following letter to his mother, which Messrs. Trescott and Wilmore were to take with them when they returned to Tati. It was the last he wrote :- 
"Pantamatenka, December 27 th, 1874 .

"I am just about to set off, to walk to the Victoria Falls, which are only three days from here. This place is somewhere about fifteen miles to the north-westward of Daka, a place you will probably see in any recent map. Neither place is a town of any sort, but each is merely a river flowing to the Zambesi. At both rivers waggons stand, as they are both out of 'the fly.' The place where I now am is quite civilized, as it is a trading-station, and the man in charge here has a snug little house, well thatched, to keep out the rain. He has lived here three years, and is in the employ of Westbeach, who is at present at the residence of Sepopo, the Zambesi chief, some distance up the river. His man, Blockley, undertakes the charge of my effects whilst I proceed to the Falls.

"You will be delighted to hear that there is a doctor here, who is going to accompany me in my walk, and is a great stickler for comforts. He was, I think, doctor on a steamer, and at last got to the Diamond Fields, and thence came here with Westbeach, and has been here now two years. He spends a good portion of his time in collecting beetles, and is apparently very good-natured. He never loses an opportunity of telling you that a thing is very unwholesome, the next thing being its rapid disappearance into his own interior. There was a grand plum-pudding made here on Christmas Day. Besides Blockley and the doctor there are two traders, who arrived here after I did, on their 
way from the Zambesi. One has been ill and the doctor prohibited him plum-pudding, so there were four of us in all. We ate nothing but pudding on Christmas Day and the day following, with scarcely an exception. The men had another pudding. My man turns out to have been originally a cook, and when he likes can cook well. The doctor was found to be five pounds heavier after dinner than before it on Christmas Day. He strongly urged upon all of us the desirability of moderation, but no one seemed to pay much attention to him, and he certainly did not practise what he preached. He has been to the Falls before, and in the rainy season too, so he knows what he is undertaking in going with me. I expect he will make very slow marches, but so much the better. I am going to take with me the identical tent I had with me in America, and which proved so effectual a shelter from the snows of the Rocky Mountains. There was a grand idea in the doctor's mind of taking a lot of cold plum-pudding with us on our walk, but the last morsel disappeared last night. However, we shall not be badly off for supplies.

"From Tamasancha, where I last wrote to you, ${ }^{1}$ and where the traders were waiting till April, I was nine days in getting here. The waggon-road all the way goes through thick bush and heavy sand. There are no rivers, but abundance of pools in the rainy season. We have not had very much rain, but of course enough to fill the pools, and enough to make the road, where it goes through turf, as it does before

1 This letter was not received in England. 
reaching this place, extremely heavy. My waggon stuck the night of my arrival, but Blockley brought his oxen and helped me out; which, however, he failed to accomplish that night, though succeeding the morning following. He then brought my waggon up here on to the top of a little hill where his house is, close to which it is now drawn up.

"This must be a comparatively healthy spot, even in the most unhealthy time, as it overlooks the flat wet country around it, and the water will run from it. There appeared to me to be much more watery land, and more pools of water, about Daka than here. It is where so much land lies under water that, about the end of the rainy season, the fever is so bad. People may get it almost any time, but February, March, and April seem to be the worst months. I think Baines is said to have stated that he would rather be on the Zambesi in January, the height of the rainy season, than in May, a lovely month, but when the moisture is perhaps not all dried up. When it is dried up, it is then all right. Another thing seems to be, that people moving about are better off than those who have to remain stationary in one place.

"One of my goats was reported to have been killed by a leopard on Christmas Eve. We all went with our guns, and I took my dogs. We found the unfortunate goat lying dead, a live companion standing over it; and, also standing over it, and facing the live goat, an animal I thought was a dog. They told me it was the leopard, but I would not fire, still thinking it a dog. At last, however, I saw what it 
was, and we shot it. Two others ran away, and my dogs killed both of them gallantly, and in next to no time. They were cheetahs, a sort of leopard, very lanky, and a good deal like greyhounds in appearance. They were very thin, and probably very hungry when they killed the goat; but the other goat must have kept them from eating it, as it had been killed a considerable time when we got to it.

"I must now get up and make ready to start. I am writing in the tent, having had a cup of coffee as usual, but not got up yet. I intended to have written this letter last night, and, having failed to do so, thought it best to make sure of its being written before I began anything else.

"I hope you are all spending a pleasant Christmas and New Year's time at home, or wherever you are; and wish every one a very happy New Year."

Starting upon their journey late that evening, the Journal resumes the narrative:-

"December 27th.-Fine hot day, with a northeasterly breeze. Wrote letter home early, and made final preparations for the walk. As my own boys had all requested to accompany me, wishing to see 'Metse-a-tunya,' I took all (eight in number) except the Bushman, whom, with two Makalakas engaged for me at Pantamatenka by the doctor, I left with Klaas. The doctor had also got me another Makalaka, whom he handed over to me, as well as allowing me to pack one of his own three boys; so I had the benefit of ten, the doctor had two, and John had three boys. We were a party, in all, of two white 
men, one colonial boy (John Mackenna), and fifteen Kafirs, and left the Pantamatenka a little before sundown; walked three miles up the river, and, crossing it, encamped for the night. During the walk I saw a fine tall palm-the first tall one I have seen. The leaves were fan-like and the tree extremely graceful.

"December 28th.-Beautiful day. Had coffee, and started soon after sunrise. Kept up the river, say five miles, then recrossed and left it, and went ten miles more, crossing a 'sandbelt,' I with two boys finding water in an open grassy space, or ' lichter.' The others missed the water, and I rejoined them in the long sandbelt, which extended beyond where we halted. Then went three miles more, passing some water, of which we were very glad, and at last reached a fine lichter, with a stream in it, running away to the east, into the Pantamatenka. On our left was a ridge, some two or three miles off, with palm on it, which the doctor says he passed on his right, when he went to the Falls last. Rose to opposite side of lichter, to high ground, and camped. "December 29th. - Fine morning, but rather cloudy; a few drops of rain in the afternoon. Had coffee, and again started early. Immediately after starting crossed another stream, also running, they say, into the Pantamatenka. Giraffe and quagga spoor seen. We only went six miles to-day, as one of the boys had to be sent back for an axe, and we waited for him. Maclinwon, who had gone on alone, presently returned, having shot two rhinoceros, and we all went to the place and camped there. 
"December 3oth.-Cloudy; a shower in the afternoon. Walked ten miles to-day, crossing at least two sandbelts, the last of which was stony, and with a very thin stratum of soil on it ; the trees few and sparsely scattered. Some dry stony spruits here, and a fine view of the opposite sandbelt. Slept at a spruit in the hollow beneath us, where we had stopped to make tea in the afternoon, but where it looked so threatening we had pitched the tent. However, the rain was trifling. Some of Tibakai's Bushmen were seen and talked to. Whilst the boys were making the huts, they pointed out the cloud on the horizon to the northward from Metse-a-tunya. It keeps rising in a white puff, and passing away in little fleecy clouds. The others hearrd the Falls; I am not sure I did.

"December 3Ist. - Rather cloudy; heavy rain about sundown. Fine night. Went, roughly, say three miles further north across turf, to the river where I thought Tibakai was encamped, but found we were too much to the left, so after crossing the river kept down it about three-quarters of a mile to his camp. John was in front, hurrying on with one of his boys, but when he came near the huts, stopped and hid behind a bush, from which he was peering when we joined him. Here he wanted to stay and send for Tibakai to talk, our object being to get two Bushmen from him to go with us to the Zambesi, for corn. I ordered him and the boys to march on to the huts, and not stop at a distance now that they knew we were there. John was in a great funk, but found, with Tibakai, a 
hunter whom he knew. I left the boys and traps under a tree amongst the huts, and went with the doctor and John to have an interview with Tibakai. $\mathrm{He}$ is a Mungwato headman, with one or two of his own people, but all the rest are Bushmen, hunting for him, and staying with him with their families. Tibakai said we could not go to the Falls-he was captain here. Hearing, however, we did not come to hunt, he said we might go but must make our scherm here, and stay till to-morrow, when we might visit the Falls and return. He then conceded that we might have two Bushmen, whom he would give us to-night when they returned from hunting, but said we must sleep here to-night. I said we must go, and he could do as he pleased about the Bushmen. After this he again said we must stay to-night. This I flatly refused to do, and had already told him we should shoot elephants if we saw them. John wanted me to stay, and refused to come away. I ordered the boys to start, they having already told me they were willing, and again for the third time called John. We then started, all but him, and there was a great stir in the place; caps snapping, and one fellow running out with his gun. We moved on, I on the flank ready to fire; but it was not necessary. John remained behind, but, seeing us get away, joined us, and, when I upbraided him, said he was only waiting to see what they would do."

And now a walk of some twelve or fifteen miles brought them to the goal. The latter part-five miles or so-of this was over rolling ground, and 
here, as they advanced, they soon began to see more clearly the distant clouds of vapour from the Falls, and hear them more distinctly. The trees, before thinly scattered, were now fine and close together, and for a time obscured the view. Then shortly, through an opening in their midst, the columns of spray again were visible, now quite near, and the party pressed quickly on. The sun was about to set, and clouds were gathering, as if for an approaching storm. Stopping to shelter from a heavy shower just above the river, the first sight of Metse-a-tunya was here caught through the trees, and a halt was ordered for the night.

Thus, the last day of 1874 , the sun set on the fulfilment-after many hindrances-of the traveller's great desire!

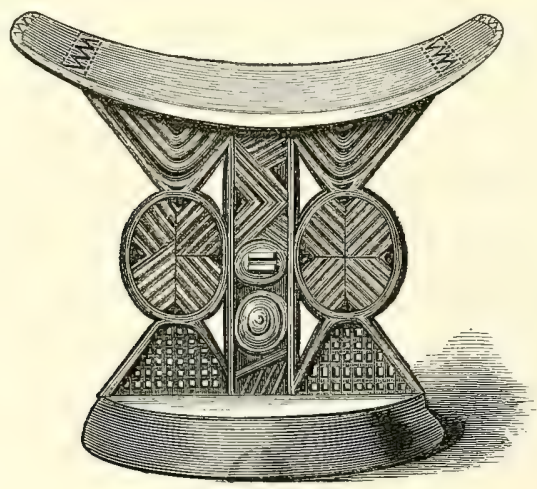

WOODEN PIILOW. 


\section{CHAPTER XII.}

Main features of the Falls - The return commenced-Frank Oates attacked by fever-Course of the illness; improvement and relapse-His death-Dr. Bradshaw takes his effects to Bamangwato-His favourite dog-Arrival of W. Oates and Mr. Gilchrist in Natal-Conclusion.

IT is to be regretted that, from the time of his reaching the Zambesi till the date of his death five weeks afterwards, the entries in Frank Oates's Journal are of the scantiest description. Indeed, the whole time that he was actually at the Falls he made no entries in it whatever. This may have been partly owing to the depressing condition of the atmosphere near the river at that time, which would make any exertion-even that of writing-burthensome; and partly from his relying on his memory for a faithful recollection of a scene at once so novel and so impressive. "After breakfast," he writes on New Year's Day, I 875, "I visited the Falls-a day never to be forgotten." This is the sole entry in his Journal till the 14th of the month, when he was again back at the Pantamatenka.

And what gives especial cause for regret at the 
absence of any further entries in his Journal of this period is the fact that all the accounts of the Falls yet published have been given by those who visited the river in the dry season of the year. Of this number Edward Mohr may have suffered least from this disadvantage, for he was there in June I870. Baines and Chapman were there together during parts of the months of July and August I 862 ; Livingstone was there, his first visit, in November I 855 , his second in August 1860 ; and Baldwin, at the time of Livingstone's second visit. On both occasions when Livingstone was at the Falls, the river, he remarks, was very low; and Chapman mentions that, when he and Baines were there, the water had recently fallen as much as seven feet. It remained for Frank Oates to visit the river at its fullest ; at the very height, in fact, of the rainy season; but, unhappily, we are left without any results of his experience, except in the shape of a few pencil and two water-colour drawings he made upon the spot. The two latter have been selected for representation in this volume-one of them coloured, the other in the form of a woodcut. Before offering any explanation regarding these, it may be well to recall to the memory of the reader the main features of the Falls, as described by previous writers.

The river for some distance-at least two miles -above the Falls is of great width, and, flowing between hills some three or four hundred feet in height, presents to the eye a smooth open surface, dotted over by a number of picturesque, tree-covered islands. 
Where the Falls occur the river is upwards of a mile in width, and the Falls extend the whole of this distance, their line broken at intervals by dark projecting buttresses of rock, forming, some of them, small islands with trees upon their tops; whilst others, of much less size, present merely a bare and jagged surface. The Falls are occasioned by what appears to have been a rift in the original bed of the rivera rending asunder of the rock in the river-bed, over the edge of which the whole waters of the Zambesi are poured down into a deep, narrow gorge below, its width varying from something like eighty to a hundred yards. The water escapes from this deep abyss, where it boils and foams tumultuously after its descent, by a still narrower channel of from twenty to thirty yards in width, and apparently about the same depth as the fissure into which the water falls, the waters of the river being thus suddenly compressed into this narrow limit immediately after flowing through a bed upwards of a mile in breadth just above the Falls. The river after this proceeds by a zigzag course from east to west for about five miles, through a continuation of this narrow cutting, before it finally flows away in a more direct line eastwards. This outlet, Livingstone informs us, ${ }^{1}$ is about I I 70 yards from the western and 600 from the eastern end of the abyss, the river at the Falls flowing nearly due north and south, whilst the fissure which receives the water lies nearly east and west. At this point the rushing waters from either side unite after they have

${ }^{1}$ Narrative of an Expedition to the Zambesi, p. 254. 
fallen. "The stream . ..," writes Chapman, in his account of the Falls, referring to this portion of the river," "which here slackens its speed before the

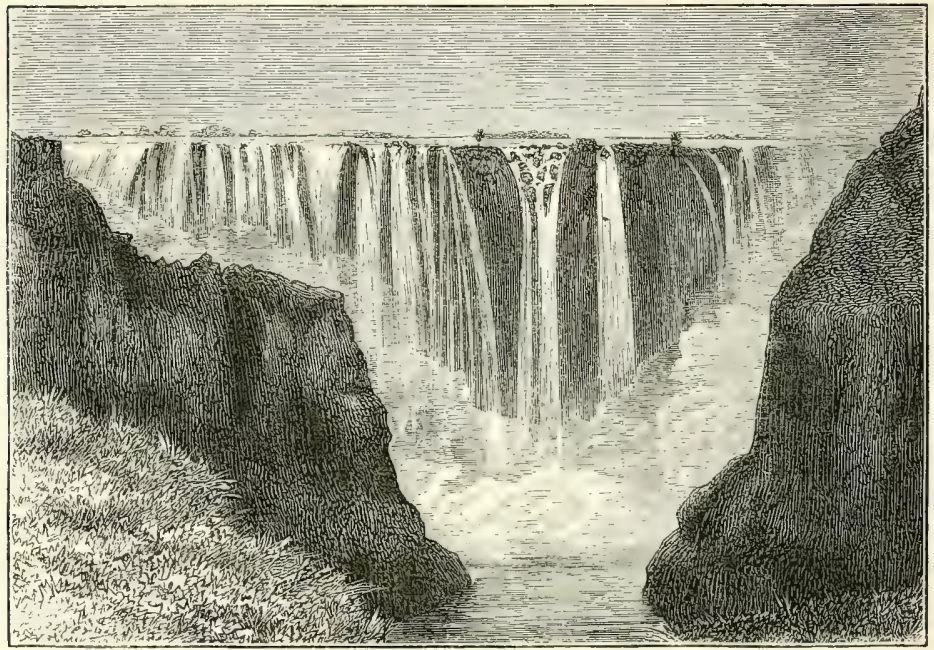

VICTORIA FALLS, ZAMBESI (THE OUTLET).

entrance, steals slowly round, at the solemn pace of a funeral procession, before it escapes from its confinement between the massive columns of rock." The water here is of "that sombre green," says Baines in his description," "which indicates great depth; the moderate rapid formed in the narrow turn below the entrance rolling in that smooth, glassy swell, almost destitute of foam, which seems so gentle and proves so overpowering when one tries to stem it."

It is the view from this point-" one of the prettiest and most comprehensive" that can be ob-

${ }^{1}$ Travels in the Interior of South Africa, vol. ii., p. I30.

2 Explorations in South-West Africa, p. 499. 
tained of the Falls, says Chapman - that is represented in the preceding woodcut; in the foreground are seen the gliding waters flowing through the escape-channel, the spray of the falling cataract rising up beyond; whilst on the horizon, above that section of the Falls which is visible from here, extends the distant outline of one of the river's banks. "This point," writes Baines, "is the only spot, with the exception of the west end in calm weather, that is free enough from spray to allow the use of watercolours."

And this brings us to our second illustration of the Falls, the coloured one, which is taken from the other point here mentioned-the west end of the cataract. In this picture is represented the first portion of the Falls, at the western extremity of the abyss, where the flow of the water over the edge is more broken than it is in many places further on (in at least one of which it continues, says Chapman, with "very little interruption" for a distance of a quarter of a mile or more), and apparently before the water in the bottom of the channel has commenced that tumultuous course which it afterwards pursues as it gathers volume further eastward. In the foreground and on the high land to the right is seen some of that brilliant tropical vegetation, the absence of which, except the evergreen part of it, was so regretted by Chapman at the time of his visit. "We see the scenery," he wrote in July I 862, "at a great disadvantage just now, as this is the time of the "scre and yellow leaf.' " In January, when Frank Oates 
was there, the vegetation of course was at its best. The trees on the right in this picture, though looking little larger than bushes when viewed from this side, rise in reality - again to quote the authority of Chapman, who penetrated their shade - to a majestic height of from eighty to ninety feet, and constitute a dense forest, always moistened by the spray from the Falls.

The remaining most characteristic feature of the Falls represented in this drawing is that of the double rainbow spanning the abyss. The marvellous colouring of these rainbows, which are frequently visible here, has struck all who have beheld them; their "tints," says Baines, "more beautiful than in England's clouded climate one can ever dream of." Whenever the sun falls upon the clouds of spray these rainbows are always present, sometimes two, sometimes three in number, and the brilliancy of their colouring can scarcely be exaggerated. "Rainbows," writes Chapman in his description of the Falls, the first day he saw them, "so bright, so vivid, are never seen in the skies. The lower one in particular [on this occasion], probably from the contrast with the black-looking rocks below, was too vivid, nay, almost blinding, to look upon, defying imitation by the most skilful artist and all the colours at his command, yet imparting its heavenly tints to every object over which it successively passed." So marked a characteristic of the spot are these rainbows that it appears, according to Livingstone, the early native name of the Falls was "Chongwe," signifying the Rainbow, or the Place of the Rainbow; a name, however, which 


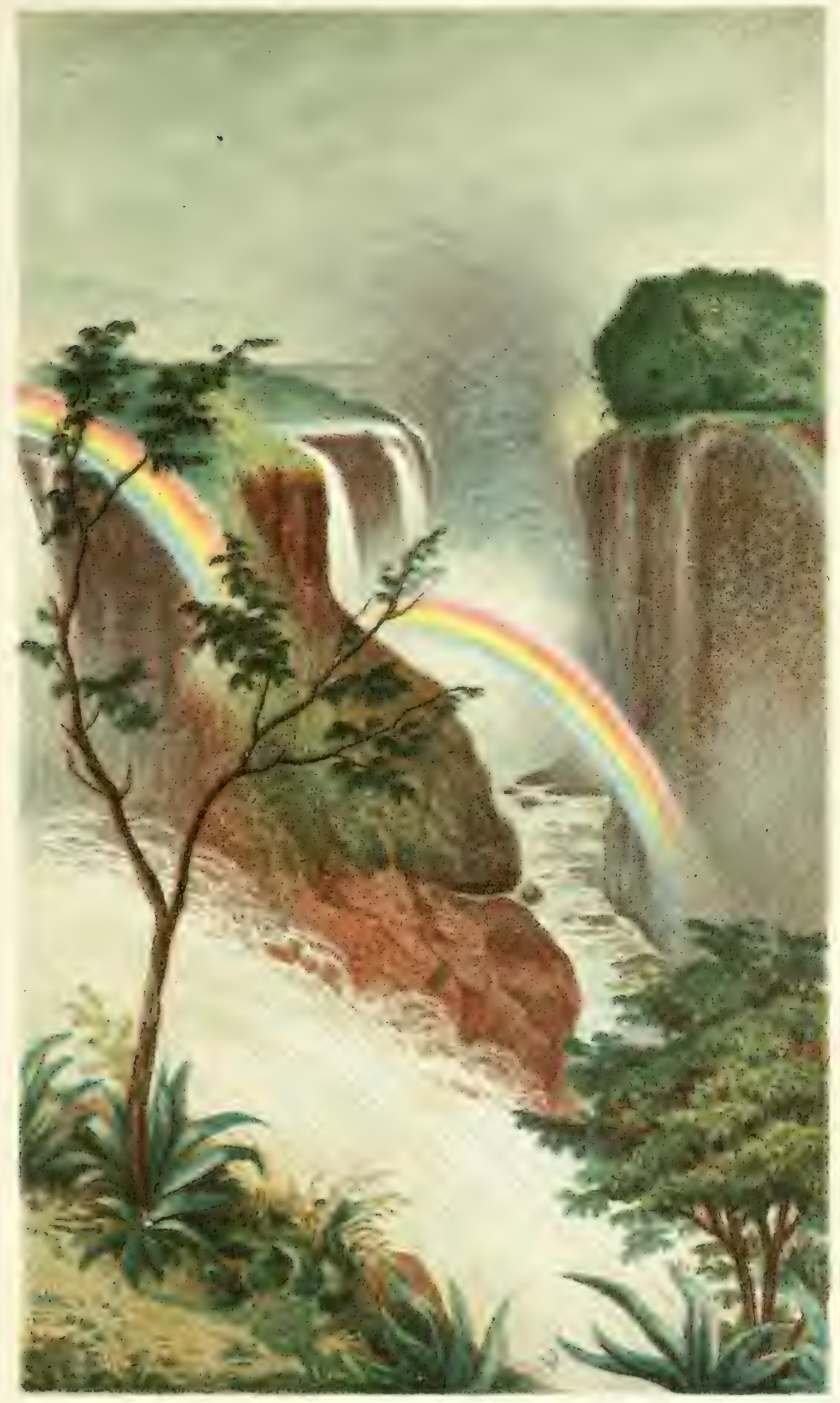

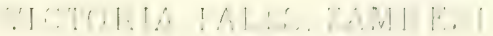



has since given place to others. Frank Oates's boys spoke of the Falls as Metse-a-tunya, a compound word, signifying "water-sounding;" whilst the name which Livingstone received for them, as used by the Makalolo at the time of both his visits, was not dissimilar, viz., Mosi-oa-tunya, or "smoke-sounding," from the smoke-like appearance of the columns of spray which rise above the cataract.

With regard to the other general features of the Falls not referred to above but little remains to be added. Their actual height, as estimated by Livingstone, is about 360 feet from the top of the precipice to the surface of the water in the abyss; the columns of spray, which are driven upwards by the rush of air from the channel as the water descends into this narrow space, ascending to a height variously estimated by those who have seen them-and no doubt varying with the state of the atmosphere and the volume of water in the river at different times - at from six to eight hundred feet, or something over. It is these vapour clouds which, visible at a distance of upwards of twenty miles, as distinctly observed by Livingstone, mark the position of the Falls long before the traveller approaches them. Frank Oates, as seen in the preceding chapter, distinguished them at a distance of about eighteen miles, and his followers heard the roaring of the water at that distance, though he was not sure of doing so himself. Chapman, after he had left the Falls, heard them, he relates, "at a distance of fifteen miles on an elevated region in the south." 
Comparing the Falls with those of Niagara, Livingstone points out that they are twice the height of the latter; whilst, "in the amount of water, Niagara," he says, "probably excels, though not during the months when the Zambesi is in flood." It is unfortunate that no general view of the Falls, except a bird's-eye one from the high ground some miles distant, can be obtained, owing to the vegetation on the south side of the fissure and the dense clouds of spray rising from the chasm. "But for this," says Chapman, "the Victoria Falls, presenting one unobstructed view, would not alone have been the most magnificent, but the most stupendous, sight of the kind on the face of the globe."

And now, resuming our story, the remaining incidents are soon related, the material for its completion being somewhat scanty. From the time of his arrival at the Falls till the date of his return to the Pantamatenka, Frank Oates made, as has been stated, no entries in his Journal. Again at the Pantamatenka,

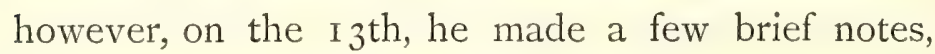
remaining there till the Igth of the month, when Mr. Westbeach, now back from the Zambesi, also started southwards, accompanied by Dr. Bradshaw. Two of Frank Oates's native servants were already by this time ill with fever, taken, no doubt, on the Zambesi, but the rest of the party so far continued well.

On the 25th, however, at the "pan" called Geruah, the beauty of which had struck him on his journey north, Frank Oates himself complained to 
his companions-for his own waggon and that of Mr. Westbeach were never far apart as they advanced - of slight headache, the usual precursor and accompaniment of African fever. In a couple of days, however, he was better again, so that he even went out hunting. But this apparent improvement unhappily proved delusive, and it soon became evident that he was suffering from an attack of fever. And now he continued for some days, with slight fluctuations, better and worse till the 29th, when his condition became alarming. Throughout his entire journey up country from the Makalakas as far as the Pantamatenka he had been engaged in taking careful observations of the country, and noting the various watering-places along the road, and this he continued to do on his way back, to check his former notes. His regular Journal had been again discontinued on the $22 \mathrm{~d}$, but he still made some brief jottings of the route until the 3 Ist of the month, when, such was his condition, even these had also to be abandoned, and he continued very ill till the morning of the 5 th of February, when there was a decided change in him for the better.

During the whole of this time Dr. Bradshaw had remained with or near him, and $\mathrm{Mr}$. Westbeach had kindly lent him the services of one of his own boys, who could speak a little English. There was now every reason, so far as the traveller was himself concerned - and had been ever since he first showed signs of illness - for the party to make all speed upon their journey south. Once at Tati he would 
be in a place of comparative civilization, affording greater comfort for an invalid, and in a far better climate. Travelling is also usually found to be beneficial in most stages of this fever. They were, therefore, all now pushing forward to the Tati with the least possible delay.

On the morning of the 5 th of February, as just stated, Frank Oates's condition was much more favourable, and there may still presumably have been hope of his recovery, when, unfortunately, a point being reached during the day where some of his boys had to be paid off and discharged, the annoyance and excitement contingent on this circumstance-for at such times the boys always manage to be troublesome- brought on a relapse, and towards the afternoon of that day he again got worse. The party, as it chanced, were then in a part of the country where there was no water for the oxen, and were travelling with all haste to reach a place where they could get some; yet so alarming were Frank Oates's symptoms, that towards evening Dr. Bradshaw, who was with his waggon, was obliged to order a halt. This occurred at a certain point in the journey, a little north of the same Makalaka kraal at which the traveller had already experienced so much trouble. He was now much exhausted, and Dr. Bradshaw got him to take some soup and a little brandy, and then left him for a few minutes to go to the other waggon. He had not been gone, however, many minutes, when Mr. Westbeach's English-speaking boy, who had been left in charge, hurried after him, 
begging him to return at once, as a sudden change appeared to be taking place. This Dr. Bradshaw did-but only in time to find his companion sinking. Frank Oates tried to speak, but in so low a whisper that the other unhappily failed to catch his meaning, and a few minutes afterwards-about a quarter of an hour before sunset-the brave spirit sank peacefully to rest.

At this point in the journey it so happened that the ground was very hard and stony, and, even had it been otherwise, there was no spade or other implement at either of the waggons with which a grave could have been made; so, hearing that Piet Jacobs, the Dutchman, was near at hand, having been at a neighbouring kraal that morning buying corn, Dr. Bradshaw sent to him for assistance. Several others of the party were by this time ill with fever, and the man who took this message-John Mackenna-was so reduced that he was scarcely able to sit the horse he rode upon.

Jacobs, in reply, sent back word for the others to come on further, where the ground was less stony, and that he would meantime find a place suitable for the grave. With this suggestion Dr. Bradshaw willingly complied, and, travelling in the night, met Jacobs early the following morning about an hour's journey at the other side of the kraal. Here the Dutchman, who was familiar with the country, had by this time found a spot well suited for the purpose. This was a disused game-trap, some eight feet in depth, at no great distance from the 
waggon-road so often traversed by the deceased, and placed by the side of a small stream or river flowing south. And here, in the deep repose of this silent spot, the traveller's remains were laid in their last resting-place. His was a burial which well became in its simplicity a true lover, like himself, of Nature and her wilds.

This ended, it now devolved on Dr. Bradshaw to convey the waggon and effects of the deceased to Bamangwato, where he left them in charge of the Rev. John Mackenzie, himself returning soon afterwards to the Zambesi district. His attentions to the deceased during the last days of his illness must have materially added to the latter's comfort, whose friends have reason to be thankful that he chanced thus accidentally to have been thrown into the company of a fellow-countryman at the close of his two years' wanderings. His interesting collections, moreover, of natural history, a part of which he now had with him, might readily have been dispersed, and his goods plundered, had his death occurred amongst unfriendly natives, with no one at hand to be responsible for their custody; whilst, as it was, all these, with his waggon and outfit, and personal effects, were faithfully delivered by Dr. Bradshaw into the charge of Mr. Mackenzie at Bamangwato, there to await instructions from his relatives in England. ${ }^{1}$

1 Dr. Bradshaw, since the above was written, has been down from the interior to the Cape, with considerable collections of birds and insects formed during his travels. Some of the former of these have reached the British Museum, and are alluded to by $\mathrm{Mr}$. Sharpe in the Appendix to this volume. 
One incident of Dr. Bradshaw's journey should not be here omitted. It appears that many miles after they had left the grave, one of Frank Oates's pointers - his favourite "Rail"- - was found to be missing, and boys were sent back in search of him. These men sought long and wandered far in vain, till at length in their pursuit they got back even to the grave, and there, patiently watching, they found the devoted creature laid. A little longer, and he must inevitably have fallen a prey to lions or other wild beasts, but now he was taken down with his companion to Bamangwato, whence they were subsequently conveyed to England. And thus it happened that, whilst Frank Oates's friends at home were rejoicing at the speedy prospect of his return, and wholly unsuspicious of the truth, this faithful dog was watching, the sole mourner, by his grave. ${ }^{1}$

The very day of Frank Oates's death his brother William-returned from his yachting trip to Spitzbergen - sailed from England for South Africa, to join him, accompanied by Mr. Gilchrist, the gentleman already mentioned in these pages, whom the brothers had met when they first reached Durban two years previously, and had afterwards travelled with in the interior, William Oates having returned with him to England. The day these two sailed from England-about an hour before the vessel left

$1 \mathrm{Mr}$. Gilchrist, whose subsequent journey into the interior is related below, and who brought the particulars of this and other incidents connected with the narrative to England, understood the dog to have gone back to his master's grave the whole way from the Tati settlement-a distance of nearly eighty miles. 
-letters were brought to them on board from Frank Oates, which had only just reached the country, giving a full account of all his plans, and of his wanderings up to the end of the October previous. The two friends reached Durban on the isth of March, and at once commenced preparations for proceeding up country to meet the returning traveller. Mr. Selous, who had met Frank Oates at Tamasancha, as mentioned in the previous chapter, had now come down from the interior, and reported having seen him early in December, then on his way to the Zambesi and in perfect health. There was indeed just at this time, as it happened, a report at Pietermaritzburg that the traveller had died of fever in the interior, but-as subsequently proved by a comparison of dates-this report had certainly no foundation in the actual fact, and was found on enquiry at the time to be unsupported by any reliable evidence. The preparations already in progress for a speedy start into the interior, to meet him on his way back, were therefore still proceeded with, and waggons, oxen, and all the necessary outfit got ready for the purpose.

Another week and William Oates and his friend would have started on their way northwards, when -on the ist of April, a fortnight only after their arrival-authentic intelligence reached them of Frank Oates's death in the interior. The object of proceeding on the journey was now therefore completely changed, and, to enable William Oates to return at once to England and there offer to his bereaved 
mother such comfort as he might be able, his friend Mr. Gilchrist, in no common spirit of self-sacrifice, himself insisted on taking the sad journey alone into the interior-to bring down thence and convey to England all the deceased's effects; to hear such particulars as he could of his death, for the satisfaction of his friends at home; and if possible-a service attended with especial difficulties - to visit the grave, and place over it, to mark the spot, a stone prepared for this purpose in Pietermaritzburg.

Gratefully availing himself of this generous offer, William Oates sailed for England on April 22d, having first seen Mr. Gilchrist leave Pietermaritzburg with two waggons, on his way up country; a sort of departure very different from that which either of them had anticipated. The journey undertaken by Mr. Gilchrist - under any circumstances a laborious and trying one enough - was rendered doubly so by the sad object with which he started; nor did he return till every purpose of the journey had been fulfilled. For not only did he bring safely to the coast-and subsequently to England-the large collections of natural history specimens and curiosities, and the notes and journals of his travels which Frank Oates had made, as well as his two pointers, "Rail" and "Rock," but, in spite of the obstacles opposed to his progress at the Tati, he even proceeded to the spot where the traveller's remains had been laid, and on his way back succeeded in obtaining an interview on the Ramaqueban River with Dr. Bradshaw, from whom 
he learnt the few additional particulars of his death which could be supplied, and which have been embodied in the preceding narrative. ${ }^{1}$

For this twofold purpose-of reaching the grave and seeing Dr. Bradshaw-Mr. Gilchrist, on reaching Bamangwato, had gone on thence with both his waggons as far as the Tati settlement, where he arrived on the i8th of July. There he found the same difficulty of proceeding further which Frank Oates himself had often previously encountered, a great fear still prevailing amongst the natives of "red water" - the Natal cattle disease-being brought into their country, and Lobengula having recently sent strict orders to the kraals on the outskirts of his territory to keep all waggons from Natal from attempting to cross their boundaries. Fortunately, however, it happened that the Dutchman, Piet Jacobs, was now at Tati, who had not only selected the spot for the late traveller's grave, but was also intimately acquainted with the whole of the surrounding district, and who had, besides, a general permission from the king to enter his country when, and as often as, he pleased; for keeping, as he did, his oxen standing at Tati, when he was not out with them in the veldt himself, there was little fear of his introducing the dreaded disease into the country. With him therefore, as guide, Mr. Gilchrist was speedily enabled to make a start north-

I By a singular coincidence, Frank Oates's devoted favourite, "Rail"-for four years after reaching England the valued companion of his late master's relatives-died on the 5th of February I880, the fifth anniversary of his master's death, followed but three weeks later by his companion, "Rock." 
wards; and, on the afternoon of the fifth day from the date of their leaving Tati, came to the point in the waggon-road where they had to leave it, in order to go down to the river's side to reach the grave. Mr. Gilchrist found it placed about six hundred yards to the left of the road, in a situation of much natural beauty, surrounded by low picturesque hills, and with trees of varied growth and foliage scattered at intervals over the grassy sward. The grave itself, over which a number of large stones had been placed when it was first made, was found quite undisturbed, and amongst these Mr. Gilchrist now inserted at its foot the small white stone, neatly cut, which he had brought from Pietermaritzburg for the purpose, bearing this simple inscription - "Frank Oates, F.R.G.S., of Meanwoodside, Leeds, England; died 5th February I 875, aged 34 years." Then, the task of friendship faithfully performed, he returned without delay to England.

Nor had this journey, painful in its objects and associations, been entirely free, on Mr. Gilchrist's part, from privations and anxieties of a graver kind. Water upon the road had many times been scarce (on one occasion he was without any for his oxentwenty-nine in number-for as much as seventy hours); the season was one of exceptional heat and drought, and the time occupied on the journey was unavoidably considerable.

And here, before concluding, it may be mentioned that at Tati, Bamangwato, or wherever he met those who had become acquainted with Frank 
Oates in this country, Mr. Gilchrist found but one opinion expressed concerning him. Many were the kindnesses treasured in men's minds and now related, which he had rendered to those he had encountered in his travels ; whilst, on the other hand, he had himself apparently been no less fortunate in the kindly services he had received from others. Friends had arisen where he least expected them, beyond the pale of European civilization, from each of whom he parted in turn with a consciousness of mutual regret. Such was the way in which he drew all hearts towards him; and after his death, the good offices of those who loved or esteemed him in his lifetime were generously placed at the service of his family. Conspicuous amongst this number stood the Rev. John Mackenzie, of Bamangwato, and Mr. F. A. Hathorn, of the Standard Bank, Pietermaritzburg, the former of whom undertook the duties of executor for the arrangement of his affairs in the interior, whilst a like responsibility was accepted by the latter for the settlement of matters in Natal. Nor was it only what these two gentlemen did, but even more the manner of their doing it, which placed the traveller's relatives under a lasting sense of obligation to them, and served not a little to soothe the first bitterness of their affliction.

And now this brief history of the efforts and too early extinction of a devoted life, otherwise it may be conjectured destined to have rendered no mean service in the extension of scientific knowledge and research, may be concluded with a few words, written 
soon after his death by Mr. Mackenzie to one of his brothers with reference to the position of his grave. "Lonely the spot, no doubt," he writes, "is, in a certain sense; but, in another, your brother's grave is surrounded by all the activities of the great Creator and Father of all. Flowers will blossom around it, though not planted by mortal hand; birds will sing over it, and never weary in repeating the sweet notes which Nature has taught them. I have not been there myself, but I have no doubt the naturalist would not think your brother's grave a lonely spot; whilst to the Christian such a spot is the quiet resting-place to which the body sank when the spirit was called away by God the Father."

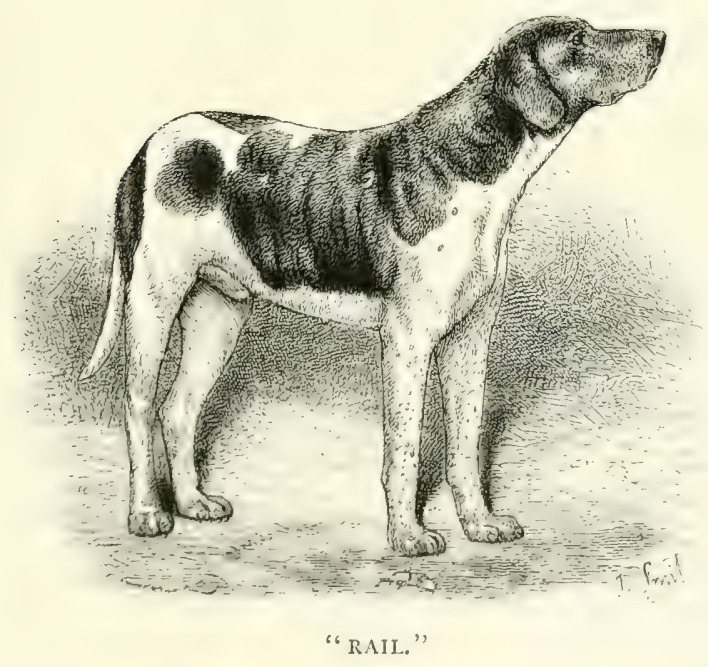





\section{APPENDIX.}

I.

ETHNOLOGY.

By George Rolleston, M.D., F.R.S.

Linacre Professor of Anatomy and Physiology in the University of Oxford.

THE following human bones-viz. four skulls, six lower jaws, four cervical vertebræ, one large and one small sized scapula, two small sized and fragmentary humeri, a fragment of a very slight but adult ulna, four cervical vertebræ, and five more or less fragmentary ribs-have been put into my hands by Mr. C. G. Oates, with information to the effect that they had belonged probably to a Bushman horde massacred somewhere between the Tati and Ramaqueban rivers, in S. lat. $20^{\circ} 54^{\prime}$, and long. $27^{\circ} 42^{\prime}$. With these human bones came some bones of Equus ( $c a-$ ballus or zebra?) ; also of one large ruminant (Bos taumus or Bos caffer ), and one smaller; and part of the skull of an ostrich (Struthio camelus); and, later, the feet-bones of an elephant (Elephas africamus). All these bones had been collected by my former pupil, Mr. Frank Oates, of Christ Church, Oxford. The four skulls had not their lower jaws assigned to them; but to three of them jaws were assignable, which in all probability had really belonged to them, being very exactly coadaptable, to say nothing of their having been sent in company with them and with 
certain cervical vertebræ. These six lower jaws are by far the most important bones as regards the question of the nationality of the entire "find." If, indeed, these half dozen lower jaws had been brought to me with no other accompaniments and with no other information than that they had been all brought from one spot in Africa, I think I should have been justified in saying that they had belonged to no other known African race than the KhoiKhoin, or its Central African-representative, the Akka. For they all six alike show the following distinctive and eminently significant peculiarities - viz. lowness of coronoid process, smallness of absolute size, and all but complete obsolescence of chin. Upon this I have already commented in British Barrozes, pp. 706, note I, 707, 7 I6, ibique citata, comparing these lower jaws with the jaws of certain other confessedly "priscan" races, which differ from them in little but in being larger in size. It is, or should be, a commonplace among craniographers that, whilst the lower jaw is a more important bone for their purposes than any other single bone of the skeleton, and even than the pelvis itself, it is often more distinctive, if not more valuable, than at least the entire calvaria. Certainly this is the case with African skulls; for though it is possible enough, as was long ago pointed out by Professor Owen (see Osteological Catalogue, Royal College of Surgeons of England, 5385, p. 838, I 853, and for a contradictory statement Retzius, Ethnol. Schriften, I 864, p. I49), and as has recently been reaffirmed by Dr. Hamy in Paris, to find brachycephalic skulls among those of undoubted Negro races, and though, as I can aver from my knowledge of the collections in the Oxford University Museum, it is by no means always possible to distinguish either such brachycephalic Negro skulls, or certain other Negro skulls of the dolichocephalic type more usual amongst such skulls, from Bushman skulls of the respective proportions, both of which are represented in this latter series, it is within my knowledge always possible to do this if the skulls under comparison are in possession of the lower 
jaws belonging to them. The Negro's lower jaw may or may not have the poorly-developed chin so constant in the lower jaws of the Bushman, and but rarely seen in the lower jaws of higher races; it may or may not have its anterior teeth sloping forwards in correlation with a prognathic upper jaw ; it may or may not, I apprehend, though I have not met with such cases, be as a whole as small and feeble as the jaws of the Bushman have, with my knowledge, invariably been; but it never has shown, so far as I know, the low coronoid process, the shallow signoid notch, and the wide ramus so very commonly, or indeed all but invariably, found amongst not only the Bushman but the Eskimo race. The existence of this peculiarity not only in these two races so widely separated in space, though so nearly on a level in certain linguistic as well as certain other points of degradation, but also in so many of the lower jaws of the earliest representatives of our species, gives it a great morphological importance; and this morphological importance is not a little enhanced when we consider a second fact, drawn from a wholly alien line of contemplation, that, namely, which shows us that teleological adaptation to special needs, or necessities rather, as to dealing with food, has nothing to do with it. The fact of six lower jaws all alike exhibiting this striking peculiarity, which may be shortly described by saying that it resembles the conformation seen in the Gibbon, whilst the larger anthropoid apes show the coronoid developed into a prominence which comes much more nearly into resemblance with that usual in our own species, is to my mind very strong evidence to the effect that we have here six Bushman jaws before us. In all of these lower jaws we find the angle roughened and projecting outwards in correspondence with the insertion of fibres of the masseter, and thereby giving a greater width to the lower portion of the face; whilst, internally, the surface below the inferior dental foramen is remarkably concave, owing in some cases to a general though slight inversion of the lower portion of the ramus, and in others to a thinning of the 
bone in the region between the alveolar process, in the region of the last molar, and the angle thickened at once by the insertions of the masseter and of the pterygoid. Of the four skulls one only fails to find a lower jaw which will in any way admit of coadaptation to it, and this skull being exaggeratedly dolichocephalous as well as of much larger size and proportions than the other three, may very well be supposed to have belonged to one of the attacking and not to one of the attacked tribe ; for I apprehend that in massacres, at least of Bushmen, the killing is not usually all on one side. The "reports," indeed, both of their enemies and of their friends, assure us that a Bushman at bay is a foe by no means to be despised, and that, though little, he is fierce. And I can say for those three crania that their tout ensemble, as compared with that of Abantu skulls placed alongside of them, impresses me with the same kind of feeling which, after detailed measurements, I have felt in comparing the crania of Lapps with those of races such as the Finns living close to them. They appear to me, in fact, to indicate that their owners were of a smaller race than the owners of the skulls beside them, though the Bushman is not always a mere dwarf, as is sometimes stated. The feebleness of the two humeri, and even more notably of the fragment of ulna, and the small size of the cervical vertebræ, and of one of the two scapulæ accompanying these bones, tells in the same direction, but does not prove feebleness of mind.

For purposes of comparison with these three presumably Bushman crania, I have had three other crania at hand from the University Museum, of the genuineness of which there can be little doubt. One of these was presented to the University Museum by the late and muchlamented Dr. W. H. J. Bleek, to whose labours ${ }^{1}$ in elucidating the language and rescuing the folklore of the Bush-

1 See his two Reports concerning his Researches into the Bushman Language and Customs and Folklore, presented to both Houses of Parliament of the Cape of Good Hope, by command of his Excellency the Governor, I873 and I875, and Journal Anthrop. Inst. I87 I. 
man tribe from perishing we owe so much. This skull, which was brought to England by Mr. Alfred Hughes of St. Asaph, bears a label, "Eland's Bun, nr. Schintpriten," Bushman's skull," and was handed over to me by that gentleman at the desire of Dr. Bleek. A second skull came into my hands through the kindness of W. G. Marshall, Esq. of Colney Hatch, having been entrusted to him by George Dunsterville, Esq., of Port Elizabeth, Algoa Bay, S. Africa, who was for some years surgeon to the hospital at Port Elizabeth. This skull, which, like the preceding, belonged to an exceedingly old man, carries the following labels:- "From the Transvaal, S. African Republic;" "Of an original Bosjesman, a tribe of small Hottentots, now nearly extinct; over age; height, $4 \mathrm{ft} .4$ in." The evidence for the authenticity of the third Bushman cranium which was in the University Museum previously to the arrival of Mr. Oates's consignment, is even more irrefragable. This cranium was procured for the University through the kindness of H. N. Moseley, Esq., F.R.S., from Mr. Fairclough of Cape Town, and with the cranium came a knife, a poison-pot, a quiver, a poisoned arrow, and an ivory wrist-protector which had belonged to the owner of the skull. This skull belonged to a man past the middle period of life, and is remarkable for its absolute height, no less than $5 \frac{4}{10}$ in.; which, however, falls short of its absolute width, which is no less than 5.6 in., by which inferiority the tapeinocephalic or platycephalic character which Mr. Busk (Journal Ethn. Soc., London, Jan. I 87 I) insisted upon as existing in Bushman crania, is preserved in it as well as in the two other crania just specified.

Retzius, in a paper first published in Swedish in I 856, subsequently in German in Müller's Archiv. for I 858 , and fully republished in the posthumously issued (1864) Ethnologische Schriften, p. I49, after saying that he had before him only a single skull of a Hottentot, and the figures which Blumenbach and Sandifort had published

1 Perhaps intended for Eland's Been, near Schietfontein, in the District of Carnarvon, Cape Colony.-Ed. 
of Hottentot and Bushman crania, declares himself unable to detect any essential difference between such skulls and those of true Negroes. His great authority, therefore, should not be quoted to the disfavour of craniological evidence in this or any other similar question, inasmuch as he only speaks, and avowedly, from very scanty materials.

If we begin our comparison of these two sets of crania by a reference to the great distinction pointed out by Retzius himself, of brachycephalic from dolichocephalic crania, we have in the first place to demur to the statement, "In Afrika, fehlt, so viel man bisher weiss, jedes Spur brachycephalischer Bevölkerung." Against it have to be set in the first place Professor Owen's words in the old Osteological Catalogue I 853, p. 838, 5385, already referred to, and in the second, Professor Flower's measurements (as recorded in the new Catalogue of the Specimens illustrating the Osteology and Dentition of Vertebrated Animals, pt. i. I 879, p. 232, I 238 ), of the " articulated skeleton of a Negress, born in the United States of North America, and about I 6 years of age," who was said, presumably by the donor, Professor L. J. Sanford of Yale College, "to have presented all the external characters indicating purity of race," the cephalic or latitudinal index of the crania belonging to this skeleton being no less than 8 I I. But though this be so, there is no doubt, firstly, that the immense majority of Negro, and of Caffre and Abantu crania are dolichocephalic, and some such, for example as the Mozambique skull, casts of which were given by the late J. South, Esq., F.R.S., to many museums, exaggeratedly so; and secondly that the cephalic index of the Bushman is considerably higher on the average than that of the Negro. One of my six Bushman crania (that named No. I, Mr. F. Oates, $788 e$ ), has a cephalic index of $8 \mathrm{I}$, being equal to that of the Negro girl just mentioned in the College of Surgeons' Museum; and though one of the six has but 70 for its cephalic index, still the average of the six is as much as 75 , and Professor Flower's six give us an average of 768 as against one of 73 I for the cir- 
cumambient "Zulus and Kaffirs," and against one of "736 for "African Negroes of various tribes."

The altitudinal index is as significant as, if not more significant than, the latitudinal ; and the tapeinocephalic or platycephalic character of the Bushman as compared with the two other assemblages of Africans just mentioned, is expressed by the figures 7 I 6 , as against altitudinal indices for them of $74 \mathrm{I}$ and 735 respectively. The average of the altitudinal indices of my six Bushman crania is 72 , the height exceeding the breadth in two cases only, and in each of them by one-tenth of an inch only.

As important a question to ask about a skull as either of the two relating to the two indices just mentioned, is, to my thinking, the question, does the cranium when resting, in the absence of its lower jaw, with the grinding surfaces of its teeth on a flat surface, touch that surface posteriorly with its occipital condyles, or with its inferior occipital squamæ? Accordingly as the former or the latter portions of the occipital bone give support posteriorly to a skull so placed, is the cranial curvature lesser or greater, and with it the antero-posterior arc described by the brain it contains. Tried by this test, first suggested by Prof. Ecker (Archiv. fiir Anthrop., iv. I870, p. 288), the six Bushman crania in the museum whence I write, have four of their number resting on the occipital squamæ, as opposed to two which show the lesser curvature. I incline to think that this is a higher average than West Coast Negro crania would show, but Abantu skulls are very frequently so well developed as to have a considerable interval left between their occipital condyles and a flat surface, touching anteriorly the grinding surface of their teeth, and posteriorly their conceptacula cerebelli.

Another important point given us in that most instructive of noma, the noma lateralis, is that of the junction or non-junction of the squamous to the frontal. This question is easily answered, as in no single one of my six Bushman crania does the squamous approximate itself at all more closely to the frontal than it would do 
in an equal number of European crania. Indeed, in all but one of these crania the alisphenoid is wide from before backwards, as though to furnish adequate lodgment for the temporo-sphenoidal lobe of the cerebrum, which, we know, alike from Gratiolet (Ménoive sur les Plis Cérébraux, p. 97), and Professor John Marshall (Phil. Trans., MDCCCLXIV, p. 5IO), to take a large development in the Bushman race. ${ }^{1}$

I have in the next place to draw attention to a striking qualitative or morphological peculiarity observable in no less than three out of my six Bushman crania; this being the presence either of a perfect, or of a rudimentary division of the malar bone into two distinct parts. The skull presented by Dr. Bleek presents us with a perfect rectangular suture, bilaterally symmetrical, as is usually the case with this suture both when it is and when it is, as here, not, rudimentary. In the two skulls, $788 e$ and $788 g$, collected by Mr. Frank Oates, the suture is rudimentary, being represented in each skull by a bilaterally symmetrical fissure running horizontally forwards from the zygomatico-malar articulation. ${ }^{2}$ When I add to these observations the fact that similar sutures have not within my knowledge and research been observed in other African crania of any of the varieties living on that continent, it will be seen that the presence of them in these skulls goes a considerable way, when coupled with other considerations, towards making it pretty certain that they were of

${ }^{1}$ For the relation of the alisphenoid, squamous, and frontal, see Broca, Instructions Craniologiques, pp. 26, 27, 1875; and Gruber, Ueber die Verbindung der Schäfenbeinschuppe mit den Stirnbein. Mém. de l'Académie Impériale des Sciences de St. Pétersbourg, tom. xxi. No. 5, 1874. Hermann Schlocker, Ueber die Anomalieen des Pterion; Inaugural Dissertation Zum. Univ. Dorpat. I879.

It is right, however, to add that the skull of the Bushwoman whose brain Professor Marshall has described, l.c., had the squamous of the left side joined to the frontal, and that with obliteration of the suture; and that though Dr. Williamson has not recorded the presence of this junction in any of the three Bushman crania described by him in his Catalogue of the Army Medical Museum, 1867, he has noted it in two out of the seven skulls of the closely affined Hottentot race.

${ }^{2}$ Similarly rudimentary sutures are observable in several of the Bushman crania in the Royal College of Surgeons of London. 
Bushman nationality. Further investigation of the distribution and non-distribution of this most significant suture amongst the several typical races of men, lends some additional force to this argument, and is besides not a little suggestive as to other views. In the Oxford University collection of crania I have not found any traces of it amongst 47 Australian, nor amongst our five Tasmanian crania, nor amongst our Stone age crania, a series well represented here. The only other race of indisputably pristine and very pristine habits, in which I have observed it to exist, is the Eskimo, and out of a large number of such skulls I have only noted it once, in the form of bilaterally symmetrical fissure. The other skulls which this museum contains possessing this suture either well or rudimentarily developed, are six in number. Four are presumably either of the Malay or of the Chinese race, as two were collected by Captain Elmhirst of the 9 th Regiment, from the sea-shore of an island in the Chinese Seas, out of a great quantity which were lying about unburied, and were supposed to have belonged to Chinese pirates, and were finally presented to the University museum by the Rev. H. Hansell, Fellow of Magdalen College; as a third was the skull of a female Moro, collected in the mountains of Sulu, and presented by Captain Chimmo, R.N. ; whilst the fourth was purchased from Mr. Cutter, the dealer in Natural History specimens, as being a Borneo pirate. The other two are from Ceylon, one being a Tamil from Central Ceylon, presented by Mr. B. F. Hartshorne, who was himself for a considerable time resident in the island, and has written upon its ethnology; the other being a "Malabar." As the absence of this suture from the Zulu and Negro series gives additional importance to its presence in the Bushman, so its absence, which I have noted in a considerable number of Prearyan skulls, such as those of the Coles and Moosahurs, procured for me by William Duthoit, Esq., D.C.L., gives additional importance to its presence in "Malabars," "Tamils," Malays, and Chinese. Of course further research may discover this suture in other 
races of mankind; as the matter stands at present $\mathrm{I}$ am tempted to think that there is possibly some significance in its having been noticed in the Eskimo, the Bushman, in certain races of the Eastern Archipelago, and in Tamil skulls, as well as in the fact of its having been found to be absent in certain other skulls also of ancient races, such as the Kolarian and the Australian. ${ }^{1}$

The main sutures I think have perhaps something peculiar about them, this consisting in their being made of denticulations which are complex but shallow, contrasting thus with the complex but deep denticulations of well developed European, and the coarse but shallow ones of Australian, crania.

The verticality of the forehead observable in so many

1 It may be well here to give the literature of "Os (Malare) bipartitum."

I779. E. Sandifort, Observat. Anat. Path., Lib. iii. II3; Tab. viii. fig. 7.

I837. Leçons d'Anatomie Comparée, par Georges Cuvier et M. Duméril. Seconde édition, par F. G. Cuvier et Laurillard. Tome ii. 1837, p. 38 I.

1844. Breschet, 'Ann. Sciences Nat., 3 ser., Zoologie. Tome i. p. 30.

1852. Schultz in Bemerkungen ïber den Bau der normalen Menschen Schädel, p. 57, Tab. ii.

1867. Canestrini, Annuario della Soc. dei Naturalisti in Modena, I867, p. 83. Gazzetta della Cliniche, Torino, I871. G. Delorenzie's Tre nuove case d'anomalia dell' osso Malare, Torino, 1872. E. Marselli, Sopra una rara anomalia dell' osso Malare, Modena, 1872.

1873. Gruber, Monographie des zweigetheilten Jochbeines bei Menschen anzd Säugethieren, Archiv. Anat. und Physiologie, p. 337.

1874. Gruber, Ann. Sci. Nat., 3 ser., Zoologie. Tome i. p. 3 o.

1878. Human Osteology, Holden and Doran, p. 99.

Laurillard's words from Cuvier's Anatomie Comparée, vol. ii. pp. 381, 2, are specially worthy of being quoted, as they were published so long ago as 1837 . They are as follows :-

"Au bord inférieur du jugal nous avons trouvé sur deux sujets un os particulier, alongé et aplati, étendu tout le long du bord inférieur du jugal, et d'articulant en avant avec l'extremité très saillante de l'apophyse malaire du maxillaire et en arrière avec l'apophyse zygomatique du temporal, laquelle se trouve ainsi présenter deux sutures, l'une verticale avec le jugal proprement dit, l'autre horizontale avec ce second jugal et faisant un angle presque droit avec la précédente. Dans les sujets ou nous l'avons rencontré, la forme de ce nouvel os, des connexions avec les os voisins, sa proportion avec l'os malaire proprement dit, étaient les mêmes et comme nous l'avons trouvé, ainsi que nous le dirons plus loin, dans certaines espèces de singes une subdivision parfaitement semblable, nous sommes portés à la considérer autrement que comme une disposition purement accidentelle." 
Bushman, and, indeed, in so many other African crania, is correlated with the comparative feebleness, and consequent lightness, of their lower jaws, which renders it unnecessary $^{l}$ that the brain and brain case should be rotated backwards to counterbalance the facial skeleton and to maintain the visual axis in a horizontal or semihorizontal plane.

I have appended to this paper the measurements given by Professor Flower, in his recently issued (1 879) Catalogue, of the six Bushman crania in the College of Surgeons' Museum, pp. 246, 247, and also the same measurements, as taken by myself, of the six Bushman crania in the Oxford University Museum. The very close correspondence of the two sets of measurements will strike any one who will compare the columns which give the averages of the two sets. The fact may be expressed in technical language by saying that both lists coincide pretty nearly in showing that, as Professor Flower has phrased it at p. 255 , l.c., the Bushman cranium is "mesaticephalic," "orthognathous" (or, at least, mesognathous, my average being 98 , which is "mesognathous," as against Professor Flower's 97.8 , which is just below the limits of mesognathy), "platyrrhine," "microseme," and " microcephalic."

By a comparison of my measurements, not with those of Professor Flower, but with my own records of the history of each skull, an even more surprising and more important fact, in the way, however, not of coincidence but of the reverse, is brought to light. The most aberrant of the six in the matter of measurements is the very skull about the authenticity of which there is the most perfect certainty. This is the skull presented by Mr. Fairclough, with which were sent the articles specified above, as the characteristic of the Bushman race. But the skull itself is, in almost cvery important particular, different from the five other crania here measured with it. Its circumference and cubical capacity, its length, breadth, and height, and their indices, its orbital and nasal indices, are all alike

${ }^{1}$ See Cleland, Phil. Trans. 1870, p. 163. 
aberrant from the average. It certainly would not have entered into the head of any craniographer to refer this skull to the Bushman variety of our species, unless he had been informed of the character of its accompaniments. A morphological point which might have served to indicate the character of its owner-I mean the feebleness of the nasal spine, a shortcoming more or less evident in all, or nearly all, Bushman crania -does not help us here; for we observe in this skull that the line of symphysis of the two halves of the upper jaw rises here anteriorly, as it does sometimes in European jaws, into a raised double ridge, which, though it slopes gradually into the plane of the alveolar border, and does not rise into a sharply-defined angular spine, and so far falls short of the typical "anterior nasal spine," is yet a very different thing from the very feebly-developed bifid process of ordinary Bushmen, and many other African and other savage jaws.

The question arises, how are we to interpret these facts? We may explain them by saying that the elasticity and plasticity of the type is such as to admit of the escape of an exceedingly aberrant individual, and its homogeneity and plasticity, nevertheless, also such as to allow of its walls joining again, and restoring the perfect circumscription which is implied in our speaking of the race as possessing well-defined limits. Or lovers of logical consistency, who may not be extensively acquainted with the width over which variability may extend itself, may prefer to suggest that some kind of error may attach or have been attached to the identification of this particular cranium. It is possible, I suppose, that a runaway Caffre, or even an outcast white man, may have betaken himself to some horde of Bushmen, and identified himself with their manners and customs, and adopted their dress and equipment. Such voluntary degradations are known to have taken place, with the consequence of the refugee becoming not merely "half a savage," but rather, as shown by the place and precedence given to him, " a savage and 
a half;" or, finally, the owner of this skull may really have been a cross between a white man and a female of the Bushman stock. To this last explanation I myself incline.

As regards the condition of the teeth, the skull presented by Mr. Fairclough, though referred by me to a man in the middle period of life, has only some seven or eight teeth, comparatively little worn, left in situ; the rest have been lost, and traces of two or three large alveolar abscesses, and great absorption elsewhere of the alveolar processes are very evident. Alveolar abscesses have similarly left their traces in the skull presented by Dr. Bleek, in which, however, the teeth have been very much worn down, though only one or two have been lost during life. The skull presented by Mr. Dunsterville had lost all its teeth, save the two central incisors, during life, and the alveolar processes have suffered a very large amount of absorption in this senile skull.

Of the entire series, as the figures giving the length of the circumference and the cubic capacity show most plainly, we can predicate smallness; the average of the latter measurement being but I 285 as against 1485 cub. cent. obtained by Professor Flower for the cubage of seven Caffres and Zulus, and, indeed, as against 1330 from his measurement of his available Bushman crania.

With this small capacity is combined, which is by no means always the case in crania of races low in the scale of human life, a short basi-cranial axis, with an average length of no more than 93 millimetres.

In none of these six skulls is the patency of the frontal suture, which corresponds very usually to a wide receptacle for the frontal lobes of the brain, observable. On the other hand, the zygomata do not come into view, when the skull is held out so as to present its norma verticalis at arm's length to one eye of the observer, with the invariability which might have been expected. In two only of these six skulls are both zygomata seen at the same time when the skull is held in this position; in three the 
zygoma of the left side only is seen; and in one neither zygoma comes into view. But these skulls, as is often the case in skulls of flesh-eating savage races, are of considerable density, and a greater thickness of walls as well as a greater development of the contents of a skull may prevent it from being phœnozygous. One other condition indeed, that of considerable development of the malar arch, which produces phœnozygy, is present in Bushmen, as in the skulls of other races exposed to the sun and glare, and other irritants of the eyes; but its working is countervailed by that of thickness of the cranial walls. All the Bushman skulls examined by Dr. Fritsch were broad in the sphenoparietal diameter (see his Die Eingeborene Siid-Afrika's, I872, p. 4I3). With two exceptions, those constituted by the skull procured by Mr. Fairclough and that presented by Dr. Bleek, the supraciliary ridges and glabellæ are comparatively feebly developed.

The parietal tubera, or the spots on the external surface of the cranium corresponding to them, are placed far back in all these crania, and what I have elsewhere spoken of at some length ${ }^{1}$ as the antero-posterior index, is consequently high. The same remark, however, may be made of Zulu and other Abantu crania.

It has often been stated that the ears in Bushmen are huge, misshapen, and outstanding. According, however, to trustworthy accounts of Professors Marshall and Flower, and Dr. Murie and Professor Wyman (Proc. Boston Nat. History Soc., ix. I 862, p. 56), the small size of the lobule appears to be the only constant character of this organ which is distinctive. (See Fritsch, l.c., p. 4I O.) Much that has been written on the peculiarity known as "steatopyga" in our own species might have been spared if what the great naturalist Pallas had written on the similar development called by the same name in one of the most widely spread varieties of the sheep, had been studied in the wonderful eleventh Fascicle of his Spicilegia

${ }^{1}$ British Barrozes, pp. 563 and 677 . 
Zoologia, from p. 63 to p. 69 . I will quote only a few of the sentences of Pallas's account, p. 64:- "In his quidem generalioribus, præsertim deformatione caudæ et auribus pendulis greges omnes conveniunt quas Nomades diversarum gentium Asiæ possident. Sed varias a temperie cœli, pascuis, aliisque causis vel cultura apud varias hasce gentes mutationes passæ sunt et ad Russos translatæ patiuntur. In Tatariæ Magnæ desertis occidentalibus, a Volga usque ad Irtin et Altaicum jugum, pascua maximam partem sunt aridissima, abundant vernalibus plantis acribus et liliaceis ; postea æstate in elatis locis quæ maxime lanigerum pecus amat præter siçcissima gramina, stipas similiaque, nil nisi artemisias amaras aromaticas, camphorosmam et salsolas succo et salibus abundantes servant. Ubique simul abundant lacunæ natroso, culinari, glauberianoque sale efflorescentes, et aquæ in desertis iisdem raræ plerumque iisdem salibus fœetæ sunt. Quæ quidem omnia ovium corpulentiæ maxime convenire pastores Europæi quoque norunt. Accedit vitæ genus et cultura." . . . .

Page 67.- "Sequitur ex istis deforme istud pulvinar sive uropygia quod in locum caudæ apud hanc varietatem ovium successit maximeque constantem ejus characterem probet superfluæ generatione pinguedinis ortum debere atque in campis salsuginosis Tatariæ occidentalioris primam patriam habuisse. In genere videmus certas corporis partes, illas puto præsertim, in quibus lentior sanguinis circulus obtinct, collectioni pinguedinis in textu celluloso maxime favere."

Page 68.- "Orta illa semel circa caudam collectio pinguedinis, veluti genialis morbus per generationes sensim adauctus fuit."

As regards the distinctiveness of steatopyga, or, in other words, as regards the reason which by polygenist writers it was supposed to furnish for considering the Hottentot and Bushman races as specifically distinct from other human beings, there is no need to refer to the analogy which the steatopygous sheep suggests. For as Hartmann (Die Nigritier, p. 489, I876) states, it is found 
also among Berber and Negro tribes, such as the Maqwa the Denqa, and the Bonqo, and, it may be added, that it may be seen figured in the English translation of Schweinfurth's Heart of Africa, by Ellen E. Frewer, vol. ii. p. I 2 I.

As against the ethnological significance of the hypertrophy of the nymphæ, which constitutes the "viel besprochene Hottentotten-Schurze," the case is still stronger. For not only may this peculiarity be found amongst other African races, such as the Berber, Egyptian, and Negro (according to Hartmann, l.c. p. 489), and the Abantu and Sudan natives (according to Fritsch, Die Eingeborene, pp. 282,283 ), where its presence might be reasonably explained by reference to peculiarities of diet or climate, but it may, according to Hartmann, be paralleled by observation carried on in the very different surroundings of North Europe. The words of the last-named authority, whose intimate acquaintance at once with Africa and Prussia will not be questioned, are to the following effect : "Die viel besprochene Hottentotten-Schurze ist für Jemanden welcher fleissig die gebürtshulfliche Station oder den Secirsaal einer grosseren Universität, z. B. Berlin besucht, auch Berber, Aegypter, und Nigritierfrauen ganz nackt gesehen hat, kein auszeichnendes Rassenmerkmal mehr." 1

The old view which ascribed a Mongolian origin to the Khoi-Khoin races is now pretty generally given up. A more important subject would, if I had space, be furnished me for discussion in the recent discoveries in Central Africa, ${ }^{2}$ which appears to point to the existence of kinship between the pigmy Akka and Obongo tribes and the Bushman.

The main points which appeared to former writers to

1 Many references to the older literature treating of the two peculiarities mentioned will be found in Waitz's Anthropologie, Th. i. pp. 120-122, 1859 . An important note regarding the latter of the two is given by a man of science residing at the Cape of Good Hope in Professor Flower and Dr. Murie's "Account of the Dissection of a Bushwoman," Journal of Anatomy and Physiology, No. II. May I867, p. 208.

2 For this see Hartmann, Die Nigritier, 1876, p. 492, who cites Schweinfurth, Heart of Africa, Eng. tran,, vol. ii. chap. xvi., Du Chaillu, and the Rev J. G. Wood, Natural History of Man. Africa, p. 538, I868. 
indicate Mongolian affinities are the yellow as opposed to the black colour of the skin, the prominence of the cheek bones, and the supposed obliquity of the opening of the eyelids. This last peculiarity, as Fritsch (Die Eingeborene Siid-Afrika's, p. 286) has shown, is due simply to the disagreeable necessity of keeping the eyelids constantly half-closed, owing to the glare and, as others have pointed out, the sandflies, to which these homeless savages are self-exposed. The Swiss Professor, Schiess-Gemuscus, of Basle, has similarly explained the causation of snowblindness (see Archiv. fiir Ophthalmologie, xxv. 3, p. I 73), by reference to the blepharospasmus and conjunctivitis, produced by the dryness and the glare of the upland snowfield; and I apprehend that the osseous structures underlying the organs protecting the eye may be reasonably supposed to undergo some modification in correlation with the increased demand for work, which "blepharospasmus" expresses as being thrown upon the muscular structures which they support. Thus the prominent malar arch and the forwardly projecting outer segments of the orbit, as seen alike in the Mongolian of the treeless steppe, in the Eskimo of the snow-desert, and the Bushman of the sun-burnt South African uplands, may receive a physiological as opposed to a morphologicai explanation. But, when we come further to consider the structure and composition of the various segments of the orbital ring in these races, we find combined with this physiologically explicable similarity a very considerable morphological difference. This is constituted by the conformation of the nasals, which in the Bushman form invariably an all but level plane between the nasal processes of the maxillaries, and contribute, being narrow, but a small factor to the interocular space, which, when the soft parts are in situ, appears disproportionately wide as compared with the same area in other races. In Mongols, Eskimos, and Australians the nasals very ordinarily form a more or less elcvated arch, and they are not by any means so narrow as they are almost always in the Bushman race. In this latter these 
bones not rarely lose not only their characteristic archshape but also their individuality, and anchylose with each other mesially. It is, however, right to add that nasals of the Bushman type are not rarely, though by no means invariably, to be found in Negro and Caffre crania.

As regards the yellow hue of the skin, the likeness to the Mongolian races proper is perhaps less disputable, but with the skin we are bound to consider the hair, the peculiarities of which, as seen in the Bushman, are as different from those seen in the Mongolian variety of mankind as it is possible for two varieties of human hair from the same area to be. "The thinnest and flattest hair is that of the Bosjesmans, Papuans, and Negroes; the most cylindrical being that of Polynesians, Malays, Siamese, Japanese, and Americans. Europeans are between the two." Such are the microscopic characters of the hair in the several great divisions of our species, according to Topinard ("Anthropology;" translated in Library of Contemporary Science by Dr. Bartley), and it is needless to contrast the spirally contorted and tufted dark hair of the Hottentot or Bushman with the coarse wire-drawn straight black hair of the Mongolian or Eskimo. It is curious, however, if indeed not otherwise significant, that the Central African "Bushmen," if so we may call them, of Ashango, occasionally bury their dead in a temporarily diverted stream-course, much as was done in the case of Attila, and, according to Mr. Wood, l.c., "in various parts of the world from the earliest known time."

The Bushman race, as is well known, have strong proclivities in the direction of musical performances. The same, however, may be said of other priscan races as well as of them and the Mongolian and Kalmuck tribes, ${ }^{1}$ and

1 The point of similarity is not, I apprehend, in the character of the music so much as in the fact that the compared peoples admire it such as it is. Of the Kalmuck music Pallas writes (and, as the work is little accessible, I quote) as follows, Sammlungen Historischer Nachrichter ïberdie Mongolischen Völkerschaften, i. p. 152-_"Die melodie der Kalmücken, besonders ihre zartliche und verliebte Musick, hat solche langgezerte klagliche Töne und solche Dissonanzen dass sie ein gutgewohntes ohr mit noch fast mehr Widerwillen als alte Französische Musik, anhört!" 
we cannot therefore lay any weight upon this point of similarity.

The custom, however explained, which the Khoi-Khoin races have of cutting off one or more joints of the little and ring fingers might, but with no great amount of probability, be taken to point to the existence of an affinity to races as far dislocated in space as the inhabitants of certain islands in Oceania, both Papuan and Malay. The Papuans, according to Sir John Lubbock (Prehistoric Times, I 869, p. 445), cut off the end both of the little toe and the little finger as a sign of mourning. The Friendly Islanders (Cook's Voyages, vol. i. 222 ; Williams's Missionary Enterprise, 547,548 ) cut off one or two joints of their little fingers, and the inhabitants of Tracy Island, which was colonized from Samoa, do the like, according to the Rev. S. J. Whitwell (Petermann's Mittheilhngen for I 87 1, p. 203). One form of the solemnization of matrimony amongst the Australians consists in the biting off by a woman of a bit of the little finger of the left hand. I do not know that the fact, deposed to by F. Müller in his contribution to the Memoirs on the Voyage of the Novara, p. 6, to the effect that Caffre women, when a child is sick, or when they themselves become widows, have a piece of their little fingers cut off, need be taken as indicating anything more than the exceeding contagiousness of bad and foolish customs, of which the old anthropologist and zoologist Zimmermann (cit. "Address to Biological Section of British Association Mecting at Liverpool," see Report for year I 87 I) spoke so caustically. Several instances of such adoption and borrowing, on the part of the Abantu tribes, from the conquered and persecuted Khoi-Khoin, might be adduced, and might be paralleled, at some distance, by the fact embodied in the two lines of Horace-

"Græcia captu ferum victorem cepit, et artes Intulit agresti Latio." 


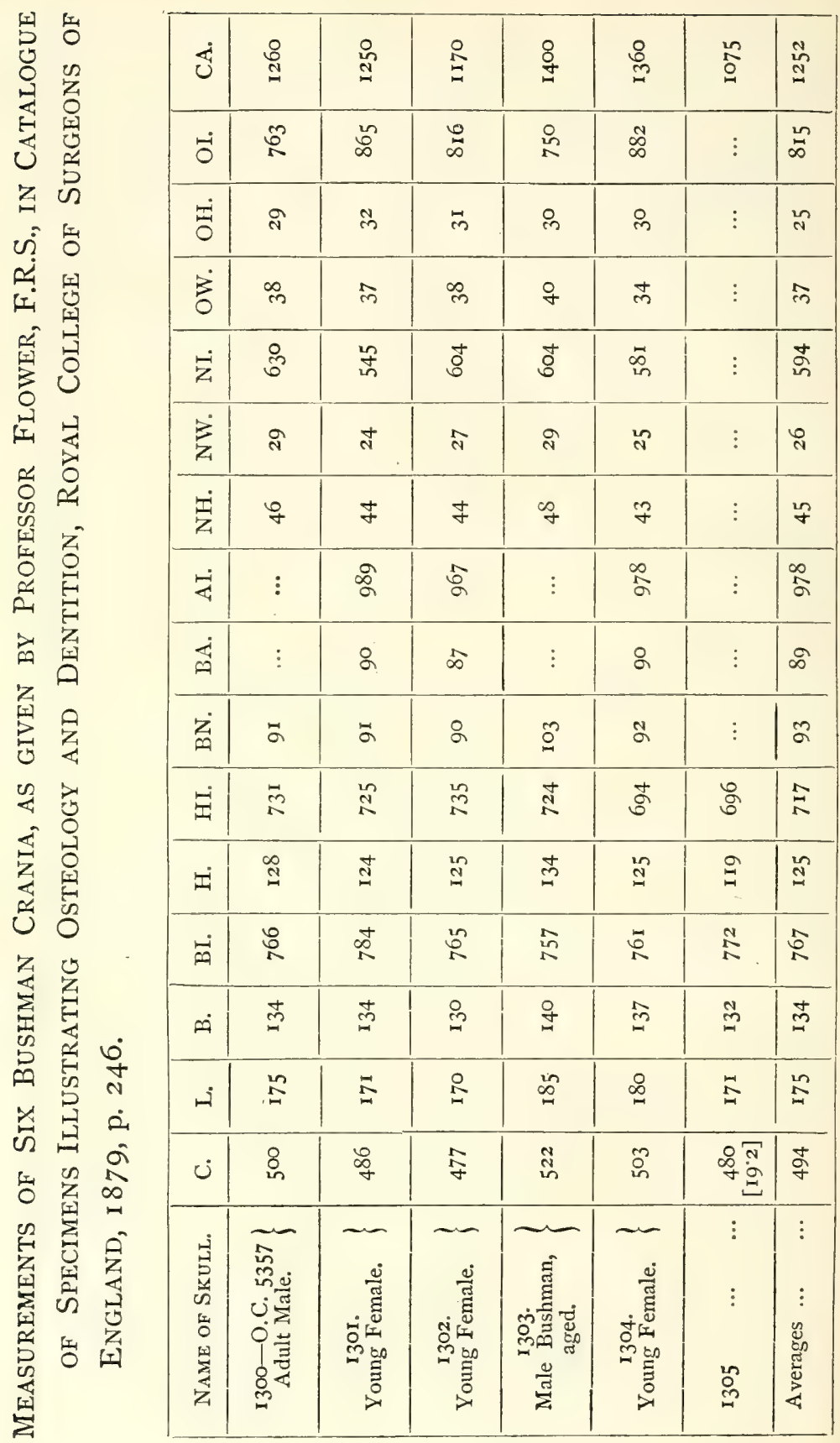




\begin{tabular}{|c|c|c|c|c|c|c|c|}
\hline 3 & $\begin{array}{l}m \\
\ddot{y}\end{array}$ & $\begin{array}{l}\infty \\
\stackrel{\infty}{0} \\
\vdots \\
\vdots\end{array}$ & $\begin{array}{l}\text { m } \\
\stackrel{y}{y}\end{array}$ & $\begin{array}{l}\stackrel{\circ}{\circ} \\
\stackrel{0}{\circ}\end{array}$ & $\begin{array}{l}0 \\
0 \\
0 \\
0\end{array}$ & $\stackrel{m}{a}$ & ఝ్ల \\
\hline$\sigma^{\circ}$ & $\stackrel{R}{R}$ & 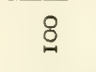 & $\infty$ & $\therefore$ & $?$ & $\approx$ & $\infty$ \\
\hline ثี่ & ल्थल & $\mathfrak{m}_{\substack{0 \\
\sim}}$ & 엉 & ఇल & 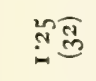 & 济 & $\approx$ \\
\hline है & $\hat{-1 \bar{g}}$ & 济 & 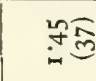 & 角 & 今复 & అ్ల & के \\
\hline$\dot{\mathrm{z}}$ & ه & ๑) & ه్ర & مُ & $?$ & 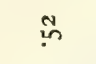 & $\breve{\varphi}$ \\
\hline 完 & $i \overline{\mathscr{C}}$ & $\lim _{i=0}^{\infty}$ & $\therefore \overline{4}$ & 词 & : & 엄 & ते \\
\hline 完 & 证 & $\stackrel{\varphi}{i} \bar{g}$ & 证 & io & 用启 & 엉 & f \\
\hline 4 & $\stackrel{8}{\circ}$ & aे & 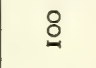 & a & $g$ & 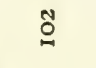 & $\stackrel{\circ}{\circ}$ \\
\hline$\dot{m}$ & in $\overline{\hat{\sigma}}$ & कod & is & ma & is $\bar{\sigma}$ & 㣢 & $\alpha$ \\
\hline 总 & in $\widehat{\sigma}$ & 的高 & $\begin{array}{l}m \bar{g} \\
\text { nूog }\end{array}$ & 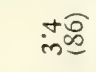 & শ్ర్ర & $\begin{array}{l}\text { ma } \\
m \infty \sqrt{m}\end{array}$ & $\kappa$ \\
\hline$\dot{H}$ & 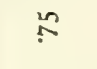 & $\mathfrak{r}$ & $\stackrel{\infty}{\wedge}$ & $\stackrel{R}{R}$ & مै & $\stackrel{R}{R}$ & $\stackrel{2}{\wedge}$ \\
\hline$I$ & 임 & 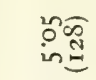 & 的总 & 牸馬 & 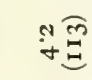 & 证鶣 & $\Xi$ \\
\hline$\dot{\tilde{m}}$ & $\bar{\varphi}$ & $?$ & $?$ & $\hat{A}$ & K & $\stackrel{\infty}{\Re}$ & $\stackrel{k}{\kappa}$ \\
\hline$\dot{\theta}$ & 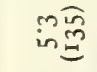 & 庆矛 & in $\sqrt{\sqrt{3}}$ & in & ii $\bar{g}$ & in $\bar{g}$ & $\tilde{m}$ \\
\hline iـ & 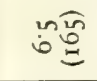 & ชn & ํํ용 & 记 & 禹蛋 & $\overrightarrow{i=\bar{a}}$ & 5 \\
\hline ن ن & 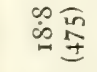 & oñ & 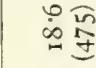 & 客 & 芯哥 & 旅点 & \& \\
\hline 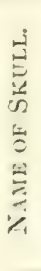 & 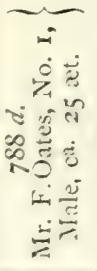 & 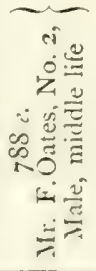 & 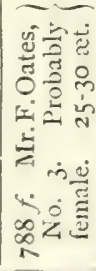 & 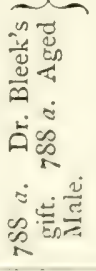 & 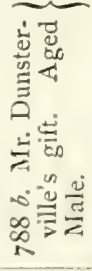 & 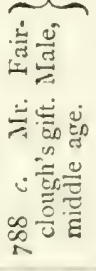 & 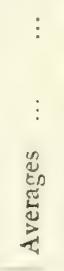 \\
\hline
\end{tabular}


II.

\section{ORNITHOLOGY.}

By R. Bowdler Sharpe, F.L.S., F.Z.S., Etc.

Senior Assistant, Zoological Department, British Museum.

(Plates A, B.)

THE Collection of Birds made by the late Mr. Frank Oates was formed by that gentleman with the greatest care, and it is seldom that it falls to the lot of the naturalist to examine a series of birds in which the particulars of capture are so carefully noted on each specimen as in the present instance. For this reason alone, therefore, the collection is of great importance; but, besides this, it represents without doubt a very fair idea of the avifauna of the parts of the Transvaal and Matabele countries through which Mr. Oates travelled. Of the birds of the former province Mr. Ayres has published several accounts in recent volumes of the "Ibis," and in the same journal for I $874, \mathrm{Mr}$. T. E. Buckley gave a list of the birds met with by him on his journey through the Matabele country, where he travelled for some part of the time with Mr. Oates: but as Mr. Buckley did not get beyond Tati, it has been left for Mr. Oates to give us the first account of the birds which are to be met with between that place and the Zambesi. His untimely death was a great loss to science, for, after his long journey to that river, he had at last reached a terra fere incognita to the ornithologist, where there is little doubt that further researches would have crowned his efforts with the discovery of many new and important facts. The avifauna of the Zambesi region is 
almost unknown, Dr. Kirk being the only naturalist who has written upon the birds, and the species which he has recorded are sufficiently interesting to arouse our interest in the further exploration of the locality. As far as one can judge from the materials at present existing in museums, the birds of the Zambesi region would appear to have their nearest affinities in those of South-western Africa, that is, the provinces of Benguela, Mossamedes, and the Ovampo country to the north of Damara Land. Thus it is that Accipiter ovampensis of Gurney, discovered in Ovampo Land, is now known from the Zambesi (Mus. Brit.), and, on the other hand, the Zambesi Kestrel (Cerchneis Dickinsoni) occurs also in South-western Africa. Instances of this kind might be multiplied to a greater extent, but an exact comparison cannot be made until the two regions have been more thoroughly explored. The Victoria Falls, up to the present time, constituted the only locality whence the peculiar Babbling-Thrush (Pinarornis plumosis) and Shelley's Wheatear (Saxicola Shelleyi) have yet been found, but one of these has now been discovered by Mr. Oates in the Matabele country. Future research may increase the known range of the other Zambesi birds in a southerly direction, and it seems unlikely that the Zambesi region possesses a peculiar birdfauna.

On its arrival in England Mr. Oates's collection was placed in the hands of my friend Captain G. E. Shelley for determination, and the species were in nearly every case identified by him. My task has therefore been a very light one. All the field-notes in the following pages are taken from Mr. Oates's labels, and I am responsible only for the remarks placed between brackets " [ ]." A reference is given to my new edition of Layard's Birds of South Africa as far as published, to the first edition of that work, to my Catalogue of African Birds, and to standard works, such as Finsch and Hartlaub's Vögel Ost-afrika's, Gurncy's cdition of Andersson's Birds of Damara Land, ctc. 
The following LIST of LOCALITIES, alluded to in the ensuing pages, where specimens were obtained by Mr. Oates, will enable the reader, by a reference to the general map in this volume, to determine the position of each locality indicated :-

Bamangwato

Bisschop's Farm, Transvaal

Blauw Krans River, Natal .

Branslow's Farm, Transvaal

Crocodile River

Daka River

Dry River (Sakasusi)

Durban

Eland's River

First Makalaka kraal on Zambesi road,

Geruah

(Wankee's Kraal)

Gokwe River

Gubuleweyo

Gwailo River

Hendrik's Vlei

Hex River

High Veldt, Transvaal .

Holfontein

Hope Fountain .

Impakwe River .

Inchlangin

Inkwesi River

Inquinquesi River

Inyati

John Scott's Farm, Transvaal

Kaar Kloof Heights, Pietermaritzburg

Ladysmith

Lion Camp, Crocodile River .

Makalapsi River

Matengwe River

Meriko River

Metli River

Mopani Pan

Motloutsi River .

Nata River

Newcastle

Palatswe River .

$$
\text { Lat. Long. }
$$

23. I S. 26.45 E. 26.7 S. 29.12 E. 28.55 S. 29.48 E. 26.4 S. 29.9 E. 25.34 S. $28.28 \mathrm{E}$. $18.45 \mathrm{~S} . \quad 25.57 \mathrm{E}$. 21.9 S. $28.10 \mathrm{E}$. 29.5I S. 31.0 E. 25.19 S. 28.3 E.

20.33 S. $\quad 27.26$ E. 19.19 S. $26.30 \mathrm{E}$. 22.8 S. $27.36 \mathrm{E}$. 20.23 S. $28.50 \mathrm{E}$. I9. I 4 S. 29.49 E. I8. 57 S. 26.26 E. 25.20 S. 28.4 E. 26.35 S. $29.40 \mathrm{E}$. $24.26 \mathrm{~S} . \quad 27.46 \mathrm{E}$. 20.22 S. $28.51 \mathrm{E}$. 21.4 S. 27.54 E. 19.42 S. 29. I 4 E. 20.55 S. 28.0 E. I 9.42 S. $29.13 \mathrm{E}$. 19.4I S. 29.15 E. 26.1 I S. 29.23 E. 29.19 S. 30.2 E. 28.37 S. $29.38 \mathrm{E}$. 24.18 S. $27.48 \mathrm{E}$. 22.58 S. 26.54 E. 20.24 S. $27.28 \mathrm{E}$. 24. 10 S. $27.30 \mathrm{E}$. 22.55 S. $\quad 26.56 \mathrm{E}$ 21. I8 S. $27.50 \mathrm{E}$. 21.52 S. 27.41 E. 19.53 S. 27.4 E. 27.47 S. $29.50 \mathrm{E}$. $22.3^{8}$ S. $\quad 27.16 \mathrm{E}$. 


\begin{tabular}{|c|c|c|c|c|c|c|}
\hline \multirow{3}{*}{\multicolumn{2}{|c|}{$\begin{array}{l}\text { Pantamatenka River } \\
\text { Pietermaritzburg }\end{array}$}} & \multirow{3}{*}{. } & \multirow[b]{2}{*}{. } & \multicolumn{2}{|r|}{ Lat. } & Long. \\
\hline & & & & - & $18.39 \mathrm{~S}$. & $25.4 \mathrm{I} \mathrm{E}$. \\
\hline & & & & - & $29.34 \mathrm{~S}$. & $30.24 \mathrm{E}$. \\
\hline Pilandsberg & - & - & - & - & $25.12 \mathrm{~S}$. & $27.35 \mathrm{E}$. \\
\hline Pinetown & - & . & . & - & $29.50 \mathrm{~S}$ & $30.50 \mathrm{E}$. \\
\hline Pretoria & . & . & . & . & $25.42 \mathrm{~S}$ & $28.5^{\circ} \mathrm{E}$. \\
\hline Ramaqueban Ri & iver & . & . & - & 2 I. I I S. & $27.52 \mathrm{E}$. \\
\hline Retief's Drift, $V$ & aal Rive & & . & . & $26.50 \mathrm{~S}$ & $29.5^{8} \mathrm{E}$. \\
\hline Sand Spruit, Tra & ansvaal & & . & $\cdot$ & 27. II S. & $30.18 \mathrm{E}$. \\
\hline Second Makalak & ka kraal & on & $\mathrm{mb}$ & oad & $20.31 \mathrm{~S}$. & $27.26 \mathrm{E}$. \\
\hline Semokwe River & $\cdot$ & . & . & . & $21.7 \mathrm{~S}$. & 28. I $7 \mathrm{E}$. \\
\hline Seruli River & . & . & . & . & $22.32 \mathrm{~S}$ & $27.29 \mathrm{E}$. \\
\hline Shashe River & . & . & . & . & $2 \mathrm{I} .34 \mathrm{~S}$. & 27.44 E. \\
\hline Sibanani & - & · & $\therefore$ & - & $19.45 \mathrm{~S}$. & $26.58 \mathrm{E}$. \\
\hline Sunday's River, & Transva & aal & . & - & 28.2 I S. & 29.49 E. \\
\hline Tamasancha & . $\quad$. & . & . & - & $19.32 \mathrm{~S}$ & $26.40 \mathrm{E}$. \\
\hline Tamasetsie & - & . & . & . & I9.10 S. & $26.28 \mathrm{E}$. \\
\hline Tati & - & . & . & . & $2 \mathrm{I} .28 \mathrm{~S}$ & $27.45 \mathrm{E}$. \\
\hline Tchakani Vlei & . & - & - & - & $22.48 \mathrm{~S}$. & $27.5 \mathrm{E}$. \\
\hline Tibakai's Pan & . & . & - & - & $18.52 \mathrm{~S}$. & $26.18 \mathrm{E}$. \\
\hline Touani River & $\therefore$ & . & . & . & $22.52 \mathrm{~S}$ & $26.59 \mathrm{E}$. \\
\hline Umvungu River & & . & . & . & I9.2I S. & $29.4 \mathrm{I} \mathrm{E}$. \\
\hline Victoria Falls, Z & Zambesi . & & . & - & $17.57 \mathrm{~S}$ & $25.48 \mathrm{E}$. \\
\hline Witfontein & . & - & - & . & $24.28 \mathrm{~S}$ & $27.46 \mathrm{E}$. \\
\hline
\end{tabular}

Order ACCIPITRES.

Sub-order FALCONES.

Family VULTURIDÆ.

I. Otogyps AURICUlaris (Daud.) : Sharpe, ed. Layard's Birds of South Africa, p. 4. Eared Vulture.

a. Shot at dead elephant, near Umvungu River, about the middle of November 1873. Iris dark hazel; bill pale horn-colour, bluish grey at base; head and neck livid and red (scabby); legs and feet pale bluish grey; claws black.

2. Neophron pileatus (Burch.): Sharpe, t. c.p. 7. Hooded Vulture.

a. Ramaqueban River, August 6, 1874. Iris dark; bill neutral tint; head and neck pale dirty blue, tinged with pink on the cheeks; legs pale dirty blue; claws black. A female, I am nearly sure.

\section{Circus Ranivorus (Daud.): Sharpe, t. c. p. I4. South African Marsh-Harrier.}

a. of Near Pretoria, June 22, 1873. Iris bright chrome; legs pale yellow. Ball of hair in stomach; mouse or rat skin in crop. 
4. Melierax CANorus (Rislach): Sharpe, t. c. p. I7. Chanting Goshawk.

a. $\delta$ Bush veldt, between Pretoria and Bamangwato, July I873. Iris bright raw sienna ; base of beak orange (?) ; legs red. Crop and stomach very full, containing large ants, rat, lizard, etc.

5. Melierax Gabar (Daud.) : Sharpe, t. c. p. 19. Red-faced Goshawk.

a. 우 (adult.) Lion Camp, Crocodile River, July 1873.

b. (juv.) Second Makalaka kraal on Zambesi road, September 3, 1874. Iris deep orange, approaching burnt sienna; bill black, orange all round the nostril and base; skin round eye pale blue; legs fine reddish, clouded and spotted with dusky black; claws black.

6. Astur POlyzonoides (Smith): Sharpe, t.c.p. 22. Many-banded Goshawk.

a. $\subsetneq$ (adult.) First Makalaka kraal on Zambesi road, August 22, 1874. Iris rich deep orange; bill black, pale bluish at base; skin round base yellow (pale); skin round eye pale bluish, inclining to yellow ; claws black. Lizard in stomach.

b. oै Hendrik's Vlei, December I8, I874. Iris crimson; bill black, becoming pale blue just under nostril ; cere and gape and skin round eye yellow; legs orange-yellow; claws black. In stomach large insects and lizard (?).

[This pretty little Goshawk is rare in South Africa, but appears to increase in numbers towards the Zambesi, whence I have recently seen a series collected by Dr. Bradshaw.]

7. Buteo JACKAL (Daud.): Sharpe, t. c. p. 26. Jackal Buzzard.

a. of Newcastle, June 4, I873. Iris pale golden hazel.

8. Milvus ÆGyptius (G.) : Sharpe, t. c. p. 49. Yellow-billed Kite.

a. of (testes well developed.) Ramaqueban River, September I7, 1874. Iris bright hazel; bill golden yellow, inclining to horn-colour on upper and lower mandibles, but bright at the base and nostrils; legs golden yellow, somewhat dusky; claws black. Lizards in stomach; very fat.

b. of Tati, October 1874 .

9. Elanus Cæruleus (Desf.) ; Sharpe, t.c. p. 52. Black-shouldered Kite.

a. of (?) (imm.) Hex River, July 1873. Iris bright raw sienna. Mouse or rat in stomach.

b. (adult.) Not labelled.

Io. Falco minor, Bp.: Sharpe, t. c., p. 57. South African Peregrine Falcon.

$a$ : (adult.) Not labelled. 
II. FAlCo BIARMicus (Temm.) : Sharpe, t. c. p. 58 , pl. ii. South African Lanner.

a. of Newcastle, June 3, 1873. Iris very dark. Remains of mouse or rat, and a great many grasshoppers' heads, in the stomach.

12. Cerchneis RUpicola (Daud.) : Sharpe, t.c. p. 62. South African Kestrel.

a. of Newcastle, June 3, 1873. Iris very dark.

b. + Newcastle, June 3, 1873 .

c. Not labelled.

13. Cerchneis tinnunculoides (Temm.) Cerchneis naumanni, Sharpe, t. c. p. 64. Lesser Kestrel.

a. $q$ (adult.) Holfontein, November 25, 1873. Iris dark hazel.

14. Cerchneis amurensis (Radde) : Sharpe, t. c. p. 66. Eastern Red-footed Kestrel.

a. $q$ (adult.) Between Sibanani and Tamasancha, December 9, 1874. Iris hazel ; skin round eye yellow; skin at base of bill orange; bill dark greyish blue, pale yellow at base, the yellow colour predominating over the blue on the lower mandible; legs and feet orange; claws pale dusky orange. In stomach flying ants, which it was catching in the air, amongst many other birds, when shot. The male, I think, is less, and more distinctly marked.

[Dr. Kirk was the first to discover this Kestrel in the Zambesi region, and there were specimens in Dr. Bradshaw's collection.]

\section{Sub-order STRIGES.}

Family Bubonidæ.

15. Bubo Lacteus (Temm.): Sharpe, t. c. p. 7I. Verreaux's Eagle Owl.

a. + (adult.) Inkwesi River, August 5, 1874. Iris dark (? dark blue), but much sunk in when I got it; bill very pale blue; claws dusky black.

r6. Bubo Maculosus (Vieill.) : Sharpe, t. c. p. 73. Spotted Eagle Owl.

a. Not labelled.

I7. SCOṔS LEUCOTIS (Temm.) : Sharpe, t. c. p. 74. White-faced Scops Owl.

a. $q$ (adult.) Near Umvungu River, November 3, I873. Native name, "Secova." Iris deep orange. Ova size of mustard sced. Remains of small rat in stomach. Sitting on nest, made, I think, in an old one, as there were many similar ones, as of a colony of birds, in the trees about. Three well-grown young ones in nest, very fierce, as was the old one. 
I8. Glaucidium perlatum (Vieill.) : Sharpe, Cat. B. ii. p. 209. Carine perlata, Sharpe, ed. Layard, p. 77. African Pearl-spotted Owlet.

a. ㅇ Tati, August 29, I873. Iris chrome yellow.

b. of Tati, October IO, I874. Iris bright yellow; bill whitish.

c. Not labelled.

19. Asio Capensis (Smith): Sharpe, t. c. p. 78. African Short-eared Owl.

a. Pietermaritzburg, about the beginning of May 1873. Iris dark brown.

b. of Marsh near Newcastle, June I, I873. Iris deep orange. I saw several of these Owls whilst snipe-shooting. Another shot was much softer in plumage, like a young bird.

\section{Family STRIGIDE.}

20. Strix Capensis, Smith : Sharpe, t. c. p. 8I. South African Grass-owl.

a. Sand Spruit, Transvaal, June 8, 1873. Iris very dark.

21. Strix flammea, L. : Sharpe, $t$. c. p. 82. Barn Owl.

a. $q$ (old bird probably). Tati, September 18, I874. Iris very dark hazel; bill pale flesh-colour.

b. $q$ (?) Tati, September I8, 1874. Very fat. Iris very dark hazel ; bill pale flesh-colour ; feet whitish ; claws black.

c. $\delta$ (?) (undeveloped). Tati, October 3, 1874. Remains of rat in stomach.

Order PICARIÆ.

Family CAPRIMULGIDE.

22. Caprimulgus europeus, L. : Sharpe, t. c. p. 83. European Nightjar.

a. Not labelled.

23. Caprimulgus Rufigenis, Smith: Sharpe, t.c. p. 85. Rufouscheeked Nightjar.

a. $\nmid$ Semokwe River, September 24, I873.

b. of Semokwe River, October I873. Iris hazel.

c. ㅇ Tati, March 21, I874.

d. ㅇ Tati, October I, I874. Iris hazel; legs pale brown.

e. $q$ Tati, October 1874 .

24. Caprimulgus mossambicus, Peters: Sharpe, t.c.p. 88. Mozambique Nightjar.

a. $q$ Tati, March 21, I874. Iris dark hazel. Stomach very full of beetles, moths, and other insects.

b. Not labelled. 
25. Cosmetornis vexillarius (Gould) : Sharpe, t.c. p. 89. Standard-winged Nightjar.

a. of (juv.) Victoria Falls, Zambesi, January 2, I875. Iris dark hazel ; upper mandible and tip of lower one dusky, the base of the latter flesh-colour; legs dirty flesh-colour. Large winged ants and large beetle in stomach.

\section{Family CYPSELIDE.}

26. Cypselus apus (L.): Sharpe, t.c. p. 90. Common Swift.

a. + (adult.) Between Sibanani and Tamasancha, December 9, I874. Iris hazel; bill black; legs and feet dirty flesh-colour, dusky towards the tips and on the claws. Flying ants in stomach.

Family MEROPIDE.

27. Merops apiaster, L. : Sharpe, t.c. p. 96. European Bee-eater.

a. of Crocodile River, November 15, I873. Iris crimson.

b. $q$ (juv.) Inchlangin, about the beginning of December 1873 . Iris pale crimson.

c. + (?) Hendrik's Vlei, December 18, I874. Iris crimson; bill black; legs brown; claws whitish.

28. Merops supericiliosus, L. : Sharpe, t.c. p. 97. Blue-cheeked Bee-eater.

a. of, b. ㅇ Hendrik's Vlei, December I8, I874. Iris crimson; bill black; legs brown; claws whitish. In stomach large flying insects (? dragon-flies).

29. Mierops nubicoides, Smith: Sharpe, t. c. p. 99, pl. iv. fig. 2. Carmine-throated Bee-eater.

a. Daka River, January 20, I875. Iris dark hazel ; bill black; legs neutral tint, marked with greyish white; claws dusky. Beetles, etc., in stomach.

b. of Geruah, January 24, I875. Iris dark hazel ; bill black ; feet, legs, and claws, dark neutral tint ; legs and feet covered with whitish scales. Beetles, wasps, etc., in stomach.

3o. Merops bullockoides, Smith: Sharpe, t. c. p. 99, pl. iv. fig. I. White-fronted Bee-eater.

a. Crocodile River, July I873. Iris hazel.

b. of Crocodile River, November 9, 1873. Iris hazel.

31. Merops pusillus, P. L. S. Müll. : Sharpe, t. c. p. Ioo. Little Bee-eater.

a. Tati, March 24, 1874. Iris crimson; bill, legs, and claws black. Stomach not at all muscular, containing remains of insects like beetles.

b. Tati, March 24, I874. Soft parts as above. Stomach contained winged insects. 
c. Tati, March 24, I874.

d. of (?) Tati, March 26, 1874 . Iris crimson. Stomach contained remains of insects-winged, I think.

32. Dicrocercus hirundinaceus (Vieill.): Sharpe, t. c. p. ioi. Swallow-tailed Bee-eater.

a. of Near the Pantamatenka River, January I2, I875. Iris crimson; bill black; legs dark neutral tint; claws black. Flying insects in stomach.

\section{Family CORACIIDE.}

33. Coracias Garrula, L. : Sharpe, t.c. p. Io2. European Roller. a. $q$ (adult.) Tati, March 26, 1874. Extremely fat. Iris hazel, darker round pupil, then light.

b. Tati, March 28, I874. Sex undeterminable, the bird being apparently young. Very fat, as was the hen bird skinned before. Stomach full of huge grasshoppers.

34. CoRaCias Nævia, Daud. : Sharpe, $t$. $c$. p. I03. White-naped Roller.

a. $\nmid$ (I believe.) First Makalaka kraal on Zambesi road, August 24,1874 . Iris pale hazel (a dark ring round the pupil?); legs dull orange, inclining to olive; bill and claws black. Grasshoppers or locusts in stomach.

b. of Second Makalaka kraal, Zambesi road, September 9, I874. Iris hazel, dark round pupil, then pale; legs pale greenish orange. Stomach contained remains of beetles.

35. CoRACIAS CAUdATA, Vieill. : Sharpe, $t$. c. p. Io4. Lilac-breasted Roller.

a. t Holfontein, November 25, I873. Iris light hazel.

b. of First Makalaka kraal, Zambesi road, August I8, I874. 'Iris deep hazel round the pupil, outside this very pale ; legs olive ; claws and bill black. Stomach very large, but not muscular, containing a snake about a foot long, and remains of grasshoppers. Head very large for size of bird.

c. of First Makalaka kraal, Zambesi road, August 24, 1874. Iris hazel; bill and claws black; legs pale dirty orange with an olive tinge. Lizard and grasshoppers or locusts in stomach.

d. $q$ Between the Pantamatenka River and Zambesi, January II, I875. Iris hazel ; bill black; legs pale greenish orange ; claws black. In stomach centipedes (?).

e. $q$ Geruah, January 24, 1875. Iris hazel; bill black; legs yellowish blue; claws blue. Soft ants in stomach.

f. Not labelled.

36. Eurystomus Afer (Lath.): Sharpe, t. c. p. io6. Cinnamon Roller.

a. of Near Umvungu River, November 3, I873. Native name 
"Tchegala." Iris hazel, not dark; bill bright yellow. Stomach muscular, containing remains of beetles.

Family Alcedinide.

37. Corythornis Cyanostiglia (Rüpp.): Sharpe, $t . c$. p. io8. Malachite-crested Kingfisher. milion.

a. Sibanani, December II, I874. Iris hazel; bill and legs ver38. Ceryle RUdis (L.): Sharpe, t. c. p. i io. Pied Kingfisher.

a. of Meriko River, November 17, I873. Iris dark hazel.

b. ot High Veldt, Transvaal, December 7, 1873. Iris dark hazel.

39. Ceryle maxima (Pall.): Sharpe, t.c. p. iri. Great African Kingfisher.

a. ㅇ Matengwe River, December 2, I874. Iris hazel; bill dark slate-colour; legs slate-colour.

40. Halcyon SEMiCeRULea (Forsk.): Sharpe, t.c. p. II4. African White-headed Kingfisher.

a. + (?) Geruah, December 15, I874. Iris dark hazel; bill orange-red, black at tip and base; legs and feet dark purplish-brown, orange at back of legs and on soles.

41. Halcyon albiventris (Vieill.) : Sharpe, t. c. p. il 5 . Brown hooded Kingfisher.

a. $\hat{o}$ (?) Crocodile River, July 1873 . Beetles and grasshoppers in stomach.

42. Halcyon Chelicutensis (Stanl.): Sharpe, t.c. p. II7. Striped Kingfisher.

a. of Crocodile River, July 1873. Stomach contained grasshoppers.

b. $q$ Crocodile River, July 1873 . Beetles and grasshoppers in stomach.

43. Halcyon cyanoleuca (Vieill.): Sharpe, t. c. p. 120. Angola Kingfisher.

a. + Crocodile River, November 15, 1873. Iris hazel.

b. of Nata River, December 5, 1874. Makalaka name "Gogoda." Iris hazel; upper mandible deep carnation, black at tip and gape; under mandible black; legs black. Stomach empty, but for a few remains of insects. This species has a twittering cry; they say it stays in the mopani.

c. of Nata River, December 6, I874. Iris hazel ; upper mandible deep carnation, black at tip and gape; lower mandible and legs black.

d. ot Nata River, December 6, 1874. Iris hazel. 


\section{Family BuCEROTIDÆ.}

44. Tockus flavirostris (Rüpp.): Sharpe, t. c. p. I3o. Yellowbilled Hornbill.

a. §, b. c. $q$ Near Crocodile River, July 1873. Iris very pale ochre. Flying ants in stomach.

d. $q$ (juv.) Motloutsi River, August 24, 1873. Iris ochreous.

45. Tockus nasutus (L.): Sharpe, $t$. c. p. I33. African Grey Hornbill.

a. Not labelled.

\section{Family UPUPIDÆ.}

46. UPUPA AFRICANA, Bechst. : Sharpe, $t$. c. p. I34. South African Hoopoe.

a. $\subsetneq$ Between Pretoria and Bamangwato, July 1873. Iris hazel (?). In stomach, a tick and seeds.

47. IRRISOR ERYTHRORHYNCHUS (Lath.) Red-billed WoodHoopoe.

$a . \quad$, $b$. 9 Crocodile River, November 1873. Iris hazel.

c. $q$ (?) Tati, June $26, \mathbf{1} 874$. Shot out of three by Cornelis, who saw them hopping about oddly on the road. Iris dark hazel; bill and legs bright orange-red; claws black. Stomach containing large chrysalides and a grasshopper.

d. ㅇ First Makalaka kraal, Zambesi road, August 30, I874. Iris dark hazel ; bill and legs vermilion, the latter less bright and inclining to orange; claws black. Stomach small and not muscular, containing remains of small insects and large grubs. This bird has a peculiar chattering note, often repeated. There were three or four of them when this was shot, climbing about on tree trunks like Creepers.

48. Rhinopomastes cyanomelas (Vieill.) Scimitar-billed WoodHoopoe.

a. of Near Metli River, August 10, 1873. Iris hazel. Stomach large, containing flying ants and large insects.

b. of Seruli River, October 18, 1873. Iris hazel.

c. If Palatswe River, October 20, 1873. Iris hazel.

d. of Tati, October 1874 .

e. Not labelled.

Family Musophagidæ.

49. Schizcerhis CONCOLOR, Smith: Sharpe, t. c. p. I44. Grey Plantain-eater.

a. Crocodile River, July 1873 . Iris deep grey.

b. đo Transvaal, December 1873 . Iris hazel. 
Family COLIIDæ.

50. Colius 'striatus, Lath.: Sharpe, Cat. Afr. B., p. 12. South African Coly.

a. Not labelled.

51. Colius erythromelon, Vieill.: Sharpe, Cat. Afr. B., p. 12. Quiriva Coly.

a. of (?) Makalapsi River, August 8, I873. Iris dark; bill black; base and skin round eyes madder; claws madder.

Family Cuculide.

52. Cuculus clamosus, Cuv.: Sharpe, ed. Layard, p. 150. Black Cuckoo.

a. + Crocodile River, November 9, 1873. Iris light hazel.

53. Cuculus cupreus, Boddaert. Chrysococcyx cupreus, Sharpe, t. c. p. I53. Golden Cuckoo.

a. of Crocodile River, November 8, 1873 . Iris scarlet.

b. $q$ Crocodile River, November 9, I873. Iris light brown.

54. Coccystes CAFER (Licht.) : Sharpe, t. c. p. 158. Le Vaillant's Cuckoo.

a. Crocodile River, November 14, 1873. Iris light hazel.

b. $q$ (?) Tati, October 17, 1874. Iris hazel; bill and legs black.

55. Centropus senegalensis (L.): Sharpe, t. c. p. 162. Larkheeled Cuckoo.

a. $q$ Tati, August 28, 1873. Iris crimson.

b. of Ramaqueban River, September 4, 1873 .

56. Centropus superciliosus (H. and E.): Sharpe, t. c. p. I63. White-eyebrowed Lark-heeled Cuckoo.

a. $q$ Crocodile River, July 1873 . Iris crimson.

Family INDICATORIDE.

57. Indicator Sparmanni (Steph.): Sharpe, t.c. p. I66. Whiteeared Honey-guide.

a. $q$ Holfontein, July I 873. Iris light brownish hazel.

$b, c$. Not labelled.

Family CAPITONIDE.

58. Pogonorhynchus leucomelas (Bodd.) : Sharpe, t. c. p. 173. Pied Barbet.

a. ㅇ Pretoria, July 24, 1873. Iris very dark. Stomach large, thin, and full of fruit; a good deal of flesh about the head.

b. + Pretoria, July 1873. Iris dark hazel.

c. Tati, October 6, 1874. Bill and legs black. 
59. Trachyphonus Cafer (Vieill.): Sharpe, t.c. p. I78. Le Vaillant's Barbet.

a. $q$ Crocodile River, July I873. Iris red.

b. + Crocodile River, November 15 , I873. Iris crimson.

c. of Crocodile River, November 30, 1873. Iris crimson.

d. Not labelled.

Family PICIDÆ.

6o. Campethera Bennetti, Smith: Sharpe, t. c. p. I8I. Bennett's Woodpecker.

a. Second Makalaka kraal, Zambesi road, September 7, I874. Iris lake; bill blackish slate-colour; legs and claws slate-colour, inclined to olive.

6r. Campethera Abingtoni, Smith: Sharpe, t.c. p. i82. Goldentailed Woodpecker.

a. Not labelled.

62. Campethera Smithil, Malh.: Sharpe, t.c. p. 184. Smith's Woodpecker.

a. Tati, October 6, I874. Bill dusky slate-colour; legs pale whitish olive.

b, c. Not labelled.

63. Dendropicus namaquUs (Licht.): Sharpe, $t . c$. p. i88. Bearded Woodpecker.

a. ot Motloutsi River, August 23, I873. 'Iris crimson lake.

b. ㅇ Ramaqueban River, July 30,1874 . Iris lake; bill slatecolour; legs dark greenish slate-colour; claws dark. Stomach containing large caterpillars.

c. If Ramaqueban River, August 2, 1874. Iris lake; bill slatecolour; legs dark greenish slate-colour; claws black. Stomach containing large caterpillars.

64. Dendropicus Cardinalis (Gm.): Sharpe, t.c. p. 190. Cardinal Woodpecker. crimson.

a. đo Between Pretoria and Bamangwato, July 1873. Iris deep

b. ô Ramaqueban River, September 4, I873. Iris crimson.

c. \& Tati, October 7, 1874. Iris red (?); bill and legs dark slatecolour (?).

65. IynX PECTORALIS (Vigors); Sharpe, t. c. p. I9I. Red-breasted Wryneck.

a. Blauw Krans River, Natal, May 22, 1873. Iris red-brown; legs pale greenish grey.

Family PsitTACIDE.

66. Psittacus Robustus, Gm.; Sharpe, $t . c$. p. 194. Le Vaillant's Parrot.

a. Not labelled. 
67. Psittacus Meyeri (Rüpp.) : Sharpe, t. c. p. 195. Meyer's Parrot.

a. Witfontein, July I 873 .

b. đt Holfontein, July I 873 . Iris very light hazel. (Another of shot, brighter in plumage, had the iris hazel round pupil, then burnt sienna.)

c. ㅇ Second Makalaka kraal, Zambesi road, September 4, 1874 . Iris hazel round pupil, then orange; bill blackish slate-colour; legs and claws dusky black.

d. of Tati, October 7, I874. Bill and legs dark slate-colour.

e. \& Tati, October 9, 1874. Bill and legs dark slate-colour Seeds in stomach.

\section{Order PASSERIFORMES,}

\section{Family TURDIDE.}

68. Turdus litsitsirupa, Smith: Sharpe, t.c. p. 198. South African Thrush.

$a$. $f, b$. $q$ Pair of thrushes shot together near Eland's River, July 1873. Iris hazel.

c. ․ (Ovary very rudimentary). Tati, March 19,1874 . Iris dark hazel ; upper mandible dusky black, under one orange; legs fleshcolour.

d. of Tati, October 1874 .

69. MYrmecocichla FORMicivora (Vieill.); Sharpe, $t$. $c$, p. 23 I. Southern Ant-eating Wheatear.

$a$, b. of Near Newcastle, May 30, 1873. Iris hazel. Stomach very muscular, containing seeds and beetles. Found perching on anthills, from which it rises with a hovering flight, something like a Skylark.

7o. Saxicola Galtoni (Strickl. and Sclater): Sharpe, t. c. p. 234. Familiar Chat.

a. of (?) Ladysmith, May 25, I873. Iris dark hazel.

b. of Inyati, October 2, 1873. Iris rich hazel-brown. Native name "Envachli."

71. Saxicola Pileata (Gm.): Sharpe, t.c.p. 238. Capped Wheatear.

a. Pietermaritzburg, about the beginning of May 1873 . hazel.

b. of, c. \& John Scott's Farm, Transvaal, June 19, I873. Iris dark

72. Saxicola Shelleyi, Sharpe, t. c. p. 246. Shelley's Wheatear. (Plate A.)

a. Ramaqueban River, a few miles above the drift, on the way to Gubuleweyo, June 24, 1874. Iris dark hazel; bill, legs, and claws black. Gravel and beetles in stomach. This bird seems to have a habit of climbing about in trees. 
b. ( $q$ probably, on account of the very bare breast.) Near Sibanani, December 8, I874. Iris hazel; bill and legs black.

[This fine species was hitherto known from a pair of birds only, which were purchased a few years back from a dealer by the British Museum, and were stated to have come from the Victoria Falls. Mr. Oates has now established the Zambesi region to be the habitat of the species, and has also procured it 300 miles off the place whence the first specimens were obtained. The occurrence of Shelley's Wheatear so far south as the Ramaqueban River is very interesting, as we may now expect that it will be found still farther to the southwards.]

73. Saxicola leucomelena, Burchell: Sharpe, t. c. p. 247. Burchell's Wheatear.

a. Desolate part of High Veldt; found on walls round corn and peach fields, June I5, I873. Iris hazel. Beetles in stomach.

74. Monticola explorator (Vieill.): Sharpe, t.c. p. 22o. Sentinel Rock-Thrush.

a. Kaar Kloof Heights, near Pietermaritzburg, May I9, I873. Iris hazel.

Family TIMELIIDÆ.

Sub-family PyCNONOTINE.

75. Phyllostrophus Capensis, Sw.: Sharpe, t. c. p. 203. Cape Bristle-necked 'Thrush.

a. Not labelled.

76. Pycnonotus Layardi Gurney: Ibis, I879, p. 39o. Layard's Bulbul.

a. Durban, April 23, 1873. Iris bright hazel.

b. $q$ (probably.) Between Pretoria and Bamangwato, July 1873 . Iris hazel. Fruit and seeds in stomach.

77. Pycnonotus nigricans (Vieill.): Sharpe, Cat. Afr. B., p. 23. Le Vaillant's Bulbul.

a. $q$ Crocodile, July I873. Iris deep crimson; skin round eye orange. Large seeds in stomach.

\section{Sub-family TIMELIINÆ.}

78. Crateropus Bicolor, Jard. : Sharpe, ed. Layard, p. 210. Pied Babbling Thrush. black.

a. of Tati, October. 2, I874. Iris bright orange; bill and legs

b. 우 Tati, October 7, 1874. Iris bright orange; bill and legs black.

c. $̛$ (?) Tati, October 1874 . 
79. Crateropus JardiniI, Smith: Sharpe, t. c. p. 2I2. Jardine's Babbling Thrush.

a. ㅇ Inkwesi River, October 8, 1873. Iris orange, with crimson rim. rim.

b. \& Meriko River, November 18,1873 . Iris orange, with crimson

c. \& Tati, October 3, 1874. Iris orange, with outer ring of crimson.

d. of Tati, October 9, 1874. Iris orange, surrounded by crimson ring ; bill black ; legs dark slate-colour. Stomach muscular, containing insects.

8o. Cossypha Natalensis (Smith): Sharpe, t.c. p. 223. Natal Chat-Thrush.

a. Durban, April 23, 1873. Iris bright hazel (?).

8I. Aedon Leucophrys (Vieill.): Sharpe, t. c. p. 252. White-eyebrowed Warbler.

a. of Transvaal, November 1873. Iris hazel.

82. Cisticola CURvirostris (Sund.); Sharpe, t. c. p. 263. Brown Fantail Warbler.

a. Tibakai's Pan, January 2I, I875. Iris pale red-brown; upper mandible of bill dusky, lower one bluish white; legs flesh-colour; claws dusky.

83. Cisticola tinniens (Licht.); Sharpe, t.c. p. 265. Le Vaillant's Fantail Warbler.

a. Marsh near Newcastle, June I, 1873. Common in marsh.

84. Cisticola Chiniana (Smith); Sharpe, t.c.p. 268. Larger Greybacked Fantail Warbler.

a. of (?) Tati, March 23, 1874 . Native name, "Ynete." Iris pale hazel-brown; upper mandible dusky, under one and legs flesh-colour.

b. \& (slightly developed). Tati, March 23, I874. Iris (I think) tawny red; upper mandible dusky black, under one dusky orange; legs yellowish flesh-colour; thighs very fleshy-these, as well as the belly, very bare of feathers. Stomach containing grubs and other insects.

c. of (well developed). Tati, March 24, 1874. Iris pale redbrown; upper mandible dusky black, under one dusky orange; legs ycllowish flesh-colour; thighs very fleshy. Stomach somewhat mus. cular, containing remains of insects.

d. Between Sibanani and Tamasancha, December 9, 1874. Iris pale reddish brown; upper mandible dusky, under one dirty fleshcolour; legs brownish flesh-colour.

85. Cisticola aberrans (Smith): Sharpe, t.c. p. 27I. Smith's Fantail Warbler.

a. Crocodile River, July 1873. Iris lake. 
86. Cisticola cursitans (Frankl.): Sharpe, t.c. p. 275. Common Fantail Warbler.

a. Near Newcastle (?) about the end of May I873. Iris very pale. Stomach of this and the reed species contained remains of beetles.

87. Bradypterus Gracilirostris, Sund.: Sharpe, t. c. p. 287. White-breasted Reed-Warbler.

a. Not labelled.

88. Sylvietta Rufescens (Vicill.) : Sharpe, t. c. p. 303. Short-tailed Bush-Warbler.

a. of (?) Tati, October I3, I874. Iris pale burnt sienna ; bill dusky, dirty flesh-colour at base (?); legs pale red-brown. Stomach rather muscular, containing large grubs.

\section{Family NECTARINIIDE.}

8. Nectarinia famosa (L.): Sharpe, $t . c$. p. 306. Malachite Sunbird.

a. Natal, I873.

9o. Cinnyris Gutturalis (L.): Sharpe, $t$. c. p. 3 II. Scarlet-chested Sun-bird.

a. Semokwe River, September 1873 .

b. of Impakwe River, February 12, 1874. Native name, "Bola-lamaholi." Iris dark hazel. Stomach very thin, containing remains of good-sized insects, some spiders amongst them. Shot creeping amongst tall-stalked flowers.

c. (Sex doubtful.) Tati, March 21, I874. Iris dark hazel; bill, egs, and claws black. Stomach not at all muscular, containing remains of soft insects.

d. Not labelled.

9i. Cinnyris AFer (L.): Sharpe, t. c. p. 3i3. Greater Doublecollared Sun-bird.

a. $f(?)$ Mossel Bay, Cape Colony, April II, 1873. Iris dark hazel. Stomach very small, not muscular, apparently containing insects ; no gravel.

92. Cinnyris mariquensis (Smith): Sharpe, t.c.p. 3ig. Southern Bifasciated Sun-bird.

a. Makalapsi River, August 7, I873. Iris dark brown.

b. Inkwesi River, October 1873 .

$c, d, e, f$. Not labelled.

Family PARIDE.

93. Parus Afer, Gm.: Sharpe, t. c. p. 329. South African Titmouse.

a. of Inyati, September 27,1873 . Iris dark hazel.

b. of Semokwe River, October 1873 . Iris burnt sienna. 
94. PARUs NIGER, Vieill.: Sharpe, t. c. p. 33I. Southern Black-andwhite Titmouse.

a. of Ramaqueban River, September 4, 1873. Iris hazel.

b. 옹 (?) Ramaqueban River, June 12, 1874. Iris dark hazel ; bill, legs, and claws black. Stomach containing sand and insects.

c. of (?) Tati, October 13, I874. Iris hazel; bill and legs black.

Family MUSCICAPIDE.

95. Pratincola torquata (L.): Sharpe, $t$. c. p. 25o. South African Stone-chat.

a. of Durban, April 23, I873.

b. oิ Pietermaritzburg, May 2, 1873 .

c. q Near Newcastle, May 31, 1873. Iris very dark hazel.

d. of (well developed). Tati, October 15, 1874. Iris hazel.

e. $q$ Tati, October I5, I874. Iris hazel.

f. $q$ (?) (young bird in pen). Tati, October I5, I874. Iris hazel. Don't remember to have seen this species here before. Is it just arrived, or merely passing as a bird of passage from the south?

96. Parisoma subceruleum (Gm.): Sharpe, t. c. p. 332 . Redcrested Fly-catcher.

a. of (?) Ladysmith, May 25, 1873. Iris pale grey, nearly white.

b. $q$ (?) Tati, September 24, I874. Iris very pale straw-colour ; bill and legs black.

c. of Tati, October 3, 1874. Iris pale straw-colour. Singing a short sweet note, and moving about amongst the bushes after the manner of a Willow-wren, looking for insects.

97. Batis Molitor (Hahn and Küst.): Sharpe, Cat. B., iv. p. I37. Eastern Yellow-eyed Fly-catcher.

a. of Dry River, October I873. Iris golden yellow.

b. Mopani Pan, near Ramaqueban River, June 25, 1874. Iris bright yellow; legs and claws black.

c. + Tati, October 16, 1874. Iris yellow; bill and legs black. Stomach muscular, containing remains of large insects like grasshoppers; also green shoots (?).

d. Not labelled.

98. Terpiphone perspicillata (Sw.): Sharpe, Cat. B., iv. p. 357. South African Paradise Fly-catcher.

a. of (highly developed). Tati, October 4, 1874. Bill dark cobalt. Insects in stomach.

\section{Family HIRUNDINIDE.}

99. Hirundo puella, Temm.: Sharpe, Cat. Afr: B.,p. 47. Smaller Striped-breasted Swallow.

a. Tati, October 4, 1874. Iris hazel. Sex indistinguishable, but 
Thomson had similar specimens, which were females and well-developed males. A similar one shot by me was a male, and well developed.

b. Tati, October 5, 1874. Iris hazel.

100. Hirundo cucullata, Bodd.: Sharpe, Cat. Afr. B., p. 46. Large Striped-breasted Swallow.

a. of Tati, October 4, 1874. Iris hazel.

ioi. Hirundo Rustica, L. : Sharpe, Cat. Afr. B., p. 45 . Common Swallow.

$a, b, c$. of Tati, October 17,1874 . Cold, wet day, after very hot weather. These birds came into the houses and were easily caught. The other species seem to have gone away; these have been here about a week.

i02. Hirundo semirufa, Sund. : Sharpe, Cat. Afr. B., p. 45. Redbreasted Swallow.

a. Inchlangin, about the beginning of December 1873 . Iris dark hazel. Many small beetles in stomach. Another I shot was either a young one or in moult.

b. $q$ Tati, October 4, 1874. Iris hazel.

\section{Family LANIIDE.}

103. Dryoscopus Boulboul (Lath.): Sharpe, Cat. Afr. B., p. 48. South African Puff-backed Bush-Shrike.

a. Crocodile River, July I873. Iris hazel.

I04. Dryoscopus cubla (Lath.) : Sharpe, Cat. Afr. B., p. 48. Pied Puff-backed Bush-Shrike.

a. of Tati, August 28, I873. Iris crimson.

$b$, c. Not labelled.

I05. LANiARIUS BAKBakiRI (Vieill): Layard's B. S. Afr. p. I6I. Bakbakiri Bush-Shrike.

$a$, b. of Mossel Bay, Cape Colony, April I I, I873. Iris dark grey. Remains of beetles and seeds in stomach.

c. of Ladysmith, May 25, I 873 . Iris dark grey.

io6. Laniarius sulphureipectus (Less.): Sharpe, Cat. Afr. $B$. p. 49. Yellow-breasted Bush-Shrike.

a. of Motloutsi River, October 15, I873. Iris dark hazel.

Io7. Laniarius atrococcineus (Burch.): Sharpe, Cat. Afr. B., p. 49. Crimson-breasted Bush-Shrike. crimson.

a. $\sigma^{\star}$ (?) Crocodile River, July 1873 . Iris, outside violet, inside

b, c. of Near Eland's River, July 1873 . Iris, outside violet, inside crimson. Insects, beetles, and grasshoppers in stomach. 
d. Makalapsi River, August 8, I873. Iris violet and crimson.

e. of Tati, September 2, 1873. Iris neutral tint.

f. of Tati, October 2, I874 Iris slate-colour ; bill and legs black. Insects (principally beetles) in stomach.

g. ot Tati, October 2I, 1874. Iris slate-colour; bill and legs black.

108. LANIARIUS SENEGalus (L.) Red-winged Bush-Shrike.

a. Second Makalaka kraal, Zambesi road, September 3, I874. Iris hazel; bill black, base of upper and a good deal of base of under mandible bright slate-colour; legs pale slate-colour; claws rather darker.

b. $q$ Pantamatenka River, January 18, I875. Iris dark hazel ; bill black; legs pale slaty blue; claws dusky.

109. LaniariUs trivirgatus (Smith): Gurney in Anderss. B. Dam. Ld., p. 15I. Three-streaked Bush-Shrike.

a. Crocodile River, July I873. Iris hazel.

b. $q$ Near Metli River, August 10, 1873. Iris dusky hazel.

c. Not labelled.

I Io. Lanius minor, Gm. : Sharpe, Cat. Afr. B., p. 5 I. Lesser Grey Shrike.

$a, b$. of Tati River, where Makalaka road leaves it, going north, November 19, 1874. Iris hazel ; bill lilac, tinged on top of upper and end of lower mandible with black; legs dark brown. Beetles in stomach.

III. Lanius collaris, Gm. : Sharpe, Cat. Afr. B., p. 51. Collared Shrike.

a. of Durban, April I873. Iris hazel.

b. \& Pietermaritzburg, May 2, I873. Iris dark hazel.

c. $q$ (?) Mossel Bay, Cape Colony, April II, I873. Iris dark hazel. Stomach full of remains of beetles; no gravel.

I 12. Lanius collurio, L. : Sharpe, Cat. Afr. B., p. 5o. Red-backed Shrike.

a. \& Meriko River, November 18, 1873. Iris hazel.

b. of (slightly developed). Tati, March 2 I, 1874. Iris dark hazel ; bill deep violet, pale at base ; legs black.

c. $q$ (?) Tati, March 2r, 1874. Iris dark hazel ; bill dusky lilac ; legs and claws black.

d. of (?) Sibanani, December I I, I874. Iris hazel; bill dark slatecolour, violet at base; legs blackish slate-colour.

$e, f$. Not labelled.

113. Urolestes melaxoleucus (Jard.): Gurney in Anderss. $B$. Dam. Ld., p. 130. Black-and-white Long-tailed Shrike.

$a, b$. of Crocodile River, July 1873. Iris hazel (?). Large ants in stomach. 
c. $q$ [brown variety]. Near Hex River, July I873. Iris ochreous hazel. Shot by Bell, who says the note is different from that of the black one, which is plentiful. This is the only brown one seen. He says it whistles. Large gnats and other insects in stomach.

d. of Tati, October 13,1873 . Iris dark brown.

e. Tati, March 25, I874. Iris dark hazel. Stomach slightly muscular, full of remains of large insects.

f. of First Makalaka kraal, Zambesi road, August 20, 1874. Iris hazel ; bill, legs, and claws black. Ants in stomach.

\section{Family PRIONOPIDÆ.}

I14. Eurocephalus anguitimens, Smith : Sharpe, Cat. B., iii. p. 279. Smith's Wood-Shrike.

a. ơ, b. + Tati, March 23, I874. Iris dark hazel; bill and legs black. Stomach muscular, containing a number of large hard seeds and one or two beetles.

I 5. Prionops talacoma, Smith : Sharpe, Cat. B., iii. p. 32 I. South African Helmet-Shrike.

a. of Near Metli River, August I0, 1873. Iris gamboge; skin round eye dentated, orange-yellow; legs pale vermilion.

b. $q$ Holfontein, November 25, 1873. Iris chrome yellow.

c. of First Makalaka kraal, Zambesi road, June 21, 1874. Iris chrome yellow; skin round eye bright orange ; legs and feet orangered; claws dusky black. Stomach pretty fleshy, and containing remains of grasshoppers and beetles.

d, e. of (?) First Makalaka kraal, Zambesi road, June 2 I, 1874. Iris chrome yellow; skin round eye light bright orange; legs and feet orange-red; claws dusky black.

116. BRADYORNis OATESII, sp. n. Oates's Wood-Shrike. (Plate B.)

a. of (adult.) First Makalaka kraal, Zambesi road, August 20, 1874. Iris dark hazel. Stomach full of ants.

b. (juv.) Geruah, January 25, I875. Iris hazel; bill and legs black.

c. (adult.) Not labelled.

[Similis B. pallido sed cineraceus; gulâ conspicue albâ: pectore et corporis lateribus pallide cinerascentibus : subcaudalibus albis.

Adult male.-General colour above ashy; the head slightly browner, with indistinct brown shaft-streaks ; least and median wingcoverts like the back; the median and greater coverts brown, edged with ashy brown, a little reddish on some of the outer greater coverts ; quills brown, externally ashy or fulvous brown, the primaries and some of the innermost secondaries edged with pale whity brown; tailfeathers ashy brown, the feathers edged with paler brown; lores and a small patch above and below the eye dull white; in front of the eye a dusky spot; ear-coverts brown, slightly washed with fawn-colour, 
and contrasting with the ashy grey head; cheeks ashy grey, like the sides of the neck; entire throat white, strongly defined; remainder of under surface pale ashy brown; whitish on the lower abdomen, vent, and under tail-coverts ; under wing-coverts and axillaries pale ashy like the breast, the lower coverts slightly tinged with fawn-colour; quills dusky brown below, pale ashy fulvous along the inner web. Total length $7 \cdot 5$ inches, culmen $0^{\circ} 55$, wing 3.85 , tail 3.1 , tarsus 0.85 .

After a careful comparison of specimens I have come to the conclusion that the present bird is new to science. At first I thought it would be B. murinus, Finsch and Hartl, but the ear-coverts in that species are described as being like the sides of the neck and crop, whereas here the ear-coverts are in strong contrast; the under wing coverts also are not fawn-colour in Mr. Oates's specimens. Having compared it with all the other species of Bradyornis represented in the British Museum, I modify the "Key to the species," given in my Catalogue of Birds, vol, iii, p. 308, as follows :-

a. Upper surface ashy or clear brown, not black.

$a^{\prime}$. Above light reddish brown, uniform; throat white, like the rest of the under surface; under wing-coverts white-mariquensis.

$b^{\prime}$. Above ashy; throat white, contrasting with the ashy under surface ; under wing-coverts like the breast.-Oatesii.

$c^{\prime}$. Above light brown, uniform; throat white, contrasting with the fawn-buff breast ; under wing-coverts fawn-colour.-pallidus, modestus, etc. etc.

The fawn-coloured under wing-coverts of $B$. pallidus, the ashy brown throat and chest of $B$. chocolatinus, the reddish brown upper surface, and entirely white under surface of $B$. mariquensis, successively prevent $B$. Oatesiz, from being considered synonymous. A bird, determined as B. murinus, $\mathrm{F}$. and $\mathrm{H}$., from the Congo (Sharpe and Bouv., Bull. Soc. Zool. France, 1877), would appear to be the same as $B$. Oatesii, but is in worn plumage.]

\section{Family DICRURIDE.}

i17. Buchanga Assmilis (Bechst.): Sharpe, Cat. B., iii. p. 247. African Drongo.

a. $q$ Crocodile River, July 1873. Iris crimson. Beetles and grasshoppers in stomach.

b. $q$ Tati, October II, I873. Ixis crimson.

c. Ramaqueban River, August 2, 1874. Iris deep red; bill, legs, and claws black.

\section{Family ORIOLIDÆ.}

118. Oriolus galbulı, L.; Sharpe, Cat. B.,iii.p. 191. Golden Oriole. a. $q$ Meriko River, November $16, \mathbf{1} 873$. Iris crimson. 
Family CoRvidæ.

I 9. Corvus scapulatus, Daud. : Sharpe, Cat. B., iii. p. 22. Whitebacked Crow.

a. Ladysmith, May"27, 1873. Iris hazel.

b. Seruli River, October 17,1873 . Iris dark hazel.

\section{Family STURNID曆.}

I20. Buphaga Africana, L. : Sharpe, Cat. Afr. B., p. 57. African Beef-eater.

$a, b$. $q$ Semokwe River, September 1873 . Iris orange.

I21. Dilophus carunculatus (Gm.): Sharpe, Cat. Afr. B., p. 56. Wattled Starling.

a. ơ Ramaqueban River, September 4, I873. Iris hazel.

b. of Second Makalaka kraal, Zambesi road, September I, I874. Iris hazel; bare skin about the eye yellowish; bill dirty flesh-colour, base and tip dusky; legs, feet, and claws dusky brown. Stomach not very muscular, containing beetles and sand.

c. of (fully developed). Tati River, where Makalaka road leaves it, going north, November I8, I874. Iris hazel ; bill white, tinged with lilac; legs dark brownish flesh-colour; bare skin of head deep black in front, bright yellow behind; round the eyes a small bluish patch. Stomach muscular, containing beetles and grasshoppers.

122. Amydrus bicolor (Gm.): Sharpe, Cat. Afr. B., p. 55. Brown Starling.

a. Mossel Bay, Cape Colony, April I I, I873. Iris pale grey with orange rim. Contents of stomach miscellaneous.

123. Amydrus morio (Daud.): Sharpe, Cat. Afr. B., p. 54. Cape Starling.

a. Not labelled.

I24. Pholidauges Verreauxi, Bocage: Sharpe, $t$. c. p. 54. Verreaux's Glossy Thrush.

a. of Near Umvungu River, October 31 , I873. Iris hazel round pupil, and bright yellow round the hazel. Stomach containing remains of insects, and a number of large white berries, and sticky yellow matter with the berries; the latter said to be used for bird-lime, the berries said to grow on trees.

b. of (?) Near Umvungu River, November 12, I873. Iris deep olive round pupil, and round the olive a bright yellow ring. Stomach not muscular, containing a few remains of small insects, but principally a quantity of vegetable matter like fine grass.

125. LAMProtornis Australis, Smith: Sharpe, t.c. p. 56. Smith's Glossy Thrush.

a. of Crocodile River, December 1, 1873. Iris hazel. 
I26. LAMprotornis Mevesi, Wahlb.: Sharpe, t.c. p. 56. Meves's Glossy Thrush.

a. of Nata River, December 5, I874. Iris hazel; bill and legs black. Stomach containing ants.

127. LAMPROCOLIUS PHGNiCOPTERUS (Sw.): Sharpe, t. c. p. 55. Red-shouldered Glossy Thrush.

a. Blauw Krans River, Natal, May 22, 1873 . Iris bright orange.

b. of Tati, October I I, 1873 . Iris orange.

c. \& Crocodile River, November 8,1873 . Iris orange.

d. I Meriko River, November I8, I873. Iris orange.

\section{Family MotaCilLide.}

128. Motacilla aguimp, Temm. : Sharpe, t. c. p. 73. African Pied Wagtail.

a. Durban, April 23, 1873 .

b. Crocodile River, July 1873 . Iris hazel. Insects in stomach.

c. Not labelled.

129. Motacilla capensis, L. : Sharpe, t.c. p. 73. Cape Wagtail.

a. Durban, April 23, 1873 .

b. of Pietermaritzburg, April 30, 1873 .

c. Inyati, October 3,1873 . Iris dark hazel. Native name "Umvemve."

130. Anthus Pyrrhonotus, Vieill. : Gurney in Anderss. B. Dam. $L d$., p. I13. Cinnamon-backed Pipit.

a. Kaar Kloof Heights, near Pietermaritzburg, May 19, 1873. Iris hazel.

b. Not labelled.

I3I. Anthus Caffer, Sund. : Sharpe, t. c. p. 72 . South African Pipit.

a. Pietermaritzburg, about the beginning of May 1873 .

132. Macronyx Capensis (L.): Sharpe, t. c. p. 73. Cape Long-claw.

$a, b$. $q$ (?) Between Ladysmith and Newcastle, about the end of May 1873. Iris hazel.

c. of Pretoria, December 7, I873. Iris hazel.

\section{Family Alaudide.}

133. Certhilauda semitorquata, Smith: Sharpe, to co p. 7 I. Grey-collared Lark.

a. of Transvaal, December 18, 1873. Iris hazel.

134. Mirafra africana (Smith): Sharpe, P. Z. S., i874, p. 642. South-African Lark.

a. of Tibakai's Pan, December 19, 1874. Iris pale reddish hazel; 
bill dirty flesh-colour ; top of upper mandible dusky ; legs flesh-colour. Insects and seeds in stomach.

135. Mirafra sabota (Smith): Sharpe, P. Z. S., I874, p. 645. Sabota Lark.

a. of Tati, October 25, I874. Iris bright light brown; upper mandible dusky, under one dirty flesh-colour; legs pale brown. Stomach muscular, containing large hard seeds.

b. Not labelled.

136. Tephrocorys cinerea (Gm.): Sharpe, P. Z. S., I874, p. 633. South African Rufous-capped Lark.

a. \& Pietermaritzburg, May 2, 1873 .

Family Ploceide.

137. Sycobrotus bicolor (Vieill.): Sharpe, Cat. Afr. B., p. 6 o. Natal Black-and-yellow Weaver-bird.

a. Not labelled.

138. TeXtor ERYThrorhynchus, Smith: Sharpe, t. c. p. 58 . Redbilled Black Weaver-bird.

a. Tati, March 25, I874. Iris dark greyish hazel; bill and legs dusky orange. Stomach very muscular, containing seeds and insects. Noisy tame bird. Shot in company with the black Long-tails (Chera); had been moulting, as feathers were loose.

b. + Tati, October 25,1874 . Iris dark; bill dusky orange; legs dusky, with an orange tinge.

c. ㅇ Near first Makalaka kraal, Zambesi road, June I7, 1874 . Iris dark hazel; bill and legs dusky orange. Stomach containing many seeds, and a few insect remains and gravel. Three nests in a high tree full of these birds.

d. I Tati, September 30, 1874. Iris hazel; bill coral-red ; legs salmon-colour; claws dusky. Shot by Thomson out of a flock of similar birds, and a black-winged white species.

139. Hyphantornis capensis (Gm.): Sharpe, t. c. p. 59. Cape Yellow Weaver-bird.

a. \& Transvaal, December 16, 1873. Iris straw-colour.

140. HyphantoRnis OlivaceUs (Hahn): Gray, Handl. B., ii. p. 4I, No. 6575. Olive-and-yellow Weaver-bird.

a. ㅇ Transvaal, December 16, 1873. Iris raw sienna.

I41. Hyphantorinis ocularis (Smith). Smith's Weaver-bird.

a. $\sigma^{+}, b$. ㅇ Pinetown, near Durban, April I873. Iris buff; bill black; legs grey.

c. \& Pietermaritzburg, April 30, 1873. Iris light hazel or golden. 
142. Hyphantornis Mariquensis (Smith): Layard, B. S. Afr., p. I82. Mariqua Weaver-bird.

a. of Seruli River, October 18 , I873. Iris bronze.

I43. Hyphantornis Nigrifrons, Cab. : Layard, t.c. p. I8o. Blackfronted Weaver-bird.

a. + Inyati, October 3, I873. Iris pale reddish hazel ; bill and legs pinkish; upper mandible tinged with dusky. This bird, and another shot the same time, were in moult. The other one is much duller; not so yellow on head, rump, and tail ; throat and breast tinged with pale yellow; belly white.

b. Ot Ishokwani, near Semokwe River, October 14, I873. Iris yellowish white.

c. of Tati, October 21, 1874. Iris straw-colour; lower mandible flesh-colour, upper one dusky; legs slate-colour. Insects in stomach.

144. Sporopipes squamifrons (Smith): Sharpe, Cat. Afr. B., p. 6I. Scutellated Finch.

a. $q$ Semokwe River, September 30, 1873. Iris burnt sienna.

I45. Vidua Verreauxi, Cass. : Finsch and Hartl., Vog. Ost-afr., p. 426. Verreaux's Widow-bird.

a. ơ (very fully developed). Tati, March 30, 1874. Iris dark hazel. Stomach containing seeds, a little grit, and remains of a beetle. 146. Vidua Regia (L.) : Sharpe, Cat. Afr. B., p. 63. Shaft-tailed Widow-bird.

$a, b, c, d$. of Tati, March 20, 21, 22, 24, 1874. Iris dark hazel; bill, legs, and claws, coral-red. Small seeds in stomach.

147. Vidua PRincipalis (L.): Sharpe, t.c. p. 63. Common Widowbird.

a. of Transvaal, December I, 1873. Iris hazel.

b. of Hope Fountain, near Gubuleweyo ; shot in Mr. Thomson's garden, about the beginning of December 1873 . Iris dark hazel.

c. ㅇ (?) Tati, March 3I, 1874. Iris dark; bill and legs coral-red. I think this may be an immature male. In one or two examined afterwards, undoubted females, the bill was pale and the legs more dusky.

d. Not labelled.

148. CHERA PROGNe (Bodd.): Sharpe, t. c. p. 63. Great Widow-bird.

a. \& Pietermaritzburg, April 30, 1873 .

$b$, c. John Scott's Farm, Transvaal, June 19, 1873. Iris hazel.

d, e. of Transvaal, December $18, \mathrm{x} 873$.

$f, g, h, i$. Not labelled.

149. Penthetria albinotata (Cass.): Finsch and Hartl., Vög. Ost-afr., p. 420. White-spotted Widow-bird. 
a. of (undeveloped). Tamasetsie, December 16, I874. Iris hazel; bill bluish ; legs black.

b. \& Between the Pantamatenka River and Zambesi, January I I, 1875. Iris hazel; bill pale bluish violet; legs black. Seeds in stomach.

150. Penthetria ardens (Bodd.): Sharpe, Cat. Afr. B., p. 63. Orange-throated Widow-bird.

a. Natal, 1873 .

I51. Euplectes Capensis (L.): Sharpe, t. c. p. 62. Cape Blackand-yellow Widow-bird.

a. Kaar Kloof Heights, near Pietermaritzburg, May 19, 1873. Iris hazel.

b. Inyati, September 29, 1873. Iris dark hazel.

c. Semokwe River, October I873. Iris hazel.

d. Hope Fountain, near Gubuleweyo, about the beginning of December 1873 . Iris dark hazel.

e. Not labelled.

152. EupleCteS ORYX (L.): Sharpe, t. c. p. 62. Red Bishop-bird.

$a, b$. of Transvaal, 1873 .

c. Hope Fountain, near Gubuleweyo, about the beginning of December 1873. Iris dark hazel.

\section{Family FRINGILLIDE.}

153. Amadina erythrocephala (L.): Sharpe, t. c. p. 65. Redheaded Wax-bill.

a. ㅇ Tati, October 1874. Iris pale hazel; skin round eye red; bill dusky blue; legs dirty flesh-colour.

I54. Pytelia melba (L.): Sharpe, t. c. p. 66. Southern Red-faced Finch.

a. of Tati, September I, I873. Iris burnt sienna.

b. of Tati, September 1873 .

c. of (?) $d$. Tati, October 28,1874 . Iris scarlet; bill coral-red; legs pale brown.

I55. Estrelda ASTRILd (L.): Sharpe, $t$. c. p. 65. Wax-bill Finch.

$a$. of,b. Tati, October 9, 1874. Iris hazel (?); bill vermilion; legs and claws black.

c. Not labelled.

156. Estrelda erythronota (Vieill.): Sharpe, t.c. p. 64. Blackcheeked Finch.

$a$., , $b$. Tati, October 3,1874 . Iris deep crimson; bill dark slatecolour. 
157. Estrelda GRANATiNA (L.): Sharpe, t. c. p. 65. Grenadier Wax-bill.

a. Semokwe River, September I873.

b. o Tati, September 30, 1874 . Iris red; bill and skin round eye scarlet-lake : legs dark brown.

I58. Estrflda Cyanogastra (Daud.) : Sharpe, t.c. p. 65. Southern Bengali Finch.

a. of Tati, March 21, 1874. Iris claret-colour; bill violet, lilac at base ; legs pale flesh-colour. Small seeds in stomach.

b. Tati, October 3, 1874. Iris claret-colour.

c. of Tati, October $2 \mathrm{I}, 1874$. Iris claret-colour; bill violet; legs pale brown (?).

d. 우 Tati, October 1874 .

159. Lagonosticta Minima (Vieill.): Sharpe, t.c. p. 66. Amadavat Finch.

a. of (?) Crocodile River, July I873. Iris very pale hazel.

b. Crocodile River, July I873. Iris lake.

16o. Ortygospiza polyzona (Temm.): Sharpe, t. c. p. 66. Little Barred-breasted Finch.

a. Desolate country near Newcastle, June 5, 1873.. Iris pheasant. colour. Two shot out of a flock.

16i. Passer motitensis, Smith: Sharpe, t.c. p. 69. Greater South African Sparrow.

a. ㅇ Palatswe River, August 13, 1873. Iris dark greyish hazel. Stomach very muscular, containing grit ; seeds in throat.

b. $q$ (probably). Tati, September 24, 1874 . Iris palish hazel; bill black; legs brown; claws darker.

c. T Tati, October I9, 1873. Iris brown.

d. Tati, October 6, I874., Bill black; legs brown.

162. PASSER Diffusus, Smith: Sharpe, t. c. p. 69. Southern Greyheaded Sparrow.

a. Crocodile River; in cultivated fields, July 1873. Iris greenish hazel.

163. Plocepasser mahal, Smith: Sharpe, t.c.p. 61. White-browed Weaver-bird.

a. of Palatswe River, August 13, 1873. Iris dark burnt sienna. Stomach muscular, containing remains of insects. Song not unlike that of a Chaffinch, but much shorter and quieter. I think I have seen these birds since the Lion Camp on the Crocodile River. They go in small parties.

b. Not labelled. 
164. PoliospizA GULARIS (Smith): Sharpe, $t$. c. p. 68. Striped-headed Grosbeak.

a. Between Pretoria and Bamangwato, July 1873. Iris pale clarettinted hazel.

165. Crithagra Chrysopyga (Sw.): Sharpe, t.c. p. 67. Goldenrumped Grosbeak.

a. ㅇ Tati, October 9, I874. Iris hazel; bill dirty violet or fleshcolour; legs brown.

166. CRithagra Angolensis (Gm.): Sharpe, t. c. p. 67. Angola Grosbeak.

a. of (?) First Makalaka kraal, Zambesi road, August 20, I874. Iris hazel: Shot out of flock.

167. Fringillaria flaviventris (Vieill.): Sharpe, t. c. p. 70. Golden-breasted Bunting.

a. of Between the Gokwe and Seruli Rivers, October I7, I873. Iris hazel.

b. of Semokwe River, October I873. Iris hazel.

c. (young bird). Inchlangin, beginning of December 1873. Iris hazel.

d. First Makalaka kraal, Zambesi road, August I9, I874. Iris dark hazel. Another I examined like this in plumage was a male. I have seen them much duller in colour, and the black stripes on the head replaced by brown.

e. of Tati, October IO, I874. Iris hazel; bill flesh-colour; legs pale brown.

i68. Fringillaria Capensis (L.): Sharpe, t. c. p. 70. Cape Bunting.

a. of Mossel Bay, Cape Colony, April II, I873. Iris dark hazel. Seeds and fly in stomach.

\section{Order COLUMBA.}

I69. Turtur CAPICOLA, Sund. : Finsch and Hartl., Vög: Ost-afr., p. 548. Cape Turtle Dove.

a. of Mossel Bay, Cape Colony, April i I, I873. Iris dark hazel. Seeds in stomach.

b. ક Pietermaritzburg, beginning of May 1873 . Iris slate-colour (?) ; legs flesh-colour.

c. $q$ (?) Between Pretoria and Bamangwato. Iris hazel.

170. Chalcopelia Afra (L.): Finsch and Hartl., t. c. p. 554. Emerald-spotted Dove.

a. Blauw Krans River, Natal, May 22, 1873. Iris chestnut.

17 I. CEnA CAPEnsis (L.): Finsch and Hartl., t. c. p. 557. Longtailed African Dove. 
a. $q$ Between Pretoria and Bamangwato, July 1873 . Iris dark hazel.

b. of Near Crocodile River, July I873. Iris hazel.

c. $\delta$ Tati, September 29, I874. Iris and bill orange; legs lake. Small black seeds in stomach.

\section{Order GALLIN Æ.}

Family PTEROCLIDÆ.

I72. Pterocles gutturalis, Smith: Layard, B. S. Afr., p. 279. Yellow-throated Sand-Grouse.

$a, b$. ‡, c. $q$ Shashe River, where Zambesi road crosses it, north of Tati ; coming to the water night and morning, August 17, 1874. Iris hazel; bill and legs dark bluish grey; claws dusky black. A small species of bean and gravel in stomach, which is very muscular.

173. Pterocles Bicinctus Temm. : Layard, t. c. p. 278. Doublebanded Sand-Grouse.

a. ot Makalapsi River, August 6, I873. Iris hazel; skin round eye yellow; bill very dark; corners of mouth and base of lower mandible yellow; legs and feet dusky yellow; claws dark dusky brownish lake.

b. of Makalapsi River, August 8, 1873. Iris hazel; skin round eye bright yellow; upper mandible deep lake, under one orange; legs and feet dull yellow; claws dusky lake. Crop very full of small pebbles; a few seeds in it.

c. ơ, d. $q$ Motloutsi River, August 1873. Iris hazel.

Family PERDICIDE.

I74. Turnix Lepurana, Smith: Layard, t. c. p. 275. Kurrichaine Hemipode.

a. Not labelled.

175. Francolinus Afer, Temm. : Layard, to c. p. 27o. Greywinged Francolin.

$a$, b. of Retief's Drift, Vaal River, June I I, I873. Iris hazel.

I76. Francolinus NATAlensis, Smith: Layard, $t$. c. p. 273. Natal Francolin.

a. O Makalapsi River, August 7, 1873. Iris hazel; bill dusky; tip and lower mandible pale orange; legs, feet, and claws palish orange.

177. Francolinus Pileatus, Smith : Layard, $t . c \cdot p \cdot 272$. Pileated Francolin. legs red.

a. ơ, b. \& Lion Camp, Crocodile River, July 1873 . Iris hazel;

c. of Gokwe River, October 16, 1873. Iris dark hazel. 
178. Coturnix Dactylisonans, Temm. : Layard, t. c. p. 274. Common Quail.

a. of High Veldt, Transvaal, December 1873. Iris hazel.

179. Coturnix Delegorguei, Delegorgue : C. histrionica, Hartl. : Layard, t. c. p. 275. Harlequin Quail.

a. Gubuleweyo, December 26, I873. Native name "Seguatha." Iris rich brown; bill black; legs pale flesh-colour. Does not lie well to a dog, but runs rapidly, and at last rises.

b. of, c. $q$ Gubuleweyo, January 3, 1874. Iris rich brown; bill black; legs and feet salmon-colour.

\section{Order GRALLÆ.}

Family RALLIDE.

180. Parra Capensis, Smith: Gurney in Anderss. B. Dam. Ld., p. 33o. Lesser African Jacana.

a. Not labelled.

181. PoRphyris Alleni, Thoms.: Gurney, t. c. p. 327. Allen's Blue Water-hen.

a. Not labelled.

182. Fulica Cristata (Gm.) : Gurney, t.c. p. 327. Rufous-knobbed Coot.

a. Transvaal, 1873 .

183. Gallinula angulata, Sund.: Gurney, t. c. p. 32 I. South African Moor-hen.

a. of Dry River; killed by the boys with sticks, February 27, 1874. Iris crimson; a narrow circle of tawny yellow within the iris, near the outside; bill crimson and yellow; legs greenish yellow. Vegetable matter in stomach.

b. \& Tibakai's Vlei, December 19, I874. Iris pale crimson; bill yellow, scarlet stripe on top of upper mandible, under one tipped with scarlet; legs pale yellowish brown; thighs pale yellow, tinged with brown. Gravel and vegetable matter in stomach.

i84. Ortygometra egregia (Peters) : Finsch and Hartl., Vög. Ostafr., p. 778. Peters's Crake.

a. Gubuleweyo; shot in marsh by spruit, December 26 , I873. Iris crimson-lake; skin round iris vermilion; lower part of base of upper mandible and whole of base of lower mandible magenta, of a lilac tinge; upper part of upper mandible dark slate-colour, lower part of it near tip lighter slate-colour, tip of lower mandible whitish; legs dusky flesh-colour.

185. Crex pratensis, Bechstein. Ortygometra crex (Gm.): Layard, B. S. Afr., p. 338. Corn-crake. 
a. of (testes slightly developed). Tati ; shot in long grass, March 22, 1874 Iris red-brown; skin round eye brick-red; bill violet; legs pale flesh-colour. Stomach muscular, containing stones and remains of large insects.

Family SCOLOPacide.

186. Philonachus pugnax (L.): Gurney in Anderss. B. Dam. Ld., p. 304. Ruff.

a. O Mopani Pan, near Ramaqueban River, November 4, I874. Iris hazel; bill dusky black, brownish at base; legs dirty orange; claws black.

187. Actitis hypoleucus(L.): Gurney, t.c. p. 303. Common Sandpiper.

a. + Inyati, October 2, 1873. Iris dark hazel; bill dusky, base of lower mandible pale neutral tint ; legs pale violet ; feet and claws dusky.

b. ㅇ Sibanani, December 7, I874. Iris hazel; legs pale dirty slate-colour; base of lower mandible slate-colour; rest of bill dusky black.

I88. Totanus Canescens (Gm.): Sharpe and Dresser, B. Eur., pl. xlii. Greenshanks.

a. I Inquinquesi River, September 29, 1873 . Native name "Tabi-tabi." Iris dark hazel ; legs dull olive.

189. Totanus glareola (L.) : Gurney, t. c. p. 302. Wood Sandpiper. green.

a. Inyati, September 28, 1873. Iris dark hazel; legs dull olive Family GLAREOLide.

190. Glareola melanoptera (Nordm.): Gurney, t. c. p. 264. Black-winged Pratincole.

$a$. of, $b$. ㅇ Branslow's Farm, Transvaal, December 8,1873 . Iris dark hazel.

\section{Family CHARADRIIDE.}

191. Hoplopterus SPeciosus (Licht.): Gurney, t.c. p. 267. Blacksmith Plover. crimson.

a. 9 Branslow's Farm, Transvaal, December 8, 1873. Iris dark

b. O Shashe River, October 16, 1874. Iris crimson; bill and legs black. Beetles in stomach.

c. Not labelled.

192. Chettusia coronata (Gm.): Gurney, t. c. p. 268. Wreathed Plover. 
a. $q$ Bisschop's Farm, Transvaal, June 20, 1873. Iris bright yellow, with hazel ring round pupil. Stomach containing beetles and grasshoppers.

b. of (testes very rudimentary). Tati, March 26, I874. Iris hazel round pupil, then yellow; bill magenta, tip black; legs and skin round eye magenta; claws black.

193. EgIALITIS ATRICOLLARIS (Vieill.) : Gurney, t. c. p. 274. Treblecollared Plover.

a. Durban, April 23, 1873 .

\section{Family OTIDIDæ.}

194. OTIS KORI, Burchell. Eupodotis cristata, Layard, t. c. p. 283. Kori Bustard.

a. (Sex doubtful; perhaps a young hen.) Near Palatswe River, May 16,1874 . Iris hazel, dark round the pupil, but becoming very pale towards the outside ; upper mandible black; under one greenish white, tipped with black; legs and feet pale greenish white; claws dusky.

195. Eupodotis C⿸reulescens (Vieill.) : Layard, t. c. p. 285. Blue Bustard.

a. ơ Near Sunday's River, May 28, 1873. Iris hazel.

196. Edicnemus Capensis, Licht.: Gurney in Anderss. B. Dam. Ld., p. 266. Spotted Thick-knee.

a. Near Pilandsberg, Transvaal, July 1873. Iris golden yellow ; eye large.

b. Not labelled.

\section{Family ARDEIDE.}

197. Ardea melanocephala, Vig. and Childr. : Gurney, t. c. p. 284. Black-throated Heron.

a. of Marsh near Pretoria, June 21, I873. Iris yellow.

ig8. Ardea purpurea, L. : Gurney, t. c. p. 286. Purple Heron.

a. Not labelled.

199. Herodias intermedia (Wagl.): Gurney, t. c. p. 289. Shortbilled Egret.

$a$. Not labelled.

200. Butorides Atricapillus (Afzel) : Gurney, t. c. p. 292. Blackheaded Dwarf Heron.

$a, 3$. Not labelled.

20r. Butorides Sturmil (Wagl.), Ardeirallà Sturmii(Wagl.) : Gurney, $t$. c. p. 29I. Sturm's Heron.

a. Not labelled. 
202. BUTORIDES RUFIVENTRIS (Sund.), Ardea mifientris (Sund.): Ayres, Ibis, IS7 I, pl. ix. Red-bellied Heron.

a. If Hendrik's Vlei, December I874. Iris dark hazel; bill black; legs slate-colour.

203. Bubulcus IBrs (Hasselq.) : Gurney, t. c. p. 288. Buff-backed Heron.

a. o Tati, September 26, I874. Iris bright yellow, inclining to orange; skin round eye chrome yellow; bill yellow; legs orangeyellow, somewhat dusky; claws blackish. Lizards, grasshoppers, and beetles in stomach. This bird not so fat as some shot at Bamangwato in May.

Family CiCONinde.

204. Ciconta AlBa (L.): Gurney, t. c. p. 280. White Stork.

a. of Ramaqueban River, where the Zambesi road leaves it, going north, November 15, 1874. Iris dark hazel; bill and legs orange-vermilion; skin about eye the same, but with a dark patch on it near the eye, and also near the under mandible.

205. Sphenorhynchus Abdimi (Licht.): Gurney, t. c. p. 280.

White-bellied Stork.

a. of Sibanani, December II, I874. Iris white, inclining to greenish ochreous; bill olive, tipped with vermilion; a flesh-coloured $\mathrm{knob}$ at the base.

206. Scopus umbretta (Gm.): Gurney, $t$. c. p. 294. Tufted Umbre.

a. of Makalapsi River, August 7, 1873. Iris dark; bill, legs, and claws black. Frogs in stomach.

\section{Order NATATORES.}

\section{Family ANATide.}

207. Sarkidiornis melanonotus (Penn.): Gurney, t. c. p. 335. Knob-billed Goose.

a. + Mopani Pan, near Ramaqueban River, March 16, 1874. Iris dark hazel; bill and legs black. Shot in a tree. The dogs caught a young one in the pan, where I suppose this Goose had its brood.

208. NetTapus auritus (Bodd.): Gurney, t. c. p. 336. African Dwarf Goose.

a. [む゙], b. [q]. Not labelled.

209. Anas xanthorhyncha, Forst. : Gurney, t. c. p. 342. Yellowbilled Duck.

a. $q$ Near Pretoria, June 18,1873 . Iris bright brown. Grit and vegetable matter in stomach. 
210. P我保onetta ERythrorhyncha (Smith): Gurney: $t$. c. p. 339. Red-billed Teal.

a. 우 Mopani Pan, near Ramaqueban River, March 16, I874. Iris dark hazel ; bill (I think) brown on top, dull orange on sides ; legs black. Caught by dog. They say this is the common small duck here.

b. of Mopani Pan, near Ramaqueban River, November 5, 1874 . Iris bright brown; bill pink with a lilac tinge, a dark lilac stroke on the top; legs slate-colour, inclining to lilac. Out of four shot, I think three were males and one a female, but the plumage differed very little. The boy found a curious swelling in the windpipe of two, which he says were males. He said the female had not got it.

Family PeLECANidæ.

2II. Graculus africanus (Gm.) : Gurney, t.c. p. 37o. Long-tailed Cormorant.

a. Not labelled.

212. Plotus Levaillanti, Licht. : Gurney, t. c. p. 367. Le Vaillant's Darter.

a. Meriko River, November 1873 .

Family PODICIPIDÆ.

213. Podiceps minor, L. : Gurney, t. c. p. 347. Little Grebe.

a. Tchakani Vlei, May I5, I874. Iris yellowish hazel, or rather deep raw sienna or amber; upper mandible dusky black; base and lower mandible orange; legs and feet black.

b. ㅇ Tamasancha, December I0, I874. Bill black, tipped with white, and spotted at base with white; legs black, fringed on webs with white. Beetles in stomach. 


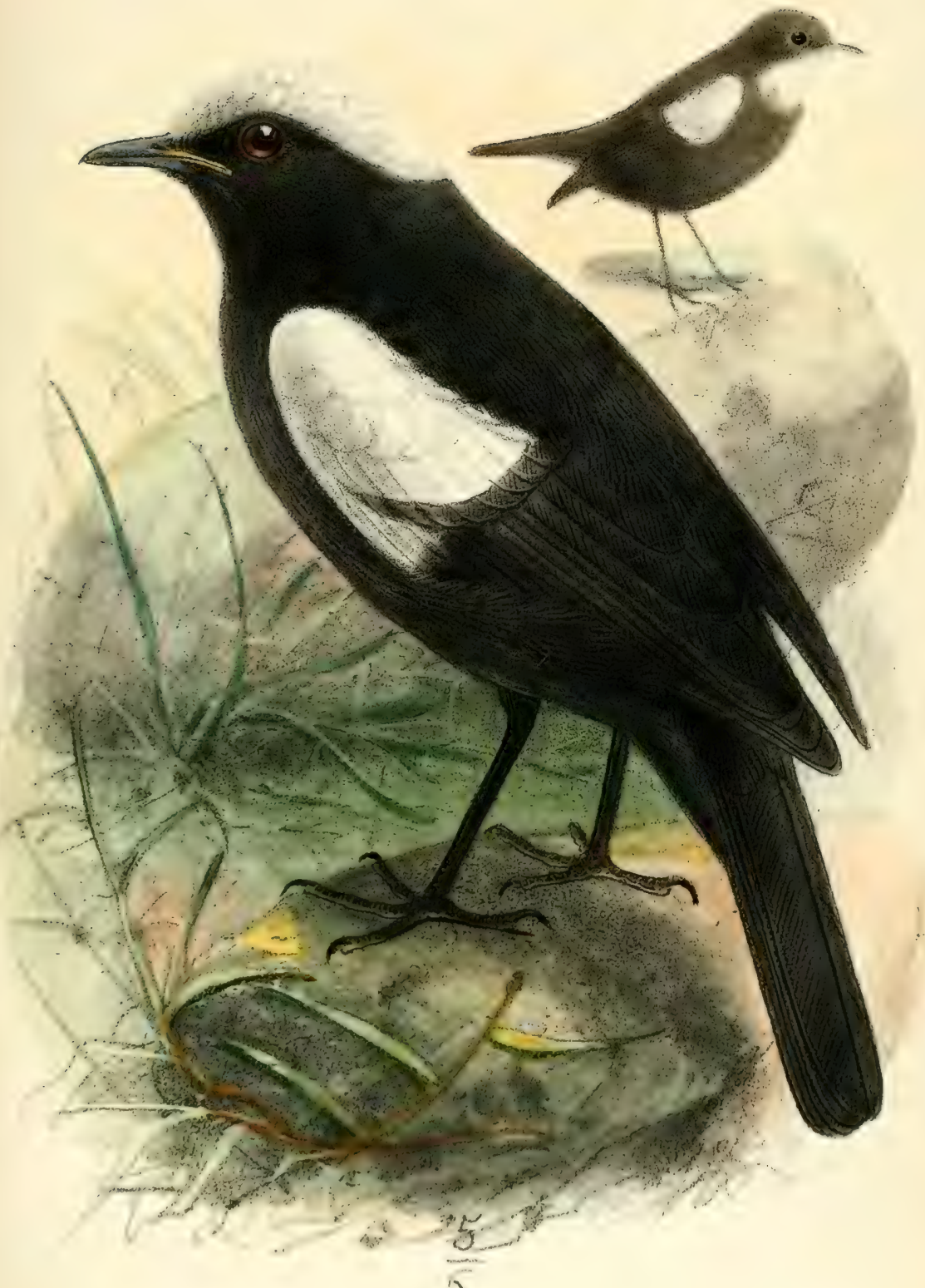



Apo PIB

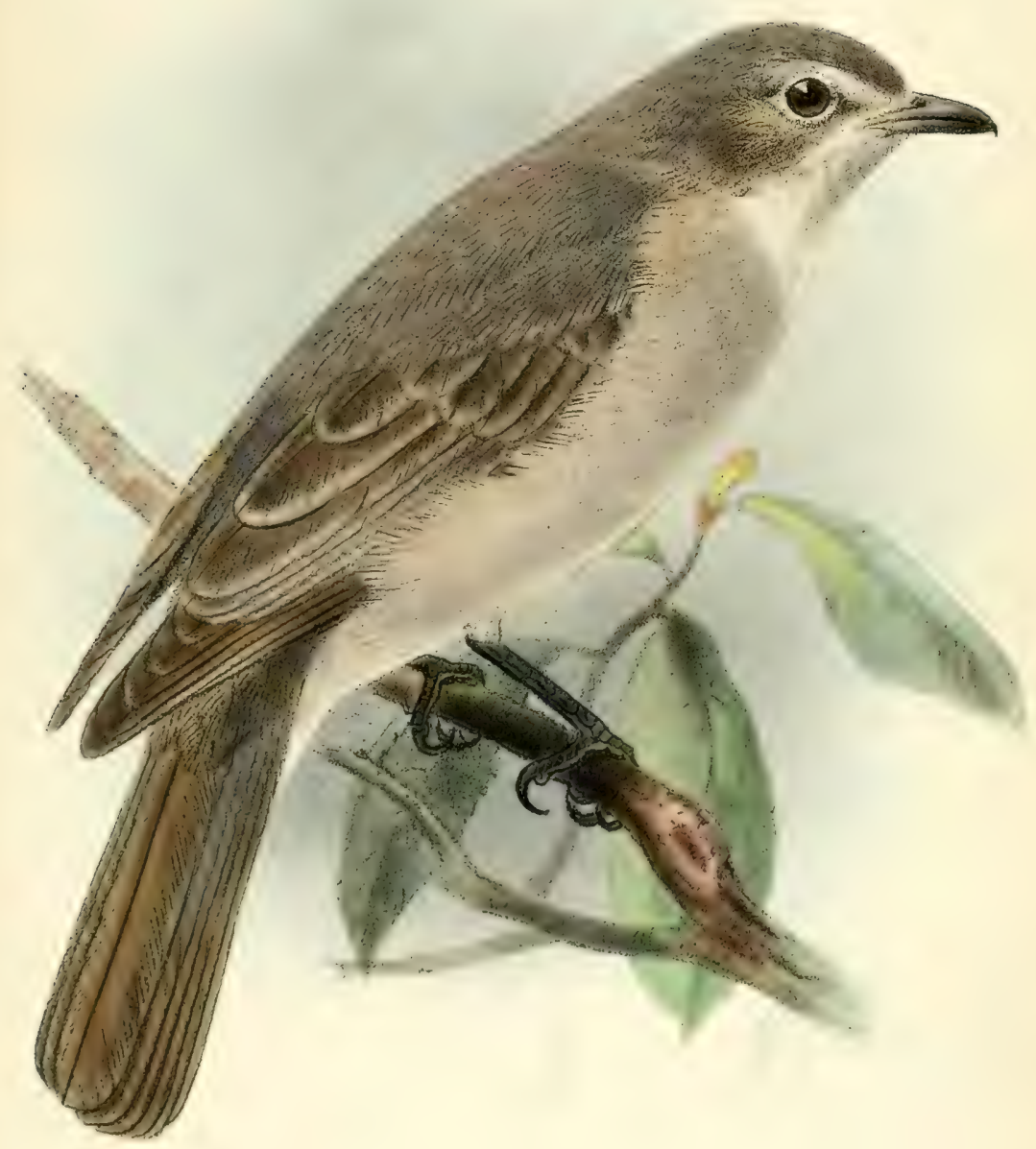





\title{
III.
}

\section{HERPETOLOGY.}

By Albert Günther, M.A., Ph.D., M.D., F.R.S.

\author{
(Plates C, D.)
}

\section{DESCRIPTIONS OF TWO NEW SPECIES OF SNAKES}

FROM SOUTH-EASTERN AFRICA.

\section{Family COLUBRIDÆ.}

CORONElla tRITÆNiA, sp. n. (Plate C.)

Vertical shield elongate, twice as long as broad, longer than the two frontals together, or than the occipital which is rounded behind. Rostral shield extending on the upper surface of the head; loreal square; anteocular large, extending to the upper surface of the head, but not reaching the vertical; two post-oculars. Eight upper labials, the fourth and fifth entering the orbit, the last small. Two large anterior temporals which are in contact with both post-oculars; the outer temporals scale-like. Scales in seventeen rows, with a single apical groove. Ventrals 168 ; anal bifid; sub-caudals 6I. Posterior maxillary tooth grooved. Ground colour light olive, with three well defined brown longitudinal bands; the median one commences behind the occipital and is lost in the middle of the tail; it occupies the median series of scales, and has a fine yellow line running along its middle; the lateral band commences underneath the canthus rostralis, and is continued to the end of the tail ; it occupies the third and fourth outer series of scales and the adjoining halves of the neighbouring series; it has narrow black edges; the outermost series of scales is white like the abdomen, but with a faint brownish line. Lower parts pure white.

Total length 19 inches; the cleft of the mouth measuring six lines, and the tail $3 \frac{1}{2}$ inches. 
Family DRYIOPHIDÆ.

Dryiophis OATESII, sp. n. (Plate D.)

Allied to Dryiophis Kirtlandii, but the rostral shield is not reverted to the upper surface of the head; the prœocular reaches to the upper surface only, remaining far distant from the vertical. Two postoculars: temporals $I+2+2$, the anterior being the smallest, and in contact with the upper post-ocular.

Head with very peculiar colouration; the upper surface is ornamented by a pink T-shaped figure, the horizontal bar stretching from eye to eye, and the vertical part occupying the middle of the occipital shields. This figure is finely mottled with black. An irregular, oblique, blackish line from the eye to the penultimate upper labial, the pink temporal scales margined with black. Body coloured as in D. Kirtlandii.

Total length 47 inches; the tail measuring 19 inches; length of the cleft of the mouth 14 lines. 
\{ 



$$
\text { 욜 }
$$



IV.

\section{ENTOMOLOGY.}

By J. O. Westwood, M.A., F.L.S., Etc.

Hope Professor of Zoology in the University of Oxford.

(Plates E-H.)

THE Collection of Insects formed by Mr. F. Oates, now in the Entomological Museum of the University of Oxford, although not of considerable extent, fortunately comprises cxamples of many of the very peculiar groups and genera characteristic of the greater part of the African continent.

The geographical distribution of animals has, during the last few years, attracted so much attention among naturalists, that a few preliminary observations on the subject will not be considered out of place.

M. Lacordaire, in the chapter on the geographical distribution of insects, in his "Introduction à l'Entonologie," divided the African continent into numerous regions, as follows :- I. Upper Egypt, Nubia, and Abyssinia ; 2. The country south of the Atlas Range, as far as the Great Desert, and including Morocco; 3. Senegambia ; 4. The coast of Guinea ; 5. Congo ; 6. The Cape of Good Hope ; 7. Madagascar; 8. The islands of Mauritius and Bourbon.

In the still more recent works of Mr. Wallace on the geographical distribution of animals, we find that (with the exception of the whole of North Africa-including the northern half of Egypt and of Arabia-which are united with the Meditcranean sub-region and regarded as a portion of the primary Polar Arctic region) the remainder of Africa, south of the tropic of Cancer, is constituted into a primary region, to which the name of "Ethiopian" has been applied, and in which the zoological productions are of a 
remarkably homogeneous character. Of this Ethiopian region the portion which extends on the western side of the continent, between the rivers Gambia and Congo, and consequently embracing Guinea and the Gold Coast, and reaching as far as $25^{\circ}$ East long., is of a distinct character, being occupied by dense forests. To this subregion the name of "West African" has been applied. Another sub-region, the "South African," is formed of that part of the continent south of the tropic of Capricorn, but extending northwards along the east coast as far as Mozambique.

The remainder of Africa, from the tropic of Cancer to the river Gambia on the west coast, and including Senegambia, Timbuctoo, South Egypt, Abyssinia, the eastern half of Africa (including the great lakes, and Zanzibar), and reaching from Mozambique on the east to Angola, Benguela, and Damara Land on the west coast, is considered as forming a third sub-region, to which the inappropriate name of "East Africa" has been applied. It is in the south-eastern portion of this third sub-region that the collection of insects formed by Mr. F. Oates was obtained.

The surface of all this sub-region is described by $\mathrm{Mr}$. A. R. Wallace as "generally open, covered with a vegetation of high grasses or thorny shrubs, with scattered trees and isolated patches of forest in favourable situations. The only parts where continuous forests occur are on the eastern and western slopes of the great Abyssinian plateau, and on the Mozambique coast from Zanzibar to Sofala. The whole of this great district has one general zoological character. Many species range from Senegal to Abyssinia ; others from Abyssinia to the Zambesi ; and a few, as Mungos fasciatus and Phacocharus athiopicus (to which great numbers of species of insects may be added), range over the entire sub-region." Various species of quadrupeds and birds are mentioned, which are found in Gambia, Abyssinia, and South-east Africa, but not in the West African sub-region; and yet Mr. Wallace adds, "Although this sub-region is so extensive and so generally uniform in physical features, it is by far the least 
peculiar part of Africa. It possesses, of course, all those wide-spread Ethiopian types which inhabit every part of the region; but it has hardly any special features of its own. The few genera which are peculiar to it have generally a limited range, and for the most part belong either to the isolated mountain-plateau of Abyssinia, which is almost as much Polar-Arctic as Ethiopian, or to the woody districts of Mozambique, where the fauna has more of a West or South African character." Surely these circumstances, if correctly stated, together with the fact connected with the existence of the Great Sahara desert, extending many hundred miles wide across Africa, lead to the conclusion that the division of Africa south of the tropic of Cancer into three principal areas is unnatural, and that, with the exception of the necessary consequence of greater lifeaction within the tropics, there is so much uniformity in the animal productions of Africa as to render it (with our present knowledge at least) undesirable to cut up the continent into these sub-regions.

\section{Order LEPIDOPTERA.}

The Lepidopterous insects (butterflies and moths) especially attracted much of the attention of Mr. Oates; and of the day-flying species (Rhopalocera) he collected seventythree different kinds, of which nineteen appear to be previously undescribed. As they form the most important part of his collection, I have given a complete catalogue of them in the following pages. These insects abound in certain districts, and in Mr. Trimen's work on South African butterflies, as many as 226 different species are recorded.

Species of the families Danaidæ, Satyridæ, Acræidæ, Nymphalidæ, Lycænidæ, Pieridæ, Papilionidæ, and Hesperiidx occur in each of the three divisions into which Mr. Wallace has divided the continent south of the Great Desert; but of the families Elymniidx, Libytheidæ, and Nemeobiidx no species have been found in the South 
African sub-region, which, however, possesses seven genera peculiar to itself,- - two belonging to the Satyridæ, one to the Acræidæ, three to the Lycænidæ, and one to the Hesperiidæ. The beautiful species of Zeritis are also peculiar to this sub-region; one additional species only inhabiting West Africa.

Of the Danaidx (including the greater part of the Heliconian butterflies), species occur in each of the four Ethiopian sub-regions. Of the Satyridæ, which also occur in all the four sub-regions, Gnophodes, Leptoneura, and a few other small genera are exclusively African. Of the Elymniidæ, which are peculiar to the Malayan and Moluccan districts, one species also occurs in Ashanti. The Morphidæ, Brassolidæ, and typical Heliconiidæ do not occur in Africa ; the Acræidæ, on the contrary, have their metropolis in this continent, which produces more than twothirds of all the known species. Of the Nymphalidæ, which is the largest and most universally distributed family of butterflies; species occur in all the sub-regions of Africa. There are fourteen genera of these butterflies exclusively African, including Lachnoptera, Amphidema, Catuna, Euryphene, Romaleosoma, Aterica, and Harma. Libythea (constituting the family Libytheidæ) is widely distributed, and occurs in Western Africa and Madagascar, but not in Central, Eastern, and Southern Africa. Such is also the case with the family Nemeobiidæ. No representative of the family Erycinidæ (proper) occurs in the old world or Australia. The Lycænidæ, on the other hand, are found in all the sub-regions of the globe, the genera Pentila, Liptena, D'Urbania, Axiocerces, Capys, Phytala, Epitola, Hewitsonia, and Deloneura, being peculiar to Africa. Of the family Pieridæ, Teracolus and Pseudopontia are the only genera exclusively African; but the species of other genera are very numerous, especially in the group of white butterflies with orange tips to their fore wings. The family Papilionidæ are very widely distributed over all the warmer regions of the globe; and although no peculiar genus belonging to the family is found in Africa, there are several very interesting groups of species, such 
as Pap. Nireus and its allies, with black wings spotted or banded with green. The Merope group, with its creamcoloured males, spotted with black and furnished with tails, is remarkable for having tailless females in South Africa, so much unlike their partners as to have been described as several distinct species; whereas in Madagascar the females of this group can scarcely be distinguished either in form or colours from the males. Lastly, of the Hesperiidæ, distributed all over the globe, thirteen of the genera contain species which are natives of Africa, three of them being peculiar to that region-namely Abantis, from Mozambique, Ceratrichia, Butler, from Western Africa, and Caprona, Wallengren, from Southern Africa.

\section{LEPIDOPTERA RHOPALOCERA.}

Family PAPILIONIDE.

Genus Papilio, Auct.

I. (I) Papilio Demoleus, Linnceus.

Papilio Demodocus, Esper.

Ranges from Western Tropical Africa to the Cape of Good Hope.

Genus Callidryas, Boisduval ; E. Doubleday, Gen. D. Lep. p. 66. Catopsitia, W. F. Kirby, Syn. Cat. p. 48 I.1 $^{1}$

2. (i) Callidryas Swainsonit, Westw.

Colias Pyrene, Swainson, Zool. Ill. vol. i. pl. 51. (Not of Linnæus, which is an Indian species, belonging to the genus Thestias, Boisduval.)

Callidryas Pyrene, Butler, Lep. Exot. pl. I6, f. 8-1o.

Callidryas Florella, Boisduval; Trimen, Rhopal. Afr. Austr. p. 68 ; but not of Fabricius nor Donovan, Nat. Repos. III. pl. 90 .

Many individuals of this species were taken at the Motloutsi River, varying in having the black spot of the disc of the fore wings, and the orange spots on the under side of the hind wings. A specimen from Guinea, received by Mr. Hope from Mr. Westermann of Copenhagen as the Florelle, Fabr, is identical with the South African speci-

$1 \mathrm{Mr}$. W. F. Kirby has injudiciously sunk Boisduval's gencric name for this group, containing 3.3 species, and adopted in its stead one of Hübner's four sub-gencric names (into which he had divided them), which only comprised four of the species. 
mens of Swainson's species. The type specimen described by Fabricius, drawn by Jones (Icones, v. 2, Dan. Cand. pl. 5, f. 3, 4), copied by Donovan, is from Sierra Leone, and was, and still is, in the Banksian Collection. C. Swainsonii is very widely dispersed.

3. (2) Callidryas Rhadia, Boisduval; Trimen, p. 69.

Callidryas Castalia, E. Doubleday, Gen. D. Lep. p. 68 (not of Fabricius).

Two specimens captured at Tati. The Rev. H. Rowley sent it from the Zambesi to the Oxford Museum.

\section{Genus Teracolus, Swainson.}

4. (I) Teracolus Subfasciatus, Swainson, Zool. Ill. 2 ser. Ins. pl. $115^{1}$; Boisduval; Trimen.

Ptychopteryx Bohemanni, Wallengren, Lep. Caffr. p. 18.

Originally described from the Burchell Collection now at Oxford. Six specimens from Tati. The species appears to be very rare, as Mr. Trimen had not seen an individual. The female has the extremity of the fore wings brilliant orange-red, instead of pale orange-yellow, as figured by Swainson.

5. (2) Teracolus Agoye, Wallengren, Lep. Caffr. p. I5 ; Trimen, p. 325 .

Anthocharis Eosphorus, Trimen, Trans. Ent. Soc. 1863, p. 523. One specimen. Locality not noted.

\section{Genus Pieris, Auct.}

6. (I) Pieris Mesentina, Cramer, pl. 27o, f. A, B; Godart; Boisduval; Trimen, p. 35.

Papilio Aurota, Fabricius, Ent. Syst. III. i. 197.

Many specimens taken at Bamangwato, the Motloutsi River, Tati, Gubuleweyo, Inyati (November 30, 1873), the Gwailo River, and at or near the Victoria Falls.

7. (2) Pieris Severina, Cramer, pl. 338, f. G, H ; Godart ; Boisduval; Trimen, p. 32.

Two specimens, of unrecorded locality.

\section{Genus IDMAIS, Boisduval.}

8. (1) Idmais ERIS, Klug, Symbol. Phys. t. 6, f. I5, I6 ; Boisduval ; Reiche in Ferret and Galinier, Voy. Abyss. pl. 31, f. I-3; Trimen, p. 59.

1 The name of this species is accidentally omitted in the classified index of the second series of Swainson's "Illustrations;" and Mr. Trimen complains that the plate is not in the copy of the work in the Public Library at Cape Town, having been probably omitted by the binder from not appearing in the classified index. 
Var. Idmais Fatma, Felder, Reise Novara, pl. 25, f. 3. Tati ; and the Ramaqueban River, July 29, 1874.

9. (2) Idmais Vesta? Reiche in Ferret and Galinier's Voy. Abyss. pl. 3I, f. 7, 8. (Not of Trimen, p. 62, which = Idmais Chrysonome, E. Doubleday, Gen. D. Lep. pl. 7, fig. 5 ; nor of Klug nor Boisduval =Idmais Hervitsoni, Kirby, Syn. Cat. p. 498.)

The specimens collected by Mr. Oates have the base of all the wings on the upper side broadly white, the remainder ochreous buff, with a large dark brown spot at the extremity of the discoidal cell of the fore wings, a dark brown, very irregular bisinuated fascia running across the fore wings beyond the middle, and extending across the middle of the hind wings, nearly reaching the anal angle ; the outer margin of the fore wings is dark brown, with two rows of ochreous buff spots, the outer ones small; the outer margin of the hind wings is brown, inwardly dentated, with a marginal row of ochre spots. Beneath, the fore wings are bright orange-yellow at the base, yellow in the middle, with the apex and the entire hind wings brownish ochre, the markings of the fore wings ill defined, and with three obscure bands across the hind wings. In the female the ground colour of the upper surface of the wings is uniformly pale yellowish buff. The fascia across the hind wings separates this species from Chrysonome Dbd., Vesta of Trimen. M. Reiche's figure apparently represents a larger and more suffused insect, the under side especially being more variegated, and the ground colour of the hind wings bright yellow.

\section{Genus TACHYRIS, Wallengren.}

Io. (I) TAChyris Agathina, Cramer, pl. 237, f. D, E; Godart; Boisduval; Trimen, p. 28; Hopffer in Peters's Reise Mossamb. t. 2I, f. II, I2.

Pieris Thysa, Hopfer in Peters's Reise Mossamb. t. 2 I, f. 7-10. Near the Victoria Falls, in January.

Genus Callosune, E. Doubleday, Gen. D. Lep. p. 57.

I I. (I) Callosune Eupompe, Klug, Symb. Phys. t. 6, f. II-14; Boisduval ; Trimen, p. 45.

Papilio Evippe, Cramer, pl. 91, f. D, E. (nec Linn.).

Pontia Acaste, Klug, Symb. Phys. pl. 7. f. I6, I7.

Pieris Polycaste, Boisduval.

Anthopsyche Theopompc, Felder, Reise Novara, ii. p. I83. no. 175 .

Motloutsi River, August 1873 .

12. (2) Callosune Danä̈, Fabricius; Donovan, Ins. India, t. 26, f. 2 ; Boisduval ; E. Doubleday, Gen. D. Lep. pl. 7, f. 2 ; Trimen, p. 44. Papilio Eborea, Cramer, pl. 352, f. C-F. 
This handsome species inhabits Natal, Damara Land, Ceylon, Bengal, Madras. Male, Inyati (November 30, 1873); females, near the Gwailo River (October 19, I873), and Impakwe River (February I2, 1874).

13. (3) Callosune Evippe, Linnæus; Clerck, Icones, pl. 40. f. 5 ; Cramer, pl. 9I, f. F, G ; Godart ; Boisduval ; Lucas, Exot. Lep. pl. 37 , f. I.

Tati; and between Inyati and Gubuleweyo, December I, 1873 .

I4. (4) Callosune Omphale, Godart; Boisduval ; Trimen, p. 50. Near the Victoria Falls, in January.

15. (5) Callosune Antigone, Boisduval, Sp. Gén. p. 572 ; Trimen, p. 52 .

Both sexes, Ramaqueban River, February I4, I874; also females at the Gwailo River in October. These females have no orange on the upper side of the fore wings.

J6. (6) Callosune Casta, Gerstaecker in Decken's Reisen in OstAfrika, pl. 15, f. I, I a.

Taken at Tati.

I7. (7) Callosune Keiskamma, Trimen, p. 56, pl. 2, f. 3, 4 .

Var. Anthopsyche Topha, Wallengren, Wien. ent. Mon. iv. p. 34 .

Ramaqueban River, July 28, 1874. Kirby cites Klug's Pontia Evame, Symb. Phys. t. 6, f. I-4, as identical with this species, but the rounded fore wings of the male, with the black exterior margin, and the submarginal row of black spots on the hind wings, at once separate these two insects. See the observations of Mr. Weale on this subject (Trans. Ent. Soc. 1877, p. 273).

18. (8) Callosune inornata, Westw.

Alis supra albis, basi nigro parum pulverosis, anticis macula trigona distincta apicali aurantia: alis anticis infra albis apice albido-lutescenti, intus magis brunnea; alis posticis lutescenti-albidis, linea recta longitudinali media paullo obscuriori. Expans. alar. antic. lin. 19.

The locality of this very simply coloured species is not recorded.

19. (9) Callosune Ione, Godart ; Boisduval ; Lucas, Exot. Lep. t. 37, f. 4 ; Reiche in Ferr. and Gal. Voy. Abyss. t. 3o, f. I-8; Hopffer in Peters's Reise Mossamb. t. 2I, f. I-6; Trimen, p. 43 . Anthopsyche speciosa, Wallengren, p. I6.

Anthocharis Erone, Angas, Kafirs Ill. pl. 30, f. 3.

Two males, taken at Tati.

The species of this genus, in which the males have the extremity 
of the fore wings marked with a brilliant blue or pale purple patch, are so closely allied together as to suggest the possibility of their being geographical sub-species; they appear indeed to be constant in their characteristic markings, and the females are even more distinct than the males, which they are generally so unlike that their sexual relations might readily be suspected.

In the male specimens of C. Ione, captured by Mr. Oates at Tati, the fore wings have the faintest trace of a very minute black discoidal dot, a brilliant silky purple subapical patch, the apex itself black, and the inner edge margined with black, which is slightly scalloped. The hind wings are pure white, with delicate black veins, without any discoidal spot. On the under side the fore wings have the minute discoidal dot, and the apical patch is replaced by pale greyish buff, with a slightly defined darker inner margin; the veins of the hind wings are not black, the basal half of the costa is orange, with a short brownish transverse dash, near the middle of the costa, extending only to the first branch of the subcostal vein; the remainder of the wing white. One of the specimens taken by Mr. Oates at Tati is very small ( $\mathrm{I} \frac{2}{3}$ inch in the expanse of the fore wings), with the black veins excessively slender.

20. (Io) Callosune Regina, Trimen, Trans. Ent. Soc. I863, p. 520. (Plate E, figs. 9, 10.)

The males have the veins of the fore wings, beyond the middle, very slender and black, and with a very minute discoidal dot. The female of this species, here for the first time represented (Pl. E, figs. 9 , Io), has the wings on the upper side white, with the veins concolorous; a large black round spot at the extremity of the discoidal cell, and a large purple-red subapical spot, down the middle of which is a richer shade of purple, edged internally with blackish brown, the apex and apical margin being of the latter colour; the base of the wings is slightly powdered with grayish scales, and there are two minute dusky dots towards the inner angle of the fore wings. On the under side the purple patch of the fore wings is replaced by dirty pale buff, having an oblique row of five pale black spots, and the hind wings are slightly fleshy buff coloured, fincly freckled all over with pale brown irrorations, with a discoidal spot, and a curved row of oblong spots beyond the middle of the wing, of pale brown; the costal margin is slightly fulvous at its base. The expansion of the fore wings is $2 \frac{5}{12}$ inches. Taken at Tati.

A male, in the Hopeian collection, from the Zambesi, has the hind wings marked along the outer margin with black dots at the extremity of the longitudinal veins.

21. (I1) Callosune Theogone, Boisduval; 'Trimen, p. 5 I.

One specimen. Locality not recorded. 
22. (12) Callosune Buxtoni. (Plate E, figs. 7, 8.) Callosune Buxtoni, Butler, MS. in British Museum.

The female (or rather the reputed female) of this species here figured differs from the male in having a large orange patch at the extremity of the fore wings, which are white with a slight yellowish tinge; a minute discoidal black dot and a curved row of brown spots within the orange mark, those towards the costa being most indistinct ; the inner margin of the orange mark is also brownish, as is the apex itself and the apical margin, the brownish margin terminating near the hinder angle in a brownish spot; the hind wings are uniformly white, with the extremity of the veins towards the outer angle more or less dusky. On the under side the orange spot of the fore wings wants both the inner and apical dark edging, and bears a curved row of brown spots; the hind wings are very pale fleshy buff, and very delicately freckled, with a bar of darker brown extending from the middle of the costa to the median vein, where it is curved backwards; there is also a brown dot on a small whitish spot near the extremity of the discoidal cell. The female varies from $I \frac{8}{4}$ to $2 \frac{1}{4}$ inches in the expansion of the fore wings. Taken at Tati.

23. (13) Callosune Evenina, Wallengren, Lep. Caffr. p. I2; Trimen, p. 322, and in Trans. Ent. Soc. I870, t. 6, f. I I.

One specimen (locality not noted), with the black markings on the upper surface of the wings much less diffused than in the figure given by Mr. Trimen; possibly a male. Another specimen in Burchell's African collection, in the Hopeian Museum, has the large dark spot on the fore wings extending over the discoidal cell, but the hind wings are almost unspotted.

24. (I4) Callosune Eione, Boisduval, p. 578 .

One broken specimen, without locality, is very closely allied to the insects noticed above, as $C$. Antigone.

\section{5. (15) Callosune pseudetrida, Westw.}

Alis supra pallide flavescentibus, apice fusco cum serie subapicali macularum 6 aurantiacarum, puncto minuto nigro discoidali, nubilaque parva fusca ante angulum posticum; alis posticis serie marginali macularum conoidearum fuscis (versus angulum analem interdum obsoletis) nubila parva pone medium costæ, fasciaque valde abbreviata pone medium disci versus angulum externum, pallide fuscis: alis anticis infra pallide flavescentibus, apice alisque posticis luteo-albidis ; anticis striga obsoleta et obliqua fuscescenti versus apicem, posticis punctis duobus fuscescentibus pone medium disci versus angulum externum. Expans. alar. antic. unc. I, lin 5.

Affinis C. Deure, Klug, et præsertim C. Etride (Indiæ orientalis incolæ).

Habitat prope Tati.

Obs. The orange subapical spots in the male are dilated into a broader yellow fașcia in the female. 
26. (i6) Callosune Wallengrenit. (Plate E, figs. 3, 4.)

Callosune Wallengrenii, Butler, MS. in British Museum.

Alis supra albis ; anticarum apice late aurantiaco ; puncto discoidali, striga angulata guttarum fuscarum pone medium apiceque fusco, intus ad venas angulatim producto; alis posticis pone medium fascia abbreviata e maculis fuscis formata, margineque postico fusco-maculato. Expans. alar. antic. unc. $\mathrm{I} \frac{5}{12}$.

Habitat ad ripas Touani fluv.; mense Augusto capta.

The wings on the upper side are white, with a slight yellow tinge, the apical half being of a fine orange-red colour; the base is suffused with brown scales; a round black dot is placed at the extremity of the discoidal cell, in front of which the costa is dusky; half way between the cell and the apex is an oblique row of four brown spots, succeeded by a-larger one, extending more towards the base of the wing, which is followed by a double spot towards the middle of the hind margin; the apical margin is brown, which colour extends upwards along the veins, forming a row of brown teeth, the largest of which is at the end of the first branch of the median vein; the hind wings are powdered with brown scales at the base; beyond the middle of the wing is a curved row of brown spots, extending from the costa to the middle, and with a row of brown spots along the outer margin. On the under side the fore wings are suffused with orange, preceding the row of subapical spots, the apical portion being buff, which is also the colour of the hind wings, which have a white spot in the centre surrounded by a brown ring, and followed by a curved row of pale brown spots, rather more dilated and somewhat ocellated in the middle of the row; the apical margin of all the wings is destitute of the brown markings of the upper side.

27. (17) Callosune Ramaquebana, Westw. (Plate E, figs. 5, 6.)

Parvus alis supra albis, albo-ciliatis anticis plaga maxima fusca marginis postici, puncto nigro discoidali, apiceque late fusco, serie macularum fulvarum inclusa ; alis posticis basi fuscis, margine postico late fusco, serie macularum albarum plus minusve confluentium, præsertim versus angulum analem, inclusa: alis subtus flavido-tinctis, posticis puncto minuto discoidali nigro, flavo supra tincto. Fœm. supra absque colore fulvo. Expans. alar. antic. unc. $\mathbf{I}_{3}^{1}$.

Habitat prope Ramaqueban fluv. ; mense Februario capta.

This pretty little species appears to be undescribed. It is nearly allied to C. Etrida and Eione, but differs in its characteristic markings. On the upper side the wings of the male are white, with a very slight yellowish tinge; the anterior have a large brown patch occupying the greater portion of the posterior margin, and extending over the greater part of the discoidal cell, at the extremity of which is a small round black spot; the extremity of the wing is very broadly brown, the dark colour commencing on the costal margin in front of the discoidal spot, and extending nearly to the postcrior angle of the 
wing, where it is much narrowed, especially in the spaces between the anal vein and the first and second branches of the median vein, extending considerably more forward between the second and third branches of the latter, so as nearly to unite with the truncated extremity of the large brown patch; the brown apex of the wing bears a row of five fulvous oval spots, the hind one of which is ill defined and less strongly coloured: the hind wings are brown at the base, and beyond the middle they are marked with a curved irregular brown bar, which is partially connected with the brown spotted hind margin of the wing, having a row of white spots between them, which become larger and more or less confluent, especially towards the anal angle. On the under side the fore wings are tinged with yellow, especially towards the tips, the large brown markings of the upper side being nearly obsolete: the hind wings are also yellowish, with a faint dusky fascia beyond the middle, with a black discoidal spot surmounted with yellow scales; the costa at the base is bright yellow, and the fringe of all the wings is white. The female is slightly larger, with the brown markings more suffused, the orange spots of the fore wings obsolete, and replaced by brown, and the white submarginal spots of the hind wings almost obliterated and replaced with brown.

\section{Genus Terias, Swainson.}

Eurema, Kirby, Syn. Cat. (haud recte).

28. (I) Terias Rahel, Fabricius; Godart; Boisduval ; Trimen, p. 76. Ramaqueban River, February; near the Victoria Falls in January; and near the Dry River, beginning of March.

29. (2) TERIAS ZOË, Hopffer in Peters's Reise Mossamb. pl. 23, f. Io; female.

Mas. Alis supra minus saturate atomosis, posticis limbo nigro omnino carentibus et unicoloribus.

Near the Ramaqueban River, in February.

3o. (3) Terias Seruli, Westw.

Alis supra pallide flavis, anticis apice macula trigona fusca intus parum curvata integra, ante angulum posticum desinente; angulo extremo apicali pallescenti ; alis posticis immaculatis : alis anticis subtus flavis, costa, apice, alisque posticis carneo-lutescentibus, omnibus immaculatis. Expans. alar. antic. fere $\mathbf{I} \frac{1}{2}$ unc.

Habitat ad ripas Seruli fluv.; mense Augusto capta.

\section{Family ACR $\mathbb{E I D}$ A.}

Genus ACRæA, Fabricius.

31. (1) ACræa Atergatis, Westw. (Plate F, figs. I, 2.) Alis supra rufo-aurantiis, nigro-maculatis, anticis apice nigro et 
sub apicem nigro-lineatis margine apicali omnium nigro. Expansio alar. antic. unc. $2 \frac{1}{12}$.

Habitat prope "Victoria Falls ; "mense Januario capta.

The upper side of the wings is of a rich orange-red colour, the base of all the wings slightly powdered with black atoms; a black spot is placed in the middle of the cell of the fore wings, followed by a smaller transverse one at the extremity of the cell ; at a little distance beyond the cell is a short black, rather oblique fascia, formed of five more or less confluent spots, the innermost being incurved and placed between the $2 \mathrm{~d}$ and $3 \mathrm{~d}$ branches of the median vein; this last spot is succeeded by two other spots, the three being parallel with the apical margin of the wing; there is also a minute round dot towards the base of the wing behind the basal part of the median vein, and two small dots near the inner angle; the veins are black in the apical part of the wing, with the interstices between the veins marked with thin black lines, the margin itself as well as the apex of the wing being also black; the hind wings are marked with twelve round black spots the six outer ones arranged in a very waved line; the margin is also black. On the under side the fore wings are of a more rosy tint, except towards the apex, where they are more orange ; the spots of the upper side are here reproduced : the hind wings on this side are more variegated; the black spots are more numerous, being about is in number, several close to the base of the wirg being visible, which are not seen on the upper side; the spots are placed on pale greyish buff spaces, which gives them an ocellated appearance; and the outer margin of the wing is pale greyish buff with a very thin black marginal line, preceded by very thin black lunules, the veins rather thickened and black along the margin, the spaces between the veins being rosy red in the part of the wing between the terminal row of spots and the lunules. Antennæ black; palpi fulvous, with the last joint black; body black, spotted with white and rose-colour; legs fulvous, tarsi black; abdomen, above black with thin yellowish edges to the segments, each of which has two fulvous spots, beneath fulvous with two rows of black specks.

Another specimen, which I cannot distinguish specifically from the preceding, was also taken at the Victoria Falls in January 1875 , and has the upper surface of the wings rather brighter orange-red, with two minute additional black dots within the discoidal cell, at about half its length from the base, and with the abdomen orange-fulvous, the three basal segments on the upper side being alone black, varied with orange. The apical margin of the fore wings in this specimen is not so rounded as in the other with the spotted aldomen, which is evidently a female, the probability being that the male has the wings rather less rounded and the abdomen not spotted.

32. (2) ACrea Atolmis, Westw. (Plate F, figs. 3, 4.)

Alis supra aurantiacis basi nigricantibus, maculis nigris minutis 
notatis, anticarum apice venis nigris margineque tenuissimo nigro maculaque postica prope angulum posticum posita. Expans. alar. antic. unc. $1 \frac{11}{12}$.

Habitat prope "Victoria Falls;" mense Januario capta.

This species is smaller than the preceding, with the various black markings very small, the interspaces of the apical portion of the fore wings not striolated with black, and the posterior spot of the fore wings placed just between the preceding spot and the hind angle of the wing. The upper surface of the wings is uniformly orange, with the basal half rather redder, the base itself being suffused with black scales; within the discoidal cell is a small kidney-shaped black spot, followed by a narrow oblique one at the extremity of the cell ; behind this (between the Ist and $2 \mathrm{~d}$ branches of the median vein) is another spot, and between the latter and the posterior angle of the wing is a third, the three forming nearly a straight row; beyond the discoidal cell is a short oblique row of small black dots, between which and the apical margin of the wing the veins are black: the hind wings have a small black dot within the discoidal cell, and a curved row of six small black dots across the wing close to the extremity of the cell; the hind margin is very slenderly black, and the veins also have their apical portions black. The wings beneath are of an uniform rosy buff-colour, with the black spots more numerous and distinct than above, the hind wings having about i 8 small but distinct ones, those at the base and near the anal margin not visible above; the apical margin of all the wings is very slenderly black, the hind wings having no trace of the lunular markings of the preceding and following species. Body black, sides of thorax with yellowish buff spots; abdomen buff, with the basal segments dusky above.

Notc.-In the engraving the apical margin of the fore wings is represented rather too much rounded.

\section{3. (3) ACræa Axina, Westw. (Plate F, figs. 5, 6.)}

Alis supra luteo-fulvis, nigro-maculatis, posticis magis aurantiacis ; anticarum apice, lineolisque abbreviatis apicalibus (inter venas) nigricantibus; alis posticis maculis minoribus, exterioribus lineam irregularem multo pone medium alæ formantibus, margine externo nigro. Expans. alar, antic. unc. $\mathrm{I} \frac{5}{6}$.

Habitat prope Tati et Gwailo fluv. ; mense Octobre capta.

This small species has the upper side of the fore wings rather dirty luteo-fulvous, that of the hind wings being brighter coloured. The extremity of the fore wings and the narrow apical margin are black, and the interspaces between the veins near the apex of the wings are marked with slender abbreviated black lines, leaving a narrow paler space beyond the fascia; the five spots between the base and the middle of the wings are strongly marked, and the abbreviated oblique black fascia beyond the cell is more continuous: the hind wings have the black spots also well marked, the outer ones forming an irregular 
row considerably beyond the middle of the wing, the central spot especially being not far from the black marginal border. On the under side the fore wings are slightly rosy, the apical portion being more buff with the spaces between the veins orange; the black spots on this side are not so strongly marked as above: the hind wings are more pale buff, with the spaces between the veins strongly marked with rose-colour, the black spots resting on pale spaces, giving them an ocellated appearance; the very narrow black outer margin of these wings is preceded by a series of small black arches, including a row of pale yellow spots. The palpi, head, and sides of the body are coloured as in the preceding species; the abdomen in one of our specimens is broken off, but in the other it is pale buff, with the upper side of the basal segments black, with two pale dots, indicating (as well as the shape of the fore wings) this individual (represented in our figures) to be of the male sex.

Note.-The orange and rosy tints described above are almost obliterated in one of the two specimens, most probably from longer exposure in the winged state.

34. (4) ACRÆA Acontias, Westw. (Plate F, figs. 7, 8.)

Alis supra obscure fusco-rufis, nigro-maculatis, maculis 4 in medio alarum anticarum, fascia abbreviata maculari, margine apicali late venisque apicalibus nigris; alis posticis basi maculisque submediis lineam irregularem formantibus, margineque postico cum venis nigris. Expans, alar, antic. unc. $1 \frac{5}{6}$.

Habitat prope "Victoria Falls;" mense Januario capta.

The dull brownish red colouring of the upper side of the wings distinguishes this species. The fore wings are marked near the base, behind the middle of the cell, with a small black dot, followed by four rather large spots of the same colour, placed so as to form an oblique triangle; beyond the cell is the ordinary abbreviated fascia, formed of four black spots, which is succeeded by a narrow paler buff space, the apex being traversed by black veins, the extremity of the anterior margin and the whole of the apical margin being also black: the hind wings have a suffused black spot near the base, the middle of the wing being crossed by zigzag rows of small but nearly uniform black spots; the outer margin is black, as are the veins beyond the middle of the wing. On the under side the fore wings are more rosy coloured from the base to the abbreviated fascia, beyond which they are paler buff, with orange stripes between the veins: the hind wings have the black dots smaller but more numerous than on the upper side, there being about 20 on each wing, the ground colour of which is buff, with the spaces between the veins in the basal portion rosy, but beyond the cell they are marked with longitudinal orange stripes between the veins; the outer margin is very narrowly black, preceded by a very narrow black line parallel with the margin. The body is black, much spotted at the sides below the wings with buff and rosy; the abdomen is orange, marked above 
with black fasciæ, forming more or less incomplete lateral circular spots; the ventral surface yellow, with two rows of black spots. The apical margin of the fore wings is but slightly convex, but the spotting of the abdomen indicates the specimen to be a female.

35. (5) ACræa Aglaonice, Westw. (Plate F, figs. 9, Io.)

Alis supra rufo-puniceis, anticis apicem versus magis aurantiacis, macula fenestrata bipartita subapicali notatis, nigro-maculatis, venis apicalibus nigris; posticis maculis minutis margineque latiori apicali nigris. Expans. alar. antic. unc. $2 \frac{1}{12}$.

Habitat prope Tati.

This species has the upper surface of the wings more richly coloured than any of the others captured by Mr. Oates, being of an orange-carmine colour, especially in the hind wings. The fore wings are marked half-way between the end of the discoidal cell and the tip of the wings with a square vitreous spot, through which runs a veinlet dividing it into two parts; the base of the wings, especially in the hind parts, is irrorated with black scales; the discoidal cell has a rather large oval black spot beyond its middle, followed by a smaller lunate one at the extremity of the cell; beyond which is an oblique row of five conjoined black dots; another round black spot is placed towards the base of the wing behind the median vein, and two other circular ones behind the extremity of the cell placed transversely; the veins at the extremity of the wings are slenderly black: the hind wings are marked with about Io minute black dots (varying, however, in size), and the hind margin of the wing is rather broadly edged with black. On the under side the fore wings are rosy coloured, with the spots of the upper side, including the vitreous spot, reproduced : the hind wings are greyish buff, with the spaces between the veins varied with rosy at the base and along the anal margin, and with rich orange between the middle of the wing and the row of submarginal black lunules, which latter rest upon a narrow yellowish buff margin ; the spots on this side, about 17 in number, are distinct, appearing partially ocellated. Body black, with rosy spots behind the eyes and on the sides of the chest, which is also spotted with pale buff; palpi orange, terminal joint black; legs orange, tarsi black; abdomen broken off.

The unique specimen of this species collected by Mr. Oates has the abdomen mutilated, but the structure of the fore legs and the shape of the fore wings prove that it is a male individual.

36. (6) Acræa Acronycta, Westw. (Plate F, figs. i I, I2.)

Alis supra luteo-aurantiacis; anticis triente basali fusco; macula ad apicem cellulæ, pone medium alæ fascia abbreviata maculari, maculisque duabus posticis (margine postico parallelis) nigris; alis posticis magis albidis, ante medium nigro-maculatis, margineque postico latiori nigro: subtus maculis magis distinctis margineque albido-maculato. Expans. alar. antic. unc. $\mathbf{I}^{\frac{3}{4}}$. 
Habitat - ?

The upper surface of the wings (especially the hind pair) of this species is whitish orange, the base being strongly suffused with dark brown scales hiding the spots in that part; one of these, near the extremity of the discoidal cell, is visible, and the cell itself is closed by a semicircular spot, followed at a short distance by an oblique abbreviated black fascia formed of conjoined spots, of which the hinder one is smallest and most distinct; two other spots appear on the disc of the wing behind the extremity of the cell, and are placed nearly parallel with the apical margin, which is very narrowly black and slightly concave : the hind wings have a somewhat more suffused whitish hue than the anterior; they are brown at the base, and are marked before the middle with an irregular series of black dots, followed by two minute ones beyond the middle; the posterior margin is widely black. On the under side the fore wings have five black spots in the middle, followed by the abbreviated macular fascia: the hind wings are more tinged with rose-colour than the anterior ones, and are marked with about twelve black dots of different sizes; the posterior margin is pale yellowish white, surmounted by a row of black arches, resting upon a very narrow black edging. The head and body are black, spotted with pale buff, the sides of the thorax beneath the wings with a reddish spot; the abdomen is nearly white, the basal segments on the upper side black, with a pair of round white dots.

37. (7) ACrÆa AMPHimalla, Westw. (Plate E, figs. I, 2.)

Alis supra fulvo vel puniceo luteis nigro-guttatis, anticarum apice late nigro triangulariter terminata, posticarum margine apicali e lunulis nigris, maculis concoloribus inclusis, notato. Expans alar. antic. unc. $1 \frac{3}{4}-2 \frac{1}{12}$.

(An Acraa Caldarene alicujus?)

Habitat prope Tati, et marg. fluv. Motloutsi ; mense Maio capta.

This very distinct species has the wings on the upper side of a buff colour, varying from dull orange to reddish; the black spots are of small size, and the fore wings have the apex broadly and triangularly black, whilst the hind wings have the slender apical outer black margin preceded by a series of slender depressed black arches enclosing spots of the ground colour of the wing; the ordinary black spot in the middle of the discoidal cell is sometimes preceded by a smaller, more or less slightly marked, dot, behind which is another small one; the cell is partially closed by a small oblique black spot, followed at some distance by a row of four small spots placed obliquely, and there are two other small spots between the middle of the wing and the posterior angle, the outer one being occasionally duplicated; in the hind wings the black spots, about twelve in number, are of nearly uniform small size. On the under side the black apex of the upper side is replaced by the ground colour of the rest of the wing, the spaces 
between the veins being more strongly marked with orange stripes: the hind wings are buff-coloured, with the spaces between the veins in the basal portion marked with red, having the black dots (about twenty in number) surrounded with buff, whilst in the apical half of the wing the intervening spaces are more orange; the black arcade preceding the slender outer black edging is marked more distinctly than on the upper side. The head and body are spotted as in the preceding species.

38. (8) ACRæa NATAlica, Boisduval in Delegorgue's Voy. Afr Austr. ii. p. 590; Hopffer in Peters's Reise Mossamb. pl. 23 , figs. I2, 13.

Acraa Bellua, Wallengren, Lep. Caffr. p. 22.

Acrea Hypatia, var. B, Trimen, p. 98.

A series of small specimens, measuring only 2 inches in expanse of the fore wings, were taken at Tati. A large specimen $\left(2 \frac{3}{4}\right.$ inches expanse) was taken near the Dry River in the beginning of March, and one ( $2 \frac{1}{2}$ inches expanse) was taken near the Motloutsi River in August.

39. (9) ACrea Anemosa, Hewitson, Ex. Butt. t. 3, Acr. 3, f. I4, 15.

Near the Umvungu River, end of October; and near the Victoria Falls in January.

40. (Io) Acrea Neobule, E. Doubleday and Hewitson, Gen. D. Lep. pl. I9, f. 3 ; Reiche in Ferr. and Gal. Voy. Abyss. pl. 33, f. 3,4 .

An var. Acrea Mahela, Boisduval, Faune Madag. pl. 6, f. I ? Ramaqueban River, February I4, I $\$ 74$.

41. (11) ACræa Rahira, Boisduval, Faune Madag. pl. 5, f. 4, 5 ; Trimen, p. IO3.

Taken on the Zambesi road, end of November.

42. (12) ACRÆA DIRCEA, Westw.

Alis supra fulvis, puniceo interdum tinctis; anticarum apice late nigris maculisque 9 parvis nigris, 4 in lineam obliquam pone medium positis; alis posticis maculis circiter 14 parvis nigris discoidalibus, margine tenui nigro fulvo-maculato: alis subtus pallidioribus, apice anticarum lutescenti, fulvo-strigoso; maculis nigris parum majoribus præsertim in alis posticis, interstitiis rubro-maculatis. Expans. alar. antic. unc. 2.

Acr. Onccee affinis sed apice lato nigro alarum anticarum optime distincta.

Numerous specimens taken at Tati and the Motloutsi River in May. 


\section{Family NyMPhaLide.}

Genus Charaxes, Ochsenheimer.

43. (i) Charaxes Pelias, Cramer, pl. 3, f. C, D ; Godart ; Trimen, p. I75; Butler, Lep. Exot. pl. 10, f. 5 .

Near the Seruli River, August 19, I873; and near the Victoria Falls in January.

\section{Genus Cynthia, Fabricius.}

44. (I) Cynthia Cardui, Linnæus.

Taken at the Indunas' Tree, near the Umvungu River, end of November.

Genus Junonia, Hübner.

45. (i) Junonia Clelia, Cramer, pl. 2I, f. E, F ; Trimen, p. I 28.

Bamangwato, Ramaqueban River, Gubuleweyo, and near Tati.

46. (2) Junonta CEnone, Linnæus: Cramer, pl. 35, f. A, C ; Trimen, p. 125.

Tati, Ramaqueban River, and about the Matengwe River.

47. (3) Junonia ORithya, Linnæus; Cramer, pl. ig, f. C, D, pl. 32, f. E, F, and pl. 290, f. A, B. Common in India, etc.

This species, not included in Trimen's work, was taken near the Victoria Falls in the month of January. The Hopeian collection also has it from Sierra Leone.

48. (4) Junonia Octavia, Cramer, pl. I35, f. B, C; Trimen, p. I 30. Near the Victoria Falls in January.

49. (5) Junonia natalica, Felder, Wien. ent. Mon. iv. p. io6. Funonia Hecate, Trimen, p. I40.

Near the Victoria Falls in January.

5o. (6) Junonia Cloantha, Cramer, pl. 338, f. A, B ; Trimen, p. I37. Near the Dry River, middle of March.

\section{Genus Diadema, Boisduval.}

51. (1) Diadema Misippus, Linnæus.

Fœm. var, Papilio Inaria, Cramer, pl. 214, f. A, B.

Near the Victoria Falls; also from Sierra Leone, the Zambesi, and Mauritius, in the Hopeian collection.

\section{Genus Aterica, Boisduval.}

52. (1) Aterica Meleagris, Cramer, pl. 66, f. A, B; Drury, Ill. Exot. Ent. vol. iii. pl. 17, f. 3, 4 ; Trimen, p. 157. Indunas' Tree, near the Umvungu River, in November. 


\section{Genus Danais, Latreille.}

53. (I) Danais Chrysippus, Linnæus; Cramer, pl. i i 8, f. B, C.

Indunas' Tree, near the Umvungu River; and near Gubuleweyo in December.

\section{Genus Hypanis, Boisduval.}

54. (I) Hypanis Ilithyia, Drury, Ill. Exot. Ent. vol. ii. pl. I7, f. I, 2 ; Cramer, pl. 2 I4, f. C, D ; Trimen, p. 2 I 4.

Tati, Ramaqueban River, Inkwesi River (March 1874), Dry River; and Indunas' Tree, near the Umvungu River.

\section{Family SATYRIDÆ.}

Genus Cyllo, Boisduval.

55. (I) Cyllo LedA, Linnæus et auct.

An extremely variable species. The specimen from the Nata River (beginning of December I 874) has an obscure fulvous subapical patch bearing two black spots in the fore wings; beneath, pale brown, with dark brown fasciæ, and scarcely any trace of ocelli on the hind wings. Specimens from Ashanti are pale brown beneath, strongly freckled all over with brown, and with large ocelli on the hind wings.

\section{Genus Erebia, Dalman.}

56. (I) Erebia Narycia, Wallengren, Lep. Caffr. p. 32 ; Trimen, p. 198.

Ramaqueban River, middle of March.

\section{Genus Ypthima, Hübner.}

57. (I) Ypthima Nareda, Kollar in Hügel's Kaschmir, vol. iv. pl. 2, p. 45 I ; Hewitson, Trans. Ent. Soc. I865, pl. I7, f. 6, 7. Near the Victoria Falls, in January.

\section{Genus Mycalesis, Hübner.}

\section{8. (I) Mycalesis Victorina, Westw.}

Sordide fusca, alis anticis pone medium nonnihil pallidioribus; ocellis duobus nigris ochreo anguste cinctis, singulo punctum album includente subapicali multo minori ; posticis concoloribus lineis duabus tenuibus submarginalibus pallidioribus serieque ocellorum ut in anticis: alis subtus pallidioribus magis lutescentibus, fascia angusta recta communi pone medium, anticis 2-posticis 7-ocellatis, ocellis valde inæqualibus, in posticis lineis pallidis valde sinuatis inclusis. Expans. alar. antic. unc. $\mathrm{I} \frac{3}{4}$.

Affinis M. Eusiro, Hopfer in Peters's Reise Mossamb. pl. 25, f. 3-6. Near the Victoria Falls. 


\section{Family LYCÆNIDÆ.}

Genus Amblypodia, Horsfield.

59. (i) Amblypodia natalensis, D. W. and H., Gen. D. Lep. pl. 75, f. 4; Hopffer in Peters's Reise Mossamb. p. 399; Trimen, p. 227. Spindasis Masilikazi, Wallengren, Lep. Caffr. p. 45.

Near the Victoria Falls, in January.

6o. (2) Amblypodia? Leroma, Wallengren, Lep. Caffr. p. 42 ; Trimen, p. 23r.

Near Tati.

\section{Genus Zeritis, Boisduval.}

6i. (I) Zeritis Perion, Cramer, pl. 379, f. B, C. ; Trimen, p. 267 ; Hopffer in Peters's Reise Mossamb. pl. 26, f. I-3.

Gubuleweyo, beginning of December.

62. (2) Zeritis Amanga, Westw.

Fœm. Alis supra læte rufo-aurantiacis; anticis macula magna basali nigra, costa pone medium margineque apicali nigris ; alis posticis, rufoaurantiacis basi nigricantibus: alis subtus purpureo-rufis, anticarum costa ad basim guttisque duabus parvis prope basim tertia parum majori submedia, alteraque subapicali, argenteis ; posticis guttis perpaucis argenteis vix notatis. Expans. alar. antic. unc. $\mathbf{I}_{\frac{1}{3}}$.

Near the Gwailo River. The red basal half of the costa of the fore wings, the outwardly angulated apical margin, the shorter hind wings, with both the anal and outer margin emarginate near the tails, and the splendid silvery base of the costa of the fore wings beneath, separate this insect from Z. Perion.

Mas. (Zambesi, Rowley. In Mus. Hopeiano Oxoniæ). Alis anticis supra fuscis, costa ad basim maculaque late trigona versus angulum externum marginis postici rufis; alis posticis rufis, basi venisque versus angulum externum nigricantibus : alis infra castaneo-rufis, costa anticarum basi, guttisque tribus argenteis ut in fœmina, squamis perpaucis argenteis in lineas transversas dispositis; alis posticis strigis tribus undulatis gracilibus obscurioribus guttisque nonnullis argenteis prope caudam. Margo externus alarum anticarum in medio angulatus, inter medium et angulum posticum emarginatus.

\section{Genus Polyomatus, Latrcille.}

63. (1) Polyomatus Telicanus, Hübner, Eur. Schm. Pap. f. 37 I-2, 553-4; Godart ; Boisduval; Trimen, p. 238.

Tati, the Gwailo River, and near the Victoria Falls.

64. (2) Polyommatus Otacilia, Trimen, Trans. Ent. Soc. i8G8, p. 9o. Near the Victoria Falls, in January. 
65. (3) Polyommatus Sybaris, Hopffer in Peters's Reise Mossamb. pl. 26, f. 6-8; Trimen, p. 242.

Near the Victoria Falls, in January.

\section{Genus Lycæna, Fabricius.}

66. (1) Lycæna Parsimon, Fabricius; Godart; Boisduval.

Papilio Celaus, Cramer, pl. 379, f. K, K ; Trimen, p. 247.

Lyccena Asteris, Godart; Wallengren, Lep. Caffr. p. 40.

Var. Lycana Methymna, Trimen, Trans. Ent. Soc. I862, p. 280. Tati.

Male, Ramaqueban River, in February; female, Bamangwato,

67. (2) Lycæna Jesous, Guérin in Lefebvre's: Voy. Abyss. pl. i I, f. 3, 4 ; Wallengren, Lep. Caffr. p. 39 ; Trimen, p. 350.

Near the Gwailo River, October 12, I873.

68. (3) LyCæNa Asopus, Hopffer in Peters's Reise Mossamb. pl. 26, f. I3-I5; Trimen, p. 249 .

\section{9. (4) LyCæNA LOCHIAS? MSS. ?}

Alis supra fuscis purpureo parum squamosis, posticis maculis duabus inequalibus nigris pallidius cinctis, submarginalibus, ciliis albis : alis subtus pallide fuscis albidoque alternatim fasciatis ; posticis macula nigra intus aurantiaco, extus argenteo, notata, alteraque simili sed multo minori ad angulum analem, cauda nulla. Expans, alar. antic. lin. Io.

Locality not indicated.

\section{Genus Chrysophanus, Hübner.}

70. (I) Chrysophanus LaRA, Linnæus; Fabricius; Trimen, p. 260. Papilio Folaus, Cramer. pl. 27o, fig. F, G.

Papilio Gorgias, Stoll, pl. 33, f. 5, 5 d.

\section{Family HESPERIIDE.}

Genus Ismene, Swainson.

71. (i) Ismene Pisistratus, Fabricius ; Jones, Icones, vol. vi. pl. 26, f. I (Typus in Mus. Britann.)

Note.-The black mark extending from near the anal margin on the under side of the hind wings, was more divided than usual in Drury's specimen, figured by Jones, so as to have led Fabricius to describe the hind wings as four-spotted.

Rhopalocampta Valmaran, Wallengren, Lep. Caffr. p. 48.

Var. Fascia alba latitudine æquali absque maculis nigris.

Papilio Forestan, Cramer, pl. 39I, f. E, F ; Godart ; Boisduval; Trimen, p. $3 \mathrm{r} 8$.

Holfontein, July I 3,1873 . 
Gentis Leucochitonea, Wallengren.

72. (1) Leucochrtonea Levubu, Wallengren, Lep. Caffr. p. 52; Trimen, p. 306.

Near the Dry River, beginning of March.

Genus CAPRONA, Wallengren.

73. (I) Caprona Pillaana, Wallengren, Lep. Caffr. p. 5 I ; Trimen, p. 308.

Near Tati or Gwailo.

Genus Panphila, Fabricius.

74. (I) Panphila Ranoha, Westw.

Alis supra nigrofuscis, costa prope basim fulvo-irrorata, fascia fulva e basi marginis interni per medium alæ extensa, sensim dilatata et ante apicem alæ desinente, maculam ovalem inter cellulam et apicem nigram gerente, ciliis fulvis; alis posticis fascia lata irregulari pone medium fulva: alis subtus fulvis, anticis linea prope basim, macula discoidali ovata strigaque subapicali ad angulum analem sensim dilatata nigro-fuscis; alis posticis fulvis nigro-guttatis, guttis novem in lineas duas margine postico parallelas dispositis. Expans, alar. antic. unc. I $\frac{1}{6}$.

Near the Victoria Falls, in January.

75. (2) Pamphila Harona, Westw.

Magnitudo $P$. Linea, Linnæus. Alis supra fulvis, anticarum costa (ad basim valde angusta) margineque apicali nigris; macula basali marginis interni, striga recta in cellula discoidali et macula conica ad apicem cellulæ nigris; alis posticis fulvis costa late nigra, ultra medium ad angulum externum angusta: alis infra fulvis, posticis pallidioribus; anticis macula magna baseos costam non attingente, altera parva transversa ad apicem cellulæ, tertiaque parva conica marginis apicalis versus angulum internum; alis posticis immaculatis; striola longitudinali magis brunnea, margine anali parallela. Expans. alar. antic. unc. $1 \frac{1}{6}$.

Near the Victoria Falls, in January.

\section{LEPIDOPTERA HETEROCERA.}

Moths of various sizes and hawk-moths appear to be very numerous in Southern Africa. A large number of species of the former were collected by Mr. Oates, chiefly of small size, the majority of which, unfortunately, were ill preserved.

\section{Family SPHINGIDE.}

The SPHINGIDE are not especially remarkable. The deatl's-head moth, Acherontia Atropos, occurs throughout South Africa, and was found between Gubuleweyo and the Gwailo River. Charocampa 
capensis, with its bright pink under wings, extends from the Cape to Natal and Zulu Land. A new species, closely allied to this last insect, was captured by Mr. Oates, which may be thus described :-

Cherocampa virgo, Westw. (Plate E, fig. II.)

Alba albido vix tincta, alis posticis plaga fere basali ovali punicea ; omnibus subtus omnino concoloribus. Expans. alar. antic, fere unc. 3 .

Habitat prope Gubuleweyo vel Gwailo fluv.

The Genus Nephele, Hübner (Zonilia, Boisduval), contains several South African species, e.g. Sphinx Peneus, Cramer; fumosa, Boisduval; comma, Gerstaecker; viridescens, Walker, and the beautiful argentifera, Walker. Several species of the silver-striped hawk-moths occur n South Africa, as Chorocampa Charis, Boisduval ; Schenkii, Moschler; Thyelia, Linn. (Eson, Cramer), etc. The lovely Smerinthus Dumolinii, Boisduval, is from Natal. The clear-winged Sesia Hylas, Linnæus, was captured at Gubuleweyo. And lastly, it may be mentioned that the Rev. H. Rowley sent the Macroglossa hirmndo, Gerstaecker in Decken's Reisen in Ost-Afrika, pl. 15, fig. 7, from the Zambesi.

It may also be mentioned as a remarkable circumstance in entomological geography that the grand Urania (Chrysiridia) Rhipheus, supposed until quite recently to be confined to Madagascar, and to be the only old world representative of the splendid new world Urania, has been found on the east coast of Africa, near Zanzibar. Gerstaecker has figured the continental individual as a distinct species, but"specimens which I have examined appear not to differ specifically from the Madagascar ones.

\section{Family ZyGæNIDÆ.}

In this family a beautiful species of Zygana, closely allied to the very striking $Z$. ochroptera, Felder, was taken at Tati, which may be thus characterised :-

ZYGenA TRICOLORATA, Westw.

Chalybea, humeris alisque anticis aurantiacis, harum margine apicali nigro; alis posticis sanguineis limbo nigro ante angulum analem desinente. Expans. alar. antic. unc. I, lin. 5.

Obs. $Z$. ochroptera, Felder, differt colore alarum limboque nigro multo angustiori.

Another species from Gubuleweyo is allied to Felder's Euctenia Zyganoides (pl. 82, f. 2I), but has the sanguineous portion of the hind wings divided by a transverse black band. On the under side the white spots at the base and middle of the fore wings are sanguineous.

The beautiful South African species, Z. caffra, Linn., ampla, Walker, concinna, Walker (Delagoa Bay), and especially $Z$. negamica, from Damara Land and Lake Nyassa, require careful examination as to their generic position. Several species of Procris and Syntomis were also taken by Mr. Oates. 


\section{Family AGARISTIDE.}

This family is represented in Mr. Oates's collection by a beautiful undescribed species of Eusemia, allied to E. Euphemia, Cramer, pl. 345, fig. A, E. longipennis, Walker, Butler, Exot. Lep. Brit. Mus. pl. 5, fig. 5 ; E. pallida, Butler, 1. c. fig. 3 ; and E. contigua, Butler, 1. c. pl. 4 , f. 8 :-

Eusemia adulatrix, Westw. (Plate G, fig. $\mathrm{I}$, and Plate $\mathrm{H}$, figs. $\left.3,3 a, 3^{b}\right)$

Alis anticis nigris, maculis duabus parvis subbasalibus, fascia obliqua integra submedia, alteraque magna late ovali inter medium et apicem, interstitiis argenteo-irroratis; striga minuta marginis interni pone medium punctoque rotundato intus angulum posticum flavoalbidis; alis posticis sanguineis, limbo nigro; abdomine luteo, nigroannulato. Expans. alar. antic. unc. 2采.

Habitat prope Tati et Gwailo fluv.

I take this opportunity of describing several other African allied species of this beautiful genus :-

EUsemia Niveosparsa, Westw.

Corpore tenui, abdomine nigro, fulvo-annulato ; alis anticis nigris maculis 7 parvis niveis,-Ima. parva in medio cellulæ; 2da. obliqua cellulam terminante; 3 tia. ovali inter cellulam et apicem alæ; 4 ta. elongata ante medium marginis interni; 5 ta. pone maculam $2 \mathrm{am}$; 6ta. bipartita inter $3 a m$ et 7 am prope angulum posticum; alis posticis sanguineis, limbo nigro. Expans. alar, antic. unc. 3.

Habitat in Montibus Cameroons, Afr. occid. In Mus. Hopeiano.

EUSEMia emUlatrix, Westw.

Mediocriter angusta, alis anticis angustis, nigris, albido-maculatis, -macula parva rotunda in medio cellulæ; 2da. majori ad apicem cellulæ; 3 tia. fasciæformi in partes quinque venis nigris divisa, angusta et in medio extus angulata; 4ta. elongata e basi ad medium marginis interni extensa; 5 ta. irregulari-ovata pone $2 \mathrm{am}$. ; 6ta. minuta intus angulum posticum; alis posticis sanguineis, limbo nigro ; abdomine fulvo, ano nigro-barbato. Expans, alar. antic. unc. $2 \frac{1}{3}$.

Habitat —? In Mus. Hopeiano.

EUsemia pardalina, Walker, Trans. N. Hist. Soc. Glasgow. vol. i. (I873).

The type of this species, from Congo, is in the Hopeian collection, together with a sccond individual brought from Angola by Monteiro. It differs from E. Euphemia in its smaller size, and in having the ground colour of the hind wings rich orange fulvous instead of sanguincous.

EUSEMIA MERETRix, Westw.

Alis anticis nigris, maculis 5 fulvis,-Ima. obliqua subbasali mar- 
ginem anticum et posticum non attingenti; 2da. ovali ad apicem cellulæ; 3tia. duplo majori oblongo-ovali et obliqua inter cellulam et apicem alæ; 4 ta. fere rotundata pone $2 \mathrm{am}$; 5 ta. parva angulo postico proxima ; costa basi albo-guttata, margine postico immaculato; alis posticis rufis, limbo nigro. Expans. alar. antic. unc. $2 \frac{3}{4}$.

Habitat in Africa merid. (D. Buxton). In Mus. Hopeiano.

EUSEMIA NUGATRIX, Westw.

Alis anticis nigris, costa ad basim biguttata, maculis 6 luteo-albidis, - Ima. subtrigona ante medium cellulæ ; 2da. subquadrata parum obliqua ante apicem cellulæ; 3 tia. magna subovali obliqua inter medium et apicem alæ, intus vena 3 tia mediana in dentem nigrum incisa; 4 ta. oblonga marginis postici, medium marginis fere attingente ; 5 ta. pone $2 \mathrm{am}$; 6ta. fere ad angulum posticum alæ; interstitiis argenteo parum squamosis; alis posticis rufo-aurantiacis, limbo simplici nigro. Expans. alar. antic. unc. $2 \frac{2}{3}-3 \frac{1}{4}$.

Habitat apud promontorium, "Cape Palmas," Afr. occid. (Savage). In Mus. Hopeiano.

Eusemia glossatrix, Westw.

Alis supra nigris, purpureo-nitidis, præsertim in alis posticis ; anticis fascia media parum curvata tripartita straminea, alteraque inter medium et apicem alæ e punctis 4 albis formata, interstitiis squamis argenteis perpaucis ornatis; alis posticis margine postico albo, intus dentato ; abdomine supra nigro, subtus fulvo ; collare et pedibus subtus fulvis. Expans. alar. antic. unc. $2 \frac{1}{4}$.

Habitat in Afric. orient-merid. In Mus. Hopeiano.

\section{Family SATURNIIDE.}

This splendid family is well represented in Africa, particularly in the south-eastern portion, where a number of beautiful species have been found, especially in Natal. A monograph of these insects, so far as then known, was published by myself in the "Proceedings of the Zoological Society," in 1849 (with four coloured plates containing thirty-three species), of which half were previously undescribed. Of these, perhaps the most striking is the long-tailed species Actias mimosa, with pale green wings, which lives upon the Mimosa, on the banks of the river Tugela, the boundary of the kingdom of Amazulu, between Delagoa Bay and Natal, the cocoons of which are used by the natives for tobacco boxes. Another fine species is Satumia Alcinoê, Cramer, pl. 322, fig. A, $(=S$. Caffraria, Stoll, pl. 31, f. 2, S. caffra, Boisduval in Delegorgue's Voy. Afr. Austr. ii. p. 6or). A specimen of this species, measuring seven inches in the expansion of the fore wings, was taken by Mr. Oates, but the precise locality was not recorded. . Another species, which appears to be undescribed, was also taken by Mr. Oates, which may be thus characterized :- 


\section{Saturnia Cervina, Westw.}

Tota roseo-cervina, alis anticis spatio minuto transverso squamis destituta ad apicem cellulæ, striolaque paullo obscuriori paullo curvata et vix distincta inter cellulam et marginem posticum; alis posticis macula parva trigona ad apicem cellulæ; abdomine magis fulvo ; alis anticis apice subrotundatis. Expans. alar. antic. unc. $4 \frac{2}{3}$.

\section{Habitat prope Tati.}

A beautiful species, nearly allied to the European emperor moth, was taken by Mr. Oates, which appears to be undescribed, although it has been named by Mr. Butler, in manuscript, in the British Museum collection :-

\section{SATURNIA FLAVIDA.}

S. Apollonia, Cramer, pl. 250, fig. A, persimilis ; differt colore fusco-griseo alarum flavido-tincto, fascia fusca pone ocellum, absque maculis duabus nigricantibus subapicalibus, colore fusco subapicali omnium alarum intus flavido latius marginato. Expans. alar. antic. unc. $3 \frac{1}{3}$.

Habitat prope Gubuleweyo.

I take this opportunity of describing two additional species of Satumia, closely allied to S. favida, in the Hopeian collection, together with a remarkable species collected by Mr. Buxton:-

SATURNia TERPSichorina, Westw.

S. Apollonice similis at multo minor et pallidior, ocello alarum anticarum ovali, fascia tenui extus connexa, hac prope apicem alæ absque maculis duabus nigris; alis posticis basi albis absque fascia indistincta subbasali, ocello ovali extus cum fascia tenui fusca conjuncta, fascia zda submarginali ut in S. Apollonia; thoracis dorso macula livido-fusca; incisuris abdominis livido-marginatis. Expans. alar. antic. unc. $2^{\frac{3}{9}}$.

Habitat in Africa merid.-orient. In Mus. Hopeiano.

SATURnia Dyops, Maassen and Weymer, Beitr., fig. 2 I.

This species is also closely allied to $S$. Apollonia, but wants the ocellus in the hind wings. Maassen obtained it from Natal. Specimens from South Eastern Africa, and from Angola (Monteiro), are in the Hopeian collection at Oxford.

\section{SATURnia Hyperbius, Westw.}

Alis anticis ferruginosis, puncto minimo vitreo ad apicem cellulx; striga recta obliqua pone medium ale cinerea, area pone strigam magis aurantiaca, margine apicali plumbeo-tincto, ciliis rufis; alis posticis fulvis ocello mediocri medio cinerco (medio albido) circulo nigro; striga angusta cinerea inter ocellum et marginem posticum plumbescentem, ciliis rufis: alis subtus saturatioribus, venis flavis, anticis macula rotunda nigra, medio vitrea; cellula in posticis fere 
obliterata, strigaque pone medium angustiori et minus distincta; corpore rufo, abdomine magis fulvo. Expans. alar. antic. fere unc. 5 . Habitat in Africa merid. (D. Buxton.) In Mus. Hopeiano.

\section{Family Bombrcidæ.}

The family BoMBycide appears to be rich in species of the subfamily LimACODIDES, the caterpillars of which are clothed with short erect bristles, which are capable of inflicting poisonous wounds ; their cocoons are very solid and egg-shaped. Notwithstanding their defensive appendages they are subject to the attacks of parasites, and in the "Transactions of the Entomological Society," I876, pl. Io, I have given the history of a curious dipterous insect, Systropus cridelis, which destroys individuals of one of the species of this group. Mr. Oates obtained a number of species, the majority of which are, however, in a very mutilated condition. Of one, which is a very showy insect and appears to be undescribed, I give the description below :-

LIMACODES ARGENTIFERA, Westw.

Læte pallido-viridis, alis anticis basi macula media fasciaque subapicali valde curvata e guttis argenteis, singulis guttis annulo brunneo cinctis, fascia externa e medio marginis postici versus apicem extensa at guttis sensim decrescentibus; alis posticis abdomineque fulvis. Expans. alar. antic. unc. $\mathbf{I} \frac{1}{4}$.

Pantoctenice Gemmanti, Felder, Reise Novara, pl. 82, fig. I6, proxima.

\section{Habitat prope Gubuleweyo.}

A large species of this family, Fana Mariana, was collected by Mr. Oates at Tati, and is figured in Plate G, fig. 6. The type specimen is in the British Museum from Congo. It belongs to the modern Genus Fana, of Boisduval, but was described by the late Adam White under the name of Bombyx Mariana (Ann. Nat. Hist. xii. 264). It is fawn-coloured, the fore wings with four slender oblique undulating brown bands. In the hind wings the bands are rather broader and more distinct, and there is a large purplish black spot at the base of the latter. The fore wings measure from 4 inches to $4^{\frac{2}{3}}$ inches in expanse.

The species of the remaining Lepidopterous families captured by Mr. Oates did not comprise any remarkable new species, and were for the most part in a much broken condition, rendering their determination very difficult.

\section{Order COLEOPTERA.}

\section{Family Cicindelid}

Of the carnivorous ground beetles five genera of CICINDELIDÆ Manticora, Platychile, and Dromica, with Ophryodera and Bostrichophorus, are peculiar to the central and eastern sub-regions of Africa. 
Of the first-named genera, Mr. Oates collected specimens of the gigantic Manticora latipennis, Waterhouse, together with a fine new species of Dromica characterized below :-

Dronica (Myrmecoptera) Oatesil, Westw. (Plate G, fig. 5, and Plate $\mathrm{H}$, figs. $\mathrm{I}, \mathrm{I} \alpha, \mathrm{I} b_{\text {. }}$ )

Nigra, capite rugose striolato, labro lævi, in medio fulvo ; pronoto subopaco transverse striolato, linea media dorsali albo-hirta, elytris obovalibus granulatis, singulis 5 -costatis, costis longe ante apicem desinentibus; costa suturæ proxima e tuberculis oblongis formata; costa $2 \mathrm{da}$ ad basim straminea, nigro-punctata; margine externo inter medium et apicem linea gracili albida notato ; antennis pone articulum 4 tum dilatatis, compressis, articulis sensim ad apicem decrescentibus. Fœm. Long. corp. unc, I, lat. med. elytr. lin. $3 \frac{1}{2}$.

\section{Family CARABIDE.}

Of this family there are I7 peculiarly South A frican Genera, including Crepidogaster, Hystrichopus, Arsinoë, and Piezic. The genera Eunostuss, Glyphodactyla, and Megalonychus, occur in Madagascar as well as in South Africa. The greater portion of the gigantic species of Anthic are African, and of these a number were collected by Mr. Oates, including A. maxillosa, Fabricius, Mellyi, De Breme, cinctipennis, Dupont, guttata, Melly, MS. in Brit. Mus., and an apparently undescribed species. Of the allied Genus Cypholoba, specimens were captured of C. alveolata, De Breme, and 7-guttata, Fabricius. Of Polyhima two species, P. macilenta, Olivier, and amabilis, Boheman (?), and two species of Graphipterns, G. cordiger, Dejean, and Westwoodii, De Breme (?) Drypta jucunda and Orthogonizes caffer, complete the list of CARABIDE.

\section{Family SCARABEIDE.}

Of the sacred bectles, SCARADæIDE, eminently characteristic of $\Lambda$ frica, and especially of the southern region, specimens of the gigantic Pachylomera femoralis, Kirby, and a Heliocantharus, the larges! species of the genus, were taken by Mr. Oates, together with H. transversus, Laporte (operosus, Dejean), and $H$. intricatus. Circellizum Bacchus, Chalconotus cuprous (varictas minor et brevior); three charming species of Gymnopleurus, G. Olivicrii, fulgidus, and speciosus; Sisyphius, one small species; Copris, eight species, including $C$. Fachus, Edipues, Nomestrinus, and colatus; six small obscure species, of Onthophagus; Onitis inuns and ciliatus:-the preceding, of all of which specimens were taken, together with several small obscure species of A pltodius, all being coprophargous in their habits, sufficiently testify to the existence of numbers of large mammalia in the regions where they occur. 


\section{Family MELOLONTHID E.}

Of this family a number of small obscure-coloured species were also collected, with two species of Trox; but of the very characteristic genera Anisonyx, Peritrichia, Lepitrix, Pachycnema, Dichelus, Monochelus, and Gymmoloma, all very numerous in species, and peculiar to South Africa, no specimens were captured by Mr. Oates.

\section{Family DyNASTIDE.}

Oryctes Boas, Fabricius, and a small Syrichthus, allied to S. gagates, were the only DYNASTID $Æ$ captured; the former in large numbers.

\section{Family CETONIIDE.}

Of the family of the Rose Chafers (CETONIIDE), containing about Iooo described species, twelve genera are peculiar to Western Africa, fourteen to South Africa, and twenty-one to Madagascar. Of the gigantic species of Goliath beetles, Goliathus albo-signatus, Boheman (Kirkii, G. R. Gray), inhabits the Zambesi country. Ceratorhina splendens, Bertoloni (Petersiana, Klug), one of the loveliest and most remarkable of beetles, inhabits the Tati district and Mozambique, but none of these singular insects were found by Mr. Oates. Six species of CETONIIDÆ were taken by Mr. Oates, including Pachnoda obsoleta, Schaum; Spilophorus plagosus; Phoxomela umbrosa, Gory and Perchéron; and Oxythyrea discicollis, Reiche, and hamorrhoidalis, Fabricius.

\section{Family LUCANIDE:}

Of this family there are ten genera in South Africa, seven of which are peculiar, and two of these are confined to the Island of Bourbon; two genera are peculiar to Western tropical Africa and three to South Africa; whilst the otherwise widely-ranging genera Lucamus and Dorcus are absent from Africa. No species of this family was taken by Mr. Oates.

\section{Family BUPRESTIDÆ.}

This family is very extensive, containing at least 2700 species, many of which are splendidly coloured insects, of gigantic size, amongst which is a group essentially African, remarkable for the numerous pencils of short erect hairs dotted over their whole upper surface (Genus Fulodis, Eschscholtz). The species of Steraspis and Sternocera are also of large size and great brilliancy. Twenty-seven genera of these insects occur in South Africa, of which six are peculiar, but Mr. Oates only collected four small and obscure species. The singular Genus Polybothris, with widely dilated elytra, is peculiar to Madagascar, no species of the genus having been found on the African continent. 


\section{Family ELATERIDE.}

This family is also of great extent, consisting of not fewer than 2700 described species, many of which are exclusively natives of South-Eastern Africa and Madagascar, the finest group being Tetralobus, and its immediate allies, having flabellate antennæ, which are almost restricted to Africa, a few only occurring in New Holland. Of this group Mr. Oates collected a very interesting species, which I have figured in Plate G, fig. 4, and which appears to be identical with Titralobus bifoveolatus of Boheman (although apparently differing in certain points).

\section{Family PAUSSIDE.}

Africa possesses a number of species of this singular family, found in Natal by Herr Guienzius in ants' nests. Mr. Oates, however, collected only one species, Pleuropterus alternans, Westw., Thesaurus Ent. p. 74, pl. 16, f. 2.

\section{Family Histeride.}

These insects, which are generally found in excrement, appear to be numerous in individuals, although only about eight species were taken, one of large size.

\section{Family SILPHIDÆ.}

Of the carrion beetles one alone, Silpha (micans, Fabricius), was captured.

\section{Family BOSTRICHIDÆ.}

Of the numerous family of wood-boring beetles, five species were found in considerable numbers, including Apate (monacha and commtus, Fabricius).

\section{Family TENEBRIONIDE.}

This extensive family, belonging to the HETEROMEROUS SECTION of the Order, in its widest extent, as catalogued by Gemminger and Von Harold, comprises more than 4500 described species, many of the largest and finest of which are peculiarly African, such as Chiroscelis and its allies (of which I published an illustrated monograph in the "Transactions of the Zoological Society," vol. iii. I849), and the gigantic species of Molaris, such as M. Bertolonii, Guérin, from Mozambique; $M$. Rowlciana, Westw., from the Zambesi ; $M$. gravida Damara Land; and $M$. Procrustes, Delagoa Bay, illustrated in my paper in "Trans. Ent. Soc." I 875, pl. 6. Many of these insects, which are especially natives of large sandy districts, were captured by Mr. Oates, including Moluris Perretii, M. gibbosa, M. albipes, etc., Dichtha inflata, Gerstaccker, Anomalipus limetus and intormedius, 
Hypomeles rugosus, Fabricius, etc. Numerous smaller species of Melasomatous Heteromera, and HeLopide, were also taken, as well as ten species of MrLABRIDE.

\section{Family Helopide.}

Amongst the HELOPIDæ, apparently allied to Centronipus and Stenochia, is an insect captured by Mr. Oates, which must be referred to a new Genus,

\section{Genus Derospherius, Westw.}

Corpus oblongum, subcylindricum; capite parvo, conico, ante oculos utrinque rotundato - elevato, antennis longitudine dimidii corporis, articulis æqualibus, externis paullo brevioribus at non crassioribus; mandibulis capitis longitudine æqualibus curvatis, supra prope basim cornu erecto, apice inciso, armatis ; labro subrotundato, antice emarginato ; palpis maxillaribus elongatis, articulo ultimo vix securiformi ; mentum transversum antice angustatum; palpis labialibus parvis, subcylindricis; prothorax rotundatus, subglobosus; pedes satis graciles; tarsis heteromeris, simplicibus, unguibus simplicibus.

Derospherius anthracinus, Westw. (Plate G, fig. 3, and Plate H, figs. $2,2 a, 2 b, 2 c$.)

Niger nitidus, capite inter antennas biimpresso, pronoto subtiliter punctatissimo ; elytris punctato-striatis. Long. corp. fere lin. 6.

\section{Family CURCULIONID瓜.}

Of the still more extensive family of the Weevils (Genus Curculio, Linnæus), of which, including the SCOLYTIDE, BRENTHIDÆ, and ANTHRIBIDE, not fewer than I200 species have been described, large numbers are peculiarly African, especially the great Genera Brachycerus, Episus, Microcerus, Platycopes, Sciobizes, and many others, the species of most of which are distinguished by their dull colours and sluggish movements, fitting them for their existence in wide arid sandy districts, where they emulate the Pimelice and Molurides. Of this great tribe only nine species were captured, including numbers of individuals of the gigantic Brachycerus apternis, remarkable for the red spots on its black body, $B$. congestus, etc.

\section{Family CeRAmbycide.}

Of the great family of Longicorn beetles (Cerambyx, Linnæus), consisting of not less than 8000 already described species, there are in South Africa 262 genera, of which no less than 67 are peculiar, namely 5 of Prionide, 25 of Cerambycide, and 37 of Lamildie. The most conspicuous of these genera are Stemotomis, Zographus, Alphitopola, Tragocephalus, Phryneta, Ceroplesis. The giant Prionides are evidently very rare, but the remarkable genera may be mentioned, Cacoscelis, Cantharoctenus, and Cantharoplatys, Westw. 
(Thes. Ent.). Of this great group only 23 species were collected by Mr. Oates, including Ceroplesis hottentotta, C. cruentata, and two other species, Phrissoma giganteum, Callichroma latipes, Hamaticherus sericeus and denticornis, and Amphidesmus analis, Olivier.

\section{Family ChRYSOMELIDÆ.}

The Phytophagous or plant-eating beetles (Chrysomela, Linn.), as may be inferred from their habits, are exceedingly numerous, both in species and individuals, in all parts of the world, more than 10,200 species having been described. Some few groups are especially African, such as Pacilomorpha, Hope, belonging to the Megalopides, numerous species of Sagra, Antipa, Melitonoma, Acolastus, Eurytus, Pansiris, Pallena, Cyno, Macrocoma, etc. Only twenty-three species of these insects were taken by Mr. Oates, including Sagra festiva, Gerst., Diamphidia femoralis, Gerst., Clythra tettensis, and various species of Eumolpus, Cassida, Hispa, Colaspis, etc.

The other orders of insects received but little attention, and but few are contained in Mr. Oates's collection.

\section{Order ORTHOPTERA.}

In this order several large and beautiful species of locusts were taken, including Acridium leprosum and scabrosum, and Petasia cruentata, Pamphagus haploscelis, and the curious wingless grasshopper, Eugaster loricatus of Gerstaecker. Two or three different kinds of Crickets and four species of BLATTIDE were also taken.

\section{Order NEUROPTERA.}

In this order a large species of Mymeleon, marked like M. Libelluloides, and the lovely Palpares citrinus, were collected.

\section{Order HYMENOPTERA.}

In this order two large species of sand wasps with steel blue wings were taken.

\section{Order HEMIPTERA.}

Of HEMIPTERA twelve species of CIMICIDE were taken.

\section{Order DIPTERA.}

In this order various species injurious to cattle and horses, including six species of TABANID E, one being the beautiful Talumus afr $i$ cannes of Gray (Griff. Anim. Kingd. Ins. pl. 114, fig. 5), were taken; also two species of Hippobosca, and various specimens of the terrible TSETSE (Glossina morsitans, Westw., Proc. Zool. Soc, roth December 1850 ), of which I have thought it would be desirable to give a fresh figure (Plate $G$, fig. 2). 'The figure which I gave of this insect, 
accompanying my original description, was afterwards copied upon the titlepage of Dr. Livingstone's Travels (without acknowledgment), and in my memoir I ventured to suggest not only that the Tsetse was identical with the Zimb of Bruce, but also possibly with the Tsaltsalya; and further, that "the fly that is in the uttermost part of the rivers of Egypt," described by the prophet Isaiah (ch. vii. I8, I9), and considered as the cause of one of the plagues of Egypt, may also have been no other than the Tsetse. Two notes recently published on this insect, with suggestions of remedying or preventing its attacks, may be added :-

Lewis Hornor, in the "Times," 25th February 1879, writes, "Having hunted in the African fly country and seen many horses and oxen die of the bite, against which no external application is, I firmly believe, any safeguard, I venture to call attention to the precautions adopted by the Boer elephant hunters in the interior. The Tsetse inhabits narrow and clearly defined strips of country, familiar to all natives, and readily evident to strangers. On approaching one of these 'fly belts' (so called) a halt is made, and inspanning again at sundown the Boer treks through at night in safety. I only remember one case of mishap, when, in crossing a belt near the confluence of the Chobé and Zambesi, two or three oxen out of nearly forty were bitten, and that, if my memory serves me, on a bright moonlight night."

The African traveller Hildebrandt recommends strongly, in the "Korrespondenzblatt der afrik. Gesellschaft," the use of petroleum for those travelling in the tropics, as a protection against insects. Occasional applications to the face and hands ensured entire freedom from mosquitoes, and the same method sufficed to preserve horses and cattle against the deadly attacks of the Dondorobo gadfly, which so often cripples the movements of the explorer. Petroleum likewise protected the Natural History Collections of the traveller from ants, moths, etc.

[The description of Plates $\mathrm{E}-\mathrm{H}$ is given on p. 365.] 


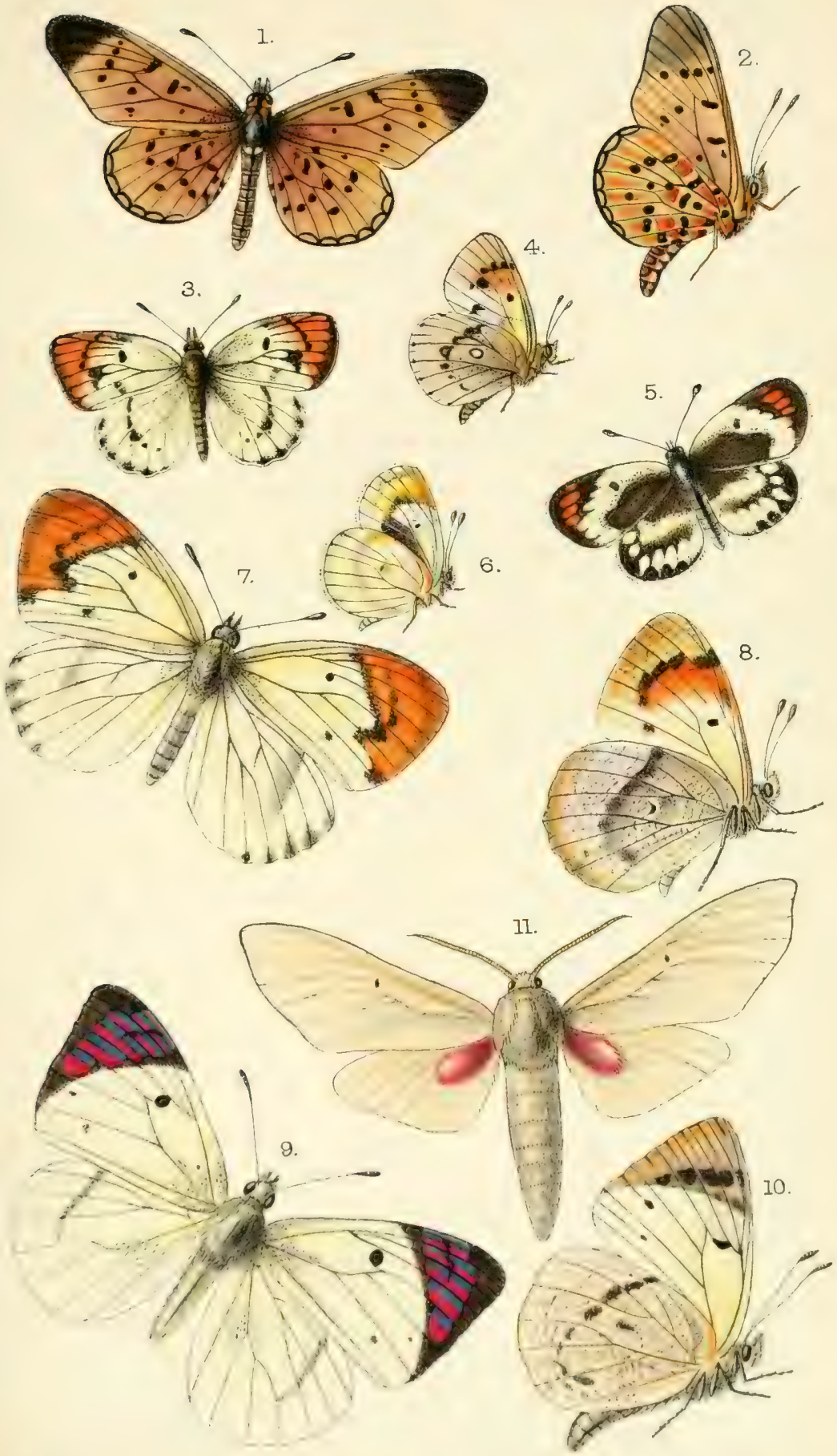





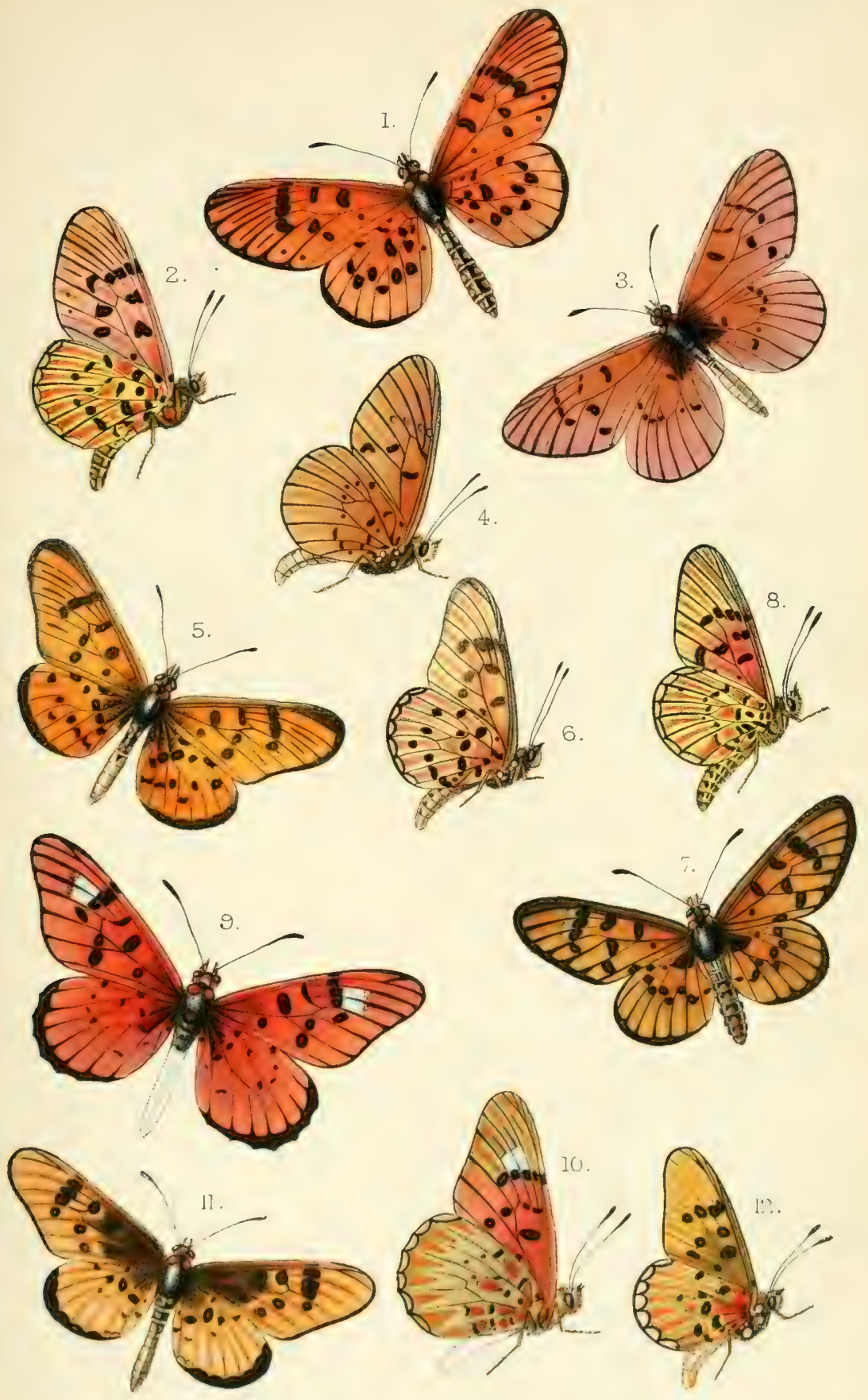




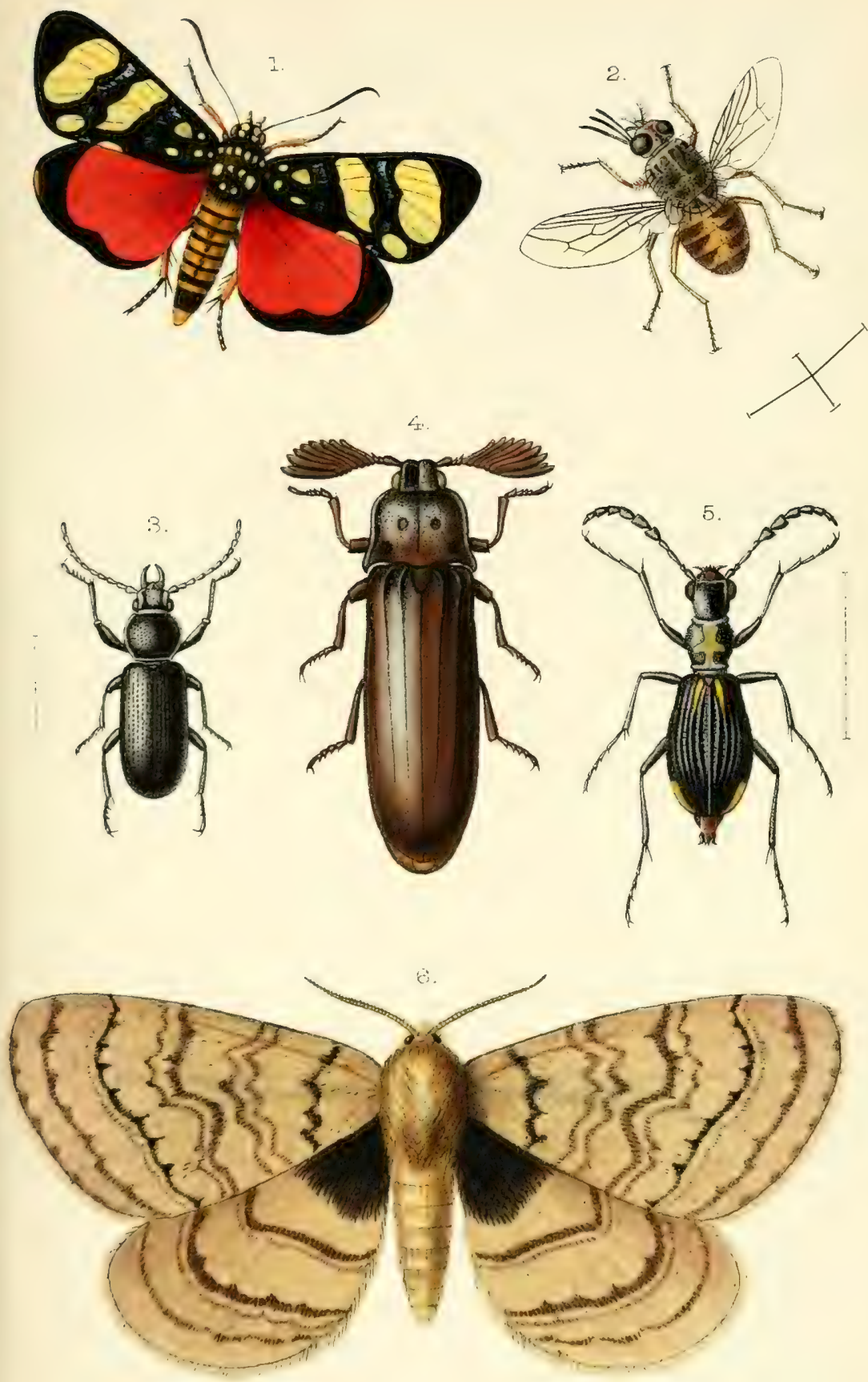


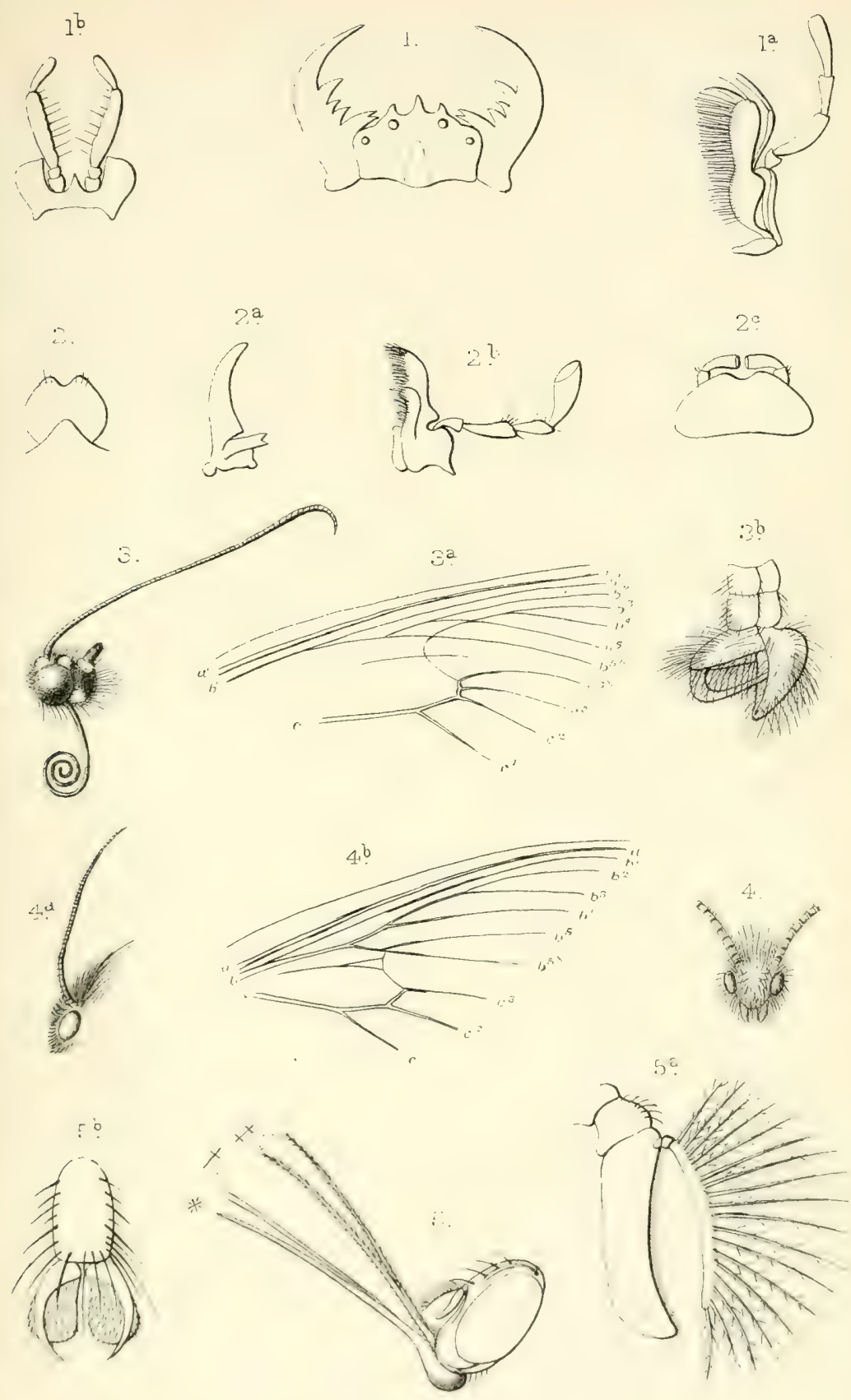



\section{Descriptions of tine Plates.}

\section{Plate E.}

Fig. I, 2. Acrea amphimalla.

" 3, 4. Callosune Wallengrenii.

„5, 6. Callosune ramaquebana.

" 7, 8. Callosune Buxtoni, female.

"9, Iо. Callosme regina, female.

"II. Charocampa virgo.

Plate F.

Fig. I, 2. Acraa Atergatis.

" 3, 4. Acrea Atolmis.

" 5, 6. Acrea Axina.

"7, 8. Acraa Acontias.

" 9, Io. Acraa Aglaonice.

, I I, I2. Acraa Acronycta.

PLATE G.

Fig. x. Eusemia adulatrix.

"2. Glossina morsitans.

"3. Derospharius anthracinus.

"4. Tetralobus bifoveolatus.

" 5. Dromica Oatesii.

,6. Fana Mariana.

Plate H.

Fig. I. Upper lip and mandibles of Dromica Oatesii; $1 a$, maxilla of do.; I $b$, lower lip and palpi of do.

Fig. 2. Upper lip of Derospharius anthracinus ; $2 a$, mandible ; $2 b$, maxilla; $2 c$, lower lip of do.

Fisg. 3. Head, antenna and spiral tongue of Eusemia adulatrix; $3^{a}$, chief veins of the fore wing of do ; $3 b$, extremity of the body of the male of do., seen sideways.

Figr. 4. Head of Fana Mariana; 4a, do., seen sideways; $4 b$, chief veins of the fore wings of do.

Fig. 5. Head of the Tsetse, seen sideways, with the parts of the sucker separated from each other; $5 a$, antenna ; $5 b$, pad of the feet of do. 


\section{BOTANY. ${ }^{1}$}

By D. Oliver, F.R.S., F.L.S., Professor of Botany in University College, London.

(Plates J, K.)

Order RANUNCULACEÆ.

* Ranunculus pinnatus, Poir.

Order POLYGALACEÆ.

* Polygala virgata, Thunb.

Order TILIACE E.

Triumfetta Welwitschil, Masters.

Order MALPIGHIACEÆ.

ACRIDOCARPUS PRURIENS, A. Juss.

Order ZYGOPHYLLACEÆ.

* Zygophyllum Dregeanum, Presl?

Order AMPELIDEÆ.

Vitis, sp.

Order LEGUMINOS E.

* Sutherlandia frutescens, R. Br.

ERYTHRINA, sp.

ERIOSEMA, sp.

BAUHinia FASSOGLensis, Kotschy.

Cassia tettensis, Bolle?

* Acacia, sp.

Order ROSACE $Æ$.

* Cliffortia linearifolia, E. and Z.?

1 The plants collected by Mr. Oates in South-East Africa have been named at Kew under the direction of Professor Oliver; the two novelties having been described by Mr. J. G. Baker, F.R.S. Those plants which are distinguished by an asterisk * were obtained between Pietermaritzburg and the Crocodile River; the rest all in Matabele Land.-Ed. 
Order SAXIFRAGACEA.

VAHLIA CAPENSIS, Berg.

Order COMBRETACEÆ.

Combretum, sp.

Combretum Zeyheri, Sond.?

Order TURNERACEA.

WORMSKIOLDIA LONGEPEDUNCULATA, Masters.

Order UMBELLIFERÆ.

Peucedanum Capense, Dietr. ?

Order RUBIACEÆ.

FADOGIA ZEYheri, Sond.?

Order COMPOSITA.

* Geigeria Zeyheri, Harv.

* Artenisia afra, Jacq.

* Deneria capensis, D. C.

Nidorella auriculata, D. C.

* Gerbera natalensis, Schultz Bip.

Order CAMPANULACE $Æ$.

Wahlenbergia Banksiana, A. D. C.

Lobelia Decipiens, Sond.?

Order ERICACEÆ.

* ERica, near coccinea, Berg.

Order OLEACE $Æ$.

JASMINUM, sp.

Order APOCYNACE E.

CARISSA, near tomentosa, A. Rich.

Order CONVOLVULACEA.

Evolvulus ALsinoIDES, Linn,, var.

Order BORAGINACEA.

TRICHOdESMA PHysaloIdES, A. D. C.

Order SOLANACEA.

Solanum SUbexarmatum, Dunal?

Order GENTIANACER.

CHIRONIA, sp. 


\section{Order SCROPHULARIACE $Æ$.}

Lyperia Burkeana, Benth.

* Limosella tenuifolia, Nutt.

* Diclis Reptans, Benth.

Order ACANTHACEE.

* Hypoestes Forskahli, R. Br.?

* Hypoestes verticillaris, R. Br.?

Order SELAGINACEÆ.

* Hebenstreitia, near dentata, Thunb.

Order VERBENACEÆ.

LIPPIA ASPERIFOLIA, Rich.

LANTANA Or LIPPIA, sp.

Order LABIAT $Æ$.

* LeOnotis LeONurus, R. Br.

OCYMUM, Or ORTHOSIPHON, sp.

Order AMARANTHACE无.

Achyranthes aspera, L.?

Order EUPHORBIACE

EUPHORBIA, sp.

Order ORCHIDACE E.

LISSOCHILUS, $2 \mathrm{sp.}$

Order IRIDACE Æ.

Gladiolus BREVifolius, Jacq.

Gladiolus, near QuARTINIANUS, A. Rich.

Order AMARYLLIDACE E.

HæMANTHUS, near MULTiFloRUs, Martyn.

Order HYPOXIDACE E.

Hypoxis ViLLOSA, L.

\section{Order LILIACEÆ.}

Anthericum (Trachyandra) OAtesil, Baker in Trimen's Foumal of Botany, 1878, p. 324. (Plate J.)

Rootstock not seen complete; outer tunics produced as a membrane round its neck. Produced leaves 5-6, contemporary with the flowers, terete above the sheathing base, $\frac{1}{2}$ foot long, $\frac{1}{2}$ line in diameter, clothed with fine soft deflexed white hairs as long as the diameter of the leaf. Scape as long as the leaves, pilose in the lower part glabrous upwards. Raceme lax, simple, $\frac{1}{2}$ a foot long, I-I $\frac{1}{4}$ inch 


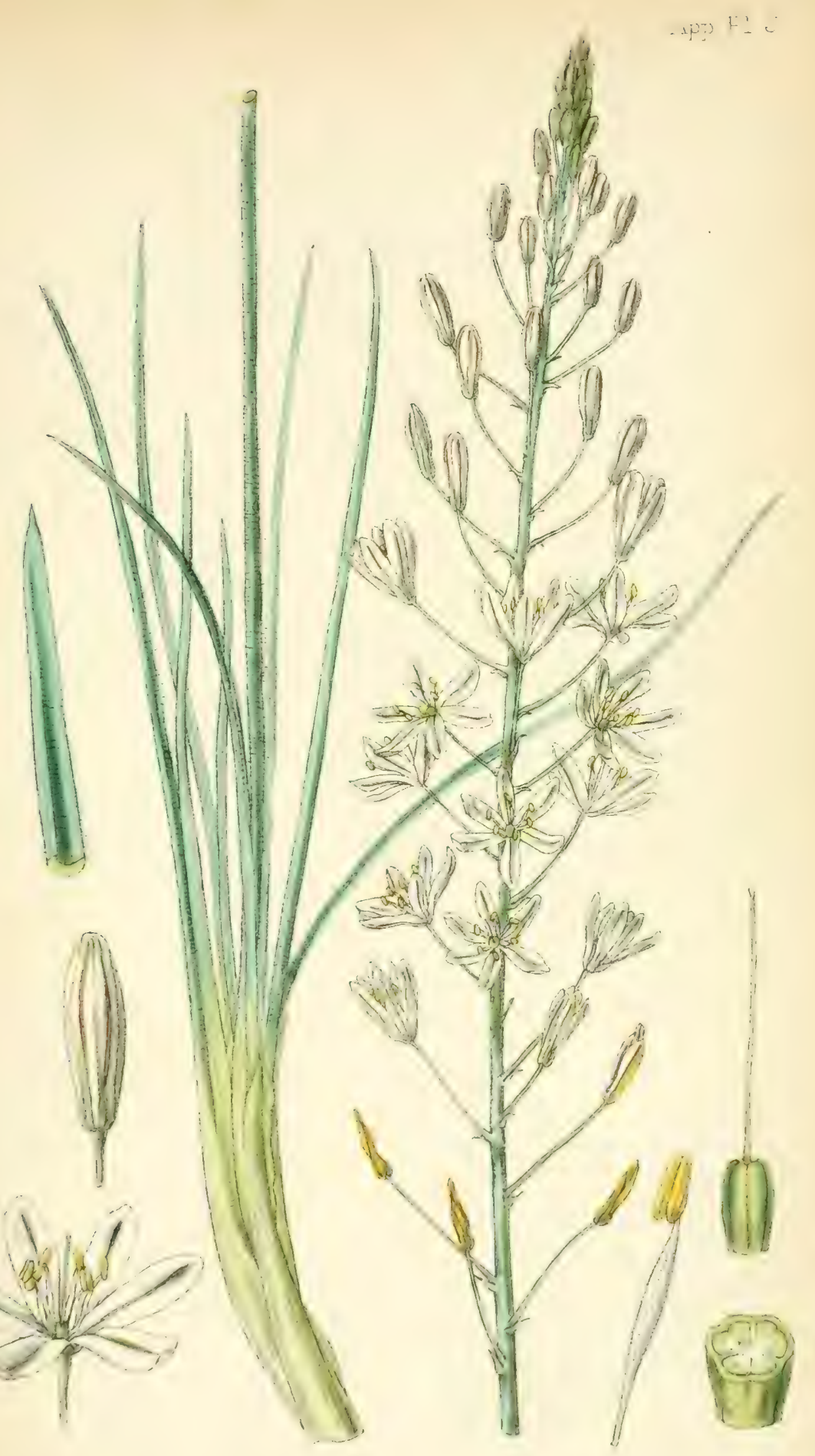





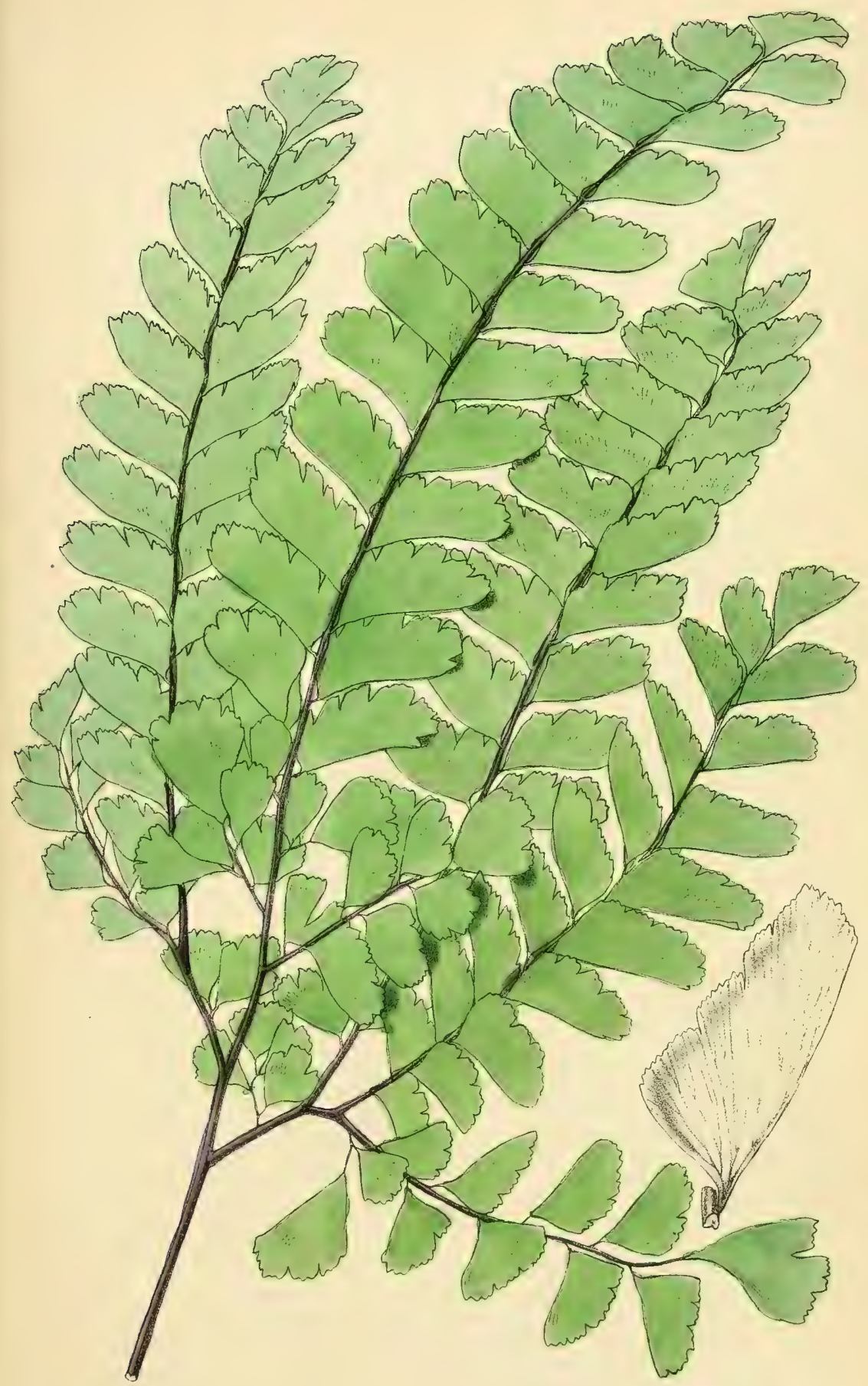



in diameter; bracts minute, deltoid; pedicels erecto-patent, the lower ones $\frac{1}{2}-\frac{3}{4}$ inch long. Perianth white, fugacious; segments $\frac{1}{4}$ inch long, lanceolate, with a distinct I-nerved or obscurely 3-nerved brown keel. Stamens falling a little short of the perianth-segments; filaments muricate; anthers oblong, very minute. Style declinate, just overtopping the anthers.

Near the Abyssinian A. Saltii, and Cape A. pubescens.

AloE, sp.

Asparagus, sp.

* Androcymbium melanthioides, Willd.

Order GRAMINEÆ.

* Panicum (Tricholena) roseum (Nees.)

* Andropogon, sp.

* Andropogon (Cymbopogon) hirtus, L.

Order FILICES.

* Pellea consobrina, Hook.

Adiantum ÆTHIOpicum, L.

Adiantum Oatesis, Baker. (Plate K.)

Stipe slender, brown, glabrous. Lamina pedate, with 6-7 pinnate divisions, the largest 6-8 inches long, $1 \frac{1}{4}-1 \frac{1}{2}$ inch broad; end segment cuneate, $\frac{1}{2}-1$ inch broad; side segments dimidiate, shortly petioled, all, except the lowest, rather ascending, imbricating over the rachis at the inner anterior corner, the largest $\frac{3}{4}-\frac{7}{8}$ inch broad, $\frac{1}{2}$ inch long, straight and truncate on the lower and inner borders, cut into deep rounded lobes on the upper and outer borders; lower segments gradually dwindling down in size; rachis quite glabrous and scaleless, bright brown ; texture thin, membranous ; both surfaces bright green and glabrous. Sori not seen. Veins close, fine, distinct, flabellate, free.

Closely allied to the American and Asiatic A. pedatum, Linn., from which it differs by the fewer divisions of the frond, the outer ones not falcately curved, and its shortly-petioled ultimate segments, which are fewer, broader, and imbricated over the rachis.

Adiantum lunulatum, Burm.

CHEILANTHES FARINOSA, Kaulf.

NEPHRODIUM MOLLE, Desv.

NePHRODIUM (LASTREA), sp.

Nephrolepis exaltata, Schott.

NePHROLEPIS CORDIFOLIA, Presl.

Mohria CAFfrorum, Desv. 


\section{LIST OF MAKALAKA WORDS AND PHRASES,}

From one of Mr. F. OAtes's Note-Books, r874-5.

Y-sloga, axe.

Sewoncha, fold, enclosure.

Inslogo, head.

Lusa, herd.

Mutwalla, package.

Le-c̈hebe, pan (of water).

Bushlune, powder.

Mouti, tree, medicine.

A-acho, our.

A-aka, his.

Hlula, to go by.

Thineula, to be lame.

Pesa, to leave off.

A-manga, to lie.

Ponsa, to shoot.

Hclanza, to be sick; also, to wash.

Thhinga, to spy out.

Londalosa, to take care of.

Incolo-ga Stoffel, Stoffel's waggon.

Gagwasasan, early this morning.

Ea gahte, a long time ago.

Eo vouta, it's cooking.

Ya chesa, it is hot.

Ngeswelle, I heard.
Ongeswanga, I have not heard.

Oeswēle? did you hear?

Gangbonanga, I have not seen.

Angetanga, I don't like.

Una manga, you lie.

Gane na manga, I don't lie.

Gang aze, I don't know.

Asea aze, we don't know.

Gneponsele, I shot.

Ngeza gon shia, I'll hit you.

Wale shia lipe? where is he?

Bangape ba fana? where are the boys?

$\mathrm{Y}$ gu bane? whom does it belong to?

$\mathrm{E}$ haubele nane? when did it go?

Koulape? where are you lame?

Mouti moone? what tree is that?

Hamba tata zinto zato, go get our things.

Ouguchen gesa inglella eang Gubuleweyo, show me the road to Gubuleweyo. 


\section{N D E X.}

Abantu Skulls, 276, 278, 279, 286 Abantu tribes, adoption of customs by, from the Khoi-Khoin races, 29I Acacia, sp., 366 Acherontia Atropos, 353 Achyranthes aspera, 368 Acrea Acontias, 345 Acronycta, 346 Aglaonice, 246 amphimalla, 347 Anemosa, 348 Atergatis, 342 Atolmis, 343 Axina, 344 Bellua, $34^{8}$ Caldarene, 347

Dircad, 348 Hypatia, 348 natalica, 348 Neobule, 348 Rahira, 348

Acreide, 342

Acridium leprosum, 363 scabrosim, 363 Acridocarpus pruriens, 366 Actitis hypolencus, 325 Adiantum athiopicum, 369 lunulatum, 369 Oatesii, 369

Aëdon leucophrys, 309

Egialitis atricollaris, 326

Egithahis, or Penduline Titmouse, nest of, 76 , note

Agaristida, 355

Alaudide, 317

Alcedinida, 303

Aloe, sp., 369

Amadavats, nests of, 76 Amadina erythrocephala, 320

Amblypodia natalensis, 35I Leroma, $35 \mathbf{I}$

Amphidesmus analis, 363

Amydrus bicolor, 316 morio, 316
Anas xanthorhyncha, 327

Anatida, 327

Androcymbium melanthioides, 369

Andropogon, sp., 369

(Cymbopogon) hirtus, 369

Anomalipus intermedius, $36 \mathbf{I}$ lineatus, 36I

Anthericum (Trachyandra) Oatesii, 368

Anthia cinctipennis, 359

guttata, 359

maxillosa, 359

Mellyi, 359

Anthocharis Eosphonus, 336 Erone, 338

Anthopsyche speciosa, $33^{8}$ Theopompe, 337

Anthus caffer, $3 \mathbf{I} 7$ pyrrhonotus, 3 I 7

Ant-eating Wheatear, Southern, 307

Ants, 40, 72. See also White ants.

Apate cormutis, $36 \mathrm{I}$ monacha, $36 \mathrm{I}$

Apricots, 4, 37, 49

Ardea melanocephala, 326 purpurea, 326 mifiventris, 327

Ardeide, 326

Ardeiralla Sturmii, 326

Artemisia afia, 367

Asio capensis, 300

Asparagus, sp., 369

Assegais, different varieties $\mathrm{Cf}$, IOI, note Astur polyzonoides, 298

Aterica Meleagris, 349

Australian skulls, 28I

Ayres, Mr. Thomas, reference to, 294

BABbling Thrush, Jardine's, 309 Pied, 308

Baines, Thomas, reference to, 247 , $254,256-8$

Baker, Mr. J. G., F.R.S., descriptions of two new species of plants obtained by Mr. Oates, by, 368 
Bamangwato, I 5-22, 36, I 47-I 59 fighting at, I 55

(or Mungwato), the usual name for Shoshong, II, note

Baobab trees, 72, 83, 145

Barbel, 51, 230

Barbet, Le Vaillant's, 306 Pied, 305

Batis molitor, $3 \mathbf{I} \mathbf{I}$

Bauhinia fassoglensis, 366

Bee-eater, Blue-cheeled, 30 r Carmine-throated, 3 or

European, 30I

Little, 30 I

Swallow-tailed, 302

White-fronted, 3 O I

Bees' nests, 73, I 35

Beef-eater, African, 3 I 6

Beetles, annoyance from, 40

Bell, Thomas, 4

Bembesi River, 68

Bengali Finch, Southern, 32 I

Biltong, meat dried in the sun, 45

Birds' nests collected by Mr. Oates, 76

Bishop-bird, Red, 320

Bleek, Dr. W. H. J., researches of, 276

Blockley, Mr., 244, 245, 247

Blue gum trees, 8

Blumenbach, J. F, reference to, 277

Boa-constrictor, 75

Boer hunters, I 54, 2 I 7

their indiscriminate slaughter of game, 223

Boers and their waggons, 220 character of, 10,225

farms of, in the Transval, 9, IO, I 2, 39

their apparent poverty, I 2

Bolinlila, Lobengula's brother, 67

Bombycida, $35^{8}$

Bombyx Mariana, 358

Bond, Mr., $2 \mathrm{O}_{3}$

Bostrichida, $36 \mathbf{I}$

Botany, by Professor Oliver, F.R.S., F.L.S., 366-369

Brachycerus apterus, 362 congestus, 362

Bradshaw, Dr., joins Mr. Oates, 244$25 \mathrm{I}$

with him at his death, 260-264

Bradyornis Oatesii, 314

Bradypterus gracilirostris, 310

Brass wire, I I 9, I 20, note
Bristle-necked Thrush, Cape, 308

Broca, P., reference to, 280 , note

Brown, Mr., I73

Brown, Mr. A., of Tati, 33, 35, I40, I63, I68, 188, 190, I98, I99,

Bubo lacteus, 299 200-202, 213, 216,222

Bubonida, 299

Bubulcus ibis, 327

Bucerotida, 304

Buchanga assimilis, 3 I 5

Buckley, Mr. T. E., 3-36, 294

Building, singular native, I 75

Bulbul, Layard's, 308

Le Vaillant's, 308

Bullocks, State slaughter of, I05

Bunting, Cape, 322

Golden-breasted, 322

Buphaga africana, $3 \mathbf{I} 6$

Buprestidce, 360

Bushman crania, 273 et seq. measurements of, 292, 293

race, Mongolian origin ascribed to, 288-290

indications of kinship with the Akka and Obongo tribes, 288

remains, failure to obtain, 136,166 finally obtained, $23 \mathbf{I}$

Bushmen, 24, 25, 28, 50, 80, 137, I 44, I 52,180

looked upon as game by the Matabele, 222

mysterious instincts of, 222

Bush-shrike, Bakbakiri, 3 I 2

Crimson-breasted, $3 \mathbf{I} 2$

Pied Puff-backed, 312

Red-winged, 3 I 3

Short-tailed, 3 I

South African Puff-backed, 3 I 2

Three-streaked, 3 I 3

Yellow-breasted, 3 I 2

Bush-warbler, Short-tailed, 310

Busk, Mr. G., reference to, 277

Bustard, Blue, 326

Kori, 326

Buteo jackal, 298

Butorides atricapillus, 326

nufiventris, 327

Sturmii, 326

Butterfies, distribution of, in Africa, 333-335

Buzzard, Jackal, 298 
Caffre skulls, 278, 285. See also $\mid$ Ceryle midis, 303

Kafir

Calabash pumpkins, I 12

Callichroma latipes, $36_{3}$

Callidryas Castalia, 336

Florella, 335

Pyrene, 335

Rhadia, 336

Swainsonii, 335

Callosune Antigone, 338

Buxtoni, 340

Casta, 338

Danaë, 337

Eione, 340

Eupompe, 337

Evenina, 340

Evippe, 338

inornata, $33 \mathrm{~S}$

Ione, 338

Keiskamma, 338

Omphale, $33^{8}$

psendetrida, 340

Ramaquebana, 341

regina, 339

Theogone, 339

Wallengrenii, 341

Campethera Abingtoni, 306

Bennetti, 306

Smithii, 306

Capitonida, 305

Caprimulgida, 300

Caprimulgus europaus, 300

mossambicus, 300

rufigenis, 300

Caprona Fillaana, 353

Carabida, 359

Carissa, sp., $3^{67}$

Carrion beetles, $36 \mathbf{I}$

Cassia teltensis, 366

Caterpillars, 96

Cattle disease, heavy losses from, in Natal, 8, 13

Cattle, Mashona breed of, 226

Centropus senegalensis, 305 superciliosus, 305

Cerambycida, 362

Cerchneis amurensis, 299 natmanni, 299

rupicola, 299

tinmunculoides, 299

Ceroplesis crucutata, 363

hottentotta, 363

Centhilauda semitorquata, 317

Ceryle maxima, 303
Cetoniida, 360

Ceylon, skulls from, 28 r

Chalconotus cuprens, 359

Chalcopelia afra, 322

Chapman, Jas., reference to, 254-26o

Charadriida, 325

Charaxes Pelias, 349

Charm, a hunter's, 54

Chat, Familiar, 307

Chat-thrush, Natal, 309

Cheetahs, goat killed by, 247

Cheilanthes farinosa, 369

Chera progne, 220, note; 319

Chettusia coronata, 325

Chinese, skulls of, 28 I

Chironia, sp., 367

Cherocampa capensis, 354 virgo, 354

Christmas Day at the Pantamatenka, 244-246

Chrysococcyx cuprezes, 305

Chrysomelida, 363

Chrysophanus Lara, 352

Cicindelida, $35^{8}$

Ciconia alba, 327

Ciconiide, 327

Cinnyris afer, 3 I 0 gutturalis, 3 I0 mariquensis, 3 10

Circellium Bacchus, 359

Circus ranivorus, 297

Cisticola aberrans, 309

chiniana, 309

cursitans, 3 I0

curairostris, 309

timiens, 309

Cleland, Prof. J., reference to, 283 , note

Cliffortia linearifolia, 366

Clythra tettensis, 363

Coccystes cafer, 305

Cokhé River, 67

Colias Pyrene, 335

Coliida, 305

Colius erythromelon, 305 striatus, 305

Colubrida, 329

Columba, 322

Coly, Quiriva, 305 South African, 305

Combretum, sp., 367 Zeyheri, 367

Cook, Captain, reference to, $29 \mathbf{I}$

Coot, Rufous-knobbed, 324 
Copris coelatus, 359

Jachus, 359

Nemestrimus, 359

Edipus, 359

Coracias caudata, 302

garrula, 302

navia, 302

Coraciide, 302

Cormorant, Long-tailed, 328

Corn-crake, 324

Coronella tritania, 329

Corvus scapulatus, 316

Corythornis cyanostigma, 303

Cosmetornis vexillarizes, $3 \mathrm{OI}$

Cossypha natalensis, 309

Cotton, wild, 69

Coturnix dactylisonans, 324

Delegorguei, 324

histrionica, 324

Crake, Peters's, 324

Crateropus bicolor, 308

Fardinii, 309

Crex pratensis, 324

Crickets, 363

Crithagra angolensis, 322 chrysopyga, 322

Crocodile River, I4-I8, 57 farms on the, 39

Crocodiles, 69, 79, I05, I62

Crow, White-backed, 3 I 6

Cucullido, 305

Cucultus clamosus, 305 cuprezes, 305

Cuckoo, Black, 305

Golden, 305

Lark-heeled, 505

Le Vaillant's, 305

White-eyebrowed Lark-heeled, 305

Curculionide, 362

Cyllo Leda, $35^{\circ}$

Cynthia Cardui, 349

Cypholoba alveolata, 359

7-guttata, 359

Cypselida, 301

Cypselus apus, 30 I

DACHA, hemp used for smoking, 193

Daka River, 240, 242, 243, 245, 247

Damaraland, elephants in, 75,80

Danais Chrysippus, 350

Dance, the Great, 98-104 preparations for, 96-98

Darter, Le Vaillant's, 328
Dawnay, the Hon. G. C., $3^{8}$

Dendropicus cardinalis, 306 namaquzus, 306

Denekia capensis, 367

Derospharius anthracinus, 362

Diadema Misippus, 349

Diamphidia fenoralis, 363

Dichtha inflata, $36 \mathrm{I}$

Dick (Kafir driver), 3I, IO7-II3, I 42

Diclis reptans, 368

Dicrocercus himundinaceuts, 302

Dicruride, 3 I 5

Dilophus carninculatus, 3 I 6

Dobie, Mr., I68, I76, note

Dog, tame, run wild, story of, $20 \mathrm{I}$

Dogs, Lobengula's, 107, I I 4 ferocity of, 98, II I

Dorehill, Mr., I84-187, 226-242

Dove, Cape Turtle, 322

Emerald-spotted, 322

Long-tailed African, 322

Dromica Oatesii, 359

Drongo, African, 315

Dryiophida, 329

Dryiophis Oatesii, 329, 330

Dryoscopus boulboul, 3 I 2 cubla, 3 I 2

Drypta jucunda, 359

Du Chaillu, M. Paul B., reference to, 288, note

Duck, Yellow-billed, 327

Dwarf Goose, African, 327

Dwarf Heron, Black-headed, 326

Dynastida, 360

EAGLE Owl, Spotted, 299

Verreaux's, 299

Echle, native hunter, 78,85

Ecker, Professor A., reference to, 279

Egret, Short-billed, 326

Eland's River, I4

Elanus caruletus, 298

Elateridce, 36 I

Elephant guns, Lee's views upon, 49

Elephants, 30, 50, 75, 76, 77, 84, I 29, I 40, I 96,203

large tusks of, $8 \mathbf{I}$

Entomology, by Professor J. O. Westwood, M.A., F.L.S., etc., 330 et seq.

Erebia Narycia, $35^{\circ}$

Erica, sp., 367

Eriosema, sp., 366

Erythrina, sp., 366

Eskimo skulls, 275, 281 
Estrelda astrild, 320

cyanogastra, 32 I

erythronota, 320

granatina, $32 \mathrm{I}$

Ethnology, by Professor Rolleston,

M.D., F.R.S., 274 et seq.

Eugaster loricatus, 363

Euphorbia, sp., 368

Euphorbias, 46, note; 58, note

Euplectes capensis, 330 oryx 320

Enpodotis carulescens, 326 cristata, 326

Eurocephalues anguitimens, 314

Eurystomus afer, $3 \mathrm{O} 2$

Euscmia adulatrix, 355

cmulatrix, 355

glossatrix, 356

meretrix, 355

niveosparsa, 355

nugatrix, 356

pardalina, 355

Evolvulus alsinoides, 367

FADOGIA ZEYHERI, 367

Fairbairn, MIr. J., 52, 59, 62, 93, 109I I $3, I_{50}, 162,168$

Falco biarmicus, 298 minor, 299

Fantail Warbler, Brown, 309

Common, 3 Io

Larger Greybacked, 309

Le Vaillant's, 309

Smith's, 309

Finch, Amadavat, 32 I

Black-cheeked, 320

Little Barred-breasted, 32 I

Scutellated, 319

Wax-bill, 320

Fires in the veldt, 54, 193

Fish held in abomination, I I I in the sand at Tati, 29

Flamakinyani, 342

Flies, annoyance from, $35,38,230$

Flirt, one of Mr. Oates's pointers, I 59

Flower, Professor, measurements of

Bushman crania by, 292 reference to, $278,28_{3}, 28_{5}, 286$

Fly-catcher, Eastern Xellow-eyed, 3 I I Red-crested, $3 \mathbf{I}$ I

South African Paradise, 3 II

Francolin, Grey-winged, 323

Natal, 323

Pileated, 323
Francolinus afer, 323

natalensis, 323

pileatus, 333

Fringillaria capensis, 322 flaviventris, 322

Fringillida, 320

Fritsch, Dr. Gustav, reference to, 286, 288,289

Frogs, noise from, at night, 40

Fulica cristata, 324

GALLINULA ANGULATA, 324

Game-drive, Makalaka, 233

Garden, Captain and Mr., I40,

Geigeria Zeyheri, 367

Gerbera natalensis, 367

Gerual, 242, 260

Gilchrist, Mr., journey to Tati and retum to England, 3-4I

second journey to South Africa, 265-270

visits Mr. Oates's grave, 269

brings his effects to England, 267

Gladiolus, sp., 368 brevifolius, 368

Glareola melanoptera, 325

Glareolida, 325

Glaucidium perlatum, 300

Glossina morsitans, 363

Glossy Thrush, Meves's, 3 I 7

Red-shouldered, 317

Smith's, 3 I 6

Verreaux's, 316

Goatsucker, nest of, 76

Gokwe River, 25, 28, 2 I 9

Goose, Knob-billed, 327

Goshawk, Chanting, 298

Many-banded, 298

Red-faced, 298

Graculus africants, 328

Grapes, wild, 49, 9 I

Graphipterns cordiger, 359

Westwoodii, 359

Grass-owl, South African, 300

Grasshoppers, 363

Gratiolet, M. P., reference to, 280

Gray, Mr. Henry, 3-I9

death of, at Lake Ngami, 157

Grebe, Little, 328

Greenshanks, 325

Griquas, party of, 235

Grosbeak, Angola, 322

Golden-rumped, 322

Striped-headed, 322 
Ground beetles, carnivorous, 358

Gruber, Prof. W., reference to, 280 , note

Gubuleweyo, 58-62, 89, 92-108, I 83I 88

Guinea-fowl, tame, story of, 201

Günther, Albert, M.A., Ph.D., M.D., F.R.S., descriptions of two new species of snakes obtained by $\mathrm{Mr}$. Oates, by, 329

Gwailo River, 72, 75

Gymnopleumus fulgidus, 359

Olivierii, 359

speciosus, 309

HCEMANTHUS, sp., 368

Halcyon albiventris, 303

chelicutensis, 303

cyanoleuca, 303

semicarulea, 303

Hanaticherus denticomis, 363 sericeus, $3^{6} 3$

Hamy, Dr. E. T., reference to, 274

Hartmann, Dr. R., quoted, $28 \mathrm{~s}$ reference to, 287

Hathorn, Mr. F. A., 20, I49, 204 undertakes the duties of executor after Mr. Oates's death, 270

Hawk-moth, Death's-head, 353

Hawk-moths, Silver-striped, 354

Head-dresses, native, variety of, 56

Hebenstreitia, sp., 368

Helmet-shrike, South African, 3 I 4

Helopide, 362

Heliocantharus intricatus, 359

operosus, 359

transversus, 359

Hemipode, Kurrichaine, 323

Hendrik, native servant, $3 \mathbf{I}, 34, \mathbf{I} 42$

Hepburn, Mr., 2I, I 49

Heron, Black-headed Divarf, 326

Black-throated, 326

Buff-backed, 327

Purple, 326

Red-bellied, 327

Sturm's, 326

Herodius intermedia, 326

Herpetology, by Albert Günther,M.A., Ph.D., M.D., F.R.S., 329

Hesperizda, 352

Hex River, I 4

High Veldt, the, 7-9, I 2, 40

Hirundinida, $3 \mathbf{I} \mathbf{I}$

Hirundo cuczullata, $3 \mathbf{I} 2$ puella, $3 \mathbf{I} \mathbf{I}$
Hirundo mustica, 312 semirufa, 3 I 2

Histerida, $36 \mathbf{I}$

Holfontein, I4

Honey-guide, White-eared, 305

Hoopoe, South African, 304

Hope Fountain, 61 , 62, 66, 86

Hoplopterus speciosus, 325

Horn, Mr, 208

Hornbill, African Grey, 304 nest of a, I 3 I

note of the, 24

Yellow-billed, 304

Horse-sickness, 40, 48, $236-238$

Horses, "salted," value of, 40,48 , 89,187, I 91

Hottentot skulls, 277, 280, note

" Hottentotten-Schurze," the, not confined to African races, 288

Hyænas, ox attacked by, 35

Hypanis Ilithyia, 350

Hyphantornis capensis, 3 i 8

mariquensis, 319

nigrifrons, 319

ocularis, 3 I 8

olivaceus, 318

Hypoestes Forskahlii, 368

verticillaris, 378

Hypomeles rugosus, 362

Hypoxis villosa, 368

IDMAIS ERIS, 337

Vesta, 337

Impakwe River, 44, 45, I3 I, I 32, 2 I7

Inchlangin, 68

Indicator Sparmanni, 305

Indicatoride, 305

Induna, a rebellious, 209

Indunas' Tree, the, 83

Inhlala, wild fruit, 90

Inkwesi River, 45, I29-I 31, I43, I85, 208

Inquinquesi River, 68

Intembin, 73

Inyati, 64, 68, 7o, 72, 85

Irrisor crythrorhynchus, 304

Ismene Pisistratus, 35?

Iynx pectoralis, 306

JACANA, Lesser African, 324

Jacob, I 07-I I 3, I 42

Jacobs, Piet, I36, I40, 231, 263-268 his house at Tati, 200

Jana Mariana, $35^{8}$ 
Jasminum, sp., 367

John, native interpreter, 65, I I8, I 53, I 81,188

Junonia Clelia, 349

Cloantha, 349

Hecate, 349

natalica, 349

Octavia, 349

Enone, 349

Orithya, 349

KAFIR PLUM, I 3 I

Kafirs, Mr. Oates threatened by, I 66 various traits of, $13,125,156$, I $64,165,218,221$

Kalmuck music, 290, note

Kama, I 55

Kamani, I 55

Kennedy, Stoffel, 188-197, 207-211, 226-242

Kestrel, Eastern Red-footed, 299

Lesser, 299

South African, 299

Khoi-Khoin race, Mongolian origin ascribed to, 288

possible argument for their affinity with Papuans and Malays, 291

Kingfisher, African White-headed, 303

Angola, 303

Brown-hooded, 303

Great African, 303

Malachite-crested, 303

Pied, 303

Striped, 303

Kirk, Dr., reference to, 295

Kite, Black-shouldered, 298

Yellow-billed, 298

Klaas, Hottentot hunter, I 28-I37

Klaas, waggon-driver, 198, 199, 218

Klipspringers, 195

Knob-kerries, 94 note

Kumala River, 97, I 77

LACORDAIRE, M. J. Theod, reference to, $33 \mathrm{I}$

Lagonosticta minima, $32 \mathrm{I}$

Lamprocolius phanicopterus, 316

Lamprotonis anstralis, $3 \times 6$ Mevesi, 316

Laniarins atrococcinces, 312 bakbakiri, 312

senzegalus, 313

sulphureipertus, 2 I 2

trivirgatus, 313
Laniide, $3^{12}$

Lanizs collaris, $3 \mathrm{I} 3$

collurio, $3 \mathbf{I} 3$

minor, $3 \mathbf{I} 3$

Lanner, South African, 299

Lantana (or Lippia), sp., 368

Lark, Grey-collared, 317

Sabota, 3 I 8

South African, 317

South African Rufous-capped, 3 I 8

Lark-heeled Cuckoo, 305

White-eyebrowed, 305

Laurillard, C. L., quoted, 282 , note

Lee, John, 42, 47-5 I, I I 2-I I 5, I 26, 127

his farm, $47-49,127$

fine scenery near, 125

Lee, Karl, I 28, I 37, I 53, note

Lelongwe River, 72, 73

Leonotis Leonumus, 368

Leucochitonea Levebu, 353

Leydenburg gold-fields, Io

Linlacodes argentifera, 358

Limosella tenuifolia, 368

Lions, I 7, 31, 60, I40, 164, 172, 208 flesh of, 174

Lippia asperifolia, 368

Lissochilus, sp., 368

Livingstone, Dr., reference to, 254260

Lobelia decipiens, 367

Lobengula, 59-65, 94-I15, 141, 183I 87

despotic power of, 36,63

equivocal conduct of, I 70 , I $\$ 6$

his dress and appearance, 103:

I I I, I I 5

his objection to Boer hunters, 223

his sister, 60, 99

his wives, 99, I 12

punishment of his subjects, 69 ,

I $13,129,168$

Locusts, $36_{3}$

value of, as food, 17, 19, 127

Long-claw, Cape, 317

Longicorn beetles, 362

Lotsani River, 23

Lubbock, Sir John, reference to, 29I

Lycana Asopus, 352

Asteris, $35^{2}$

Jesous, 352

Lochias, 352

Parsimon, 352

Lyeconida, $35 \mathrm{I}$

Lyperia Burkana, 368 
Mackenna, John, 24I, 248-25 I, 263 Meriko River, 37

Mackenzie, Rev. John, 2 I, 37, I 49, 264 extract from a letter of, $27 \mathrm{I}$ undertakes the duties of executor after $\mathrm{Mr}$. Oates's death, 270

Macloule, Mosilikatze's nephew, 76, $85,88,96$

Macronyx capensis, 3 I 7

Maholies, natives near the Lelongwe, 73

Makabo, Matabele guide, I83, I86, I 93, 194, 207, 212

Makalaka words and phrases, list of, 370

Makalakas, the, I78-I82, I96-I99, 2 II -2 I 6

their state of subjection, 152,185 , 222

obstructive conduct of, I70, I80

Makobi, Bamangwato chief, 45

Makobi's kraal, I 29

Malabars, skulls of, 28I

Malays, skulls of, 28 I

Mandy, Mr., of Inchlangin, 69, 93, I05

Manéko, wild fruit, 90

Mangwe River, I 23

Manticora latipennis, 359

Manyami, 5I-53, 55, I 2I, 207

Marabastadt goldfields, the, Io

Marsh-harrier, South African, 297

Marshall, Professor John, reference to, 280

Marula, wild fruit, $13 \mathbf{r}$

Mashonas, their dress and demeanour, I 19

their gradual absorption by the Matabele, $\mathbf{I}_{52}$

Matabele raids against, 59,79

Matabele, the, $45,49,54,79$, I I I

best articles for trade with, 45, 53

kingdom, extent and products of, 36,62

their ruthless treatment of Bushmen, 222

the Mashonas and Makalakas in bondage under them, 79, I 52

warriors, Mr. Oates threatened by, I 92,2 I 4

Matchin, Bamangwato attacked by, 155

Matengwe River, 235, 236, 238, 242

Melierax canoms, 298

gabar, 298

Melolonthida, 360

Menon, Makalaka headman, 235

Meropida, 301

Merops apiaster, $30 \mathbf{I}$

bullockoides, 39 I

mubicoides, 301

pusillus, $30 \mathrm{I}$

superciliosus, 301

Metse-a-tunya, I 43, 248, 250, 259. See also Victoria Falls.

Mimosas, 33

Milvins agyptins, 298

Mirafra africana, 317

sabota, 3 I 8

Mohr, Edward, reference to, 254

Mohrib caffromum, 369

Moluris albipes, $36 \mathrm{I}$

gibbosa, 36 I

Perretii, $36 \mathrm{i}$

Monticola explorator, 308

Moon, eclipse of, 84

Moor-hen, South African, 324

Mopani Pan, 229

veldt, $\mathbf{1} 76$

Mosilikatze, 49, 62

his wives, at the Great Dance, 98

Motacilla aguimp, 3 I 7 capensis, $3 \mathbf{I} 7$

Motacillida, 3 I 7

Motloutsi River, 26-28, I62

Mozanga, native servant, grief of, 182

Müller, F, reference to, 291

Murie, Dr. James, reference to, 286, 288, note

Muscicapide, 3II

Musician, native, at the Semokwe, I43

Musophagida, 304

Mycalesis Victorina, $35^{\circ}$

Myrmecocichla formicivora, 307

Myrmeleon Libelluloides, 363

NATA River, 242

Nectarina famosa, 3 10

Nectarinizide, $3 \mathbf{1 0}$

Negro skulls, 274, 275, 278, 279, 28I

Nelson, Mr., experiences of, $75^{-82}$

Nelson, Mr., of Tati, 29, 33, 35, I 39

Neophron pileatus, 297

Nephrodium molle, 369

(Lastrea), sp., 369

Nephrolepis cordifolia, 369

exaltata, 369

Nettapus auritus, 327

New Year's Day at Hope Fountain, 93 
Newcastle, 6, 7

Ngami, Lake, fever at, I 57

Nidorella auriculata, 367

Night-hawk, call of the, 24

Nightjar, European, 300

Mozambique, 300

Rufous-cheeked, 300

Standard-winged, 30 I

Nina, sister of Lobengula, 97, I I I-I I 3

Nose-bleeding, native cure for, 78

Notuani River, I 5

Nymphalida, 349

OAtes, Mr. F., arrival at the Tati settlement, 29

journeys towards the Zambesi, 42-

138, I69-191, I92-226

arrival at the Victoria Falls, 252

attacked by fever, 261

his death, 263

Oates, Mr. W. E., accompanies his brother to the Tati, and returns to England, I-4I

second journey to South Africa, $265-267$

Ocymum (or Orthosiphon), sp., 368

Edicnemus capensis, 326

Ena capensis, 322

Oliver, Professor, F.R.S., F.Z.S., on the plants collected by Mr. Oates, 366-369

Onitis ciliatus, 359

inutus, 359

Oranges, 4, 8, 39, 49

Oriole, Golden, 315

Oriolida, $3 \mathbf{I} 5$

Oriolus galbula, 3 I 5

Ornithology, by Mr. R. Bowdler Sharpe,

F.L.S., F.Z.S., etc., $294 \mathrm{ct} s \mathrm{sq}$.

Orthogonizs caffer, 359

Ortygometra crex, 324 egregia, 324

Ortygospiza polyzona, 321

Oryctes Boas, 360

Os (Malare) bipartitum, literature of, 282 , note

Ostrich eggs, best mode of cooking, 24

Ostriches, young, 79

Otididee, 326

Otis kori, 326

Otogyps auricularis, 297

Owen, Professor R., reference to, 274, 278

Owl, African Short-eared, 300
Owl, Barn, 300

Spotted Eagle, 299

Verreaux's Eagle, 299

White-faced Scops, 299

Owlet, African Pearl-spotted, 300

Oxythyrea discicollis, 360 heemorrhoidalis, 360

PACHNODA OBSOLETA, 360

Pachylomera femoralis, 359

Palatswe River, 23, I61

Pallas, P. S., quoted, 286, 290, irote

Palpares citrinus, 363

Pamphagus haploscelis, 363

Pamphila Harona, 333

Ranoha, 353

Panicum (Tricholcna) roseum, 369

Pantamatenka, the, 243, 245, 249, 260

Papilio Aurota, 336

Celaus, 352

Demodocus, 335

Demoleus, 335

Eborea, 237

Evippe, 337

Gorgias, $35^{2}$

Folaus, 352

Papilionide, 335

Paride, 3 Io

Parisoma subcarulentm, 3I I

Parra capensis, 324

Parrot, Le Vaillant's,`306

Meyer's, 307

Panus afer, 3 Io

niger, 3 I I

Passer diffusus, $32 \mathrm{I}$

motitensis, $32 \mathbf{I}$

Paussida, $36 \mathbf{1}$

Peaches, 4, I0, 39, 49

Pelecanida, 328

Pellaca consobrina, 369

Petersen, Mr., 43, 44, 59, 93

Penthetria albinotata, 319 ardens, 320

Perdicida, 323

Peregrine Falcon, South African, 298

Pctasia crucntata, 363

Petroleum, useful against insects, 364

Pencedanum capense, 367

Philomachus pugnax, 325

Pholidanges Verreanxi, 316

Phoxomcla umbrosa, 360

Phrissoma gigantcum, 363

Phyllostrophus capensis, 308 
Phytophagus (or plant-eating) beetles, 363

Picida, 306

Pieris Mesentina, 336

Polycaste, 337

Severina, 336

Thysa, 337

Pietermaritzburg, 2-6, 4I

Pipit, Cinnamon-backed, $3 \mathbf{I} 7$

South African, 3 I 7

Plantain-eater, Grey, 304

Pleuropterus alternans, $36 \mathrm{I}$

Ploceida, $3 \mathbf{I} 8$

Plocepasser mahali, $32 \mathrm{I}$

Plotus Levaillantii, 328

Plover, Blacksmith, 325

Treble-collared, 326

Wreathed, 325

Podiceps minor, 328

Podicipida, 328

Pacilonetta erythrorhyncha, 328

Pogonorhynchus leucomelas, 305

Poison-plant, 243

Poliospiza gularis, 322

Polygala virgata, 366

Polyhirma amabilis, 359 macilenta, 359

Polyommatus Otacilia, $35 \mathrm{I}$

Sybaris, 352

Telicanus, $35 \mathrm{I}$

Pomegranates, 49

Pontia Acaste, 337

Evarne, 338

" Poort," the, Tati River, 196, 233

Porphyris Alleni, 324

Potatoes, 49

Præaryan skulls, 28 I

Pratincola torquata, 3 I I

Pratincole, Black-winged, 325

Pretoria, 6-I4, 37

Prionopida, 3 I 4

Prionops talacoma, 314

Psittacida, 306

Psittacus Meyeri, 306 robustus, 307

Pterocles bicinctus, 323 gutturalis, 323

Pteroclide, 323

Ptychopteryx Bohemani, 336

Pycnonotince, 308

Pycnonotus Layardi, 308 nigricans, 308

Pytelia melba, 320
QUAGGA, large herd of, 194

Quail, Common, 324

Harlequin, 324

"Quilp," Bushman servant, I 52

RaIL, Mr. Oates's favourite pointer, 43,89, I 59, I60, 226, 267, 268, note

return of, to the grave, after his master's death, 265

Rains, commencement of the, 37, 6I, $7 \mathrm{I}, 205,220,224,24 \mathrm{I}$

Rallida, 324

Ramaqueban River, 43, I3 I, I33-I 38 , I 43, I 72-I 74, I 92-195, 208-2 I I, $217,229-231$

graves of Englishmen at the, I 34

Ranunculus pinnatus, 366

Red-faced Finch, Southern, 320

Reed-warbler, White-breasted, 3 Io

Retzius, Professor A., reference to, 274, 277, 278

Rhinoponastes cyanomelas, 304

Rhopalocampta Valmaran, 352

Rock, one of Mr. Oates's pointers, $43,89,226,235,267,268$, note

Rock-thrush, Sentinel, 308

Roller, Cinnạmon, 302

European, 302

Lilac-breasted, 302

White-naped, 302

Rolleston, Professor, M.D., F.R.S., on Bushman and other bones obtained by Mr. Oates, 274-293

Rose chafers, 360

Roses, monthly, 8

Ruff, 325

SABLE antelope, young, 50

Sagra festiva, 363

Sakasusi, or Dry River, I43, I 46

Salt lakes, in winter, I 47 , note

Sand-grouse, Double-banded, 323 Yellow-throated, 323

Sand wasps, 363

Sandifort, E., reference to, 277

Sandpiper, Common, 325

Wood, 325

Sarkidiornis melanonotns, 327

Saturnia Alcinö, 356

caffra, 356

Caffraria, $35^{6}$

cervina, 357 
Saturnia Dyops, 357

flavida, 357

Hyperbius, 357

Terpsichorina, 357

Saturniide, 356

Satyride, 350

Saxicola Galtoni, 307

lencomelana, 308

pileata, 307

Shelleyi, 295, 307

Scarabcida, 359

Schiess-Gemuscus, Professor, reference to, 289

Schizarhris concolor, 304

Schlocker, H., reference to, 280 , note

Schweinfurth, Dr. Georg, reference to, 288 , and note

Scolopacida, 325

Scops leucotis, 299

Scops Owl. White-faced, 299

Scopus zimbretta, 327

Sekomi, I6, I 9, 37, 39, 155

Selous, Mr. F. C., 104, I51, 238-242, 266

Semokwe River, 36, I40, 143-146

Seribi River, 26

Seruli River, 24

Sesia Hylas, 354

Sharpe, Mr. R. Bowdler, F.L.S., F.Z.S., etc., on the birds collected by Mr. Oates, 294 et seq.

Shashani River, 54, 55, I I 7, I 20

fine scenery near the, I I 7-I I 9

Shashe River, 28, 31, 147, 162 course of the, 176 , note

Short-eared Owl, African, 300

Shoshong, 16. See also Bamangwato

Shrike, Black-and-white Long-tailed, 313

Collared, $3 \times 3$

Lesser Grey, $3 \mathbf{I} 3$

Red-backed, 313

Silpha micans, $36 \mathbf{1}$

Silphida, 36 I

Skelton, MIr. H., the late, 204

Smelting funiace, native, 132

Smith, Mr. W., Dutch hunter, 44-47, 128.136

Snakes, 162

Solanum subexarmatum, 367

Solomon, native waggon-driver, 39, 143

Sparrow, Greater South African, 321

Southern Grey-header, 321
Sphingide, 333

Sphenorhynchus Abdimii, 327

Spilophornes plagosus, 360

Spindacis Massilicatzi, $35 \mathbf{I}$

Sporopipes squamifrons, 319

"Stamped" corn, I 30

Starling, Brown, 3 I 6

Cape, 316

Wattled, 3 I 6

Stone Age crania, 28 I

Stone-chat, South African, 3I I

Stork, White, 327

White-bellied, 327

Strigida, 300

Strix capensis, 300

flammea, 300

Sturnide, $3 \mathrm{I} 6$

Sun-bird, Greater Double-collared, 3 Io

Malachite, 3 Io

Scarlet-chested, 3 Io

Southern Bifasciated, 3 Io

Sunsets, fine, 27, I I 7

Sutherlandia frutescens, 366

Swallow, Common, 3I 2

Large Striped-breasted, 312

Red-breasted, 3 I 2

Smaller Striped-breasted, 3I I

Swinburne, Sir John, 29, 34

Swift, Common, 301

Sicrobrotas bicolor, $3 \mathrm{I} 8$

Sylvietta mufescens, 3 Iо

TABANIDAE, 363

Tabanus Africanuls, 363

Tachyris Agathina, 337

Tamasancha, 235, 242, 246

Tamasetsie, 242

Tamils, skulls of, $28 \mathrm{I}$

Tasmanian skulls, 28I

Tati gold-fields, 10

River, I74, 175, 195, 196, 233

settlement, 29-36, I 39-I 4I, 146, I 6 I-I69, I 83-I 92, I 99-268

T'chakani Vlei, I6I

Tchangani River, 73

Teal, Red-billed, 328

Tenebrionida, 36

Tephrocorys cinerea, 3 I 8

Teracolis Agoye, 336 subfasciatus, 336

Torias Rahel, 342

Seruli, 342

Zö̈, 342

Terpsiphane persficillata, $3 \mathbf{I I}$ 
Tetralobus bifoveolatus, $36 \mathrm{I}$

Textor erythrorhynchius, 3 I 8 nests of, II 7

Thick-knee, Spotted, 326

"Thirst Land," the, 30

Thomson, Rev. J. B., 59, 61, 64, 86, 93, 99, I 39, I40, I 49, I87, I 88, note, 197

Thorns, annoyance from, in travelling, 33,35

Thrush, Cape Bristle-necked, 308 South African, 307

Tibakai, Bamangwato headman, 250

Timeliide, 308

Timeliince, 308

Titmouse, South African, 3 Io Southern Black-and-white, 3 I I

Tobacco-gardens, I $78, \mathbf{1} 82$

Tockus flavirostris, 304 nasutus, 304

Topinard, Dr. P., reference to, 290

Tortoises, superstition regarding, 78

Totanus canescens, 325 glareola, 325

Touani River, 23

Trachyphonus cafer, 306

Transvaal, the, 6-I 5, 37-39

Trees, flowering, 53, 68, 69

Trescott, Mr., 244

Trichodesma physaloides, 367

Trimen, Mr. Roland, reference to, 333

Triumfetta Welwitschii, 366

Tsetse-fly, the, $38,48,363-365$ precautions against, 364

Turdida, 307

Turdus litsitsinupa, 307

Tumix lepurana, 323

Turtle-dove, Cape, 322

Turtur capicola, 322

UMBre, Tufted, 327

Umgeni River, 6

Umgwanya River, 72, 75

Umtegan, Matabele headman, 59

Umvungu River, 72, 74, 83, I4I

Upupa africana, 304

Upupida, 304

Urolestes melanolencus, 313

VAHLIA CAPENSTS, 367

Van Roozen, I58, I59, I64-I68, I 72I 74, I88, 23I, 232

Victoria Falls, approach to, 250-252 description of, $254-260$
Vidua principalis, 319

regia, 319

Verreauxi, $3 \mathbf{1 9}$

Vincent, Mr., I 22-I 24, I 43

Vitis, sp., 366

Vulture, Eared, 297

Hooded, 297

Vulturida, 297

WAGGON-DRIVERS, IO3, 218

Wagtail, African Pied, 317 Cape, $3 \mathbf{I} 7$

Wahlenbergia Banksiana, 367

Waitz, Th., reference to, 288 , note

Wallace, Mr. A. R., reference to, 33 I

Wankee, native waggon-driver, 98, I I 9I 2 I

Wankee's kraal, I 78, I 96, 234

Warbler, Brown Fantail, 309

Common Fantail, 3 Io

Larger Grey-backed Fantail, 309

Le Vaillant's Fantail, 309

Smith's Fantail, 309

White-eyebrowed, 309

Water, scarcity of, I6, I 8, 34, I 5 I, note, 2 I9

Water-hen, Allen's Blue, 324

Wax-bill, Grenadier, 32 I

Red-headed, 320

Weaver-bird, Black-fronted, 319

Cape Yellow, 3i 8

Mariqua, 3I 9

Natal Black-and-yellow, 3 I 8

Olive-and-yellow, 3 I 8

Red-billed Black, 3 I 8 nest of, I 77

Smith's, 3 I 8

White-browed, 32 I

Weevils, 362

Westbeach, Mr., 244, 245, 260, 26I

Westwood, Professor J. O., M.A., F.L.S., etc., on the insects collected by Mr. Oates, 330 et seq.

Wheatear, Burchell's, 308

Capped, 307

Shelley's, 295, 307

Southern Ant-eating, 307

White ants, I 34

Whitwell, Rev. J. S., reference to, 291

Whydah-finches, 220, note

Widow-bird, Cape Black-and-yellow, 320

Common, 3 I 9 
Widow-bird, Great, 319

Orange-throated, 320

Shaft-tailed, 319

Verreaux's, 319

White-spotted, 319

Wild dogs, I19, 200, 234

fruit, 49, 89-91, 1 77, 233

pigs, $15,82,134,242$

Williams, Rev. J., reference to, 29I

Williamson, Dr., reference to, 280 , note

Wood, Mr. George, I 5 I, 238-242

Wood, Rev. J. G., reference to, 288, note, 290

Wood-boring beetles, $36 \mathrm{I}$

Wood-hoopoe, Red-billed, 304

Scimitar-billed, 304

Woodpecker, Bearded, 306

Bennett's, 306

Cardinal, 306

Golden-tailed, 306
Woodpecker, Smith's, 306

Wood-shrike, Oates's, 314 Smith's, 3 I 4

Wormskioldia longepedunculata, 367

Wryneck, Red-breasted, 306

Wyman, Prof. Jeffries, reference to, 286

YPTHIIIA NAREDA, $35^{\circ}$

Zambesi, the, fever at, 188, 235, 239, 244,260

worst months for, I $89,238-240$, 247

Zeritis Amanga, $35 \mathrm{I}$

Perion, $35 \mathbf{I}$

Zimmermann, reference to, 29 I

Zygena tricolorata, 354

Zyganide, 354

Zygophyllum Dregeanum, 366

Zulu skulls, 278, 28 1, 285, 286

THE END. 

A LIST OF

C. KEGAN PAUL \& CO.'S PUBLICATIONS. 


\section{A LIST OF \\ C. KEGAN PAUL \& CO.'S PUBLICATIONS.}

ADAMS (F. O.) F.R.G.S.-The History of Japan. From the Earliest Period to the Present Time. New Edition, revised. 2 volumes. With Maps and Plans. Demy 8vo. price 2Is, each.

ADAMSON (H. T.) B.D.-The Truth as it is in Jesus. Crown 8 vo. cloth, price $8 s .6 \%$.

The Three Sevens. Crown 8vo. cloth, price $5 s .6 d$.

A. $K$. H. B.-From a Quiet Place. A New Volume of Sermons. Crown 8 vo. cloth, price 5 s.

ALBERT (Mary).-Holland AND HeR HeRoes to THE yeAR I585. An Adaptation from 'Motley's Rise of the Dutch Republic.' Small crown 8vo. price $4 s .6 d$.

ALLEN (Rev. R.) M.A.-Abraham; his Life, Times, and Travels, 3, 800 years ago. With Map. Second Edition. Post 8vo. price 6s.

ALLEN (Grant) B.A.-Physiological Esthetics. Large post 8vo. 9s. ALLIES (T.W.) M.A.-Per Crucem ad Lucem. The Result of a Life. 2 vols. Demy 8 vo. cloth, price $25 s$.

A Life's Decision. Crown 8vo. cloth, price $7 s .6 d$.

ANDERSON (R. C.) C.E.-Tables for Facilitating the Calculation of Every Detail in CONNECTION Witth EARTHEN aNd Masonry DAMs. Royal 8vo. price $£ 2.2 s$.

ARCHER (Thomas)-About my Father's Businfss. Work amidst the Sick, the Sad, and the Sorrowing. Cheaper Edition. Crown 8vo. price 2s. $6 d$. ARNOLD (Arthur)-Social Politics. Demy 8vo. cloth, price i 4 s.

Free Land. Crown 8vo. cloth, price $6 s$.

BADGER (George Percy) D.C.L.-An EngLish-Arabic Lexicon. In which the equivalent for English Words and Idiomatic Sentences are rendered into literary and colloquial Arabic. Royal 4to, cloth, price $69.9 s$.

BAGEHOT (Walter)-The English Constitution. A New Edition, Revised and Corrected, with an Introductory Dissertation on Recent Changes and Events. Crown 8vo. price 7s. $6 d$.

Lombard Street. A Description of the Money Market. Seventh Edition. Crown 8vo. price $7 s .6 d$.

Some Articles on the Depreciation of Silver, and Topics CONNECTED With IT. Demy 8vo. price 5 s.

BAGOT (Alan)-Accidents in Mines: Their Causes and Prevention. Crown 8vo. price $6 s$. 
BAKER (Sir Sherston, Bart.)-Halleck's International Law ; or, Rules Regulating the Intercourse of States in Peace and War. A New Edition, revised, with Notes and Cases. 2 vols. Demy 8vo. price $38 s$.

The Laws Relating to Quarantine. Crown 8vo. cloth, price i $2 s .6 d$. BALDWIN (Capt.J. H.) F.Z.S. Bengal Staff Corps.-The LaRge AND Small Game of Bengal and the North-Western Provinces of INDIA. 4to. With numerous Illustrations. Second Edition. Price 2Is.

BARNES (William)-An Outline of English Speechcraft. Crown 8 vo. price 4 s.

Outlines of Redecraft (Logic). With English Wording. Crown 8vo. cloth, price 3 s.

BARTLEY $(G . C . T$.)-Domestic Economy : Thrift in Every-Day Life. Taught in Dialogues suitable for children of all ages. Small cr. 8vo. price $2 s$.

BAUR (Ferdinand) Dr. Ph., Professor in Maulbromn.-A Philological Introduction to Greek and Latin for StUdents. Translated and adapted from the German. By C. Kegan PaUl, M.A. Oxon., and the Rev. E. D. Stone, M.A., late Fellow of King's College, Cambridge, and Assistant Master at Eton. Crown 8vo. price $6 s$.

BA YNES (Rev. Canon R. H.)-At the Communion Time. A Manual for Holy Communion. With a preface by the Right Rev, the Lord Bishop of Derry and Raphoe. Cloth, price $1 s .6 d$.

BELLINGHAM (Henry) M.P., Barrister-at-Law-Social Aspects of Catholicism and Protestantism in their Civil Bearing úpon Nations. Translated and adapted from the French of M. le Baron de Haulleville. With a preface by His Eminence Cardinal Manning. Second and Cheaper Edition. Crown 8vo. price $3 s .6 d$.

BENT (J. Theodore)-GeNOA : How the Republic Rose and Fell. With I8 Illustrations. Demy 8vo, cloth, price I8s.

BONWICK (J.) F.R.G.S.-Pyramid Facts and Fancies. Crown 8vo. price 5 s.

Egyptian Belief and Modern Thought. Large Post 8vo. cloth, price Ios. $6 d$.

BOWEN (H. C.) M.A., Head Master of the Grocers' Company's Middle Class School at Hackney.

Studies in English, for the use of Modern Schools. Small crown 8vo. price Is. $6 d$.

English Grammar for Beginners. Fcap. 8vo. cloth, price is. BOWRING (Sir John).-Autobiographical Recollections of Sir John Bowring. With Memoir by Lewin B. Bowring. Demy 8vo. price I 4 s. BRIDGETT (Rev. T. E.)- History of the Holy Eucharist iN GREAT BRITAin. 2 vols. demy 8vo. cloth, price I8s.

BRODRICK (the Hon. G. C.)-Political Studies. Demy 8vo. cloth, price I 4 s.

BROOKE (Rev. S. A.) M.A., Chaplain in Ordinary to Her Majesty the Queen, and Minister of Bedford Chapel, Bloomsbury.

Life and Letters of the Late Rev. F. W. Robertson, M.A., Edited by.

I. Uniform with the Sermons, 2 vols. With Steel Portrait. Price $7 s, 6 d$.

II. Library Edition. 8vo. With Portrait. Price I2s.

III. A Popular Edition. In I vol. 8vo. price 6s. 
BROOKE (Rev. S. A.) M.A.-cont.

The Fight of Faith. Sermons preached on various occasions. Third Edition. Crown 8vo. price $7 s .6 d$.

Theology in the English Poets.-Cowper, Coleridge, Wordsworth, and Burns. Fourth and Cheaper Edition. Post 8vo. price $5^{s .}$

Christ in Modern Life. Fourteenth and Cheaper Edition. Crown 8 vo. price 5 s.

Sermons. First Series. Eleventh Edition. Crown 8vo. price $6 s$.

Sermons. Second Series. Third Edition. Crown 8vo. price $7 s$.

Frederick Denison Maurice: The Life and Work of. A Memorial Sermon. Crown 8vo. sewed, price Is.

BROOKE (W. G.) M.A.-The Public Worship Regrlation Act. With a Classified Statement of its Provisions, Notes, and Index. Third Edition, revised and corrected. Crown 8vo. price 3s. $6 d^{\text {. }}$

Six Privy Council Judgments-1850-72. Annotated by. Third Edition. Crown 8vo. price $9 s$.

BROUN ( $J . A$.$) -Magnetic Observations at Trevandrum and$ Augustia Malley. Vol. I. 4to. price 63 s.

The Report from above, separately, sewed, price $21 s$.

BROWN (Rev. J. Baldwin) B.A.-The Higher Life. Its Reality, Experience, and Destiny. Fifth Edition. Crown 8vo. price $5^{s}$.

Doctrine of Annihilation in the Light of the Gospel of Love. Five Discourses. Third Edition. Crown 8vo. price 2s. 6d.

The Christian Policy of Life. A Book for Young Men of Business. New and Cheaper Edition. Crown 8vo. cloth, price, 3s. 6d.

BROWN (J. Cronmbie) LL.D.-Reboisement in France; or, Records of the Replanting of the Alps, the Cevennes, and the Pyrenees with Trees, Herbage, and Bush. Demy 8vo. price 12s. $6 d$.

The Hydrology of Southern Africa. Demy Svo. price ios. $6 d$.

BROWNE ( $W . R$. ) - The Inspiration of the New Testament. With a Preface by the Rev. J. P. Norris, D.D. Fcp. 8vo, cloth, $2 s, 6 d$.

BURCKHARDT (Jacob)-The Civilization of the Period of the Renaissance in Italy. Authorised translation, by S. G. C. Middlemore. 2 vols. Deny 8 vo. price $24 s$.

BURton (Mrs. Richard) - The Inner Life of Syria, Palestine, and THE HoLy LAND. With Maps, Photographs, and Coloured Plates. 2 vols. Second Edition. Demy 8vo. price 245.

* * Also a Cheaper Edition in one volume. Large post 8vo. cloth, price Ios. $6 d$.

BURTON (Capt. Richard F.)-The Gold Mines of Midian and the RUined Midianite Cities. A Fortnight's Tour in North Western Arabia. With numerous illustrations. Second Edition. Demy 8vo. price I8s.

The Land of Midian Revisited. With numerous Illustrations on Wood and by Chromolithography. 2 vols. Demy 8vo. cloth, price 325.

BUSBECQ (Ogier Ghiselin de)-His Life and Letters. By Charles Thornton Forster, M.A., and F. H. Blackburne Daniell, M.A. 2 vols. With Frontispieces. Demy 8vo. cloth, price 24s. 
CANDLER (FI.)-THE GRoundwork of Belier. Crown 8vo. cloth, price 75 .

CARPENTER (Dr: Philip P.)-HIS LIFE AND WORK. Edited by his brother, Russell Lant Carpenter. With Portrait and Vignettes. Second Edition. Crown 8vo. cloth, price $7 s .6 d$.

CARPENTER (W. B.) LL.D., M.D., F.R.S., Evc.The Principles of Mental Physiology. With their Applications to the Training and Discipline of the Mind, and the Study of its Morbid Conditions. Illustrated. Fifth Edition. 8vo. price I2s.

CER VANTES-The Ingenious KNight Don Quixote de LA Mancha. A New Translation from the Originals of 1605 and $\mathbf{1 6 0 8}$. By A. J. Duffield. With Notes. 3 vols. Demy 8vo. price $42 s$.

CHE YNE (Reż. T. K.)-The Prophecies of Isaiah. Translated with Critical Notes and Dissertations. 2 vols. Demy 8vo. cloth, price 25 s.

CLAYDEN (P. W.)-England UNder LORD Beaconsfield. The Political History of the Last Six Years, from the end of 1873 to the beginning of 1880 . Second Edition, with Index and continuation to March 1880. Demy 8vo. cloth, price $16 s$.

CLODD (Edward) F.R.A.S.-The ChILdhood of THE WorLd: a Simple Account of Man in Early Times. Sixth Edition. Crown 8vo. price 35 . A Special Edition for Schools. Price Is.

The Childhood of Religions. Including a Simple Account of the Birth and Growth of Myths and Legends. Third Thousand. Crown 8vo. price 5 s.

A Special Edition for Schools, Price Is. $6 d$.

Jesus of NAZARETH. With a brief sketch of Jewish History to the Time of His Birth. Small crown 8vo. cloth, price 6s.

COGHLAN (J. Cole) D.D.- The Modern Pharisee and other SERmons. Edited by the Very Rev. H. H. DiCKinson, D.D., Dean of Chapel Royal, Dublin. New and Cheaper Edition. Crown 8vo. cloth, 7s. 6d.

COLERIDGE (Sara)-Phantasmion. A Fairy Tale. With an Introductory Preface by the Right Hon. Lord Coleridge, of Ottery St. Mary. A New Edition. Illustrated. Crown 8vo. price $7 s .6 d$.

Memoir and Letters of Sara Coleridge. Edited by her Daughter. With Index. Cheap Edition. With one Portrait. Price $7 s .6 d$.

COLLINS (Mortimer)-The Secret of Long Life. Small crown 8 vo. cloth, price 3 s. $6 d$.

$\operatorname{CONNELL}(A . K$. -Discontent And Danger in India. Small crown 8vo. cloth, price 3 s. $6 d$.

COOKE (Prof. J. P.) of the Harrard Univcrsity.-Scientific Culture. Crown 8vo. price is.

COOPER (H. J.)-The ART OF FurNisHing on Rational AND Estietic Principles. New and Cheaper Edition. Fcap. 8vo, cloth, price $1 s .6 d$.

CORFIELD (Professor) M.D.-Health. Crown 8vo. cloth, price 6s.

CORY (William)-A Guide to Modern English History. Part I. MDCCCXV.-MDCCCXXX. Demy 8vo. cloth, price $9 s$.

COURTNEY $(W$. L.)-The Metaphysics of John Stuart Mill. Crown 8vo, cloth, price 5 s. $6 d$. 
COX (Rev. Sir George W.) M.A., Bart.-A History of Greece from the Earliest Period to the end of the Persian War. New Edition. 2 vols. Demy 8vo. price $36 s$.

The Mythology of the Aryan Nations. New Edition. 2 vols. Demy 8 vo. price $28 s$.

A General History of Greece from the Earliest Period to the DeATH OF Alexander the Great, with a sketch of the subsequent History to the present time. New Edition. Crown 8vo. price $7 s .6 d$.

Tales of Ancient Greece. New Edition. Small crown 8vo. price $6 s$.

School History of Greece. New Edition. With Maps. Fcp. 8vo. price $3 s .6 d$.

The Great Persian War from the History of Herodotus. New Edition. Fcp. 8vo. price $3 s .6 d$.

A Manual of Mythology in the form of Question and Answer. New Edition. Fcp. 8vo. price 3 s.

COX (Rev. Sir G. W.) M.A., Bart., and JONES (Eustace Hinton)Popular Romances of the Middle Ages. Second Edition; in 1 vol. Crown 8vo. cloth, price $6 s$.

COX (Rev. Samuel)-Salvator Mundi ; or, Is Christ the Saviour of all Men? Sixth Edition. Crown Svo. price 5 s.

The Genesis of Evil, AND other Sermons, mainly expository. Second Edition. Crown 8vo. cloth, price $6 s$.

A Commentary on the Book of Job. With a Translation. Demy Svo. cloth, price 15 s.

CRAUFURD (A. H.)-SeEking FOR Light: Sermons. Crown 8vo. cloth, price $5^{s}$.

CRAVEN (Mrs.) - A YeAR's Meditations. Crown 8vo. cloth, price 6s.

CRAWFURD (Oswald)-PORTUGaL, OLd AND NEw. With Illustrations and Maps. Demy 8vo. cloth, price 16 s.

CROMPTON (Henry) - Industrial Conciliation. Fcap. 8vo. price $2 s .6 d$.

CROZIER (John Beattie) M.B.-THE Religion of the Future. Crown 8 vo, cloth, price $6 s$.

DALTON (John Neale) M.A., R.N.-Sermons to Naval Cadets. Preached on board H.M.S. 'Britannia.' Second Edition. Small crown 8 vo. cloth, price $3 s .6 d$.

DAVIDSON (Rev. Samuel) D.D., LL.D. - The New Testament, translated from the Latest Greek Text of Tischendorf. A New and thoroughly revised Edition. Post 8vo. price Ios. $6 d$.

Canon of the Bible: Its Formation, History, and Fluctuations. Third and revised Edition. Small crown 8vo. price $5^{s}$.

DAVIES (Rev. T. L.) M.A.-Theology and Morality. Essays on Questions of Belief and Practice. Crown 8vo. price 7s. 6d.

DAWSON (Geo.) M.A.-Prayers, with a Discourse on Prayer. Edited by his Wife. Fifth Edition. Crown 8vo. 6s.

Sermons on Disputed Points and Special Occasions. Edited by his Wife. Third Edition. Crown 8vo. price $6 s$.

Sermons on Daily Life and Duty. Edited by his Wife. Third Edition. Crown 8vo. price $6 s$. 
DE REDCLIFFE (Viscount Stratford) P.C., K.G., G.C.B.-Wну Aм I A Christian? Fifth Edition. Crown 8vo. price $3 s$.

DESPREZ (PhilipS.) B.D.-DANIEL AND JoHN ; or, the Apocalypse of the Old and that of the New Testament. Demy 8 vo. cloth, price I2s.

DE TOCQUEVILLE (A.)-CoRrespondence AND Conversations of, With Nassau WILliam SEnior, from 1834 to 1859 . Edited by M. C. M. Simpson. 2 vols. post 8vo. price $21 s$.

DOIVDEN (Edward) LL.D.-ShaKspere : a Critical Study of his Mind and Art. Fifth Edition. Post 8vo. price I2s.

Studies in Literature, I 789-I877. Large Post 8vo. price izs.

DRE WRY (G. O.) M.D.-The Common-Sense Management of the Stomach. Fifth Edition. Fcp. 8vo. price $2 s .6 d$.

DREWRY (G. O.) M.D., and BARTLETT (H. C.) Ph.D., F.C.S.

Cup and Platter: or, Notes on Food and its Effects. New and Cheaper Edition. Small 8vo. price Is. $6 d$.

DU MONCEL (Count)-The Telephone, the Microphone, and the PhonograpH. With 74 Illustrations. Small crown 8vo. cloth, price $5 \mathrm{~s}$.

EDEN (Frederick)-The Nile without a Dragoman. Second Edition. Crown 8vo. price $7 s .6 d$.

EDGEWORTH (F. Y.).-Mathenatical Psychics. An Essay on the Application of Mathematics to Social Science. Demy 8vo cloth $7 s .6 d$.

EDIS (Robert W.) F.S.A. E.c.-Decoration And Furniture of Town Houses : a Series of Cantor Lectures, delivered before the Society of Arts, I880. Second Edition, Amplified and Enlarged. With 29 Full-page Illustrations and numerous Sketches. Square 8vo, cloth, price I2s. $6 d$.

Educational Code of the Prussian Nation, in its Present Form. In accordance with the Decisions of the Common Provincial Law, and with those of Recent Legislation. Crown 8vo, cloth, price $2 s .6 d$.

ELSDALE (Henry)-Studies in Tennyson's Idylls. Crown svo. price 5 s.

ELYOT (Sir Thomas)-The Boke NAMed the Gouernour. Edited from the First Edition of 153 I by Henry Herbert Stephen Croft, M.A., Barrister-at-Law. With Portraits of Sir Thomas and Lady Elyot, copied by permission of her Majesty from Holbein's Original Drawings at Windsor Castle. 2 vols. fcp. 4to. cloth, price 50 s.

EVANS (Mark) - The Story of our Father's Love, told to Children. Fifth and Cheaper Edition. With Four Illustrations. Fcp. Svo. price I $s, 6 d$.

A Book of Common Prayer and Worship for Household Use, compiled exclusively from the Holy Scriptures. Fcp. 8vo. price Is.

'The Gospel of Home Life. Crown 8vo. cloth, price $4 s .6 d$.

The King's Story-Book. In Three Parts. Fcap. 8vo. cloth, price Is. $6 d$. each.

*** Parts I. and II. with Eight Illustrations and Two Picture Maps, now ready.

EX-CIVILIAN.-Life IN THE Mofussil, or Civilian Life in Lower Bengal. 2 vols. Large post 8 vo. price 14 s. 
FIE LD (Horace) B.A. Lond.-The Ultimate Triumph of Christianity. Small crown 8vo. cloth, price $3^{s .6} 6$

FINN (The late James) M.R.A.S.-STIRRING Times; or, Records from Jerusalem Consular Chronicles of 1853 to 1856 . Edited and Compiled by his Widow ; with a Preface by the Viscountess Strangford. 2 vols. Demy 8vo. price 30 s.

Folkestone Ritual Case : the Arguments, Proceedings, Judgment, and Report. Demy 8vo. price 25s.

FORMBY (Rev. Henry)-Ancient Rome and its Connection with the Christian Religion: An Outline of the History of the City from its First Foundation down to the Erection of the Chair of St. Peter, A.D. 42-47. With numerous Illustrations of Ancient Monuments, Sculpture, and Coinage, and of the Antiquities of the Christian Catacombs. Royal ' $n$, cloth extra, $£ 2$. ros; roxburgh half-morocco, £2. I2s. $6 d$.

FOWLE (Rev. T. W.) M.A.-The Reconciliation of Religion and ScIence. Being Essays on Immortality, Inspiration, Miracles, and the Being of Christ. Demy 8vo. price Ios. $6 d$.

The Divine Legation of Christ. Crown 8vo. cloth, price $7 s$.

FRASER (Donald)-Exchange Tables of Sterling and Indian RUPEE CURRENCY, upon a new and extended system, embracing Values from One Farthing to One Hundred Thousand Pounds, and at rates prozressing, in Sixteenths of a Penny, from $\mathbf{I} s .9 d$. to $2 s$. $3 d$. per Rupee. Royal 8vo. price Ios. $6 d$.

FRISWELL ( J. Hain)-The Better Self. Essays for Home Life. Crown 8vo. price 6 s.

GardNer (J.) M.D.-Longevity : The Means of Prolonging LIFE AFTer Middle AGe. Fourth Edition, revised and enlarged. Small crown 8vo. price $4 \mathrm{~s}$.

GEBLER (Karl Von)-Galileo Galilei and the Roman Curia, from Authentic Sources. Translated with the sanction of the Author, by Mrs. George Sturge. Demy 8vo. cloth, price I $2 s$.

GEDDES (James)-History of the Administration of John DE WitT, Grand Pensionary of Holland. Vol. I. 1623-1654. With Portrait. Demy 8vo. cloth, price I $5 s$.

GEORGE (Henry)-Progress and Poverty : an Inquiry into the Causes of Industrial Depressions, and of Increase of Want with Increase of Wealth. The Remedy. Post 8vo. cloth, price 7s. $6 d$.

GILBERT (Mrs.)-Autobiography and other Memorials. Edited by Josiah Gilbert. Third and Cheaper Edition. With Steel Portrait and several Wood Engravings, Crown 8vo. price 7s. 6d.

GILL (Rev. $W . W$. . B. $A$.-Myths and Songs from the South Pacific. With a Preface by F. Max Müller, M.A., Professor of Comparative Philology at Oxford. Post 8vo. price 9s.

GLOVER (F.) M.A.-Exempla Latina. A First Construing Book with Short Notes, Lexicon, and an Introduction to the Analysis of Sentences. Fcp. 8vo. cloth, price $2 s$. 
GODWIN (William)-William Godwin: His Friends and ContemPORARIES. With Portraits and Facsimiles of the Handwriting of Godwin and his Wife. By C. Kegan Paul. 2 vols. Large post 8vo. price 28 s.

The Genius of Christianity Unveiled. Being Essays never before published. Edited, with a Preface, by C. Kegan Paul. Crown 8vo. price 7 s. $6 d$.

GOLDSMID (Sir Francis Henry) Bart., Q.C., M.P.-MEMOIR of. With Portrait. Crown 8vo. cloth, price 5 s.

GOODENOUGH (Commodore J.G.) R.N., C.B., C.M.G.-MEMOIR of, with Extracts from his Letters and Journals. Edited by his Widow. With Steel Engraved Portrait. Square 8vo. cloth, 58.

** Also a Library Edition with Maps, Woodcuts, and Steel Engraved Portrait. Square post 8 vo. price I 4 s.

GOSSE (Edmund $W$.)-STUdies in THE LITERATURE OF NoRTHERN Europe. With a Frontispiece designed and etched by Alma Tadema. Large post 8 vo. cloth, price $\mathbf{I} 2$ s.

GOULD (Rez. S. Baring) M.A.-The ViCaR of Morwenstow: a Memoir of the Rev. R. S. Hawker. With Portrait. Third Edition, revised. Square post 8 vo. IOs. $6 \mathrm{~d}$.

Germany, Present and Past. 2 vols. Large crown 8vo. cloth, price $21 s$.

GRIFFITH (Thomas) A.M.-The Gospel of the Divine Life: a Study of the Fourth Evangelist. Demy 8vo. cloth, price I4s.

GRIMLEY (Rev. H. N.) M.A.-Tremadoc Sermons, chiefly on the Spiritual Body, the Unseen World, and the Divine Humanity. Second Edition, Crown 8vo. price 6s.

GR $\ddot{U} N E R$ (M. L.)-Studies of Blast Furnace Phenomena. Translated by L. D. B. Gordon, F.R.S.E., F.G.S. Demy 8vo. price 7s. $6 d$.

GURNEY (Rev. Archer)-Words of Faith and Cheer. A Mission of Instruction and Suggestion. Crown 8vo, price 6s.

HAECKEL (Prof. Ernst)-The History of Creation. Translation revised by Professor E. Ray Lankester, M.A., F.R.S. With Coloured Plates and Genealogical Trees of the various groups of both plants and animals. 2 vols. Second Edition. Post 8vo. cloth, price $32 s$.

The History of the Evolution of MaN. With numerous Illustrations. 2 vols. Post 8 vo. price $32 s$.

Freedom in Science and Teaching. With a Prefatory Note by T. H. HuXley, F.R.S. Crown 8 vo. cloth, price 5 s.

HAKE (A. Egmont)-Paris Originals, with Twenty Etchings, by LEON RICHETON. Large post 8vo, price I4s.

HALLECK'S InternationaL Law; or, Rules Regulating the Intercourse of States in Peace and War. A New Edition, revised, with Notes and Cases, by Sir Sherston Baker, Bart. 2 vols. Demy 8vo. price 38 s. 
HARTINGTON (The Right Hon. the Marquis of) M.P.-ELECTION SPEECHES IN 1879 AND I880. With Address to the Electors of North East Lancashire. Crown 8vo. cloth, price $3^{s} .6 d$.

HAWEIS (Rev. H. R.) M.A.-CURRENT CoIn. Materialism-The Devil - Crime - Drunkenness - Pauperism - Emotion - Recreation - The Sabbath. Third Edition. Crown 8vo. price 6s.

Speech in Season. Fourth Edition. Crown 8vo. price $9 s$.

Thovghts For the Times. Eleventh Edition. Crown 8vo. price $7 s .6 d$. Unsectarian Family Prayers. New and Cheaper Edition. Fcp. 8vo. price Is. $6 d$.

Arrows in the Air. Second Edition. Crown 8vo. cloth, price 6s. HAWKINS (Edwards Comerforl) - SPIRIT AND FORM. Sermons preached in the Parish Church of Leatherhead. Crown 8vo. cloth, price 6s.

hayes $(A . H$.$) , Junr.-New Colorado and the Santa Fé Trail.$ With Map and 6o Illustrations. Crown 8vo. cloth, price 9s.

HEIDENHAIN (Rudolf) M.D.-Animal Magnetism : Physiological Observations. Translated from the Fourth German Edition by L. C. Wooldridge, with a Preface by G. R. Romanes, F.R.S. Crown 8 vo. price $2 s .6 d$.

HELLWALD (Baron F. Von)-The Russians in Central Asia. A Critical Examination, down to the Present Time, of the Geography and History of Central Asia. Translated by Lieut.-Col. Theodore Wirgman, LL. B. With Map. Large post 8vo. price I2s.

hinton $(J$.$) - The Place of the Physician. To which is added$ Essays ON THE LAW OF HUMAN LifE, and on THE RELATIONS BETWEeN ORGANIC AND INORGANIC WORLDS. Second Edition. Crown Svo. price 3 s. $6 d$.

Physiology for Practical Use. By Various Writers. With 50 Illustrations. Third and Cheaper Edition. Crown 8vo. price $5^{s}$.

An Atrlas of Diseases of the Membrana Tympani. With Descriptive Text. Post 8vo. price £6.6s.

The Questions of Aural Surgery. With Illustrations. 2 vols. Post 8vo. price $12 s .6 d$.

Chapters on the Art of Thinking, and other Essays. With an Introduction by Shadworth Hodgson. Edited by C. H. Hinton, Crown 8 vo. cloth, price $8 s .6 d$.

The Mystery of Pain. New Edition. Fcap. 8vo. cloth limp, is.

Life and LetTers. Edited by Ellice Hopkins, with an Introduction by Sir W. W. Guld, Bart., and Portrait engraved on Steel by C. H. JeEns. Third Edition. Crown 8vo. price 8s, $6 d$.

HOOPER (Mary)-Little Dinners: How to Serve them with Elegance and ECononiy. Thirteenth Edition. Crown 8vo. price $5 s$.

Cookery for Invalids, Persons of Delicate Digestion, and Children. Crown 8vo. price $3 s .6 d$.

Every-Day Meals. Being Economical and Wholesome Recipes for Breakfast, Luncheon, and Supper. Second Edition. Crown 8vo. cloth, price $5 s^{\circ}$ 
HOPKINS (Ellice)-LIFE AND LETTERS OF JAMES Hinton, with an Introduction by Sir W. W. GuLL, Bart., and Portrait engraved on Steel by C. H. JeEns. Third Edition, Crown 8vo. price 8s, $6 d$.

HORNER (The Misses)-TVALKS IN FLoRENCE. A New and thoroughly Revised Edition. 2 vols. Crown 8vo. Cloth limp. IVith Illustrations.

Vol. I.-Churches, Streets, and Palaces. Price IOs. $6 a$.

VOL. II.-Public Galleries and Museums. Price $5 s$.

HULL (Edmund C. P.)-The European IN India. With a Medical Guide for Anglo-Indians. By R. S. MAIR, M.D., F.R.C.S.E. Third Edition, Revised and Corrected. Post 8vo. price $6 s$.

HUTTON (Arthur) M.A.-The ANGLICAN Ministry: its Nature and Value in relation to the Catholic Priesthood. With a Preface by His Eminence Cardinal Newman. Demy 8vo. cloth, price I4s.

JENKINS (E.) and RAYMOND (J.)-ThE ARCHITECT'S LEGAL HANDBOOK. Third Edition, Revised. Crown 8vo. price $6 s$.

JENKINS (Rez. R. C.) M.A.-The Privilege of Peter and the Claims of the Roman Church confronted with the Scriptures, the Councils, and the Testimony of the Popes themselves. Fcap. 8vo. price 3 s. $6 d$.

JENNINGS (Mrs. Vaughan)-RAHEL: Her LifE ANd LetTers. With a Portrait from the Painting by Daffinger. Square post 8vo. price $7 s .6 d$.

JOEL $(L$.$) - A Consul's Manual and Shipowner's \Lambda$ d S Shipmaster's Practical Guide in their Transactions ABroad. With Definitions of Nautical, Mercantile, and Legal Terms; a Glossary of Mercantile Terms in English, French, German, Italian, and Spanish; Tables of the Money, Weights, and Measures of the Principal Commercial Nations and their Equivalents in British Standards; and Forms of Consular and Notarial Acts. Demy 8vo. cloth, price I2s.

JOHNSTONE (C. F.) M.A.-Historical ABstracts: being Outlines of the History of some of the less known States of Europe. Crown Svo. cloth, price $7 s .6 d$.

JONES (Lucy) - PUdDiNgs AND SweEts; being Three Hundred and Sixty-five Receipts approved by experience. Crown 8vo. price $2 s, 6 d$.

JOYCE (P. W.) LL.D. Ëc.-Old Celtic Romances. Translated from the Gaelic. Crown 8vo. cloth, price $7 s, 6 d$.

KAUFMANN (Rev. M.) B.A.-Socialism: Its Nature, its Dangers, and its Remedies considered. Crown 8vo. price $7 s .6 d$.

Utoprss; or, Schemes of Social Improvement, from Sir Thomas More to Karl Marx. Crown 8vo. cloth, price 5 s.

$K A Y$ (Joseph) M.A., Q.C.-Free Trade IN LAND. Edited by his Widow. With Preface by the Right Hon. Join Brignt, M.P. Sixth Edition. Crown 8 vo. cloth, price 5 s.

KEMPIS (Thomas $\mathcal{A}$ )-OF the ImITATION of CHRIst. A revised Translation, choicely printed on hand-made paper, with a Miniature Frontispiece on India paper from a design by W. B. RICHMOND. Limp parchment, antique, price $6 s$, ; vellum, $7 s, 6 d$. 
KENT (C.)-Corona Catholica ad Petri successoris Pedes Oblata. De Summi Pontificis Leonis XIII. Assumptione Epigramma. In Quinquaginta Linguis. Fcp. 4 to. cloth, price $\mathbf{1} 5$ s.

KERNER (Dr. A.) Professor of Botany in the University of Innsbruck.Flowers AND THEIR UnBIDDEN GUeSTS. Translation edited by W. OgLe, M.A., M.D. With Illustrations. Square 8vo. cloth, price 9s.

KIDD (Joseph) M.D.-The Laws of Therapeutics ; or, the Science and Art of Medicine. Second Edition. Crown 8vo. price 6s.

KINAHAN (G. Henry) M.R.I.A., of H.M.'s Geological Survey.-ThE GEOLOGY OF IRELAND, with numerous Illustrations and a Geological Map of Ireland. Square 8vo. cloth.

KINGSLE $Y$ (Charles) M.A.-LetTers AND MeMories of His Life. Edited by his WIFE. With Two Steel Engraved Portraits, and Illustrations on Wood, and a Facsimile of his Handwriting. Thirteenth Edition. 2 vols. Demy 8vo. price $36 s$.

$*_{*}^{*}$ Also the Ninth Cabinet Edition, in 2 vols. Crown 8vo. cloth, price I2s.

All Saints' Day, and other Sermons. Edited by the Rev. W. HARrison. Third Edition. Crown 8vo. price $7 s .6 d$.

TRUE Words for BRAve Men. A Book for Soldiers' and Sailors' Libraries. Eighth Edition. Crown 8vo. price 2s. $6 d$.

KNIGHT (Professor $W$.) -Studies in Philosophy and Literature. Large post 8 vo. cloth, price $7 s .6 d$.

KNOX (Alexander A.)-The New Playground; or, Wanderings in Algeria. Large crown 8vo. cloth, price Ios. $6 d$.

LACORDAIRE (Rev. Père)-Life : Conferences delivered at Toulouse. A New and Cheaper Edition. Crown 8vo. price $3 s .6 d$.

LEE (Rev. F. G.) D.C.L.-The Other WorLd; or, Glimpses of the Supernatural. 2 vols. A New Edition. Crown 8vo. price 15 s.

LEWIS (Edward Dillon)-A Draft Code of Criminal Law and Procedure. Demy 8vo. cloth, price $2 \mathrm{I} s$.

Life in the Mofussil ; or, Civilian Life in Lower Bengal. By an ExCivilian. Large post 8vo. price I4s.

LINDSA Y (W. Lauder) M.D., F.R.S.E., S.c.-MIND IN THE LOWER Animals in Health and Disease. 2 vols. Demy 8vo. cloth, price $32 s$.

Vol. I.-Mind in Health. Vol. II.-Mind in Disease.

LLOYD (Francis), and TEBBITT (Charles)-ExTENSION of EMPIRE, Weakness? Deficits, Ruin? With a Practical Scheme for the Reconstruction of Asiatic Turkey. Small crown 8vc. cloth, price 3s. $6 d$.

LONSDALE (Margaret)-SisTer Dora: a Biography. With Portrait, engraved on Steel by C. H. Jeens, and one Illustration. Nineteenth Edition. Crown 8vo. cloth, price 2s. $6 \dot{d}$.

LORIMER (Peter) D.D.-John Knox and the Church of England. His Work in her Pulpit, and his Influence upon her Liturgy, Articles, and Parties.- Demy 8vo. price I2s.

John Wiclif and his English Precursors. By Gerhard Victor LECHLER. Translated from the German, with additional Notes. 2 vols. Demy 8vo. price 2Is. 
MACLACHLAN (Mrs.)-Notes and Extracts on Everlasting PUNishment AND ETERNAl Life, ACCoRding to Literal InTERPRETATION. Small crown 8 vo. cloth, price $3 s .6 d$.

MACNAUGHT (Rev. John)-Cena Domini : An Essay on the Lord's Supper, its Primitive Institution, Apostolic Uses, and Subsequent History. Demy 8vo. price I4s.

MAGNUS (Mrs.)-About the Jews since Bible Times. From the Babylonian Exile till the English Exodus. Small crown 8ro, cloth, price $5 s$.

MAIR (R. S.) M.D., F.R.C.S.E.-The Medical Guide for AngloIndiANs. Being a Compendium of Advice to Europeans in India, relating to the Preservation and Regulation of Health. With a Supplement on the Management of Children in India. Second Edition. Crown 8vo. limp cloth, price 3 s. $6 d$.

MANNING (His Eminence Cardinal)-The True Story of the Vatican Council. Crown 8vo. price 5 s.

MARKHAM (Capt. Albert Hastings) R.N.-The Great Frozen Sea : A Personal Narrative of the Voyage of the Alert during the Arctic Expedition of 1875-6. With Six Full-page Illustrations, Two Maps, and Twenty-seven Woodcuts. Fourth and Cheaper Edition. Crown 8vo. cloth, price $6 s$.

A Polar Reconnaissance: being the Voyage of the 'Isbjörn' to Novaya Zemlya in 1879 . With Io Illustrations. Demy 8 vo. cloth, price 16 s.

McGRATH (Terence)-Pictures from Ireland. New and Cheaper Edition. Crown 8vo. cloth, price $2 s$.

MERRITT (Henry) -ART-Criticism and RoMance. With Recollections and Twenty-three Illustrations in eaz-forte, by Anna Lea Merritt. Two vols. Large post 8 vo, cloth, price 25 s.

MILLER (Edzeard)-The History and Doctrines of IRvingism; or, the so-called Catholic and Apostolic Church. 2 vols. Large post 8vo. price 25 s.

The Church in Relation to the State. Large crown 8vo. cloth, price $7 s .6 d$.

MILNE (James)-Tables of Exchange for the Conversion of Sterling Money into Indian and Ceylon Currency, at Rates from Is. 8d. to $2 s .3 d$. per Rupee. Second Edition. Demy 8vo. Cloth, price £2. $2 s$.

$\operatorname{MINCHIN}(J . G$.)-Bulgaria since the WaR: Notes of a Tour in the Autumn of 1879 . Small crown 8vo. cloth, price 3 s. $6 d$.

MOCKLER (E.)-A Gramiar of the Baloochee Language, as it is spoken in Makran (Ancient Gedrosia), in the Persia-Arabic and Roman characters. Fcap. 8vo. price 5 s.

MOFFAT (R. S.)-Economy of Consumption: a Study in Political Economy. Demy 8vo, price $18 s$.

The Principles of a Time Policy: being an Exposition of a Method of Settling Disputes between Employers and Employed in regard to Time and Wages, by a simple Process of Mercantile Barter, without recourse to Strikes or Locks-out. Reprinted from 'The Economy of Consumption,' with a Preface and Appendix containing Observations on some Reviews of that book, and a Re-criticism of the Theories of Ricardo and J. S. Mill on Rent, Value, and Cost of Production. Demy 8vo. price 3s. $6 d$. 
MOLTKE (Field-Marshal Von)-LetTERS From Russia. Translated by Robina Napier. Crown 8vo. price 6s.

Notes of Travel. Being Extracts from the Journals of. Crown 8vo. cloth, price $6 s$.

MORELL ( $J$. R.)-Euclid Simplified in Method and Language. Being a Manual of Geometry. Compiled from the most important French Works, approved by the University of Paris and the Minister of Public Instruction. Fcap. 8vo. price $2 s .6 d$.

MORSE (E. S.) Ph.D.-First Book of Zoology. With numerous Illustrations. New and Cheaper Edition. Crown 8vo. price $2 s, 6 d$.

NEWMAN (J. H.) D.D.-Characteristics From the Writings of. Being Selections from his various Works. Arranged with the Author's personal Approval. Third Edition. With Portrait. Crown 8vo. price 6s.

* * A Portrait of the Rev. Dr. J. H. Newman, mounted for framing, can be had price $2 s .6 d$.

New Werther. By Loki. Small crown 8vo. cloth, 2s. 6 .

NiCholas (T.)-The Pedigree of the English People. Fifth Edition. Demy 8vo. price 16 s.

NICHOLSON (Edward Byron)-ThE GOSPEL ACCORDING TO THE HEBREws. Its Fragments Translated and Annotated with a Critical Analysis of the External and Internal Evidence relating to it. Demy 8vo. cloth, price 9s. $6 d$.

The Rights of an Animal. Crown 8vo. cloth, price $3 s .6 d$.

NICOLS (Arthur) F.G.S., F.R.G.S.-Chapters From the Physical History OF THE EARTH : an Introduction to Geology and Palæontology. With numerous Illustrations. Crown 8 vo. cloth, price 5 s.

Norman People (The), and their Existing Descendants in the British Dominions and the United States of America. Demy 8vo. price 2rs.

Nuces : Exercises on the Syntax of the Public School Latin Primer. New Edition in Three Parts. Crown 8vo. each Is.

$*_{*}^{*}$ The Three Parts can also be had bound together in cloth, price 35.

O'MEARA (Kathleen)-Frederic Ozanam, Professor of the Sorbonne: His Life and Work. Second Edition. Crown 8vo. cloth, price $7 s .6 d$.

Our Public Schools-Eton, Harrow, Winchester, Rugby, Westminster, Marlborough, The Charterhouse. Crown 8vo. cloth, price $6 s$.

OWEN (F.M.)-John Keats : a Study. Crown 8vo. cloth, price $6 s$.

OWEN (Rev. Robert) B.D.-Sanctorale Catholicum; or, Book of Saints. With Notes, Critical, Exegetical, and Historical. Demy Svo. cloth, price $18 s$.

An Essay on the Communion of Saints. Including an Examination of the Cultus Sanctorum. Price $2 s$.

PARKER (Josepr) D.D.-The Paraclete : An Essay on the Personality and Ministry of the Holy Ghost, with some reference to current discussions. Second Edition. Demy 8vo. price I2s.

PARR (Capt. H. Hallam, C. M. G.)-A Sketch of the Kafir and Zulu Wars: Guadana to Isandhlwana. With Maps. Small Crown 8vo. cloth, price $5 s$.

PARSLOE (Joseph) - OUr RaILways. Sketches, Historical and Descriptive. With Practical Information as to Fares and Rates, \&c., and a Chapter on Railway Reform. Crown Svo. price 6s. 
PATTISON (Mirs. Mark)-The Renaissance, of Art in France. With Nineteen Steel Engravings. 2 vols. demy 8vo. cloth, price 32s.

PAUL (C. Kegan)-IVillian Godwin: His Friends and ContemPORARIES. With Portraits and Facsimiles of the Handwriting of Godwin and his Wife. 2 vols. Square post 8vo. price 28 s.

The Genius of Christianity Unveiled. Being Essays by William Godwin never before published. Edited, with a Preface, by C. Kegan Paul. Crown 8vo. price 7 s. $6 d$.

Miary Wollstonecraft. Letters to Imlay. New Edition with Prefatory Memoir by. Two Portraits in eaz-forte by AnNa Lea MerritT. Crown 8vo. cloth, $6 s$.

PA YNE (Prof. J. F.)-Lectures on Education. Price $6 d$. each.

II. Fröbel and the Kindergarten System. Second Edition.

A Visit to German Schools: Elementary Schools in Germany. Notes of a Professional Tour to inspect some of the Kindergartens, Primary Schools, Public Girls' Schools, and Schools for Technical Instruction in Hamburgh, Berlin, Dresden, Weimar, Gotha, Eisenach, in the autumn of 1874. With Critical Discussions of the General Principles and Practice of Kindergartens and other Schemes of Elementary Education. Crown 8vo. price 4 s. $6 d$.

PENRICE (Maj. J.) B.A.-A Dictionary and Glossary of the Ko-RAN. With Copious Grammatical References and Explanations of the Text. 4to. price $2 \mathrm{r} s$.

PESCHEL (Dr. Oscar) - The Races of Man and their Geographical Distribution. Large crown 8vo. price gs.

PINCHES (Thomas) M.A.-Samued Wileerforce: Faith-ServiceRECOMPENSE. Three Sermons. With a Portrait of Bishop Wilberforce (after a Portrait by Charles Watkins). Crown 8vo. cloth, price $4 s .6 d$.

PLAYFAIR (Lieut-Col.) Her Britamic Majesty's Consul-General in Algiers.

Travels in the Footsteps of Bruce in Algeria and Tunis. Illustrated by facsimiles of Bruce's original Drawings, Photographs, Maps, \&c. Royal 4to. cloth, bevelled boards, gilt leaves, price $£ 3.3$ s.

POLLOCK (Fralerick)-Spixoza, his Life and Philosophy. Demy 8vo. cloth, price $16 s$.

POLLOCK ( $W . H$. $)$ - Lectures on French Poets. Delivered at the Royal Institution. Small crown 8vo. cloth, price 5s.

POOR (Laura E.) - Sinskrit and its Kindred Literatures. Studies in Comparative Mythology. Small crown 8vo. cloth, 5 s.

POUSHKIN (A.S.)-Russian Rourance. Translated from the Tales of Belkin, Sic. By Mrs. J. Buchan Telfer (née Mouravieff). New and Cheaper Edition. Crown 8vo. price $3 s, 6 d$. PRESB Y TER-UNFordivgs OF CHRISTIAN Hope. An Essay shewing
that the Doctrine contained in the Damnatory Clauses of the Creed commonly called Athanasian is Unscriptural. Small crown 8vo. price 4s. $6 d$.

PRICE (Prof. Bonamy)-Currency and Banking. Crown Sro. Price 6s.

Chatrters on Practical Political liconoms: Being the Substance of Lectures delivered before the University of Oxford. Large post Svo. price $12 s$. 
Proteus and Amadeus. A Correspondence. Edited by Aubrey De Vere. Crown 8vo. price 5 s.

Pulpit Commentary (The). Edited by the Rev. J. S. Exell and the Rev. Canon H. D. M. SPENCE.

Ezra, Nehemiah, and Esther. By Rev. Canon G. Rawlinson, M.A.; with Homilies by Rev. Prof. J. R. Thomson, M.A., Rev. Prof. R. A. REDFORD, LL.B., M.A., Rev. W. S. Lewis, M.A., Rev. J. A. MACDONALD, Rev. A. Mackennal, B.A., Rev. W. Clarkson, B.A., Rev. F. Hastings, Rev. W. Dinwiddie, LL. B., Rev. Prof. Rowlands, B.A., Rev. G. Wood, B.A., Rev. Prof. P. C. Barker, Ll.B., M.A., and Rev. J. S. Exell. Third Edition. One vol, price I2s. $6 d$.

I Sanuel. By the Very Rev. R. P. Smith, D.D.; with Homilies by Rev. Donald Fraser, D.D., Rev. Prof. Chapman, and Rev, B. Dale. Third Edition. Price I5s.

Genesis. By Rev. T. Whitelaw, M.A. ; with Homilies by the Very Rev. J. F. Montgomery, D.D., Rev. Prof. R. A. Redford, M.A., LL.B., Rev. F. Hastings, Rev. W. Roberts, M.A. An Introduction to the Study of the Old Testament by the Rev. Canon FARrar, D.D., F.R.S. ; and Introductions to the Pentateuch by the Right Rev. H. CotTerili, D.D., and Rev. T. Whitelaw, M.A. Third Edition. One vol. price I5s.

Judges and Ruth. By the Right Rev. Lord A. C. Hervey, D.D., and Rev. J. Morrison, D.D. ; with Homilies by Rev. A. F. Muir, M.A., Rev. W. F. Adeney, M.A., Rev. W. M. Statham, and Rev. Professor J. Thomson, M.A. Super-royal 8vo. cloth, price Ios. $6 d$.

Joshua. By Rev. J. J. Lias, M.A. ; with Homilies by Rev. S. R. Aldridge, LL.B., Rev. R. Glover, Rev. E. De Pressense, D.D., Rev. J. WAITE, B.A., Rev. F. W. ADENEY, M.A. ; and an Introduction by the Rev. A. Plummer, M.A. Price i2s. $6 d$.

Punjaub (The) and North-Western Frontier of India. By an Old Punjaubee. Crown 8vo. price 5 s.

Rabbi Jeshua. An Eastern Story. Crown 8vo. cloth, price $3 s .6 d$.

RAVENSHAW (John Henry) B.C.S.-GaUR: ITS RUINS AND INSCRIPTIONS. Edited by his Widow. With 44 Photographic Illustrations, and 25 facsimiles of Inscriptions. Royal 4to. cloth, price $£ 3$. I 3 s. $6 d$.

READ (Carveth)-On the Theory of Logic: An Essay. Crown 8vo. price $6 s$.

Realities of the Future Life. Small crown 8vo. cloth, price is. $6 d$.

RENDELL ( $J . M$.)-Concise Handbook of the Island of Madeira. With Plan of Funchal and Map of the Island. Fcp. 8vo. cloth, Is. $6 d$.

REYNOLDS (Rev. J. W.)-The Supernatural in Nature, a Verification by Free Use of Science. Second Edition, revised and enlarged. Demy 8vo. cloth, price I 4 s.

The Mystery of Miracles. By the Author of 'The Supernatural in Nature.' Crown 8vo. cloth, price 6s.

RIBOT (Prof. Th.)-English Psycholggy. Second Edition. A Revised and Corrected Translation from the latest French Edition. Large post 8vo. price $9 s$.

Heredity: A Psychological Study on its Phenomena, its Laws, its Causes, and its Consequences. - Large crown 8vo. price gs. 
RINK (Chevalier Dr. Henry)-Greenland : Its People and its ProDUCTs. By the Chevalier Dr. Henry Rink, President of the Greenland Board of Trade. IVith sixteen Illustrations, drawn by the Eskimo, and a Map. Edited by Dr. Robert Brown. Crown 8vo. price Ios. $6 d$.

ROBERTSON (The late Rev. F. W.) M.A., of Brighton.-LifE AND LETTERS OF. Edited by the Rev. Stopford Brooke, M.A., Chaplain in Ordinary to the Queen.

I. Two vols., uniform with the Sermons. With Steel Portrait. Crown 8vo. price $7 s, 6 d$.

II. Library Edition, in Demy 8vo. with Portrait. Price I2s.

III. A Popular Edition, in I vol. Crown 8vo. price $6 s$.

Sermons. Four Series. Small crown 8vo. price $35.6 \pi$. each.

The Human Race, and other Sermons. Preached at Cheltenham, Oxford, and Brighton. Large post 8vo. cloth, price 7s. $6 d$.

Notes on Genesis. New and Cheaper Edition. Crown svo. price 35. $6 d^{\circ}$.

Expositori Lectures on St. Paul's Epistles to the Corinthians. A New Edition. Small crown 8vo. price 5 s.

Lectures AND AdDRESSES, with other Literary Remains. A New Edition. Crown 8vo. price 5 s.

An Analysis of Mr. 'Tennyson's 'In Memoriam.' (Dedicated by Permission to the Poet-Laureate.) Fcp. 8vo. price $2 s$.

The Education of the Human Race. Translated from the Gcrman of Gotthold Ephraim Lessing. Fcp. 8vo. price 2s. $6 d$.

The above Works can also be had, bound in half-morocco.

** A Portrait of the late Rev. F. W. Robertson, mounted for framing, can be had, price $2 s .6 d$.

RODWELL (G. F.) F.R.A.S., F.C.S.-Etna: A History oF the Mountain ANd its ERuptions. With Maps and Illustrations. Square 8vo. cloth, price $9 s$.

ROSS (Alexander) D.D.-Memoir of Alexander Ewing, Bishop of Argyll and the Isles. Second and Cheaper Edition. Demy Svo. cloth, price IOS. $6 d$.

SALTS (Rev. Alfred) LL.D.-Godparents at Confirmation. With a Preface by the Bishop of Manchester. Small crown 8vo. cloth limp, price $2 s$.

SAMUEL (Sydiney M.)-Jewish Life in the East. Small crown 8vo. cloth, price $3{ }^{s .6} .6$.

SAYCE (Rei: Archibald Henry)-Introduction to the Science of LANGUAGE. 2 vols. Large post 8 vo. cloth, price 25 s.

Scientific Liman. The New Truth and the Old Faith: are they Incompatible? Demy 8vo. cloth, price 10s. $6 d$.

SCOONES ( $\mathrm{W}$. Baptistc)-Four Centuries of English LetTers : A Selection of 350 Letters by 150 Writers, from the Period of the l'aston Letters to the P'resent Time. Second Edition. Large crown Svo. cloth, price 9 s.

SCOTT (Rolent H.) - Weather Charts and Storm Warnings. Second Edition. Illustrated. Crown 8vo, price $3 s .6 d$. 
SCOTT (Leader)-A Nook IN the APENNINES: A Summer beneath the Chestnuts. With Frontispiece, and Twenty-seven Illustrations in the Text, chiefly from Original Sketches. Crown 8vo. cloth, price 75. $6 d$.

SENIOR $(N . W$.$) -Alexis De Tocqueville. Correspondence and$ Conversations with Nassau W. Senior, from 1833 to I 859 . Edited by M. C. M Simpson. 2 vols. Large post 8 vo. price $21 s$.

SHAKSPEARE (Charles)-Saint PaUl at Athens. Spiritual Christianity in relation to some aspects of Modern Thought. Five Sermons preached at St. Stephen's Church, Westbourne Park. With a Preface by the Rev. Canon FARrar.

SHELLE Y (Lady)-Shelley Memorials from Authentic Sources. With (now first printed) an Essay on Christianity by Percy Bysshe Shelley. With Portrait. Third Edition. Crown 8vo. price 5 s.

SHILLITO (Rev. Joseph)-Womanhood : its Duties, Temptations, and Privileges. A Book for Young Women. Third Edition. Crown 8vo. price 3 s. $6 d$.

SHIPLEY (Rev.Orby) M.A.-Church Tracts: or, Studies in Modern Problems. By various. Writers. 2 vols. Crown 8 vo. price $5 s$, each.

Principles of the Faith in Relation to Sin. Topics for Thought in Times of Retreat. Eleven Addresses delivered during a Retreat of Three Days to Persons living in the World. Demy 8vo. cloth, price I $2 s$.

Sister Augustine, Superior of the Sisters of Charity at the St. Johannis Hospital at Bonn. Authorised Translation by Hans THARAu, from the German 'Memorials of Amalie vos LasaulX.' Second Edition. Large crown 8 vo. cloth, price $7 s .6 d$.

SMITH (Edward) M.D., LL.B., F.R.S.-Health and Disease, as Influenced by the Daily, Seasonal, and other Cyclical Changes in the Human System. A New Edition. Post 8vo. price $7 s .6 d$.

Practical Dietary for Families, Schools, and the Labouring Classes. A New Edition. Post 8ro. price 3s. $6 d$.

Tubercular Consumption in its Early and Remediable Stages. Second Edition. Crown 8vo. price 6s.

SPEDDING (James)-Reviews and Discussions, Literary, Political, and Historical not relating to Bacon. Demy 8vo. cloth, price I2s. $6 d_{0}$.

STAPFER (Paul)-Shakspeare and Classical Antiquity: Greek and Latin Antiquity as presented in Shakspeare's Plays. Translated by EMILY J. CAREY. Large post 8vo. cloth, price $12 s$.

St. Bernard. A Little Book on the Love of God. Translated by Marianne Caroline and Coventry Patmore. Cloth extra, gilt tops, $45.6 d$.

STEPHENS (Archibald John) LL.D.-The Folkestone Ritual CASE. The Substance of the Argument delivered before the Judicial Committee of the Privy Council on behalf of the Respondents. Demy 8vo. cloth, price $6 s$.

STEVENSON (Rev. W. F.)-Hymns For the CHURCH aNd Home. Selected and Edited by the Rev. W. Fleming Stevenson.

The most complete Hymn Book published.

The Hymn Book consists of Three Parts:-I. For Public Worship.II. For Family and Private Worship.-III. For Children.

** Published in various forms and prices, the latter ranging from $8 d$. to $6 s$. Lists and full particulars will be furnished on application to the Publishers. 
STEVENSON (Robert Louis)-AN INLANd Voyage. With Frontispiece by Walter Crane. Crown 8 vo. price $7 s .6 d$.

Travels with a Donkey in the Cevennes. With Frontispiece by Walter Crane. Crown 8vo. cloth, price $7 s_{0} 6 d$.

Virginibes Puerisque, and other Papers. Crown 8vo. cloth $6 s$. SULLY (James) M.A. - Sensation and Intuition. Demy 8vo. price IOs. $6 d$.

Pessimisir : a History and a Criticism. Second Edition. Demy 8vo. price $\mathbf{1} 4$ s.

SYME (David)-Outlines of an Industrial Science. Second Edition. Crown 8vo. price $6 s$.

TAYLOR (Algernon)-GuienNe. Notes of an Autumn Tour. Crown 8vo cloth, price 4 s. $6 d$.

THOMSON ( $J$. Tumbull)-Social Problems; or, An Inquiry into THE LAWS OF INFLUENCE. With Diagrams. Demy 8vo. cloth, price Ios, $6 d$.

TODHUNTER (Dr.J.)-A Study of Shelley. Crown 8vo. cloth, price 75 .

TWINING (Louisa)-Workhouse Visiting and Management during TWENTY-FIVE Years. Small crown 8vo. cloth, price 3 s. $6 d$.

VAUGHAN (H. Halford)-NEW READINGS AND RENDERINGS OF Shakespeare's TRAGEDIES. 2 vols, demy 8vo, cloth, price 25 s.

VILLARI (Professor)-Niccolo Machiavelli and his Times. Translated by Linda Villari. 2 vols. Large post $8 \mathrm{vo}$. price 24 s.

VYNER (Lady Mary)-Every Day a Portion. Adapted from the Bible and the Prayer Book. for the Private Devotions of those living in Widowhood. Collected and Edited by Lady Mary Vyner. Square crown 8vo. extra, price 5 .

WALDSTEIN (Charles) Ph.D.-The Balance of Emotion and INTELLeCT; an Introductory Essay to the Study of Philosophy. Crown 8vo. cloth, price $6 s$.

WALLER (Rev. C. B.)-The Apocalypse, reviewed under the Light of the Doctrine of the Unfolding Ages, and the Relation of All Things. Demy 8vo. price I2s.

WATSON (Sir Thomas) Bart., M.D.-The ABolition of Zymotic DISEASES, and of other simiłar Enemies of Mankind. Small crown 8vo. cloth, price $3 s .6 d$.

WEDMORE (Frederick)-The Masters of Genre Painting. With Sixteen Illustrations. Crown 8 vo. cloth, price $7 s .6 d$.

WELLS (Capt. John C.) R.N.-Spitzbergen-The Gateway to the PolyniA; or, a Voyage to Spitzbergen. With numerous Illustrations by Whymper and others, and Map. New and Cheaper Edition. Demy 8vo. price $6 s$.

Wetmore ( $W . \quad$ S.)-Commercial Telegraphic Code. Second Edition. Post 4to, boards, price $42 s$.

White $(A . D$.$) LL.D.-Warfare or Science. With Prefatory Note$ by Professor Tyndall. Second Edition. Crown 8vo, price 3 s. $6 d$.

WHITNE Y (Prof. William Dwrght)-Essentials of Engilish Grammar, for the Use of Schools. Crown 8vo, price $3 s .6 d$. 
WICKSTEED (P. H.)-Dante: Six Sermons. Crown 8vo. cloth, price 5 .

WILLIAMS (Rowland) D.D.-LifE AND LeTTERS of; with Extracts from his Note-Books. Edited by Mrs. Rowland Williams. With a Photographic Portrait. 2 vols, large post 8 vo. price 24s.

Psalms, Litanies, Counsels, and Collects for Devout Persons. Edited by his Widow. New and Popular Edition. Crown 8vo. price 3i. $6 d$.

Stray Thoughts Collected from the Writings of the late Rowland Winliams, D.D. Edited by his Widow. Crown 8 vo. cloth, price 3 s. $6 d$.

WILLIS (R.) M.D.-Servetus and Calvin : a Study of an Important Epoch in the Early History of the Reformation. 8vo. price I6s.

William Harvey. A History of the Discovery of the Circulation of the Blood : with a Portrait of Harvey after Faithorne. Demy 8vo. cloth, price 14s. Portrait separate.

IVILSON (H. Schiïtz)-The Tower and Scaffold. A Miniature Monograph. Large fcap. 8vo. price Is.

WOLLSTONECRAFT (Mary)-LetTers to ImLAy. New Edition with Prefatory Memoir by C. KEgan PAUL, author of 'William Godwin : His Friends and Contemporaries,' \&c. Two Portraits in earl-forte by Anna Lea Merritt. Crown 8vo. cloth, price 6s.

WOLTMANN (Dr. Alfred), and WOERMANN (Dr. Karl)History of Painting. Edited by Sidney Colvin. Vol. I. Painting in Antiquity and the Middle Ages. With numerous Illustrations. Medium 8vo. cloth, price $28 s$; ; bevelled boards, gilt leaves, price $30 s$.

WOOD (Major-General J. Creighton)-Doubling the Consonant. Small crown 8vo. cloth, price Is. $6 d$.

WORD waS MAdE Flesh. Short Family Readings on the Epistles for each Sunday of the Christian Year. Demy 8vo. cloth, price 10s. $6 u$.

WRIGHT (Rev. David) M.A.-WAiting For The Light, AND other Sermons. Crown 8vo. price 6s.

YOUMANS (Eliza A.)-An Essay on the Culture of the Observing Powers of ChILDREN, especially in connection with the Study of Botany. Edited, with Notes and a Supplement, by Joseph Payne, F.C.P., Author of 'Lectures on the Science and Art of Education,' \&c. Crown 8vo. price 2s. 6 d.

First Book of Botany. Designed to Cultivate the Observing Powers of Children. With 300 Engravings. New and Cheaper Edition. Crown 8vo. price 2s. 6 d.

YOUMANS (Edward L.) M.D.-A Class Book of Chemistry, on the Basis of the New System. With 200 Illustrations. Crown 8vo. price 5 s.

\section{THE INTERNATIONAL SCIENTIFIC SERIES.}

I. FORMS OF WATER : a Familiar Exposition of the Origin and Phenomena of Glaciers. By J. Tyndall, LL.D., F.R.S. With 25 Illustrations. Seventh Edition. Crown 8vo. price $5^{s}$.
II. Physics And Politics; or, Thoughts on the Application of the Principles of 'Natural Selection' and 'Inheritance' to Political Society. By Walter Bagehot. Fifth Edition. Crown 8 vo. price 4 s. 
III. Foons. By Edward Smith, M.D., LL.B., F.R.S. With numerous Illus. trations. Seventh Edition. Crown 8vo. price 5 s.

IV. MIND AND BoDy: the Theories of their Relation. By Alexander Bain, LL.D. With Four Illustrations. Seventh Edition. Crown 8vo. price 4 s.

V. The Study of Socrology. By Herbert Spencer. Tenth Edition. Crown Svo. price $5^{s}$.

VI. ON THE CONSERvation OF ENERGY. By Balfour Stewart, M.A., LL.D., F.R.S. With I4 Illustrations. Fifth Edition. Crown 8vo. price 5 s.

VII. ANimal Locomotion; or, Walking, Swimming, and Flying. By J. B. Pettigrew, M.D., F.R.S., \&c. With I 30 Illustrations. Second Edition. Crown 8vo. price 5 s.

VIII. RESPONSIBILITY IN MENTAL Disease. By Henry Maudsley, M.D. Third Edition. Crown 8vo. price 5 .

IX. The New Chemistry. By Professor J. P. Cooke, of the Harvard University. With 3 I Illustrations. Fifth Edition. Crown 8vo. price 5 s.

X. The Science of Law. By Professor Sheldon Amos. Fourth Edition. Crown 8vo. price $5 s$.

XI. Animal Mechanism: a Treatise on Terrestrial and Aerial Locomotion. By Professor E. J. Marey. With 117 Illustrations. Second Edition. Crown 8 vo. price $5 s$.

XII. The Doctrine of Descent and DARUINISM. By Professor Oscar Schmidt (Strasburg University). With 26 Illustrations. Fourth Edit. Crown 8 vo. price 5 s.

XIII. The History of the Conflict BETWEEN RELIGION AND SCIENCE. By J. W. Draper, M.D., LL.D. Fourteenth Edition. Crown 8vo. price 5 s.

XIV. FUNGI: their Nature, Influences, Uses, \&c. By M. C. Cooke, M.D., LL.D. Edited by the Rev. M. J. Berkeley, M.A., F.L.S. With numerous Illustrations. Second Edition. Crown 8vo. price 5 .

XV. The Chemical Effects of Ligh' and Photography. By Dr. Hermann Vogel (Polytechnic Academy of Berlin). Translation thoroughly revised. With 100 Illustrations. Third Edition. Crown 8vo. price 5 s.
XVI. The Life And Growth of LAN. GUAGE. By William Dwight Whitney, Professor of Sanscrit and Comparative Philology in Yale College, Newhaven. Second Edition. Crown 8vo. price $5 s$.

XVII. Money and the Mechanism of Exchange. By W. Stanley Jevons, M.A., F.R.S. Fourth Edition. Crown 8vo. price $5 s$.

XVIII. The Nature of Light. With a General Account of Physical Optics. By Dr. Eugene Lommel, Professor of Physics in the University of Erlangen. With 188 Illustrations and a Table of Spectra in Chromo-lithography. Third Edition. Crown 8vo. price 5 s.

XIX. Animal Parasites and Messmates. By Monsieur Van Beneden, Professor of the University of Louvain, Correspondent of the Institute of France. With 83 Illustrations. Second Edition. Crown 8vo, price 5 .

XX. Fermentation. By Professor Schuitzenberger, Director of the Chemical Laboratory at the Sorbonne. With 28 Illustrations. Third Edition. Crown 8vo. price 5 s.

XXI. The Five Senses of Man. By Professor Bernstein, of the University of Halle. With 9x Illustrations. Second Edition. Crown 8vo. price 5s.

XXII. THE THEORY OF SOUND IN ITS Relation to Music. By Professor Pietro Blaserna, of the Royal University of Rome. With numerous Illustrations. Second Edition. Crown 8vo. price $5^{s}$.

XXIII. Studies in SPeCTRUM ANalySIs. By J. Norman Lockyer. F. R.S. With six photographic Illustrations of Spectra, and numerous engravings on Wood. Crown 8vo. Second Edition. Price $6 s .6 d$.

XXIV. A History of the Growth of the Steam Engine. By Professor R. H. Thurston. With numerous Illustrations. Second Edition. Crown 8vo. cloth, price $6 s, 6 \%$.

XXV. Education as a Science. By Alexander Bain, LL.D. Third Edition. Crown 8vo. cloth, price $5^{s}$.

XXVI. The Human Species. By Prof. A. de Quatrefages. Third Edition. Crown 8 vo. cloth, price 5 s. 
XXVII. MOdern Chromatics. With Applications to Art and Industry. By Ogden N. Rood. With 130 original Illustrations. Second Edition. Crown 8 vo. cloth, price 5 s.

XXVIII. The CRAYFISH: an Introduction to the Study of Zoology. By Professor T. H. Huxley. With $\mathbf{8 2}$ Illustrations. Second Edition. Crown 8 vo. cloth, price $5 s$.

XXIX. The Brain as an ORgan OF Mind. By H. Charlton Bastian, M.D. With numerous Illustrations. Second Edition. Crown 8vo, cloth, price $5^{s}$.

\section{MILITARY}

ANDERSON (Col. R. P.)-VICTORIES AND DEFEATS : an Attempt to explain the Causes which have led to them. An Officer's Manual. Demy 8vo. price I4s.

Army of the North German CoNFEDERATION : a Brief Description of its Organisation, of the Different Branches of the Service and their rôle in War, of its Mode of Fighting, \&c. Translated from the Corrected Edition, by permission of the Author, by Colonel Edward Newdigate. Demy 8 vo. price 5 s.

BLUME (Maj. W.)-The Operations of the German Armies in France, from Sedan to the end of the War of 1870-71. With Map. From the Journals of the Head-quarters Staff. Translated by the late E. M. Jones, Maj. 2oth Foot, Prof. of Mil. Hist., Sandhurst. Demy 8vo price $9 s$.

BOGUSLAWSKI (Capt. A. von)-TAC. TICAL DEDUCTIONS FROM THE WAR OF I $870-\mathbf{I}$. Translated by Colonel Sir Lumley Graham, Bart., late I8th (Royal Irish) Regiment. Third Edition, Revisea and Corrected. Demy 8vo. price $7 s$.

BRACKENBURY (Lieut.-Col.) C.B., R.A., A.A.G. Militaky HandBOOKS FOR REGIMENTAL OFFICERS. I. Military Sketching and Reconnaissance, by Lieut.-Col. F. J. Hutchison, and Capt. H. G. MacGregor. Second Edition. With 15 Plates. Small 8vo. cloth, price $6 s$. II. The Elements of Modern Tactics Practically applied to English Formations, by Major Wilkinson Shaw. Second and Cheaper Edition. With 25 Plates and Maps. Small cr. 8vo. cloth, price $9 s$.
XXX. The Atomic Theory. By Prof. Wurtz. Translated by G. Cleminshaw, F.C.S. Second Edition. Crown 8 vo. cloth, price $5 s$.

XXXI. The Natural Conditions of EXISTENCE AS THEY AFFECT ANIMAL LifE. By Karl Semper. With 2 Maps and 106 Woodcuts. Second Edition. Crown 8vo. cloth, price 5 s.

XXXII. General Physiology of Muscles and Nerves. By Prof. J. Rosenthal. Second Edition. With Illustrations. Crown 8vo. cloth, price $5 s$.

\section{WORKS.}

BRIALMONT (Col. A.)-HASTY INTRENCHMENTS. Translated by Lieut. Charles A. Empson, R.A. With Nine Plates. Demy 8vo. price $6 s$.

CLERY (C.) Lieut.-Col.-Minor TAC: TICS. With 26 Maps and Plans. Fifth and revised Edition. Demy Svo. cloth, price $16 s$.

DU VERNOIS (Col. von Verdy)Studies in Leading Troops. An authorised and accurate Translation by Lieutenant $\mathrm{H}$. J. T. Hildyard, 7Ist Foot. Parts I. and II. Demy Svo. price $7 s$.

GOETZE: (Capt. A. von)-OPERATIONS OF THE GERMAN ENGINEERS DURING THE WAR OF I870-I. Published by Authority, and in accordance with Official Documents. Translated from the German by Colonel G. Graham, V.C., C.B., R.E. With 6 large Maps. Demy 8vo. price $2 \mathrm{I} s$.

HARRISON : Lieut.-Col. R.) - THE OFFICER'S. MEMORANDUM BOOK FOR PEACE AND WAR. Third Edition. Oblong $32 \mathrm{mo}$. roan, with pencil, price $3^{s .} 6 d$.

HELVIG (Capt. H.)-The OPERATIONS OF THE Bavarian ARMY CoRPS. Translated by Captain G. S. Schwabe. With Five large Maps, In 2 vols. Demy 8vo, price 245 .

TACTICAL Examples: Vol. I. The Battalion, price I5s. Vol. II. The Regiment and Brigade, price Ios. $6 d$. Translated from the German by Col. Sir Lumley Graham. With nearly 300 Diagrams. Demy 8vo. cloth. 
HOFFBAUER (Capt.)-ThE GermaN Artillery in the Battles NeAR METZ. Based on the Official Reports of the German Artillery. Translated by Captain E. O. Hollist. With Map and Plans. Demy Svo. price $21 s$.

LAYMANN (Capt.)-The FrontaL ATTACK OF INFANTRY. Translated by Colonel Edward Newdigate. Crown 8 vo. price $2 s .6 d$.

Notes on Cavalry Tactics, ORganiSAtion, \&c. By a Cavalry Officer. With Diagrams. Demy Svo. cloth, price $12 s$.

PARR (Capt H. Hallam) C.M.G.-THE DRESS, Horses, AND EQUIPMENT OF INFANTRY AND STAFF OFFICERS. Crown Svo. cloth, price Is.

SCHELL (Maj. vori)-THE OPERATIONS OF THE FIRST ARMIY UNDER GEN. voN Goeben. Tranşated by Col. C. H. von Wright. Four Maps. demy Svo. price $9 s$.

The Operations of time First Army UNDER Gen. von STEINMETz. Translated by Captain E. O. Hollist. Demy 8vo. price ros. $6 d$.

SCHELLENDORF (Major-Gen. B. von) The Duties of the General STAFF. Translated from the German by Lieutenant Hare. Vol. I. Demy 8vo. cloth, Ios. $6 d$.

SCHERFF (Maj. W. von)-STUDIES IN THE NEW INFANTRY TACTICS. Parts I. and II. Translated from the German by Colonel Lumley Graham. Demy 8vo. price $7 s .6 d$.

SHADWELL (Maj.-Gen.) C.B.-MouNTAIN WARFARE. Illustrated by the Campaign of I799 in Switzerland. Being a Translation of the Swiss Narrative compiled from the Works of the Archduke Charles, Jomini, and others. Also of Notes by General $H$. Dufour on the Campaign of the Valtelline in 1635. With Appendix, Maps, and Introductory Remarks. Demy 8 vo. price $16 s$.

SHERMAN (Gen. W. T.)-MEMOIRS OF General W. T. Sherman, Commander of the Federal Forces in the American Civil War. By Himself. 2 vols. With Map. Demy 8 vo. price 245. Copyright English Edition.
STUBBS (Lieut.-Col. F. $\left.W_{0}\right)-\mathrm{THE}_{\mathrm{H}}$ Regiment of Bengat. Artillery. The History of its Organisation, Equipment, and War Services. Compiled from Published Works, Official Records, and various Private Sources. With numerous Maps and Illustrations. 2 vols. demy 8 vo. price 32 s.

\section{STUMM (Lieut. Hugo), German Military} Attache to the Khivan Expedition. Russia's AdVANCE EAsTWARD Based on the Official Reports of. Translated by Capt. C.E.H. VINCENT, With Map. Crown 8vo. price $6 s$.

VINCENT (Capt. C. E. H.)-ELEMENtary Military Geography, ReCONNOITRING, AND SKETCHING. Compiled for Non-commissioned Officers and Soldiers of all Arms. Square crown 8vo. price $2 s, 6 d$.

Volunteer, the Militiaman, and the Regular Soldier, by a Public Schoolboy. Crown 8vo. cloth, price 5 .

WARTENSLEBEN (Count H. von.)The Operations of THE South ARMY IN JANUARY AND FEbRUARY, 1871. Compiled from the Official War Documents of the Head-quarters of the Southern Army. Trans. lated by Colonel C. H. von Wright. With Maps. Demy 8vo. price 6s.

The Operations of the First Army UNDER GEN, VON MANTEUfFet. Translated by Colonel C. $\mathrm{H}$. von Wright. Uniform with the above. Demy 8vo. price $9 s$.

WICKHAM (Capt. E. H., R.A.)INFLUENCE OF FIREARMS UPON TACTICS: Historical and Critical Investigations. By an OFFICER OF SUPERIOR RANK (in the German Army). Translated by Captain E. H. Wickham, R.A. Demy 8vo, price $7 s .6 d$.

WOINOVITS (Capt. I.) - Austrian Cavalry Exercise. Translated by Captain IV. S. Cooke. Crown Svo. price $7 s$. 


\section{POETRY.}

ADAMS ( $W$. D.-Lyrics OF Love, from Shakespeare to Tennyson. Selected and arranged by. Fcp. 8vo. cloth extra, gilt edges, price $3 s .6 d$.

Also, a Cheaper Edition. Fcp. 8vo. cloth, 2s. $6 d$.

AMATEUR-A FEW LyRics. Small crown $8 \mathrm{vo}$. cloth, price $2 s$.

ANTILOPE: a Tragedy. Large crown 8vo. cloth, price $6 s$.

AUBERTIN(Ұ. Ұ.)-CaMoENS' Lusiads. Portuguese Text, with Translation by. Map and Portraits. 2 vols. Demy 8vo. price 30 s.

Seventy Sonnets of Canroens. Portuguese Text and Translation, with some original Poems. Dedicated to Capt. Richard F. Burton. Printed on hand made paper, cloth, bevelled boards, gilt tops, price $7 s .6 d$.

AVIA-The Odyssey of Homer. Done into English Verse by. Fcp. 4to. cloth, price $15 \mathrm{~s}$.

BANKS (Mrs. G. L.)-RIPPLES AND Breakers : Poems, Square Svo. cloth, price 5 s.

BARNES (William)-POEMS OF RURAL LifE, in THE DORSET Dialect. New Edition, complete in one vol. Crown 8vo. cloth, price $8 s, 6 d$.

BAYNES (Rcv. Canon R. H.) M.A.HoMe SONGS For QUieT Hours. Fourth Edition. Fcp. 8vo. price 2s.6d.

This may also be had handsomely bound in morocco with gilt edges.

BENNETT (Dr. W. C.)-NarRative Poems and Ballads. Fcp. 8vo. sewed, in Coloured Wrapper, price is.

SONGS FOR SAILORS. Dedicated by Special Request to H.R.H. the Duke of Edinburgh. With Steel Portrait and Illustrations. Crown 8vo. price 3s. $6 d$.

An Edition in Illustrated Paper Covers, price Is.

SONGS OF A SONG Writer. Crown 8 vo. price $6 s$.

BEVINGTON (L. S.)-KeX Notes. Small crown 8vo. cloth, price $5^{s}$.
BOWEN (HI. C.) M.A.-Sinple EvGLISI POEMS. English Literature for Junior Classes. In Four Parts. Parts I. II. and III. price $6 d$. each, and Part IV. price I $s$.

BRYANT (W. C. $)$ - Poems. Red-line Edition. With 24 Illustrations and Portrait of the Author. Crown 8vas cloth extra, price $7 s .6 d$.

A Cheap Edition, with Frontispiece. Small crown 8 vo. price 3 s. $6 d$.

BUTLER (Alfred F.)-AMARANTH AND ASPIIODEL. Songs from the Greek Anthology. Small crown 8vo. cloth, price $2 s$.

Calderon's Dramas : the WonderWorking Magician-Life is a Dream -the Purgatory of St. Patrick. Translated by Denis Florence MacCarthy. Pust 8vo. price Ios.

COLOMB (Colonel) - THE CARDINAL ARCHBISHOP : a Spanish Legend. In 29 Cancions. Small Crown 8vo. cloth, price $5^{s}$.

CONIVAY.(Hugh)-A LIFE'S IDYLLS. Small crown 8 vo. cloth, price $3 s .6 d$.

COPPÉE (Francois)-L'EXILEE. Done into English Verse, with the sanction of the Author, by I. O. L. Crown 8 vo. vellum, price 5 s.

COWAN (Rev. Willian)-POEMs : chiefly Sacred, including Translations from some Ancient Latin Hymns. Fcp. 8 vo. cloth, price $5 s$.

CRESSWELL (Mrs. G.)-THE KING'S BANNER : Drama in Four Acts. Five Illustrations. 4to. price IOs. $6 d$.

DAVIES (T. Hart.)-Catullus, Translated into English Verse. Crown 8vo. cloth, price $6 s$.

DENNIS (Ұ) - English Sonnets. Collected and Arranged. Elegantly bound. New and Cheaper Edition. Fcp. 8vo. price 2s. 6d.

DE VERE (Aubrey)-ALEXANDER THE Great : a Dramatic Poem. Small crown 8 vo. price 5 s. 
DE VERE (Aubrey)-con.

THE INFANT BRIDAL, and other Poems. A New and Enlarged Edition. Fcp. 8vo. price $7 s .6 d$.

LEgENDS OF THE SAXON SAINTS Small crown 8 vo. cloth, price $6 s$.

The Legends of St. Patrick, and other Poems. Small cr. 8vo. price $5 s$.

St. Thomas of Canterhury : a Dramatic Poem. Large fcp. 8vo. price $5 s$.

ANTAR ANd ZARA: an Eastern Romance. INISFAIL, and other Poems, Meditative and Lyrical. Fcp. 8vo. price $6 s$.

The Fall of Rora, The Search AFTer Proserpine, and other Poems, Meditative and Lyrical. Fcp. 8vo. 6s.

DOBELL (Mrs. Horace)-ETHeLstone, Eveline, and other Poems. Crown 8 vo. cloth, $6 s$.

DOBSON (Austin) - VIGNETTES IN RHYMe, and Vers de Société. Third Edition. Fcp. 8vo. price 5s.

Proveris in Porcelain. By the Author of 'Vignettes in Rhyme.' Second Edition. Crown 8vo. price $6 s$.

DOLORES : a Theme with Variations. In Three Parts. Small crown 8vo. cloth, price 5 s.

Dorothy : a Country Story in Elegiac Verse. With Preface. Demy Svo. cloth, price 5s.

DOWDEN (Edzuard) LL.D.-POEMS. Second Edition. Fcp. 8vo. price 5 s.

DOWNTON (Rev. H.) M.A.-HyMNs AND VERSES. Original and Trans. lated. Small crown 8 vo. cloth, price 3s. $6 d$.

DUTT (Toru)-A SHEAF GLEANED IN French FIELDS. New Eaition, with Portrait. Demy 8vo. cloth, Ios. $6 d$.

EDIVARDS (Rचv. Basil) - MINOR CHORDS ; or, Songs for the Suffering : a Volume of Verse. Fcp. 8vo. cloth, price 3 s. $6 d$.; paper, price $2 s .6 d$.

ELLIOT (Lady Charlotte)-MEDUSA and other Poems. Crown 8vo. cloth, price $6 s$.

ELLIOTT (Ebenezer), The Corn Law Rhymer.-Poems. Edited by his son, the Rev. Edwin Elliott, of St. John's, Antigua. 2 vols, crown 8vo. price 18s.
ENGLISH ODEs. Selected, with a Critical Introduction by EDMUND W. Gosse, and a miniature frontispiece by Hamo Thornycroft, A.R.A. Elzevir 8vo. limp parchment antique, price 6s. ; vellum, 7s. $6 d$.

Epic of Hades (The). By the Author of 'Songs of 'Two Worlds.' Twelfth Edition. Fcp. 8 vo. price $7 s .6 d$.

* * Also an Illustrated Edition, with seventeen full-page designs in photomezzotint by George R. Chapman. 4to. cloth, extra gilt leaves, price 255 ; and a Large Paper Edition with Portrait, price 1os. $6 d$.

EVANS (Amne)-PoEMS AND MUSIC. With Memorial Preface by ANN ThACkeray RITCHIE. Large crown 8vo. cloth, price 7 s.

G. $H$. T.-VERSES, mostly written in India. Crown 8vo, cloth, price $6 s$.

Ginevra and the Duke of Guise : Two Tragedies. Crown 8vo. cloth, price $6 s$.

GOSSE (Edmund W.)-New PoEMs, Crown 8vo. cloth, price 7s. $6 d$.

GREENOUGH (Mrs. Richard)-MARY Magdalene : a Poem. Large post 8 vo. parchment antique, bevelled boards, price $6 s$.

Given : a Drama in Monologue. By the Author of the 'Epic of Hades.' Third Edition. Fcp. 8vo. cloth, price 5s.

HAWKER (Robt. Stephen)-_The PoetiCAL WORKS OF. Now first collected and arranged. With a Prefatory Notice by J. G. Godwin. With Portrait. Crown 8 vo. cloth, price 12 s.

HAWTREY (Edward M.)-CORYDALLS : a Story of the Sicilian Expedition. Small crown 8 vo. cloth, price $3 s .6 t$.

HOLMES (E. G. A.)-PoEMs. First and Second Series. Fcp. 8vo. price 5 s. each.

INCHBOLD (F. W.)-ANNUS AMORIS: Sonnets. Fcp. 8vo. price 4 r. $6 d$.

FENKINS (Rev. Canon)-THE GIRDLE LEgEND OF PRATO. Small crown 8 vo. cloth, price $2 s$.

JerovenM's WiFe, and other Poems. Fcp. 8vo. cloth, price $3 s, 6 d$.

KING (Edward)-EcHOES FROM THE Orient. With Miscellaneous Poems. Small crown 8vo. cloth, price 3 s. $6 d$. 
KING (Møs. Hamilton)-THE Disciples. Fourth Edition, with Portrait and Notes. Crown 8vo. price $7 s .6 d$.

Aspromonte, and other Poems. Second Edition. Fcp. 8vo price $4 s .6 d$.

LAIRD-CLOWES (W.)-LOVE'S REBELLION : a Poem. Fcp. 8vo. cloth, price 3s. 6 d.

LANG $(A$.)-XXII Ballades in Blue China. Elzevir 8vo. parchment. price $3 s .6 d$.

LEIGHTON (Robert)-RECORDS AND OTHER Poems. With Portrait. Small crown 8vo. cloth, price $7 s .6 d$.

LOCKER (F.)-LONDON LYRICS. A New and Revised Edition, with Additions and a Portrait of the Author. Crown 8vo. cloth elegant, price $6 s$.

Also, an Edition for the People. Fcp. 8vo. price $2 s .6 d$.

LOKI.-The NeW Werther. Small crown 8vo, cloth, price $3 s .6 d$.

Love's Gamut and other Poems Small crown 8vo. cloth, price $3 s .6 d$.

Love Sonnets of Proteus. With Frontispiece by the Author. Elzevir 8vo. cloth, price $5 s$.

LOWNDES (Heiry) - POEMS AND Translations: Crown 8vo. cloth, price $6 s$.

LUMSDEN (Lieut.-Col. H. W.)-BEOWULF : an Old English Poem. Translated into Modern Rhymes. Small crown 8 vo. cloth, price $5 s$.

MACLEAN (Charles Donald)-LATIN AND GREEK VERSE TRANSLATIONS. Small crown 8vo. cloth, 2s.

MAGNUSSON (Eirikr) M.A., and PALMER (E. H.) M.A.-JOHAN LUdVIG RUNEBERG'S LYRICAL SONGS, IDYlis, AND EPIGRAMs. Fcp. 8vo. cloth, price $5 s$.

Marie Antionette : a Drama: Small crown 8 vo. cloth, price 5 .

MIDDLETON (The Lady)-BALLADS. Square I6mo. cloth, price $3 s .6 d$.

Monmouth : a Drama, of which the outline is Historical. (Dedicated, by permission, to Mr. Henry Irving.) Small crown 8vo. cloth, price 5 s.

MOORE (Mrs. Blooinfield)-GoNDALINE's Lesson : The Warden's Tale, Stories for Children, and other Poems. Crown 8vo. cloth, price 5 s.
MORICE (R'ev. F. D.) M.A.-The Olympian and Pythian Odes of Pindar. A New Translation in English Verse. Crown 8vo. price 7s. $6 d$.

MORSHEAD (E. D. A.)-The AGAMEMNON OF ESCHYLUS, Translated into English Verse. : With an Introductory Essay. Crown 8vo. cloth, price $5^{s}$.

MORTERRA (Felix)-THE LEGEND OF Allandale, and other Poems. Small crown 8 vo. cloth, price $6 s$.

My Old PoRtFolio. A Volume of Poems. Crown 8 vo. cloth, price 4s. 6 d.

NICHOLSON (Edward B.) Librarian of the London Institution-THE CHRIST CHILD, and other Poems. Crown 8vo. cloth, price $4 s .6 d$.

NOAKE (Major R. Compton) - THE BIvouAC ; or, Martial Lyrist. With an Appendix: Advice to the Soldier. Fcp. 8vo. price 5s. $6 d$.

NOEL (The Hon Roden)-A LitTLE CHILD's MoNument. Small crown 8vo. cloth, 3s. $6 d$.

NORRIS (Rev. Alfred) -THE INNER AND OUTER Life Poems. Ficp. Svo. cloth, price $6 s$.

ODE OF LIFE (THE). By the Author of 'The Epic of Hades' \&c. : Third Edition. Crown 8 vo. cloth, price 5 s.

O'HAGAN (fohn) - THE SONG OF ROLAND: Translated into English Verse. Large post 8vo. parchment antique, price ros. $6 d$.

Palace and Prison and Fair GeralDINE : two Tragedies. By the Author of 'Ginevra' and the 'Duke of Guise.' Crown 8vo. cloth, price $6 s$.

PALMER (Charles Walter) -THE WEED: a Poem. Small crown 8vo. cloth, price $3 s$.

PAUL (C. Kegan)-Goetre's Faust. A New Translation in Rhyme. Crown 8 vo. price $6 s$.

PAYNE (fohn)-SONGS OF LIFE AND Death. Crown 8vo. cloth, price 5 s.

PENNELL (H. Cholmondeley)-PEGASUS RESADDled.' By the Author of 'Puck on Pegasus,' \&c. \&c. With Ten Fullpage Illustrations by George Du Maurier. Second Edition. Fcp. 4to. cloth elegant, I2s. $6 d$. 
PFEIFFER (Emily)-GLAN ALARCH : His Silence and Song: a Poem. Second Edition. Crown 8vo. price 6s. Gerard's Monument and other Poems. Second Edition. Crown 8vo. cloth, price $6 s$.

Quarterman's Grace, and other Poems, Crown 8vo. cloth, price $5 s$.

Poems. Second Edition. Crown 8vo. cloth, price $6 s$.

SONNETS AND Songs. New Edition. r6mo. handsomely printed and bound in cloth, gilt edges, price $4 s$.

RHOADES (fames). - THE GEORGICS OF VIRGIL, Translated into English Verse. Small crown 8vo. cloth, price 5 .

ROBINSON (A. Mary $\left.F_{0}\right)$-A HANDFUL of Honeysuckle. Fcp. 8vo. cloth, price 3s: $6 d$.

Safpho. A Dream, by the Author of 'Palace and Prison' \&c. Crown 8vo. cloth, $3 s .6 d$.

SHELLEY (Percy Bysshe) - PoEms Selected From. Dedicated to Lady Shelley. With Preface by Richard Garnett. Printed on hand-made paper, with miniature frontispiece, elzevir $8 v o$. limp parchment antique, price $6 s$.; vellum, $7 s .6 d$.

SKINNER (fames)-Celestia. The Manual of St. Augustine. The Latin Text side by side with an English Interpretation in Thirty-six Odes with Notes, and a plea for the study of Mystical Theology. Large crown 8vo. cloth, 6s.

Songs of Two Worlds. By the Author of 'The Epic of Hades.' Fifth Edition. Complete in one Volume, with Portrait. Fcp. 8vo. cloth, 7s. 6.

SONGS FOR MUSic. By Four Friends. Containing Songs by Reginald A. Gatty, Stephen H. Gatty, Greville J. Chester, and Juliana Ewing. Square crown 8vo. price $5 s$.

STEDMAN (Edmund Clarence)-LYRICS AND IDYLLS, with other Poems. Crown 8vo. cloth, price $7 s .6 d$.

STEVENS (William)-THE TRUCE OF GoD, and other Poems. Small crown 8vo. cloth, price 3 s. $6 d$.

Sweet Silvery Sayings of ShakeSPEARE. Crown 8vo. cloth gilt, $7 s, 6 d$.
TAYLOR (Sir H.)-Works Complete in Five Volumes. Crown 8vo. cloth, price $30 s$.

\section{TENNYSON (Alfred) - Works Com- plete:-}

The Imperial Library Edition. Complete in 7 vols. demy 8vo. price IOs. $6 d$. each; in Roxburgh binding, I2s. $6 d$.

AUthor's Edition. In Six Volumes. Post 8vo. cloth gilt; or half-morocco. Roxburgh style.

Cabinet Edition. 12 Volumes. Each with Frontispiece. Fcp. 8vo. price 2s. $6 d$. each.

Cabinet Edition. 12 vols. Complete in handsome Ornamental Case.

Pocket Volume Edition. 13 vols. in neat case, price $36 s$.

Ditto, ditto. Extra cloth gilt, in case, price $42 s$.

The Royal Edition. In I vol. With 25 Illustrations and Portrait. Cloth extra, bevelled boards, gilt leaves, price $2 \mathbf{I} s$.

The Guinea Edition. Complete in I 2 vols. neatly bound and enclosed in box. Cloth, price 2Is.; French morocco, price $3 I s .6 d$ :

SHILling EDITION. In 12 vols. pocket size, Is, each, sewed.

The Crown Edition. Complete in I vol. strongly bound in cloth, price $6 s$.; cloth, extra gilt leaves, price 7s. $6 d$.; Roxburgh, half-morocco, price $8 s .6 d$.

$*_{*}^{*}$ Can also be had in a variety of other bindings.

In Memoriam. Choicely printed on hand-made paper, with a miniature portrait in eaz-forte by Le Rat, after a photograph by the late Mrs. Cameron. Bound in limp parchment, antique, price $6 s$, ; vellum, $7 s, 6 d$.

The Princess: A Medley. Choicely printed on hand-made paper, with a miniature frontispiece by $H$. M. Paget and a tail-piece in outline by Gordon Browne. Limp parchment, antique, price $6 s$.; vellum, price $7 s$. 
TENNYSON (Alfred)-cont.

Tennyson's Songs Set to Music by various Composers. Edited by W. J. Cusins. Dedicated, by express permission, to Her Majesty the Queen. Royal 4to. cloth extra, gilt leaves, price $21 s$.; or in half-morocco, price 25 s.

Original Editions :-

Ballads, and other Poems. Fcp. 8vo. cloth, price 5 s.

Poens. Small 8vo. price $6 s$.

MAUd, and other Poems. Small 8vo. price $3^{s} .6 d$.

The Princess. Small 8vo. price $3 s .6 d$.

IDYLLS OF THE KING. Small 8vo. price 5 s.

IDYLIS OF THE KING. Complete. Small 8vo. price $6 s$.

The Holy Grail, and other Poems. Small 8vo. price $4 s .6 d$.

Gareth and Lynette. Small 8vo. price 3 s.

ENoch ARDeN, \&c. Small 8vo. price 3s. $6 d$.

In Memoriam. Small 8vo. price $4 s$.

HAROLD : a Drama. New Edition. Crown Svo. price $6 s$.

Queen Mary: a Drama. New Edition. Crown 8vo. price 6s.

The Lover's Tale. Fcap. 8vo. cloth, 3s. $6 d$.

SELections From the ABOVE IVORKS. Super royal I $6 \mathrm{mo}$. price $3 s_{0} 6 d_{0}$; cloth gilt extra, price $4 s$.

SONGS FROM THE ABOVE WORKS. I6mo. cloth, price $2 s .6 d$.; cloth extra, $3 s .6 d$.

IDylls of THE King, and other Poems. Illustrated by Julia Margaret Cameron. 2 vols. folio, half-bound morocco, cloth sides, price $6_{6} 6$. 6 s. each.

TENNYSON FOR THE YOUNG AND FOR REcitation. Specially arranged. Fcp. 8vo. Is. 6d.

The Tennyson Birthday Book. Edited by Emily Shakespear. 32mo. cloth limp, 2s. ; cloth extra, $3 s$.

* * A superior Edition, printed in red and black, on antique paper, specially prepared. Small crown 8vo. cloth, extra gilt leaves, price $5^{s_{0}}$; and in various calf and morocco bindings.
THOMPSON (Alice C.)-PRELUdES : a Volume: of Poems. Illustrated by Elizabeth Thompson (Painter of 'The Roll Call'). 8vo. price 7s. 6d.

THRING (Rev. Godfrey), B.As.-Hyмns AND SACRED Lyrics. Fcp.8vo. price 3 s. $6 d$.

TODHUNTER (Dr. F.) - LaURella, and other Poems. Crown 8vo. 6s. $6 d$.

AICESTIS: a Dramatic Poem. Extra fcp. 8vo. cloth, 5 s.

A Study of Shelley. Crown 8vo. cloth, price $7 s$.

TOLINGSBY (Frere)-ELNORA: an Indian Mythological Poem. Fcp. 8vo. cloth, price $6 s$.

Translations from Dante, Petrarch, Michael Angelo, and Vittoria Colons. Fcp. 8vo. cloth, price 7s. $6 d$.

TURNER (Rev. C. Tennyson)-SoNNETS, LYRICS, AND TRanslations. Crown 8 vo. cloth, price $4 s .6 d$.

Collected Sonnets, Old and New. With Preface by Alfred Tennyson; also some Marginal Notes by S. T. COLERIDGE, and a Critical Essay by JAMES SPEDDING. Fcp. 8vo cloth, price $7 s .6 d$.

WALTERS (Sophia Lydia)-THE BROoK: a Poem. Small crown 8vo. cloth, price $3 s .6 d$.

A Dreamer's Sketch Book. With 2I Illustrations by Percival Skelton, R. P. Leitch, W. H. J. ВоOт, and T. R. PRITChetT. Engraved by J. D. Cooper. Fcp. 4to. cloth, price I2s. $6 d$.

WATERFIELD (W.) - HYMNS FOR Holy Days and Seasons. $32 \mathrm{mo}$. cloth, price Is. $6 d$.

WATSON (William)-THE PRINCE'S QUEST, and other Poems. Crown 8 vo. cloth, price $5^{s}$.

WA $Y(A) M .$.$A . - THE Odes OF Horace$ Literally Translated in Metre. Fcp. 8vo. price $2 s$.

WEBSTER (Augzista)-Disguises : a Drama. Small crown 8vo. cloth, price $5 s$. 
Wfet Dars. By a Farmer. Small crown 8 vo. cloth, price $6 s$.

WILLOUGHBY (The Hors. ATrs.)-ON THE NORTH WIND-THISTLEDOWN : a Volume of Poems. Elegantly bound, small crown 8vo, price $75.6 d$.
WOODS (fames Chapman)-A CHILd of THE PEOPLE, and other Poems. Small crown 8 ro. cloth, price $5 s$.

YOUNG (Wm.)-GotTlon, ETCETERA. Small crown 8vo. cloth, price $3 s .6 d$.

\section{WORKS OF FICTION IN ONE VOLUME.}

BANKS (Mrs. G. L.)-GoD's PROVIDENCE House. New Edition. Crown 8vo. cloth, price $3 s .6 d$.

BETHAM-EDWARDS (Miss MI.)

KITTY. With a Frontispiece. Crown 8vo. price $6 s$.

Blue Roses; or, Helen Malinofska's Marriage. By the Author of 'Véra.' New and Cheaper Edition. With Frontispiece. Crown 8vo. cloth, price $6 s$.

FRISWELL (F. Hain)-ONE OF TwO; or, The Left-Handerl Bride. Crown 8vo. cloth, price 3 s. $6 d$.

GARRETT (E.)-BY STILL WATERS : a Story for Quiet Hours. With Seven Illustrations. Crown 8vo. price 6s.

HARDY (Thomas)-A PAIR of BLUE Eyes. Author of ' Far from the Madding Crowd.' New Edition. Crown 8 ro. price $6 s$.

The Return of the Native. New Edition. With Frontispiece. Crown 8 vo. cloth, price $6 s$.

HOOPER (Mrs. G.)-THE HOUSE OF RABY. Crown 8vo. cloth, price $3 s .6 d$.

INGELOW (Fan)-OFF THE SKELLIGS: a Novel. With Frontispiece. Second Edition. Crown 8vo. cloth, price $6 s$. MACDONALD (G.)-MALCOLM. With Portrait of the Author engraved on Steel. Fourth Edition. Crown Svo. price $6 s$.

The Marguis of Losstr. Second Edition. With Frontispiece. Crown 8 vo, cloth, price $6 s$.

St. George avid St. Michari. Second Edition. With Frontispiece. Crown 8vo. cloth, $6 s$.

MASTERMAN (f.)-IIALF-A-DOZEN Daughters. Crown Swis, cinth, price 3s. $6 d$.

MEREDITIT (Giorsi') - ORDHAL, OF Richard Feverel. New Edition. Crown $8 \% 0$, cloth, price 6 s.
MEREDITH (George)-cont.

The Egorst : A Comedy in Narratire. New, and Cheaper Edition, with Frontispiece. Crown 8vo. cloth, price $6 s$.

PALGRAVE (W. Gifford)-Hermanis AgHA : an Eastern Narrative. Third Edition. Crown 8vo. cloth, price $6 s$.

Pandurang Hari; or, Memoirs of a Hindoo. With an Introductory Preface by Sir H. Bartle E. Frere, G.C.S.I., C.B. Crown 8vo price 6s.

PAUL (Margaret Agnes)-GENTLE AND Simple: A Story. New and Cheaper Edition, with Frontispiece. Crown Svo. price 6s.

SAUNDERS (Fohn) - ISRAEL, MORT, Overman: a Story of the Mine. Crown 8vo. price 6s.

ABEL DRAKE'S WifE. Crown Sro. cloth, price 3 s. $6 d$.

Hirell. Crown 8vo. cloth, price $3 s .6 d$. SHAW (Flore L.)-CASTLE Blair; a Story of Youthful Lives. New and Cheaper Edition, with Frontispiece. Crown 8vo, price 6s.

STRETTON (Hesba) - THROUGI A NeEdle's Eye : a Story. New and Cheaper Edition, with Frontispiece. Crown 8 ro. cloth, price $6 s$.

TAYLOR (Col.Mcadows) C.S.I., M.R.I.A.

Seeta : a Novel. New and Cheaper Edition. With Frontispiece. Crown Svo cloth, price 6s.

Tirroo Sultaun : a Tale of the Mysore War. New Edition, with Frontispiece. Crown Sro. cloth, price 6s.

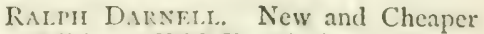
Edition. With Frontispiece. Crown 8vo. cloth, price $6 s$.

A Nonlr: (uUerex. New and Cheaper Edition. With Frontispiece. Crown Svo. cloth, price 6s. 
TAYLOR (Col. Meadows)-cont.

The Confessions of a Thug. Crown 8vo. price $6 s$.

TARA: a Mahratta Tale. Crown Svo. price $6 s$.
THOMAS (MOy)-A FIGHT FOR LIFE. Crown 8 vo. cloth, price $3 s .6 d$.

IVITHIN Sound of THE SEA. New and Cheaper Edition, with Frontispiece. Crown $8 v o$. cloth, price $6 s$.

\section{BOOKS FOR}

Aunt Mary's Bran Pie. By the Author of 'St. Olave's.' Illustrated. Price 3s. $6 d$.

BARLEE (Ellen)-Locked Out: a Tale of the Strike. With a Frontispiece. Royal I6mo. price $1 s .6 d$.

BONWICK (Ұ.) F.R.G.S.-THE TASMANIAN LiLy. With Frontispiece. Crown 8vo. price 5 s.

Mike Howe, the Bushranger of Van Diemen's Land. New and Cheaper Edition. With Frontispiece. Crown 8 vo. price 3 s. $6 d$.

Brave Men's Footsteps. By the Editor of 'Men who have Risen.' A Book of Example and Anecdote for Young People. With Four Illustrations by C. - Doyle. Sixth Edition. Crown 8vo. price $3 s, 6 d$.

CHILDREN's Toys, and some Elementary Lessons in General Knowledge which they teach. Illustrated. Crown 8vo. cloth, price 5 s.

COLERIDGE (Sara)-PRETTY Lessons IN VERSE FOR GOOD CHILDREN, with some Lessons in Latin, in Easy Rhyme, A New Edition. Illustrated. - Fcp. 8vo. cloth, price 3s. $6 d$.

D'ANVERS ( $N . R$.)-Little Minnie's Troubles : an Every-day Chronicle. With 4 Tllustrations by W. H. Hughes. Fcp. cloth, price $3 s .6 d$.

PARTED : a Tale of Clouds and Sunshine. With 4 Illustrations. Extra fcp. 8vo. cloth, price $3 s .6 d$.

Pixie's Adventures; or, the Tale of a Terrier. With 2 I Illustrations. I6mo. cloth, price $4 s .6 d$.

Nanny's Adventures : or, the Tale of Goat. With I 2 Illustrations. $16 \mathrm{mo}$. loth, price $4 s .6 d$.

DAVIES (G. Christopher) - RAMBLES AND ADVENTURES OF OUR SCHOOL Field Club. With Four Illustrations. Crown 8vo. price 5 s.

\section{THE YOUNG.}

DRUMMOND (Miss)-TRIPP'S BüILDINGS. A Study from Life, with Frontispiece. Small crown 8vo. price 3s. $6 d$.

EDMONDS (Herbert)-WeLl. SPENT LIVES: a Series of Modern Biographies. Crown 8vo. price 5 s.

EVANS (Mark)-THE STORY OF OUR FATHER'S LOve, told to Children; Fourth and Cheaper Edition of Theology for Children. With Four Illustrations. Fcap. 8vo. price Is. $6 d$.

\section{FARQUHARSON (M.)}

I. Elsie Dinsmore. Crown 8vo. price $3^{s .} 6 d$.

II. Elsie's Girlhood. Crown 8vo. price $3^{s .} 6 d$.

III. Elsie's Holidays at Roselands. Crown 8vo. price $3 s$. $6 d$.

HERFORD (Brooke)-THE STORY OF RELIGION IN ENGLAND: a Book for Young Folk. Cr. 8vo. cloth, price 5 s.

INGELOW (Fean)-THE. LITTLE WONDER-HORN. With Fifteen Illustrations. Small 8vo, price $2 s, 6 d$.

FOHNSON (VirginiaW.)_THE CATSKILL FAIRIES. Illustrated by ALFRED Fredericks. Cloth, price $5^{5}$.

KER (David)-The Boy SLave IN BoKhara: a Tale of Central Asia. With Illustrations. New and Cheaper Edition. Crown 8vo. price 3s. $6 d$.

The Wild Horseman of tile Pampas. Illustrated. New and Cheaper Edition. Crown 8vo. price $3 s .6$.

LAMONT (Martha MacDonald)-THE GLADIATOR : a Life under the Roman Empire in the beginning of the Third Century. With 4 Illustrations by H. M. Paget. Extra fcp. 8vo. cloth, price $3 s .6 d$. 
LEANDER (Richard)- FANTASTIC STORIES. Translated from the German by Paulina B. Granville. With Eight Full-page Illustrations by M. E. Fraser-Tytler. Crown 8vo. price $5^{s .}$

LEE (Holme)-HeR TITLE OF HoNour. A Book for Girls. New Edition. With a Frontispiece. Crown Svo. price $5^{s .}$

LEWIS (Mary A.) -A RAT With ThreE TAles. New and Cheaper Edition. With Four Illustrations by Catherine F. Frere. Price 3s. 6d.

MC CLINTOCK (L.)-SiR SPANGLE AND THE Dingy Hen. Illustrated. Square crown 8vo. price 2s. $6 d$.

MAC KENNA (S. 7.)-PLUCKY FELLows. A Book for Boys. With Six Illustrations. Fourth Edition. Crown 8vo. price $3 s .6 d$.

At School, with ax Old Dragoon, With Six Illustrations. Third Edition. Crown Svo. price $5^{5}$.

MALDEN (H. E.)-PRINCES AND PRINCESSES : Two Fairy Tales. Illustrated Small crown Svo. price $2 s, 6 d$.

MAster BobBy. By the Author of 'Christina North.' With Six Illustrations. Fcp. Svo. cloth, price $3 s .6 d$.

NAAKE (F. T.) - SLAVONIC FAIRY Tales, From Russian, Servian, Polish, and Bohemian Sources. With Four Illustrations. Crown 8vo. price 5s.

PELLETAN(E.)-TheDeser'T PAstor. JeAN JAROUSSEAU. Translated from the French. By Colonel E. P. De L'Hoste. With a Frontispiece. New Edition. Fcap. 8vo price $3 s .6 d$.

REANEY (Mrs. G. S.)-WAKING AND WorkING; or, From Girlhood to Womanhood. New and Cheaper Edition. With a Frontispiece. Cr. 8vo. price $3 s .6 d$.

BLESSING AND Blessed: a Sketch of Girl Life. New and Cheaper Edition. Crown 8vo. cloth, price $3 s .6 d$.

Rosf. Gurney's Discovery. A Book for Girls. Dedicated to their Mothers. Crown 8vo, cloth, price 3 s. $6 d$.

Exglisir Girzs: Their Place and Power. With Preface by the Rev, R. W. Dale. Third Edition. Fcap. 8vo. cloth, price $2 s .6 d$.
REANEY (Mrs. G. S.) - cont.

Just Anyone, and other Stories. Three Illustrations. Royal $16 \mathrm{mo}$. cloth, price Is. $6 d$.

SUNBEAyI WILLIE, and other Stories. Three Illustrations. Royal $16 \mathrm{mo}$. price. $1 s .6 d$.

Sunshine Jenny and other Stories. 3 Illustrations. Royal 16mo. cloth, price $\mathbf{I} s, 6 d$.

ROSS (Mrs. E.), ('Nelsie Brook')DADDY'S PET. A Sketch from Humble Life." IVith Six Illustrations. Royal I6mo. price Is.

SADLER (S. W.) R.N.-THE AFRICAN CRUISER: a Midshipman's Adventures on the West. Coast. With Three Illustrations. New and Cheaper Edition. Crown 8vo. price 2s. $6 d$.

SEEkiNg His Fortune, and other Stories. With Four Illustrations. New and Cheaper Edition. Crown 8vo. 2s. 6d.

Seven Autumn Leaves from Fairy LAND. Illustrated with Nine Etchings. Square crown 8vo. price $3 s .6 d$.

STOCKTON (Frank R.)-A JOLLY FELLOWSHIP. With 20 Illustrations, Crown 8vo. cloth, price 5 s.

STORR (Francis) and TURNER (Hawes). -Canterbury Chimes; or, Chancer Tales retold to Children. With Six Illustrations from the Ellesmere MIS. Fcap. 8vo. cloth, price 3 s. $6 d$.

STRETTON (Hesba)-DAvid LIOYD'S LAST WILL. With Four Illustrations. Royal $16 \mathrm{mo}$. price $2 s .6 d$.

The Wonderful LIFE. Thirteenth Thousand. Fcap. Svo, cloth, price $2 s .6 d$.

Suvinyand Stories. By the Author of 'Aunt Mary's Bran Pic.' Illustrated. Small Svo. price $3 s .6 d$.

TALES FROM ARIOSTO RE-TOLN FOR CHILDREN. By a Lady. With 3 Illustrations. Crown Svo. cloth, price $45.6 d$.

IVHITAKER (Florence)-CHRISTY'S INHERITANCE. A London Story. Illus. trated. Royal $16 \mathrm{mo}$, price $\mathbf{I} s, 6 d$.

ZTMMERN (H.)-STORIES IN PRECIOUS STONES. With Six Illustrations: Third Edition, Crown Svo, price $5^{s}$. 


\section{MR. TENNYSON'S WORKS.}

\section{THE IMPERIAL LIBRARY EDITION,}

IN SEVEN OCTAVO VOLUMES.

Cloth, price zos. $6 d$. per vol.; r2s. $6 d$. Roxburgh binding. Contents.

Vo1. I.-MISCELLANEOUS POEMS.

II.-MISCELLANEOUS POEMS.

1II.-PRINCESS, AND OTHER POEMS.

Vol. IV.-IN MEMORIAM and MAUD.

V.-IDYLLS OF THE KING.

VI.-IDYLLS OF THE KING.

VII.-DRAMAS.

Printed in large, clear, old-faced type, with a Steel Engraved Portrait of the Author, the set complete, cloth, price $£_{3}$. $13 s_{*} .6 d$. ; or Roxburgh half-morocco, price $£_{4 \cdot} .7 s, 6 d$. * * The handsomest Edition published.

\section{THE AUTHOR'S EDITION,}

IN SIX VOLUMES. Bound in cloth, $38 \mathrm{~s} .6 \mathrm{~d}$.

Contents.

Vol. I.-EARLY POEMS and ENGLISH | Vol. IV.-THE PRINCESS and MAUD. 6s. IDYLLS. $6 s$.

II.-LOCKSLEY HALL, LUCRE-

TIUS, and other Poems. 6s.

III.-THE IDYLLS OF THE KING, complete. $7 s, 6 d$.

V.-ENOCH ARDEN and IN MEMORIAM. G.

VI.-QUEEN MARY and HAROLD. $7 s$.

This Edition can also be had bound in half-morocco, Roxburgh, price is. $6 d$. per vol. extra.

\section{THE CABINET EDITION,}

IN TWELVE VOLUMES. Price $2 s .6 d$, each.

Contents.

Wol. I-EARLY POEMS. Illustrated with|Vol. VI.-IDYLLS OF THE KING. Illusa Photographic Portrait of Mr. Tennyson.

II.-ENGLISH IDYLLS, and other POEMS. Containing an Engraving of Mr. Tennyson's Residence at Aldworth.

III.-LOCKSLEY HALL, and other POEMS. With an Engraved Picture of Farringford.

IV.-LUCRETIUS, and other POEMS. Containing an Engraving of a Scene in the Garden at Swainston.

V.-IDYLLS OF THE KING. With an Autotype of the Bust of Mr. Tennyson by T. Woolner, R.A.

trated with an Engraved Portrait of 'Elaine,' from a Photographic Study by Julia M. Cameron.

VII,-IDYLLS OF THE KING. Con. taining an Engraving of 'Arthur,' from a Photographic Study by Julia M. Cameron.

VIII. - THE PRINCESS. With an Engraved Frontispiece.

IX. - MAUD and ENOCH ARDEN. With a Picture of 'Maud,' taken from a Photographic Study by Julia M. Cameron.

X.-IN MEMORIAM. With a Steel Engraving of Arthur H. Hallam, engraved from a picture in possession of the Author, by J. C. Armytage.

XI.-QUEEN MARY: a Drama. With Frontispiece by Walter Crane.

XII.-HAROLD : a Drama. With Frontispiece by Walter Crane.

* These Volumes may be had separately, or the Edition complete, in a handsome omamental case, price 325 .

\section{THE MINIATURE EDITION,}

IN THIRTEEN VOLUMES.

Vol. I.-POEMS.

II.-POEMS.

III.-POEMS.

IV.-IDYLLS OF THE RING.

V.-IDYLLS OF THE KING.

VI.-IDYLLS OF THE KING.
Contents.

VoL, XIII.-HAROLD.

Vol. VII.-IDYLLS OF THE KING.

VIII.-IN MEMORIAM.

IX.-PRINCESS.

X.-MAUD.

XI. - ENOCH ARDEN.

XII.-QUEEN MARY.

Bound in imitation vellum, ornamented in gilt and gilt edges, in case, price 425 . This Edition can also be had in plain binding and case, price $36 s$.

Spottiswoode \& Co., Printers, Nezv-street Square, London. 



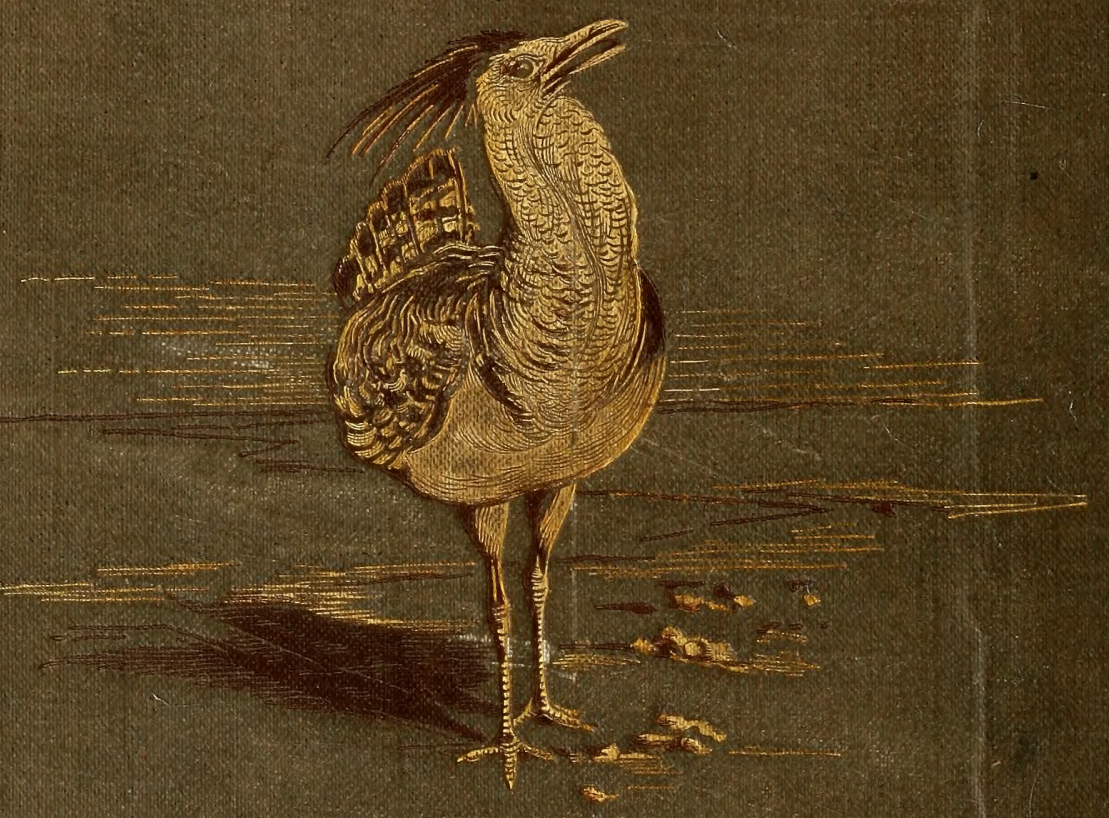


We only have 1889 volume. Please add this as electronic resource. Thanks!

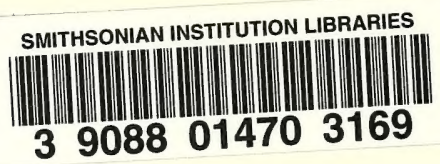

DP 731.018 